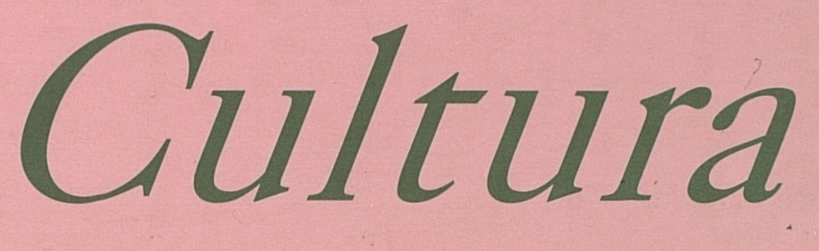

Revista de História e Teoria das Ideias

\title{
IDEIAS POLÍTICAS
}

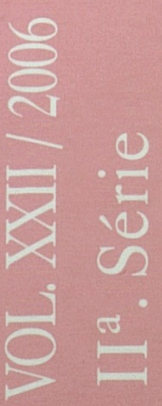




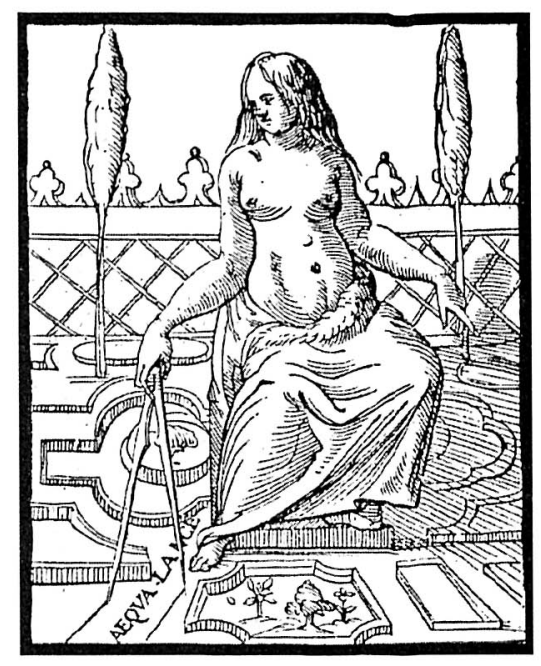

\section{LEGGE NATURALE}

\section{(Lei Natural)}

Uma belíssima senhora, que estará semi-nua e com os cabelos de modo natural, soltos, e não cuidadosamente entrançados. Estarão veladas as partes menos honestas com uma pele de Cordeiro, sentada num belíssimo jardim, e terá um compasso na mão, delineando duas linhas paralelas sobre o motto AEQUA. LANCE. e terá esta figura uma sombra de si mesma a qual mostrará com o indicador da mão esquerda. Pinta-se belíssima porque Deus, desde o princípio e sempre, fez todas as suas coisas belas e perfeitas como está escrito no Deuterónimos cap. 32 Dei perfecta sunt opera, e representa-se seminua, com os cabelos naturais, porque esta lei é simples como feita por Deus. Tem cobertas as partes menos honestas com a pele do Cordeiro, porque no estado da Inocência, o homem submetia-se à lei divina, a qual, depois de contrariada, quebrou o mandamento. Desta sorte, perdida a graça depois do pecado, está coberto pela misericórdia de Deus com a pele do cordeiro, símbolo de Cristo, o qual fuit occisus ab origine mundi como escreve São João no Apocalipse, no cap. 13.

Representa-se sentada num belíssimo jardim porque foi colocada no paraíso terrestre, do qual foi depois expulsa, e com a própria fadiga e engenho cultivou essa Terra, para que produzisse tudo quanto de belo hoje nela se vislumbra. Tem o compasso delineando duas paralelas sobre o motto AEQUALANCE de modo a que se compreenda a Justeza com a Justiça, a qual consiste em fazer aos outros, Quod tibi vis fieri, e não fazer quod tibi non vis fieri. A sua sombra é representada para que melhor se descubra a lei natural, a qual opera com o próximo, de forma a torna-lo semelhante a si próprio, e por essa razão os Filósofos disseram Amicus est alter idem.

(Trad. Nuno Saldanha) 


\section{Cultura Revista de História e Teoria das Ideias}

Junto envio cheque $n .^{\circ}$ do Banco passado à ordem de FCSH, UNL, na quantia de para assinatura da revista Cultura.

Data: assinatura:

(enviar para CHC UNL, Av. Berna 26-C, 1069-061 LISBOA)

dados do assinante:

nome:

morada:

código postal:

tel.:

e-mail:

2 números - 22 e 23 (IVA incl.)

normal $€ 24 \_$, estudante $€ 16 \_$, UE $€ 38 \_$, resto do mundo $€ 48$ _. 
Publicação Semestral do Centro de História da Cultura da Universidade Nova de Lisboa Vol. XXII - 2006

Em Cultura. Revista de História e Teoria das Ideias, encontram-se saberes diversos, em particular juntando-se as perspectivas da história, da filosofia e dos estudos literários. Dedica-se a estudos de ideias e práticas políticas, religiosas, científicas, económicas, sociais, estéticas e filosóficas, com destaque para a ligação entre o espaço português e o espaço ibérico, brasileiro e ibero-americano e o estudo dos veículos e formas de expressão e difusão das ideias.

Fundador: J. S. da Silva Dias

Director: José Esteves Pereira

Director Adjunto: Zília Osório de Castro

Coordenação Editorial: Cristina Montalvão Sarmento

Conselho de Redacção: José Esteves Pereira; José Henrique Dias; Zília Osório de Castro; António Camões Gouveia; Nuno Saldanha; Isabel Cluny; Margarida Amoedo; Luís Crespo Andrade; João Luís Lisboa; Cristina Montalvão Sarmento.

Comissão de Acompanhamento Científico: Claude Gilbert Dubois, Universidade de Bordéus (França); Onésimo Teotónio de Almeida, Brown University (EUA); Luís de Oliveira Ramos, Universidade do Porto; Norberto Cunha, Universidade do Minho; Armando Savignano, Universidade de Trieste (Itália); Roger Chartier (EHESS Paris).

Colaboraram como referees deste número: Ana Cristina Araújo (FL - Univ. Coimbra); António Hespanha (F. Direito - UNL); António Horta Fernandes (Dep. Estudos Políticos - FCSH-UNL); António Marques Bessa (ISCSP - FCSH-UTL); António Paim (Univ. Gama Filho, Rio de Janeiro); António Pedro Vicente (Dep. História - UNL); Avelino de Freitas Menezes (Univ. Açores); Bernardo Vasconcelos e Sousa (Dep. História - FCSH-UNL); Francisco Ribeiro da Silva (Fac. Letras - Univ. Porto); Isabel Vargues (FL - Univ. Coimbra); Ivete Centeno (FCSH UNL); João Carlos Espada (IEP - Univ. Católica); José Bragança de Miranda (FCSH - UNL); Luís Salgado de Matos (ICS - Lisboa); Maria Teresa Almeida (Faces de Eva - FCSH-UNL).

Design: Nuno Saldanha (nunosaldanha@mail.pt)

Editor: Centro de História da Cultura da Universidade Nova de Lisboa

Composição e Impressão: ARTIPOL - Artes Tipográficas, Lda. - Apartado 3051 - 3750-901 Águeda Tel. 234644435 - Fax 234645600 • e-mail: artipol@telepac.pt

Dep. Legal n..$^{\circ}$ 97341/96 • ISBN: 0870-4546

Preço deste número: $15,00 €$ - Assinatura: $24,00 €$

A correspondência relativa a colaboração de permuta, oferta de publicações e assinturas, deve ser dirigida ao

\section{CENTRO DE HISTÓRIA DA CULTURA/UNL}

Av. de Berna, 26-C - 1069-061 LISBOA - Telefax 217939228 - e-mail: chc@fcsh.unl.pt

Esta publicação é subsidiada ao abrigo do Financiamento Plurianual da FCT

(Fundação para a Ciência e Tecnologia)

A Cultura. Revista de História e Teoria das Ideias está referenciada no catálogo LATINDEX - Sistema de Informação Internacional de Revistas Científicas (http://www.latindex.org.) 


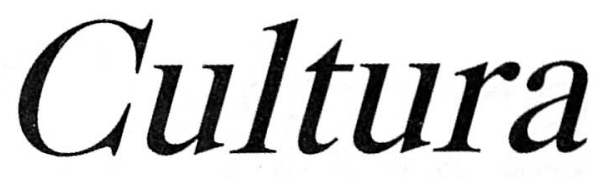

Revista de História e Teoria das Ideias 


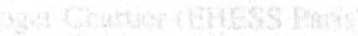

-

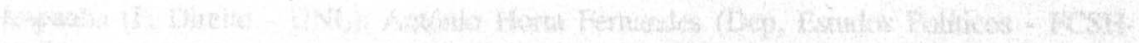

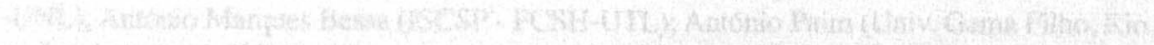

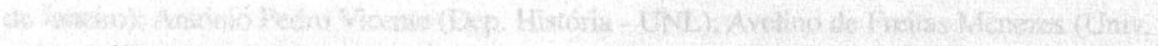
Prage

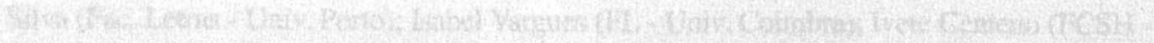

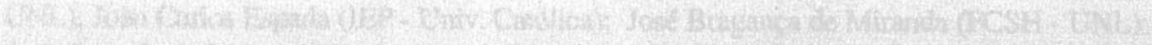

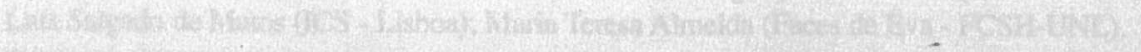

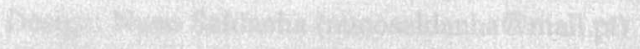

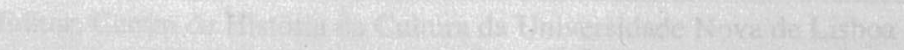

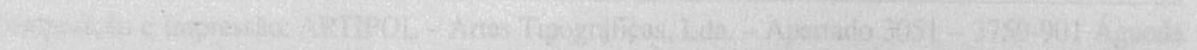

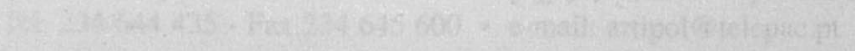

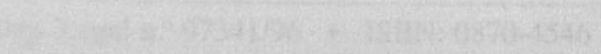

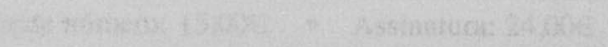

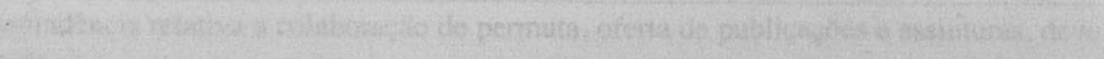

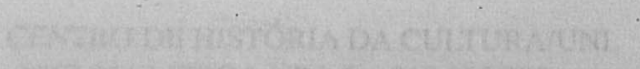

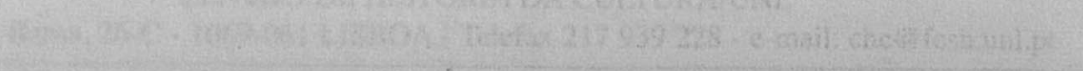

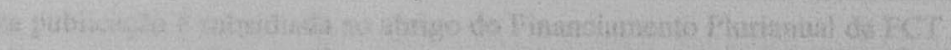

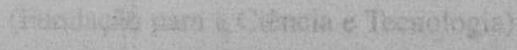

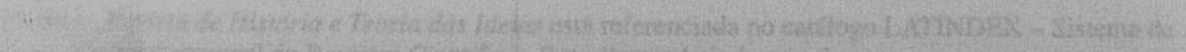

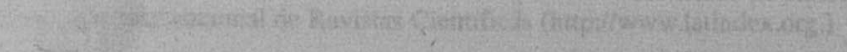




\title{
Cultura
}

Revista de História e Teoria das Ideias

\section{Ideias Políticas}

\author{
Em homenagem
}

a

Zília Osório de Castro

\author{
VOL. XXII/2006 \\ II Série
}

Centro de História da Cultura 


\section{megsmomon mA \\ S \\ OTz20 gh ofròzO Dils.}

doOS UIXXX..10V

\section{sitio2 II}

suuluo ab sindall sb oners 


\section{Zília Osório de Castro}

Licenciada em História (Universidade de Coimbra) e doutora em Filosofia e Cultura Portuguesa (Universidade Nova de Lisboa), é hoje Professora Catedrática Jubilada de História das Ideias na FCSH, UNL continuando a desenvolver a sua actividade nas áreas de História das Ideias Políticas e dos Estudos sobre as mulheres.

Tem sido responsável por vários projectos e seminários de investigação, de que resultaram:

- Lisboa 1821. A cidade e os políti$\cos ,(1997)$;

- Portugal e os caminhos do mar (séculos XVII e XVIII), (1998);

- Piedade popular em Portugal, (1998);

- Dreyfus e a responsabilidade intelectual, (1999);

- Dicionário do vintismo e do $1 .{ }^{\circ}$ Cartismo, (2001);

- Revistas. Ideias e Cultura, (2003);

- Diplomatas e Diplomacia. Práticas e Representações, (2004);

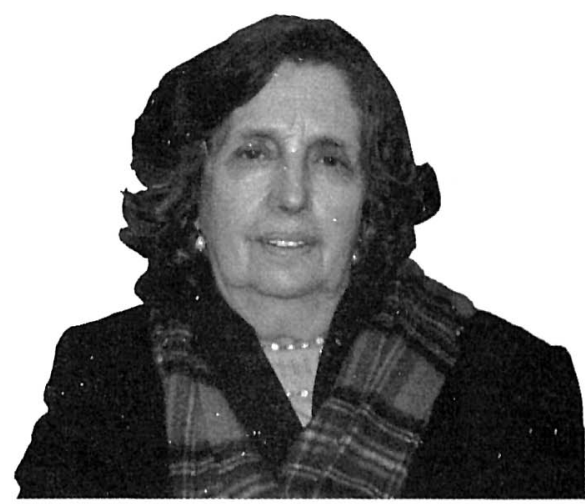

- Dicionário no Feminino, (2005);

- Tratados do Atlântico Sul. Portugal-Brasil 1825-2000, (2006).

Presentemente coordena no Centro de História da Cultura da UNL um grupo de investigação em Ciência Política e Relações Internacionais. Dirige também o Seminário Livre de História das Ideias, sendo responsável do projecto "Revistas: Ideias e Cultura", apoiado pela Fundação para a Ciência e Tecnologia e em parceria com a Biblioteca Nacional e a Fundação Mário Soares.

Dirige ainda a revista Faces de Eva. Estudos sobre a mulher (título que também identifica o grupo de investigação), tendo iniciado na Faculdade de Ciências Sociais e Humanas da UNL os estudos de género.

Publicou ainda, Cultura e Política. Manuel Borges Carneiro e o vintismo, 2 vols. (1990), Portugal e Brasil. Debates Parlamentares. 1821-1836. (2002) e Ideias políticas (séculos XVII-XIX) (2002). 


\section{thed kith}

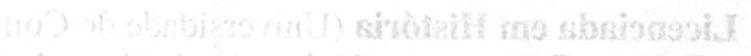

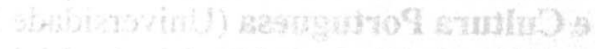

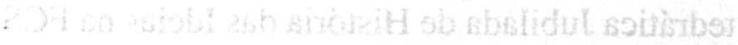

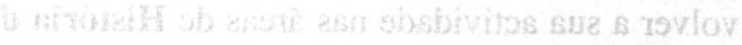
- agrantlan ar stofor aobut

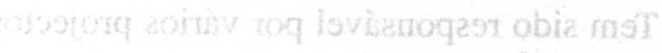
smatalleret oup

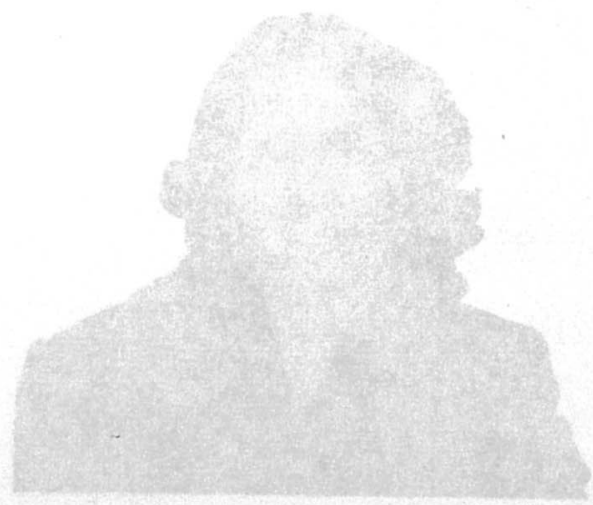

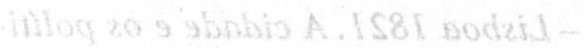
(Fеet), 209

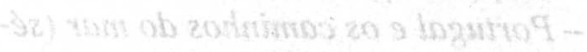
:(8eet) (MIIVX a HVX zolws

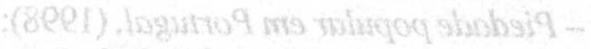

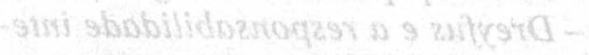
z(Qeel), Jwมy

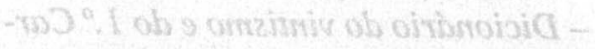
(1005) , omsit

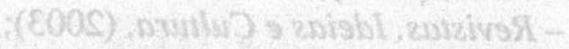

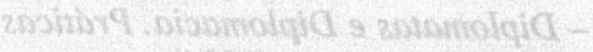

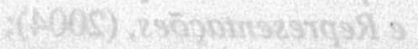

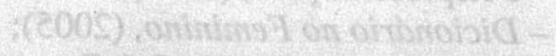

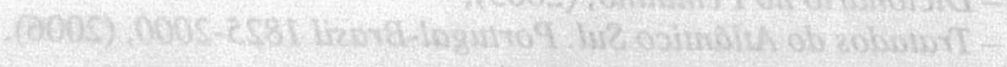

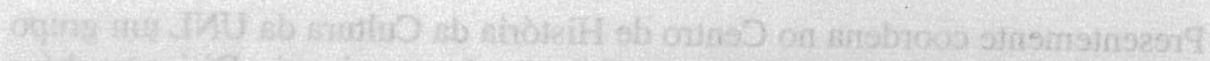

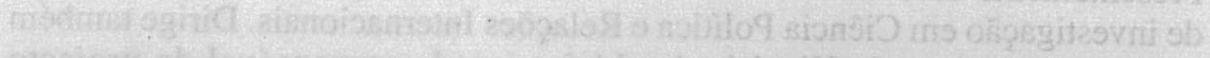

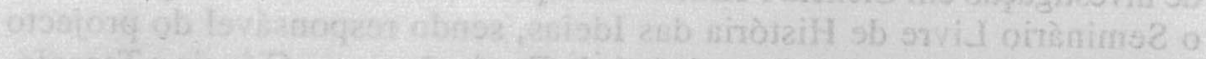

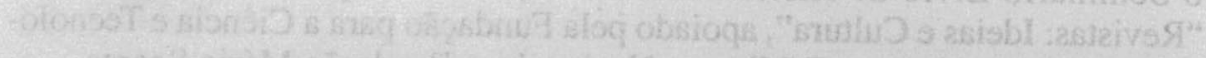

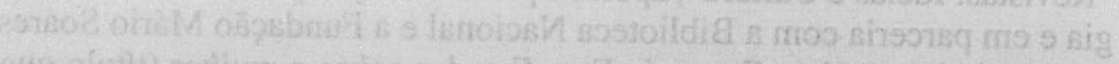

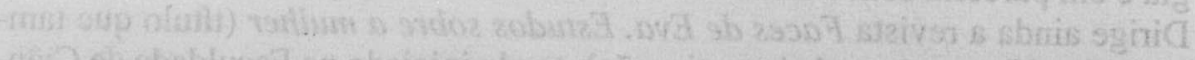

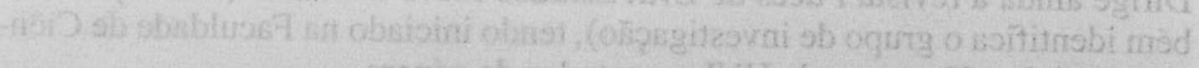

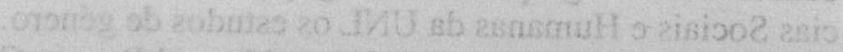

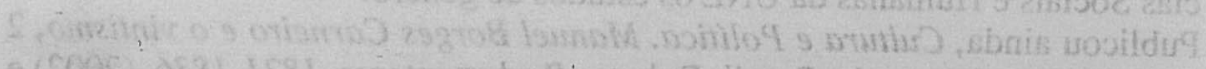

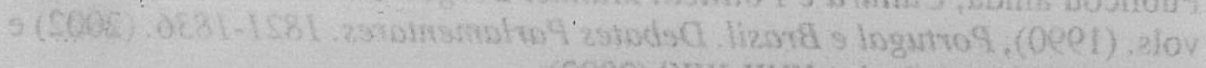

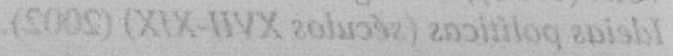


eorxintinos? 


\section{A HISTÓRIA DAS IDEIAS POLÍTICAS EM CONTEXTO (em homenagem a Zília Osório de Castro)}

João Luís Lisboa CHC-UNL

A história das ideias das últimas décadas tem sido, antes do mais, marcada pela história das ideias políticas, quer pela quantidade de estudos produzidos e editados, quer pela forma como têm condicionado a reflexão e a imagem do que é trabalhar neste campo.

Fizeram-se, é certo, trabalhos importantes sobre ideias científicas, estéticas ou filosóficas, domínios de fronteira, que estão vivos também pelas tensões do seu fazer e da sua identificação. O que se faz em História da Ciência, História da Filosofia, ou História da Arte, é definido muitas vezes em oposição a perspectivas "externalistas" que se atribuem à história das ideias com a qual, por isso, com frequência, há relações conflituais. Num posicionamento bem diverso, estudar ideias sociais, económicas ou jurídicas tem estado sempre muito marcado pelas suas relações políticas, encontrando-se tantas vezes a dificuldade inversa, ou seja, a preocupação em não se ficar amarrado a perspectivas excessivamente conceptuais, ou a aquilo que seria o mundo "platónico" das ideias.

Quanto ao estudo do pensamento, das representações, ou das doutrinas políticas tem sido conduzido de forma a que as dimensões simultaneamente relacionais e conceptuais do político se adequem perfeitamente às perspectivas da história das ideias, campo onde muitos dos trabalhos realizados se reconhecem explicitamente.

$\mathrm{E}$, no entanto, os métodos para apuramento dos significados das fontes não são claros e indisputados. Há questões por resolver, problemas por identificar e discussões a aprofundar. Com Quentin Skinner, Anthony Pagden e John Pocock como referências maiores das últimas décadas, a discussão sobre a história das ideias políticas colocou durante muito tempo o problema de como relacionar doutrinas e contextos. Ou seja, os autores mais influentes da história das ideias, e Skinner em primeiro lugar, para além dos pensadores a que se dedicam, interrogam-se sobre os conceitos que usam, sobretudo a noção de contexto e, em particular, a questão dos contextos semânticos, ou seja, a importância do conhecimento da linguagem e dos seus mecanismos considerados historicamente para se entender os sentidos de cada formulação política. "Contexto", nesta acepção, não é o que está fora, nem o que está antes da formulação, mas a sua própria condição.

Tem-se considerado fundamental proceder a uma operação associando 
o apuramento dos sentidos de um texto, tomados pelos argumentos e referências tecidos por um autor identificado, a partir de uma intenção original, e as circunstâncias em que essa formulação aparecia. As circunstâncias, não sendo assimiláveis à formulação, foram vistas contudo como dominantemente exteriores, e poderiam marcar sobretudo as várias vidas de um texto e das doutrinas a que ele dava corpo. Podia tratar-se de circunstâncias políticas, sociais e económicas, determinando a utilidade, a necessidade ou o carácter transgressor do que se expunha em discurso ou tratado.

Questões como as da natureza ou do exercício do poder, dos tipos de governo, do perfil da cidadania ou das fronteiras da liberdade teriam, assim, de ser entendidas no âmbito de cada momento concreto de formulação, não sendo a sua validade projectável de forma intemporal. É certo que a reflexão sobre os textos de Maquiavel, de Bodin ou de Hobbes alimentaram sempre as discussões de cada momento, independentemente das vicissitudes dos autores de referência, as suas relações com os poderes instáveis que conheceram e que tinham como horizonte. Não interessará a posição de Maquiavel junto dos Medici quando o que está em causa é a compreensão de mecanismos cuja validade se imagina perene. Donde frequentemente não interessar o pensamento político do século XV em Florença, quando se fala do autor do Principe.

Antonio Gramsci, que lhe dedicou tantas páginas e notas, via este livro, não como fria utopia ou raciocínio doutrinário, "mas como uma criação de fantasia concreta que opera sobre um povo disperso e pulverizado para the suscitar e lhe organizar a vontade colectiva" (Quaderni, 13). Por conseguinte, enquanto sublinhava a historicidade dos textos que lhe interessavam, estava preocupado com o que fosse "vontade colectiva" e as suas formas de organização, pensando na acção teoricamente fundamentada, no século XX.

Neste sentido, é apenas aparentemente paradoxal o facto de o autor mais associado às contingências da acção política ser lido de forma recorrente e transtemporal, ao contrário do anti-maquiavel Jean Bodin. A atenção ao concreto, e a plasticidade da "arte" política são o que, precisamente, fazem a vitalidade dos textos do pensador florentino.

A história das ideias tem, assim, tendencialmente, recusado um tempo plano, onde o raciocínio válido numa circunstância é tendencialmente válido em qualquer outra, pela força da sua própria racionalidade. Ou seja, reproduzindo uma discussão sem fronteiras, podendo chamar qualquer autor, articulando aquilo que se apresenta como a racionalidade própria dos seus discursos, e a bondade dos seus argumentos ou dos seus sistemas, o sentido do texto está preso a uma determinação constituinte. Percebe-se que, perante o constrangimento da informação ou do ambiente, os textos antigos não possam reflectir a vastidão de possibilidades que a razão actual permite. Novo paradoxo aparente: se considerar um tempo plano e abstracto leva a tratar com 
benevolência autores como Montesquieu ou Locke, é na relativização dos momentos de escrita que se pode valorizar a sua dimensão, mesmo pensando na sua releitura.

A história das ideias políticas também não se tem desenvolvido sobre um historicismo estrito, considerando as formulações inseridas em sequências que lhes determinam os significados. O que está antes, e em menor grau o que sucede posteriormente, não certifica o valor do que se propõe. Não há sucessão que se desenrole linearmente, nem memória que acumule e assimile como adquirido o que passou. Nem é produtivo fazer o exercício inverso, percebendo o que foi pelo que passou a ser, sobretudo se se pode apurar que "o que foi" era entendido de forma muito diversa do que entretanto veio a verificar-se. Este desvio de perspectiva, se aparentemente considera contextos diferentes, acaba por se aproximar da sua exclusão ao fazer uma de duas operações: a finalista, que procede a projecções do presente sobre o passado, ignorando elementos de diferença; a meramente cumulativa, que também não permite considerar a descontinuidade.

Estas considerações levam-nos a um exemplo concreto de como se tem feito e pensado as ideias políticas entre nós. Claramente dominante na história das ideias que se faz, a ter presente o número de trabalhos de mestrado e doutoramento defendidos nos últimos vinte anos, a história das ideias políticas é o campo de actuação de Zília Osório de Castro, tanto na investigação e estudos publicados em nome próprio, como nos muitos projectos que dinamiza ou orienta. Responsável por tantos investigadores e por tantos trabalhos, como entende o sentido dos textos que estuda, e como se apresenta, nos seus trabalhos, a noção de contexto?

Leitora atenta de Carmen Iglésias e David Thompson, é patente a importância atribuída por Zília Osório de Castro aos "homens portadores de ideias", aos indivíduos que procuram romper horizontes, com a sua intencionalidade, à inovação e à dimensão teórica e conceptual do pensamento político. Mas ao mesmo tempo, preocupa-se com as expressões de diferença que são as que reconhece na perspectiva histórica, com a atenção ao concreto que dá corpo à formulação. Do mesmo modo, preocupa-a a representatividade do pensado.

Daí recorrer a uma forma de raciocínio por binómios, contrastando circunstâncias não necessariamente antagónicas ou exclusivas, mas que operam como moduladores dos textos ou formulações a analisar. Os três binómios que nos interessam para esclarecer a questão do contexto e do sentido são os seguintes: ideias ou conceitos; indivíduo ou colectivo; ideias dominantes ou ideias dinâmicas.

A natureza do primeiro binómio, distinta dos outros, pressupõe que há formulações com graus diferentes de abstracção e que, na hipótese limite, se encontra o conceito, fora das diferenças que as circunstâncias implicam. As 
ideias têm história na medida em que formulações e sentidos das palavras mudam. Os conceitos, pelo contrário, não teriam história adaptando-se à formulação mais abstracta possível em cada momento, aquela que identificando ainda a expressão a que corresponde o seu sentido, seja tão lata que abarque ideias diferentes, de tempos e circunstâncias diferentes. Como consequência, a seguir esta distinção clássica, a riqueza do significado está na aplicação, já que o conceito, por tão extenso, não dá conta de distinções e contradições. Para ficar numa palavra que foi trabalhada em todo o percurso académico de Zília Osório de Castro, Liberdade como conceito admite mas não transmite as possibilidades semânticas que as ideias de Liberdade foram assumindo ao longo dos tempos. Mas a possibilidade de as ideias apresentarem contradições que levem a questionar a pertinência ou a adequação do próprio conceito implica, não só seguir o modo como aquelas se representam, como a forma como este é pensável num dado momento.

O segundo binómio remete para uma possível diferença entre tratar ideias como sistemas ou doutrinas, propostas e assumidas por alguém com rosto e nome, e uma história social das ideias, ou uma história cultural. Para além da diferença de perspectiva que Zília Osório de Castro compreende na sua visão pluralista de História das Ideias, a questão do sentido e dos seus contextos pode ser interrogada a partir deste binómio. Começa-se por ter de admitir que não há um sentido mais verdadeiro porque esteja mais próximo de intenções autorais, ou mais próximo de como a norma autoriza as interpretações. Mas esta diferença não pressupõe também um paralelo com o que seja a denotação e a conotação, presentes tanto no plano individual como no colectivo. Ou seja, os jogos de sentido não estão prisioneiros das subtilezas individuais. Pressupondo entendimento particular, implica também a partilha de referentes sem os quais não há sequer a possibilidade da conotação. Pelo que se pode procurar o testemunho, não apenas da "difusão", mas da partilha, na definição do contexto que dá sentido ao que se lê. Mais, não havendo ideias sem suporte, textura, materialidade e forma, a partilha começa por decifrar essa forma como contexto. Daí que a história das ideias, podendo isolar um pensador, realiza sempre o que sejam as várias hipóteses de leitura (na proximidade ou na distância), que as formas de partilha permitem.

É natural que nestas considerações nos afastemos do que são as posições privilegiadas por Zília Osório de Castro. No entanto, se lermos o seu "Borges Carneiro" reparamos que aquilo que sobressai não é um discurso meramente "criativo" ou "inovador", mas as tensões de um tempo onde nascem dúvidas, conflitos e rupturas. Naqueles que (na minha opinião) são os estudos mais importantes sobre a ideia de liberdade na primeira metade do século XIX em Portugal, encontramos a sistematização analítica do pensamento de um agente histórico, através da recolha de intervenções muito marcadas pelas circunstâncias 
do processo político. Precisamente por isso, esta história das ideias políticas é também a do processo político, com as suas contradições e diferenças de leitura. Em momentos em que todos parecem ter o mesmo anseio por essa "liberdade" prometida, Zília Osório de Castro mostra-nos as diferenças e as subtilezas, pensa as fundamentações e analisa as circunstâncias dos discursos.

E de novo sublinhamos que estas circunstâncias não são apenas o que está para além do que se lê, o auditório que se imagina, ou a resistência que se quer contrariar. As circunstâncias que significam estão no próprio discurso que se ouve nas Cortes ou que se lê.

Mas se prestarmos atenção a outro domínio de interesse da autora, os estudos sobre as mulheres, mais do que a dimensão colectiva do objecto, sobressaem os problemas colocados, nomeadamente em torno das representações de identidade, mesmo se partindo de pessoas particulares, diferenciadas e inimitáveis.

Finalmente, o terceiro binómio está muito associado a este segundo porque o que é da inovação e das resistências, do brilho ou do lastro, muitas vezes se vê em paralelo com os papéis assumidos pelos indivíduos e pelas massas. Também aqui o que me prende a atenção não coincide com o ponto de vista da autora. Penso, por um lado, que esse paralelo não é operacional. O que é representativo não coincide necessariamente com o que é dominante, já que o que é dominante não esgota o que é representativo. As formas de dominação destinam-se, precisamente, a tentar evitar aquilo que pode ser representativo. Por outro lado, a noção de "dinâmico" é problemática. Ou se entende que o dinâmico reside na própria racionalidade dos textos, o que levaria a que esse carácter estivesse na sua essência, ou é uma relação que se estabelece com quem pode dar valor ao que se diz ou escreve, mesmo que a grande distância. E, se uma condição do "dinâmico" está em verificações a posteriori, quando um gesto deixou de pertencer apenas a um individuo, ganhando expressão, esse gesto só tem essa característica quando em interacção, ou seja, sempre perante um critério de representatividade. Refira-se que o que está aqui em causa não é a "verdade" de uma proposição ou uma ideia, sobre que não me debruço, mas o seu carácter resistente ou transformador.

$\mathrm{E}$, no que diz respeito à questão do sentido do político, a proposta fecunda apresentada pela autora é esta: Ideias dinâmicas e ideias dominantes significam de modo diverso para formulações aparentemente idênticas. Falar de formulações aparentemente idênticas corresponde a marcar distâncias perante uma visão essencialista do pensamento. A autora assume-o quando afirma que ideias dinâmicas se podem transformar em ideias dominantes. Ou seja, de novo, o contexto transforma umas nas outras, entendendo-se aqui por contexto as dimensões transformadora ou resistente que assumem. Refira-se a crítica, em estudo recente, de Quentin Skinner a uma tendência de historiadores 
das ideias em pensar em termos de fracturas, perante as evidências da lentidão e das permanências (Renaissance virtues, Cambridge U.P., 2002).

O que torna mais complexo este raciocínio é ainda a pluralidade de sentidos que inovação ou permanência têm, já que se podem conceber ideias que, sendo marginais, são conservadoras ou que, sendo dominantes, contrariam outras ideias também dominantes (em níveis diferentes de dominação ou representação) ou que, sendo resistentes, incorporam o que há de dinâmico numa determinada cultura. Por outro lado, o individual também não esgota as possibilidades do que é dinâmico, embora seja a nível do singular que as diferenças mais se notam. No colectivo, esbatem-se distinções, representando-se o que é partilhável. O que não quer dizer que a representação que se partilha seja mais abstracta ou mais próxima do nível conceptual, já que pode, pelo contrário, integrar o complexo e até o contraditório. Também aqui a questão do sentido reside na articulação destas possíveis contradições, considerando-se os efeitos locais que essas contradições produzem e os protocolos que permitem que o que se diz e escreve seja entendido nessas circunstâncias.

Zília Osório de Castro trabalha numa perspectiva que valoriza as intenções individuais, que assume um ponto de vista presencista, gostando de frisar que não entende o trabalho do historiador nem como objectivo nem como "útil", adoptando uma posição que sublinha o lado estético e contemplativo do que faz. Mas uma perspectiva que se pensa a si própria, que não se satisfaz com o que se pode descrever, que defende uma dimensão reflexiva e interrogante do acontecido será tudo menos inútil.

Se o problema do sentido dos textos se decifra na articulação do que diz com o como o diz, e em que circunstâncias, então a história das ideias políticas também é feita de textos que se decifram do mesmo modo. Procuremos conhecer as circunstâncias, os contextos e as pessoas que fazem a história das ideias políticas. Para além da dimensão do que está feito ou da profundidade das investigações, o valor das perguntas, de um olhar (como o de Zília Osório de Castro) que não se rende ao alegado valor facial de doutrinas ou de discursos, justifica o nosso interesse.

foram considerados, para estas considerações, os seguintes trabalhos de Zília Osório de Castro:

- Cultura e Política. Manuel Borges Carneiro e o Vintismo, 2 tomos, Lisboa, INIC, 1990.

- "A História Cultural em Portugal" in La Nueva História Cultural: la influencia del protestructuralismo y el auge de la interdisciplinaridade, Madrid, Editorial Complutense, 1996, pp.303-309.

- "Da História das Ideias à História das Ideias Políticas", Cultura, Revista de História e Teoria das Ideias, 1996, pp.11-21).

- Ideias Políticas (séculos XVII - XVIII). Lisboa, Livros Horizonte, 2002.

- "Os Intelectuais e o Feminismo", Revista de História das Ideias, 24, 2003, pp. 453-474.

- "Mulheres. Histórias na História", Faces de Eva. Estudos sobre a Mulher, .3, 2000, pp.103-119.

- "Dos tempos da História" in Vértice, 87, Novembro - Dezembro 1998, pp.56-60. 


\section{HISTÓRIA DAS IDEIAS \\ Percursos e horizontes de um grupo de investigação}

Isabel Cluny

CHC-UNL

A proposta que me lançaram, no sentido de escrever um texto para uma revista de homenagem a Zília Osório de Castro, fez-me hesitar entre a realização um estudo de natureza académica, repescado e reelaborado a partir de papéis e notas entretanto postos à margem pelas contingências da vida profissional, ou a escrita de uma simples evocação, de tudo aquilo que vivenciámos, enquanto equipa de investigação. Ao dar-me conta que quinze anos haviam passado, desde que o primeiro Seminário Livre de História das Ideias da UNL deu início às actividades, que culminariam na sua primeira obra, Lisboa 1821, A Cidade e os Políticos, a opção estava tomada, sendo este meu testemunho, por certo parcial, como todas as memórias, a forma que encontrei para homenagear a Professora Doutora Zília Osório de Castro.

Em 1991, entrei num pequeno grupo que reunido em torno de Zília Osório de Castro procurava então, fora do contexto estrito dos cursos e dos centros de investigação, um espaço de pesquisa e discussão livre de ideias. Lembro alguns dos nomes que o integravam, Nuno Saldanha, Conceição Quintas, Cecília Cameira, João Brigola, Francisco Vaz, Carla Bugalho entre outros.

$\mathrm{Na}$ altura os graus académicos pouco contavam, passando a unidade do grupo pela amizade comum com a Professora Zília, como sempre lhe chamámos, e pela vontade que todos tínhamos de estudar e investigar em conjunto. Longe ainda das competições profissionais e pessoais, que o futuro acabaria por impor, sedimentámos entre nós uma sólida amizade que passados quinze anos permite dizer que valeu a pena termos acreditado no projecto do Seminário Livre de História das Ideias.

Hoje muitos de nós seguimos rumos diferentes mas todos, de uma forma ou de outra, podemos afirmar que foi a partir daquele projecto que encontrámos a vocação para os nossos estudos posteriores.

Foi nesse estimular do espírito de investigação, nessa capacidade de dinamizar grupos de pessoas todas diferentes e de lhes dar convicção para levar a bom termo o trabalho, até mesmo à fase final da divulgação, que a Professora Zília se revelou diferente de todos os mestres com quem até então trabalhámos. Na UNL o ambiente de proximidade entre docentes e discentes talvez tenha facilitado a formação deste grupo, mas não podemos deixar de reconhe- 
cer que a Professora Zília, mais do que qualquer um tinha a capacidade ímpar de entrosar pessoas, escolher perfis, aquilo que por graça chamávamos fazer castings.

Outra qualidade que sem dúvida não podíamos deixar de referir, era sua imensa disponibilidade para nos apoiar quando as dúvidas nos assaltavam e de nos incentivar quando o desânimo ou o cansaço tomavam conta de nós.

A primeira publicação, Lisboa 1821, A Cidade e os Políticos, saiu em 1996 sem apoios institucionais, reuniu, numa só obra, a investigação sobre a Lisboa post-revolução liberal, as biografias dos primeiros parlamentares chegados à capital e as lindíssimas fotografias das ruas, onde outrora estes políticos habitaram, da autoria de Luísa Ferreira. Começava então uma frutuosa colaboração entre o projecto do Seminário Livre e os Livros Horizonte.

Animados com os resultados lançámo-nos então num projecto mais ousado.

Sob a orientação de Zília Osório de Castro, a proposta do Seminário Livre para realizar o Dicionário do Vintismo e Cartismo seria escolhida na Assembleia da República. Pouco tempo depois, o grupo alargado a novos elementos e após o abandono de outros por razões profissionais, veria seu projecto coroado de êxito, quando em 2002 as quinhentas biografias dos deputados da primeira revolução e as respectivas intervenções parlamentares foram finalmente publicadas em dois volumes sob a chancela da Assembleia da República e das Edições Afrontamento.

Foi então que a mudança dos tempos se repercutiu no Seminário. Os centros de investigação das universidades públicas e privadas multiplicaram-se e de certa forma já não era possível manter aquela "inocência" inicial já que à margem dos apoios institucionais, a sobrevivência do grupo de investigação dependia agora, e apenas, da sua capacidade de despertar interesse junto das editoras privadas, ou da Fundação para a Ciência e Tecnologia, pelas suas pesquisas.

Manter a autonomia e identidade do Seminário Livre revelava-se difícil. Os elementos que compunham o grupo trabalhavam quase todos fora do universo académico e conjugar as vidas profissionais e até pessoais de cada um, com as reuniões regulares que o trabalho impunha era uma tarefa cada vez mais delicada. Uns abandonavam o grupo por impossibilidade de manter compromissos regulares, outros por que surgiam outras oportunidades profissionais. De cada vez que tal sucedia, era preciso chamar novos elementos, integrá-los e fazê-los comungar no espírito do grupo, que pressupunha não esperar recompensa de qualquer tipo. Não havia subsídios, pagamento de viagens para participar em colóquios fora do país, ou outros aliciantes para oferecer a quem ali investigava. Apenas se podia garantir um esforço de todos no sentido de 
alcançar a publicação da investigação desenvolvida, com a qualidade de algumas das melhores editoras a trabalharem no mercado.

Perdida a designação de Seminário Livre de História das Ideias, para um projecto denominado Edição de Revistas de Ideias e Cultura, alguns membros do grupo inicial formaram o Projecto de Ciência Politica e Relações Internacionais.

O estudo desenvolvido foi apoiado pela Inapa e a edição datada de 1998, Portugal e os Caminhos do Mar, seria um marco para a história do Seminário, já que seria uma das publicações mais requintadas produzidas pela equipa de investigação de Zília Osório de Castro. A obra abordava "a realidade de Portugal enquanto país que teve, e tem, uma vocação marítima primordial e um relacionamento internacional profundamente ligado aos oceanos". O seu "objectivo era sistematizar as grandes questões relacionadas com a evolução do domínio e controlo de espaços marítimos e terrestres ligados ao papel do Mar, entendendo-o como veículo fundamental para o desenvolvimento das relações internacionais globais". Para tal publicaram-se alguns dos tratados que nos séculos XVII, XVIII e XIX, deram a Portugal um lugar de destaque. Cada tratado era devidamente comentado e anotado por um autor diferente e toda a obra foi alvo de um cuidado particular na sua ilustração.

Pouco tempo depois seria a vez de da publicação das actas de um colóquio internacional realizado num espaço cedido pela Assembleia da República. Diplomatas e diplomacia: retratos, cerimónias e práticas, seria de novo uma publicação dos Livros Horizonte em 2004.

Em todos estas publicações Zília Osório de Castro teve um papel determinante, quer dando início aos projectos, quer evitando que os co-responsáveis pelas investigações desistissem quando as dificuldades se agravavam, ou quando estas pareciam por vezes insuperáveis.

Mais teimosa que qualquer um de nós, mais confiante e determinada nunca aceitou um não como resposta para a consecução de qualquer projecto. O último, Os Tratados do Atlântico Sul (Portugal-Brasil, 1825-2000) é um bom exemplo dessa firmeza. Devidamente comentados Os Tratados do Atlântico Sul terão finalmente a sua publicação concluída em 2006, desta vez sob a chancela do MNE/ Instituto Diplomático.

Ao lado da Professora Doutora Zília Osório de Castro trabalharam vários grupos, as memórias que aqui ficam apenas dizem respeito àqueles em que participei, mas outros grupos lhe ficaram a dever a iniciativa, como tais como: A Piedade Popular, Edição de Revistas de Ideias e Cultura, projecto do qual resultou as recentes publicações on line e em $c d$-rom, conjuntamente com a Biblioteca Nacional da revista Portugália (1925-1926), a de Estudos Sociais (1905-1911) e da Nação Portuguesa (1914-1938) em colaboração com Fundação Mário Soares. Também as Faces de Eva, cuja publicação 
marcante nos estudos de género - Dicionário no Feminino - seria um bom exemplo do que de muito inovador se fez na UNL em grupos coordenados por Zília Osório de Castro.

Certamente muitos de nós poderíamos subscrever estas palavras de homenagem a quem contribuiu, com o seu esforço, para um novo entendimento do trabalho de pesquisa em grupo. Creio sinceramente que o um dos maiores méritos de Zília Osório de Castro foi sem dúvida romper com o tabu estabelecido do investigador solitário, a trabalhar apenas para si e fechado às contribuições de outros investigadores. Muitos grupos depois destes se têm constituído, mas sem dúvida que este foi pioneiro numa nova forma de fazer investigação, já que à tradicional fórmula de coordenador científico responsável pela elaboração do texto de investigação e seus tarefeiros, responsáveis pela busca de documentação, deu lugar à associação livre de todos os colaboradores, sem distinção, sendo da responsabilidade individual de cada um a pesquisa e o texto respectivo de síntese. Mais, promoveu coordenadores diferentes por projecto e responsabilizou-os pelos resultados do trabalho conjunto. Foi essa nova forma de dirigir que a Zília nos habituou, fazendo de cada um de nós mais capazes para trabalhar na investigação, na coordenação de grupos e até nos legou a determinação, tão necessária muita vezes na nossa vida particular. 


\title{
MAS, AFINAL, O QUE É UMA BIBLIOTECA? \\ - como se de uma aula de História Moderna se tratasse -
}

\author{
António Camões Gouveia \\ FCSH-UNL e CHC
}

\section{Primeiro registo - o histórico \\ $O$ que é uma Biblioteca 1 \\ Apontamentos. (para aulas e futuras investigações)}

A importância da leitura, e das suas aprendizagens, e do livro, na sua construção enquanto objecto de saber. O livro como "bem cultural", depois, temporalmente explorado como património, ou por um conjunto de leitores credenciados, normalmente intelectualizados, a quem poderemos chamar "produtores de ideias", ou por um grupo local, "eruditos", ou nacional, "políticos" (?), constroem o livro como objecto de valor acumulado, fruto da técnica e transporte expresso de pensamento.

Toda esta constatação é mais flagrante e perceptível, uma vez abandonado, ou pelo menos acantonado, o livro do copista, raro, precioso e muito religioso e imposto o objecto impresso, percorrendo espaços de línguas diferentes, tornando o autor existente mas não conhecível.

Aperfeiçoadas as técnicas, por novas profissões da cidade, os exímios técnicos e artistas, detentores de saberes próprios, impressores-tipógrafos e gravadores, multiplicado o livro, embaratecido na produção e consequente aquisição, desenvolve-se um comércio pouco suspeitado até aí, o mercado livreiro, possivelmente uma das primeiras áreas de comércio cultural desenvolvidas na história da Europa. Porque tudo isto é Europa, uma Europa muito do centro, articulado com um eixo renano próspero e, sobretudo, necessitando de afirmação de autonomia.

É importante voltar aos conteúdos. O crescimento dos livros em circulação, e consequente número possível de leitores, obriga a referir que as temáticas religosas se mantêm e predominam. A ideia do livro "muito religioso", escrito por gente da religião para gente da religião e dentro dos cânones da religião, é agora, este agora refere o tempo explosivo da primeira modernidade, o tempo do Renascimento/Reformas, uma necessidade de diferença.

No livro se passam a condensar os saberes críticos que ultrapassam a "relectio" escolástica, numa afirmação do acesso aos textos originais, "nascimento", libertos de comentários e glosas interlineares e marginais, descomplexificados dos saberes de interpretações de vário nível, todas elas proporcio- 
nadoras de envolventes cerzimentos de "ideias feitas", como que filtros de acesso ao original. Aceder a esses originais, "re-nascer", implicou, pois que o livro religioso mantivesse a primazia de impressão, divulgação, venda e leitores.

Mas esse religioso era construído num racional exercício de "livre-exame". Fixam-se textos, comparando versões, recusando intromissões de escribas anteriores, apontando novas possibilidades de leitura, novas e diferentes linhas e páginas restauradas. Procura fixar-se o complexo conjunto de livros que é a Bíblia (neste sentido a Bíblia não é um exemplo acabado de Biblioteca?). Intrometem-se autores, mais ou menos teólogos, "humanistas", na árdua tarefa de descortinar historicidade nos textos de "mão divina". Vão mais longe. Tentam rectificar as traduções, o que ali se diz a alguns em latim, pode ser dito, e por vezes de forma mais correcta, a muitos, em linguagem de todos os dias. Revolução que se soma à da imprensa, ou fusão de ideias e práticas de cultura?

Paralelo aos livros do religioso crescem os de outros poderes, do Príncipe e sobre o Príncipe, daqueles que executam ou têm formas próprias de executar, com leis (juristas, "burocratas modernos", ...), com aritmética e álgebra (mercadores, navegadores,...), com novos saberes (cartógrafos, astrónomos, botânicos, anatomistas, ...) ou simplesmente dos que "civilizam", as mais das vezes "cristãmente" (missionários, pregadores, ...), e querem deixar correr os seus sentimentos e gosto de adorar a Deus, ver e criticar os homens, suspirar pelo amor das mulheres e observar o mundo (poetas, viajantes, ... mas, também músicos, gravadores, que indelevelmente tão associados estão ao livro!, pintores, ... gente do nascente teatro).

Livro, livros, muito mais livros; uma circulação que cria novas profissões, um mercado, um primeiro mercado de cultura, uma diferença que tem por base a crítica e que resulta em multiplicação.

Muitos livros. Livros que crescem longe dos "scriptorium", que se coleccionam, que se arrumam, que, fisicamente, conduzem o saber do autor, condensado em escrita impressa até à Biblioteca (a ideia e este percurso estão desde logo expressos no título da feliz síntese de Bouza Álvarez). A Biblioteca como acumulação/colecção não é novidade, tem até o mérito de possibilitar um excurso a propósito das Bibliotecas da Antiguidade, sobretodas, Alexandria. Mas a Biblioteca pode ser "não física", pode ser uma colecção de saberes e opiniões que estão contidos em livros que se referem, citam ou "arrumam" em catálogo (aqui nunca será de mais referir a magistral e majestática Bibliotheca Lusitana (1741-1759) de Diogo Barbosa Machado e remeter para o exemplar trabalho sobre a "Biblioteca" de Jorge Cardoso estudada por Maria de Lurdes Correia Fernandes). 
Tudo isto são deias de síntese, com muitas problemáticas a desenvolver e chamadas de atenção aos limites da interpretação.

Primeira conclusão possível: uma Biblioteca é um conjunto de livros.

\section{Primeiro registo - o histórico-documental \\ $O$ que é uma Biblioteca 2 \\ Fichas de excertos de antologia. (passagens a comentar ou a citar)}

[uma biblioteca de poetas lusitanos]

Diogo Bernardes (1530-1605). O Lima (1596).

Carta XXX. A Gaspar de Sousa sobrinho do mesmo Dom Cristovão de Moura.

“(...).

Naõ morri nunca por juntar tisouro,

Nunca pretendi mais que defenderme

Da graã fome, e do frio de que mouro,

Se vejo, como espero responderme

De maneira, que possa a mais quieto

Co as Musas em ocio recolherme:

De juntar os bons versos vos prometto

Dos Poetas insignes Lusitanos

Aprovados por Febo, em seu decreto."

(ed. Marques Braga. Lisboa: Sá da Costa, 1946, vol.II, p.323)

[as matérias/"géneros" dos livros de uma biblioteca]

Francisco Rodrigues Lobo (1580-1622). Corte na Aldeia (1619).

Diálogo I

“(...).

Cada um diga a sua opinião nos livros que mais the contentam e das razões que tem para os aprovar; e, deste modo, ou afeiçoados ou convencidos, saberemos os que são de maior gosto e utilidade. (...).

E, não tratando dos Livros Divinos, nem dos necessários, dos de recreação nos podeis dizer quais e por que razões vos contentam. (...).

Sou particularmente afeiçoado a livros de história verdadeira, e, mais que às outras, às do Reino em que vivo e da terra onde nasci. (...).

$E$ havendo um homem de ler o que não é, ou o que sai tão caldeado e tão batido da forja dos autores que mudado traz o metal, a cor e a natureza, estou melhor com os livros de cavalarias e histórias fingidas, que, se não são verdadeiros, não os vendem por esses; e são tão bem inventados que levam após si os olhos e os desejos dos que os lêem. (...). 
Poesia levantada sobre os bons conceitos e versos. (...).

Como exceptuastes Livros Divinos, nesse número devem estar os dos poetas que mereceram este nome. (...).

O melhor modo de escrever são os diálogos escritos em prosa, com figuras introduzidas que disputem e tratem matérias proveitosas, políticas, engraçadas e cheias de galantaria, sendo a primeira figura da obra o autor dela; e esse que vá guiando e introduzindo as mais, que sejam apropriadas àquelas matérias de que hão-de tratar entre si.(...).

Porque a mim me parece que à escritura se deve o melhor lugar, e que antes merecia a prática por se parecer com ela."

(ed. José Adriano de Carvalho. Lisboa: Editorial Presença, 1992, p.60, $61,64,65,66)$.

[as grandes secções de uma Biblioteca Lusitana]

Francisco Manuel de Melo (1608-1666). Cartas Familiares (1664).

Ao Dr. Manuel Temudo da Fonseca, Vigairo Geral do Arcebispado de

Lisboa (1650).

“(...).

Levado deste pensamento, procurei por mimesmo, e despois persuadi a alguas pessoas doutas, publicássemos ua Biblioteca Lusitana dos Autores Modernos, novamente estimulado da falta que padecemos nesta parte. (...)

Nas ciências divinas e humanas (...). A Filosofia (...). Na Retórica e letras humanas (...). A Latinidade (...). Nas Matemáticas (...). Na Medicina (...). Logo passando aos Políticos (...). Não terá a História dos portugueses agora aquela antiga queixa de que se aplicavam menos a escrevê-la que a merecê-la. (...). As Apologias (...). A Teologia (...). O Moral (...). Não menos a Música (...). As ciências políticas (...). Nos Cânones sagrados (...).”

(ed.Maria da Conceição Morais Sarmento. Lisboa; I.N.-C.M., 1981, p.412-422).

[o poder e a organização dos livros, o louvor ambivalente da grandeza] Diogo Barbosa Machado (1682-1772). Bibliotheca Lusitana (17411759).

(Prólogo) (1741).

"(...).

Com mysteriosa disposiçã̃ da Providencia esperou a Bibliotheca Lusitana ideada hà mais de hum Seculo pelo laborioso disvelo de varoens eruditos o feliz Reynado de V. Magestade para sahir ao theatro do Mundo. (...).

Verà reduzido a hum Sucinto Mappa a elegante facundia dos Oradores, a suave afluencia dos Poetas, a armonia sem dissonancia dos Musicos, e a ex- 
plicação das fabulas nos Mythologicos; aos Interpretes Sagrados correndo o veo ao Sanctuario das Escrituras; aos Theologos decifrando os mysterios dos divinos Attributos; aos Jurisconsultos penetrando as dificuldades dos Canones Ecclesiasticos, e das Leys Imperiaes; aos Historiadores referindo os Sucessos das idades passadas; aos Chronologos computando o tempo por Lustros, e Olympiadas, aos Astronomos compassando o movimento dos Ceos, $e$ observando os aspectos dos Planetas; aos Anatomicos examinando a organização dos corpos, e os Medicos descubrindo saudaveis remedios para conservaçaõ da vida."

(Lisboa Occidental: na Oficina de Antonio Isidoro da Fonseca, 1741, t.I, s/p.)

[a biblioteca espaço de língua e de memória]

Memorias de Literatura Portugueza, publicadas pela Academia Real das Sciencias de Lisboa (1792).

Prologo (1792).

“(...).

Saõ por conseguinte a Lingua, e a Historia Portugueza, consideradas em todos os possiveis aspectos, e relações, os dous objectos que constituem, o que a Academia quiz entender por Litteratura Portugueza; objectos naõ só entre si análogos, mas tambem diversos, e separados de toda a outra erudiçaõ, que, ou compete a póvos estranhos, ou pela generalidade dos seus assumptos, pertence a todo o genero humano sem respeito particular a naçã̃ alguma."

(Lisboa: Officina da Academia Real das Sciencias, 1792, tomo I, s/p.).

[a biblioteca como factor de bem-estar]

Alvará de D.Maria I criando A Real Bibliotheca Pública da Corte (1796).

“(...).

Ordeno que na Minha Corte, e Cidade de Lisboa se erija, e estabeleça logo huma Pública, e bem provída Livraria, que se denominará A Real Bibliotheca Pública da Corte, e na qual haja todas as competentes Officinas, que são indispensaveis em estabelecimentos desta natureza: E quero que o uso especial, e proprio desta Bibliotheca seja o de ser perpetuamente destinada ao bem das Letras, e beneficio contínuo dos Meus Vassallos."

(Lisboa: Biblioteca Nacional, 1969, p.1)

Segunda conclusão possível: uma Biblioteca é a organização de um conjunto de livros para que assim possam ser fruídos. 


\section{Segundo registo - relato de memória \\ O que é uma Biblioteca 3}

Um caso. (a Biblioteca J. S. da Silva Dias do C.H.C.)

Pelo final dos anos 70 do século XX, a Faculdade de Ciências Sociais e Humanas da Universidade Nova de Lisboa viu o seu corpo docente acrescido com a integração de um conjunto de novos nomes e rostos chegados de Coimbra. Coordenava e orientava o grupo, todo ele da área da história da cultura e das ideias, o Prof. Silva Dias.

Com um percurso universitário de qualidade e em constante afirmação, uma obra historiográfica notável na erudição e em algumas novidades e sínteses, o Prof. Silva Dias não tinha já provas a prestar, mas sim um projecto a implementar. Esse projecto era simples: criar um grupo de estudo de história das ideias.

Essa intenção foi imediatamente visível nas práticas pedagógicas assumidas na licenciatura em História (História Cultural e das Mentalidades, Cultura Portuguesa, Teoria da História e, mesmo, História de Portugal, disciplinas estas que versavam matérias dos séculos XVIII e XIX) e nas cadeiras introdutórias de História das Ideias das licenciaturas em Línguas e Literaturas Modernas. No início dos anos 80 , tornou-se mais palpável com a criação de um espaço de investigação na dependência do Instituto Nacional de Investigação Científica (I.N.I.C.), o Centro de História da Cultura (C.H.C.).

Nesse Centro existiam várias linhas de investigação, mesmo muito variadas, e em forte articulação com ele a docência de um dos primeiros mestrados a funcionar na F.C.S.H., o de História Cultural e Política, também ele de pendor setecentista e, sobretudo, oitocentista.

Um grupo de docentes e de investigadores apostados no ensino da história das ideias, licenciaturas e um mestrado. Mas para tudo ter uma lógica, um pano de fundo comum, o Prof. Silva Dias criou uma Revista, esta mesma onde se registam estas palavras, e uma Biblioteca.

Descarregaram-se em Lisboa, o termo correcto é "descarregar" porque assim aconteceu, milhares, muitos milhares de fichas bibliográficas, nos seus tradicionais $75 \mathrm{mmx} 125 \mathrm{~mm}$, que mais não eram do que a fotocópia integral do ficheiro temático do Instituto de História das Ideias da Universidade de Coimbra. Para estas fichas organizaram-se paredes de gavetas de ficheiros metálicos onde aquelas deviam reganhar uma ordem que, com a operação fotocopiadora e com o transporte, se perdera!

A mesma empresa de transportes que trouxe as fichas até Lisboa carregou, também, umas largas dezenas de volumes de livros de edição da Universidade de Coimbra. A estes livros, amontoadas pelo chão do espaço destinado 
a Biblioteca, foram-se rapidamente juntando muitos e muitos mais, listas imensas de encomenda que alimentavam a Biblioteca.

Foi necessário escolher, adoptar critérios de classificação, criar secções, arrumar em estantes a partir do chão, pensar em leitores que deles fizessem uso, criar sistemas rudimentares de controlo da leitura domiciliária. Os livros foram arrumados (as fichas nunca!), os leitores (professores, investigadores e alunos do mestrado) usaram-nos e tiveram-nos na sua posse todo o tempo de que necessitaram, o hábito de requisitar livros estabeleceu-se.

Deste trabalho biblioteconómico, até por causa da sua formação nesta área, foi encarregue a Prof ${ }^{a}$ Zília Osório de Castro. Dele tivemos a sorte de participar e ver, assim, crescer uma Biblioteca das mais apetrechadas e recheadas de preciosidades nas áreas em investigação no Centro de História da Cultura (pela Porbase pode verificar-se que cerca de dois milhares de títulos nela existentes não se repetem em qualquer outra Biblioteca da rede). Os leitores são os que mais beneficiam desta "originalidade".

Terceira conclusão possível: uma Biblioteca é um conjunto de leitores.

\section{Segundo registo - relato de memória-opinião}

Mas, afinal, o que é uma Biblioteca?

Conclusões.

(percursos? construções? ... porque de homenagem não se trata!)

Comecemos pela conclusão possível: uma Biblioteca é um conjunto de livros organizados e utilizáveis pelos leitores.

Tentemos agora explicar porque é que a Biblioteca J. S. da Silva Dias é uma Biblioteca. Como é que se conseguiu fazer de muitos livros, muitas fichas e ficheiros, um mau espaço de leitura e de trabalho uma Biblioteca? Uma Biblioteca, diga-se, formativa, esclarecedora, cordial e amigável ao utilizador e, sobretudo, peça fundamental da investigação e na construção dos saberes expressos por muitos dos seus leitores.

A explicação não nos é muito difícil de dar. Concerteza que, em muito, ela está no saber, na paciência, na capacidade de criar equipa e de autonomizar deveres funcionais que a Profesora Zília Osório de Castro consegue transmitir aos que com ela desinteressadamente trabalham.

O Centro de História da Cultura possui um conjunto largo e diversificado de livros, livros que estão organizados dando resposta aos seus constantes e fiéis leitores, mercê durante anos dos cuidados da Prof ${ }^{a}$ Zília Osório de Castro que, afinal, assim construiu uma Biblioteca. 
Bibliografia. (a compreensão dos problemas por investigadores)

Álvarez Márquez, Maria del Carmen - El libro manuscrito en Sevilla (siglo XVI). Sevilla: Ayuntamiento de Sevilla, 2000.

Bouza Álvarez, Fernando J. - Del escribano a la biblioteca. La civilización escrita europea en la Alta Edad Moderna (siglos XV-XVII). Madrid: Editorial Síntesis, 1992.

Chartier, Roger - El orden de los libros. Lectores, autores, bibliotecas en Europa entre los siglos XIV y XVIII. Barcelona: Editorial Gedisa, 1994. Eisenstein, Elizabeth L. - The printing revolution in early modern Europe. Cambridge: University Press, 1993.

Febvre, Lucien; Martin, Henri-Jean - L'apparition du livre. Paris: Éditions Albin Michel, 1971, 2. . ed.

Fernandes, Maria de Lurdes Correia - A biblioteca de Jorge Cardoso (+1669), autor do Agiológio Lusitano. Cultura, erudição e sentimento religioso no Portugal Moderno. Porto: Faculdade de Letras da Universidade do Porto, 2000.

Gouveia, António Camões - "Educação e aprendizagens. Formas de poder na paideia do Portugal Moderno", Ler História. Lisboa: n. ${ }^{\circ} 35,1998$, p.11-44.

Gravura e conhecimento do mundo. O livro impresso ilustrado nas colecções da BN. Coordenação Joaquim Oliveira Caetano. Lisboa: Biblioteca Nacional, 1998.

Marquilhas, Rita - A faculdade das letras. Leitura e escrita em Portugal no séc. XVII. Lisboa: I.N.-C.M., 2000.

Print and Culture in the Renaissance. Essays on the advent of printing in Europe. Edição de Gerald P. Tyson, Sylvia S. Wagonheim. Newark: University of Delaware Press, 1986.

As utilizações do objecto impresso (séculos XV-XIX). Coordenação de Roger Chartier. Lisboa: Difel, 1998. 


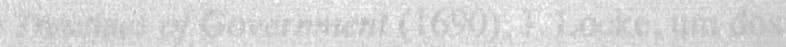

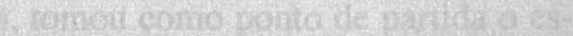

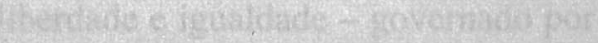

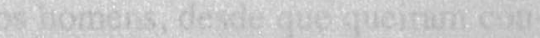

CONCEITOS 


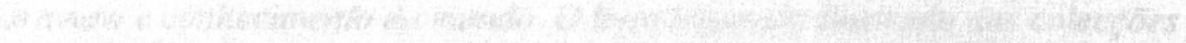

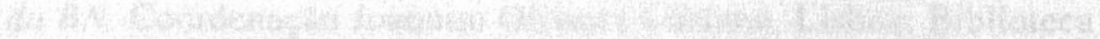

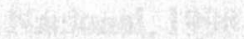

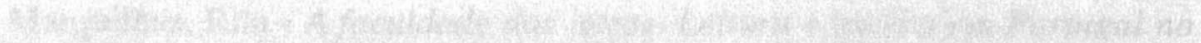

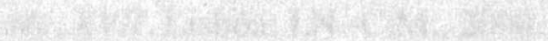

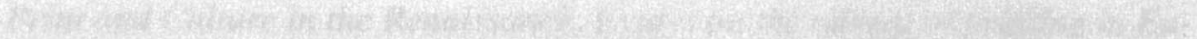

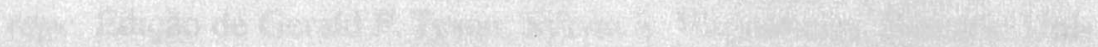

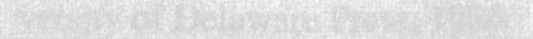

$\cos 20$

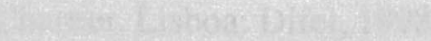

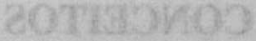




\section{LIBERDADE - LIBERALISMO E DEMOCRACIA}

\section{Maria João Cabrita*}

Se estar vivo é estar desperto para o que de novo se apresenta ao mundo, a mestria mede-se pelo espaço de reflexão que se abre e deixa aos outros. Esta capacidade para alumiar caminhos sobressai no percurso de Zília Osório de Castro, caracterizando o modo como ministra o saber nas suas aulas, na orientação de trabalhos de investigação e, ainda, pela sua escrita. O texto que se segue nasceu de um dos vários exercícios de reflexão propostos pela professora no mestrado em História Cultural e Política, no ano lectivo de 1995/6. Consciente ou inconscientemente a ele retornei várias vezes ao longo da última década, como quem regressa às origens depois de se aventurar por vários trilhos... e nesse volver é lançado para a frente.

A análise do tema «Liberdade - Liberalismo e Democracia» requer, em primeira instância, que elucidemos a distinção entre o liberalismo e a democracia, na sequência da qual poderemos responder à questão: o que é a liberdade? Na acepção mais comum do termo, entende-se por liberalismo «uma determinada concepção do Estado, aquela concepção pela qual o Estado tem poder e função limitada, e como tal contrapõe-se seja ao Estado absoluto seja ao Estado que hoje chamamos de social» ${ }^{\perp}$. Se por um lado, o liberalismo se assume como Estado de direito conforme a questão sobre o limite de poder, fundamentada no direito natural; por outro lado, quanto à problemática da função do Estado identifica-se com o Estado mínimo.

O liberalismo tem por pressuposto filosófico o jusnaturalismo, «a doutrina segundo a qual existem leis não formuladas pela vontade do homem, e enquanto tal, precede a formação de cada grupo social, reconhecível pela riqueza nacional, da qual deriva, como de cada lei moral ou jurídica, direito e dever que são, pelo estrito facto de serem derivados de uma lei natural, direito e dever natural» ${ }^{2}$. Em Two Treatises of Government (1690), J. Locke, um dos impulsionadores do liberalismo clássico, tomou como ponto de partida o estado de natureza - estado de perfeita liberdade e igualdade - governado por uma lei de natureza que «ensina a todos os homens, desde que queiram con-

* Doutoranda na área de História das Ideias Políticas, no Departamento de Filosofia da F.C.S.H./U.N.L., desenvolve o projecto O Liberalismo, a Justiça Social e o Papel do Estado: As Propostas de John Rawls e Robert Nozick, subsidiado pela F.C.T.

BOBBIO, Norberto, Liberalismo e Democrazia, Milano, Franco Angeli, 2. Edizione, 1986, p. 7.

2 Idem, p. 9. 
sultá-la, que, sendo tudo igual e independente, nenhum deve fazer dano a outro na vida, na saúde, na liberdade, ou no domínio» ${ }^{3}$. Esta doutrina alega uma razão justificativa do limite do poder do Estado, a conservação do próprio direito natural.

Na sua esteira, a Declaração do Direito do Estado da América do Norte (1776) e a Revolução Francesa (1789) considerariam o Estado limitado como princípio fundamental do Estado liberal. Neste sentido, Noberto Bobbio adverte-nos de que, racionalmente, «o Estado liberal é justificado como o resultado de um acordo entre o indivíduo inicialmente livre que converge no estabelecimento do vínculo estritamente necessário a uma convivência duradoura e pacífica $\aleph^{4}$. A coligação da doutrina do direito natural com o contratualismo - o pressuposto do consenso entre aqueles sobre os quais o poder deve ser exercido, sem que para tal o indivíduo tenha dispensado os seus direitos - deu origem à mais comum concepção individualista da sociedade, à perspectiva que, contrariamente ao organicismo, defende que o indivíduo precede a sociedade - a sociedade política, como uma sociedade de soberania limitada, preserva os direitos naturais do homem, a liberdade. Porém, ao se alicerçar no «poder» a doutrina do direito natural acabaria por inverter o sentido do percurso histórico.

Do ponto de vista do individualismo, subjacente ao liberalismo, o Estado não passa de um mal necessário e, como tal, deve-se intrometer o menos possível na esfera de acção do indivíduo. À compreensão do Estado como parte do poder do soberano sucede a concepção de Estado como parte do poder dos súbditos, da nação ou corpo moral do Estado que envolve a ideia de povo. A ideia de nação, opondo-se à perspectiva que considerava estar a soberania nas mãos de um único homem, torna possível a unidade do Estado moderno. Ao Estado absoluto o liberalismo contrapôs o Estado de direito - Estado em que o poder público regula a norma geral (lei fundamental ou constitucional), devendo ser exercido no âmbito da mesma, salvo o direito do cidadão em recorrer a um juiz independente, que reconheça e permita resistir ao excesso do poder. O Estado de direito pressupõe a superioridade do governo da lei sobre o governo do homem, mais exactamente a constitucionalização do direito natural, consistindo esta na transformação deste em direito juridicamente protector, direito positivo.

Nem todo o Estado de direito tem, em simultâneo, de ser Estado mínimo; porém, é precisamente este o caso da concepção liberal - em detrimento do Estado máximo o liberalismo advoga o Estado mínimo, mais fácil de controlar dado o seu diminuto horizonte de intervenção. Neste sentido, é visível a

\footnotetext{
3 Idem, p. 10.

4 Idem, p. 11.
} 
sincronia entre o alargamento da esfera de liberdade do indivíduo e a progressiva emancipação da sociedade civil, do Estado. Isto não significa que o Estado trate os seus súbditos como um pai trata os filhos, pois estes não são subalternos ou menores. Neste sentido, J. Locke considerou ter o poder civil nascido para garantir a liberdade e a propriedade do indivíduo, que se associa com o intuito de se autogovernar, distinto do governo paternalista; e Wilhelm von Humboldt apresentou a ideia de um sábio limite da actividade do Estado. Este teórico do liberalismo concebeu o Estado não como um fim, mas como um meio para a formação do homem - a organização estatal deve garantir que os indivíduos prossigam os seus fins, a liberdade individual. Em termos conclusivos, podemos afirmar que o Estado tem por fim a segurança, tanto como a afirmação da liberdade no âmbito da lei.

Em Ideia de um Sábio Limite da Actividade do Estado (1792) Humboldt apresentou outras questões de interesse para a reconstrução da doutrina liberal - caso do elogio da variedade ou diversidade individual, em contraposição à uniformidade estatal, e do tema da fecundidade do antagonismo, em contraposição à harmonia e concórdia da concepção orgânica da sociedade. $\mathrm{Na}$ sua esteira, Kant apreciou o contraste entre o indivíduo e o grupo como um benefício, senão mesmo como condição necessária ao progresso técnico e moral da humanidade. Este antagonismo reflecte a tendência do homem em satisfazer o seu próprio interesse em concorrência com o interesse de todo o outro; trata-se de uma disposição que reside na natureza humana, da «sociabilidade insociável dos homens» ${ }^{5}$. Nesta perspectiva, o juízo kantiano «sem a insociabilidade todo o talento restaria encerrado, desde o seu nascimento, numa vida pastoral arcaica» ${ }^{6}$ constitui o núcleo essencial de todo pensamento liberal.

Se devemos entender o liberalismo como uma concepção de Estado, por democracia entende-se uma forma de Estado. Se o liberalismo emergiu apenas na modernidade, contrariamente, a democracia é bastante antiga. $\mathrm{O}$ termo «democracia» foi utilizado pela primeira vez por Heródoto, no séc. V a.c. Nele encontramos a combinação entre os termos gregos demos - povo - e Kratein - poder, governo. A concepção clássica de democracia, ligada à clássica tripartição das formas do Estado, que toma por critério quem detém a soberania, baseia-se nos ideais de isonomia - igualdade perante a lei - e de eleuteria - igualdade política. Deste último fazem parte a isocratia, a igualdade de poder ou de direito de participação, e a isogonia, a igualdade de voz ou de direito de expressão. A democracia substancia, deste modo, a forma de Estado

5 KANT, Immanuel, (1784), «Ideia de uma História Universal com um Propósito Cosmopolita», in A Paz Perpétua e Outros Opúsculos, Lisboa, Edições 70, 1995, p. 25.

6 BOBBIO, Norberto, Liberalismo e Democrazia, Milano, Franco Angeli, 2. ${ }^{a}$ Edizione, 1986, p. 20. 
em que, de qualquer maneira, o povo é detentor do poder - acepção subscrita pela Política de Aristóteles. Como assinala A. Cabral Moncada, «o Estado em que de qualquer modo o povo for, de facto, o detentor do poder e o exercer, como melhor garantia para se alcançar aquilo que aí acima de tudo se procura, a utilidade e proveito do maior número de cidadãos, em vez de uma minoria da fórmula de Péricles, será democrático; aquele em que isto não se der não o será» ${ }^{7}$. Na primeira metade do séc. XIX, Abraham Lincoln definiu a democracia como «o governo do povo, pelo povo, para o povo» ${ }^{8}$. Deste modo, encontramo-nos perante uma representação mental extraída dos factos históricos.

A ambígua evolução semântica dos termos «povo» e «governo», assim como a aplicação diversa do termo «democracia» e as suas respectivas valorações axiológicas, dificultam a definição precisa e unívoca do mesmo. Ao se debruçar sobre esta questão Barry Holden sublinha o contratempo inerente à terminologia política, dado concernir a entidades por si mesmo complexas e sobre as quais, na maioria das vezes, desenvolvemos pensamentos vagos e confusos. Primeiro que tudo há a salientar que, se inicialmente a democracia começou por ser considerada como uma forma de representatividade directa, na actualidade também a forma de representatividade indirecta se encontra incluída no seu significado. Por sua vez, a tendência actual para se denominar de democrático qualquer sistema aprovado obscurece ainda mais o seu significado. A dificuldade não dimana tanto na palavra em si mesma como da sua utilização abusiva.

Não existe consenso quanto à aplicação correcta do termo «democracia» - por exemplo, os E.U.A. jamais concordaram com a adaptação deste termo ao «governo do povo» que existiu na União Soviética. Barry Holden considera que a proximidade a um acordo, a este nível, depende da distinção entre «características definidoras» e «condições necessárias»" ${ }^{9}$, pois uma coisa é a natureza da democracia, outra a natureza dos seus pré-requisitos necessários. É de se salientar que o desacordo sobre as condições necessárias à existência da democracia implica o desacordo sobre a definição de democracia.

Embora o significado descritivo de democracia se tivesse mantido ao longo dos tempos, o seu significado valorativo mudou. Esta mutação não pôs em causa a questão sobre o titular do poder político, o povo, mas sim o modo mais ou menos amplo do exercício desse direito. Ou seja, foi-se passando de uma democracia directa a uma democracia representativa - os vários partidos da Assembleia dos Representantes constituem a grande razão do Estado Mo-

7 MONCADA, A. Cabral, Problemas de Filosofia Política, Coimbra, Arménio Amando Editor, 1963, p. 63.

${ }^{8}$ HOLDEN, Barry, Understanding Liberal Democracy, New York, Harvester Wheatsheaf, Second Edition, 1993, p. 7.

9 Idem, p. 4. 
derno. E logo no seu acolhimento inicial despontou a controvérsia sobre a sua exequibilidade. Sob a convicção de que a soberania não pode ser representada, Rousseau alertou para a impossibilidade da verdadeira democracia - a sua perfeição ultrapassa os limites da finitude humana.

A democracia tornou-se representativa a partir do momento em que os deputados eleitos passaram a representar a nação e não a facção que os elegeu; ou seja, a partir do momento em que se excluiu o vínculo entre o eleitor e o eleito. Em virtude deste princípio, o sistema parlamentar pôde distinguir-se do estado de classes (ou castas) assente no vínculo do mandato do delegado, libertando o indivíduo na sua singularidade e autonomia. A democracia moderna, como democracia representativa, pressupõe a atomização da nação e a sua recomposição a um nível quer mais elevado, quer mais estrito, que é o da Assembleia parlamentar. Este processo de atomização é, na opinião de Bobbio, o processo «do qual nasce a concepção do Estado liberal, de que o fundamento deve ser procurado (...) na afirmação do direito natural e inviolável do indivíduo» ${ }^{10}$.

No seguimento desta exposição resta-nos colocar a questão: existe algum ponto comum entre o liberalismo e a democracia? Se tanto aquela concepção como esta forma de Estado assentam numa compreensão individualista da sociedade, pode-se concluir, na esteira dos autores analisados, que o indivíduo constitui o ponto comum a ambas. Se o organicismo, ao considerar Estado como um todo, embargou a autonomia do sujeito, o individualismo, ao considerar o Estado como resultante do trabalho e relação de um conjunto de indivíduos, tornou-a possível. Todavia, como assinala Bobbio, o indivíduo do liberalismo não é, em estrito, o indivíduo da democracia. Considerando que o indivíduo reside no corpo orgânico da sociedade, o liberalismo fá-lo viver grande parte da sua vida fora da família materna, no seio de um mundo desconhecido e repleto dos perigos inerentes à luta pela sobrevivência; diferentemente, na democracia reconhece-se o «outro», já que se considera a sociedade como um todo de indivíduos livres.

O liberalismo preza o indivíduo como o protagonista de toda a actividade que se desenrola fora do Estado, colocando em evidência a sua capacidade de autoformação, o desenvolvimento das suas faculdades e o seu progresso intelectual e moral (na máxima liberdade em relação aos vínculos externos impostos coercivamente); diferentemente, a democracia considera o indivíduo como protagonista de uma forma de Estado em que a decisão colectiva é tomada directamente dos indivíduos. Em sequência, exalta a capacidade do indivíduo para superar o isolamento através de vários acordos que instituem um

${ }^{10}$ BOBBIO, Norberto, Liberalismo e Democrazia, Franco Angeli, 2. ${ }^{a}$ Edizione, Milano, 1986, p. 25. 
poder comum. Pode-se concluir, deste modo, que a democracia exalta aquilo que é extrínseco ao indivíduo - a igualdade entre os indivíduos -, enquanto o liberalismo exalta a liberdade do indivíduo, algo que lhe é intrínseco.

A liberdade foi a primeira grande paixão da democracia - a partir do findar do séc. XVIII a democracia apresentou como bandeira e ideologia a sua luta contra os excessos do poder real. Segundo o critério de valores desta ideologia liberal, a liberdade - ideal que subjaz às revoluções inglesa (1688) e francesa (1789) - apresentava-se como o valor máximo do indivíduo e, como tal, o valor fundamental a preservar na relação entre este e a sociedade, em prol do bem comum. Os grandes teóricos das revoluções anteriormente mencionadas, J. Locke e Rousseau, delinearam as suas doutrinas políticas tendo por base a ideia de liberdade. O primeiro considerou, acima de tudo, que o Estado só serve para proteger e garantir a liberdade e propriedade do indivíduo. Rousseau, por sua vez, observou que «para realizar uma tal forma de convivência entre os homens, nascidos livres, que estes, abdicando apenas nas mãos de uma «vontade geral», que seria afinal sempre a sua, viessem a encontrar-se no fim tão livres como no «estado de natureza» do qual pelo «contrato social» tinham saído» ${ }^{11}$.

Divinizando a doutrina do povo e das suas maiorias, portadoras da vontade geral, a doutrina de Rousseau caiu na maior das contradições teóricas. Isto porque, no Contrato Social, se por um lado se considera a prática representativa como incompatível com o princípio da vontade geral; por outro lado, refere-se à lei como expressão da vontade geral, tendo todos os cidadãos o direito de concorrer pessoalmente ou por representação para a sua formação. Benjamin Constant (1767-1830) apreciou este paradoxo como a imagem do conflito entre liberdade e igualdade, que em termos factuais despontaria apenas na segunda metade do séc. XIX.

Sob a forma de contraposição entre a «liberdade dos antigos» e a «liberdade dos modernos», Constant enunciou e argumentou a antítese entre o liberalismo e a democracia. Contraste que acentua, de resto, a distinção radical entre as condições sociais e políticas da felicidade humana na cidade antiga e nos Estados modernos - tomar-se umas pelas outras traduz-se num anacronismo. Deu-se início, assim, à história da relação difícil e controversa entre as duas exigências fundamentais peculiares ao Estado contemporâneo, sem as quais não seria possível o desenvolvimento económico e social, a saber: por um lado, a limitação de poder, sustentada pelo liberalismo; por outro, a distribuição do poder, sustentada pela democracia.

A distinção de Constant entre a «liberdade dos antigos» e a «liberdade

"MONCADA, L. Cabral, Problemas de Filosofia Política, Coimbra, Arménio Amando Editor, 1963, p. 86. 
dos modernos» justifica a sua crítica à ideia de democracia directa veiculada, segundo a sua leitura, no Contrato Social e que se baseia na identificação da liberdade política com a autonomia. Ao privilegiar a liberdade dos antigos, Rousseau e, na sua esteira, os revolucionários de 1793 não lograram compreender a emergência de uma nova forma de liberdade. Enquanto os antigos distribuíam o poder político por todos os cidadãos de uma mesma pátria e, consequentemente, enfatizaram a liberdade relativa à participação nos assuntos públicos, ou autonomia política; os modernos têm por objectivo assegurar o usufruto dos prazeres privados, a independência - «chamamos liberdade à garantia acordada pela instituição a este usufruto» ${ }^{12}$. É evidente o contraste entre estes dois desígnios, tanto mais que a participação activa e constante do cidadão na decisão colectiva acaba por sujeitar o indivíduo à autoridade, por encurtar, senão mesmo aniquilar, o espaço da sua liberdade privada. À liberdade de participar de modo igual na vida política, os modernos contrapõem uma acepção que focaliza a liberdade do pensamento e de consciência, a liberdade da pessoa e as liberdades civis.

$\mathrm{Na}$ linguagem política o conceito de liberdade assume dois significados distintos: o de «liberdade negativa» - «liberdade de» - e o de «liberdade positiva» - «liberdade para». A primeira compreende «a situação em que um sujeito tem a possibilidade de agir ou não, sem que a isso seja obrigado ou impedido» ${ }^{13}$. Trata-se da «liberdade como ausência de impedimento» ${ }^{14}$ ou «liberdade como ausência de constrangimento» ${ }^{15}$; compreendendo, como tal, tanto a «possibilidade de fazer» quanto a «possibilidade de não fazer», a qualificação da acção. Neste sentido, Hobbes considerou a liberdade negativa como «aquela parte do direito natural que as leis civis permitem e deixam à discrição dos cidadãos» ${ }^{16}$. Esta acepção coaduna-se com a perspectiva liberal, pois segundo este ponto de vista «todo o ser humano deve ter uma esfera de actividade pessoal protegida contra a ingerência de todo o poder externo» ${ }^{17}$.

No sentido político, «liberdade para» sugere a capacidade do indivíduo para orientar a sua vontade conforme um determinado objectivo, sem qualquer ingerência da vontade exterior. Consequentemente, o indivíduo é autónomo, autodetermina-se. Foi precisamente neste sentido que, na sua doutrina político, Rousseau se referiu à liberdade. A liberdade é a obediência à lei prescrita, obedecendo o indivíduo apenas à lei que dita a si mesmo. Na sua esteira, Kant definiu a liberdade externa (jurídica) como a faculdade de não obedecer a

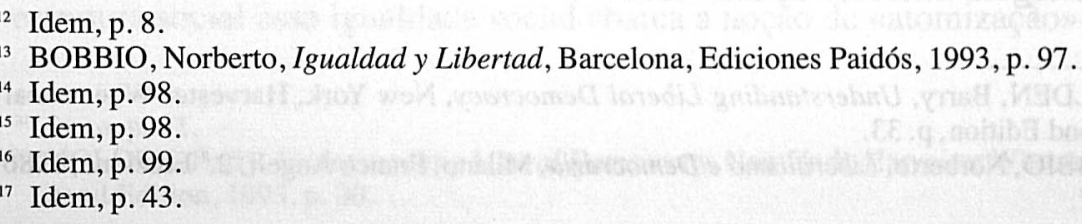


outras leis senão àquelas que tenhamos podido dar o nosso assentimento. Da autonomia da nossa vontade não se pode concluir, todavia, que a nossa acção seja livre, dado podermos ser impedidos ou constrangidos - as «condições positivas da acção» são distintas das «condições de constrangimento» ${ }^{18}$. A liberdade positiva qualifica a nossa vontade, não a nossa acção. O que vale para esta não tem que valer para a vontade, pois enquanto a causa da acção não livre é um impedimento ou constrangimento, a causa da vontade não livre é determinada por um outro sujeito que não aquele que quer.

Da diferença entre estas duas acepções de liberdade não se pode concluir a sua incompatibilidade. Pelo contrário, como sugere Norberto Bobbio, embora completamente independentes podem compatibilizar-se ou mesmo fundir-se uma na outra. No domínio político, a sociedade ou o Estado são livres quando a liberdade negativa dos indivíduos ou dos grupos, manifesta na sua acção, se une à liberdade positiva da colectividade, que se reflecte na sua vontade. Trata-se, assim, da sociedade ou do Estado em que uma grande margem das liberdades civis - liberdade negativa dos indivíduos ou dos grupos é condição para o exercício da liberdade positiva do conjunto - a liberdade política. A dificuldade reside em que a vontade colectiva e as decisões por ela tomada se assumam como a máxima expressão da vontade de cada indivíduo.

O mecanismo constitucional que caracteriza o Estado de direito, com o qual se identifica a concepção de Estado liberal, como acima referido, tem por objectivo defender o indivíduo de qualquer abuso do poder; ou seja, no âmbito da lei procura garantir e assegurar a liberdade dos indivíduos. Trata-se aqui da liberdade negativa, acepção segundo a qual os termos «liberdade» e «poder» são contrários entre si, na medida em que anunciam duas realidades antagónicas. Na relação entre duas pessoas o poder, poder de comandar ou de impedir, subentende uma diminuição da liberdade, enquanto o alargamento da esfera da liberdade pressupõe uma diminuição do poder. No sentido da concepção liberal, da oposição entre o poder do Estado e a liberdade do indivíduo, a liberdade consiste no silêncio da lei. Consequentemente, a sua propagação depende da limitação do poder do Estado, que tem o dever de proteger os indivíduos uns em relação aos outros. Tanto Kant como Adam Smith, conquanto em domínios distintos, consideraram que a doutrina do limite do poder do Estado se funda «sobre o primado da liberdade do indivíduo em relação ao poder soberano e consequentemente sobre a subordinação do dever do soberano ao direito ou a algum interesse do indivíduo» ${ }^{19}$.

${ }_{18}$ HOLDEN, Barry, Understanding Liberal Democracy, New York, Harvester Wheatsheaf, Second Edition, p. 33.

19 BOBBIO, Norberto, Liberalismo e Democrazia, Milano, Franco Angeli, 2. ${ }^{a}$ Edizione, 1986, p. 17. 
Entre a democracia e o liberalismo, tal como, na actualidade, entre a democracia e o socialismo, existem diferentes tipos de relação: de possibilidade, de impossibilidade e de necessidade. No séc. XIX emergiriam no seio do pensamento liberal duas correntes antagónicas quanto à relação entre o Estado liberal e a democracia - o liberalismo radical e o liberalismo conservador. $\mathrm{O}$ primeiro defendeu e identificou-se com essa relação; enquanto o segundo, ao não renunciar mais à luta contra a proposta de alargamento do direito de voto, considerado como uma ameaça à liberdade, diz-se liberal mas não democrático. Alexis de Tocqueville e John Stuart Mill foram os representantes maiores destas duas vias liberais. Face ao emergir da democracia, Tocqueville questionou a sobrevivência quer da estrita imagem da democracia, quer da liberdade na sociedade democrática. Tanto para este, como para Stuart Mill, a democracia vai ao encontro de uma enorme ameaça, a tirania da maioria. Como progressiva actuação do ideal igualitário, encaminha-se para o nivelamento que tem por esboço final o despotismo. Ao cuidar que a força do número prevaleça sobre a do indivíduo singular, o princípio da maioria é um princípio de igualdade, trata-se da «teoria da igualdade aplicada à inteligência» ${ }^{20}$.

A acção implementada pela vontade do povo pode entrar em conflito com as vontades individuais, ameaçando a autonomia de determinados indivíduos. Neste sentido, a liberdade surge como fonte de conflito entre o indivíduo e o povo. $\mathrm{O}$ argumento utilizado pelos que vislumbram a degeneração da democracia numa tirania majoritária, como assinala Barry Holden, focaliza a ameaça às liberdades minoritárias, para a qual contribui o papel da maioria nas democracias - «a minoria é governada despoticamente pela maioria ${ }^{21}$.

Em nome do interesse colectivo, da fórmula que garante a igualdade face ao direito, o Estado democrático tende para a liberdade individual, de imprensa e de associação - direito do indivíduo. Tocqueville considerou o socialismo como o adversário da democracia, pois enquanto esta defende uma sociedade de homens livres, aquele dá origem a uma sociedade de castas. Se a igualdade é aquilo que existe de comum à democracia e ao socialismo, a ambição que lhe subjaz é distinta - a democracia deseja a igualdade na liberdade, o socialismo deseja a igualdade na modéstia e na servidão. Ou seja, na concepção de Estado do socialismo a liberdade não constitui um valor fundamental. A igualdade social constitui, segundo Tocqueville e Stuart Mill, uma verdadeira ameaça à liberdade individual. Se a busca pela igualdade pode levar o Estado a invadir a liberdade do indivíduo; por sua vez, ao destruir a variada estrutura social essa igualdade social abarca a noção de «atomização» - a so-

${ }^{20}$ Idem, p. 41.

21 HOLDEN, Barry, Understanding Liberal Democracy, New York, Harvester Wheatsheaf, Second Edition, 1993, p. 30. 
ciedade é reduzida ao conjunto de indivíduos, vulneráveis ao governo e às pressões sociais, em que se inscreve a opinião das massas.

Bobbio considera que todas as formas de democracia - a democracia real, não a ideal de Rousseau - salvaguardam o princípio da liberdade através da decisão maioritária. O paradigma da democracia moderna assenta nas ideias de igualdade, de liberdade e de participação de todos os membros da sociedade na vida colectiva; não estando apenas em causa o domínio político, mas também o económico, o social e o cultural, as diversas dimensões da vida do homem em sociedade. Porém, se na democracia liberal prevalecem os valores da liberdade, na democracia social prevalecem os da igualdade. Num «face a face», estes dois modelos da democracia moderna têm-se envolvido em querelas, apostando nos respectivos mecanismos e invocando a distinção entre «democracia formal»-concerne à legalidade dos processos e ao respeito das regras de liberdade dos indivíduos, independentemente da igualdade em todos os domínios sociais - e «democracia substancial» - em detrimento da liberdade política visa a igualdade social e económica. O primeiro caso decorre no âmbito da democracia como governo do povo, enquanto no segundo a democracia é tomada como o governo para o povo.

A formulação do Estado liberal encontra-se historicamente ligada à democracia formal, não à democracia substancial; pois só assim o problema da relação entre a democracia e o liberalismo não advém tão complexo, tornando-se resolúvel quando colocada sob o âmbito da relação entre liberdade e igualdade. Neste sentido, a liberdade, a igualdade e a democracia substanciam os três vértices de um triângulo.

Do ponto de vista histórico, o Estado liberal emergiu de uma «contínua e progressiva erupção do poder absoluto do rei, no período de crise mais aguda, de uma ruptura revolucionária ${ }^{22}$. Desviando o olhar para o contexto português, mais especificamente para o que se passou na «governação vintista», entre 1820 e 1823, procuraremos responder às questões: «a ideia de Constituição e a lei eleitoral são ou não expressão da liberdade?» e «a maioria vintista corresponde ou não a um ideal de liberdade?». Pretende-se, aqui, recuperar a ideia de liberdade do vintismo, a qual se situa no rastro da ideia de liberdade associada aos direitos e deveres da sociedade, delineada pelo movimento das Luzes.

Na perspectiva liberal, a liberdade afirma-se como libertação em dois sentidos: libertação do homem face à sociedade e libertação da sociedade face ao poder. Se a liberdade natural se espelhou nas questões acerca da tolerância religiosa e da liberdade de imprensa, assim como a liberdade social nas do

${ }^{22}$ BOBBIO, Norberto, Liberalismo e Democrazia, Milano, Franco Angeli, 2. . Edizione, 1986, p. 11. 
direito de propriedade e garantias judiciais, é nas questões relativas ao direito de voto e à participação política que nos é susceptível trazer à presença a ideia de liberdade política. A teoria do poder do vintismo, na esteira de todos os outros regimes liberais, delineia como questão essencial o princípio da soberania nacional. Neste sentido, coloca-se no encalço dos princípios liberais subjacentes à «Declaração dos Direitos do Homem e do Cidadão», que no seu artigo 3. ${ }^{\circ}$ enuncia: «o princípio de toda a soberania reside essencialmente na nação» ${ }^{23}$. O pensamento revolucionário reconheceu a capacidade da nação para exercer o poder que lhe é próprio, tendo esta a sua origem na acção livre de todos os indivíduos, que por um processo contratualista se uniram em sociedade. Sem se intrometer nos direitos naturais do indivíduo, o Estado tem por dever harmonizar as diferenças entre todos. Deste modo, o bem comum adquire um significado atómico, pois trata-se do bem de qualquer um, já que o indivíduo precede a sociedade.

No seio de uma monarquia constitucional hereditária, com leis fundamentais que regulam o exercício dos poderes legislativo, executivo e jurídico - forma de governo institucionalizada pelo vintismo -, o rei passa a fazer parte da nação, a ser considerado como um magistrado. Arredado do lugar de figura política central, «transformou-se no supremo «servidor» do bem comum, cabendo-lhe apenas a participação no exercício do poder que a sociedade livre e soberana the quisesse conceder» ${ }^{24}$. Afirmou-se o primado do parlamento em relação ao rei, a primazia do poder legislativo. O parlamento vintista constituiu-se de representantes da nação, pois os deputados foram por esta eleitos a fim de defenderem os direitos particulares de todos os seus constituintes, sem para isso necessitarem de uma procuração - em detrimento do mandato imperial, surge o mandato livre. Deste modo, a prática liberal desfez o elo entre eleitor e eleito - concorreu para isso uma nova perspectiva acerca do indivíduo, da sociedade e das suas relações. Assistiu-se à conjugação entre o plano legislativo - o estabelecimento de leis - e o plano da prática política, ficando-se face a um Estado de direito em que a lei não apenas determina o que é a liberdade, mas também os seus limites. Como acima referido, trata-se da constitucionalização dos direitos naturais, da sua positivização com o objectivo proteccionista.

A ideia de Constituição surge como o expoente da legitimidade, pois através da imagem de unidade expressa no termo «nação» estabelece o equilíbrio entre a coacção inerente ao poder dos representantes e a liberdade, o di-

${ }^{23}$ MIRANDA, Jorge, Textos Históricos do Direito Constitucional, Lisboa, Imprensa Nacional

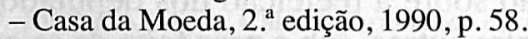

${ }^{24}$ CASTRO,Zilia Osório, «Soberania e Política - Teoria e Prática do Vintismo», in Cultura Revista de História e Teoria das Ideias, Centro de História da Cultura, Vol. VIII, 1996, p.183. 
reito e o poder. Ou seja, permite resolver a questão alusiva à compatibilidade entre a liberdade e o poder, dando «ser» ao Estado. A Constituição dá autoridade às decisões tomadas pela nação, protege os indivíduos. Sublinhe-se «indivíduos», pois num Estado liberal são os seus valores que são assegurados, não os valores sociais. O liberalismo considera que os homens são livres e que por serem livres são iguais, daí a Constituição ser a medida da maior ou menor perversidade.

Através da Constituição, o vintismo implementou não o governo dos homens, mas o governo das leis, expressão da vontade da nação, confluência da vontade de todos os indivíduos. O constitucionalismo surge como expressão de um Estado mínimo, de um Estado que, em prol da preservação dos direitos do indivíduo, da sua liberdade, detém o mínimo possível de poder, dado este ser inversamente proporcional à liberdade. A Constituição e o projecto de leis surgiram no seguimento do desejo liberal de se limitar o poder e a autoridade do governo.

A lei eleitoral vintista delineia a eleição dos deputados ou representantes da nação pela pluralidade de votos secretos; concebendo-se o voto como um exercício de cidadania, exercido apenas pelo homem livre, e não como um exercício de soberania - o que pressupõe a distinção nítida entre os direitos civis e os direitos políticos. A questão reside, então, em saber quais os critérios inerentes à cidadania e à possibilidade de se ser deputado. O sufrágio universal foi estabelecido, mas fez-se acompanhar de um extenso número cláusulas em que, entre outras coisas, se decreta a exclusão dos domésticos - dependentes de outrem no exercício das suas vontades, não gozando por isso de uma liberdade de opinião - e dos regulares, de todos aqueles que por não serem livres não podem vir a ser reconhecidos como cidadãos.

$\mathrm{Na}$ perspectiva liberal, o sufrágio universal constitui a única fonte legítima do direito, assim como o poder legislativo é a única essência do Estado. A soberania da nação exprime-se pelo voto e materializa-se na lei. Pela participação, ainda que indirecta, do maior número possível de cidadãos na formulação da lei, o liberalismo propõe um remédio para o abuso do poder. Sobre este aspecto, o direito político é um complemento natural do da liberdade e do direito civil. Ao votar o cidadão exerce correcta e eficazmente um poder político.

Urge questionar: a maioria vintista da lei eleitoral foi ou não opressora das minorias vencidas? O perigo das minorias virem a ser oprimida pela maioria é constante, dado que esta, ao dar forma às leis reguladoras do poder político, deixa transparecer a ideologia que lhe subjaz. A liberdade das minorias é ameaçada sempre que a maioria exerce sobre elas a pressão de uma autoridade despótica. A este nível, quer na discussão sobre a reeleição dos deputados, quer no caso da instituição dos jurados, entre outros, sob o propósito de se garantir os direitos e liberdades dos cidadãos, assistiu-se ao confronto entre os 
moderados e os radicais, opondo a pureza dos princípios ao peso da realidade. Com o objectivo de se evitar a ditadura do legislativo e a manipulação das eleições, pela possibilidade de se ser reeleito, ergueu-se o direito à liberdade de voto como direito essencial do cidadão.

A maioria vintista corresponde a um ideal de liberdade, contribuindo, por isso mesmo, para a constituição de um Estado de direito que se fez acompanhar por um Estado mínimo. Neste sentido, somos advertidos de que «o Estado liberal vintista, mais do que expressão, era o garante da liberdade do cidadão» ${ }^{25}$. Porém, não logrou manter o equilíbrio entre os seus princípios teóricos e a prática. Se o vintismo falhou foi, sobretudo, na sequência da deficiência da função do equilíbrio dos poderes. Neste sentido, há a sublinhar a vulnerabilidade do equilíbrio entre o poder régio e o poder da nação pela ausência de uma verdadeira representatividade deste. Por outro lado, aos poderes legislativo e executivo subjazeram correntes ideológicas completamente distintas.

Ao se identificar o cariz político da democracia com a escolha dos meios adequados à realização da sua ideia; fins e valores essenciais, passa a estar em causa a conformidade destes, não o seu valor e legitimidade. Não basta saber que o Estado deve procurar o bem comum dos cidadãos; que para tal se deve conferir a todos, no mínimo a uma maioria, a possibilidade de participação ou intervenção na vida pública; ou ainda que estes homens jamais poderão ser convenientemente tratados como pessoas - como fins e não como meios - caso não lhes seja garantido um certo grau de liberdade e, em simultâneo, determinadas circunstâncias de igualdade no gozo e fruição de um mínimo de vantagens, bens e direitos. Para além disso, urge saber «qual a melhor maneira de se alcançar tudo isto, para a democracia ser um facto: como, até onde e por que meios deve ela realizar-se ${ }^{26}$.

Neste âmbito, em Problemas da Filosofia Política A. Cabral Moncada considera que às diferentes concepções de sociedade e de Estado, como às diferentes culturas, convêm formas distintas de democracia. Conquanto à primeira vista nada exista de semelhante entre elas, partilham de um mesmo fundo - «todas se esforçam por dizer a mesma palavra amor nas suas diferentes línguas sem lá chegarem ${ }^{27}$, todas reconhecem o direito dos governados participarem na obra dos governantes, assim como o dever destes ouvirem aqueles. Seja qual for a sua aparência, a democracia acaba sempre por conhecer a crise - próprias da finitude humana, as crises sucedem-se umas às outras, não permitindo a cristalização da democracia numa expressão única. Tratam-

${ }^{25}$ CASTRO, Zilia Osório, «Soberania e Política - Teoria e Prática do Vintismo» in Cultura Revista de História e Teoria das Ideias, Centro de História da Cultura, vol. VIII, 1996, p. 189.

${ }^{26}$ MONCADA, A. Cabral, Problemas da Filosofia Política, Coimbra, Arménio Amando Editor, 1963, p. 78.

${ }^{27}$ Idem, p. 80. 
se de crises de crescimento, decorrentes do desajuste entre as formas políticas e as infra-estruturas económicas da sociedade em perpétuo devir, ou de morte, provocadas por disposições antidemocráticas.

$\mathrm{Na}$ contemporaneidade, a democracia individualista e liberal ou demoliberalismo e a democracia totalitária ou de massas substanciam as duas formas mais evoluídas da democracia. A primeira surgiu no séc. XVIII, como a expressão política mais directa do capitalismo; a segunda proveio do movimento socialista utópico, que despontou na Europa a partir de 1848. Como assinala Bobbio, a democracia pode ser pensada como o denominador comum a todos os regimes que se desenvolveram nos países económica e politicamente mais progressivos - a «democracia social», assente na primazia da ideia de igualdade em relação à de liberdade; a «democracia liberal», pelo contrário, na excelência da ideia de liberdade. Porém, daqui não se deve concluir ser o conceito de democracia restrito à passagem do primeiro para o segundo regime.

No binómio «democracia liberal», democracia significa, principalmente, «sufrágio universal», um meio de expressão da livre vontade do indivíduo singular. Trata-se de uma consequência, completando, neste sentido, a série da liberdade particular com a liberdade política. No binómio «democracia socialista», democracia significa «ideal igualitário», unicamente possível através da reforma da sociedade proposta pelo socialismo. Neste sentido, ficamos face a um desígnio, um propósito consumado pela futura transformação socialista da sociedade capitalista. A aliança do demoliberalismo com o capitalismo - oriundos dos mesmos ventos do individualismo filosófico - viria a encaminhá-lo numa autêntica ruína. No momento em que demoliberalismo atingiu o cume no domínio político, entre 1830 e 1850 , foi perdendo terreno no domínio económico face ao emergir das ideias socialistas.

Como podemos definir o demoliberalismo? Barry Holden adverte-nos da dificuldade emergente da tentativa de clarificação do termo «demoliberalismo» - contrariedade análoga à decorrente das tentativas de definição da democracia. Se os demoliberais tendem a considerar o modelo que seguem como o único possível da democracia, pelo contrário, os que o criticam enfatizam a sua falsidade. Estes pontos de vista, completamente opostos, acabam por complicar a conexão entre os significados de democracia e de demoliberalismo. Se considerarmos a democracia como referência da localização do poder do Estado e o liberalismo como alusivo à limitação do poder do Estado, podemos concluir ser o demoliberalismo o sistema político no qual o povo toma decisões políticas básicas, mas no qual existem limitações em relação às decisões políticas que pode tomar. Ou seja, a esfera legítima da autoridade pública é limitada.

Pressuposto do demoliberalismo, a democracia formal, ou a democra- 
cia como o governo do povo, está historicamente ligada à formulação do Estado liberal. Como já assinalado, a árdua relação entre o liberalismo e a democracia resolve-se na relação entre a liberdade e a igualdade, o que subentende uma resposta unívoca às seguintes questões: «que liberdade?» e «que igualdade?». O libertarismo e o igualitarismo encontram-se fundados em concepções de «homem» e de «sociedade» completamente distintas: o primeiro na individualista, conflitualista e pluralista; o segundo na igualitária, na totalizante, harmónica e monística. Neste sentido, Bobbio adverte: «para o libertário o fim principal é a expansão da personalidade individual (...); para o igualitário o fim principal é o desenvolvimento da comunidade no seu conjunto, mas à custa da diminuição da liberdade do indivíduo ${ }^{28}$. A igualdade na liberdade é a única forma de igualdade compatível com a liberdade, o que significa que cada um deve gozar de tanta liberdade quanto a compatível com a liberdade do outro. Esta forma de igualdade inspira dois princípios fundamentais, enun-

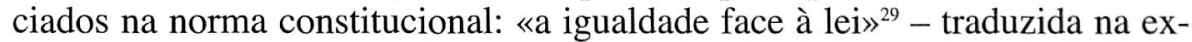
pressão jurídica «a lei é igual para todos» - e a «igualdade do direito ${ }^{30}$ ou igual usufruto de qualquer cidadão em relação aos direitos fundamentais constitucionalmente estabelecidos. Quanto à questão relativa aos vários significados de igualdade, o liberalismo e a democracia estão destinados a não se encontrarem.

$\mathrm{O}$ encontro entre o liberalismo e a democracia decorre no contexto político prescrito pela fórmula «soberania popular». Neste horizonte, não só se tornam compatíveis, como se reconhece na democracia o desenvolvimento natural do liberalismo. A possibilidade do exercício da soberania popular depende «da maior extensão possível do direito político senão ao limite último do sufrágio universal (...) ao limite do Estado $»^{31}$. Na contemporaneidade é-nos impossível pensar num Estado liberal que não seja democrático, assim como num Estado democrático que não seja liberal, dado supor-se, por um lado, que a protecção do direito fundamental da pessoa, fundamento do Estado liberal, carece do método democrático; por outro, que a salvaguarda deste direito seja necessária ao correcto funcionamento do sistema democrático. Todos os estados autoritários são em si mesmos antiliberais e antidemocráticos. Só o Estado oriundo da revolução liberal é considerado de democrático e somente este protege o direito do homem.

$\mathrm{O}$ vigor da teoria demoliberal dimana, segundo Barry Holden, da diferença entre a liberdade do povo e a liberdade do indivíduo. Será que a liber-

${ }^{28}$ BOBBIO, Norberto, Liberalismo e Democrazia, Milano, Franco Angeli, 2. ${ }^{a}$ Edizione, 1986, p. 27.

${ }^{29}$ Idem, p. 27.

${ }^{30}$ Idem, p. 27.

${ }^{31}$ Idem, p. 30. 
dade do povo se envolve ou interfere com a liberdade do indivíduo? A verdade é que a liberdade pode ameaçar a liberdade, como fonte de conflito entre o indivíduo e o povo. Neste sentido, encontramos dois tipos distintos de argumentação: o primeiro concerne à ameaça da liberdade do indivíduo inerente à instituição do Estado; o segundo focaliza a diferença entre o indivíduo e o povo. No primeiro caso a ameaça é reconhecida pela existência de uma falha frequente na discriminação entre as ameaças do indivíduo e as ameaças do povo. O segundo evidencia que o caminho tomado pelo indivíduo poder ser obstruído pela massa do povo.

Em 1848 o «clarão sangrento de Paris» fez estremecer a burguesia europeia, arrastando, por consequência, a subjugação do amor pela liberdade ao zelo pela segurança. Consequência que se alastraria pela quase totalidade dos países da Europa. Na segunda metade do séc. XIX assistiu-se a um restabelecimento das instituições liberais. Porém, este liberalismo foi em si distinto do da primeira metade do século, pois perdera a pureza doutrinária que lhe havia proporcionado as teorias de J. Locke, Bentham, Stuart Mill e Spencer. Com uma nova fisionomia, o liberalismo fez algumas concessões a novas ideias. A ideia de liberdade circunscrevia-se, então, ao campo da ideologia política, quanto muito ao literário. Vindo a perder terreno tanto no domínio da economia quanto no da política, pois a sua aliança ao supercapitalismo encaminhou- a na contradição - assistiu-se no domínio dos factos ao que no domínio teórico havia sido apontado por Rousseau.

A democracia viu-se obrigada a procurar uma nova ideia que lhe servisse de base. A igualdade assumiu-se, então, como a nova ideia a realizar, como a nova grande paixão da democracia, que no dizer de Herculano se viria a configurar como sendo a mais profunda. No decorrer da segunda metade do séc. XIX, a igualdade foi impondo à liberdade uma série de compromissos numa complexa teoria de limitações, negações e vexames - «Estado e direito sociais; democracia e socialismo cristãos; estados corporativos das doutrinas krausistas e das Encíclicas de Roma, socialismos reformistas e catedráticos de todas as cores; estados fascistas e orgânico-integralistas; New Deal americano e os terceiros caminhos do neoliberalismo contemporâneo; etc. $\aleph^{32}$. Se a ideia de liberdade conduziu a democracia a uma crise profunda, na actualidade apercebemo-nos que as ideias sociais, assentes na ideia de igualdade, são também elas expansivas e imperialistas.

Existe uma diferença a sublinhar entre as distintas formas de irradiação das ideias de liberdade e de igualdade. Enquanto a propagação da ideia de liberdade decorreu em circunstâncias propícias, algo de distinto se passou em

${ }^{32}$ MONCADA, A. Cabral, Problemas de Filosofia Política, Coimbra, Arménio Amando Editor, 1963 , p. 93. 
relação à difusão da igualdade. Neste sentido, Cabral Moncada adverte-nos de que a propagação da ideia de igualdade «carece de muitos órgãos de administração e de governo, de muitas leis com abundante regulamentação, e inclusive de uma determinada concepção do homem e da sociedade, totalmente diferentes das do indivíduo liberal ${ }^{33}$. Esta disseminação requereu uma posição dirigista por parte do Estado, uma posição de força. De outro modo, a igualdade corria o risco de ser devorada pela liberdade.

Coloca-se a questão: quais as relações próximas entre a democracia e a igualdade? Barry Holden considera que no sentido subsidiário a democracia assume o significado da sociedade em que existe igualdade, não apenas no domínio político, mas também no económico e social. Em relação à democracia liberal, a democracia social apresenta-se como uma fase ulterior, na qual em detrimento dos valores individuais passam a estar em causa os valores sociais. As pessoas são iguais quando sobre elas recai o mesmo respeito. Que todas as pessoas sejam tratadas do mesmo modo conștitui a exigência central à igualdade. A igualdade tem por essência moral a dignidade espiritual do homem, tal como a liberdade a verdadeira fraternidade e o amor da pessoa humana.

No conceito de democracia existem conexões, tanto directas como indirectas, entre os conceitos de igualdade e de liberdade, elementos básicos do credo democrata. Primeiro urge referir as tensões entre elas. Numa situação em que a igualdade é aquela que é permitida pela liberdade, em que as condições da liberdade são gratas à desigualdade na distribuição dos bens materiais, corre-se o risco do poder, tanto político como económico, caírem numa única mão. Diversamente, numa situação de igualdade social a liberdade acaba por ser ameaçada. Se por um lado, a busca da igualdade pode envolver a invasão da liberdade individual, por parte do Estado; por outro lado, a igualdade social destrói a variada estrutura do Estado, controlando-o através da protecção promovida contra o poder governamental. A ameaça da igualdade à liberdade abarca a ideia de ameaça da democracia à liberdade. De modo similar, ao se envolver com a liberdade a democracia pode constituir uma verdadeira ameaça para a igualdade. Do ponto de vista da «igualdade liberal» a liberdade e a igualdade não são vistas como tensão, mas antes na sua interdependência ou conexão, como fundidas num único valor básico. A «igualdade liberal» sustenta que todos os indivíduos devem ter igual liberdade, pois se todas as pessoas têm direitos iguais a liberdade do indivíduo e a liberdade do povo tornam-se compatíveis.

${ }^{33}$ Idem, p. 95. 


\section{Bibliografia}

BOBBIO, Norberto, Liberalismo e Democrazia, Milano, Franco Angeli, 2. Edizione, 1986.

BOBBIO, Norberto, Igualdade y Libertad, Barcelona, Ediciones Paidós, 1993.

CASTRO, Zilia Osório de, «Soberania e Política - Teoria e Prática do Vintismo», in Cultura - Revista deHistória e Teoria das Ideias, Centro de História da Cultura, vol. VIII, 1996, pp. 183 - 213.

HOLDEN, Barry, Understanding Liberal Democracy, New York, Harvester Wheatsheaf, Second Edition, 1993.

KANT, Immanuel, (1784), «Ideia de uma História Universal com um Propósito Cosmopolita», in A Paz Perpétua e Outros Opúsculos, Lisboa, Edições 70, 1995, pp. 21-37.

MIRANDA, Jorge, Textos Históricos do Direito Constitucional, Lisboa, Imprensa Nacional - Casa da Moeda, 2. edição, 1990.

MONCADA, A. Cabral, Problemas de Filosofia Política, Coimbra, Arménio Amando Editor, 1963. 


\section{MODERNIDADE, PÓS-MODERNIDADE E OUTRAS NUBLOSIDADES}

Onésimo Teotónio Almeida

Brown University

É dado adquirido que a frequência de uso de um termo multiplica-lhe os sentidos; o abuso dele multiplica-os indefinidamente. Esta experiência é corroborada no caso do termo "pós-modernismo"" e derivados ("pós-modernidade", "pós-moderno", mas também "moderno" e "modernidade", por implicação), pois no debate de ideias contemporâneo o pós-modernismo tem ocupado um lugar primordial, penetrando uma miríade de questões diversas com ramificações políticas da mais variada ordem. Curiosamente, Richard Rorty, um dos nomes mais frequentemente associados ao termo, terá dito que ninguém faz a mais vaga ideia do significado de pós-modernismo. "Seria bom eliminar o termo," tanto mais que "não é exactamente uma ideia; é uma palavra que pretende expressar uma ideia." Estranhas declarações para quem tem escrito tanto sobre o pós-modernismo, e sobretudo vindas de quem provocou o mais duro golpe na filosofia analítica com The Linguistic Turn e depois Philosophy and the Mirror of Nature, que abriu caminho para a proliferação de caminhos no até então monolítico ambiente da filosofia analítica.

O Rhode Island Council for the Humanities anunciou em tempos uma conferência intitulada "What the Hell is Post-Modernism?" Num ensaio de revista de que não guardei nota, vi a referência a um congresso sobre o pós-modernismo. Dez participantes de renome não conseguiram, numa sessão sobre o sentido do termo, chegar a acordo sobre o seu significado.

Joyce Appleby, Lynn Hunt e Margaret Jacob, no seu livro Telling the Truth About History, referem-se à ubiquidade do termo "nas mais recentes guerras culturais entre tradicionalistas e os seus oponentes" e comentam:

it is a notoriously slippery label. At times, it seems as if everyone is a postmodernist; at others, that everyone avoids a category that can be synonymous with nihilism and ridiculous self-posturing. (If you think of both Jacques Derrida and Madonna as postmodernists you get some sense of the definitional problem.) ${ }^{3}$

Prefiro os termos "pós-modernidade" e "modernidade", uma vez que "modernismo" é mais usado como corrente estética.

2 Citado em Mark Leyner, "Geraldo, Eat Your Avant-Pop Heart Out", The New York Times, 21 Dezembro 1997.

3 Joyce Appleby,Lynn Hunt\& Margaret Jacob, Telling the Truth About History, New York: W. W. Norton \& Company, pp. 200-1. 
E, no entanto, num volume de Proceedings of the American Philosophical Association, entre uma série de anúncios sobre futuros congressos, aparecia um intitulado: "After Postmodernism", aceitando sem problemas aquilo que a American Philosophical Association ainda há década e meia considerava, sem o dizer explicitamente, completamente desinteressante, ainda que usasse de tolerância permitindo a existência de todo o género de sub-associações no seu seio. Na descrição dos propósitos e planos do mesmo lia-se:

The Conference poses a specific question: If we absorb postmodernism, if we recognize the variety and ungroundedness of grounds, but do not want to stop in arbitrariness, relativism, or aporia, WHAT COMES AFTER POSTMODERNISM? Postmodernism brought much that we wish to retain. It brought play and humor, no small contribution. It made visible the economic, political, gender, and colonizing hegemony inherent in western "objectivity" and "universality". Postmodernism puts the recognition of the ungrounded variety of assumptions first. ${ }^{4}$

Cada novo livro publicado sobre o tema procura definir ou redefinir o termo, mas de facto, quanto mais ele é debatido mais significados adquire e menos útil se torna. Aconteceu algo semelhante ao conceito de "revolução científica", de Thomas Kuhn. Depois de décadas de uso e abuso da expressão, vem agora Stephen Shapin, num livro ainda intitulado The Scientific Revolution $^{5}$, dizer que não existiu nenhuma revolução científica.

Neville Kirk tentou identificar as características constituintes do pós-modernismo contrapondo-as às do modernismo em duas colunas separadas ${ }^{6}$ :

${ }^{4}$ Proceedings of the American Phiolosophical Association, 71:2 (1997) 142.

5 Stephen Shapin, The Scientific Revolution (Chicago: The University of Chicago Press, 1996). Tive uma experiência semelhante com o termo "ideologia" sobre que escrevi uma tese de doutoramento. Na defesa oral, ao perguntarem-me que recomendação fazia quanto ao sentido mais apropriado do termo, respondi que era tal a confusão e a carga política dos seus diversos sentidos que o melhor seria eliminá-lo da circulação. Eu próprio fiz isso durante cerca de dez anos. Depois voltei ao tema, mas sem entusiasmo. Ver "Ideologia - Revisitação de um conceito", Revista de Comunicação e Linguagem, Número especial "Comunicação e Política", n. 21-22 (1995), pp. 69-79.

${ }^{6}$ Neville Kirk, "History, language, ideas and postmodernism: a materialist view", in Keith Jenkins, The Postmodern History Reader (London and New York: Routledge, 1997), p. 317. 
Elitism, closure

authoritarianism and

social engineering

("Fordism")

High culture and

tradition, profundity

Austerity and discipline

Fixed meanings, centres, absolute laws and truths ("meta narratives," such as Marxism and

Freudianism)

Holism

Planning

Homogeneity

Signified

Certainty, unitary

structures, e.g. class and deconstruction, discursive systems, synthesis, reality externality (i.e. reality

"out there")
Popular consumerism

flexibility, choice

openness, opportunity

Popular culture and the commodification of leisure and culture, "irreverent pastiche",

"contrived

depthlessness"

Playfulness, "laid back" hedonism

Relativity, indeterminacy, contingency, fragments of being, decentring, life (or "petite") histories

Individualism Experimentation, pragmatism Heterogeneity Signifier Scepticism, 
Ihab Hassan elaborou uma lista ainda mais desenvolvida, mas a que chamou "esquemática", das diferenças entre modernismo e pós-modernismo7.

modernism

romanticism/Symbolism

form (conjunctive, closed)

purpose

design

hierarchy

mastery/logos

art object/finished work

distance

creation/totalization/synthesis

presence

centring

genre/boundary

semantics

paradigm

hypotaxis

metaphor

selection

root/depth

interpretation/reading

signified

lisible (readerly)

narrative/grande histoire

master code

symptom

type

genital/phallic postmodernism

paraphysics/Dadaism

antiform (disjunctive, open)

play

chance

anarchy

exhaustion/silence

process/performance/happening

participation

decreation/deconstruction/antithesis

absence

dispersal

text/intertext

rhetoric

syntagm

parataxis

metonymy

combination

rhizome/surface

against interpretation/misreading

signifier

scriptible (writerly)

anti-narrative/petite histoire

idiolect

desire

mutant

polymorphous/androgynous

7 Transcrito em David Harvey, The Condition of Postmodernism. An Enquiry into the Origins of Cultural Change (Oxford: Basil Blackwell, 1989), p. 43. 
paranoia

origin/cause

God the Father

metaphysics

determinacy

transcendence schizophrenia

difference-difference/trace

The Holy Ghost

irony

indeterminacy

immanence

Parecerá assim temeridade da minha parte escolher revisitar um tema tão controverso, sobretudo depois do apelo de Richard Rorty. E no entanto vou prosseguir no meu atrevimento. Tanto mais que Rorty sabe perfeitamente o que é e não é o pós-modernismo. Suspeito que o seu desabafo seja mero gesto de impaciência contra a confusão generalizada, quando ninguém parece ouvir nem dialogar com ninguém. Enfim, outra coisa se não pode esperar do que, para muitos, é a legitimização de "anything goes", já que hoje nenhuma mundividência se pode legitimar.

Não queria enveredar aqui muito detalhadamente pela história do termo que, por acaso histórico, leva associado o nome de Lyotard. De vez em quando surge uma descoberta do seu uso ainda anterior aos já conhecidos.

Quando se tornou cliché referir que o termo proviera da arquitectura, usado por Joseph Hudnot no livro Architecture and the Spirit of Man (1949) e se repetia que Charles Jenks ajudara a popularizá-lo duas décadas mais tarde em conexão com a dança estilo-Judson, portanto antes de Lyotard, Werener Sollors veio revelar que ele surgiu primeiro impresso num conjunto de reflexões "étnicas" de Randolph Bourne". Todavia Steven Best e Douglas Kellner elaboraram uma "arqueologia do pós-moderno" que fazem recuar ainda mais o aparecimento do termo: usou-o Rudolf Pannwitz, em Die Krisis der Europaischen Kultur, para descrever precisamente o nihilismo e o colapso dos valores na cultura europeia coeva ${ }^{10}$. Mas anteriormente, indicam ainda Best e

7 Transcrito em David Harvey, The Condition of Postmodernism. An Enquiry into the Origins of Cultural Change (Oxford: Basil Blackwell, 1989), p. 43.

8 A expressão generalizou-se a partir de Paul Feyeranbend e o seu Against Method.

9 Werer Sollors, "The Idea of Ethnicity", in Walter Truett Anderson, ed., The Truth About Truth. De-confusing and Re-constructing the Postmodern World (New York: G. Putnam's Sons, 1995), p. 62.

10 Steven Best and Douglas Kellner, Postmodern Theory. Critical Interrogations (New York: The Guilford Press, 1991), p. 4. Os autores indicam terem encontrado essa informação em Wolfgang Welsch, Unsere postmoderne Moderne (Weinheim: VCH, 1988), pp.12-13. 
Kellner, já o pintor inglês John Watkins Chapman, por volta de 1870 , falou de "pintura pós-moderna" para designar a pintura francesa mais moderna e avant-garde do que a impressionista. Curiosamente, Arnold Toynbee adoptou o termo que D. C. Somervell empregara na versão abreviada de A Study of History. Somervell e Toynbee sugeriram a designação de "idade pós-moderna" a começar em 1875, um período segundo Toynbee caracterizado por guerras, agitação social e revolução, uma época de anarquia e relativismo total. O historiador contrapusera à idade moderna, caracterizada pela estabilidade social, racionalismo e progresso, outra que, por contraste, lhe sucedera, uma idade de crise ("time of troubles"), marcada pelo colapso do racionalismo e do ethos do iluminismo." A arqueologia de Best e Kellner prossegue incluindo mesmo o sociólogo americano C. Wright Mills que terá usado o termo em 1959 para referir a época que se segue à Idade Moderna. ${ }^{12}$ A lista prossegue e merece ser consultada como exemplo do fenómeno da voga intelectual que acaba por associar um termo a um autor a quem a paternidade não pertence.

Seria altura de tentarmos uma definição de pós-modernidade. O que se segue é a tentativa de filtrar, de uma infindável lista bibliográfica, o que me parece constitutir o cerne da questão. Para levá-lo a cabo com algum sucesso, evitarei tanto quanto possível a terminologia que me faria inclinar para a posição de A ou B. Procurarei sobretudo analisar e argumentar com a maior limpidez conceptual que me for possível. Porque "pós-moderno", como dizem Agnes Heller e Ferene Fehér, "é um conceito em todos os aspectos parasítico de modernidade" 13 , convém começarmos então por esse outro de "moderno" ou, se preferirem, "modernidade".

O melhor processo de uma aproximação do conteúdo do conceito será identificarmos as crenças dominantes associadas à visão que se sobrepôs à mundividência medieval. Elas são:

1. ${ }^{\circ}$ - O universo é conhecível e o ser humano é senhor do seu uso

$2 .^{\circ}-$ Todos os seres humanos são livres e iguais

$3 .^{\circ}-\mathrm{O}$ ser humano é perfectível ${ }^{14}$

"Best and Kellner, op. cit., p. 6.

12 Ibidem. Em epígrafe, o livro de Best e Kellner traz uma série de citações que remontam ao poeta John Donne e parecem "pós-modernas". A de John Donne é: "Tis all in pieces, all coherence gone". (p. viii)

13 Agnes Heller and Ferenc Féher. The Postmodern Political Condition (New York: Columbia University Press, 1988), p. 11.

${ }^{14}$ Devo a Cora du Bois o texto inspirador desta síntese, que tenho procurado desenvolver: "The Dominant Value Profile of American Culture", in Ronald Shinn, ed., Culture and School. SocioCultural Significances (San Francisco: Intext Educational Publishers, 1972), pp. 76-80. A autora pretendia apenas captar o perfil da cultura norte-americana, mas apercebi-me de que não era apenas isso que estava em presença. Os três axiomas fundamentais que apontava como fundamentais da mundividência da cultura dos EUA são, no fim de contas, os mesmos da modernidade. 
Creio, todavia, que anteriormente a todos esses axiomas, e servindo-lhes de suporte, embora eles sejam aceites como dados ${ }^{15}$, temos de pressupor a crença de que o mundo é bom ${ }^{16}$. Assim, a razão será a linguagem-ponte que permitirá interligar e harmonizar aqueles axiomas entre si.

Do primeiro axioma resulta toda a legitimidade da ciência, da tecnologia e do capitalismo. Não será necessário entrarmos aqui em localizações históricas do surgimento dessas crenças, mas presumo estar a pisar terreno seguro apontando a reforma protestante e, em parte, o Renascimento, como as marcas mais fortes dessa viragem. ${ }^{17} \mathrm{Na}$ ciência, como em tudo o mais, o critério fundamental de verdade vai fundamentar-se na experiência e na razão, já não na autoridade nem na revelação. ${ }^{18}$

Do segundo axioma resulta a democracia, com os seus conflitivos ideais de liberdade e igualdade em busca de harmonização, mas nem por isso menos fundamentais. ${ }^{19}$

15 Os autores da constituição americana, um belo exemplo da tentativa de pôr em prática toda a mundividência da modernidade, chamaram-lhes "self-evident truths".

${ }^{16}$ Ao aplicar à modernidade esses axiomas de Du Bois, apercebi-me de que lhes faltava um outro mais abrangente relativo à bondade do mundo. A ideia de um tetraedro com três faces assentes nessa nova attitude perante o mundo, não mais "inimigo da alma" mas lugar para se estar e viver em condições que podem melhorar.

${ }_{17}$ Max Weber, A Ética Protestante e o Espírito do Capitalismo e Robert Merton, Science and Technology in Seventeenth Century England (New York: Howard Fertig, Inc., 1970)

18 A mentalidade científica moderna está magistralmente captada nestes dois parágrafos de Telling the Truth About History:

"One of the earliest histories of science survives from the 1750s in a set of scientific lectures given to aristocratic gentlemen and ladies in The Hague. It told the story of science from Copernicus onward, as one of genius following upon genius, and the tale unwound while the lecturer taught the fundamentals of the new science: heliocentricity, Boyle's law of gases, Newton's law of universal gravitation. The truth of the laws only seemed to confirm the truth of history. The lecturer also explained how the universe was an ordered and harmonious place to be mastered by science, to be improved by simple machines and mathematical rigor applied to earthly as well as celestial phenomena. This eighteenth-century history of science did not differ substantially from what was taught right up to the 1950s.

For the philosophes of the Enlightenment the victory of science had been revolutionary. It meant the victory of reason over superstition, or as they put it, of light over the powers of darkness. "Let Newton be and all was light,"said Alexander Pope. Predictably, given the force of Christian imagery in the West, science also had its prophets, saints, and martyrs who preached not dogma for new heavens but method for inventing a new earth." (pp.18-19) As autoras indicam em nota que as ditas conferências mencionadas foram proferidas pelo Prof. S. Koenig, em Haia, nos anos de 1751-52.

19 A teoria da justiça proposta por John Rawls é a mais eloquente demonstração de que as grandes questões da ética contemporânea se resumem a uma harmonização dos princípios da liberdade e da justiça. Ver John Rawls, A Theory of Justice (Cambridge, MA: Harvard University Press, 1971). 
Ao terceiro axioma está inerentemente associada a ideia de progresso e dela resultam todas as instituições destinadas a melhorar o ser humano e a torná-lo mais apto a usufruir dos bens viabilizados pelos axiomas anteriores. A educação, como meio de perfectibilidade, enquadra-se neste conjunto.

Atrás, disse assentar este tripé - ciência/tecnologia, liberdade/igualdade e progresso - numa valoração ética fundamental: o mundo é bom. Não no sentido rousseauano, mas em contraposição à atitude da teologia cristã medieval que considerava o mundo um lugar de passagem, para mais, capaz de pôr em perigo o Outro Mundo, o Bom. Todos nós sabemos quanta influência a teologia protestante (a teologia das realidades terrestres) exerceu na teologia católica que precedeu a criação de um documento como a Gaudium et Spes, no Vaticano II. Quanto à origem protestante dessa atitude positiva em relação ao mundo material, basta recordarmos aqui a tese de Max Weber sobre a ética protestante e o espírito do capitalismo, nomeadamente os capítulos relativos ao surgimento do "ascetismo terreno" por oposição ao ascetismo voltado para o "Outro Mundo".

Se esta síntese consegue englobar os axiomas fundamentais da ideia de modernidade, será então altura de passarmos à de "pós-modernidade". Vou sugerir, e tentar argumentar devidamente, que esta última não é propriamente a substituição da mundividência moderna, mas uma tomada de consciência das limitações resultantes da implementação dos seus postulados desta.

Na verdade, ao lermos Lyotard ou Foucault, Derrida ou Rorty, Habermas ou Baudrillard, fica-nos a sensação de que o edifício da modernidade não é destruído, mas as suas bases, que até há um século pareciam sólidas e inamovíveis, já não assentam mais (aliás, não assentaram nunca, apenas se acreditou que assentavam) em superfície inabalável. Todavia, o edifício não se desmorona só por nos apercebermos de que os seus alicerces têm limites.

Mas será melhor irmos por partes analisando um por um os axiomas da modernidade postos em causa pelo pós-modernismo:

1. ${ }^{\circ}$ - Não mudou a atitude geral sobre a ciência. Cada vez mais desmembrada em novas sub-áreas, ela prossegue a sua busca de respostas sobre a constituição do universo.

O conhecimento empírico-racional continua a não ser posto em causa e por todo o lado poderíamos traduzir o discurso politico, desde Clinton a qualquer ministro português ou francês da Educação, nesse conceito chave de Francis Bacon: "knowledge is power". Os países desenvolvidos não substituiram as suas crenças na ciência e na tecnologia; aperceberam-se simplesmente de que os recursos naturais têm limites e o seu uso pode levar ao abuso e redundar em prejuízo dos próprios interesses humanos. As legítimas preocupações com a poluição, a clonagem, a contaminação do ambiente, as experiên- 
cias com animais nos laboratórios, não constituem obstáculo nem argumento contra a ciência e/ou a tecnologia, mas levantam sérias questões pontuais sobre abusos. ${ }^{20}$

Vejamos, porém, o que acontece em relação ao segundo axioma. A liberdade continua a ser um ideal que se quer intocável, e uma considerável franja da humanidade exige agora dos poderes mais atenção a esse outro ideal, o da igualdade ${ }^{21}$. A democracia, por mais defeitos que lhe queiramos pôr (lembremos a afirmação de Churchill: "a democracia é o pior dos regimes políticos, exceptuados todos os outros") continua igualmente no topo da escala de valores euro-norte-americana. Qualquer que seja a nossa posição sobre as teses de Fukuyama acerca do fim da história, não resta dúvida de que a democracia como regime político continua a não ser posta em causa, e nem sequer os arautos do pós-modernismo o têm feito. O que acontece é esta sensação de crescente dificuldade de se conseguir harmonizar os princípios da justiça e liberdade. Quer dizer, o segundo axioma continua intocável, embora hoje, graças a pensadores que vão de Marx a Foucault, tenhamos uma visão muito menos nä̈ve sobre as forças de poder que toldam a limpeza dos conflitos de harmonização. O século XX foi testemunha, e parece que o novo milénio continuará a sê-lo também, de tragédias resultantes da prossecução desses dois princípios. Como muito bem disse Armand Petitjean, "o mundo está cheio de ideias europeias que se tornaram loucas" ${ }^{\text {"22 }}$. Curiosamente, foi a morte de uma dessas "ideias europeias que se tornaram loucas" - o marxismo - que chamou a atenção para as consequências dramáticas dos outros postulados da modernidade. Outra, o nazismo, teve o seu impacto, mas não acelerou a disseminação do pós-modernismo. A isso voltaremos adiante.

Antes de passarmos ao axioma seguinte, gostaria de frisar um pormenor

${ }^{20}$ Com o subtítulo "Science, logic, mathematics, well formulated theories, empirical research", no texto introdutório às comunicações do congresso intitulado "After Postmodernism" pode ler-se: "We think that postmodernism does not relate pertinently to these topics. The postmodern critique of science provides no re-understanding of anything specific in science; it has no import for how we understand scientific procedures and findings, or how we might reconceptualize a scientific object. It has little to say to science beyond globally denigrating all of it as obviously not "objective," not free of all sorts of assumptions. This insight must lead to more than arbitrariness." Ver na Internet http://www.focusing.org/philo.html. Versão colhida em 28 de Dezembro de 1997.

${ }^{21}$ Recordo que, nos Estados Unidos, são os liberais e a esquerda (os círculos em que mais se fala de pós-modernismo) os maiores objectores de qualquer intervenção do estado na Internet, apesar dos sérios perigos que correm as crianças e os adolescentes. A defesa tem sido feita sempre com base na Primeira Emenda à Constituição, isto é, o direito à liberdade de expressão.

${ }^{22}$ Armand Petitjean, "L'Europe, continent de l'avenir", in Science Culture Information (lettre du groupe Science Culture), 14 de Maio de 1986. 
relativamente à questão da igualdade, uma vez que a minha categorização não parece acomodar devidamente a insistência pós-moderna na diferença, ou melhor, no direito à diferença. Do meu ponto de vista, essa continua ainda a ser uma luta pela igualdade, mas aqui com um ajustamento semântico. Os movimentos pós-modernos de afirmação de minorias reclamam que seja estabelecida a sua diferença do mainstream, que se lhes reconheça uma identidade própria para que melhor lhes seja reconhecido o direito à igualdade, que significa, ao fim e ao cabo, uma igualdade de direitos nas sociedades em que vivem. Portanto, o objectivo global é ainda a igualdade, na sua dupla dimensão de liberdade e justiça $a^{23}$.

O terceiro axioma é, dos três, o que mais tem sido afectado, sem no entanto estar completamente posto em causa. Se a ideia hegeliana, positivista e marxista de história em contínuo crescimento é hoje encarada como uma utopia, os movimentos feminista, gay, verde, anti-racista, anti-colonialista, e tantos outros, prosseguem na sua confiança quase ilimitada no progresso da sua causa. O pós-modernismo tem entusiastas entre muitos membros desses grupos. A democratização do ensino continua a ser um dos objectivos de todos os programas governamentais e não conheço pós-modernista que a ponha em causa a necessidade da sua existência. Pugnam, sim, por tipos de educação diferentes da institucional. Mas acreditam nela, no progresso e na perfectibilidade dos seres humanos.

De onde, pois, os abalos provocados pelo pós-modernismo?

O mais sério vem da tomada de consciência das limitações da linguagem. Wittgenstein, Heidegger, Davidson, Derrida, Rorty são alguns dos pensadores que mais contribuiram para ele. Posta em causa a capacidade de a linguagem espelhar o real, em causa fica também toda a epistemologia e, portanto, em princípio, a ciência, já que a linguagem por ela usada não permite sair de si própria de modo a poder usufruir-se de um olhar objectivo, plenamente isento, sobre o real.

Depois, um segundo golpe vem da tomada de consciência dos limites se ter alastrado à esfera da razão. O reconhecimento da existência de uma zona imensa da realidade que cai fora da alçada da razão deixa expostos à vista desarmada os limites da mesma. ${ }^{24}$

Um terceiro golpe vem da tomada de consciência da contingência dos valores, ao ser-lhes retirado o alicerce segurado na ideia de Deus. Foi a conclusão temida por Dostoievski: "Se Deus não existe tudo é possível."25

${ }^{23}$ A tolerância, por exemplo, não figura no tetraedo básico por ser um postulado resultante de outros dois valores: a liberdade e a justiça.

${ }^{24}$ Desenvolvi um pouco esta temática numa nota introdutória à tradução portuguesa de A Inteligência Emocional, de Daniel Goleman (Lisboa: Círculo de Leitores, 1997), pp. 9-15.

${ }_{25}$ Voltaire expressara essa mesma ideia de outro modo, incidindo no importante papel de freio exercido pela religião. 
Adivinho já as perguntas fervilhando na mente do leitor: Mas que há de novo nisso? Então Kant não abalou a objectividade do conhecimento? E não teve ele que inventar a razão prática para salvaguardar os princípios éticos e os valores do iluminismo? E Nietzsche não anunciou a morte de Deus e levou a cabo a desconstrução da moral elaborada pelo cristianismo? E o existencialismo não nos familiarizou com a questão da ausência de sentido? E Heidegger, e mais ainda o "segundo Wittgenstein", não nos deixaram bem conscientes de estarmos enredados nos (e um pouco à mercê dos) jogos da nossa linguagem? E Karl Popper não abalou irremediavelmente os sistemas metafísicos de fundamentação transcendente, tornando-nos conscientes da natureza incompleta das verdades em que hoje acreditamos? E toda a estética modernista da viragem do século XIX e de todo o século XX, não é afinal pós-modernista?

Precisamente. Essas dúvidas e interrogações tenho-as eu tido e expressado em debates sem fim sobre o pós-modernismo. Com efeito, como já escrevi noutros lugares ${ }^{26}$, estou convencido de que o pós-modernismo é uma questão que preocupou e preocupa sobretudo as elites intelectuais de esquerda que, após terem durante muito tempo abraçado o marxismo nas suas diversas variantes, perderam a fé nele e viram-se repentinamente sem os fundamentos sobre que assentava a sua mundividência, ou pelo menos a estrutura fundamental dela. O marxismo foi a religião secular dos intelectuais de esquerda, tendo substituído para muitos a ética do cristianismo ${ }^{27}$. Afirmei antes que o holocausto não provocou nesses sectores o desaire que agora a queda do marxismo desencadeia. É que as camadas intelectuais partilhavam uma ética inspirada pelo marxismo que lhes ditava crenças de fundo. Foi aliás essa mesma fé que funcionou como cegueira perante as denúncias de Gulag.

A agravante vem do papel hoje desempenhado pelos media que vulgarizam a sensação de contingência, trivializam os problemas e banalizam o relativismo.

Deixarei, porém, de lado estas considerações que pertencem mais a uma sociologia do pós-modernismo, embora não tenha podido deixar de referir a questão por ela nos ajudar a compreender precisamente esse tão tardio deflagrar da consciência pós-moderna, quando afinal a sua origem remonta mesmo ao auge da euforia modernista. Tudo isso explica por que motivo o marxismo

${ }^{26}$ Ver "O renascimento da "morte da ideologia"" e "Da inevitabilidade da ética e do imperativo dialógico entre alternativas", ambos publicados na Revista de Comunicação e Linguagens, n. ${ }^{\circ}$ 6/7 (1988), pp. 63-69 e n. ${ }^{\circ} 15 / 16$ (1992), pp. 51-60 respectivamente.

${ }^{27}$ Não conheço modo mais claro nem exemplo mais significativo de expressar esta realidade do que a quadra atribuída ao poeta Armindo Rodrigues:

Ó meu querido Partido

Comunista português,

Ao dares à vida sentido

Deste-me a vida outra vez. 
nunca suportou Nietszche e o erradicou da sua periferia até à década de sessenta deste século.

Abandonarei, todavia, agora e até ao fim deste ensaio estas considerações sociológicas para enveredar por outro caminho. Gostaria, na verdade, de questionar alguns excessos e desfocagens pós-modernistas em matéria de epistemologia, que grassam abusiva e levianamente mesmo entre académicos e intelectuais.

No ar paira hoje, um pouco por todas as sociedades avançadas, uma sensação de insegurança, de descrédito nas grandes utopias e até mesmo em ideais e projectos de largo alcance. Huyassens identificou esse estado de espírito colectivo nos seguintes termos:

\begin{abstract}
What appears on one level as the latest fad, advertising pitch and hollow spectacle is part of a slowly emerging cultural transformation in Western societies, a change in sensibility for which the term 'post-modern' is actually, at least for now, wholly adequate. The nature and depth of that transformation are debatable, but transformation it is. I don't want to be misunderstood as claiming that there is a wholesale paradigm shift of the cultural, social, and economic orders; any such claim clearly would be overblown. But in an important sector of our culture there is a noticeable shift in sensibility, practices and discourse formations which distinguishes a post-modern set of assumptions, experiences and propositions from that of a preceeding period..$^{28}$
\end{abstract}

Creio ser o sentido dos limites e das obstruções de toda a ordem; o reconhecimento das distâncias entre as utopias e a sua concretização, entre as ideologias e a praxis; a consciência mais funda dos conflitos inevitáveis na obtenção de bens antinómicos - como a liberdade e a justiça, por exemplo - e das tensões entre tendências divergentes - como o indivíduo e a sociedade que caracterizam o cerne da mundividência pós-moderna. Daí aos exageros do anything goes $^{29}$. Do reconhecimento do facto de nenhuma proposta ética ter qualquer justificação última puramente racional, ou de todas estarem no mesmo plano, à conclusão de que desapareceram os cânones, as hierarquias estéticas, éticas e mesmo epistemológicas, vai um salto abissal. E no entanto vemo-lo dado com enorme frequência.

Porque tenho abordado noutros lugares a falácia do anything goes aplicada à ética e à estética ${ }^{30}$, limitar-me-ei aqui a desenvolver um argumento de carácter epistemológico.

${ }^{28}$ Huyssens (1984), citado em David Harvey, op. cit., p.39.

29 Paul Feyerabend, que popularizou a expressão em relação à metodologia científica, mostrou-se surpreendido com (e discordante do) alargamento dessa sua perspectiva crítica a áreas não previstas por ele.

${ }_{30}$ Ver os dois ensaios atrás mencionados publicados na Revista de Comunicação e Linguagens, e bem como "Jacinto do Prado Coelho e a sua serena concepção da crítica literária", em Ana 
Com frequência encontramos asserções mais ou menos explícitas sobre a impossibilidade de se estabelecerem distinções analíticas entre dicotomias até há pouco tidas como plenamente defensáveis: sujeito-objecto; facto-valor; análise-sintese; história-ficção; razão-emoção; aparência-realidade; descriçãoavaliação, realidade-discurso e tantas outras mais. $\mathrm{O}$ erro corrente consiste em declarar-se a impossibilidade de se estabelecer qualquer distinção, transformando tudo numa imensa mónada leibnitziana. O que, com um pouco de esforço argumentativo, se poderia mesmo levar ao reducionismo total, nada mais nos restando do que uma mónada imensa como o universo, sobre o qual nada será possível dizer. Mas ou tudo é uma mónada, ou se reconhece diferenças.

Ocorre-me aquela estória (e faço notar que o humor é um excelente processo de argumentação filosófica por permitir rápidas reduções ao absurdo de pontos de vista à primeira vista defensáveis) de um rei que quis abolir o racismo no seu país e por isso mandou pintar toda a gente de azul. Um condutor de autocarro apôs então uma tabuleta, à entrada do seu veículo: "Azul claro para a frente, azul escuro para trás."

Os intelectuais e académicos poderão achar que não é legítimo falar em diferenças, mas o resto da humanidade fá-lo. E os intelectuais também, aliás, pois ganham a vida precisamente a estabelecer distinções conceptuais. Quando a questão é pessoal, como um caso de plágio ou difamação na imprensa, até recorrem aos tribunais para fazerem valer a força das suas distinções. Nunca vi nenhum pós-modernista aceitar a explicação de não se poder estabelecer diferença entre um comentário e uma difamação.

Os conceitos têm um centro, mas são abertos. Todos sabemos o que é uma mesa, mas não há dicionário capaz de explicar todas as características que a distinguem de um banco. E no entanto todos sabemos distinguir uma mesa de um banco. Os problemas surgem é nos casos intermédios. Mas pelo facto de surgirem dificuldades, ambiguidades, indefinições, aporias relativamente a situações intermédias, ninguém deixa de saber o que seja uma mesa e um banco. Outro exemplo? Por ninguém conseguir estabelecer com rigor onde termina o braço e começa a mão, ninguém vai negar a existência da mão ou do braço. O problema complica-se com o surgimento do pulso. No entanto, trata-se apenas de uma questão de reducionismo. Fazemos um zoom sobre uma realidade mais pequena. Continua a existir um pulso, embora ninguém saiba exactamente em que décimo de milímetro ele é já mão ou braço. Um exemplo idêntico poderá ser constituído pela cabeça, o tronco e o pescoço de permeio. O problema está, pois, nas periferias, nas sobreposições, e nas indeterminações inerentes a qualquer conceito, sobretudo aos conceitos abstractos que

Hatherly e Silvina Rodrigues Lopes (orgs.), O Sentido e os Sentidos. Homenageando Jacinto do Prado Coelho (Lisboa: Cosmos, 1997), pp.57-69. 
captam realidades humanas. Isso torna muito problemática a linguagem estética, a da ética, mas também, embora menos, a da história e a das ciências sociais. A essas mesmas dificuldades não escapam nem a biologia nem a química ou a física, se bem quem em muitíssimo menor grau.

A indefinibilidade, a ambiguidade, a polissemia e tantos outros termos do gosto pós-moderno cometem a falácia que poderíamos chamar de generalização do cinzento. Por existirem zonas cinzentas onde dois termos osmoticamente se misturam, não significa deixarem de existir zonas brancas (ou a tenderem para o branco), suficientemente distintas de outras pretas (ou a tenderem para ele). Isto equivale a dizer-se que com os conceitos ocorre o fenómeno captado nos diagramas das curvas de Bell. Os dicionários são a maior prova dessa realidade inultrapassável. Cada termo é definido por aproximações a outros. Mas isso não significa que exista identidade entre todos eles. Cada termo esbate-se mais e mais à medida que se afasta do centro. Se cada um tem um vizinho semântico que lhe é quase idêntico, ele vai-se distanciando gradativamente, como se num desenho de Escher.

As semelhanças entre um termo e os seus vizinhos diminuem à medida que aumenta a série destes. Uma mesa, a dada altura da série de muitas formas em que pode surgir, passa a ser um banco, como no arco-íris o amarelo se transforma em laranja. Na maior parte dos casos, o que pode debater-se é se ainda é amarelo ou já laranja. As divisões que estabelecemos são na verdade convencionais e por isso não indispensáveis. Variam mesmo de língua para língua ${ }^{31}$. Em momentos específicos, é possível determinar analiticamente que a realidade até então coberta pelo termo $x$ se transformou o suficiente para se passar a denominar $y$. Não estou a escalpelizar a questão. Fiz um seminário inteiro com Roderick Chisholm sobre ceasing to be e becoming, e tenho plena consciência das sérias dificuldades levantadas pelas áreas cinzentas. Voltando a Chisholm, lembro-me de um colega meu ter escrito um ensaio inteiro a demonstrar que não só existia a realidade da sombra e a do buraco do doughnut, de que falara Chisholm na aula, mas existia igualmente essa outra realidade distinta que era a do buraco na sombra do doughnut. No entanto, como nos argumentos de Zenão, a possibilidade de divisão é infinita, na prática ninguém funciona assim.

Os tribunais estão cheios de exemplos de gradações semânticas. Exemplifico com esta história real:

Um dia telefonou-me um advogado meu amigo. Irlandês-americano, aprendeu algum português no Brasil e, na Nova Inglaterra, tem com frequência clientes portugueses. Queria pedir-me para ir depor no tribunal. Um cliente

${ }^{31}$ Em português estabelecemos a distinção entre ser e estar, que não existe em línguas como o francês e o inglês. Distinguimos também maçã de pêro, que os ingleses englobam num só termo: apple. No entanto, os ingleses distinguem entre hope, expect e wait, enquanto nós temos apenas um termo para esses três verbos: esperar. 
seu, em altercação num bar com um compatriota, chamara puta à mulher dele. De mim, que queria então o advogado? Que fosse ao tribunal, como perito em língua portuguesa, explicar pura e simplesmente que em português a palavra "puta" tem inúmeros sentidos. O resto seria com ele. Respondi-lhe então: "Meu caro Sandy, compreendo teres de, no papel de advogado, defender o teu cliente. É verdade, sim, que a palavra "puta" em português tem muitos sentidos, mas quando um português num bar, zangado com outro, lhe diz "A tua mulher é uma puta", só tem um." E declinei o convite.

Dir-me-ão: Mas essa não é uma questão filosófica. Poderá não ser. É todavia um argumento contra o abuso, comum no discurso pós-modernista, de generalizar indevidamente a dificuldade de se lidar com os espaços cinzentos entre as palavras, como acontece por exemplo quando se pretende reduzir todo o real a texto, ou discurso.

Da dificuldade analítica de se distinguir absolutamente entre facto e valor não poderá concluir-se pela não existência de factos. Nenhum pós-modernista acreditará nisso a sério.

Como disse, elaborei alguns argumentos sobre estética e ética noutros lugares e, por isso, limito-me aqui apenas a argumentos de ordem epistemológica. Estou a ser pragmático, reconheço. Evidentemente que pressuponho a geral aceitação da possibilidade do conhecimento, enquanto ignoro o cepticismo, apesar de sabê-lo um sério problema filosófico. De acordo. Mas prossigo dentro da atitude pragmática de responder ad hominem a alguns exageros pós-modernistas. Se teoricamente o conhecimento - o knowledge as justified true belief da filosofia analítica - é metafisicamente impossível de obter-se e demonstrar-se em absoluto, na prática o cepticismo coerente é indefensável. Com efeito, não conheço cépticos a sério. E creio que se conhecesse, aplicaria a solução proposta por já não sei quem: Dêem-me um céptico que eu mandá-lo-ei caminhar em direcção a um precipício com ordem de nunca parar. Se ele se deter à beira do precipício, acabou-se o cepticismo. Se continuar, acabou-se o céptico.

Gostaria, antes de concluir, de aplicar pragmaticamente essa minha crítica à falácia da generalização ou universalização do cinzento. Deter-me-ei por isso em algumas das dicotomias acima mencionadas:

\section{Sujeito-objecto}

A fragmentação do eu, a despersonalização, a ausência de centro, o infindável debate sobre a mente-corpo ou sobre a consciência ${ }^{32}$ não eliminam

\footnotetext{
${ }^{32}$ Nos Estados Unidos é este um dos grandes debates contemporâneos. Veja-se a polémica entre Daniel Dennett (por exemplo, Explaining Consciousness) e John Searle (The Rediscovery of the Mind, entre outros).
} 
nenhuma das nossas questões diárias, nem o facto de existirmos como indivíduos com necessidades, interesses e desejos. Tal como a teoria da relatividade não alterou a vida do planeta e os cientistas continuaram a servir-se normalmente das leis de Newton. Quando muito, voltaremos de novo ao eterno problema da liberdade e do determinismo, tão antigo como a filosofia, nada pós-moderno portanto. A falta de solução teórica para questões milenárias sobre o ser humano nunca impediu a humanidade de agir e funcionar como se tivesse respostas. Nenhum postulado do pós-modernismo parece iluminar essas questões. Poderá, todavia, desmobilizar aqueles que acham que a busca, a procura de respostas, deve continuar a animar os que sentem inquietações.

Depois, se é verdade que, em última análise, o sujeito nunca consegue libertar-se completamente de si próprio na busca da realidade que se propõe conhecer, isso não signiifca que seja legítimo estabelecer-se um continuum intransponível entre o sujeito e a realidade a ponto de se negar toda e qualquer objectividade. A teoria da relatividade tem quase um século, o princípio da indeterminação tem pelo menos meio. Mas essas são realidades do universo microfísico. Para todos os devidos efeitos o mundo continua a funcionar em moldes semelhantes aos da engenharia: não temos respostas últimas sobre os strings, os genes, ou o núcleo do átomo (e nunca eventualmente as teremos), mas continuamos a construir as alicerces cada vez mais sólidos para pontes e arranha-céus, capazes de resistirem aos mais violentos desastres naturais conhecidos.

Entretanto, porque esta dicotomia é demasiado abrangente e problemática, permitam-me que passe à segunda, afinal um aspecto parcelar da primeira, e por isso mais facilmente tratável:

\section{Facto-valor}

Da dificuldade de claramente se distinguir entre facto e valor não se pode concluir pela abolição da diferença. As consequências seriam contra-intuitivas e imobilizadoras, nomeadamente no caso da história.

Atrás referi o congresso sobre o tema "After Postmodernism" anunciado nos Proceedings of the American Philosophical Association e realizado na Universidade de Chicago. Consultei na Internet a página indicada na notícia. Na nota introdutória à publicação electrónica das comunicações deparei com estas afirmações dos organizadores: "What postmodernism teaches is not new. Heraclitus said, "You cannot step into the same river twice" and his student added, "not even once, since there is no same river." E mais adiante: "recently a competent anthropologist's report on his field work engendered lively questions. Then he said: 'From postmodernism we know that there are no facts, so 
I can really say anything I want.' It stopped the discussion." Este pequeno incidente capta e ilustra na perfeição o cerne do problema no debate actual sobre a objectividade em história.

Peter Novick escreveu uma obra monumental narrando a odisseia da crença na objectividade na historiografia americana dos últimos cem anos That Noble Dream ${ }^{33}$. A sua tese é difícil de refutar: a objectividade é um mito. Depois, duas posições também recentemente argumentadas em livro exemplificam as duas tendências principais desse postulado: por um lado, David Harlan, em The Degradation of American History, ${ }^{34}$ propõe o abandono da busca quixotesca da verdade histórica e recomenda o retorno da disciplina à categoria de ciência moral, em que a história é interpretada como moralmente instrutiva da vida contemporânea. Joyce Appleby, Lynn Hunt e Margaret Jacob, propõem, por outro lado, em Telling the Truth About History ${ }^{35}$ que se continue incansavelmente à procura, mesmo sabendo de antemão que a objectividade total será sempre inalcançável.

Com efeito, se a objectividade é impossível, desastroso será deixar de procurá-la. Sou do tempo em que, como graduate student, tive de estudar o covering-law model de Carl Hempel, supostamente capaz de estabelecer as condições necessárias para o explanans captar toda a realidade do explanandum, tanto nas ciências naturais como nas sociais e até mesmo na história. Desconfiei sempre desse modelo, bem como da crença nas ciências, sobretudo as sociais, como value-free. Escrevi mesmo nesses idos anos 70 um ensaio em debate com o meu professor, Philip Quinn, que por sinal me vira um dia com o livro What is History, de E. Carr, e me dissera: "Esse é um mau livro." Carr defendia a impossibilidade de objectividade em história. Eu advogava no referido ensaio o que ainda hoje julgo defensável: a realidade é multifacetada, poliédrica. É impossível abarcá-la toda, qualquer que seja a nossa posição em epistemologia. Mas há que procurá-la, apesar das limitações. Estou, por isso, com as autoras de Telling the Truth About History, quando escrevem:

A democratic practice of history (...) encourages skepticism about dominant views, but at the same time trusts in the reality of the past and its knowability. All histories are provisional; none will have the last word. ${ }^{36}$

${ }^{33}$ Peter Novick, That Noble Dream. The "Objectivity Question" and the American Historical Profession (Cambridge: Cambridge University Press, 1988).

${ }^{34}$ David Harlan, The Degradation of American History (Chicago: the University of Chicago Press, 1997).

35 Joyce Appleby, Lynn Hunt and Margaret Jacob, Telling the Truth About History (New York: W. W. Norton \& Co., 1994).

${ }^{36}$ Op. cit., p. 10. 
O mesmo se poderia dizer sobre as ciências sociais em geral, onde a questão do facto e valor é crucial. $O$ Capital, de Karl Marx, quer se concorde com ele ou não, é uma tentativa séria de compreender e interpretar a realidade, uma tentativa de abordá-la científicamente. O Manifesto Comunista, porém, é um programa político, uma agenda política, com o objectivo de intervir na realidade para a alterar. Busca-se ou promove-se valores e não explicações científicas. O debate democrático das ideias é que deverá fazer vingar as interpretações do real com maior poder de penetração nele.

Voltando à história e a Telling the Truth About History, junto-me às autoras quando afirmam:

in contrast to the critics who decry the impending death of education, we endorse the insights and revisions made possible by (...) democratization. In this book we embrace a healthy skepticism, and we applaud the research that has laid the foundations for a multicultural approach to human histoy. But we reject the cynicism and nihilism that accompany contemporary relativism. We seek a vision of the past and an intellectual stance for the present that will promote an ever more democratic society. To achieve this aim, we think it essential to confront the current controversies over national history, scientific integrity, and the possibility of achieving truth and objectivity in human knowledge of the past. ${ }^{37}$

Em resumo, embora conscientes da incapacidade de sermos objectivos, não podemos deixar de tentar. E todas as nossas tentativas serão sempre de um determinado ponto de vista, porque o privilégio da God's eye view ${ }^{38}$ não estará jamais ao nosso alcance. Não podemos aspirar mais à verdade com letra maiúscula, essa terceira verdade da canção dos "Extreme", o famoso grupo de rock que tem um luso-americano por estrela, Nuno Bettencourt: "Há sempre três verdades: a tua, a minha e a verdade". Essa, que como uma bola de mercúrio parece constantemente evadir-se-nos das mãos, que nos surge multifacetada, poliédrica, às vezes gestáltica, contraditória e desconexa, deve continuar a ser o motor da busca tri-milenária em que embarcámos. Mesmo com a conviç̧ão de, quando supomos possui-la, nunca podermos ter a certeza absoluta dela, nem de ela continuar a parecer-nos a mesma no dia seguinte. De qualquer modo, a própria dúvida do dia seguinte deverá ser motivada por aquela pergunta que o velhinho Roderick Chisholm nos fazia nas aulas de Metafísica quando laboriosamente, durante um seminário de duas horas, procurávamos aperfeiçoar o rigor de uma afirmação escrita no quadro: "Are we getting closer to the truth?"

${ }^{37}$ Id., p. 4.

${ }^{38}$ Expressão preferível a God's point of view, frequentemente usada, uma vez que, por definição, a visão de Deus seria panóptica, sem ponto de vista. 
Como corolário do acima dito, acrescento apenas um ponto sobre a terceira dicotomia:

\section{Ficção-história}

Se aquilo que se procura fazer nas teses de doutoramento em história, por exemplo, não é uma tentativa de aproximação da verdade do acontecido, então é ficção e deveríamos, por coerência, fundir os departamentos de História com os de Literatura. Com efeito, quem diz que toda a história é ficção, e por isso a história se reduz a um capítulo da ficção literária, peca por usar o termo "ficção" equivocamente, falhando assim contra a primeira regra do silogismo aristotélico. Se a história é ficção, é-o por não termos a certeza, nem talvez podermos saber a verdade toda sobre o que se passou. Mas essa verdade foi procurada (ou pelo menos deveria tê-lo sido) por todos os meios disponíveis. A ficção literária não tem nunca a obrigatoriedade de buscar qualquer tipo de objectividade, não tem nenhuma obrigação de procurar reproduzir o real. Está livre de tentá-lo, se assim o quiser, mesmo na escrita realista. Pode inventá-lo, transformá-lo a seu bel-prazer, porque o objectivo da ficção é criar arte. Os dois géneros de escrita operam em planos radicalmente diferentes, com propósitos distintos, se bem que os resultados por vezes sejam pouco diferenciáveis. Mas essa é outra questão.

A tentação de reduzir toda a realidade à ficção (e o mesmo se diga ao texto) é provavelmente derivada da tendência logocentrista que persegue os intelectuais. Aqui, o argumento melhor é o daquele personagem-filósofo de uma história de Woody Allen: "Ele odeia a realidade embora reconheça ser ela o único lugar onde se pode encontrar um bom bife."

\section{Racionalidade-emotividade}

Porque futuramente tenciono debruçar-me sobre esta dicotomia, gostaria apenas de chamar a atenção para uma confusão frequente surgida a propósito de António Damásio e a dicotomia emotividade-racionalidade. Não foi Damásio quem descobriu as emoções nem que elas se misturavam com a racionalidade. O que o justamente prestigiado investigador português demonstrou em Descartes's Error foi que ambas essas dimensões são, em última análise, indissociáveis uma vez que uma região do cérebro parece ser responsável pelas emoções e que, na ausência delas (mesmo por razões físicas, como no caso estudado por Damásio, em que o doente ficara com um furo no cérebro), a pessoa fica sem motivações para optar por $A$ ou $B$. Isso não significa que a 
ideia de racionalidade deva desaparecer das nossas vidas porque tudo passa agora a ser apenas emotividade. A racionalidade há muito que vem sendo entendida como uma grelha ou rede de implicações que, aplicada a opções de fundo que a ultrapassam e transcendem, oferece regras de trânsito lógico entre elas. Os valores, as crenças estão para além a racionalidade, que apenas estabelece essas conexões lógicas entre uns e outras e ainda entre as opções e objectivos que uma pessoa faz ou se propõe.

\section{Conclusão}

De uma vez, num debate animado sobre multicuralismo, o famoso autor de um livro sobre o relativismo ético ${ }^{39}$ respondeu a uma observação minha com a frase: Você está absolutamente errado! Ao que respondi: Assim falou o relativista.

No atrás citado texto que introduz as comunicações ao congresso sobre "After Postmodernism", lê-se:

Many people sense that there is somewhere further to go. Yes, every assertion is made from some vantage point, and depends at least partly on culture, politics, and language, which we can only pretend to control. All assertions seem to pretend to control. All words bring an unavoidable "metaphysics." But, since it is unavoidable, can we do no more than constantly remind each other of it? Is the furthest thinking only decentering, undecidability, rupture, limbo, aporia, flux? For the most part it results in arbitrariness, stoppage, an inability to think further. ${ }^{40}$

Em epígrafe ao capítulo final do seu livro Truth. A History and a Guide to the Perplexed, Felipe Fernández-Armesto cita do filósofo Roger Scrutton a seguinte afirmação retirada da obra Modern Philosophy: "The man who tells you truth does not exist is asking you not to believe him. So don't". ${ }^{41} \mathrm{E}$, já agora nesta série de citações, recordo a frase do filósofo Hillary Putnam: "Desconstrução sem reconstrução é irresponsabilidade".

Como argumenta Cristopher Norris, o pós-modernismo nada pode fazer para pôr em causa as formas de injustiça e opressão, uma vez que não oferece argumentos, recursos críticos, nem critérios de fundamentação. A condição pós-moderna é hoje real. Quer queiramos quer não, a fragmentação operou-se

39 John Ladd, Ethical Relativism.

${ }^{40}$ Ver Introdução às comunicações do congresso publicadas na Internet: http://www.focusing. .org/philo.html

${ }^{41}$ Felipe Fernández_Armesto, Truth. A History and a Guide to the Perplexed (London:Bantam Press, 1997), p. 203. 
e os argumentos podem geralmente pouco contra qualquer fé. Para além da importância do reconhecimento das limitações teóricas e práticas que a história intelectual dos últimos cem anos nos tornou patentes, argumentos como este que aí fica à consideração do leitor servem pelo menos para confirmar a opinião dos convencidos de que os ideais da modernidade ainda não estão ultrapassados. Eles poderão, aliás, dentro do melhor espírito pós-modernista, continuar a investigar na área ou áreas que os apaixonam. Se o mundo de hoje é fragmentado e poliédrico, no mínimo essa atitude enriquecerá o pluralismo democrático das ideias.

Jürgen Habermas, um dos pensadores contemporâneos que mais se tem debruçado sobre a questão da modernidade, afirmou que "até onde é possível descortinarmos, ainda não existe nenhuma alternativa à modernidade que está hoje consciente das suas contigências ${ }^{42}$. Nesta frase, encontrada depois de escrito já este texto, serve perfeitamente para terminá-lo. Dir-se-ia que o iluminismo, apesar das luzes que nos trouxe, se vê hoje menos claro (o antropólogo Clifford Geertz usou uma magnífica expressão em título de um dos seus mais recentes livros: Available Light $^{43}$ ). Mas é o que podemos ver com a luz de que dispomos. Essa pouca luz é ainda bem melhor que as trevas. Além disso, como nos lembrou Rorty, essa é a nossa melhor esperança ${ }^{44}$

${ }^{42}$ Jürgen Habermas, A Berlin Republic: Writings on Germany. Trans. by Steven Rendall. Intro. By P. U. Hohendahl. Lincoln: University of Nebraska Press, 1997, p. 61.

${ }^{43}$ Clifford Geertz, Available Light: Anthropological Reflections on Philosophical Topics (Princeton: Princeton University Press, 2000).

${ }^{44}$ Richard Rorty, Philosophy and Social Hope (Middlesex: Penguin Books. 1999). 


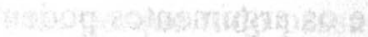

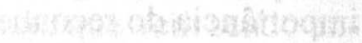

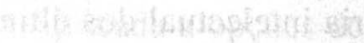
w

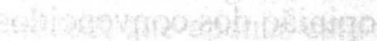

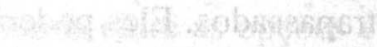

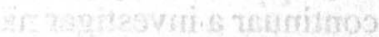

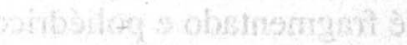

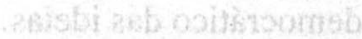

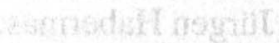

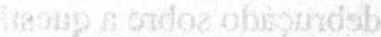

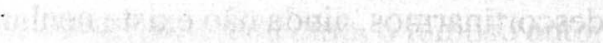

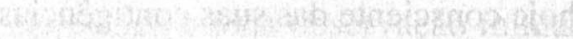

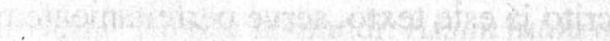

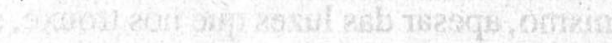

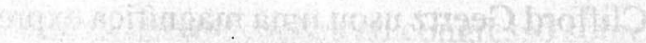

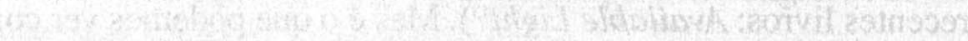

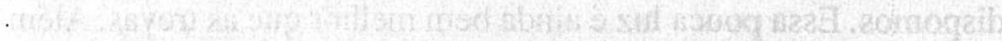

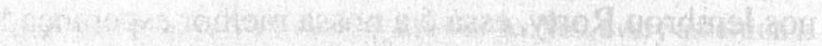

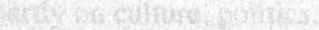
20.

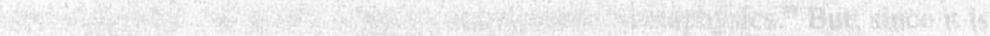

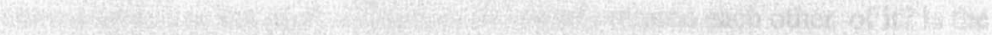
(a)

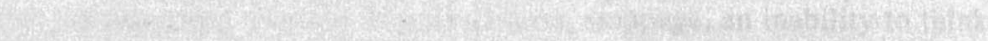

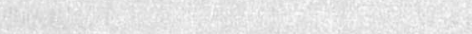

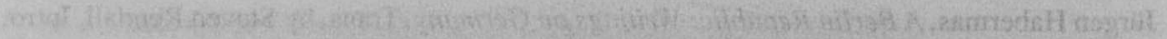

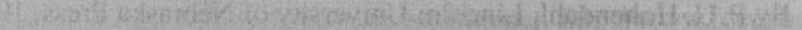

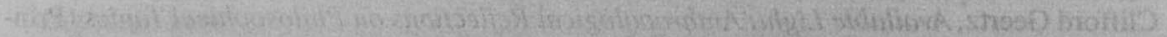

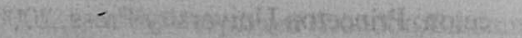

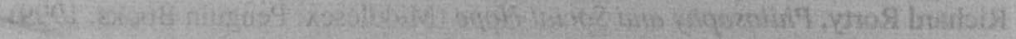




\section{UTOPIA \\ Conceito e concepção}

Luis Crespo de Andrade

FCSH-UNL e CHC

A publicação de De optimo Reipublicae Statu, deque nova insula Utopia, libellus vere aureus, nec minus salutaris quam festivus, de Thomas More, em Lovaina, no final do ano de $1516^{1}$, está na origem de um novo género literário e de uma nova modalidade de reflexão política, que passam a combinar-se entre si de forma indissociável.

A dificuldade em classificar esta obra inaugural à luz das categorias literárias e políticas tradicionais encontra-se assinalada no próprio título, complexo e ambíguo, quando considerado no seu enunciado inicial.

Ao indicar como objecto da obra a "melhor das repúblicas" e a "nova ilha da Utopia", More cria o vínculo inusitado que passa a unir a reflexão política à criação literária.

A tentativa de determinar a melhor forma de governo, seja em termos ideais seja por via comparativa, caracteriza o pensamento político antigo, como a evocação, no De optimo Reipublicae Statu, de A República de Platão recorda ${ }^{2}$. Narrativas de viagens a lugares imaginários encontram-se igualmente na literatura clássica, por exemplo na História verdadeira, em que Luciano de Samosata, cujo encanto atraía os utopianos ${ }^{3}$, conta uma hilariante ida à Lua. $\mathrm{O}$ ensejo de criar cidades racionais remota a legisladores célebres, designadamente a Licurgo, que Plutarco, igualmente apreciado pelos cidadãos da ilha imaginada ${ }^{4}$, celebra, em obra muito divulgada (conferindo-lhe o prestígio suficiente para a Constituição Espartana ser encarada como o antecedente a que a organização utopiana daria sequência ${ }^{5}$ ).

Seguimos a terceira edição - em que Thomas More altera e corrige alguns aspectos das duas primeiras edições, publicada em Basileia, em Novembro de 1518.

2 A evocação de $A$ República, implícita ou explícita, repete-se ao longo da obra, como a sestilha, o estatuto de marinheiro-filósofo do narrador e o tema do relacionamento entre o filósofo e o monarca, adiante referidos, documentam.

3 Utopia, p. 117.

4 Ibidem.

5 A ilha da Utopia remontaria, segundo os anais que conservaria, a mil setecentos e sessenta anos atrás (Utopia, p. 77). Feitas as contas e supondo que a obra foi escrita em 1515, a ilha teria sido criada em 245 a. C., ano em que Agis IV tentou, sem sucesso, restabelecer a constituição de Licurgo em Esparta (cf. André Prévost, L' Utopie de Thomas More, Paris, Éditions Mame, 1979, p. 677). A escolha da data da derradeira tentativa de repor a civilização espartana é, obviamente, simbólica. O seu significado transitara para a ilha a que Hitlodeu aportou. 
A novidade de De optimo Reipublicae consiste na síntese que a obra faz entre estes diferentes aspectos, ao tornar o seu vínculo uno e conexo, mesmo quando se supõe possível destrinçar os vários registos com que a sua trama se tece.

A simbiose indicada no título é desenvolvida num dos antetextos que acompanham a primeira edição, reproduzidos nas restantes edições publicadas enquanto More foi vivo, e ausente, por regra, nas edições posteriores.

Em sextilha intitulada a Ilha da Utopia, com suposta autoria de "Anémolius, poeta laureado, sobrinho de Hitlodeu pelo lado da sua irmã"6 mas saída, muito provavelmente, da pena de Thomas More, a novidade que torna a De optimo Reipublicae Satu preferível à própria A República de Platão é indicada e realçada:

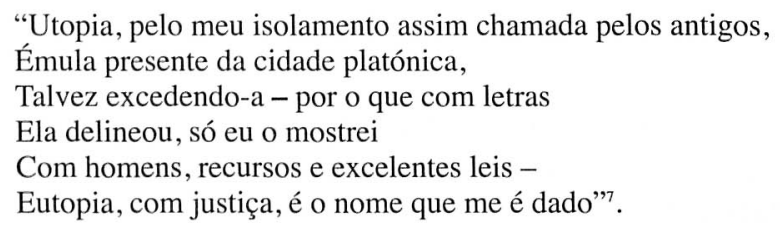

A vantagem da obra de More face à República de Platão residiria, à luz deste poema, na síntese do conceptual com o concreto, na medida em que o futuro chanceler inglês conferiria realidade existencial ao que o filósofo ateniense expusera dentro dos limites do discurso teórico.

A narrativa revelaria a vida quotidiana da boa cidade e demonstraria, ao mesmo tempo, os seus fundamentos.

É, certamente, esta dupla condição que legitima, aos olhos do autor, a qualificação da obra, na própria folha de rosto, como "libellus vere aureus, nec minus salutaris quam festivus".

Por um lado, o tema seria de grande relevância na análise da condição humana, pois só a boa disposição da vida pública poderia proporcionar uma existência conforme aos fins que se postulam para os homens. Por outro lado, a narrativa juntaria o salutar ao agradável, ao permitir uma leitura acessível e envolvente, seja do ponto de vista da satisfação racional seja por despertar sentimentos e aspirações elevados.

Nada indica melhor a natureza literária da obra do que o nome que Thomas More inventa para a nova ilha que Rafael Hitlodeu, o marinheiro-filósofo português, descreve.

Como se sabe, o prefixo "u", indica uma negação, mas não uma ausência.

Utopia, p. 11.

Ibidem. 
O novo vocábulo designa um "inlugar", um lugar que é um não-lugar. Ora, o lugar do não-lugar é, em primeira linha, um lugar de natureza ficcional A realidade da ilha não é física, mas literária. Na vintena de vocábulos, com raiz etimológica grega, que o humanista inglês cria ao longo da narrativa é possível ver tantas outras chamadas de atenção para a inventiva da narrativa, num efeito de denúncia da sua própria condição. O nome de Rafael Hitlodeu, o narrador, evoca simultaneamente o arcanjo Rafael, que curou Tobias da cegueira, e, de, forma aparentemente paradoxal, a prosápia do bem-falante, presente nos étimos clássicos do apelido. Amaurote - designada Mentirano, na primeira edição - é a capital da ilha da Utopia, um cidade obscura, semelhante a uma miragem, governada por um Ademo, magistrado «sem-povo», e atravessada pelo rio Anidro, transparentemente, o rio «sem-água» ${ }^{8}$.

Mas esta construção de uma realidade, que de si própria se distancia ao denunciar a sua condição imaginária, não seria arbitrária. Daria, pelo contrário, expressão concreta às aspirações de justiça e de humanidade, sentidas pela generalidade dos homens. Conferiria conteúdo ético-político e forma institucional à sociedade conforme à razão e ao são desejo humanos.

Neste jogo vocabular, a utopia seria também "eutopia", ainda que a presença explícita deste termo se encontre unicamente na sestilha transcrita.

Não se trata de um projecto político nem de uma realidade perspectivada pelo lado da sua eventual tangibilidade. A fala final em que o narrador, que Thomas More identifica consigo através de episódios de fundo autobiográfico, comenta o discurso de Hitlodeu é a este respeito clara: "é-me fácil confessar que, na República dos Utopianos, existe um grande número de disposições que desejaria ver nas nossas cidades; em minha opinião, seria mais verdadeiro desejá-lo do que esperá-lo"

Se a leitura programática parece, pois, deslocada, a leitura alegórica, ao ver na obra simplesmente um sentido edificante, resultante do confronto entre o mundo quotidiano e uma realidade exemplar, afigura-se parcelar e redutora.

Enquanto expressão do imaginário simultaneamente racional e social, a utopia é uma ideia-imagem, para utilizarmos a expressão Bronislaw Baczko ${ }^{10}$, à semelhança de algumas outras representações correntes, como a de Paraíso ou, mais tarde, a das ilhas dos mares do Sul, em que a representação sensível e a construção conceptual se complementam reciprocamente.

Este conceito ambígeno, resistente à apreciação através das categorias filosóficas e literárias correntes, consubstancia uma modalidade de abordagem

${ }^{8}$ Cf. Utopia, pp. 74, 75, 84.

9 Ibidem, p. 162.

${ }^{10}$ Cf. Bronislaw Baczko, Les imaginaires sociaux. Mémoires et espoirs collectifs, Paris, Payot, 1984, p. 109. 
dos fenómenos políticos e sociais, que interroga e analisa segundo uma inteligibilidade específica.

Para a captar, basta considerar a organização da obra de More, dividida em dois livros: o primeiro sobre a vida política do seu tempo, que tornara as ovelhas mais ferozes do que os lobos, e o segundo constituído pela narrativa em que Hitlodeu dá conhecer a "República santa que mesmo os cristãos deviam imitar" (apesar de os seus habitantes desconhecerem a Boa-Nova cristã).

A distância entre estes dois mundos diametralmente opostos é incomensurável. Tão fundo é o hiato, literal e figurativo, que separa a Inglaterra e a restante Europa da Ilha da Utopia, situada muito para além do ponto mais afastado dos oceanos que o homem atingira, exactamente aquele que Vespúcio descreve no muito célebre Quatuor Americi Vespuccii navigationes, publicado em 1507, e que More escolhe como ponto de partida de Rafael Hitlodeu para o novíssimo mundo.

Esta oposição, sem meio-termo viável, pois o filósofo encontrar-se-ia excluído da cidade e a via oblíqua dos compromissos reformistas estaria afas$\operatorname{tada}^{12}$, separa irremediavelmente a ordem social existente da que seria justa e desejável.

Este desencontro contém, em si, um duplo sentido. Por um lado, confere à utopia o significado corrente de um devaneio irrealista. Por outro lado, transfere o âmbito da reflexão política para o domínio da ordem social que proporcionaria a satisfação dos anseios humanos tidos por mais substanciais.

A inteligibilidade política utópica, cujo sentido assim se esboça, resulta de duas grandes interrogações que determinam os pressupostos e o teor gerais das suas formulações.

Pretende, por um lado, esclarecer a forma e o conteúdo da sociedade feita à medida da satisfação da condição humana, isto é, definir os contornos institucionais e sociais que possibilitariam que cada indivíduo cultivasse frutuosamente os atributos de humanidade que lhe seriam próprios.

Levanta, por outro lado, a questão, ainda que implícita, de saber o que impede o homem, que tudo tende a ordenar e a transformar à sua medida, de agir racionalmente no domínio que lhe é mais importante, isto é, naquele que lhe proporcionaria o seu bem-estar mais profundo, já que os homens não estenderam a sua vontade e poder à criação de uma ordem social justa, a única que favoreceria e permitiria alcançar os seus anseios mais intensos.

Estas interrogações conduzem a que a reflexão sobre a organização política e social se veja colocada no domínio do dever-ser político, no foro do fundamento e da figuração da sociedade justa.

\footnotetext{
11 Ibidem, p. 94.

12 Vide ibidem, pp. 53 e ss.
} 
Nesta aspecto central, a abordagem de Thomas More contrasta manifestamente com a de Maquiavel, que redige $O$ Príncipe exactamente na mesma época, já que o pensador florentino, ao se ocupar da realidade política tal como esta se apresenta a quem governa, confina o objecto do saber político ao mundo do primeiro livro da Utopia, recusando o percurso que conduza ao confronto com uma qualquer cidade idealizada.

Sendo assim, a modalidade de reflexão política utópica distingue-se, antes de mais, pela alteridade radical.

Trata-se de conceber uma nova realidade política, antitética da existente. Um novo mundo, não só por a ilha ter a forma premonitória de quarto crescente, mas também por a sua criação, resultante do corte do istmo que a ligava a outras paragens, ser a primeira obra dos utopianos ${ }^{13}$. Um novo homem, na medida em que se "eleva uma horda grosseira e selvagem ao grau de civilização e cultura que a coloca acima de quase todos os outros povos"'14. Uma nova comunidade, com instituições justas e democráticas. Uma nova e definitiva era, sem história nem alternativa, pois a ordem criada por Utopus é definitiva, como é próprio de qualquer legislação ideal ${ }^{15}$.

A Utopia faz tábua rasa do passado. Assenta no pressuposto de que o mundo injusto comporta uma inércia inultrapassável, enquanto a irrupção dos homens numa ordem social justa leva-os a reproduzi-la, na medida em que reconhecem a bondade das instituições.

A cidade nova é naturalmente a cidade racional: ordena o espaço, fazendo que aquele que tenha visto uma das vastas e magníficas cidades conheça as cinquenta e três restantes ${ }^{16}$; reforma os costumes, ao eliminar a propriedade e prevenir a vaidade ${ }^{17}$; regulamenta o quotidiano, quando dispõe sobre a actividade própria de cada hora ${ }^{18}$.

Porém, o essencial da sua racionalidade manifesta-se na definição da finalidade que a nova ordem social visaria: fazer com que cada um despenda o mínimo de horas "com as servidões do corpo, a fim de permitir a todos os cidadãos consagrá-las à liberdade da alma e à cultura do espírito (...) em que residiria (...) a felicidade da existência"'

A generalidade dos utopianos dedicava, aliás, as primeiras quatro horas de cada manhã ao estudo, frequentando conferências públicas ${ }^{20}$.

\footnotetext{
Cf. Utopia, p. 71.

Ibidem.

Cf. ibidem, p. 86.

Cf. ibidem, p. 72.

Cf. ibidem, p. 76

Cf. ibidem, p. 80.

Ibidem, p. 81 .

Cf. ibidem, p. 81.
} 
A cidade racional - distinta do milenarismo porque alheia a qualquer revelação ou profecia - é-o exactamente porque dispõe as suas instituições de modo a tomar o homem como fim, ao possibilitar a cada um e a todos as condições mais propícias para cumprir as tarefas imputadas à humanidade que lhes seria intrínseca.

Envolve, naturalmente, uma representação optimista da condição humana. As percepções do homem como ser sofredor que expia uma falta insanável em vida, como lobo do seu semelhante, ou, mesmo, como madeiro irremediavelmente torto encontram-se excluídas, pois revelam-se incompatíveis com a possibilidade de conceber a boa comunidade. O homem é visto, ao invés, como salvação e consolo do próprio homem: "é necessário glorificar sob o título de humanidade - escreve More - o facto de que o homem é para o homem salvação e consolo, porque é essencialmente 'humano' - e não há nenhuma virtude que seja mais própria do homem do que esta - de suavizar tanto quanto possível as dores dos outros, de fazer esquecer a tristeza, de trazer o gosto de viver, isto é, prazer"21.

Trata-se, assim, de uma cidade solar, como Tommaso Campanella, the chamará nos primeiros anos do século XVII, de tal modo a razão, alheia a qualquer sombra, se revelaria capaz de conferir forma e conteúdo ao desejo de criar um mundo à escala dos homens.

Se perspectivarmos a literatura e o pensamento utópicos como representações idealizadas da organização política, expressas na concepção de sociedades racionais e justas, que se instituem a si mesmas na obediência estrita a imperativos ético-políticos, nomeadamente os decorrentes das finalidades imputadas à condição humana, aproximamo-nos de um conceito em que a utopia se define como modalidade peculiar de reflexão e de desenho da cidade, abarcando um leque amplo e diversificado de discursos e imaginários sociais, da simples ficção à aplicação da lei revolucionária.

Esta aproximação, de fundo conceptual e analítico, sobre uma modalidade particular do pensamento político não faz esquecer que também as cidades ideais são históricas (e, nesse sentido, o reverso da ausência de mudança que caracterizaria a ilha da Utopia).

A liberdade de espírito que se manifesta na crítica severa às instituições inglesas e dos restantes reinos da cristandade, explícita no primeiro livro, estende-se a toda obra, num jogo irónico e contundente de contrastes. A circunstância de a ilha ter cinquenta e quatro cidades e a Inglaterra ter Londres mais cinquenta e três condados, ou de Amaurote, a capital, se distinguir por uma ponte emblemática são algumas das referências em que se apela ao leitor para confrontar dois mundos colocados em paralelo. A transferência da crítica para local remoto ou a simples demonstração de que o possível excede em muito o

${ }^{21}$ Ibidem, p. 104. 
existente são artifícios proporcionados pelo género com óbvia intervenção na vida colectiva próxima.

O próprio imaginário utópico surge inscrito no imaginário muito mais vasto que envolve a descoberta de novos mares, de novas terras e de novas gentes Como se sabe, não só as cartografias míticas, clássica e cristã, com as suas sereias e o próprio Paraíso Terrestre, não se encontravam excluídas dos mapas por que estes mareantes se guiavam, como também os relatos destes últimos, testemunhos empíricos lidos com a avidez própria de quem se vê confrontado com seres desconhecidos, serviam-lhe de confirmação, reflectindo muitas vezes mais as expectativas prévias do que o rigor posto na observação que se documentava. $\mathrm{O}$ imaginário utópico prolonga e recria a verosimilhança fantástica e maravilhosa dos oceanos e dos mundos desconhecidos.

Já o quotidiano da vida entre os utopianos encontra a sua inspiração na vida conventual. More conhecia-a bem, pois fora familiar na Cartuxa, em Londres. A ausência de propriedade privada, a uniformidade no vestuário, a partilha das refeições, a divisão das tarefas colectivas e a sucessão das diferentes actividades ao longo do dia - das quatro horas matinais de estudo às oito nocturnas previstas para o sono - exemplificam-no, ao revelarem afinidades claras com as regras conventuais, mormente com a regra beneditina.

$\mathrm{O}$ interesse pelos textos antigos manifestado pelos utopianos, já referido a propósito de obras de Luciano de Samosata e de Plutarco, presente igualmente no empenho colocado na aprendizagem do grego $^{22}$, bem como na simpatia que manifestada pelo exemplo da vida de Cristo com os apóstolos ${ }^{23}$, são convergentes com o retorno às fontes, clássicas e bíblicas, que rompe com os critérios de autoridade e de transmissão tradicionais, próprios da erudição e do empenho dos autores humanistas.

Em limite, a própria ilha da Utopia pode ser legitimamente interpretada como a projecção, à escala de um país, dos grandes desígnios da República das Letras, mormente os do cultivo do espírito e da amizade, qualidades maiores, realçadas, desde as primeiras páginas, na caracterização de Pierre Gilles ${ }^{24}$ (anfitrião a quem More dedica a primeira edição). Na origem do interesse que os utopianos dedicavam ao estudo das letras e do empenho colocado no consolo do semelhante, em que o ideal de utopiano de felicidade se exprime, encontram-se as grandes finalidades e as motivações do ideário humanista.

Assim considerada, a Utopia apresenta-se como encenação política e social que proporcionaria o melhor contexto para a efectivação, individual e generalizada, de um conjunto particular de postulados acerca da consumação

\footnotetext{
22 Ibidem, p. 116.

${ }^{23}$ Ibidem, p.142.

${ }^{24}$ Ibidem, p. 26.
} 
do humano nos homens, pois é na perspectiva de concerto auspicioso entre os fins imputáveis à natureza humana e as condições concretas de vida dos indivíduos que os fundamentos da cidade desejável se alicerçam.

No seu sentido geral, a melhor república representa uma hipóstase política e social da concepção humanista da humanidade.

A distinção analítica entre a modalidade utópica de inteligibilidade política e o ideário histórico de que cada utopia é o expoente apresenta ainda a vantagem de permitir relacionar o discurso utópico moderno com o contemporâneo, ao evitar que os diferentes registos em que a reflexão sobre a melhor comunidade se expõe sejam compreendidos como constituindo realidades dissemelhantes (ou mesmo opostas entre si). Desde logo, contraditórias nos termos, na medida em que a pretensão de implantar uma república que seria - à luz de um entendimento que se confine ao significado inicial da sua designação - um simples produto da imaginação, representaria um desígnio insano e um empreendimento quimérico.

A inclusão num mesmo olhar da literatura utópica, tal como surge nos tempos modernos, e do discurso utópico, tal como se afirma no século XVIII, é, a vários títulos, relevante.

Permite, em primeiro lugar, relacionar, à luz de uma mesma aproximação, duas épocas "quentes" na história do pensamento utópico, em que as "utopias florescem, onde a imaginação utópica toma as formas mais diversas da actividade intelectual, política, literária, época em que as linhas de força divergentes parecem encontrar o seu ponto de convergência na produção de representações utópicas"25.

Possibilita, em segundo lugar, captar, na origem, algumas dos principais modelos de reflexão sobre a forma de governo idealizada e do imaginário que necessariamente a acompanha.

A própria Fortuna encarregou-se de combinar a transição do modelo da narrativa utópica moderna para o modelo do discurso que apresenta a cidade nova como projecto doutrinário, assim como para a própria acção revolucionária que visa alcançá-la, numa sucessão de momentos sequenciais.

$\mathrm{O}$ Code de la nature ou le véritable esprit de ses lois de tout le temps negligé ou méconnu, de Morelly, editado em 1755, simboliza esta passagem.

Nesta obra, o autor, relativamente obscuro, fundamenta, de forma sistemática, os pressupostos a partir dos quais elaborara a narrativa que intitulara Naufrage des îles flottantes ou basililiade di célébre Pilpai, ficção em que canta "o reino aprazível da Verdade e da Natureza, estabelecido definitivamente para um povo afortunado"26.

25 Bronislaw Baczko, Lumières de l' utopie, Paris, Payot, 1978, p. 19.

${ }^{26}$ Morelly, Naufrage des îles flottantes ou basiliade du célébre Pilpai, Messina, Par une Société de Libraires, 1753 , p. 1. 
Recorre, nesta resposta àqueles que criticaram o poema, quer à argumentação doutrinária, quer à enunciação da legislação que lhe conferiria à narrativa verosimilhança, crente de que uma moral conforme à "afeição beneficente" e ao "desenvolvimento da razão" imporia "o espírito e os motivos da sociabilidade, uma indústria, uma previsão unânime, enfim, todas as ideias directa ou indirectamente respeitantes á felicidade comum"27.

A doutrina então exposta, inicialmente atribuída a Diderot, converteu-se, poucas décadas volvidas, em fundamento da acção política revolucionária, sendo apresentada por Graccus Babeuf e por aqueles que com ele se conjuraram como contendo os fundamentos ideário que perseguiam ${ }^{28}$.

Ao compartilhar o optimismo racionalista da época, Morelly é levado a supor que o seu Código enuncia leis similares às das ciências naturais, revelando como o prestígio próprio do conhecimento científico, tido como razão definitiva, tendia a fazer que este se sobrepusesse aos saberes anteriores, designadamente à cultura de teor literário.

A par da compreensão da mecânica celeste e de outros saberes deslumbrantes, o saber científico facultaria o conhecimento necessário para os homens atingirem a "felicidade comum", convertida ao longo do século XVIII, de acordo Paul Hazard, não só num direito mas também num dever ${ }^{29}$.

Ainda que o discurso utópico se apresente como doutrinário, as figurações, explicitas e implícitas, da cidade prometida nunca deixam de definir o fundo em que se inscreve, pois a evocação da prodigalidade das graças naturais e humanas é, ao longo do texto, tão permanente quanto os sentimentos e as emoções de agrado que despertaria seriam inevitáveis.

Reúne-se-lhe, aliás, um outro imaginário poderoso: o imaginário revolucionário.

Uma nova era estaria de tal modo ao alcance do homem que a criação épica de uma república feita à medida das aspirações e da vontade gerais passa à ordem do dia.

A convergência entre o discurso utópico e o imaginário revolucionário radica, antes de mais, na oposição comum entre o existente e o desejável, concebidos como duas realidades entre si opostas. Em ambos, a reforma da ordem em vigor é uma hipótese excluída. A escolha recai sobre o radicalmente novo,

${ }^{27}$ Morelly, Code de la nature ou le véritable esprit des lois de tout le temps négligé ou méconnu, Partout chez le vrai sage, 1755, p. 22.

${ }^{28}$ Cf. Charles Rihs, Les philosophes utopistes. Le mythe de la cite communautaire en France au XVIII siècle, Paris, Marcel Rivière, 1970, p. 184; Jean-Jacques Chevalier, Histoire de la pensée politique, Paris, Payot, 1993, pp. 825 e ss.

29 Cf. Paul Hazard, Crise da consciência europeia, Lisboa, Edições Cosmos, 1948, p. 227 e ss, e $O$ pensamento europeu do século XVIII, Lisboa, Editorial Presença, 1989, p. 24. 
o que supõe a ruptura entre dois mundos, seja literária e reflexiva, seja doutrinária e política.

Neste quadro, o discurso revolucionário confere ao discurso utópico a dimensão activa de um projecto político que se concebe a si como emancipador, ou seja, capaz de vencer o artifício individual e colectivo, de estabelecer uma ordem conforme ao código natural, de assegurar as condições efectivas da autonomia pessoal e da autodeterminação política e social.

A representação do novo mundo transfere-se, então, dos lugares isolados e remotos dos arquipélagos utópicos para os tempos por vir.

O próprio regresso à ordem natural proposto por Morelly supõe a superioridade do presente, e do futuro prognosticado, relativamente ao passado, pelo menos, ao passado próximo, na exacta medida em que o retorno ao mundo natural passa a obedecer à compreensão das leis que lhe são imputadas, ao deixar de consistir numa vivência inocente, sujeita à corrupção, e constituir uma escolha esclarecida ${ }^{30}$.

Porém, a deslocação do discurso utópico para o futuro - a ucronia ocorre um pouco mais tarde, com a publicação de L'An deux mille quatre cent quarante. Rêve s'il en fut jamais, de Louis Sébastien Mercier, no ano de 1771. A frase de Leibniz que Mercier escolhe para epígrafe desta edição - "o tempo está carregado de futuro"31 - indicia inequivocamente que a percepção do tempo passa a assentar numa expectativa positiva do devir.

Além de ser contemporânea do fim das viagens e dos relatos marítimos a destinos desconhecidos, o que diminui decisivamente a possibilidade de adicionar, na Terra, novos lugares maravilhosos ou fantásticos, a transferência do imaginário utópico para o porvir é uma das expressões mais relevantes da afirmação da ideia de progresso como chave de compreensão do trajecto humano.

Ao ser apresentado como resultado da evolução linear, ainda que irregular no seu decurso, do conjunto do evolução da humanidade, o futuro, visto à luz da ideia de progresso, surge necessariamente como a promessa ou, mesmo, como a profecia de uma nova e feliz idade do mundo.

De Voltaire a Condorcet, a história, dita universal, passa a surgir como o registo dos avanços cumulativos do espírito humano, presente nos diferentes domínios em que a cultura e a acção humanas se fazem sentir.

${ }^{30}$ A sugestão é insinuada pelo próprio Morelly: "quase todos os povos tiveram e têm ainda uma idade do ouro, que seria verdadeiramente aquela em que reinou entre os homens a perfeita sociabilidade de que desenvolvi as leis. Talvez essa primeira inocência tenha sido praticada durante séculos sem reflexão e, consequentemente, sujeita a corromper-se" (Morelly, Code de la nature ...,p. 141). Face ao exposto, a conclusão de Charles Rihs parece óbvia: "Morelly (...) coloca a nova idade do ouro à nossa frente. Seria um estado de Natureza no qual o homem teria atingido plenamente a consciência do seu destino universal (Charles Rihs, op . cit., p. 171).

31 Louis Sébastien Mercier, L'an deux mille quatre cent quarante, Bordéus, Éditions Ducros, 1971,p. 3. 
Nesta visão geral dos tempos, ainda que o presente surja como clímax do evoluir histórico, seja a propósito de Luís XIV seja a propósito da Revolução Francesa, o foco que lhe confere sentido está colocado adiante, como se todos os acontecimentos humanos nele convergissem e só à sua luz ganhassem, de forma retrospectiva, pleno sentido.

O Esquisse d'un tableau historique des progrès de l'esprit humain, que Condorcet escreve nos meses anteriores à sua morte, em 1794, é, a este respeito, representativo e significativo.

Representativo, já que Condorcet é classificado, por autores de diferentes orientações, como o último dos philosophes, ao mesmo tempo que a sua obra derradeira é vista como a súmula do iluminismo francês ${ }^{32}$.

Significativo, na medida em que a décima e última época do Esquisse... tem os "progressos futuros do espírito humano" por objecto ${ }^{33}$, não no âmbito próprio da construção literária, como se verificara com L'an deux mille quare cent quarante, de Mercier, muito menos no domínio do vislumbre profético, mas nos termos de uma antevisão filosófica e política, assente em legitimidade semelhante à da previsão científica.

O capítulo inicia-se exactamente com o esclarecer desta pretensão: "se o homem pode predizer, com quase inteira segurança, os fenómenos de que conhece as leis (...) que nos leva a olhar como empreendimento quimérico a tentativa de traçar com verosimilhança o quadro dos destinos futuros da espécie humana, de acordo com os resultados da sua história?"34.

Partindo de uma resposta positiva a esta interrogação, de fundo retórico, Condorcet esclarece, de seguida, que "as nossas esperanças sobre o estado futuro da espécie humana podem reduzir-se a três pontos importantes: a des-

${ }^{32}$ Louis Bonald classificou o Esquisse ... como "a última produção da filosofia no processo que instaurou à sociedade" (Louis Bonald, Oeuvres complètes, Paris, Migne, 1859, p. 721), Jean Jaurès referiu-se a Condorcet como sendo o "nobre herdeiro da filosofia do século XVIII" (Jean Jaurès, História socialista, Lisboa, Antiga Casa Bertrand - João Bastos, livreiro-editor, 1901, v. II, p. 394), enquanto Alexandre Koyré diz-nos que Condorcet não inovou e que o seu papel foi o de "ordenar, de sintetizar, de sistematizar e de conduzir à sua conclusão lógica as concepções do seu tempo" (Alexandre Koyré, Études d' histoire de la pensée philosophique, Paris, Éditions Gallimard, 1981, p. 112).

${ }_{33}$ Condorcet, Esquisse d' un tableau historique des progrès de l' esprit humain, Paris, Flammarion, 1988, p. 285.

${ }^{34}$ Ibidem. A analogia assenta na convicção de que o objecto da história é susceptível de ser conhecido de forma semelhante aos objectos das ciências naturais, como da interrogação, igualmente retórica, que segue o texto acima transcrito: "o único fundamento da crença nas ciências naturais é a ideia de que leis gerais, conhecidas ou ignoradas, que regulam os fenómenos do universo, são necessárias e constantes; e por que razão este princípio seria menos verdadeiro para o desenvolvimento das faculdades intelectuais e morais do homem do que para as outras operações da natureza?" (Condorcet, ibidem). 
truição da desigualdade entre as nações; os progressos da igualdade num mesmo povo, enfim o aperfeiçoamento real do homem".

Tudo se encaminharia para que chegasse o tempo em que "o Sol não iluminaria, na Terra, senão homens livres, que não reconheceriam outro senhor para além da sua razão" 35 , época em que o aperfeiçoamento da espécie levaria os homens a "abraçar tudo o que interessa verdadeiramente à sua felicidade" $"$.

Como se faz depender o sentido da história da perfectibilidade humana e esta é concebida como indefinida, entre os progressos futuros dos homens não se encontra a determinação de um quadro preciso de fins últimos, mas tão-só a conquista progressiva da racionalidade, da liberdade, da igualdade por parte de cada um e da comunidade como um todo.

$\mathrm{O}$ aspecto que sobressai neste discurso utópico que pretende descrever a dinâmica que presidiria ao evoluir histórico é o de que o dever-ser se encontra inscrito no próprio ser como necessidade, na medida em que a sua figuração surge como a meta para que a disposição que rege o percurso temporal da humanidade se encaminha.

Como a história é feita pelos homens, ou melhor, pelas suas respostas ao vocativo para o aperfeiçoamento, não há futuro alheio aos projectos e à vontade dos próprios, ainda que seja claro que a revelação do sentido da história, pela qual a espécie ganha consciência de si, constitua um poderoso incentivo na ascensão da humanidade a patamares futuros ${ }^{37}$.

As realizações da revolução vitoriosa, no passado recente, a instrução pública universal e laica, em projecto e debate ${ }^{38}$, o combate a favor da ordem republicana, que daria lugar à constituição de uma comunidade cidadãos livres e iguais, mostrariam que o vão que vai do existente ao necessário é constituído por um intervalo que a acção humana depressa poderia vencer.

As expectativas que a visão conjunta da história legitimaria são muito variadas e sugestivas, seja pelos seus resultados seja pela dinâmica que lhe preside.

Anuncia-se a maioridade individual e colectiva ${ }^{39}$. Sugere-se que a atribuição de cargos dependerá unicamente do mérito ${ }^{40}$. Supõe-se que a propagação do

${ }^{35}$ Ibidem, p. 271.

36 Ibidem, p. 277.

${ }^{37}$ Cf. ibidem, p. 89

${ }^{38}$ Condorcet é o autor de um projecto de instrução pública, apresentado na Convenção, bem como de Cinq mémoires sur l'instruction pubique, publicadas em 1791.

39 "Os homens - escreve Condorcet - aproximar-se-ão deste estado em que todos terão as luzes necessárias para se conduzirem segundo a própria razão nos negócios comuns da vida e para a manterem isenta de preconceitos" (Condorcet, Esquisse..., p. 266).

40 "Os povos livres - escreve Condorcet - não conhecem outros motivos de distinção nas suas escolhas além dos talentos e das virtudes" (Condorcet citado por Catherine Kintzler, Condorcet, l'instruction publique et la naissance du citoyen, Paris, Le Sycomore, 1984, p. 223). 
saber criará uma opinião pública esclarecida, capaz de fazer prevalecer o interesse comum" . Afirma-se que "os progressos da virtude acompanham sempre os das luzes"42. Acredita-se que: "o amor ao bem geral e mesmo a coragem para se lhe devotar é, por assim dizer, o estado do homem esclarecido"43.

Como a "natureza não colocou qualquer limite às nossas esperanças" toda a expectativa resultante de aperfeiçoamento humano torna-se razoável: "o grau de virtude a que, um dia, o homem pode chegar - escreve Condorcet, em texto evocativo da Nova Atlântida, de Francis Bacon - é-nos tão inconcebível quanto aquele a que a força do génio pode ser conduzida"45.

Todas as imagens em que as aspirações tidas por legítimas se tinham vertido passam a surgir, no espírito festivo e refundador revolucionário, como possibilidades plausíveis. O seu brilho faz cintilar o fulgor audaz dos discursos, o ânimo épico dos combatentes, as bandeiras intrépidas das barricadas.

Ainda que as obras referidas de More, Morelly, Mercier e Condorcet constituam marcos paradigmáticos na história da literatura utópica correntemente aceites, os sentidos do discurso utópico, ao longo do período considerado, excedem em muito o teor das suas páginas.

A ambiguidade do conceito e a complexidade do género criado por More proporcionam a polissemia e a plasticidade, dando lugar a manifestações muito distintas entre si, desde o simples jogo literário, à congeminação arquitectónica e urbana ou ao devaneio nostálgico em que mundos áureos e vivências perdidas são perseverados da usura do tempo.

As próprias regras canónicas das disciplinas e dos géneros conhecem, neste processo, metamorfoses significativas: a narrativa pode primar pela ausência de personagens e de enredo, a reflexão ter a escassez de argumentos teóricos como atributo, a imagética restringir-se à sugestão, resultante da evocação genérica do acervo geral das figuras pelas quais o desejo de bem-estar comum se deixou, ao longo dos séculos, representar.

Porém, a diversidade e a peculiaridade de manifestações não retiram pertinência à apreciação da literatura utópica como modalidade de inteligibilidade política, já que cada criador de uma nova cidade não pode deixar de retomar, a seu modo, os problemas inerentes ao cumprimento da tarefa que Utopus dera por concluída.

${ }^{41}$ Esquisse..., p. 275.

${ }^{42}$ Ibidem, p. 137.

${ }^{43}$ Condorcet citado por Frank Alengry, Condorcet, guide de la révolution française, Genebra, Slatkine Reprints, 1971, p. 754.

${ }^{44}$ Esquisse, p. 267.

45 Ibidem, p. 323. 


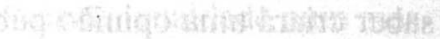

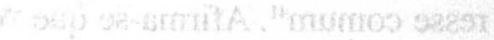

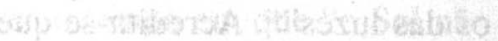

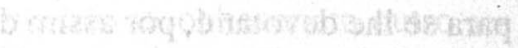
What on

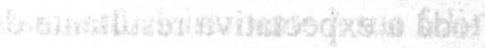

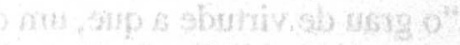

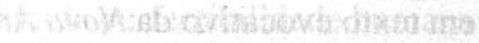

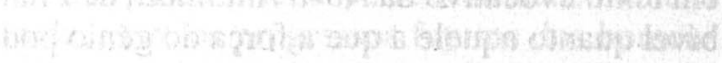

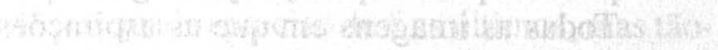

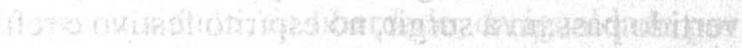

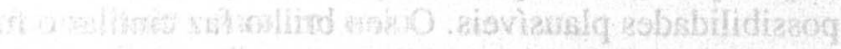

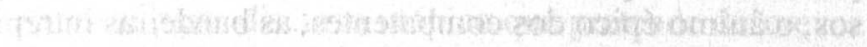

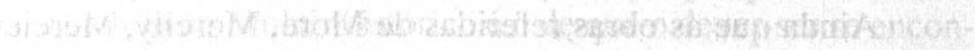

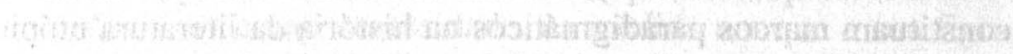

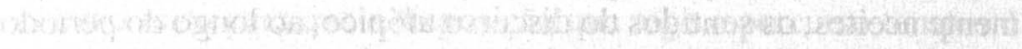
- 24:

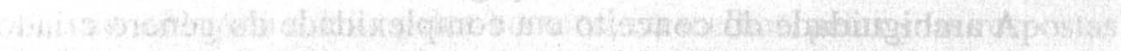

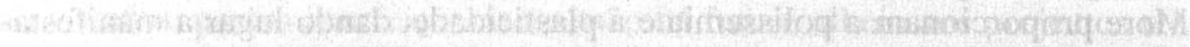

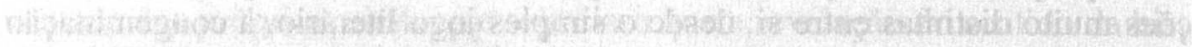

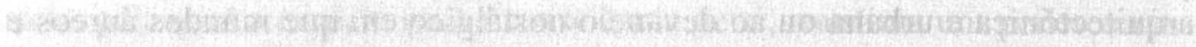

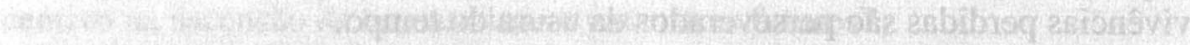

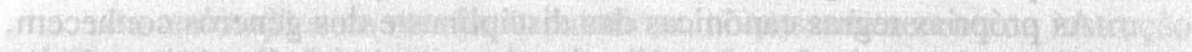

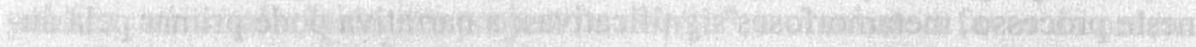

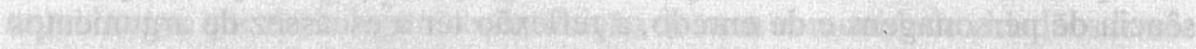

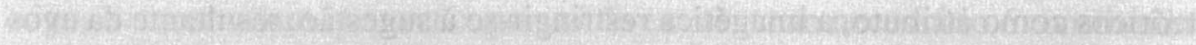

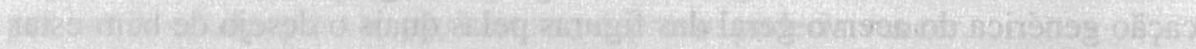

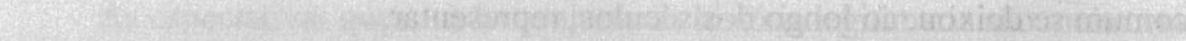

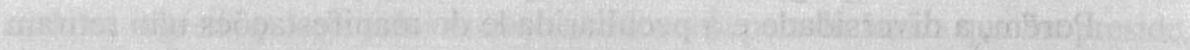

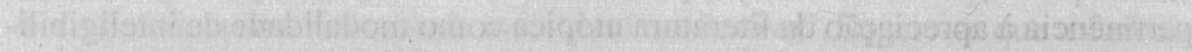

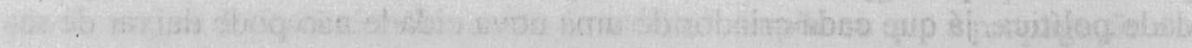

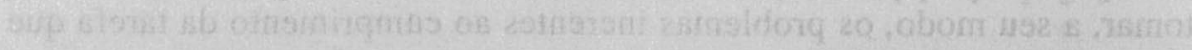

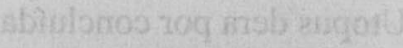




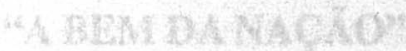

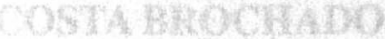

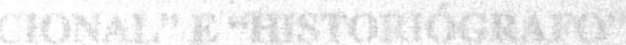

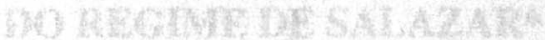

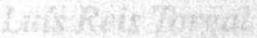

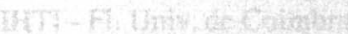

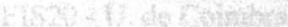

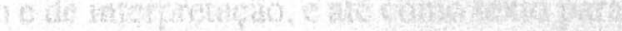

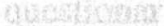

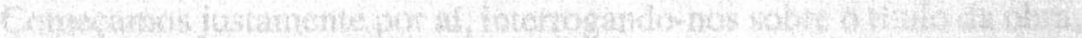

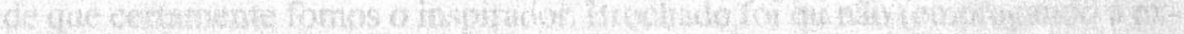

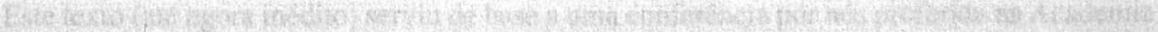

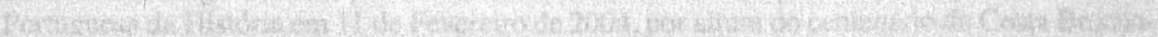

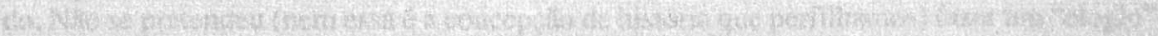

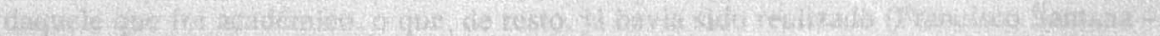

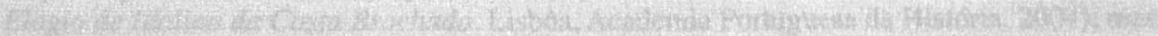

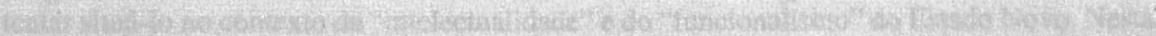
5in.

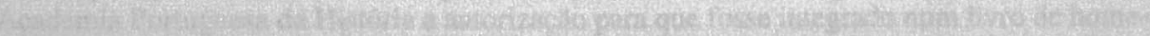

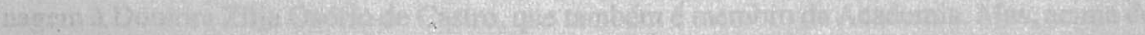

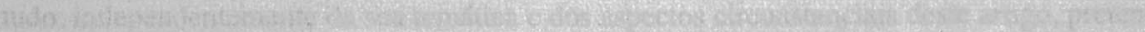

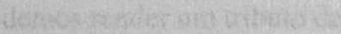

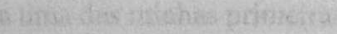

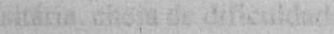

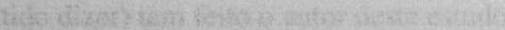

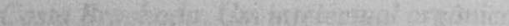

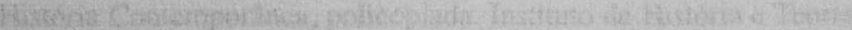

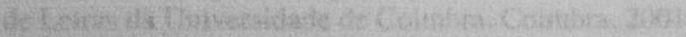

PERCURSOS

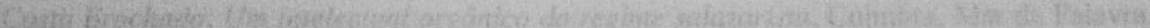
2004 


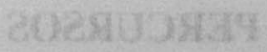




\title{
"A BEM DA NAÇÃO" \\ COSTA BROCHADO \\ "POLÍTICO FUNCIONAL" E "HISTORIÓGRAFO" AO SERVIÇO DO REGIME DE SALAZAR*
}

\author{
Luís Reis Torgal \\ IHTI - Fl. Univ. de Coimbra \\ CEIS20 - U. de Coimbra
}

\section{Costa Brochado, um "intelectual orgânico"?}

Idalino Ferreira da Costa Brochado nasceu há pouco mais de cem anos, em Vilarinho, concelho de Santo Tirso, no dia 9 de Fevereiro de 1904. Poderemos, pois, dizer que ultrapassámos já o seu centenário. Como deveremos nós caracterizá-lo no contexto do Estado Novo de Salazar, a quem votou uma total dedicação política?

Orientámos uma tese de mestrado, da autoria de João Tiago de Sousa, apresentada à Faculdade de Letras da Universidade de Coimbra, em 2001, intitulada Costa Brochado. Um intelectual orgânico do regime salazarista ${ }^{1}$, tese essa (publicada posteriormente com o mesmo título ${ }^{2}$ ) que teremos sempre em referência, como texto de informação e de interpretação, e até como texto para questionar.

Começamos justamente por aí, interrogando-nos sobre o título da obra, de que certamente fomos o inspirador. Brochado foi ou não (empregando a ex-

* Este texto (até agora inédito) serviu de base a uma conferência por nós proferida na Academia Portuguesa da História em 11 de Fevereiro de 2004, por altura do centenário de Costa Brochado. Não se pretendeu (nem essa é a concepção de história que perfilhamos) fazer um "elogio" daquele que foi académico, o que, de resto, já havia sido realizado (Francisco Santana Elogio de Idalino da Costa Brochado. Lisboa, Academia Portuguesa da História, 2004), mas tentar situá-lo no contexto da "intelectualidade" e do "funcionalismo" do Estado Novo. Nesta publicação apenas se eliminaram aspectos conjunturais do texto original, agradecendo aqui à Academia Portuguesa da História a autorização para que fosse integrado num livro de homenagem à Doutora Zília Osório de Castro, que também é membro da Academia. Mas, acima de tudo, independentemente da sua temática e dos aspectos circunstanciais deste artigo, pretendemos render um tributo de agradecimento à professora competente, à investigadora rigorosa, a uma das minhas primeiras alunas, à colega e à amiga de horas boas e más desta vida universitária, cheia de dificuldades, a que a Zília se dedicou abnegadamente, como (se nos é permitido dizer) tem feito o autor deste estudo.

1 Costa Brochado. Um intelectual orgânico do regime salazarista. Dissertação de Mestrado em História Contemporânea, policopiada. Instituto de História e Teoria das Ideias - Faculdade de Letras da Universidade de Coimbra. Coimbra, 2001.

${ }^{2}$ Costa Brochado. Um intelectual orgânico do regime salazarista. Coimbra, Mar da Palavra, 2004. 
pressão, de sabor gramsciano, usada por João Tiago de Sousa) um “intelectual orgânico"?

Para já, comecemos por acentuar que o estudo dos intelectuais tem sido objecto de vários trabalhos e tem-lhe sido dada tanta importância, reportando-se sobretudo aos séculos XIX e XX, ou ao período que se desenvolve a partir do Iluminismo do século XVIII, que o historiador francês Michel Winock, referindo-se à centúria passada, intitulou um livro de síntese Le Siècle des Intellectuels ${ }^{3}$. Entretanto, concedendo um papel fundamental aos dois últimos decénios do século XIX para o processo de formação dos "intelectuais", Christophe Charle (que se tem dedicado sobretudo ao estudo dos "intelectuais" de oitocentos) já havia publicado, anos antes, o livro com o título significativo e ousado Naissance des “Intellectuels". 1880-19004.

O tema dos "intelectuais” é, porém, um tema já antigo na problemática da história e da fillosofia da história, que tem sido abordado de várias feições. Em termos de ideologia, recorde-se - para não recuarmos mais atrás e descermos às polémicas entre iluministas-liberais e tradicionalistas ou à célebre polémica dos "antigos" e dos "modernos" - o famoso livro de Léon Daudet, do movimento de direita revolucionária Action Française, Le Stupide XIX. ${ }^{e}$ Siècle (1922), questionador da cultura do século XIX, obra que tanta influência teve no pensamento contra-revolucionário ou revolucionário de direita, ou mesmo no pensamento católico conservador (o caso de A Igreja e o Pensamento Contemporâneo, 1924, de Manuel Gonçalves Cerejeira). Noutra frequência, lembremos a não menos conhecida obra de Julien Benda, La Trahison des Clercs (1927), que procurou reflectir sobre o sentido da "intelectualidade", vista numa forma independente, como culto da razão e do universal (como pretendia) ou no "engajamento" realista, mesmo que assumindo uma forma idealista, a uma ideia ou a um regime, questão fundamental no século XX, que originou grandes disputas político-culturais à direita e à esquerda. A consciência do aparecimento de "novas gerações", viradas para "novas culturas", originou muitas obras com títulos inspirados nesta lógica e nestas palavras, de tipo conservador ou de direita - baseadas, por exemplo, na famosa obra de Agathon (que outro não era senão Henri Massis e Alfred de Tarde, o primeiro que tanto defendeu a "cultura ocidental" e veio a elogiar o Estado Novo de Salazar) Les Jeunes Gens d'Aujourd'hui (1913) -, como levou a afirmações modernistas e futuristas, "antiburguesas", que não deixa-

3 Le Siècle des Intellectuels. Paris, Éditions du Seuil, 1997. Segunda edição revista e aumentada, em livro de bolso: 1999; edição portuguesa: Lisboa, Terramar, 2000. Na mesma editora, Jacques Julliard publicou com Winock o Dictionnaire des Intellectuels Français. Les Personnes, les Lieux, les Moments, Paris, Ed. Du Seuil, 1996.

“ Naissance des “Intellectuels". 1880-1900. Paris, Éditions Minuit, 1990. 
ram de proporcionar também experiências culturais e políticas de direita, como criaram a noção de uma cultura crítica, sem dependências sociais, políticas ou estéticas. Noutro sentido, intelectuais soviéticos integraram-se também na lógica da cultura engagée (ao serviço do que consideravam servir a "classe operária"), dentro da concepção, de autoria duvidosa, dos "engenheiros das almas", posição que será contestada mesmo entre outros intelectuais que viviam no "sistema", com duras consequências. Apesar de ter inspirado uma corrente comunista mais aberta, o próprio Gramsci, ao reflectir sobre o conceito de "intelectual", não deixou de se situar no domínio "organicista", pensando no intelectual "organicamente", ao serviço da formação de uma sociedade socialista, justificando assim a hegemonia de poder do proletariado.

Mas, para além destas breves considerações acerca da filosofia e da ideologia políticas relativas ao conceito de "intelectual", retomamos a ideia de que os historiadores tiveram um interesse particular em estudar, em várias épocas, os “intelectuais". É já clássico, como se sabe, o estudo de síntese, para um tempo bem diferente daquele de que falámos, de Jacques Le Goff, Les Intellectuels au Moyen Âge $e^{6}$. Atendo-nos, porém, apenas à temática geral a que nos temos dedicado - os "fascismos" ou os "novos Estados", de tipo autoritário / totalitário, revolucionário ou conservador -, recorde-se, para a situação exemplar de Itália, os livros de Renzo de Felice, Intelletuali di fronte al fascismo $^{7}$, ou de Mario Isnenghi, Intellettuali militanti e intellettuali funzionari. Appunti sulla cultura fascista ${ }^{8}$. Mas, se quisermos ultrapassar esta área estrita, de maior pendor político (de que demos apenas dois exemplos - recorde-se ainda os trabalhos, de sentido mais lato, de Zeev Sternhell ${ }^{9}$, sobre as origens da ideologia fascista, ou o estudo clássico sobre a sociedade e a cultura fascista de Edward Tannenbaum ${ }^{10}$ ), e falar de estudos dos intelectuais relativamente à temática religiosa, poderíamos aqui citar o livro recente de Frédéric Gugelot, La Conversion des Intellectuels au Catholicisme en France (1885-1935) ${ }^{11}$.

\footnotetext{
${ }^{5}$ Veja-se o complexo ensaio de Gramsci, "Appunti e note per un gruppo di saggi sulla storia degli intellettualli", Quaderni, 12 (XXIX), 1932, in Quaderni del carcere, vol. terzo, Torino, Einaudi, $1975 / 2001$, p. 1511 ss.

${ }^{6}$ Les Intellectuels au Moyen Âge. Paris, Éditions du Seuil, 1957. Primeira edição portuguesa: Os intelectuais na Idade Média. Lisboa, Estúdios Cor, 1973.

Intelletuali di fronte al fascismo. Roma, Bonacci Editore, 1985.

${ }^{8}$ Intellettuali militanti e intellettuali funzionari. Appunti sulla cultura fascista. Turim, Giulio Einaudi, 1979.

9 Naissance de l'idéologie fasciste. Com a colaboração de Mario Sznajder e Maïa Ashéri. Paris, Fayard, 1989. Edição portuguesa: Venda Nova, Bertrand, 1995.

10 The Fascist experience - italian society and culture, 1922-1945. Nova Yorque, Basic Books, 1972.

"La Conversion des Intellectuels au Catholicisme en France. 1885-1935. Paris, CNRS Éditions, 1998.
} 
Mas, estudar os "intelectuais" supõe a situação difícil de definir "intelectual". É aqui precisamente que se pode pôr o problema de saber se Costa Brochado pode ser entendido ou não como um "intelectual" e como um "intelectual orgânico". Gugelot, na obra referida, escreve, utilizando algumas referências de outros autores em obras também dedicadas ao tema:

L'intellectuel résiste, lui aussi, à toute classification nette. Pascal Ory et JeanFrançois Sirinelli le définissent comme "un homme du culturel, créateur et médiateur, mis en situation d'homme du politque, producteur ou consommateur d'idéologie" [Les intellectuels en France de l'Affaire Dreyfus à nos jours, Paris, Armand Colin, 1986, p. 10]. La définition de Michel Trebitsch, plus large, a l'avantage de ne négliger aucun espace: "Ce qui caractérisait l'intellectuel, c'est le va-et-vient, la relation consubstantielle qu'il opère entre ses choix esthétiques et ses choix idéologiques que ce soit la mode de l'académisme ou de l'avant-garde: l'activité intelectual consiste en quelque sorte à ne cesser d'éclairer et de justifier l'un par l'autre, et c'est en cela qu'il existe une relation struturelle entre les valeurs et les formes de sociabilités" ["Sociabilités intellectuelles. Lieux, milieux, réseaux", Cahiers de l'IHTP, n. ${ }^{\circ}$ 20, mars 1992, p. 20$]^{12}$.

Esta reflexão ou estas reflexões, tendo como base as lógicas de investigadores que encararam o conceito de "intelectual" sobre diferentes pontos de vista, prova como é difícil definir um termo deste género que pode ser, inclusivamente, entendido numa perspectiva ideológica, até de sentido pejorativo. É o próprio Costa Brochado que o faz e - como se sabe - era corrente no tempo do Estado Novo, de um lado e de outro da barreira política, considerar como "intelectual" o "homem de esquerda". Brochado fala pejorativamente, num discurso de 1960, dos "intelectuais" como "doutrinários da chamada oposição", "intelectuais idealistas preocupados, seriamente, com a garantia das liberdades essenciais, a defesa dos pequenos contra os grandes, a moralização da administração pública, etc.". Esses "intelectuais" - no dizer de Costa Brochado - limitam-se a falar genericamente contra o Estado Novo, não tendo "nada a dizer, de substancial e procedente, contra o Regime". E asseverava que, se alguns eram, ainda assim, "sinceros", regra geral não tinham escrúpulos, eram movidos por "baixos sentimentos", limitando-se a chamar e a convencer "as multidões ingénuas" de que os defensores do Estado Novo não respeitavam a Constituição, eram "fascistas, totalitários, inimigos natos do povo trabalhador e das liberdades públicas"13.

Claro que não é neste contexto polémico - ou em outro qualquer desse

12 Ob. cit., pp. 11-12. Mantivemos, neste e noutros casos, em que transcrevemos Prefácios ou outros textos, o itálico do original.

13 Passado, Presente e Futuro. Conferência realizada em Viseu em 14 de Junho de 1960, perante as comissões políticas do distrito e sob a presidência do Governador Civil. Lisboa, Companhia Nacional Editora, 1960, p. 19 ss. 
tipo - que nos poderíamos referir (como fez João Tiago de Sousa) a Costa Brochado como "intelectual" ou, mais precisamente, como "intelectual orgânico". Segundo o nosso modo de ver, o conceito de "intelectual" supõe um certo nível de produção e intervenção cultural e uma problematização de conceitos, servidos por uma leitura, mais ou menos complexa ou simples, de obras e de autores, de estéticas, de sociedades, de políticas ou de religiões, que dificilmente encontramos em Costa Brochado. É isso com que deparamos, por exemplo, em alguns indiscutíveis "intelectuais do Estado Novo" como António Ferro ou Augusto de Castro, como sucede na Itália pré-fascista e fascista com Gabrielle D'Annunzio ou Marinetti, com Giovanni Gentile ou Giuseppe Bottai. O norte-americano Ezra Pound, considerado um dos escritores mais influentes do século XX, foi um firme defensor do Fascismo, permanecendo na Itália durante todo o tempo da guerra, onde foi feito prisioneiro para ser julgado como "traidor à Pátria". E algo de idêntico, com um fim mais trágico, sucedeu com o escritor francês, do chamado "romantismo fascista", Robert Brasilach, acusado de colaboracionista e executado em 1945. Ou seja, os "intelectuais" podem, evidentemente, ter um processo de relação simpática e empática ou serem mesmo defensores de uma ideologia fascista sem deixarem de ser "intelectuais". Por isso lhes poderemos chamar "intelectuais orgânicos" (dado que o "organicismo" faz parte essencialmente da lógica corporativa), que preferimos talvez a "intelectuais funcionários", expressão utilizada por Mario Isnenghi. O mesmo sucedeu - noutro pólo - com tantos "intelectuais" que se deixaram seduzir pela ideologia comunista de tipo soviético, mesmo de tipo estalinista, colocando-se alguns, indeclinavelmente, ao seu serviço. $\mathrm{O}$ que, no presente caso, pomos em causa - já o dissemos afinal - é se Costa Brochado, pelas suas características, pode efectivamente ser considerado um "intelectual".

Na verdade, ele foi sobretudo um autodidacta, formado já tardiamente numa escola técnica (a Escola Comercial de Oliveira Martins, no Porto), foi um "prático", que aprendeu a viver com a vida, um jornalista que começou a escrever desde jovem (desde o jornal da referida escola, Alvor do Provir, e do periódico de Gondomar, A Nossa Terra). Mesmo que tenha sido responsável por uma revista literária, Sangue Novo (1925), que durou apenas cerca de seis meses, e tenha convivido com o grupo da "Renascença", do Porto, não se pode dizer que se tenha destacado no domínio das letras ou da filosofia política. Foi o jornalismo prático, de $O$ Comércio do Porto, depois de ter passado pelo hebdomadário político Semana (1932-1933), também ainda do Porto, que o levou ao "jornalismo de regime", de A Verdade (1933-1939), publicado em Lisboa, a convite do responsável da Propaganda, António Ferro, esse (como dissemos) um verdadeiro "intelectual orgânico". 
Costa Brochado foi sim - a nosso ver - não tanto sequer um "ideólogo orgânico", mas um "funcionário político", ou um "político funcional", ao serviço do Estado Novo. O seu jornalismo político - primeiramente arma de combate contra outro jornal do mesmo nome, publicado na clandestinidade, e genericamente contra o "reviralho" (é Brochado que utiliza o termo, que era, de resto, comum), tornou-se depois arma de doutrinação contra as "heresias" que surgissem no âmbito do regime, lendo a "bíblia do Estado Novo", ou seja, no seu dizer, "todas as declarações publicamente feitas pelo sr. Doutor Salazar, único evangelista seguro no que toca à ortodoxia da doutrina, às suas interpretações, adaptações, corrigendas, etc." ${ }^{14}$ Esteve, pois, directamente, ao serviço do que considerava o "único e verdadeiro ideólogo" do regime e ao serviço do Secretariado Propaganda Nacional (conforme confessará nas Memórias, afastou-se, então, cada vez mais, do "mundo jornalístico" e passou a ter como "centro de convívio profissional e político" o $\mathrm{SPN}^{15}$ ). Nesse proselitismo, exprimiu-se através de uma ideologia simplista, que, por vezes, tem uma grande eficácia, mesmo que seja atreita a originar polémicas, até no seio dos próprios defensores do regime. Mais tarde, no final dos anos cinquenta, como membro da Comissão Executiva da União Nacional, proferiu várias conferências ideológicas, mas sempre elas eram revistas (conforme afirmou de forma simples e quase ingénua) pelo próprio Salazar, que lhe introduzia alterações ou cortava algumas frases ${ }^{16}$.

Apesar de ter convivido com intelectuais, entre eles o próprio Fernando Pessoa, e com políticos de todas as cores ("desde comunistas a integralistas, convivi com todos quantos tinham interesse intelectual", como também confessava nas suas Memórias $^{17}$ ), isso não faz dele um "intelectual”, ainda que seja senhor de uma escrita fácil, clara e contundente.

Aliás, também a sua fama oficial de "historiador" não o credita, à luz dos nossos conceitos, como um "intelectual", nem mesmo como um... historiador. Na verdade, não se pode dizer que, pelas suas obras, se possa entender Brochado como um cientista da história. Pese embora o aparato erudito que pretende dar a algumas das suas obras, elas são sobretudo guiadas por conceitos ideológicos perfeitamente claros e coerentes. Por isso entendemos que Costa Brochado foi, sobretudo, o que chamámos um "historiógrafo", um historiógrafo ao serviço do regime, de Salazar e do Estado Novo, mesmo que a sua obra não incida directamente sobre o seu mundo contemporâneo, mas sim

14 Salazar e “A Verdade”, Porto, Edição de Autor? (Depositária: Livraria Educação Nacional), 1937, p. 24.

15 Memórias de Costa Brochado. Lisboa, Edição de Autor (Depositária: Livraria Popular Francisco Franco), 1987, p. 119.

${ }^{16}$ Cfr. ob. cit., pp. 342-344.

17 Ob. cit., p. 238. 
sobre figuras emblemáticas da história de Portugal medieval e moderno aproveitadas pelo regime. Neste sentido, aproxima-se de outro "homem do Salazarismo", que, como ele, também pertenceu à Academia Portugesa da História, João Ameal, ainda que, pelas suas reflexões, se possa considerar este, com maior justeza, como uma "intelectual orgânico" do Estado Novo. Já outro membro desta Academia, Alfredo Pimenta, ideólogo e intelectual, se expressou de forma mais cultural e cientificamente rica e foi, como historiador, apesar das concepções ideológicas que lhe estão subjacentes (ligadas a uma linha mais claramente "fascista" e germanófila), uma personalidade mais marcante, até pelo sentido complexo das suas polémicas. Enfant térrible, haveria, por isso, de não se integrar, afinal, completamente, no regime e em nenhuma instituição orgânica. Daí o facto de ter acabado por ser demitido da Academia Portuguesa da História ${ }^{18}$.

\section{"Passado, Presente e Futuro" de Portugal A ideologia política de Costa Brochado}

A conferência proferida em Viseu, em 14 de Junho de 1960, por Costa Brochado, intitulada Passado, Presente e Futuro, pode sintetizar uma linha fundamental da sua ideologia. Com efeito, ele interpretou de uma forma simplista e maniqueia, mas coerente, os três ciclos do tempo em Portugal.

A tentativa para explicar a sua posição ideológica, nomeadamente nas suas Memórias, é apenas superficial. Fala vagamente do republicanismo do seu pai, professor primário na escola Conde Ferreira em Gondomar, que ele próprio frequentou, da sua tendência juvenil para o Partido Evolucionista, da sua simpatia pelo Sidonismo e, afinal, da adesão ao Partido Socialista, de Ramado Curto, no qual votara nas eleições de $1925^{19}$. Mas, valoriza sobretudo a sua formação católica, vinda da mãe e do Padre António Valente da Fonseca, pároco em São Cosme de Gondomar. É por essa via que adere à ideia de um "Estado Social" frente ao que chama (de resto, com alguma propriedade, referindo-se à realidade da Primeira República), a "desordem republicana". Mais precisamente, considera que foi o corporativismo católico, da Rerum Novarum (1891), de Leão XIII, que justificou tanto a sua posição "socialista", como a sua adesão ao corporativismo de Salazar, em oposição ao comunismo e ao demoliberalismo, ou ao "liberalismo" e à "democracia directa" (como lhe chama, numa expressão pouco rigorosa, pois faz coincidir o conceito de "demo-

18 Vide Luís Reis Torgal, José Amado Mendes e Fernando Catroga - História da História em Portugal. Séculos XIX-XX. Lisboa, Temas e Debates, 1998, vol. 1, sobretudo p. 283 ss.

${ }^{19}$ Memórias, passim e p. 73. 
cracia directa", que tem outro significado politológico, com a "democracia representativa" parlamentar e de tipo partidário). Por isso, se esforça por provar que Salazar nunca foi "fascista", mas integrou-se numa lógica de Estado Corporativo e, por isso, mesmo que, nas entrevistas que lhe concedeu, no jornal A Verdade, sempre o Presidente do Conselho (o "Chefe", como se tornou também conhecido) tenha dado como exemplo de comportamento político comparativo Hitler e Mussolinii ${ }^{20}$, o certo é que Brochado se confessou como anglófilo ${ }^{21}$, posição que lhe terá custado a extinção do seu jornal, sempre publicado ao serviço do Estado Novo e do seu fundador.

Para além desta lógica, poucas ou nenhumas reflexões teóricas surgem na ideologia de Costa Brochado. Divisamos apenas o reflexo de leituras que eram comuns nas gentes do Estado Novo que não foram militantes de nenhum ideal mais afirmado, de tipo católico, nacional-sindicalista ou integralista (que têm, no geral, leituras e reflexões mais complexas). Por exemplo, breves considerações sobre o amoralismo de Maquiavel, citação da obra de Léon Daudet, Le Stupide XIX.e Siècle, referências à teoria da psicologia das multidões de Gustave Le Bon, admiração pelo personalismo científico de Alexis Carrel e pela sua obra, de grande divulgação, O Homem, esse Desconhecido, ou então as leituras, numa versão contra-revolucionária, de Herculano, Garrett, Antero, Eça, Ramalho, etc.

Mais do que um pensamento sólido, como se aludiu, Brochado foi um "prático", defensor de "verdades" e, para ele, a "única verdade política" era Salazar. E esta é afinal a fonte de todas as ideias e acções e que o leva a não aceitar qualquer tipo de diálogo com alguma força política que estivesse para além de Salazar. Como escrevia em 1937, referindo-se à sua experiência de $A$ Verdade: "É que, para nós, ontem como hoje, só há uma verdade, um caminho e uma luz: Salazar!"22

E nessa luta - que nunca reflecte sobre a "verdade do outro" - vai usar de toda uma metodologia simultaneamente de louvor e de combate. Neste último caso, conforme refere quando fala de $A$ Verdade nas suas Memórias, através da sua "ideia genial" de pôr os "reviralhistas" e os republicanos a usar as suas palavras contra o próprio regime que diziam defender, ou, explicando melhor, a criticar a República por que tanto se haviam batido. Assim, utiliza frases como estas: António José de Almeida escreveu - "O terror campeia no País! É uma onda de pavor que invade a terra portuguesa e a estrangula nos elos do boato, do assalto, da prisão, da intriga". Ou cita José Domingues dos Santos, da Esquerda Democrática, um mês antes do 28 de Maio: "O Partido

\footnotetext{
${ }^{20}$ Ver essas entrevistas no próprio jornal ou na obra de Brochado, Salazar e "A Verdade", Porto, Edição de Autor? (Depositária: Livraria Educação Nacional), 1937, p. 43 ss.

${ }^{21}$ Memórias, p. 124 ss.

${ }^{22}$ Salazar e "A Verdade",p. 24.
} 
Democrático é hoje uma agência de negócios em véspera de falência fraudulenta..." Ou Junqueiro: "Isto para aí está um bacanal de percevejos numa enxerga podre" 23 .

Essa "ideia genial" (segundo as suas palavras), se tinha eficácia propagandística, e continuou a ter em momentos de crise política do Estado Novo, não tinha, porém, nenhuma originalidade. Os integralistas, desde os primeiros momentos de luta no interior da República, usavam semelhante processo que Brochado utilizou em $A$ Verdade e em momentos posteriores da sua acção política. Lembremos alguns títulos de artigos dos primeiros números da Nação Portuguesa: "O 'liberalismo' de Alexandre Herculano", "O testamento de Garrett", "Pensamento político de Eça de Queirós", "Teófilo Braga mestre da Contra-Revolução"....2. Teófilo ... "Mestre da Contra-Revolução", como, de resto, os ideólogos da Action Française representaram Proudhon. Só que Brochado usava esse processo em plena lógica de propaganda e de pura polémica, como desde há muito sucedera com alguns militantes legitimistas do século XIX, e não em termos de "teorização".

Foi esta afinal a sua prática em momentos diversos, como, por exemplo, quando atacou Norton de Matos, durante a sua candidatura à Presidência da República, escrevendo um volumoso livro, com algumas pretensões historiográficas, visando sobretudo a Primeira República, em que o candidato desempenhara um papel de relevo, o qual intitulou $O$ Sr. Norton de Matos e a sua Candidatura $(1948)^{25}$. Não hesitou - utilizando as palavras de republicanos e liberais, que usavam o seu direito à crítica, em liberdade de expressão, por vezes (é certo) crítica bem forte, ou os seus próprios argumentos - em atacá-lo como governador de Angola e, depois, como Alto Comissário, como membro do Partido Democrático e até como Ministro da Guerra, considerando-o, se não "o responsável pela nossa entrada nessa guerra" (a Primeira Guerra Mundial, evidentemente, cuja intervenção criticava), "um dos mais responsáveis" ${ }^{26}$, e mesmo pondo em dúvida a sua defesa da ideia de "Unidade Nacional", de unidade de Portugal e das colónias, que de resto viria a ser explicitada no livro, marginalizado pelo regime, A Nação Una ${ }^{27}$. Acima de tudo,

${ }^{23}$ Memórias, p. 116.

${ }^{24}$ Vide Nação Portuguesa, n. ${ }^{\text {s }} 1,4,10,11,12$.

${ }^{25}$ O Sr. Norton de Matos e a sua Candidatura. Lisboa, Portugália Editora, 1949. No Prefácio desta obra, afirmando-se como estudioso do "periodo que vai de 1910 a 1926", pergunta. "Como poderia um português consagrado ao estudo da história pátria ficar silencioso ao vê-la deturpada? Como havia de ficar inerte, perante o que vinha de ler [refere-se ao manifesto de Norton de Matos como candidato à Presidência da República], um homem que está estudando o regime republicano? $O$ escritor não pode furtar-se aos deveres do patriotismo, nem ficar neutro nas batalhas entre a Verdade e a Mentira" (pp. 8-9).

${ }^{26}$ Ob. cit., p. 19.

${ }^{27}$ A Nação Una. Com um Prefácio do Prof. Egas Moniz. Lisboa, Paulino Ferreira, Filhos, [1952]. 
o que estava em causa é que Norton era Grão-Mestre da Maçonaria (foi esta a principal arma da propaganda salazarista para o atacar) e aceitara, aos 80 anos, ser líder da oposição, com o apoio dos comunistas, que criticava ${ }^{28}$. Suprema heresia! Mesmo tratando-se de um homem - como confessará mais tarde nas Memórias, já longe da luta política - que "era um dos melhores portugueses do meu tempo, patriota inconcussso". ${ }^{29}$

No próprio ano das eleições, 1949 (o Prefácio é de Janeiro, mês anterior ao do sufrágio presidencial, de que Norton desistiu, devido à falta de condições políticas para ir às urnas), vai mais longe e tenta ultrapassar a figura de Norton de Matos para criticar o regime republicano, em que ele se destacara, através da sua "história". Aí está a história ao serviço do regime de Salazar, como já havia feito antes, da mesma forma e de outra, como iremos ver. $\mathrm{Na}$ obra Para a História de um Regime ${ }^{30}$ procurará provar que a Primeira República era um regime cheio de defeitos estruturais, tendo em conta o significado precário do Chefe do Estado, a desordem do Parlamento, as manobras políticas do Exército e da Armada, a má organização das Finanças, da Administração, da Assistência, ou o carácter desenfreado da Imprensa. Cumpria afinal, como dizia no Prefácio, o "elementar dever de optar pela verdade contra a mentira, pela ordem contra a anarquia, pelo direito contra o arbitrio". No fundo, desejava mostrar, como quem lança um panfleto, como o governo de Salazar, depois da "desordem republicana", significava - no seu dizer - "na história política contemporânea, a última possibilidade da Pátria Portuguesa, no que toca à realização da indispensável unidade nacional, condição sine qua non para a consolidação definitiva da independência nacional"s1.

A tese da "catástrofe", considerada uma fatalidade no caso de os republicanos voltarem a governar, era afinal a linha de rumo de toda a sua ideologia de combate:

A interrupção deste Governo [de Salazar], no momento presente, arrastaria o País irremediavelmente, à maior catástrofe da história.

Há momentos da história dos povos, e este é um deles, em que uma série de circunstâncias estranhas à vontade e ao domínio dos homens, põem as nações dependentes de condutores em quem se reúnem as misteriosas forças ancestrais que constituem a maior razão de ser da independência colectiva. Vivemos, hoje, uma dessas horas, e só por inconsciência ou má fé se pode conceber a ideia de perturbar a ordem nacional, tendo apenas em vista a restauração de mitos e palavras vãs cuja experiência está feita em longos anos de misérias sem nome e sem perdão ?2 $^{32}$

${ }^{28}$ Ob. cit, passim.

29 Memórias, p. 275.

${ }^{30}$ Para a História de um Regime. Lisboa, Editorial Império, 1949.

${ }^{31}$ Ob. cit., Prefácio, p. 6.

${ }^{32}$ Ob. cit., Prefácio, pp. 6-7. 
Mais tarde, em 1959, ano seguinte ao grande acontecimento eleitoral das candidaturas, pelas oposições, de Arlindo Vicente e do General Humberto Delgado, as eleições haveriam de lhe recordar o que chamou, referindo-se às de 1948-1949, o "vendaval político, cuja força destruidora se baseava muito na confusão em que geralmente vivem os Portugueses acerca da história política dos últimos cento e cinquenta anos". E, assim, resolveu publicar outra obra de carácter pretensamente "histórico" (já há muito programada, segundo dizia, embora com outra estrutura) mas de sentido mais vasto, pois abrangia não só a República, mas também a Monarquia liberal, intitulada Para a História do Liberalismo e da Democracia Directa em Portugal ${ }^{33}$. Dentro da mesma lógica "catastrofista", procurava criar a ideia de que só havia um caminho, a via do Estado Novo:

O grave dilema que está posto à Nação Portuguesa, em nossos dias, é realizar o Estado Novo ou cair na anarquia infrene que precede sempre, de perto, na História, a perda da independência! ${ }^{34}$

Nesse pequeno livro, que era apresentado como "uma conclusão da larga e demorada investigação a que o autor procedeu, durante muito tempo, para se instruir acerca da história política dos últimos cem anos", surge uma análise histórica superficial, cuja matriz se radicava nas concepções contra-revolucionárias do século XIX, ou seja, a ideia de que Portugal perdera, com a influência da Revolução Francesa e da Revolução de 1820 (ou do reinado de D. José - como veio a dizer nas Memórias $^{35}$ ), o seu fio natural da História. O "liberalismo e a democracia directa" só poderiam lançar Portugal na anarquia e só o Estado Novo poderia fazer sair o país desse "percurso errado", reencontrando-se noutro tipo de democracia, a "democracia orgânica", inspirada por Leão $\mathrm{XIII}^{36}$. Era esta (segundo ele) a tese salazarista, que o levava a afirmar, como vimos, que o Estado Novo não era um regime fascista, como o levará a sublinhar que não era capitalista (como sucedia no mundo liberal e no mundo soviético, neste caso "capitalista de Estado") mas corporativista ${ }^{37}$.

Homem do Estado Novo e da União Nacional, multiplica então as suas intervenções no sentido de opor a existência de "duas políticas". É este, ou um pouco mais, Duas Políticas. Duas Épocas, o título de uma conferência reali-

\footnotetext{
33 Para a História do Liberalismo e da Democracia Directa em Portugal. Lisboa, Parceria António Maria Pereira, 1959.

${ }^{34}$ Ob. cit., p. 11.

${ }^{35}$ Memórias, p. 156.

${ }^{36}$ Cfr., por exemplo, Para a História do Liberalismo..., pp. 10-11 e 15 ss.

${ }_{37}$ Vide, por exemplo, Ética do Estado Novo. Conferência realizada em Lisboa, em 9 de Abril de 1959, perante as Comissões Políticas da União Nacional. Lisboa, Companhia Nacional Editora, 1959, p. 22.
} 
zada em Braga, no dia 28 de Abril de 1959, na posse da Comissão Distrital da União Nacional ${ }^{38}$. O título era por certo inspirado na nota oficiosa de Salazar de 16 de Julho de 1934, Duas Escolas Políticas ${ }^{39}$, em resposta à entrevista dada por Afonso Costa, em Paris, ao jornalista brasileiro José Jobim ${ }^{40}$. Do mesmo modo responderá ao documento assinado por 138 cidadãos, de várias profissões, que pretendiam provar a ilegitimidade e a ilegalidade política do Estado Novo, dirigido a Salazar, para que abandonasse voluntariamente o poder. Resposta a 138 Amigos do "Bem Público" - assim chamou Brochado, ironicamente, a uma conferência proferida em 18 de Abril de 1959 perante as Comissões Políticas da União Nacional de Lisboa ${ }^{41}$.

E, como é óbvio, nessa oposição de "duas políticas", sobressai a lógica oficial - sempre referida nos seus textos - de que o Estado Novo é a única salvação para Portugal. São muitos os discursos e as conferências realizadas nesses anos fundamentais para a sobrevivência do regime, de 1959 a 1961: Política do Estado Novo (1959) $)^{42}$, Actualidade do Estado Novo (1959) ${ }^{43}$, Ética do Estado Novo (1959) $)^{44}$, Passado, Presente e Futuro (1960) ${ }^{45}$, A Missão de Salazar (1960) ${ }^{46}$, Teoria da União Nacional e Realidades da África Portuguesa $(1961)^{47}$.

Alguns títulos são idênticos e outros não, mas as ideias são praticamente repetidas nestas várias intervenções do político de Salazar. Desde os textos de $A$ Verdade continuava a mitificar o Presidente do Governo, que identificava com a "alma nacional":

${ }_{38}$ Duas Políticas. Duas Épocas. Lisboa, Companhia Nacional Editora, 1959.

39 Duas Escolas Políticas. Nota oficiosa da Presidência do Conselho de Ministros de 16 de Jutho de 1934. Lisboa, Edições SPN, 1934. Vide o artigo da nossa autoria "Duas 'verdades'. Salazar e Afonso Costa", in Revista de História das Ideias, n. ${ }^{\circ} 23$, "História e Verdade(s)", Coimbra, Faculdade de Letras, 2002, pp. 409-446.

${ }^{40}$ A Verdade sobre Salazar. Prefácio de Danton Jobim. Rio de Janeiro, Calvino Filho Editor, 1934.

${ }^{41}$ Resposta a 138 Amigos do "Bem Público". Lisboa, Companhia Nacional Editora, 1969.

${ }_{42}$ Política do Estado Novo. Conferência realizada em Bragança na posse da Comissão Distrital da União Nacional em 9 de Março de 1959. Lisboa, Companhia Nacional Editora, 1959.

${ }^{43}$ Actualidade do Estado Novo. Conferência realizada na sede da União Nacional perante as Comissões Políticas de Lisboa, em 2 de Abril de 1959. Lisboa, Companhia Nacional Editora, 1959.

${ }^{44}$ Ética do Estado Novo. Conferência realizada em Lisboa perante as Comissões Políticas da União Nacional de Lisboa, em 9 de Abril, de 1959. Lisboa, Companhia Nacional Editora, 1959.

45 Texto já citado: Passado, Presente e Futuro. Conferência realizada em Viseu em 14 de Junho de 1960, perante as comissões políticas do distrito e sob a presidência do Governador Civil. Lisboa, Companhia Nacional Editora, 1960.

${ }^{46}$ A Missão de Salazar. Discurso proferido na "Liga 28 de Maio", em 27 de Abril de 1960, sob a presidência do ministro do Interior. Lisboa, Companhia Nacional Editora, 1960.

47 Teoria da União Nacional e Realidades da África Portuguesa. Lisboa, Companhia Nacional Editora, 1961. 
Salazar não é um político - é a própria política nacional dos nossos dias; também não é um chefe de partido, nem de escola, nem de regime - é a alma viva da Nação à procura do seu futuro, no mar revolto das paixões e dos interesses nacionais e internacionais. ${ }^{48}$

Portanto, Portugal, longe de estar à margem dos povos, é também o seu condutor, dirigido por Salazar. A "democracia directa", o "liberalismo político-económico", estava a morrer, assim como deveria morrer a "democracia popular exemplificada na Rússia e seus países satélites”. Mas mantinha-se vivo o "Liberalismo-filosofia-da-Vida-e-do-Homem, que é uma das maiores aquisições do Cristianismo, como fundamento pelo respeito sagrado pela dignidade da pessoa humana". Brochado acrescentará: "desse somos nós os defensores e é nele, precisamente, que baseamos a nossa doutrina". E continuará: "E o mesmo diremos da Democracia orgânica, outra conquista do Cristianismo, através da teoria do direito divino providencial, de que a nossa política é, de que nós somos, os legítimos defensores, ninguém o tendo defendido melhor do que nós em todo o Ocidente". Dirá ainda mais, como uma conclusão fundamental a coroar todo o raciocínio: "Não regressaremos, portanto, ao regime de partidos, à Democracia directa, que aliás fez a sua época, e temos a certeza de que todo o Ocidente terá de nos seguir, mais cedo ou mais tarde, como está fazendo a França (pátria da democracia directa, fonte dos partidos!), se se quiser efectivamente vencer o totalitarismo soviético que já abarca meio mundo"49.

Nesta lógica de Portugal e de Salazar condutores de povos - a própria França gaullista nos estaria a dar razão - era preciso fazer compreender (eis a suprema dificuldade!) que Salazar não era eterno e que haveria em Portugal de se continuar o caminho por ele traçado: "Salazar há-de desaparecer do número dos vivos, como sucede a todos os homens, e a Nação Portuguesa tem de continuar a sua História" ${ }^{50}$. Por isso, haveria que dinamizar a União Nacional - e essa tarefa ia-se tornando praticamente impossível nesse final dos anos cinquenta, que marcam uma viragem da sociedade -, que, paradoxalmente, mas de forma coerente com o pensamento do Estado Novo, era entendida como o partido "não partido" ou não era considerado mesmo um partido:

Seremos, então, o partido dos que não querem partidos?

A União Nacional, por isso que não é um partido mas serviço político da Nação, não se dirige a alguns mas a todos os Portugueses, e não existe para os dividir em lutas fratricidas, à roda de mitos e paixões, mas unicamente para os servir -

48 Política do Estado Novo, p. 11.

49 Ob. cit., pp. 14-15.

${ }^{50}$ Idem, p. 11. 
como a força de coesão que une as moléculas de um corpo que não deseja pulverizar-se.

É isso mesmo: somos, nesta hora apocalíptica do Mundo em revolução permanente, a força de coesão destinada a manter a unidade e a vida do grande corpo nacional de aquém e além mar. ${ }^{51}$

Nesta lógica, não haveria, portanto, lugar para qualquer mudança política em Portugal, pois seria o próprio Portugal o motor da verdadeira mudança, já que se, ao contrário, se modelasse politicamente pelos regimes existentes nos Estados Unidos, na Inglaterra ou na França, iria afinal lutar contra as dificuldades do capitalismo, porque eles passam, e iria entrar num processo de revisão de sistemas político-económicos, que era o problema "mais grave de toda a história da Europa" ${ }^{52}$.

Salazar era, para Costa Brochado (insistimos nesta ideia), um "génio político" ${ }_{53}$ (terminologia que, curiosamente, o próprio Salazar utilizou quando, em 1938, se referiu a Mussolini ${ }^{54}$ ). No seu dizer, porventura ainda mais expressivo: "Salazar, historicamente falando, não é um Homem mas sim uma Obra - uma obra de salvação nacional" ${ }^{55}$. Era - se empregarmos ainda mais outra significativa forma de dizer de Brochado, quando se referia ao dia 28 de Abril, data do seu nascimento, em 1889 - "um Português anónimo" em que "a providência [...] infundiu os misteriosos segredos e as virtudes heróicas de que a Pátria carecia, no governo do Estado, para não soçobrar, de vez, em nossos dias" ${ }^{56}$. Um homem com uma missão semelhante ao Infante D. Henrique era outra imagem apresentada pelo ideólogo, inspirando-se, curiosamente, num discurso de Eisenhower ${ }^{57}$, numa concepção que pretende salientar o papel dos "guias", dos "chefes de eleição", cuja função consistia, no seu discurso carlyliano, "em interpretar a universalidade do presente, traçando as linhas mestras do futuro, por forma que os povos perdidos em atalhos reencontrem a estrada lisa dos seus destinos" ${ }^{\prime 58}$.

Assim, se era considerado "um crime de lesa-Pátria destruí-lo no caos e na anarquia moral e intelectual dos grupos e facções revolucionárias" ${ }^{\text {"59 }}$, tam-

${ }^{51}$ Idem,pp. 16-17.

${ }^{52}$ Ética do Estado Novo,pp. 20-21.

53 A Missão de Salazar, p. 17.

54 "Preocupação da Paz e Preocupação da Vida", discurso proferido na Emissora Nacional, no encerramento da campanha eleitoral para a nova Assembleia Nacional, em 27 de Outubro de 1938, Discursos, II, p. 105. Salazar pronunciava-se no contexto da conferência de Munique (29 de Setembro de 1938).

55 A Missão de Salazar, p. 18.

${ }^{56}$ A Missão de Salazar, p. 18.

57 Passado, Presente e Futuro, pp. 9-10.

${ }_{58}$ Ob. cit., p. 12.

59 A Missão de Salazar, p. 16. 
bém seria criminoso pensar que "o Estado Novo é Salazar, regime pessoal para o tempo da sua vida". O Estado Novo fora também realizado pelas elites, que são no fundo o que mais precioso existe na sociedade portuguesa, dado que os restantes grupos sociais não têm expressão. Vejamos como Brochado descreve essas elites, também construtoras do Estado Novo, numa evocação que não esquece, para lhe dar força, a "história gloriosa da Pátria":

Na verdade, jamais houve Estadista, desde a Restauração para cá, que reunisse à sua volta, em qualidade e quantidade, um escol de colaboradores como aqueles que vem trabalhando com Salazar, há três décadas memoráveis. Assim como também não há memória, na nossa história política, desde os séculos XV e XVI, de algum Regime ter interessado a Nação inteira, a Nação orgânica, como o Estado Novo vem interessando Portugal sob a égide de Salazar.

Noventa e tantos por cento das aristocracias nacionais têm colaborado e continuam colaborando, activamente, com Salazar e o Estado Novo, sendo historicamente impossível dissociar a Nação do Regime e do seu fundador, visto que Nação, Regime e Salazar se fundiram, há muito, num todo - fora do qual já não será possível vida social nem unidade nacional que nos permitam continuarmos a nossa história.

Não quer isto dizer, é evidente, que fora dos quadros do Regime, e do escol que o vai realizando, não haja portugueses valiosos; são, porém, minoria sem expressão, que a Nação orgânica não entende nem escuta e que, por isso, vivem vida intelectual especulativa, à margem das realidades positivas da sociedade portuguesa. ${ }^{60}$

Era esta a grande questão para os defensores do Estado Novo, ou seja, a impossibilidade de o pensarem como regime com a oposição daqueles que não pensavam como eles, isto é, como Salazar e os salazaristas. Na verdade, há uma lógica "totalitária" nesta forma de pensamento, que o colocou num beco sem saída. A "utopia" da "união nacional" era, efectivamente, impossível de manter, mas, como acabámos de observar, era a única maneira de defender o regime, mesmo nesses conturbados anos sessenta. Daí a dificuldade de poder entender o Estado Novo fora da lógica fascista mussoliniana em que "tudo" reside no Estado. Também afinal no regime de Salazar toda a Nação se identificava ou tenderia a identificar-se com o Estado Novo, pois, para além dos seus apoiantes ou militantes, apenas existia, no dizer de Brochado, uma "minoria sem expressão", relegada (por mais valor que tivesse) para a categoria dos "intelectuais especulativos". Se não fala directamente em repressão justificada destes "intelectuais", como explicitamente se referia o décimo mandamento do Decálogo do Estado Novo ${ }^{61}$, era apenas talvez porque Costa Bro-

${ }^{60}$ Passado, Presente e Futuro, pp. 15-16.

${ }_{61}$ "Os inimigos do Estado Novo são inimigos da Nação. Ao serviço da Nação-isto é: da ordem, do interesse comum e da justiça para todos - pode e deve ser usada a força, que realiza, neste caso, a legítima defesa da Pátria" (Decálogo do Estado Novo, Lisboa, SPN, 1934, p. 87). 
chado - amigo de integralistas como de comunistas, como (conforme vimos) confessou nas suas Memórias - teria, pelo menos formalmente e até certo ponto, um sentido de tolerância que o regime não queria manifestar, através da pena provável de João Ameal, num documento de 1934, tempo de construção do Novo Estado, que seria considerado um texto de propaganda fundamental e dissuasor de qualquer atitude oposicionista.

Nos anos sessenta, Brochado apenas queria acreditar, o mais serenamente possível, que o "futuro" do Estado Novo, identificado com o da Nação, ainda seria possível, apesar das tempestades internas e externas que já se sentiam. Por isso, dizia na sua conferência de Viseu, um dos seus últimos textos políticos, em 14 de Junho de 1960:

Nós podemos, de facto, voltar a ser, se quisermos, como disse Salazar, uma grande e próspera Nação. Mas a hora é esta, neste ano centenário do Infante D. Henrique, sob a égide de Salazar. E o caminho é só um: realizar o Estado Novo, com todos os Portugueses e para todos os Portugueses, criando mais riqueza e aplicando-a e distribuindo-a melhor, numa política de verdadeira união nacional que pode e deve ser melhorada e actualizada mas jamais mistificada sob crime de lesa Pátria. [...]

[...] Quando o Estado Novo estiver devidamente explicado, em suas origens e fins, a todos os Portugueses, por forma a não lhes ficarem dúvidas nenhumas, acabará a oposição em Portugal - porque o comunismo não é oposição mas revolução permanente e todos os outros vivem apenas das confusões que nós deixámos criar, em torno do Regime, esquecidos de que o povo português é muito inteligente e não gosta de confusões...62

Fraca ilusão, porque os alegados "criminosos de lesa-Pátria" (com ideias de todas as tendências) de que fala iam multiplicar-se nesses derradeiros anos do Salazarismo, como se multiplicarão mesmo durante a chamada "Primavera marcelista", na qual Brochado já não colaborará. O próprio Brochado veio a ter disso, posteriormente, uma consciência crítica, quando escreveu estas linhas amargas no Post-Scriptum das sua Memórias: "E quando legiões de advogados, médicos, engenheiros, etc., começaram a pôr em dúvida Salazar e a própria Pátria, falando a mesma linguagem dos Estados Unidos e seus pares, o Povo Português perdeu o pé e afundou-se..." "63

O Estado Novo, com o espírito de "união nacional", no qual ainda queria acreditar em tempos críticos, revelou-se uma fortaleza com alicerces de barro e desfez-se com a "guerra colonial" ou as "campanhas ultramarinas" que atravessaram esses anos sessenta e a década seguinte, e, enfim, com o putch militar e o movimento nacional do 25 de Abril de 1974. Também os textos

${ }_{62}$ Passado, Presente, Futuro, pp. 28-29.

${ }^{63}$ Memórias, p. 521. 
propriamente historiográficos de Costa Brochado não puderam contribuir em nada para evitar essa derrocada. Como, aliás, seria de esperar, pois a história, pela mesma altura, começara a ser encarada em outras perspectivas.

\section{O historiógrafo}

Costa Brochado entra em 19 de Julho de 1957 na Academia Portuguesa da História, em 21 de Março de 1969 é académico com o número 16 e em 18 de Fevereiro 1972 é promovido a vogal do Conselho Académico. Já tinha, porém, um longo currículo como historiógrafo, desde pelo menos os anos quarenta. Mais tarde, nas suas Memórias, Brochado dirá, curiosamente, que "a Academia das Ciências era o bastião intelectual da Maçonaria e a Academia da História havia sido restaurada para se lhe opor do ponto de vista católico"64.

Criada em 19 de Maio de 1936, quando era ministro da Educação Nacional António Carneiro Pacheco, teve como símbolos, visíveis, por exemplo nos primeiros números do Boletim da Academia Portuguesa da História, os símbolos católicos, mas acima de tudo manifesta, desde o seu início, nos estatutos de 31 de Julho de 1937, um sentido nacionalista. No seu artigo 2. ${ }^{\circ}$ pode ler-se como fins primeiros da Academia: "Estimular e coordenar os esforços tendentes à investigação, revisão e rectificação da história nacional, no sentido superior da contribuição portuguesa para o progresso da civilização, bem como enriquecer a documentação dos inauferíveis direitos de Portugal". Além disso, entre os primeiros académicos podem contar-se vários monárquicos e sacerdotes católicos, a começar pelo presidente, o Doutor António de Vasconcelos, professor da Faculdade de Letras da Universidade de Coimbra ${ }^{65}$.

Brochado, católico e monárquico desde os anos quarenta - "por inteligência e por contraste..." (conforme confessa nas suas Memórias ${ }^{66}$ ), considerando que "a Monarquia como a da nossa 1. a Dinastia é o melhor dos regimes em confronto com quantos têm sido experimentados..." -, salazarista confesso e incondicional, articulava-se bem com o espírito da Academia nesse tempo do Estado Novo. Mas, não será tanto nas suas comunicações, sobre temas específicos - nas quais se incluem o elogio ao Monsenhor Miguel de Oliveira, autor de uma conhecida História Eclesiástica de Portugal, bem integrada na lógica do salazarismo e no espírito eclesiástico tradicional, ven-

${ }^{64}$ Memórias, p. 328.

65 Vide, sobre as tendências da Academia Portuguesa da História na sua fase inicial, o título da nossa autoria "A 'Restauração' da Academia Portuguesa da História", in História da História em Portugal, p. 283 ss. O itálico do passo transcrito dos estatutos da Academia é da nossa responsabilidade.

${ }^{66}$ Memórias, p. 371. 
cedora, em 1940, do Prémio Alexandre Herculano do Secretariado de Propaganda Nacional (SPN) - que encontramos a linha de rumo da historiografia de Brochado. Como dizíamos, ela é muito anterior e surge - segundo as suas confidências memoriais - quando foi nomeado em 1935 redactor do Diário das Sessões da Assembleia Nacional, altura em que Joaquim Leitão lhe pediu para dirigir os Serviços de Biblioteca e Arquivo. Foi a partir dessa altura, até ao momento em que, nos anos cinquenta, volta à liça política no interior da União Nacional, período que designou como "travessia do deserto", que se desenrola, pois, a sua prática mais profícua de historiógrafo ${ }^{67}$.

Seguindo uma linha de rumo de acordo com a "razão de Deus" e com a "razão de Estado" (salazarista), vai, pois, ser reconhecido pelo regime. O seu primeiro livro, D. Sebastião, O Desejado $(1941)^{68}$, recebe uma menção honrosa no Concurso Nacional de História, que atribuía o Prémio Alexandre Herculano, do SPN, nesse ano ganho pela História de Portugal, de João Ameal. A obra Infante D. Henrique ${ }^{69}$, publicada no ano seguinte, foi a vencedora do referido prémio. Logo no ano imediato, 1943, publica Afonso de Albuquerque ${ }^{70}$, vencedor do prémio de História no concurso de Literatura Colonial.

E, a estas obras, longas e prolixas (com uma média de 400 páginas por livro), sempre servidas de pretensa justificação erudita e de interpretações consideradas pelo autor como "originais", mas também escritas de forma divulgativa, capazes de captar o leitor, segue-se D. Afonso Henriques, que vem à luz em 1947 (o ano do Centenário da Conquista de Lisboa aos Mouros, que constituiu um dos acontecimentos marcantes dos espectáculos históricos do Estado Novo $)^{71}$.

A premiar este vasto labor - que teve também uma obra de "historiografia religiosa", de tipo fideísta (Fátima à luz da História, com o nihil obstat do jesuíta Padre Agostinho Veloso, datado dia da Anunciação de Nossa Senhora, e o Imprimatur do Cardeal Cerejeira, de 28 de Abril de $1948^{72}$ ) - é nomeado, em 1950, secretário geral da Comissão das Comemorações do IV Centenário da Morte de S. João de Deus, vindo também a produzir um estudo sobre o tema ${ }^{73}$. E, em 1958 (era já académico), vem a integrar a Comissão Executiva das Comemorações do V Centenário da Morte do Infante D. Hen-

${ }^{67}$ Memórias, p. 227 ss.

${ }_{68}$ D. Sebastião, O Desejado. Lisboa, Editorial Império, 1941.

${ }^{69}$ Infante D. Henrique. Lisboa, Editorial Império, 1942.

70 Afonso de Albuquerque. Portugália Editora, 1943.

71 D. Afonso Henriques. Lisboa, Portugália Editora, 1947.

${ }^{2}$ Fátima à luz da História. Portugália Editora, 1948.

73 S. João de Deus. Lisboa, Portugália Editora, 1950. O referido estudo era inicialmente um capítulo da obra do Centenário e só depois foi individualizado como livro. 
rique. Neste contexto, escreve vários textos, entre eles um dos volumes da "Colecção Henriquina", Descobrimento do Atlântico (1958) ${ }^{74}$.

Entretanto, nos anos quarenta, envolvera-se numa polémica com Duarte Leite acerca do seu livro Infante D. Henrique. Não era, naturalmente, apenas uma polémica historiográfica, mas ideológica, já que Duarte Leite fora uma das personalidades mais importantes da Primeira República e nessa altura a historiografia era também uma arma de combate, da "situação" e da "oposição". Parte do debate veio publicado na revista Seara Nova, mas Costa Brochado publicou o seu próprio livro, intitulado precisamente História de uma Polémica $(1944)^{75}$. Igualmente as Comemorações Henriquinas iriam originar outra polémica de grande significado mas de menor ressonância, ligada ao impedimento da publicação da obra de Vitorino Magalhães Godinho, Os Descobrimentos e a Economia Mundial", na "Colecção Henriquina", por alegados intuitos economicistas, o que desvirtuaria o "verdadeiro sentido, essencialmente espiritual" - segundo a óptica de Costa Brochado - da nossa expansão.

Ainda no final dos anos quarenta escreve um texto de sabor historiográfico que tem um sentido de intervenção mais directa nos assuntos políticos de carácter luso, já que, à aproximação do Brasil no tempo de Getúlio Vargas, se sucedeu, depois da guerra, ou no seu final, uma clara tentativa de estabilização (sempre difícil) das relações luso-brasileiras. Além disso, era também uma arma contra o anticolonialismo que começava a propagar-se nesses anos do pós-guerra. O livro, publicado em 1949, ano da fundação da NATO, intitula-se A Lição do Brasil ${ }^{77}$. Nos anos cinquenta, em que de novo se começa a integrar activamente na política, produz obras de menor fôlego do que as primeiras e com um carácter mais directamente de política funcional. Para além de $A$ Conquista de Lisboa aos Mouros (1952), escrita - segundo dizia no breve Prefácio - por verificar que "constituiu acontecimento fundamental da política europeia daqueles tempos", escreve, no contexto do agudizar dos problemas indianos, o opúsculo Que significa a Índia para os Portugueses $(1954)^{78}$.

1960 é o ano do Centenário Henriquino. Passado esse tempo, é a vez de escrever outra longa obra (com cerca de 300 páginas), mas desta vez sem uma só nota de rodapé, abandonando pois uma pretensa erudição historiográfica para entrar decididamente na divulgação, uma divulgação de tipo ideológico. Trata-se do livro com o título significativo D. Pedro I. "Em prol do seu poboo" (1965)

${ }^{74}$ Descobrimento do Atlântico. Lisboa, Comissão Executiva das Comemorações do Quinto Centenário da Morte do Infante D. Henrique, 1958.

75 História de uma Polémica. Lisboa, Portugália Editora, 1944.

76 Os Descobrimentos e a Economia Mundial. Lisboa, Sá da Costa, 1962.

77 A Lição do Brasil. Lisboa, Portugália Editora, 1949.

${ }^{78}$ Que significa a Índia para os Portugueses. Lisboa, Editorial Império, 1954.

79 D. Pedro I. "Em prol do seu poboo". Lisboa, Edição de Autor? (Depositária: Livraria Sá da Costa), 1965. 
O seu labor historiográfico vai prolongar-se para além da sua actividade política, através das comunicações referidas, apresentadas na Academia Portuguesa da História: desde o texto Tentativas de Canonização de El-Rei D. Afonso Henriques (1957) ${ }^{80}$ até $O$ Povo Eleito na História da Civilização $(1976)^{81}$, já publicado, portanto, depois do 25 de Abril.

Só as suas Memórias, publicadas em 1987 (nesse mesmo ano saiu a segunda e a terceira edição), em que narra a sua história e as suas "estórias", vão pôr fim às suas publicações. Morre em 20 de Novembro de 1989, com 85 anos. Antes, porém, de "entrar no outro Mundo", terá escrito ao Conselho Académico da Academia Portuguesa da História, com data de 17 de Março de 1987, uma carta em que pedia para "renunciar à qualidade de sócio do Número". Conforme dizia, ao contrário da sua crença no "outro Mundo", descria da "imortalidade Académica"... ${ }^{82}$

Foi, porém, um gesto sentimental, que pretendia ser de coerência - Brochado entenderia que a Academia teria perdido, com o regime democrático do pós-25 de Abril, a sua razão de ser -, mas que logo foi ultrapassado, devido a um acto de conciliação que a instituição académica lhe promoveu. Por isso, Costa Brochado transcreve essa carta somente na 1. a edição das referidas $\mathrm{Me}$ mórias, apagando-a nas edições posteriores. ${ }^{83}$

\section{A "história" ao serviço da "Razão de Deus" e da "Razão de Estado"}

Finalmente, procuremos entender melhor o sentido da historiografia de Costa Brochado que já dissemos estar ao serviço da "Razão de Deus" e da "Razão de Estado" (salazarista).

Sigamos agora uma linha essencialmente cronológica dos acontecimentos históricos tratados, para percebermos a ideologia que está por detrás da sua interpretação histórica, que vamos destacar, não nos envolvendo tanto em críticas metodológicas e de conteúdo.

Obviamente que a Fundação da Nacionalidade tinha, para Brochado, um papel fundamental. Mas não só a nível nacional, pois pretende integrar sempre a história de Portugal na história do Mundo, centrada na ideia de Civilização Cristã Ocidental, que ultrapassava também, em muito, a realidade do

${ }_{80}$ Tentativas de Canonização de El-Rei D. Afonso Henriques. Academia Portuguesa da História, 1957.

${ }^{81}$ O Povo Eleito na História da Civilização. Academia Portuguesa da História, 1976.

${ }^{82}$ Memórias, p. 523. Esta nota, em Post-Scriptum, encontra-se (como em cima se diz) apenas na 1. ${ }^{a}$ edição.

83 Esta informação foi-nos dada pelo então Presidente da Academia, Prof. Doutor Joaquim Veríssimo Serrão. 
século XII. Afonso Henriques, como as outras figuras que tratou, eram afinal uma espécie de heróis carlylianos (recorde-se o livro de Thomas Carlyle, On heroes, heroworship and the heroic in the history), espécie de personagens providenciais a quem cabe dirigir a sociedade em determinados momentos, competindo ao povo seguir activamente os seus desígnios. Assim, o nosso primeiro rei aparece, em dado momento, na sequência do processo iniciado séculos atrás, a dirigir todo o movimento de Reconquista Cristã, não só congraçando portugueses mas cruzados de várias partes da Cristandade. Daí a importância referida que Brochado concede - como vimos - à conquista de Lisboa aos mouros. Afinal o livro D. Afonso Henriques, o primeiro herói da sua cronologia heróica, embora seja o terceiro da sua cronologia bibliográfica, aponta, por isso, para outras missões a serem desenvolvidas por outros heróis, não só em Portugal, mas em Espanha, ou seja, todo o processo seguinte da Reconquista, que tem como ponto alto o Salado mas que culmina, na Península Ibérica, com Fernando e Isabel, os Reis Católicos de Aragão e Castela, e que terá outro desenvolvimento com as Descobertas e'as Conquistas ultramarinas, de que destaca nomeadamente o Infante D. Henrique e Afonso de Albuquerque. São estas as derradeiras palavras do seu livro, publicado (como dissemos) em 1947, sobre o "rei fundador":

Expulsos, enfim, os mouros da península ibérica, ergueu-se a Cruz de Cristo desde as montanhas das Astúrias às praias de Algeciras, e a Igreja Católica pôde respirar fundo e sossegar um instante das suas porfiadas canseiras de tantos séculos seguidos.

Mas o Mundo Cristão, apesar de livre do afiado punhal de aço que lhe ameaçava as costas há centenas de anos, não se podia considerar definitivamente constituído e consagrado, à face do mundo conhecido, só porque os árabes haviam sido expulsos da Espanha. O Mundo Árabe, de que a península ibérica não fora mais do que uma das muitas partes que o compunham, continuava a dominar os recursos vitais da humanidade, desde as indispensáveis matérias primas asiáticas ao comércio de toda a cristandade. Era preciso, portanto, para que o Mundo Cristão se estendesse a toda a terra, erguendo a cruz de Cristo entre todos os filhos de Deus, que os árabes fossem privados das riquezas fabulosas com que alimentavam a harmonia e a força dos seus exércitos. Sobretudo, era indispensável arrancar-lhes o domínio do comércio indiano.

Essa tarefa gigantesca, que decidiu em sentido cristão os destinos da humanidade, foi reservada aos Portugueses, os quais a realizaram, conforme demonstro nos meus livros Infante D. Henrique e Afonso de Albuquerque, de uma forma que ainda hoje infunde espanto ${ }^{84}$

D. Henrique é, pois, o símbolo dos Descobrimentos, que, por sua vez, têm um papel fundamental no "Mundo Cristão" e não têm apenas que ver com

${ }^{84}$ D. Afonso Henriques, pp. 297-298. 
uma simples epopeia portuguesa ${ }^{85}$. O Infante é um "herói": "Não era um homem galante, nem um sportman, nem um cabecilha para qualquer das facções que dividiam o país. O seu espírito pairava muito acima das pequenas lutas da política. Enchia-o a beleza estranha das coisas novas que sonhava. A meditação, o estudo, aquela surpreendente disciplina moral e mental que o afasta do mundo para ao mundo dar formas novas, fizeram dele uma pessoa estranha, que realiza o paradoxo de renunciar à vida para a tornar mais bela e confortável!" 86 . Não se admire que digamos que Brochado, ao interpretar assim a figura do Infante de Sagres, estivesse também a pensar em Salazar, pois, como vimos, ele próprio não deixou de aproximar os dois "heróis", como fizeram, de resto, outros salazaristas ${ }^{87}$. Por sua vez, o Infante D. Pedro pode também, na sua lógica de encontrar o "anti-herói", aproximar-se do "intelectual" da oposição ao salazarismo: "Decididamente o Infante D. Pedro, apesar da experiência e da cultura que o exornavam e de que deixou provas nalguns bons serviços prestados ao pais, cedia à cobiça de mandar, e as grandes qualidades que possuía perdiam-se no orgulho e na paixão que essa ideia dominante incendiava. Por este caminho, cuidando da sua pessoa e supondo-se superior a todos, criou ódios mortais entre a nobreza, que o não podia ver. [...] E na pessoa deste Duque se foram concentrando, através da Regência de D. Pedro, todas as más vontades que ele provocava"88. Alfarrobeira fora assim o justo castigo para a oposição que este "intelectual" com espírito de partido representava.

É nesta dialéctica entre o bem e o mal que, para Brochado, se desenvolve a história. Venceu D. Henrique e o seu desejo heróico de constituir além-Europa uma outra realidade, percurso que o historiógrafo-ideólogo procurou acompanhar. "E assim foi que a Civilização ocidental cristã começou a dominar o Mundo!" 89 - termina com estas palavras retumbantes o livro sobre o seu "herói" solitário, sacrificado ao estudo e a uma causa.

Outro "herói", da Conquista do Império e do Mundo Cristão, é Afonso de Albuquerque, cuja "história", sempre integrada na história da Europa e do Mundo, analisa, num livro que é o mais volumoso de quantos escreveu (quase 500 páginas). Outros "heróis" serão, no seu modo de pensar e de dizer, S. João de Deus, "figura moral sem par na história dos grandes apóstolos da Caridade", o santo português que vivera para os pobres por essa Europa cristã ${ }^{90}$, e os missionários que levarão a cruz de Cristo a todos os cantos do Mundo. Com

${ }^{85}$ Infante D. Henrique, por exemplo cfr. p. 13.

${ }_{86}$ Ob. cit., p. 214.

${ }^{87}$ Cfr. António Ferro - Salazar. O Homem e a sua Obra. 3. ${ }^{a}$ edição, Lisboa, Emprêsa Nacional de Publicidade, s.d., pp. 161-165.

${ }^{88}$ Infante D. Henrique, p. 295.

${ }^{89}$ Idem, p. 398.

90 Vide o obra citada S. João de Deus (1950). 
a "agonia e morte do Gigante" Afonso de Albuquerque também se verifica o "sonho desfeito" do Império cristão em Portugal: "A chama sagrada do Mundo Cristão, que os Portugueses detinham desde os tempos do Infante D. Henrique, passa para as mãos de Carlos V.É ele, agora, quem, imperador da Europa cristã, benzido e coroado pelo Papa, assume o encargo de destruir os turcos e salvar o Mundo Cristão. Vibra-lhes o primeiro golpe mortal em Tunes, e nunca mais os deixa em situação de poderem dominar. Mas, ainda assim, era tal a vitalidade do império Otomano que ele subsistiu até os nossos dias, só perdendo importância militar e política a partir da ocupação francesa, em 1830 !"91

Nesta história dialéctica de Costa Brochado aparece, portanto, sempre, o pólo cristão e o pólo muçulmano, "pólo demoníaco", que será substituído por outros. Serão esses pólos o "liberalismo" e a maçonaria do século XIX (o "estúpido século XIX", segundo Daudet ${ }^{92}$ ), que se prolongará pelo século XX, com a República em Portugal e o Comunismo no Oriente. E se Fátima representará, no campo religioso, a vitória da Cruz sobre o Triângulo e as profecias da derrota do Comunismo, no domínio mais estrito da política Salazar será o derradeiro "herói" do Mundo Cristão ocidental. No fundo, ambos representam Portugal, que tentará levar o seu credo aos outros povos que perigosamente mantiveram o regime "ultrapassado" dos partidos, permitindo assim a afirmação da foice e do martelo.

Neste contexto histórico de longo curso, surgem outros "heróis". É o caso do rei D. Pedro I, símbolo da justiça e amado pelo povo, que conseguiu ultrapassar as lutas internas, combatendo contra os privilégios e os "partidos":

O reinado de El-Rei D. Pedro I foi, como já sabemos, um período de paz, de ordem e de progresso, do princípio até ao fim. [...] A paz e a ordem em que a vida nacional decorreu durante o governo deste Monarca singular, favoreceu, naturalmente, o desenvolvimento económico e social do País, de forma que, à morte de D. Pedro, toda a gente chorou, considerando que ele a todos havia proporcionado, com o seu governo justo e sua administração exemplar, os dez anos mais tranquilos e abastados que Portugal, até aí, tinha vivido.

$[\ldots]$

O segredo de D. Pedro I consistiu, quanto a nós, em conseguir, antes de mais nada, através de uma hábil e firme política externa, manter a neutralidade do País, não só nas querelas intestinas dos Reinos peninsulares, mas também nos graves dissídios europeus que estão na base da guerra dos cem anos; e, depois, em extinguir os vestígios de guerra civil no Pais, quer esquecendo-se, ele mesmo, dos graves conflitos do tempo de seu pai, quer abafando, com uma política interna tão sensata como lúcida, as pretensões políticas do Clero e da Nobreza. Tornando-se rapidamente popular, sem demagogia, mas com sincera naturali-

91 Afonso de Albuquerque, p. 496.

${ }_{92}$ Cfr. Fátima à luz da História, p. 48. 
dade, $[\ldots]$ logo que surpreendeu o País com as suas primeiras medidas inovadoras e justiceiras passou a ser amado do Povo que lhe emprestou toda a força de que carecia..$^{93}$

Publicada em 1965, esta obra sobre D. Pedro não pode - na lógica de Brochado, em que sempre pressentimos um vai-vem no tempo, um caminhar do passado para o presente e do presente para o passado - deixar de nos levar a pensar no retrato que ele tinha de Salazar, que formara desde os inícios do Estado Novo e que consolidara agora, numa altura que já era de crise para o regime, mas num tempo que se adivinhava cada vez mais crítico.

Falando, nas suas Memórias, da entrevista que Salazar lhe concedera para o jornal A Verdade, já nos afastados anos trinta, dá-nos esta surpreendente (ou talvez não) imagem do "Chefe": "Retenho dessa nossa primeira entrevista, a sós, que Salazar era sinceramente antimilitarista, anticlerical, justo, recto e verdadeiro!"’94 Como é que um militante católico do Centro Académico de Democracia Cristã (CADC) e de Centro Católico Português poderia ser considerado "anticlerical"? Obviamente que na perspectiva de que o clero poderia constituir um poder, como os militares, contra a "política popular", sem partidos nem privilégios. Tal como via $\mathrm{D}$. Pedro, o monarca justo que estava acima de privilégios das ordens. Por isso, nos anos sessenta do século XX, todo o povo deveria seguir Salazar, como o povo seguira D. Pedro no século XIV. Era afinal isso que o próprio Brochado escrevera no Prefácio do livro, datado de 9 de Fevereiro de 1965: "Praza a Deus que todos nós, os Portugueses de hoje, saibamos estar à altura de El-Rei D. Pedro I, e 'do Poboo', na hora turva e amarga que aí vem". ${ }^{95}$

Outro "herói" (talvez menos "herói”), a quem dedicou (como vimos) o seu primeiro livro, foi D. Sebastião. Procurou afinal apresentá-lo livre de críticas que lhe eram comummente feitas - em especial pela corrente republicana, na polémica sobre a crise do final do século XVI e o Seiscentismo -, entendendo-o, ao invés, como "bom católico", casto e pudorado. Contra a corrente do tempo, contra mesmo o que lhe indicavam os seus autênticos conselheiros (os jesuítas irmãos Câmara), ludibriado pelo "partido espanhol", D. Sebastião, sentindo-se "disposto e obrigado a aplicar-se no serviço da Fé e do Império", pensou Marrocos como "questão vital para a Nação e a Igreja". Daí adveio o desastre de Alcácer Quibir, mas permaneceu a lenda do rei santo e "desejado", mesmo - segundo Brochado, inspirado no livro polémico de Afonso Dornelas ${ }^{96}$, escrito contra os juízos republicanos - entre os muçulmanos. E excla-

93 D. Pedro,pp. 199-200.

${ }^{94}$ Memórias, p. 133.

95 D. Pedro, Prefácio, p. [13].

96 De Ceuta a Alcácer-Quibir em 1923. Lisboa, 1925. 
mava, com a inspiração de Chateaubriand: "Como "junto do grande Rei português', pareciam 'ignóbeis e pequenos' certos príncipes favoritos da fortuna, 'tão pouco dignos da sua alta jerarquia'!"'97.

Eram igualmente "heróis" os missionários do Brasil, que tentaram livrar os índios da escravatura e suavizar a escravatura dos negros, considerada uma necessidade na época e uma necessidade para a economia portuguesa. Contrariando Gilberto Freire, que mostrava os índios de forma benigna, "ensinando aos Portugueses benefícios da sua civilização", sobretudo no que tocava a hábitos higiénicos, apresenta os autóctones do Brasil com palavras duras e mesmo chocantes: "o índio brasileiro era imundo, física e moralmente, metendo-se nas águas dos rios pelos mesmo motivos que o Europeu via os cevados banharem-se nos charcos e ribeiros..." ${ }^{\text {98 }}$ Foram, portanto, os portugueses os únicos civilizadores, assim como teriam tratado os escravos negros com humanidade, ao contrário do que sucedera com os anglo-americanos, os franceses ou os holandeses. No período do pós-guerra em que a campanha anticolonial se começava a acender, Costa Brochado procurava dar ênfase ao que considerava a "lição do Brasil", ou seja, a forma de "colonização exemplar" de Portugal, em comparação com a colonização de outros povos. O capítulo "Confronto esclarecedor" era o desenvolvimento deste tema ${ }^{99}$.

O citado opúsculo sobre a Índia, de 1954, era ainda mais evidente quanto aos propósitos políticos. Portugal é o símbolo da Civilização Cristã no Oriente, tendo levado a efeito uma política de miscigenação, que levou essa civilização directamente ao povo indiano. Assim, os povos da Índia Portuguesa - dizia no seu tom eurocentrista - "são Portugueses e não Indianos; porque são Cristãos e não adoradores de bichos; porque são, sobretudo, Ocidentais e não Orientais!"”100 E, dentro da lógica do "herói" - neste caso não o "herói condutor", mas o "herói povo" - cita o caso de Aniceto do Rosário, indo-português, vítima da guerra contra a Índia Portuguesa pela força de Nehru. A concepção promovida pelo Estado Novo de Salazar, através dos seus discursos, em que se assume como "missionário" quase isolado de uma "ideia", foi naturalmente assimilada por Brochado, o qual não se cansa de afirmar que, ao contrário de Portugal, as nações europeias esqueceram o seu dever civilizacional para com o mundo. Portugal é, pois, o "herói" que persiste, personalizado pelo líder Salazar:

Foi no rasto dos Portugueses que todos os povos europeus, que a Civilização Ocidental penetrou em toda a Ásia, dando volta ao Mundo inteiro, e dominando

D. Sebastião, p. 362 (cit. de Chateaubriand: Histoire de France. Analyse raisoné. Paris, 1857, t. II, p. 87).

${ }_{98}$ A Lição do Brasil, p. 151.

99 Cfr. ob. cit., p. 157 ss.

${ }_{100}$ Que significa a Índia para os Portugueses, p. 45. 
a humanidade desde então aos nossos dias. E assim veio a florescer e triunfar, nas cinco partes do Mundo, a mais bela civilização de que fala a história do Homem sobre a Terra.

Mas as nações europeias que nos últimos séculos têm conduzido, em toda a parte, o facho dessa civilização, parece terem-se demitido, voluntariamente, da sua altíssima missão, conspurcando, primeiro, os seus princípios fundamentais, e abandonando, agora, o Mundo, ao milenário imperialismo asiático renascido, enquanto o cerco da Europa se vai apertando com uma força nunca vista em tempo algum.

Cabe a Portugal, ainda nesta hora conturbada e decisiva, a honra e a glória de poder afirmar, perante a História, que nunca traiu a sua missão ocidentalista, nem jamais se demitiu, voluntariamente, dos seus deveres, perante o inimigo permanente da nossa civilização e da própria espécie humana.

Por onde quer que passaram, em todos os pontos do Globo que lhes coube ocidentalizar, ergueram os Portugueses comunidades cristãs, onde legiões de seres humanos subiram das trevas para a luz da nossa civilização, transformados em testemunhos vivos do nosso dever cumprido $[\ldots] .{ }^{101}$

Portugal é, pois, o grande "herói" desta tragédia, é "O Povo Eleito na História da Civilização", conforme intitulava - como dissemos - uma comunicação tardia apresentada à Academia Portuguesa da História, em 1976. Costa Brochado, coerentemente, nunca se deu conta de que o tempo tinha passado e as sua Memórias, de 1987, tinham na capa uma foto de Cerejeira e de Salazar, que para ele constituíam os símbolos, os "heróis" da Civilização Cristã portuguesa, que defendera até quando e quanto pudera, utilizando a ideologia e a historiografia, a historiografia e a ideologia, profundamente ligadas, a ponto de podermos perguntar se os seus escritos não são afinal textos de ideologia historiográfica ou de historiografia ideológica.

\section{A concluir}

Costa Brochado não passou de Secretário Geral da Assembleia Nacional e de membro influente da União Nacional, mas a sua acção, se não se caracterizou pelo sentido da "política do espírito" de António Ferro ou do jornalismo intelectual de Augusto de Castro, salientou-se, pelo menos, pela fidelidade às suas ideias - o ideal da Civilização Cristã, que foi procurando detectar ao longo da História e que culminou com a personalidade, para ele ímpar (como o foram os outros "heróis") de Salazar. Assistindo à sua morte e à morte do regime pela qual lutou ao longo da vida, que considerou representar Portugal ou a Nação portuguesa, restou-lhe contar a história da sua vida, à sua maneira, através das Memórias que publicou poucos anos antes de morrer.

${ }_{101}$ Ob. cit., pp. 32-35. 
Por isso intitulámos, com um sentido simbólico, este texto, com a expressão com que terminavam obrigatoriamente os documentos oficiais durante o Estado Novo, "A Bem da Nação". Foi essa a intenção de Costa Brochado ao escrever os seus textos ideológicos e historiográficos. Mas deve entender-se aqui por "Nação" não apenas a "Nação Portuguesa", mas a "Nação Cristã Europeia e Ocidental", também de sentido "Universal". E, nesta defesa dogmática, opunha-se a todos "demónios" que - a seu ver - a procuravam destruir, quer fosse o Islão, quer fosse o demoliberalismo, quer fosse a maçonaria, quer fosse o comunismo, quer fosse mesmo... a traição do próprio "Ocidente". Assim, também ele, como Salazar, se sentiria, no fim da sua vida, "orgulhosamente só". 


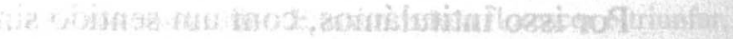

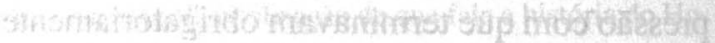

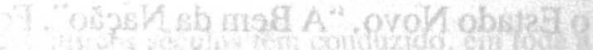

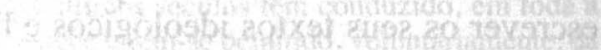

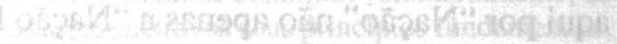

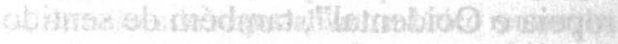

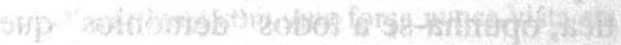

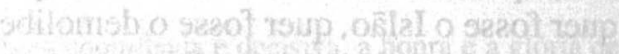

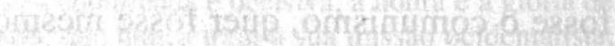

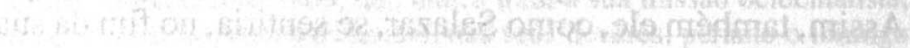
"Des stasis

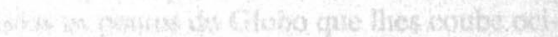

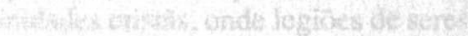

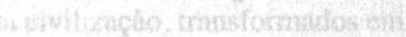

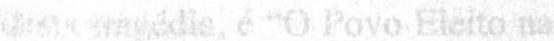

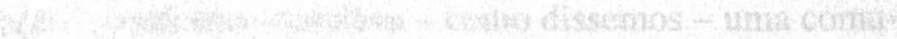
a How

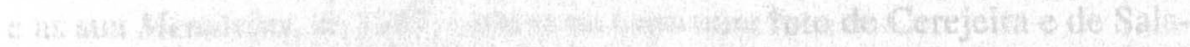

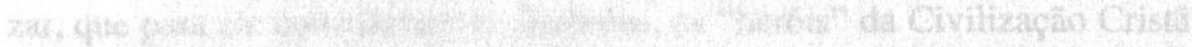

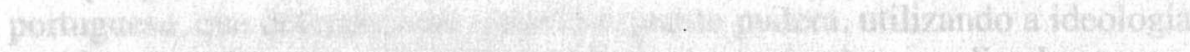

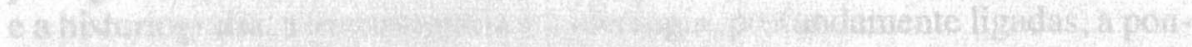
rod d

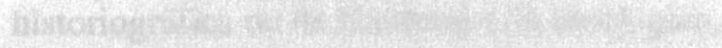

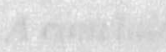

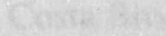

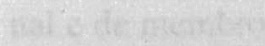

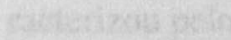

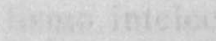

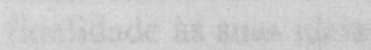

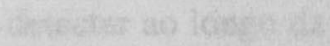

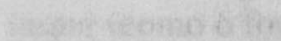

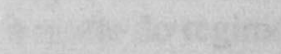

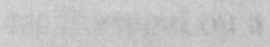

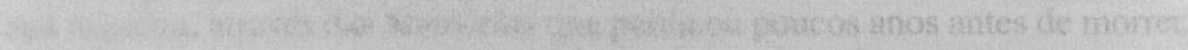




\title{
LOUISE WEISS - VIAGENS DE UMA EUROPEIA
}

\author{
Maria Manuela Tavares Ribeiro* \\ IHTI - FL. Univ. de Coimbra \\ CEIS20 - U. de Coimbra
}

Louise Weiss (1893-1983), após a I Guerra Mundial, preocupa-se com denodado interesse em analisar a situação conjuntural da Europa em mutação e redobra essa sua perspicaz atenção no pós-II Guerra Mundial. De facto, durante várias décadas, com uma disciplina exemplar, com uma vontade tenaz e notável método de uma profissional, Louise Weiss percorre, em múltiplas viagens, o mundo em plena transformação. Conhece e dá a conhecer outras civilizações, outros povos, outras culturas ${ }^{1}$.

Para além da palavra escrita em jornais, em revistas, em livro, Louise Weiss deixou-nos o registo da imagem, reproduz a entrevista, fixa as vozes, grava as músicas num considerável e sugestivo conjunto de documentários fílmicos.

Das suas Mémoires d'une Européenne, o volume intitulado Tempête sur l'Occident. 1945-1975 é um testemunho eloquente dessa «força da natureza» numa busca incessante que estimula Louise Weiss a observar, a analisar, a compreender as raízes de civilizações diversas no processo de mutação acelerada do mundo. Por isso mesmo, ela não perscruta apenas, mas explora o espaço e embrenha-se nas culturas. Na verdade, como sublinha um seu biógrafo, «la longue vie de Louise Weiss, c'est un siècle-ou presque-tant d'actions que de réflexions $»^{2}$.

Louise Weiss nasce em Arras, em 25 de Janeiro de 1893, no seio de uma família burguesa que reunia tradições da Alsácia, da Alemanha e da Europa Central. O pai, Paul Louis Weiss (1867-1945), alsaciano, de educação protestante, fez os seus estudos na Escola Politécnica e trabalhou em Arras como en-

\footnotetext{
* Professora da Faculdade de Letras da Universidade de Coimbra e Vice-Coordenadora do Centro de Estudos Interdisciplinares do Século XX da Universidade de Coimbra - CEIS20. Homenagem sentida à Professora, à Investigadora, à Académica, mas também à Amiga de sempre, Prof. Doutora Zília Osório de Castro, com o justo reconhecimento pela sua brilhante carreira, pela escola que criou, pelo companheirismo e solidariedade de que eu própria sou devedora.

Veja-se Henri Rieben, «De la Société des Nations à l'Europe communautaire. En suivant les pas de Jean Monnet et de Louise Weiss», préface in Louise Weiss. L'Européenne, Lausanne, Fondation Jean Monnet pour l'Europe, Centre de recherches européennes, 1994, p.44.

2 Jean Leclant, «Introduction», in Louise Weiss. L'Européenne, cit., p.15. Jean Leclant era, nesta data, Presidente da Associação Europeia dos Amigos de Louise Weiss.
} 
genheiro de minas. Exerceu as funções de inspector e em 1914 superintendia, como oficial superior, a direcção de Minas do Ministério das Obras Públicas, em Paris. A este propósito, Louise Weiss recorda :«Un débat s'était institué, sous la direction de mon père, sur la mise en commun par la France et l'Angleterre de leurs ressources en fer et en charbon, oh! pour la durée de la guerre seulement. L'idée de ces accords était nouvelle. Quel remue-ménage dans les esprits. On verrait davantage si elle se matérialisait également par des accords industriels et financiers. Il fallait tellement de charbon pour toujours plus de munitions! J'entendis alors pour la première fois mentionner le nom de Jean Monnet» ${ }^{3}$.

A mãe, Jeanne Javal (1871-1956), era oriunda de uma numerosa família judia, em que se destacam, para além do seu pai, reconhecido médico, banqueiros e comerciantes que haviam enriquecido com a venda de produtos raros e que estabeleceram redes comerciais pela Europa e nos Estados Unidos. Pelas suas raízes familiares, mas não só, a mãe de Louise Weiss era verdadeiramente Europeia.

Jeanne Weiss tinha herdado dos seus antepassados um arreigado sentimento patriótico e o gosto pela política. Com o marido, Paul Weiss, organizava todos os anos a sempre esperada peregrinação às terras alsacianas. Os pais de Louise procuravam, também desta forma, inculcar nos seus filhos sentimentos profundos - o patriotismo e o amor à República. Como refere Célia Bertin: «Les enfants aprirent ainsi, sur le terrain, les drames qu'avait engendrés, au sein des familles, la perte de cette province» ${ }^{4}$. Recorde-se, ainda, a este propósito: «Ceux qui croient à l'hérédité retrouvent sans surprise les traces brillantes de ces qualités chez Louise Weiss et dans les récits de Mémoires» ${ }^{5}$.

Como Robert Schuman, Jean Monnet, Konrad Adenauer e Alcide de Gasperi, Louise Weiss é uma mulher de fronteira, e esta fronteira é traçada pelo Reno, o rio simultaneamente separador e unificador ${ }^{6}$, qual «arbre gigante qui dessine le cœur de l'histoire européenne, de ses empires, de ses nations et de son union à venir» ${ }^{7}$, como o define Victor Hugo. E acrescenta este escritor:

3 Louise Weiss, Mémoires d'une Européenne, t. II, Combats pour l'Europe, 1919-1934, Paris, Albin Michel, 1979, p. 57.

${ }^{4}$ Célia Bertin, Louise Weiss, Paris, Éditions Albin Michel, 1999, p. 28. Leia-se ainda Claude Tixier et Gudrun von Nida, «art. cit.», in ob. cit., pp. 99-135 e Martin Nathusius, «Les origines alsaciennes de Louise Weiss. Eléments de son ascendence paternelle», in Louise Weiss. L'Européenne, cit., pp. 137-183.

5 Claude Tixier et Gudrun von Nida, «L'ascendence maternelle de Louise Weiss», in Louise Weiss. L'Européenne..., cit., p. 126.

6 Leia-se Maria Manuela Tavares Ribeiro, « Victor Hugo - o Profeta dos Estados Unidos da Europa », in Portugal e o Outro :Imagens e Viagens, Aveiro, Universidade de Aveiro, 2004, pp. 13-24.

Victor Hugo, «Le Rhin, lettres à un ami», in OC, Voyages, Paris, Laffont, pp. 99-100. 
«noble fleuve, féodal, républicain, impérial, digne à la fois d'être français et allemand... ce fleuve des guerriers et des penseurs, dans cette vague superbe qui fait bondir la France dans ce murmure profond qui fait rêver l'Allemagne ${ }^{8}$. Rio este por onde se faz a circulação de pessoas, de bens, de ideias, lugar de passagem de exércitos, de homens, de riquezas. O Reno do viajante, referente histórico, espaço simbólico, também ele ponto estratégico das relações franco-alemãs e centro da Europa. Lembrem-se, de novo, as palavras hugolianas: «c'est là que la civilisation européenne trouve ses fondations pour se construire....».

Louise Weiss frequenta o liceu com outras jovens da burguesia liberal. É a sua mãe Jeanne que, como toda a família dos Javal, prefere a escola laica e republicana. É também sua a decisão de enviar Louise para o liceu Molière ${ }^{10}$, pese embora a reserva paterna. Com dezassete anos, acaba o ciclo liceal, laureada e com vários prémios. Seu pai não hesita então em exclamar: «Et maintenant, trêve de plaisanterie! À la soupe! En Allemagne» ${ }^{11}$. Porém, Louise Weiss irá aperfeiçoar a sua aprendizagem da língua alemã e inglesa e conclui a agregação em letras, na Universidade de Oxford, em 1911. Nesse mesmo ano, viaja num cruzeiro até à Síria e à Palestina. A convite de seu pai, percorre em Agosto de 1912, terras de Espanha: Léon, Orense, Vigo e ainda terras de fronteira de Portugal.

É importante sublinhar como lhe interessaram as condições de vida das populações do interior de Espanha. Regista-as, com pormenor, e não deixa de exprimir a sua indignação «par le spectacle de son chaos, de son ignorance, de son dénouement» ${ }^{12}$. A sua observação atenta e análise crítica pressupunham, todavia, um conhecimento do contexto histórico e político dos acontecimentos, dos factos, dos movimentos políticos, sociais, culturais ${ }^{13}$. A jovem agregada em letras é então estimulada pela necessidade de servir a França, em 1914. Ela descreve com detalhe a complexa situação da Europa e interroga-se: «ce

Idem, p. 109.

Apud Nicole Savy, «L'Europe de Victor Hugo: du gothique au géopolitique», in L'Europe, naissance d'une utopie? Genèse de l'idée d'Europe du XVIème siècle au XIXème siècles, coord. par Michèle Madonna Desbazeille, Paris, L'Harmattan, 1996, p. 180.

${ }^{10}$ «Au lycée, comme il se doit, elle obtient sans grand effort les premières places et ses rapports avec les autres élèves sont bons» (Célia Bertin, ob. cit., p. 38).

${ }^{11}$ Louise Weiss, Mémoires d'une Européenne, t. I, Une petite fille du siècle 1893-1919, Paris, Albin Michel, 1978, p. 94.

${ }_{12}$ Louise Weiss, Mémoires d'une Européenne, $t$. I, Une petite fille du siècle, 1893-1919, cit., pp. 121 e ss.

13 A sua obra Mémoires d'une Européenne, em seis volumes, constitui a única fonte de informação já que jornais, cadernos de notas e correspondência, que Louise Weiss mantém com várias personalidades da Europa no período entre as duas guerras, desapareceram. O acervo documental existente data sobretudo do pós-II Guerra Mundial. 
qu'est la guerre, comment celle-ci affecte les hommes et comment lutter pour tenter de l'éradiquer des consciences qui la considèrent comme une inévitable catastrophe naturelle? $\gg^{14}$.

Mas é precisamente a sua «alma pacifista» que a incentiva a concretizar um desejo estimulante - ser jornalista. Assim, inicia a sua colaboração no periódico Le Radical. Assina os seus artigos com o pseudónimo Louis Lefranc. Como ela própria afirmava, «le journalisme m'enivrait». E os seus textos colheram aceitação e mesmo considerável sucesso ${ }^{15}$. Compreende-se que Louise Weiss se tivesse preocupado com uma carreira no campo do jornalismo político. De facto, não a cativava a função pública. O reconhecimento do seu valor pessoal era uma prioridade, num meio, como outros tocados pela guerra.

As relações familiares e sociais permitiram-lhe consolidar um lugar na sociedade parisiense, em particular, nos meios intelectuais: Paul Claudel (1868-1955), Jean Giraudoux (1882-1944), Anatole France (1844-1924), militares como Peppino Garibaldi (descendente do herói italiano) e Gabriele d'Annunzio (1863-1938), já então um nome bem reconhecido a nível literário. Poeta este que entusiasmou Louise Weiss. Reconhecia-o, como diz claramente, «incroyablement laid et charmant $»^{16}$.

Teve então o convite para testemunhar, em Quarto, perto de Génova, o Tratado de 26 de Abril de 1915 entre a Itália e os Aliados. O carimbo da cerimónia e a descrição dos acontecimentos deixou-os num artigo, o primeiro publicado no estrangeiro, no jornal La Vie féminine. Na verdade, a sua ambição e os seus projectos não se realizavam, tão-só, nos limites destas folhas periódicas. Os meios políticos atraem-na. Consciente do seu talento, a jovem Weiss tem necessidade de uma tribuna livre que lhe permita divulgar as suas experiências de viagem, as suas ideias, mas também que lhe permita demonstrar o seu sentido prático, bem pragmático, as suas tomadas de posição, influenciando, pelo seu empenhamento, decisões importantes.

A vida, mais imprevisível do que inventiva, iria abrir-lhe novas oportunidades.

${ }^{14}$ Leia-se Louise Weiss, ob. cit., t. I, p. 203. Durante a I Guerra Mundial, Louise Weiss foi enfermeira e teve uma acção meritória junto dos refugiados e no tratamento dos feridos. Como ela própria confessa: «Je voulais comprendre la guerre et aider à la victoire autrement qu'en garde-malade et en gestionnaire de clinique» (Louise Weiss, Mémoires d'une Européenne, cit. t. I, p. 196).

${ }^{15}$ Lembra Célia Bertin que «dans tous les souvenirs de cette période de sa vie, Louise rapporte, sans le signaler, une distance étrange entre ce qu'elle accomplit et l'attitude de sa famille qui la traite comme une adolescente irresponsable», (Célia Bertin, Louise Weiss, cit., p. 80).

${ }^{16}$ Louise Weiss, Mémoires d'une Européenne..., cit., t. I, p.226. 


\section{A utopia de uma "Europa Nova"}

O encontro casual com Milan Stefanik (1880-1919) despertou em Louise uma paixão amorosa, mas também a paixão pela causa checa. Filho de um pastor protestante, Stefanik estudou em Praga e fez os seus estudos em astronomia, matemática e seguiu o curso do filósofo Thomas Masaryk (18501937). Desde 1901, ele escreve em revistas liberais, nacionalistas, e empenha-se na luta pela independência dos checos. Em 1912, Stefanik, para fugir à pressão húngara e ao domínio dos Habsbourg, parte para França e, em Paris, pede a nacionalidade francesa. E criou aí, com Thomas Masaryk e Edvard Benès (1918-1935), o Conselho Nacional dos Países Checos. O encontro com os refugiados políticos checos é recriado pela memória de Louise Weiss. A sua admiração por Thomas Masaryk espelha-se explicitamente nas suas palavras: «ce grand maître de la pensée démocratique, ce révolutionnaire contempteur d'un ordre datant de Charles Quint». Eles seriam os fundadores da futura república checa. O Estado checo independente foi reconhecido em 3 de Setembro de 1918 pela Inglaterra e pelos Estados Unidos, depois pela França e pela Itália.

É um crescente e forte ardor político que alimenta em Weiss particular ensejo em trabalhar como «publicista». Aliciava-a, então, um projecto - criar uma revista política com o título L'Europe Nouvelle ${ }^{17}$. De facto, o seu primeiro número é dado a público em 12 de Janeiro de 1918. À maneira das revistas britânicas da época, com cinquenta e seis páginas e duas colunas, com o sumário programático na capa, também esta ilustrada com uma bola alada - a Terra - que voa no Cosmos, L'Europe Nouvelle perdurará até 1934.

$\mathrm{O}$ armistício entra em vigor a 11 de Novembro e, a 14 de Dezembro de 1918, Louise Weiss encontra-se, em Paris, com o Presidente Woodrow Wilson (1856-1924). A sua alocução sobre a paz entusiasma-a. É então, em 1919, depois da assinatura do Tratado de Versalhes, em 28 de Junho, que Louise Weiss parte para a sua viagem à Checoslováquia ${ }^{18}$. Move-a uma vontade inflamada de conhecer a nova geografia política da Europa central. Tem uma clarividente noção da importância nodal dos novos países, dos seus povos, dos

${ }^{17}$ Louise Weiss deixou a sua colaboração no periódico Le Radical para trabalhar com Hyacinthe Philouze, jornalista colaborador de folhas periódicas como o Nouvelliste e a página financeira do Journal. A ele se refere Weiss como bom profissional que a ensinou «à rédiger... à m'introduire de force dans les cercles où naissaient les évènements» (Louise Weiss, Mémoires d'une Européenne..., cit., t. I, p. 250).

${ }^{18}$ Como relata Célia Bertin, Louise Weiss toma o comboio para Praga:«Ce premier voyage, elle s'entreprend dans l'angoisse. Elle pense à son amour mort [Milan Stefanik morre a 4 de Maio de 1919 num acidente de avião], à ces rêves qu'elle ne peut oublier, aussi aux déceptions apportées par le cortège d'erreurs de jugement qui ont présidé aux traités de paix» (Célia Bertin, ob.cit., p. 110). 
seus dirigentes, para o necessário equilíbrio e para a desejada paz na Europa. Consciente das permanências, das mutações, mas também das fracturas, a jornalista Weiss documenta as suas impressões em L'Information e no Petit Parisien. De Praga à Eslováquia, da Boémia aos Cárpatos, de Budapeste a Viena, depois em Varsóvia, Louise Weiss deixa-nos uma diegese circunstanciada dos eventos, retrata-nos personagens sem deixar de confessar o seu credo de convicta republicana. Nem totalmente objectiva, nem sempre imparcial, ela denuncia o seu empenhamento político, a sua visão crítica e a sua compreensão do presente vivido. Assim o refere nestas palavras: «D'ailleurs mes voyages devaient assez rapidement me persuader qu'en matière de doctrine politique l'alternative était la suivante : ou bien les hommes étaient faits pour les principes et donc modélés, contraints, conduits, voire occis au nom de ces principes... Ou bien les principes étaient faits pour les hommes, afin de les développer, de les protéger, de les réconforter, de les aider à mourir dans leur lit. Alors que vivent les valeurs morales des libres démocraties, celles de choix individuel, continu, délibéré» ${ }^{19}$.

Como escreve a propósito do discurso do presidente Wilson, o único meio é o de «faire la guerre à la guerre». Louise Weiss percorre uma Europa partilhada, uma Europa que, a seu ver, e nas suas palavras, perdera o seu carácter «de família». Testemunha ocular das ocorrências, conhecedora dos problemas da Europa central, Weiss regressa a Paris e recupera a sua actividade jornalística em L'Europe Nouvelle.

Este hebdomadário tinha então como objectivo primordial, e bem definido, estimular o combate pela segurança, pela paz, pelo equilíbrio, pela justiça. Era também nesta linha que Weiss concebia a recém-criada Sociedade das Nações que reuniu o seu primeiro conselho, em Paris, em Janeiro de 1920. A seu ver, a Sociedade das Nações era uma organização internacional nova. Assim sendo, era preciso familiarizar o público com esta concepção democrática de regulação de conflitos entre nações ${ }^{20}$.

A jovem directora de L'Europe Nouvelle rodeia-se de colaboradores que viriam a exercer cargos políticos de destaque durante a IV República francesa. Entre outros, Roger Auboin, René Massigli ou ainda de redactores ocasionais, de que são exemplo Aristide Briand, Léon Blum, Paul Valéry. No livro de memórias Combats pour l'Europe, a jornalista dá-nos conta do seu envolvimento na política internacional, do núcleo de escritores, homens políticos e artistas com que se reunia no seu gabinete, na rue de Lille, em Paris, ou que conhecera no curso das suas viagens a Belgrado, a Budapeste, a Berlim, a

${ }^{19}$ Louise Weiss, Mémoires d'une Européenne, cit., t. II, Combats pour l'Europe 1919-1934, Paris, Albin Michel, 1979, p. 48.

${ }^{20}$ É sua preocupação insistente seguir a evolução da Sociedade das Nações (SDN) e antecipar nos seus artigos, em L'Europe Nouvelle, as decisões a tomar, questionando os fins a atingir. 
Riga e a Moscovo, em $1921^{21}$. Aqui conheceu Trostski, a quem consagra páginas interessantes das suas Mémoires; encontrou-se com Alexandra Kollontaï, militante e activista da secção feminina do comité central do partido comunista, e assistiu aos espectáculos de dança da célebre Isadora Duncan. Retornaria a Moscovo em 1922, mas manteve a sua atitude crítica ao regime soviético e não se converteu à ideologia comunista. Ela própria confessa: «non, les communistes ne pouvaient pas compter sur moi. Je les laisserais à leur monde inexorable où les hommes n'étaient que les souffre-douleur d'un irréalisme supérieur. La matérialiste, c'était moi» ${ }^{22}$.

A complexidade da situação internacional levara Aristide Briand (18621932) a deslocar-se aos Estados Unidos enquanto a sua amiga Louise Weiss se encontrava na Rússia. O britânico John Maynard Keynes (1883-1946) publicara a sua obra The Economic Consequences of the Peace.

Durante este período, a Europa que Louise Weiss sonhava ainda não se consumara. Em comunhão com Aristide Briand partilhava a mesma concepção de pacifismo. Com este «apóstolo da paz» participa nas reuniões internacionais e secunda os seus ideais - segurança pela arbitragem, reconciliação, segurança colectiva. Antes de Richard Coudenhove-Kalergi ter publicitado os seus primeiros apelos à unidade europeia, ocorre a Conferência internacional de Génova. A paz no mundo e na Europa continuava a ser a preocupação maior de Louise Weiss. Não admira, portanto, que o acalorado discurso de Briand, na Assembleia plenária da SDN, em 1 de Outubro de 1924, ao evocar a necessária reconstrução da paz europeia mediante a assinatura de um protocolo franco-britânico que visava a arbitragem, a segurança e o desarmamento, tivesse sido rememorado por Weiss nestas palavras de admiração: «je vi's Aristide Briand composer son personnage de Pélerin de la Paix... Son nouvel avatar de Pélerin de la Paix ne résultait pas d'une métamorphose, mais d'un accomplissement. Si les hommes voulaient éviter les guerres, il les y aiderait de toutes les forces de sa nature contemplative que la politique avait contrainte à l'action ${ }^{23}$. E acrescenta que, por esta razão, se reaproximou do amigo Briand, colocando-se modestamente ao seu serviço $\mathrm{O}^{24}$.

Os acordos de Locarno, em 1925, cimentam a reconciliação franco-alemã. Briand, ao recordar esse momento na declaração na Câmara dos

${ }^{21}$ «Les souvenirs de ce voyage à Moscou... forment un des passages les plus attachants de ses Mémoires» (Célia Bertin, ob. cit., p. 152). Veja-se Maria Manuela Tavares Ribeiro, «A Europa dos Intelectuais nos alvores do século XX», Estudos do Século XX, n. ${ }^{\circ} 2$, CEIS20, Europa-Utopia/Europa-Realidade, coord. de Maria Manuela Tavares Ribeiro, Coimbra, Quarteto Editora, 2002,pp. 111-133.

${ }^{22}$ Louise Weiss, Mémoires d'une Européenne, t. II, cit., pp. 177-179.

${ }^{23}$ Louise Weiss, Mémoires...cit., t. II, Combats pour l'Europe, pp. 217-218.

${ }^{24}$ Idem, ibidem, p. 217. 
Deputados, relembraria: «J'y suis allé et nous avons parlé européen. C'est une langue nouvelle qu'il faudra bien que l'on apprenne ${ }^{25}$. Após a admissão da Alemanha à SDN, em 8 de Novembro de 1926, e na recepção oficial do novo membro naquela reunião internacional, Gustav Stresemann (1878-1929) e de imediato Briand exaltam o fim de encontros dolorosos e sangrentos. É o momento da conciliação e da paz. Não admira, portanto, que em Dezembro de 1926, Aristide Briand e Stresemann tenham recebido o Prémio Nobel da Paz. Dois anos mais tarde, a 27 de Agosto de 1928, assinava-se o pacto KellogBriand no Salon de l'Horloge do Quai d'Orsay, em Paris. O apelo à união dos europeus, em Setembro de 1929, por um «lien fédéral», é preparado por Briand como laço de solidariedade entre as nações.

Mas Louise Weiss prefere partir para os Estados Unidos e, em Nova Iorque, participa numa série de conferências organizadas pela Foreign Policy Association. Aí convive com Richard de Coudenhove-Kalergi, como ela própria define, «l'étrange et charmant bâtard gréco-autrichien métissé de japonais qui avait inventé le terme Pan-Europe» ${ }^{26}$.

Tempos difíceis se avizinhavam. E a morte de Aristide Briand foi para alguns, como para Louise Weiss, uma catástrofe no processo de construção da paz. $^{27}$

O título da sua revista, L'Europe Nouvelle, é, a um tempo, uma bandeira e um programa. A bandeira que agita e simboliza a ideia de uma Europa Nova. Um programa, porque define muito objectivamente o seu intuito e a sua praxis - a informação rigorosa, e mesmo científica, sobre a conjuntura internacional, sobre as políticas externas, sobre os problemas económicos e a sua importância fundamental na (re)construção europeia.

Com L'Europe Nouvelle, Louise Weiss procura apresentar um método e simultaneamente um instrumento de trabalho a todos quantos querem construir a paz na Europa e no mundo. São claras as suas intenções quando afirma: «une méthode-elle écrit-qui fait de la politique une science, la science de la paix fondée sur l'exacte connaissance des faits. Cette science doit être l'instrument qui, d'une part, étudie la connaissance des moyens favorisant les pro-

${ }^{25}$ A. Briand, Discours devant l'Assemblée Générale de la SDN, 5 septembre 1929. O pacto de Locarno criaria condições de paz para a Europa. Veja-se Gérard Bossuat, Les fondateurs de l'Europe unie, Bruxelles, Éditions Belin, 2001 e Le Plan Briand d'Union fédérale européenne, édité par Antoine Fleury et Lubor Jílek, Bern, Peter Lang, 1991.

${ }^{26}$ Louise Weiss, ob. cit., t. II, pp. 282 e ss.

${ }^{27}$ Louise Weiss, $o b$. cit., t.II, pp. 293-294, p. 315. Veja-se Corinne Rousseau, «Louise Weiss. L' Europe et la paix durant l'entre-deux-guerres», in Louise Weiss. L'Européenne, cit., pp. 228-229. Veja-se ainda Hélène d'Encausse, Othon de Habourg, Pierre Pflimlin, Jacques Delors, Louise Weiss, Lausanne, Fondation Jean Monnet, Centre de recherches européennes, 1989. 
grès de la coexistence pacifique et, d'autre part, contribue à former des gens mieux qualifiés en matière de prévention de guerre ${ }^{28}$.

\section{A nova Escola da Paz}

A morte de Aristide Briand foi, como já referi, um acontecimento trágico na vida de Louise Weiss. De facto, os apelos de Briand deram maior alento ao seu ardor pacifista. Assim sendo, não lhe bastava já a palavra como jornalista e directora de L'Europe Nouvelle. Mais vital do que nunca era atingir um público mais alargado, influenciando a opinião pública. Por que não uma Escola? Esta seria espaço de informação e de formação de cultura para a Paz. Completar-se-ia, desta forma, a função didáctica do jornal com o ensino superior. Assim, a Nouvelle École de la Paix foi inaugurada em 3 de Novembro de 1930. E foi um membro da Academia das Ciências, e então Presidente do Conselho de Administração do Instituto Internacional de Cooperação Intelectual, Paul Painlevé, que pronunciou a alocução de abertura. Sob a égide de Aristide Briand, a Nouvelle École de la Paix tornou-se palco de sessões de magistério e de debate com conferencistas de renome internacional ${ }^{29}$.

Louise Weiss exercia, ela própria, na sua escola, a arte da comunicação com particular mestria. Temas como a Sociedade das Nações, a construção da "união europeia", o desarmamento, a paz, a união aduaneira eram discutidos por especialistas. Fazia-se ouvir igualmente a voz dos poetas e a palavra dos escritores: Paul Valéry, André Chamson, Jean Prévost, Julian Benda. Em 1932, as questões políticas da Alemanha, da Europa central, da política externa britânica, das relações com os Estados Unidos foram objecto de conferências de Élie Halévy, professor da École libre des Sciences politiques, André Siegfried (professor de economia política), de M. Tchlenoff (conselheiro jurídico soviético). E em 26 de Fevereiro de 1934, Julien Benda falava sobre "Hitler et les valeurs morales".

Louise Weiss escrevia em 3 de Fevereiro de 1934 o seu último artigo

${ }^{28}$ Louise Weiss, Mémoires d'une Europénne, t. III, Combats pour les femmes 1934 - 1939, Paris, Albin Michel, 1979, p.7. Veja-se também Marianne Walle, «Louise Weiss, l'Européenne: Actrice et grand témoin de la mutation déchirante du vingtième siécle», in L'identité culturelle, laboratoire de la conscience européenne. Actes du Colloque international organisé à l'Université de Franche - Comté les 3,4 et 5 Novembre 1994, réunis et édités par Marita Gilli, Paris, Diffusion Les Belles Lettres, 1995, pp. 129-136.

${ }^{29}$ Foram muitos os delegados da SDN, como muitos foram os políticos, intelectuais, diplomatas e estudantes que passaram pela instituição, de formação variada e de quadrantes políticos diversos. Entre outros nomes, pode referir-se o de Léon Blum, André Gide, Georges Duhamel, Bertrand de Jouvenel, Jules Romains, Pierre Drieu la Rochelle. 
editorial no jornal L'Europe Nouvelle. Nele espelha o percurso da Europa durante dezasseis anos, que não era, de facto, a Europa Nova que ela desejava e pela qual lutava. O seu texto "Adieux aux lecteurs" é um lamento confesso do seu desencanto profundo. Como refere Célia Bertin, «Ce devoir de paix auquel elle avait cru, elle ne pourra pas l'accomplir». ${ }^{30}$

Também a precipitação dos acontecimentos políticos em 1939 fariam sossobrar a actividade da Nouvelle École de la Paix.

\section{$O$ apostolado feminista}

A ex-directora do jornal L'Europe Nouvelle, entregar-se-ia à causa feminista em 1934. Uma outra luta que atrairia, como bem gostava, a atenção do público. Pretendia reparar a injustiça da condição feminina. A sua experiência como estudante universitária comprovara-lhe, desde cedo, a situação política da mulher.

Sublinhe-se, porém, que a relação de Louise Weiss com as mulheres não era fácil. Não a preocupava particularmente a mulher do povo e as mulheres de classes sociais mais favorecidas não the suscitavam qualquer indulgência.

O seu apostolado feminista vai-se centrar particularmente na questão do direito de voto da mulher. Combate, sim, pela igualdade civil e política. Distancia-se das associações feministas e funda a sua própria Associação para a Igualdade dos direitos civis entre franceses e francesas - La Femme nouvelle - criada oficialmente em 6 de Outubro de 1934. Apresentará a sua candidatura às eleições municipais, em Paris, em Montmartre, em Maio de 1935. Mas a feminista Weiss, como já referi, não deixava nunca de se interessar pelo destino da Europa. Na verdade, em 1937, como recorda nas suas Mémoires, estava bem persuadida que as reivindicações feministas estavam ultrapassadas. A seu ver, era já demasiado tarde para obter a igualdade de direitos. Por outro lado, a situação catastrófica provocada pela II Guerra Mundial estimulará, uma vez mais, o seu ardor patriótico e o seu sentimento de solidariedade. Nesse sentido, Louise Weiss cria, em 1939, um Comité de Refugiados. Em 1945, funda com Gaston Bouthoul o Instituto de Palemologia, com sede em Londres $^{31}$. Coopera com o movimento de Resistência Patriam Recuperare. Nesse mesmo ano, assiste como jornalista aos julgamentos em Nuremberga. Depois, durante duas décadas, ela viaja pelo mundo. Longas e distantes viagens pelo Canadá, México, Estados Unidos, Japão, China, Cambodja, Síria,

${ }^{30}$ Célia Bertin, Louise Weiss, Paris, Albin Michel, 1999, p. 210.

${ }^{31}$ François Saint-Ouen, Les grandes figures de la construction européenne, Genève, Georg Editeur, 1997, pp. 53-77. 
depois por vários países do continente africano. Viagens que lhe propiciam a observação do Outro: dos seus costumes, das suas religiões, enfim, das relações Ocidente-Oriente. Ainda, de 1951 a 1966, acompanhada pelo cineasta Georges Bourdelon, ela realiza filmes - documentários, registos das suas "impressões" de viagem, dos povos, das civilizações, das culturas ${ }^{32}$. Uma das particularidades de Louise Weiss e, em geral, dos viajantes é a utilização do espaço da viagem como lugar de experimentação, de encontro ou de confronto com o Outro $^{33}$.A busca incessante da alma das civilizações e dos povos alimentou a sua curiosidade e estimulou a sua incerteza constante sobre o tempo presente - o dos movimentos descolonizadores e de todo o processo de metamorfose da construção da Europa. Com efeito, pode afirmar-se que "a união da Europa" era, para Louise Weiss, o farol possível, o farol necessário para o mundo, no mundo que se perdia.... Weiss apercebia-se, com particular perspicácia e inteligência, das ameaças do seu tempo ${ }^{34}$.

\section{Um combate pela Europa}

Eleita para o Parlamento Europeu, por sufrágio universal, em 1979, Weiss, gaullista, proferiu então o discurso de abertura que intitulou sugestivamente Un combat pour l'Europe. «Doyenne d'âge, elle a l'honneur de présider, le 17 juillet 1979, la séance inaugurale de la nouvelle Assemblée démocratiquement élue. Son discours - qui met l'accent sur l'histoire, la culture et les diversités fécondes de l'Europe - n'a pas les accents lénifiants du technocratisme mou que l'on reproche parfois aux institutions communautaires». ${ }^{35}$

De facto, Louise Weiss, durante a sua longa vida, teve uma participação activa e militante a que se consagrou sucessivamente em vários combates. Nas palavras de Andrée e Hubert Martin, “... Weiss a eu une existence à thèmes, auxquels elle se consacrait autant par choix que par conviction ${ }^{36}$. Combate pela paz total, numa visão a um tempo realista e idealista da Europa e do mun-

${ }^{32}$ Célia Bertin, ob. cit. pp. 261-482. Leia-se também Louise Weiss, Mémoires d'une Européenne, cit., t. VI, Tempête sur l'Occident, 1945 - 1975, Paris, Albin Michel, 1976.

${ }^{33}$ Veja Jean-Xavier Ridon, Le Voyage en son miroir. Essai sur quelques tentatives de réinvention du voyage au 20 ème siècle, Paris, Éditions Kimé, 2002, pp. 9-20.

${ }^{34}$ Em 1975, Louise Weiss escrevia: «L'Europe: elle se sait une âme. Or, elle ne parle que serpents, cochons et vinasse. Le serpent est monétaire». E em 1979 reforça esta mesma ideia: «Les institutions communautaires ont fait des betteraves, du beurre, du fromage, des vins, des veaux, voire des cochons européens. Elles n'ont pas fait d'hommes européens» (Mémoires d'une Européenne, t. VI. Tempête sur l'Occident, cit., p. 512).

${ }^{35}$ François Saint-Ouen, ob. cit., p. 75.

${ }^{36}$ Andrée et Hubert Martin, «Louise Weiss toujours avec nous», in Louise Weiss. L'Européenne, cit, pp. 546-548. 
do. Para Weiss, a paz não era apenas a não violência, mas era também o meio de impedir que conflitos latentes deflagrassem em destruidoras guerras. Lutou com ardor pelo voto das mulheres, não hesitando, todavia, em assumir posições pessoais menos consonantes com as de muitas sufragistas dos anos 30 .

A vida da Europeia Louise Weiss centrou-se em três pólos: combate pela paz, combate pelo voto feminino e combate pela construção da Europa. Assim, é autora, entre outras obras, das Mémoires d'une Européenne: Combats pour l'Europe 1919 - 1934, Combats pour les Femmes 1934-1934, La Marseillaise, Le Voyage enchanté, Tempête sur l'Ocident, Dernières Voluptés.

A sua obra é um manancial rico de informações e revela-se um testemunho crítico do processo de construção europeia e das relações Europa - Mundo ao longo do século $\mathrm{XX} \cdot{ }^{37}$

À luz do que foi dito, pode reafirmar-se que um desejo permanente estimulou sempre a força anímica de Weiss - "participer à l'aventure de son siècle". Assim foi para esta mulher que se queria Louise l'Européenne.

${ }^{37}$ Louise Weiss recebeu o Prémio Robert Schuman (1978) e a medalha de ouro pelas suas Mémoires e, entre outros títulos, foi agraciada com o Grand Commandeur de La Légion d'Honneur. 


\section{JORGE LUÍS BORGES: NACIONALISTA E COSMOPOLITA}

Vamireh Chacon

Universidade de Brasília

Não há cultura inocente.

Dizer que não se está a fazer política, é uma das formas de fazê-la.

Jorge Luís Borges passa por apolítico, até seus íntimos pretendem testemunhá-lo, mas envolvem-se em contradições, ao apontarem Borges, tão cerebral, deixar-se levar por paixões políticas inclusive motivadas pelos seus interesses de classe e família.'

Volodia Teitelboim - que tem a grandeza de estudar objetivamente Borges, apesar de ele, Teitelboim, haver estado sob perseguição na época em que Borges apoiava abertamente os opressores ditatoriais militares argentinos Teitelboim interroga-se e responde: "Borges apolítico? Não parece tão certo. Já conhecemos suas proclamações anarquistas e comunistas de juventude".

O próprio Borges mais uma vez se encarregou de explicar-se, em seu Um Ensaio Autobiográfico, ter começado politicamente pelo elogio da "revolução russa, a fraternidade do homem e o pacifismo", em livro destruído pelo autor, Os Salmos Vermelhos ou Os Ritmos Vermelhos, em versos livres em parte publicados... Eram influências de Pio Baroja, confessa Borges, e da recente Primeira Guerra Mundial vista quase de perto, de Genebra, onde seus pais passavam temporada, a alongar-se por cinco inesquecíveis anos de formação. Fiel a eles, Borges optará por passar seus últimos dias na Suíça. Interessante também a iniciação de Borges na poesia por Walt Whitman, cujo intenso amor ao povo deve ter contribuído para aquela fase inicial.

Em lenta volta a Buenos Aires, a família de Borges passa quase três

\footnotetext{
Estela CANTO, amor platónico segundo ela, conheceu e conviveu muito de perto com Jorge Luís BORGES ao longo de décadas, abruptamente interrompidas. Ela testemunha os elos políticos e de classe dele em Borges a contraluz. 2. ${ }^{\mathrm{a}}$ ed. Madrid: $\mathrm{n} .{ }^{\circ} 93$ da Colección Austral, Espasa Calpe, 1999, pp. 33-48. BORGES entreteve diversos relacionamentos muito ambíguos com mulheres, até casar-se, já tarde, com Maria Kodama, de mãe japonesa e pai uruguaio, nascida na Argentina.

2 TEITELBOIM, Volodia. 2. ed. Los dos Borges. Buenos Aires: Editorial Sudamericana, 1996, p. 149. O próprio BORGES reconhece no seu Um Ensaio Autobiográfico, a propósito da sua juventude, sob o impacto da Primeira Guerra Mundial: "eu ainda era anarquista, livre-pensador e a favor do pacifismo". Este texto foi ditado originalmente em inglês ao seu colaborador Norman Thomas di GIOVANNI, An Autobiographical Essay (1970), aqui cit. na tradução em português brasileiro Um Ensaio Autobiográfico (1899-1970). São Paulo: Globo, 2000 , pp. 58 e 59.
} 
anos na Espanha, em Sevilha e Madrid interessa-se pelo ultraísmo a ponto de trazê-lo à Argentina e por ele, depois, desinteressar-se. ${ }^{3}$

Daí em diante, Jorge Luís Borges entra numa espiral nacionalista-cosmopolita, pendulando, por assim dizer dialeticamente, entre os dois extremos, dos vários do seu temperamento inquieto e paradoxal.

No Brasil, Mário de Andrade, já em 1928, captou muito bem esta bipolaridade íntima, entre outras, em Borges: "eu falei que o nacionalismo argentino era mais inconsciente que rotular". "Quem se preocupa mais com ele é Jorge Luís Borges. Este poeta e ensaísta me parece a personalidade mais saliente da geração moderna da Argentina. Depois de Ricardo Güiraldes”, o autor do celebrado romance gauchesco Dom Segundo Sombra. ${ }^{4}$

Mário de Andrade referia-se aos livros de poemas Fervor de Buenos Aires (1923) e Luna de enfrente (1925) e ao de ensaios Inquisiciones (1925), todos por Borges renegados, mais, na mesma linha argentinista, El tamaño de mi esperanza (1926), El idioma de los argentinos (1928), ambos de ensaios, e Cuaderno San Martín (1929) com nome não por conta do Libertador e sim pelo tipo (!) de caderno usado, todos igualmente refugados pelo autor por idênticos motivos.

Na sua busca de universalidade, Borges confessava haver concluído pela necessidade de "evitar hispanismos, argentinismos, arcaísmos e neologismos" na sua estilística. Mas, antes, "Fui ao outro extremo: tentei ser o mais argentino que pude. Peguei o dicionário de argentinismos de Segóvia e introduzi tantos termos locais que muitos de meus compatriotas mal conseguiram entender. Como perdi o dicionário, não estou seguro de que eu mesmo possa entender o livro, de modo que o abandonei por estar além de qualquer esperança" (sic). ${ }^{5}$

Apesar do expresso repúdio a estas obras por Borges, a viúva Maria Kodama decidiu republicá-las após o falecimento do autor, e elas vêm demonstrando ainda ter um grande público favorável, ao lado das mundialmente aclamadas de sua autoria.

Rafael Olea Franco demonstrou como o crioulismo, sinônimo de argentinidade literária, permaneceu subjacente actuante em toda produção de Borges: crioulismo versus europeísmo, nacionalismo versus cosmopolitismo, emergindo, por exemplo, na sua mudança de opinião sobre Sarmiento, o presidente pedagogo da Argentina, diante de Rosas, o ditador xenófobo, um urbano (a "civilização") e o outro rural (a "barbárie") como se vê no clássico Facundo,

3 Um Ensaio Autobiográfico, ob. cit., pp. 67-70.

4 ANDRADE, Mário. "Literatura Modernista III". São Paulo: Diário Nacional, 13 de maio de 1928.

5 Um Ensaio Autobiográfico,ob.cit., p. 82. 
biografia sociológica de um dos caudilhos por Sarmiento incansavelmente combatidos na prática e na teoria. ${ }^{6}$ Estela Canto, sua íntima por décadas, vai adiante, testemunha a inseparabilidade entre Borges e Buenos Aires num relacionamento profundo e indissolúvel de amor e ódio recíprocos: ${ }^{7}$ Jorge Luís Borges conseguiu, muito no seu estilo de vida paradoxal, não só literário, ser pelos seus conterrâneos o mais amado e o mais odiado dos autores e dos personagens da sua época, com frequiência ao mesmo tempo...

Os motivos desta repulsa-atração vêm de longe, já o pai e a mãe de Borges desde criança lhe ensinavam as trágicas sagas das famílias paterna e materna, esta com ainda maior intensidade passional.

O avô Borges, coronel, era, "em princípios da década de 1870, comandante-em-chefe nas fronteiras do norte e oeste de Buenos Aires". Morreu em combate numa das guerras civis argentinas. Romanticamente, na "sua derrota em La Verde, envolto em um poncho branco, montou um cavalo e, seguido por dez ou doze soldados, avançou devagar em direção ás linhas inimigas, onde foi atingido por duas balas..." O pai de Borges gostava de lembrar isso ao filho.

Um dos bisavôs maternos, Suárez, também coronel, "comandou o famoso ataque de cavalaria peruana e colombiana que decidiu a Batalha de Junín, no Peru. Essa foi a penúltima guerra sul-americana pela independência. Embora fosse primo em segundo grau de Juan Manuel Rosas, ditador na Argentina de 1835 a 1852, Suárez preferiu o desterro e a pobreza em Montevidéu a viver sob uma tirania em Buenos Aires. Suas terras foram, evidentemente, confiscadas, e um dos seus irmãos foi executado". A mãe gostava de lembrar isso ao filho.

Donde Jorge Luís Borges conclui, com auto-ironia bem típica sua: "Assim, de ambos os lados da família tenho antepassados militares; isso talvez explique minha nostalgia desse destino épico que as divindades me negaram, sem dúvida sabiamente".

Cedo falecido o pai, a mãe, antes do filho, protestou de público ao ver a chegada do coronel populista, auto-promovido general, Juan Domingo Perón,

- OLEA FRANCO, Rafael. El otro Borges, el primer Borges. México: Fondo de Cultura Económica, 1993, pp. 108, 109, 102, 103 e 105-108.

7 Estela CANTO insiste longamente na fundamental argentinidade de Jorge Luís BORGES, tanto por opção, como ele reconhecia, quanto por imposição das circunstâncias mais profundas de formação e até de deformação pessoais, desde o berço e ao longo da maior parte da vida em Buenos Aires, daí Borges ser tão desta cidade, isto é, portenho, como se diz. Vide, mais uma vez, Borges a contraluz, ob. cit., pp. 11,48, 56, 57, 202, 69, 64, 65 e 53. Alicia JURADO, outra colaboradora de Borges, também testemunha a visceral paixão de BORGES pela Argentina e Buenos Aires em Genio y figura de Jorge Luís Borges. Buenos Aires: Editorial Universitaria de Buenos Aires: 3. ${ }^{a}$ ed., 1996 (1. a em 1964), p. 164 e passim.

${ }^{8}$ Um Ensaio Autobiográfico, ob. cit., pp. 15, 16, 20 e 21. 
ao poder. A mãe, presa pela polícia política peronista, confirmou, aos olhos do filho, a vulgaridade, a baixeza e a brutalidade do regime de Perón. ${ }^{9}$

Daí a adesão dos Borges aos militares que depuseram Perón.

Entende-se: estes militares reintegraram Borges na direcção da Biblioteca Nacional, da qual havia sido demitido com humilhação. Borges, em crescente reacção, foi ao ponto de apoiar publicamente a ditadura chilena de Pinochet, o que talvez lhe tenha causada a perda do Prêmio Nobel, para o qual estava muito celebrado pela imprensa mundial. ${ }^{10}$

Em tempo, durante a Guerra das Malvinas (lembremos também a admiração de Borges pelos britânicos, herdada da avó inglesa...), Borges voltou-se contra a ditadura militar no seu país e em todo o continente, como se vê na sua resposta, em 1984, a um jornalista ("E o que o senhor pensa sobre os militares latino-americanos?"): "Uma calamidade, realmente. Mas veja: quando eles tomaram o poder na Argentina, eu acreditava neles". "Eu falei contra os militares quando eles ainda estavam no poder e era perigoso fazê-lo. De modo que minha consciência está tranqüila"."

O desdém de Borges pelos políticos, aliás antigo, insere-se no seu elitismo intelectual, relativismo filosófico e niilismo religioso, envoltos na sua erudição humanística e estilo literário.

O relativismo filosófico borgiano está muito bem analisado por Juan Nuño em La filosofía de Borges, onde se demonstram as influências recebidas principalmente do ultra-idealista inglês Berkeley, dele a Plotino, enfim a Platão, com a preocupação central girando em torno da irrealidade do tempo em ciclos de pesadelos, no caso de Borges pesadelos até pessoais, pesadelos de cego.

Assim Borges evita Heidegger ("Heidegger inventou um dialeto alemão, nada mais"). Lembre-se também o interesse de Borges pelo empirismo

9 A mãe de BORGES, Leonor Acevedo - descendente de cristãos-novos portugueses (cuja ascendência lusa se combinava com a dos Borges paternos de Moncorvo), mais motivo de grande enaltecimento pessoal, repetidas vezes, para o filho - era uma católica liberal conservadora e contra o populismo de Perón, depois despeitado por sua esposa Evita não receber homenagens do Vaticano. Por essas e outras, Dona Leonor, em companhia da filha Norah, foram presas pela polícia política peronista numa ruidosa manifestação de protesto no centro de Buenos Aires, o que evidentemente serviu para cada vez maior repulsa do filho contra o peronismo. Estela CANTO privava da amizade dos Borges naquela fase e deu testemunho no seu livro Borges a Contraluz. ob. cit., pp. 47, 48, 68 e 92.

10 TEITELBOIM (ob. cit., pp. 226-228) descreve reações negativas contra BORGES no Conselho da Fundação Nobel em Estolcomo, a propósito do seu apoio explícito e veemente à ditadura de Pinochet no Chile (ademais de apoios dele, então, também à ditadura militar argentina, só muito depois repudiados).

1 Entrevista a Renato MODERNELL na revista Status, São Paulo, agosto, 1984, sob o título "Um Encontro de Status com gente muito importante". 
de Hume e até pela filosofia analítica de Korzybski, na busca da impossível exactidão. $^{12}$

Deste trágico impasse, o Borges final crê encontrar solução em Buda ${ }^{13}$, o que o devolve ao Schopenhauer, sua primeira influência filosófica, ${ }^{14}$ Schopenhauer acreditando encontrar no Nirvana oriental a solução das suas dúvidas racionalistas ocidentais. Ainda tão ocidental, Borges fica na admiração, não vai à adesão a Buda. Permanece a angústia profunda em Borges. Portanto, não é de estranhar sua preferência extremada por Unamuno ("o primeiro escritor do nosso idioma") ${ }^{15}$ e seu paralelo desprezo pelas amenidades de Ortega y Gasset. ${ }^{16}$

Daí não haver também surpresa diante da repulsa de Borges a Pablo Neruda, que em vão o procurou pessoalmente, e mesmo ao humanismo social tão puro e despretencioso de Gabriela Mistral. As opções de Jorge Luís Borges iam noutra direcção muito diferente, tanto a André Malraux quanto a Ernst Jünger: ao primeiro desejava que recebesse o Prêmio Nobel e ao segundo chegou a visitar pessoalmente e com ele entreter longo diálogo, menos sobre filosofias de vida que sobre promenores dela. ${ }^{17}$

Ao ficar ao mesmo tempo com Jünger e Malraux, Borges demonstrava

${ }^{12}$ NUÑO, Juan. La filosofía de Borges. México: Fondo de Cultura Económica, 1986, pp. 10, 133 e 134.

${ }^{13}$ Buda (coletânea por Jorge Luís BORGES e Alicia JURADO). Madrid: Alianza Editorial, 2000.

${ }^{14}$ Schopenhauer permaneceu o autor filosófico mais preferido por BORGES do começo ao fim da vida, como se vê no seu final Um Ensaio Autobiográfico (ob. cit., p. 44): "Enquanto vivíamos na Suíça, comecei a ler Schopenhauer. Hoje, se tivesse de escolher um único filósofo, eu o escolheria. Se o enigma do universo pudesse ser formulado em palavras, penso que essas palavras estariam na obra dele. Eu o li muitas vezes em alemão...” Borges, naquele livro (breve como os dele), explica ter aprendido alemão quando adolescente estudante de liceu na Suíça, mas por conta própria. Gostou muito do expressionismo alemão, a seu ver superior aos outros modernismos vindos da França, não lhe agradando, porém, o romantismo tido e havido como tão fundamental na Alemanha, muito menos o iluminismo prototípico em Kant. "Na literatura alemã eu procurava algo germânico [...], mas só o encontraria, mais tarde, no inglês e no escandinavo antigos"(idem, pp. 42-44). Mesmo assim incluiu o idioma alemão, ao lado deles, num dos poemas de louvor: "doce língua da Alemanha,/ te escolhi e busquei solitário [...]. Hoje, na linde/ dos anos cansados, te diviso/ distante como a álgebra e a lua", pois "meu destino é a língua castelhana" ("Ao Idioma Alemão").

15 "Presença de Unamuno". Obras Completas também em tradução no Brasil pela Editora Globo. São Paulo: 2001, IV vol., p. 289.

${ }^{16}$ CANTO (ob. cit.) testemunha-o (p. 253).

17 TEITELBOIM, ob. cit., pp. 190-193, 196, 241 e 242, reproduz as anotações de JÜNGER sobre seu longo diálogo com BORGES na Alemanha em 27 de outubro de 1982, e, em entrevista ao brasileiro Álvaro Alves de FARIA, BORGES insiste que "seu candidato ao Nobel sempre foi André Malraux", o "grande Malraux", Borges (O Mesmo e o Outro). São Paulo: Escrituras, 2001, p. 40. 
pairar acima da política fascista e antifascista, embora nem uma posição, nem outra, nem de longe esgotasse cada um destes, por mais que adversários e adeptos tentassem a isto limitá-los. O interessante a respeito, na época, foi a obra do então iniciante Jorge Luís Borges ter atraído a atenção nada menos que de Drieu la Rochelle de visita a Buenos Aires ${ }^{18}$ : Drieu em tão acidentado itinerário de herói nacional na Primeira Guerra Mundial a anti-herói colaboracionista em breve na Segunda.

Em defesa de Borges, diante das intermináveis acusações posteriores em relação às suas simpatias autoritárias senão totalitárias, lembre-se ter ele protestado contra os triunfos militares nazistas, ao auge em 1940, e seu regozijo com as derrotas deles em $1944 .{ }^{19}$

Quanto aos ditatoriais militares argentinos, Borges deles esperava um anti-populismo dirigido contra Peron $^{20}$, substituído por populismo ainda pior porque belicista na Guerra das Malvinas ${ }^{21}$, para decepção de Borges, culminando no mútuo repúdio entre ele e aqueles militares..$^{22} \mathrm{O}$ caso de Pinochet foi de muito maior complicação para Borges, dado o maior envolvimento deste com aquele. ${ }^{23}$ Terminando pela generalizada decepção borgiana diante de todos os militaristas latino-americanos, a quem acabou dedicando acerbas condenações por suas incompetências e seus desmandos. ${ }^{24}$

Antes de Borges, era análoga a tragédia de Leopoldo Lugones, atraído pela ilusão militarista, da qual fez vibrante elogio no seu A Hora da Espada,

${ }^{18}$ TEITELBOIM, ob. cit., p. 260.

${ }^{19}$ BORGES contra os nazistas em "Definição de Germanófilo" (Obras Completas, ob. cit., IV vol., p. 514): "O hitlerista, sempre, é um rancoroso, um adorador secreto, e às vezes público, da 'esperteza' foragida e da crueldade"; e "o grau físico de minha felicidade quando me comunicaram a libertação de Paris". "Anotação ao 23 de Agosto de 1944" (Otras inquisiciones. Madrid: Alianza Editorial, 1976, p. 130).

${ }^{20}$ CANTO, ob. cit., p. 245.

${ }^{21}$ María Esther VÁZQUEZ relata uma tentativa de suicídio de BORGES em julho de 1982, pouco depois da derrota militar argentina diante dos britânicos na Guerra das Malvinas (Borges. Esplendor y derrota. Barcelona: Fábula Tusquets Editores, 1999, pp. 314 e 315), durante a qual ele se dissociara publicamente da causa argentina e elogiara os britânicos. Terá sido mera coincidência?... Ou mais uma das profundas contradições borgianas???

${ }^{22}$ Vide TEITELBOIM, ob. cit., pp. 211 e 212, contudo também a p. 221.

${ }^{23}$ Vide nota 11.

${ }^{24}$ BORGES por um lado declarava "imbecis" os oficiais argentinos que haviam sacrificado, por incompetência, os despreparados soldados argentinos (entrevista a Roberto d' ÁVILA e Walter SALLES JR in Borges no Brasil org. por Jorge SCHWARTZ. São Paulo: Editora UNESP-Imprensa Oficial do Estado de São Paulo, 2001, p. 532) e, por outro, prometia prefácio a Ruben Oscar MORO, patriota historiador de La guerra inaudita (Historia del conflicto del Atlántico Sur). Buenos Aires: Edvern, 2000, p. VIII). Esta e outras contradições, políticas e filosóficas sublimadas literariamente, podem tê-lo induzido à tentativa de suicídio da nota 21 . 
sua decepção o levando ao suicídio. A relação Borges-Lugones foi do elogio ao afastamento e a reaproximação daquele diante deste.

Após a Guerra das Malvinas, em 31 de dezembro de 1982, no jornal El Mercurio de Santiago do Chile, Borges declarava textualmente: "No mundo há atualmente um erro ao qual todos temos propensão, do que também eu tenho sido culpado: este erro se chama nacionalismo. É causador de muitos males. Eu, por exemplo, até pouco tempo me sentia orgulhoso dos meus antepassados militares. Agora, não".

Acontece que um dos historiadores argentinos da Guerra das Malvinas, Rubén Oscar Moro, relata haver procurado em casa Jorge Luís Borges, para pedir-lhe o prefácio ao seu La guerra inaudita (Historia del conflito del Atlántico Sur), e Borges aceitou, relembrando seu avô o coronel Borges tombado numa das guerras civis argentinas. Muito pouco tempo depois, Borges faleceu sem concluir a tarefa. Contudo, aquele autor dedica-lhe o livro e começa-o com um dos últimos poemas borgianos (sobre Caim e Abel), que termina assim: "Enterraram-nos juntos. A neve e'a decomposição os conhecem. O facto referido ocorreu num tempo ao qual não podemos entender".

Mais uma das tantas fundamentais contradições de Jorge Luís Borges?

Claro que sim, mas, nós todos, não somos menos ou mais contraditórios?... As novas gerações argentinas vêm conseguindo entender as fontes das contradições de Borges. ${ }^{25}$

O crítico Juan Nuño, que foi o primeiro a alongar-se na subjacente filosofia de Borges, demonstrou o seu básico solipsismo (Borges sempre cita favoravelmente Berkeley), sua consciência do dilema moral ("Ainda ignoro a ética do sistema por mim esboçado"), portanto a ausência nele, Borges, sequer de um refugium peccatorum. Enfim, na última inclinação na direção de Hume (do idealismo alemão Borges só aceita Schopenhauer na constatação da necessidade de total desprendimento dos sentimentos, não só das paixões, excepto a estética, noutra grande contradição, como se vê no seu ensaio sobre Swedenborg), conclui sob o brutal impacto da realidade: "Negar a sucessão temporal, negar o eu, negar a ordem astronómica, são desesperos aparentes e consolos

${ }^{25}$ Pedro ORGAMBIDE mostra como as atitudes políticas de Borges estão enraizadas "em seu próprio pensamento político", de difícil análise. Seus contemporâneos Martínez Estrada e Eduardo Mallea haviam optado por visões opostas da Argentina: Estrada, a visão objetiva, ensaística; Mallea, a subjetiva, novelística. BORGES declarava-se mais "poeta", que "intérprete da realidade". Acontece que Leopoldo Lugones foi dos grandes poetas argentinos e veio do socialismo universalista ao "nacionalismo imperial" e ao "culto da coragem", itinerário freqüente na época, décadas de 1920 e 1930, inclusive entre intelectuais (vide ORGAMBIDE, Pedro. "Borges y su pensamiento político" in Antiborges. Compilações e comentários reunidos por Martín LAFFORGUE. Buenos Aires: Ediciones Argentina/Javier Vergara EditorGrupo Zeta, 1999, pp. 257, 271, 272 e 261). O comportamento político de BORGES complicava-se pelo seu gosto do "paradoxo como provocação" (p. 258). 
secretos. Nosso destino [...] é espantoso porque é irreversível e de ferro. O tempo é a substância de que sou feito. O tempo é um rio que me arrebata, mas eu sou o rio; é um tigre que me destroça, mas eu sou o tigre; é um fogo que me consome, mas eu sou o fogo. O mundo desgraçadamente é real; eu, desgraçadamente, sou Borges". Ao término da vida, foi que acabou aceitando: "A já avançada idade me ensinou a resignação de ser Borges" ${ }^{26}$ Textualmente: "El tiempo está viviéndome".

O médico, que assistiu seus derradeiros momentos, testemunhou que nunca vira um paciente tão indiferente à morte. Mesmo assim um padre católico e um pastor protestante foram para a beira do seu túmulo, na hora do sepultamento em Genebra, reivindicar suposta conversão final de Jorge Luís Borges $^{27}$... Dele que certa vez polemizou com um bispo católico argentino, sobre a existência de Deus ${ }^{28}$, e que, mais de uma vez, reconheceu a única influência religiosa mais íntima, proveniente da avó metodista inglesa ${ }^{29} \ldots$

A minha própria explicação consiste na permanente argentinidade pessoal de Borges, em especial sua portenhidade, isto é, a permanência de entranhado amor à sua portenha Buenos Aires querida, tão mutante como tudo na vida, em mudanças nem sempre aceitas por cada um de nós: este foi o derradeiro refúgio afetivo profundo, mais que vagamente psicológico, muito menos filosófico. Seus amigos mais próximos testemunham a complexa relação amor-ódio de Jorge Luis Borges com a Argentina em geral e Buenos Aires em especial, onipresente em tudo que disse e escreveu, de modo direto ou indireto, em menor ou maior intensidade, mas sempre, sempre, presente. Relação muito típica da elite argentina, em especial a de Buenos Aires.

Este cosmopolita assumido - que dizia pertencer à literatura universal e não propriamente à argentina, daí proibir a republicação póstuma dos seus primeiros livros, O Idioma dos Argentinos, O Tamanho da minha Esperança, não só o polêmico Inquisições - o cosmopolita assumido que preferiu agonizar e morrer na Genebra querida da adolescência, em vez de receber em Buenos Aires as homenagens finais às quais foi tão instado nos últimos momentos, o cosmopolita repetiu, intermitente, ao longo da vida, a sua profunda, inerradicável, argentinidade em autênticos literais atos de fé: "Pertencer a um país é, antes de tudo, um acto de fé". "Que significa ser europeu, ser argentino? Um acto de fé". Enfim, "Ser argentino é um irrevogável acto de fé, ou então um

\footnotetext{
${ }^{26}$ NUÑO (ob. cit., p. 136) comenta-o extensamente.

27 TEITELBOIM, ob. cit., pp. 298, 306 e 307.

${ }^{28}$ Foi com o bispo de Jujuy, norte da Argentina, onde BORGES havia pronunciado uma conferência na universidade local e dissera que era ateu. $\mathrm{O}$ incidente repercutiu intensamente nos jornais de Buenos Aires (vide FARIA, ob. cit., pp. 36 e 37).

${ }^{29}$ Vide, por exemplo, CANTO, ob. cit.,pp. 45, 46 e 283.
} 
acto diante do espelho, uma simulação, uma aparência" ${ }^{\text {30 }}$. Ou um europeu exilado na América.

Quanto à sua cidade natal - tão mudada fisicamente pela substituição dos edifícios e humanamente pela das pessoas, em ambos os casos nem sempre para melhor, da qual Borges podia refugiar-se por cegueira numa cidade etérea, parada no espaço e no tempo, tentação de todos nós - dela Borges disse, no seu poema "Fundação Mítica de Buenos Aires", ser "tão eterna quanto a água e o ar".

O radical cosmopolita anglófilo, que escrevia em inglês as cartas amorosas mais íntimas, ${ }^{31}$ também permaneceu sempre fiel à iberidade em mais de um verso ("estais, Espanha, silenciosa entre nós", "incessante e fatal"; o Quixote foi um sonho de Cervante e o Quixote recriou Cervantes, personagem e autor confundidos numa só pessoa; mais Luís de Camões, "flor de Portugal" em "tua Eneida lusitana": "Bem pouco sei de meus antecessores/ portugueses, os Borges: vaga gente/ que prossegue em minha carne", Borges de Moncorvo, Trás-os-Montes, aos quais procurou quando visitou Lisboa); portanto, o não tão cosmopolita como se dizia, menos crendo nisto do que querendo nos fazer crer, este paradoxal cosmopolita ibérico-argentino-bonaerense também foi muito bem recebido nada menos de quatro vezes no Brasil, do que deixou longas entrevistas reunidas em livro. ${ }^{32}$

Borges não fugiu mesmo ao mais delicado momento histórico das relações Brasil-Argentina, a participação militar brasileira ao lado dos argentinos querendo se libertar do caudilho Juan Manuel Rosas nas guerras platinas do século XIX, ainda hoje tão discutidas pelos dois lados: "Brasil e o tirano. Aquela história/ desenfreada. O todo pelo todo". ("Elegia da Pátria").

Nas suas passagens pelo Rio de Janeiro e São Paulo, então aclamadas mais pelos brasileiros que pelos argentinos em seu próprio país, Jorge Luís Borges demonstrava conhecer Euclides da Cunha e Carlos Drummond de Andrade, e confessava haver Gonçalves Dias se incorporado tanto à sua memória e sentimento, que sequer se lembrava do nome do autor, ao recordar os versos que lhe ensinaram, menino: "Minha terra tem palmeiras,/ onde canta o sabiá;/ as aves que aqui gorjeiam,/ não gorjeiam como lá..." Versos por ele repetidos, com seu sorriso habitualmente irônico, no mais puro sotaque brasileiro ${ }^{33} \ldots$

\footnotetext{
${ }^{30}$ Vide $O$ Dicionário de Borges (O Borges Oral, o Borges das Declarações e das Polêmicas) reunido por Carlos R. STORTINI. Rio de Janeiro: Editora Bertrand Brasil, 1990, pp. 20 e 78.

${ }^{31}$ A Estela CANTO, por exemplo, ob. cit., p. 143.

${ }^{32}$ Reunidas por Jorge SCHWARTZ em Borges no Brasil (vide nota 24).

${ }^{33}$ Na primeira entrevista, a Leo Gilson RIBEIRO em 1970 e na quarta e última (a Roberto d' ÁVILA e Walter SALLES JR.), em Borges no Brasil, ob. cit., pp. 498 e 538.
} 


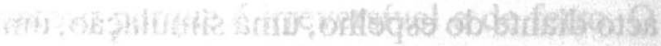

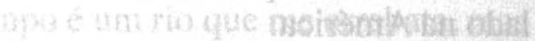

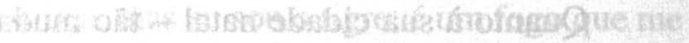

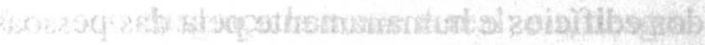

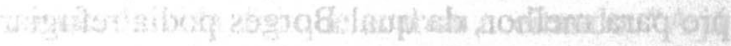

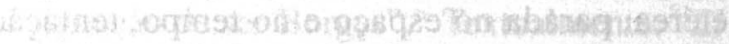

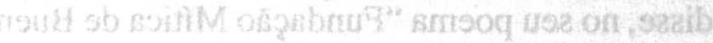

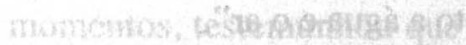

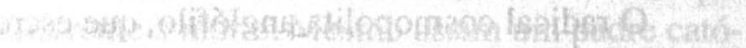

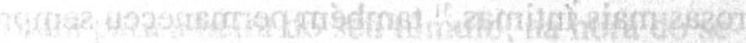

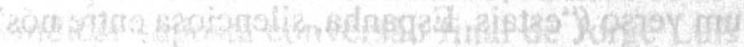
dif

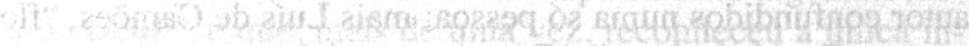

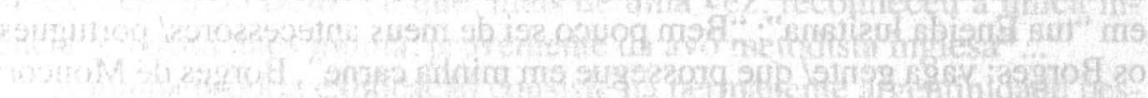

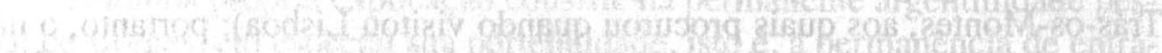

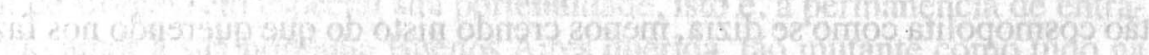

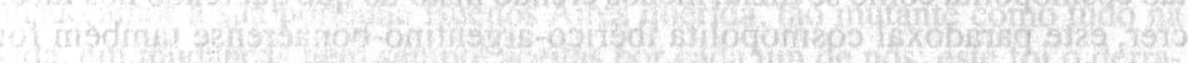

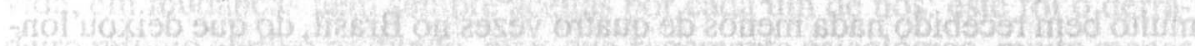

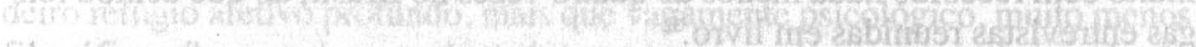

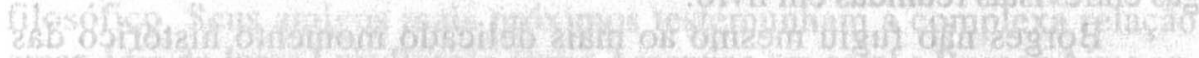

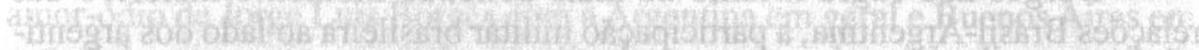

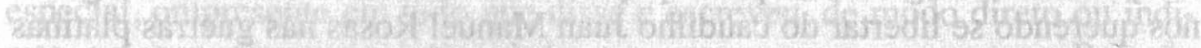

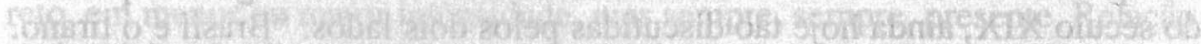
Amatre te

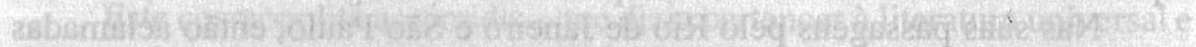

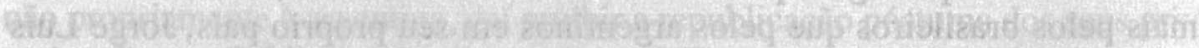

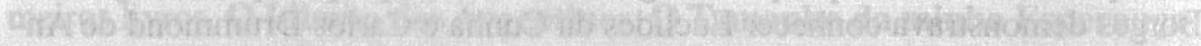

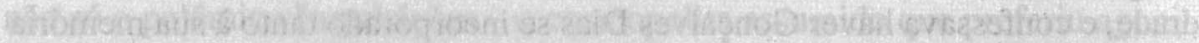

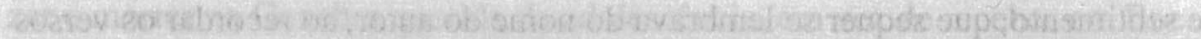

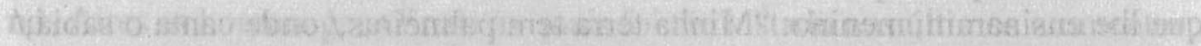

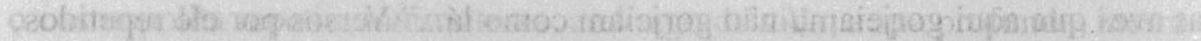

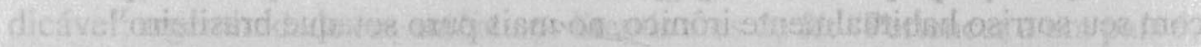

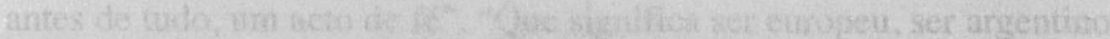

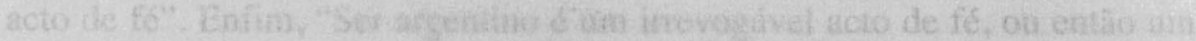

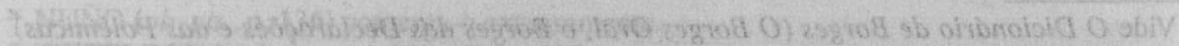

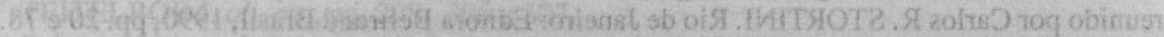

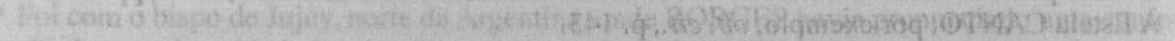

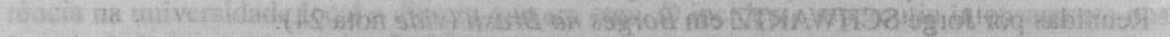

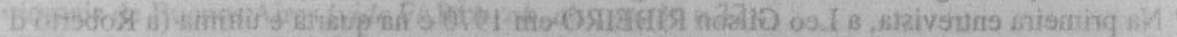

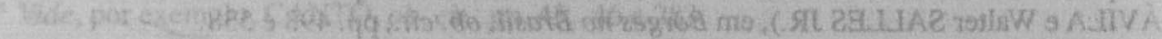




\title{
A BIBLIOTECA DA SOCIEDADE MARTINS SARMENTO
}

\author{
Fernando Pinto dos Santos \\ Prof. Ensino Secundário - Guimarães
}

\section{Fundação}

Conta as areias da praia, o grande Mago do Mundo; só não mente quem não sente que o Mistério não tem fundo.

José Afonso

Para entrarmos na história (e mistérios) da Sociedade Martins Sarmento, a sua Biblioteca, e o motivo ou os motivos que estiveram na base da sua fundação, é preciso perceber como a elite liberal da primeira metade de oitocentos pretendeu realizar a secularização da sociedade, da cultura e das consciências. "Se a Revolução de 1820 não conseguira transformar as estruturas religiosas do Antigo Regime, teve a virtualidade de pré-anunciar as mudanças empreendidas, a partir de 1832, por Mouzinho da Silveira, Silva Carvalho e Joaquim António de Aguiar" (VITOR NETO, Hist. Port. VoI.V; 1993; 265).

Como aconteceu em muito período revolucionário, o relacionamento entre o Estado e a Igreja não foi pacífico. A partir de 1834, a elite governativa procurou reduzir o peso da Igreja na sociedade "e subtrair à influência do clero miguelista vastas camadas da população" (NETO: 1993; 266). Nos Açores, tal tarefa esteve a cargo de Mouzinho da Silveira. No continente, as alterações no interior da instituição religiosa, prolongamento das levadas a efeito nos arquipélago, estiveram a cargo de Silva Carvalho e Joaquim António de Aguiar.

No decorrer do processo revolucionário, o bloco social dominante levou a cabo uma política de destruição do poder exercido pela Igreja. Teve importância decisiva Joaquim António de Aguiar que, em 30 de Maio de 1834 extinguiu as ordens religiosas masculinas e nacionalizou todos os seus bens. "Com este decreto, os liberais retiraram grande parte do poder económico à instituição eclesiástica, facto que aumentou a dependência em relação ao estado e diminuiu a sua influência política. Tal medida, comum a outros países, representava a aplicação dos princípios liberais no plano económico. Na verdade, o liberalismo revelava-se, na teoria e na prática, incompatível com a 
existência das congregações religiosas e com o regime de propriedade que as sustentava" (NETO: 1993; 268).

Este estado de coisas levou a que ficasse decidida, por um lado, a sorte dos expropriados; por outro lado, permitiu definir o destino dos bens. Diversos tipos de bens foram classificados e inventariados. Para o que nos interessa, temos de referir uma categoria particular de bens constituída por livrarias e obras de arte. Nelas se compreendiam livros e manuscritos, por exemplo. "Inicialmente pouco se fez para definir o destino destes objectos e, depois de muitas preciosidades se terem perdido, é que estes valores culturais foram encaminhados para estabelecimentos de ensino, cultura, arte e ciência que, entretanto, foram criados ou reestruturados" (MARTINS da SILVA; 1993; 345). Estas instituições, sobretudo bibliotecas e museus, foram criadas nas capitais de distrito por decisão do ministro Agostinho José Freire, em 1836. Em 30 de Dezembro desse ano, é nomeada por Passos Manuel, uma espécie de Comissão de Gestão para as livrarias resultantes das apreensões dos livros que faziam parte do espólio dos Conventos extintos. (Cf. MANUELA RIBEIRO: 1999; 197).

É neste cenário de instabilidade e de perturbação que se levanta o problema da criação dum local onde pudessem ser acondicionados os livros apreendidos em resultado da extinção das ordens religiosas e do encerramento dos respectivos conventos, nomeadamente os que faziam parte do espólio dos Dominicanos. Não sabemos se esta atitude corresponderia a um vivo desejo ou se não seria já o embrião duma rivalidade secular e quase patológica existente entre Guimarães e Braga. Não esqueçamos que, como dissemos, todos os livros foram para as capitais de distrito.

Seja como for, numa reunião extraordinária da Câmara Municipal, efectuada em 22 de Setembro de 1834, a pedido de Joaquim Cardoso de Freitas, este faz um caloroso apelo a que os responsáveis locais movam influências junto do Reino, para que os citados livros do Convento de S. Domingos regressem à sua origem, ou seja, a Guimarães. Nada mais urgente, então, do que a criação duma Biblioteca, local próprio para a recolha de livros (Cf. Livro de Actas das Reuniões Camarárias: 1834; 56 vs/57/ 58). O local que o dito vereador camarário considerava ideal era o das antigas instalações do Mosteiro de S. Domingos.

Após esta reunião extraordinária da Câmara Municipal e deste insistente apelo, não deixa de ser curioso que a resposta à solicitação apresentada só tenha surgido no ano de 1866, através duma portaria régia de 4 de Setembro, e que, mesmo assim, impunha algumas restrições. Só poderiam regressar a Guimarães todas as obras que em Braga, capital de distrito existissem em duplicado.

Perante este intervalo no tempo, é legítimo perguntar: terá parado o relógio da História? Sofreu, esta, uma longa amnésia de trinta e seis anos? Ou 
será que, parafraseando Jean Baudrillard, terá havido uma greve dos acontecimentos? Nem uma coisa nem outra. O que houve foi uma grande instabilidade governativa provocada, com frequência, por conflitos partidários que impediam o funcionamento da vida política, económica e social do país, com o mínimo de estabilidade. "Entre Maio de 1834 e finais de 1835 houve cinco governos, para além de algumas substituições pontuais; todos se identificavam com a facção liberal mais conservadora, à excepção do último, que era nitidamente de esquerda" (MARTINS da SILVA: 1993; 97-98). Talvez pelos confrontos partidários existentes, o desentendimento entre os poderes executivo e legislativo agravava ainda mais a situação, obrigando a sistemáticas alterações, já que, frequentemente, "um projecto aprovado na Câmara dos Deputados não passava sem alterações substanciais na Câmara dos Pares" (MARTINS da SILVA: 1993; 100).

Podemos concluir que o que se passou ao longo de trinta e seis anos foi o confronto entre diferentes concepções de liberalismo, umas mais conservadoras, outras progressistas, que teve como elemento importante de acalmia, pelo menos temporária, a Regeneração, movimento que pretendia viabilizar a construção dum Portugal moderno. Numa época de tantas convulsões, é natural que a informação disponível não seja muito abundante, mesmo tratando-se de documentação ligada à História local, o que não nos pode surpreender: a instabilidade política não é um fenómeno pontualmente localizado, regionalizável, mas assume um âmbito nacional. Não quer isto dizer que não haja qualquer movimentação. Em 1858, sendo presidente da Câmara de Guimarães o Visconde de Pindela, verificou-se uma deslocação a Lisboa, a uma representação do governo de Sua Majestade, no sentido de que a Câmara de Braga entregasse um exemplar de cada obra existente em duplicado, na Biblioteca Pública desta cidade, para que também se pudesse criar em Guimarães uma Biblioteca (Cf. M -1858 - Fls.141/Vs e 142).

Mas foi preciso esperar pelo dia 2 de Agosto de 1870 e pelo dia 20 de Janeiro de 1871, para que fosse promulgado o Decreto que estabelecia as Bibliotecas, no primeiro caso e, no segundo, o seu Regulamento.

Lembremo-nos de que estamos em plena época Romântica e que os novos intelectuais, ainda com os anos do "Antigo Regime" bem presentes, apontavam para a necessidade de "regenerar" ou "refundar" a Nação, expressões utilizadas pelo Professor Fernando Catroga (CATROGA: 1998; 46), desejo esse que se traduzia num movimento nacionalizador e num apelo ao regresso às origens.

Sendo assim "o culto do passado ganhou, na cultura romântica, um grande relevo. Daí a importância que os românticos conferiram aos "vestígios", aos "monumentos" do passado enquanto expressões da memória popular; daí também a sua particular sensibilidade em relação à urgente necessi- 
dade de os preservar, atitude que os fez, sobretudo a Alexandre Herculano, os primeiros grandes defensores do património cultural" (CATROGA: 1998; 46-47).

Este regresso às origens, este revitalizar das raízes, foi uma opção inspirada em fenómenos similares ocorridos na Alemanha, em França ou em Espanha, com o objectivo de elevar a cultura popular a fonte inspiradora, a nacionalizadora das consciências.

Alexandre Herculano desempenhou um papel de grande relevo neste particular, pois foi ele que recolheu milhares de documentos dispersos por igrejas e conventos do país e em risco de desaparecimento devido às vicissitudes políticas e sociais da época (Cf. CATROGA: 1998; 69). Talvez por isso possa ser considerado o verdadeiro construtor dum novo olhar sobre o nosso passado e, ao mesmo tempo, o motor de arranque da criação das Bibliotecas, já que em 1839 era director da Biblioteca da Ajuda.

"Neste contexto de instabilidade, mais do que nunca, uma das tarefas fundamentais das grandes Bibliotecas era coleccionar, proteger, inventariar e, finalmente, tornar acessível a herança da cultura escrita" (CHARTIER: 2000; 30).

\title{
2. Constituição de um fundo
}

\author{
“(...) o trajecto duma vida, a sua narrativa, \\ nunca se poderá limitar a uma apreciação \\ estática e pontual, baseada no bilhete \\ de identidade e na esperança de vida \\ média do momento. A nossa história \\ é a história das relações com quem \\ nos rodeia e dos fantasmas respectivos."
}

Júlio Machado Vaz, Estilhaços

É no contexto político, social e cultural do movimento Romântico, que não será devidamente compreendido se não se tiver presente o modo como os seus intelectuais entenderam as relações entre a cultura e a sociedade, que são dados os primeiros passos na construção duma Biblioteca em Guimarães.

Com tal objectivo, um grupo de intelectuais, com destaque para Domingos José Ferreira Júnior, Domingos Leite Castro, Avelino Germano da Costa Freitas, José da Cunha Sampaio e Avelino da Silva Guimarães, reuniu-se em Guimarães no dia 20 de Novembro de 1881 e apresentou um relatório em que expunha um conjunto de argumentos, que considerava válidos, para a criação duma Instituição nesta cidade. Justificava ainda a razão da atribuição do nome de Martins Sarmento e a associação deste a um tão grande acontecimento local. 
Vejamos alguns dos argumentos escritos pela pena do relator, Avelino da Silva Guimarães: "Não há uma só pessoa ilustrada desta terra que desconheça o alto merecimento literário e científico do seu conterrâneo, o Ex. Sr. Francisco Martins de Gouveia Morais Sarmento; não há quem ignore que sua Exa., sendo um dos espíritos mais cultos do Minho, na frase do nosso eminente romancista Camilo Castelo Branco, conquistou um lugar de honra entre os mais sabedores do seu país.

Não há também nesta cidade quem o não respeite, quem lhe não preste o tributo da sua consideração e simpatia, como cavalheiro de exemplar pundonor, como homem de letras do mais subido quilate.

É certo, porém, que até hoje ninguém tomou a iniciativa de promover que esse sentimento geral, acidentalmente revelado em manifestações individuais, viesse à luz pública por uma fórmula mais distinta e colectiva" (Cf. Relatório da Criação da Inst. 20/11/1881). Os redactores do Relatório não deixam de manifestar estranheza pelo "silêncio desta terra". Será assim tão estranho? Poder-se-ia colocar ainda hoje a questão! - perante uma figura de destaque, que foi condecorada pelo governo da República Francesa, não só pelas suas qualidades de arqueólogo, investigador e cientista, como pela sua apetência por todas as manifestações de carácter cultural, inclusivamente literárias e políticas. Isto transportou o seu nome e o nome da terra que o viu nascer, para além fronteiras. Por isso, este grupo de intelectuais subscritores da criação duma Instituição em Guimarães, com o nome de Martins Sarmento, pensou que esta seria uma forma e, na sua opinião, a única possível de lhe prestar homenagem já que "uma festa ruidosa, expressão de entusiasmo súbito, em que largamente a alma se expande, mas que não deixa da intensidade dos sentimentos senão um fulgor que pouco a pouco se esvai, não era o que mais convinha como manifestação colectiva e pública duma cidade" (Cf. Relatório: 1881; 51). Resolvem dar, com prévia autorização do homenageado, o nome deste à Instituição, propõem que seja inaugurada a 9 de Março, data do seu nascimento, e fixar para este dia os actos mais solenes em homenagem perpétua.

Inicialmente a Instituição teria objectivos mais restritos mas, nem por isso, importantes, a saber: o desenvolvimento da instrução, concretamente com a criação de institutos secundários; a criação de escolas profissionais para apoio à indústria com objectivo de adaptar os industriais às novas tecnologias.

Como acontece em todas as manifestações de carácter cultural, onde, e inevitavelmente, o aspecto político não pode ser subestimado, surgiram opiniões a favor e contra. Estes últimos perguntavam, mesmo, se a criação da Instituição não seria anacrónica. Mais uma vez, vejamos o que a pena do relator, Avelino da Silva Guimarães, escreve como contra argumentos e aproveitando a capacidade argumentativa que lhe forneceu a licenciatura em Direito: "O momento pode desaparecer com uma tempestade ou uma guerra; a instituição, 
se cria raízes, se preenche uma necessidade real, se representa um progresso na educação social, vive além das convulsões, adquire condições de perpetuidade, permanece enquanto não está satisfeito o seu fim, ou enquanto se não torna inútil para novos progressos, vivendo ainda assim na memória dos que lerem as páginas da sua história" (Relatório: 1881; 51-55).

Posteriormente, os horizontes foram-se alargando e o sonho de um conjunto de intelectuais, que se alinharam à volta da figura de Martins Sarmento, passava a ser mais realidade, surgindo assim a Biblioteca Municipal de Guimarães, que teve a sua primeira sede nas instalações da Sociedade Martins Sarmento. O Regulamento da Sociedade foi aprovado em 1 de Agosto de 1882; o Regulamento da Biblioteca foi aprovado na reunião da direcção de 11 de Outubro de 1882.

Convém fazer referência aos artigos que consideramos mais importantes dos seis capítulos que compõem o Regulamento da Biblioteca. Ao consultarmos o referido Regulamento, verificamos que, logo no seu primeiro artigo é feita a distinção entre Biblioteca Pública e Biblioteca Popular, divisão típica da época de consolidação do Regime Liberal, e que tem por base o tipo de obras que possui. No entanto, não deixam, uma e outra, de pertencer a um núcleo que é a Biblioteca Municipal de Guimarães, criada, segundo consta do Artigo Primeiro, do Capítulo I, pelas deliberações da Sociedade Martins Sarmento de 8 de Março e 1 de Junho de 1882 e pelas da Câmara Municipal, de 22 de Março e 5 de Maio, do mesmo ano.

Citaremos, na íntegra, os Artigos $2 .^{\circ}$ e $3 .^{\circ}$, este com mais dois parágrafos, que podem fornecer algumas pistas.

O Artigo $2 .^{\circ}$ diz-nos que "a biblioteca pública constará de todas as obras de erudição e ciência pura, de todas as obras e colecções de grande valor artístico, das edições raras dos manuscritos, e, em geral, de todas as produções literárias e artísticas que não tenham imediata aplicação ao ensino popular". Afirma o Artigo $3 .^{\circ}$ que "a biblioteca popular conterá duas classes de produções: classe geral e classe especial". O parágrafo primeiro do mesmo Artigo diz que "a primeira abrange livros de religião, moral, história, direitos e deveres políticos, viagens, literatura, higiene, obras recreativas e quaisquer outras necessárias aos usos de vida das classes populares"; o segundo parágrafo afirma que "a segunda abrange revistas, modelos, manuais industriais, agrícolas, comerciais, desenhos e inventos relativos às artes e ofícios de Guimarães".

Estes dois Artigos e outros tantos parágrafos levam-nos a colocar algumas questões: qual o critério que levou a esta catalogação? Estará aqui implícita alguma influência do pensamento positivista? Achamos legítimo pensar afirmativamente, já que a catalogação obedece a um critério de ordem e, segundo o positivismo Comteano, "ordem significa sempre, ao mesmo tempo, mandamento e arrumação. A ordem é concebida de maneira rígida e coisifi- 
cada, como o encaixar das peças num mecanismo. A ideia de ordem está ligada à ideia de hierarquia" (VERDENAL: 1975; 205). Além disso, a classificação das diferentes obras segundo uma determinada arrumação temática, de acordo com uma "escala enciclopédica," corresponde às mesmas exigências de ordem (Cf. VERDENAL: 1975; 206). Podemos observar, ainda, que o conteúdo do Artigo $2 .^{\circ}$, não é de menosprezar, já que reflecte um conceito demasiado privado do que é público e, nessa medida, torna-se altamente elitista e classista, visão tipicamente do positivismo: "a mania da classificação ilustra constantemente esta obsessão da ordem. Conhecer a sociedade é decompô-Ia em "classes" segundo relações hierárquicas: classe proletária, classe industrial, classe feminina, classe sacerdotal" (VERDENAL: 1975; 206). Esta "mania" pode ser transposta para o conteúdo da Biblioteca pública:" obras de erudição e ciência pura, obras e colecções de grande valor artístico, edições raras, manuscritos e todas as produções literárias e artísticas que não tenham imediata aplicação ao ensino popular (Cf. Supra Artigo 2..$^{\circ}$ ) e, acrescentámos nós, que fossem mais acessíveis a uma burguesia mais ou menos culta do que a um proletariado semianalfabeto.

Vamos deter-nos, por momentos, no Artigo $5 .^{\circ}$, porque pensamos ser de interesse para nos explicar como surgiu o fundo da Biblioteca: "as obras truncadas serão recolhidas num compartimento especial e distinto. O director da Biblioteca esforçar-se-á por as completar, quer seja por donativo ou compra ou por outra forma qualquer, distribuindo-as, depois de completas, pelas secções respectivas". Numa primeira fase faz-se referência a obras que possam ser adquiridas; numa fase posterior, aquela que viria a ser a Biblioteca da Sociedade Martins Sarmento, vive de doações, de legados “post-mortem”. É assim que se constitui o seu fundo e que figuras ilustres da terra dão o seu contributo, como acontece como Francisco Martins Sarmento, o Conde de Vila Pouca e Domingos Leite Castro, entre outros.

\section{Acessibilidade e organização da biblioteca}

"A Biblioteca é (...) antes de mais, retiro do mundo, liberdade conquistada longe do público,

local de onde se vê sem forçosamente se ser visto."

Roger Chartier

Analisando os Capítulos 11 e 111 podemos verificar que são considerados dois tipos de leitura: uma leitura no estabelecimento e uma leitura no domicílio, de acordo com o tipo de livros e, provavelmente, com o tipo de lei- 
tores. Este critério de classificação não é, mais uma vez, arbitrário. Obedece, novamente, a uma ideia de hierarquia que se prende com a ideia de materialidade. Era perfeitamente natural que determinados livros, de elevado valor pela sua raridade e pelo seu conteúdo, não pudessem ser lidos a não ser na Biblioteca; no entanto, o reverso da medalha também era verdadeiro, já que havia determinados livros que podiam ser requisitados para leitura no domicílio, fazendo-se alusão aos habitantes de ambos os sexos, embora essas requisições obedecessem a determinados parâmetros.

Voltando aos Capítulos supracitados pensamos poder referir alguns aspectos que nos parecem relevantes pela época que, então, se vivia. Referiremos, em primeiro lugar, o tipo de modelo organizacional relativamente aos livros de leitura no estabelecimento, isto é, na Biblioteca, e aos de leitura no domicílio. Pensamos que tal modelo obedece a critérios Encíclopédicos, no sentido Diderotiano do termo. No escalonamento dos livros "destacamos os livros de biblioteca (os que não se destinam a ser lidos de uma só vez mas a serem consultados à medida das necessidades). Particularmente interessante é ainda a designação de bons livros, geralmente os livros de devoção e de piedade, mas também um livro que vende bem (segundo a linguagem dos editores), um livro raro (para os curiosos) e ainda um livro instrutivo (para os homens de bom senso)" (FURTADO: 2000; 15).

É curioso verificar que no Capítulo 11, "Da Leitura no Estabelecimento", não é feita qualquer referência aos livros que estão vedados ao exterior, embora haja referência a alguns, no Capítulo 111, Artigo 15..$^{\circ}$, parágrafo único. Alguns Artigos deste Capítulo 11 são importantes para percebermos o funcionamento da biblioteca. Comecemos pelo Artigo $9 .^{\circ}$ que, a nosso ver, enferma duma imprecisão de linguagem na sua redacção. Diz o referido Artigo: "A leitura na Biblioteca Municipal de Guimarães é ministrada em todos os dias feriados e na véspera dos mesmos dias". Atentando na redacção deste Artigo, a questão que imediatamente se nos coloca é esta: e nos outros dias? A Biblioteca estará fechada?

Uma curiosidade que nos levanta o Artigo $10 .^{\circ}$ prende-se, em primeiro lugar, com o horário de funcionamento: duas horas depois do anoitecer; seguidamente, com o facto do director da Biblioteca se obrigar a anunciar num jornal da localidade a hora precisa da sua abertura e encerramento, de acordo com as épocas do ano. No primeiro caso, seria a criação dum horário pós laboral, que facilitasse a sua frequência às camadas da população laboriosa, como sugere o Professor Amado Mendes" às bibliotecas populares foi dedicada especial atenção, competindo-lhes reunir os livros e publicações necessárias à instrução do povo, à rápida informação e ao entretenimento. Para que estes objectivos fossem atingidos, estabeleceu-se um horário de funcionamento alargado (das 10 às 16 horas e das 19 às 23 horas) a fazer inveja aos utiliza- 
dores da maior parte das actuais bibliotecas" (MENDES:1998;191) No segundo, seria uma for ma de desprivatizar, no sentido de democratizar, o acesso a um local público.

Tanto no caso da prorrogação de prazos como na restrição a determinadas concessões, a direcção da Sociedade tinha autonomia de decisão, sem no entanto deixar de fazer a publicitação de tais alterações, quer nos jornais locais que fossem publicados no espaço duma semana, quer por meio dum edital afixado na porta da casa da Sociedade, como consta no Artigo $11 .^{\circ}$ e nos parágrafos primeiro e segundo do referido Artigo.

Se havia a intenção de que tudo funcionasse dentro duma certa ordem e com algum método, a requisição dos livros para leitura no estabelecimento é o espelho que reflecte esse desejo, como podemos ver nos Artigos $12 .^{\circ}, 13 .^{\circ} \mathrm{e}$ $14 .^{\circ}$. Assim, o Artigo 12. diz que "a requisição de livros para leitura no estabelecimento só pode ser feita por escrito, devidamente assinada, e nas mesmas horas destinadas à leitura" (Cf. Regulamento da Biblioteca: Artigo 12. ${ }^{\circ}$; 1882). Os Artigos seguintes, $13 .^{\circ}$ e $14 .^{\circ}$, atribuem competências ao secretário da Biblioteca e prioridades na requisição de livros. O secretário, mediante requisição prévia, entrega os livros e, passada a hora, procede à sua recolha para os guardar convenientemente. Os livros são entregues aos leitores por ordem de requisição e a solicitação do livro não é negada, mesmo quando requisitada a mesma obra por mais dum leitor ao mesmo tempo.

Passemos agora à análise de alguns Artigos que se prendem com a leitura ao domicílio.

Embora saibamos que o grau de alfabetização nesta época não era o mesmo para ambos os sexos e variava de acordo com a classe social a que cada um pertencia, não deixa de ser curioso salientar o que refere o Artigo 15 . $^{\circ}$ do Capítulo III: "Os habitantes de ambos os sexos do concelho de Guimarães podem requisitar na Biblioteca Municipal qualquer obra impressa, pertencente à 2. a secção, para leitura ao domicílio" (Regulamento da Biblioteca: Cap. III, Art. ${ }^{\circ} 15^{\circ}, 1982$ ), com algumas excepções no que diz respeito aos "dicionários, atlas ou quaisquer outras estampas que só podem ser fornecidas para leitura ou exame no estabelecimento" (Cf. Art. o supra, parágrafo único). Qual então o critério para efectuar empréstimos de livros? Que instrumento usava o responsável pela aceitação das requisições para efectuar o empréstimo? Possuía um livro de termos onde mencionava todas as obras que eram requisitadas, bem como a taxa a pagar pelo requisitante, que ficava em depósito na Biblioteca até ao momento da devolução da obra. Os livros não eram todos taxados no mesmo montante, como se pode ver no parágrafo $10^{\circ}$ do Art. ${ }^{\circ} 16 .^{\circ}$. "A quantia depositada será equivalente ao valor total da obra quando esta constar de mais de um volume" (Regulamento: Art. $.^{\circ} 16 .^{\circ}, \S 1$. . $^{\circ}$ 1882).

Este depósito que o requisitante da obra tinha de efectuar na Biblioteca 
era uma forma de o responsabilizar, em caso de dano ou de extravio. Vejamos, a este respeito, o que nos é revelado pelo parágrafo $2 .^{\circ}$. Do mesmo Artigo: "ninguém pode eximir-se, sejam quais forem as circunstâncias, nem à assinatura do termo, nem à responsabilidade pela falta do livro ou pelo dano nele causado" (Cf. Regulamento: Artigo $\left.16 .^{\circ}, \S 2 .^{\circ} ; 1882\right)$. Este tipo de disposição regulamentar ainda hoje vigora em muitas Bibliotecas. O requisitante compromete-se a devolver o livro, no estado em que encontrou, dentro dum período previamente estabelecido. No caso de tal não acontecer, estará sujeito ao pagamento duma multa.

O regulamento da Biblioteca, de que estamos a analisar alguns Artigos, mostra-nos a tentativa de impor uma certa disciplina, ordem e responsabilidade, relativamente a todos aqueles que pretendem requisitar livros. É isso que podemos ler no Artigo 21. , "enquanto o volume não for restituído, ou outro idêntico entregue em substituição, o seu preço definitivamente adjudicado à Biblioteca, não pode fazer-se novo empréstimo ao mesmo indivíduo" (Cf. Regulamento: Artigo 21..$^{\circ}$; 1882). O capítulo IV do Regulamento da Biblioteca "Das Leituras Públicas e Conferências", mostra-nos até que ponto os seus fundadores, amigos e correligionários de Francisco Martins Sarmento, tinham a plena consciência do papel interventivo que uma Biblioteca podia assumir, enquanto espaço de reflexão e debate, na sociedade Vimaranense, em particular, e até que ponto essa troca de opiniões poderia ser um pequeno contributo para a consciencialização mais ampla de que a Monarquia era um tipo de regime que se encontrava em degenerescência. É curioso que este tipo de leituras, comentadas e debatidas, teve o mesmo eco na Espanha de meados do séc. XIX. Em Janeiro de 1869 "recomendava-se o estabelecimento de leituras populares, nas que o mestre ou outra pessoa ilustrada da população lesse ao público ou explicasse parágrafos, lições ou capítulos das obras da Biblioteca, de forma periódica ou ocasional" (ESCOLAR SOBRINO: 1990; 446- 447).

Não deixa de ser interessante que na leitura fosse permitida a análise ou crítica de opiniões do autor, que cada leitor pudesse fazer ampliações, correcções e apresentar uma gama variada de explicações e, ao mesmo tempo, the fosse vedado o direito a fazer apreciações ou depoimentos, isto é, a apresentar a sua opinião sobre determinadas pessoas ou colectividades. É isto que conseguimos ler no Artigo $28 .^{\circ}$ e $29 .^{\circ}$ do Regulamento da Biblioteca.

Assim como em Espanha, as autarquias deviam ser informadas e tinham uma palavra a dizer relativamente à realização de qualquer leitura colectiva, conferência e/ou debate. O mesmo acontecia com a Biblioteca Pública e da Sociedade Martins Sarmento, em que o director ficava encarregado de participar ao administrador do concelho o dia e a hora da leitura ou conferência, o que devia acontecer mediante um oficio enviado com a devida antecedência. 
Passando ao que diz o Capítulo V "Do Pessoal da Biblioteca e Forma dos Serviços Respectivos", devemos ver alguns aspectos que nos mostram como para uma Biblioteca finissecular que, no primeiro ano da sua fundação, possuía já um espólio constituído por 5345 volumes, todos doados por figuras de Guimarães, ou à cidade afectivamente ligadas, o pessoal nela a trabalhar era reduzidíssimo. Falamos em pessoal e não em "quadro de pessoal", no sentido técnico e administrativo do termo, porque este só há muito poucos anos, na década de 80 do séc. XX, é que foi instituído, talvez ainda de forma incipiente.

$\mathrm{O}$ pessoal da Biblioteca era constituído por um director, um secretário e um contínuo. A nomeação do director da Biblioteca era feita anualmente pela direcção da Sociedade, que o escolhia de entre os outros elementos a quem tinham sido confiados cargos de direcção. Não era um cargo vitalício já que este, a seu pedido e devido a qualquer impedimento, podia ser substituído por outro membro da direcção da Sociedade, desde que o presidente fosse avisado, atempadamente. No caso de isso não se verificar, cabia ao secretário da Biblioteca assumir as funções de direcção, unicamente para "supervisionar e fiscalizar todo o serviço da Biblioteca", de acordo com o número um do Artigo $35 .^{\circ}$. Além disso, o cargo de director da Biblioteca não era passível de qualquer remuneração, o que mostra bem a militância cultural duma certa elite vimaranense, talvez desempenhando outras funções prioritariamente relacionadas com as respectivas profissões, essas sim, remuneradas. Isto mostra no entanto, um carácter de abertura relativamente à dinamização cultural das populações da cidade, o que não quer dizer que não tivesse, a longo prazo a procura de contrapartidas.

Só o cargo de secretário era remunerado, talvez atendendo à responsabilidade estatutária que lhe era conferida e ao trabalho de pendor altamente burocrático que executava, o que não significava, de modo algum, que fosse de complexidade inferior. Vejamos, pelos Artigos $37 .^{\circ}$ e $38 .^{\circ}$ como era feita a sua nomeação e quais as atribuições que lhe esta vam confiadas. A nomeação do secretário da Biblioteca era feita pelo respectivo director que, de comum acordo, depois de ouvida a direcção e desta ter aprovado, lhe atribuía uma determinada remuneração. No caso de faltar, poderia ser substituído por outro indivíduo por si indicado desde que a escolha fosse aprovada pelo director respectivo. Também podia acontecer o seu despedimento e ser obrigado ao pagamento duma multa, conforme o director da Biblioteca achasse conveniente.

Perante este grau de responsabilização, cumpre perguntar: que funções lhe estavam destinadas? O secretário era o responsável por um conjunto de tarefas que iam desde o simples preenchimento dos livros de secretaria, à inventariação da mobília da Biblioteca, passando pela catalogação dos livros e a organização, semestral, duma estatística dos leitores, que enviaria, depois de 
aprovada pelo director, ao Governo e à Câmara (Cf. Regulamento da Biblioteca: Artigo $38 .^{\circ} ; 1882$ ).

O Artigo $39 .^{\circ}$ parece-nos interessante em termos organizacionais da $\mathrm{Bi}-$ blioteca. Em primeiro lugar, porque, a nosso ver está mais uma vez implícita a ideia positivista de ordem / arrumação; depois porque é uma forma de tornar perene, em nossa opinião, aquilo que, segundo a expressão de Jacques Le Goff, deveria transformar-se na "memória histórica".

Na secretaria, poder-se-iam encontrar cinco tipos de livros, a cargo, exclusivamente, do secretário da Biblioteca. O Livro dos Visitantes, onde estes assinalariam a sua presença através do nome, indicação do ano, mês e dia; o Livro dos Leitores, onde constaria o número de leitores, quer no estabelecimento, quer no domicílio e o tipo de obras consultadas ou requisitadas; o Livro dos Termos, que encerraria a actividade de cada ano; o Copiador, onde se transcreviam os relatórios, estatísticas e todo o tipo de correspondência enviada ao Governo e à Câmara e, finalmente, o Livro de Expediente onde constavam todas as despesas de expediente e de secretaria, bem como anotações relativas aos gastos na compra de livros e que tinham uma comparticipação camarária. Este tipo de informação ou, se se preferir, de registo, é importante que exista já que acaba por ser, como diz José Afonso Furtado, citando Yvonne Johannot, é "o lugar de contacto entre matéria e imaterial que permite que passado e presente sejam transmitidos ao futuro" (Johannot, Yvonne- cito FURTADO: 2000;22). Sem este tipo de registos, como poderíamos saber a tipologia do leitor, o tipo de livros para a leitura e a frequência da sua requisição? Quanto material, fonte inesgotável de investigação, não se terá perdido, pelo facto de não haver um registo escrito, devidamente conservado?

Outro pormenor que julgamos de grande relevo prende-se com a catalogação dos livros. Se anteriormente questionávamos a perda de material, por falta de registo escrito, de fontes, agora podemos perguntar se não teria havido, em muitos casos, uma incorrecta catalogação dos livros e de outros textos impressos, que originou uma incorrecta arrumação. Houve, pelo menos em intenção, uma tentativa para que tal não acontecesse, como nos mostra o Artigo 41. e o seu parágrafo único, que passamos a citar: " o catálogo dos livros será feito segundo o modelo adoptado na Biblioteca Nacional de Lisboa e há-de estar patente na casa da leitura"; e diz-nos o mesmo: "uma cópia deste catálogo será entregue à Câmara, indicando-se nela os volumes da propriedade Municipal" (Cf. Regulamento da Biblioteca: Artigo 41. ${ }^{\circ} \S 1 .^{\circ} ; 1882$ ).

É legítimo perguntar, após a leitura deste Artigo e referido parágrafo, qual a razão da referência à Câmara Municipal? Tal alusão surge um pouco por todo o Regulamento da Biblioteca, o que não se pode estranhar. É que havia uma confusão lógica e institucional entre a Biblioteca da Sociedade Martins Sarmento e a Biblioteca Municipal, porque esta só apareceu como or- 
ganismo autónomo em 1991, quando se criou a Biblioteca Municipal Raul Brandão. Até esse momento, os livros pertencentes ao Município estavam depositados nas instalações da Sociedade Martins Sarmento e competia ao Governo e à Câmara Municipal proceder à inspecção e fiscalização da Biblioteca, no sentido de verificar se todos os Artigos do Regulamento estavam ou não a ser cumpridos. É isso que nos revelam quase todos os Artigos do Capítulo VI do Regulamento da Biblioteca, onde se aborda o problema da fiscalização. Temos a considerar dois tipos de fiscalização: ao serviço público e ao serviço interno.

Vejamos o que nos é descrito no Artigo $47 .^{\circ}$ e no seu parágrafo único. Diz o citado Artigo que "a fiscalização quanto ao serviço público no estabelecimento é feita durante as horas destinadas à leitura" e o referido parágrafo avisa-nos que "nesta ocasião e para este fim não são patenteados documentos de qualidade alguma, nem os empregados da Biblioteca podem ser desviados do seu serviço, seja qual for o pretexto" (Cf. CapítuloVI - Reg. Biblioteca; Artigo $47 .^{\circ}$ e $\S$ único: 1882 ). Isto significa que o fiscal não pode interromper a actividade: levanta o auto e vai embora. Podemos daqui inferir que a leitura é uma actividade extremamente séria, levada a sério e quase sacralizada. Como diz Italo Calvino "ler significa aproximarmo-nos de algo que está nesse momento em devir" (Cf. Italo Calvino, Se numa noite de Inverno um viajante, 1979); por isso o nosso recolhimento para percorrermos a caminhada em direcção ao que queremos, neste caso lermos, não pode ser perturbada, porque nos iria afastar cada vez mais do ponto de chegada e, consequentemente, aproximar do ponto de partida. Além disso se "ler não é um processo automático de captar um texto, mas um processo de reconstrução confuso, labiríntico, comum e, no entanto, pessoal" (MANGUEL: 1998; 50) nada mais errado do que alguém se intrometer, no sentido etimológico do termo, isto é, meter-se dentro duma relação existente entre leitor, leitura e livro.

Já os Artigos sequentes, $48 .^{\circ}$ e $49 .^{\circ}$ mostram em que medida a fiscalização relativamente ao serviço interno funcionava em moldes diferentes. Aquela poderia ser levada a cabo sempre que a Câmara o solicitasse. Era unicamente preciso respeitar uma tramitação legal, que consistia em avisar, por ofício, e com uma antecedência de pelo menos vinte e quatro horas, o director, indicando o nome do vereador encarregado da fiscalização. Também seria marcada, a título particular, entre o director e o vereador responsável pela fiscalização, a hora para a levar a cabo. Do mesmo modo se estabelecia que o director da Biblioteca facultaria ao exame dos vereadores fiscais todos os documentos que lhe fossem solicitados. Estes não podiam sair da Biblioteca, mas era autorizada a sua cópia ou a tomada de apontamentos, no sentido de se proceder a uma boa fiscalização (Cf. Regulamento: Artigos $48 .^{\circ}$ e $49 .^{\circ}$; 1882). 
Isto mostra que não era in tenção dos membros fundadores da Sociedade Martins Sarmento sonegar qualquer tipo de informação.

Podemos concluir que este Regulamento que cria a primeira Biblioteca Pública em Guimarães é o resultado dum longo e arrastado processo. Surge, também, com o objectivo de lutar, por todos os meios legais ao alcance, pelo desenvolvimento da instrução popular na cidade e no concelho de Guimarães. Tal facto deve-se a que os seus mentores, homens cultos, letrados e dedicados, tinham a percepção que a cidade e o país deveriam acompanhar o processo evolutivo do estrangeiro.

Na Alemanha é decretada a organização da Biblioteca em Wurtemberg em 6 de Dezembro de 1791. Entre nós, tal só acontece em 2 de Agosto de 1870 e o seu Regulamento só é promulgado em 20 de Janeiro de 1871.

Em 1870 nos Estados Unidos verificava-se a existência de 164815 Bibliotecas, com 45629938 volumes, pertencendo às igrejas e escolas dominicais 38 058, com 9981068 volumes.

A Itália não despreza este elemento de instrução, e possuí 687 Bibliotecas com 51055176 volumes, um pouco mais que a França, cujo número de volumes atinge nas suas Bibliotecas 4389 000. Estes elementos são-nos indicados pelo Relatório do Serviço e Movimento da Biblioteca de 1882/ 1883.

Sendo assim, com estas considerações tomadas em linha de conta, a Sociedade Martins Sarmento, consciente da necessidade duma Biblioteca numa cidade que, na época, tinha cerca de 12000 habitantes, e onde os diferentes ramos de indústria tinham prosperado, ofereceu a sua cooperação e os seus serviços gratuitos à edilidade Vimaranense, para que se organizasse uma Biblioteca sem grandes encargos camarários. Isto verificou-se "ainda que houvesse quem pudesse duvidar que o estabelecimento de Bibliotecas populares, bem providas de livros úteis, é um dos meios mais eficazes para democratizar a ciência, o infiltrar no espírito do povo a instrução correspondente ao alargamento da sua esfera de direitos" (Cf. Relatório do Serviço e Movimento da Biblioteca: 1882/ 1883). 


\section{SIMÃO JOSÉ DA LUZ SORIANO \\ E O LIBERALISMO MODERADO (1858-1860)}

Júlio Rodrigues da Silva
CHC - UNL

Simão José da Luz Soriano (1802-1891) é universalmente conhecido pelos seus livros de história, referentes à guerra civil entre liberais e miguelistas de 1828-1834 e à instalação do regime liberal no Portugal de oitocentos. Na viragem da década de 50 para a de 60 do século XIX produziu um conjunto de reflexões sobre o sistema constitucional, num momento especialmente marcante da sua vida: a passagem da acção política do passado para a actividade de escritor público do presente.

\section{Memória histórica e ideário político}

A análise crítica da sua evolução política na primeira e segunda metade do século XIX está expressa em dois livros: Utopias desmascaradas do systema liberal em Portugal ou epítome do que entre nós tem sido este sistema (1858) e Revelações da minha vida, e memórias de alguns factos e homens meus contemporâneos (1860). Estes textos antecedem a produção da sua obra monumental referente à História da guerra civil e do estabelecimento do governo parlamentar em Portugal, compreendendo a história diplomática, militar e política deste reino de 1777 até 1834 (1866-1890) e a História do reinado de D. José e da administração do Marquês de Pombal (1867)1. Os dois trabalhos, referidos produzidos no final da década de 50 e princípios da seguinte, situam-se cronologicamente num período intermédio da produção historiográfica e ideológica do autor. Os anos 40 de oitocentos tinham já sido

\footnotetext{
No resto do texto e para não estarmos sistematicamente a repetir o título completo das duas obras utilizaremos para a primeira apenas a palavra Utopias e para a segunda só Revelações: Soriano, Simão José da Luz, Utopias desmascaradas do sistema liberal em Portugal ou epítome do que entre nós tem sido este sistema, Lisboa, Imprensa União Tipográfica, 1858 e Soriano, Simão José da Luz, Revelações da minha vida, e memórias de alguns factos e homens meus contemporâneos, Lisboa, Tipografia Universal, 1860. Ver para os textos posteriores: Soriano, Simão José da Luz, História da guerra civil e do estabelecimento do governo parlamentar em Portugal compreendendo a história diplomática, militar e política deste reino de 1777 até 1834, Lisboa, Imprensa Nacional, 1866-1890 e a História do reinado de D. José e da administração do Marquês de Pombal, Lisboa, Tipografia Universal, 1867.
} 
assinalados por forte actividade no campo da história com a História do cerco do Porto, precedida de uma extensa notícia sobre as diferentes fases políticas da monarquia, desde os mais remotos tempos até ao ano de 1820, e desde este mesmo ano até ao começo do sobredito cerco (1846-1849). Neste trabalho, a análise histórica e o ideário liberal do escritor entrelaçam-se constantemente permitindo seguir a evolução do seu pensamento no final do cabralismo. De igual modo a biografia do marquês de Sá da Bandeira, de 1887, permite a leitura desse ideário senão mesmo da sua ideologia no período final da sua vida ${ }^{2}$. Assim sendo, não é fácil nem praticável introduzir uma absoluta cesura entre as investigações históricas e as reflexões políticas sem impossibilitar a sua mútua compreensão. As duas obras atrás referidas publicadas respectivamente em 1858 e 1860, permitem compreender claramente a sua transformação doutrinal desde as origens republicanas à adesão crítica à monarquia constitucional. Traduzem a profunda desilusão com o sistema liberal pelo qual arriscara tudo na sua juventude e pelo qual quer continuar a bater-se no tempo presente. Todavia, o liberalismo ideal, sonhado na emigração e no cerco do Porto, não se compadece com as duras realidades da vida política do constitucionalismo triunfante após 1834. Nesta perspectiva é um Simão José da Luz Soriano, profundamente ferido e desiludido com os homens do seu tempo, que resolve operar a revisão extremamente crítica das promessas liberais do passado. No entanto, o trabalho de luto pelo "paraíso perdido" não exclui o forte empenho pessoal e emocional que o leva a introduzir referências aos seus problemas pessoais. Estão neste caso os confrontos com os adversários políticos no Ministério da Marinha e Ultramar e do final dos anos 50 e início da década seguinte do século XIX lusitano. Repensa simultaneamente o itinerário da sua vida e a evolução do regime representativo quando se aproxima dos 60 anos de idade. Tempo de fazer um balanço provisório do caminho percorrido numa fase decisiva da vida que se prolongou ainda por três décadas. Podemos, assim, considerar os dois livros como elementos essenciais da sua concepção da política, numa fase intermédia da produção doutrinária, antes da grande

\footnotetext{
Soriano, Simão José da Luz, História do cerco do Porto, precedida de uma extensa notícia sobre as diferentes fases políticas da monarquia, desde os mais remotos tempos até ao ano de 1820, e desde este mesmo ano até ao começo do sobredito cerco, Lisboa, Imprensa Nacional, 1846-1849 e Soriano, Simão José da Luz, Vida do marquês de Sá da Bandeira e reminiscência de alguns sucessos mais notáveis que durante ela tiveram lugar em Portugal, Lisboa, Tipografia da Viuva Sousa Neves, 1887-1888. Sobre as abordagens especificamente historiográficas da obra de Simão José da Luz Soriano consultar as seguintes obras: Serrão, Joaquim Veríssimo, História Breve da Historiografia Portuguesa, Lisboa, Editorial Verbo, 1962, p. 259, Matos, Sérgio Campos, Historiografia e Memória Nacional (1846-1898), Lisboa, Edições Colibri, 1998, p. 24-123 e p. 473-498 e Catroga, Fernando, «Positivistas e republicanos», Torgal, Luís Reis, Mendes, Amado, José Maria e Catroga, Fernando, História da História de Portugal, sécs. XIX-XX, Lisboa, Círculo de Leitores e Autores, 1996, p. 87-115.
} 
obra histórica de meados de 60 de oitocentos; e apercebermo-nos do esforço teórico para tentar transformar a sua desilusão e ressentimento com o liberalismo triunfante dos partidos do seu tempo numa análise do sistema representativo do Portugal da segunda metade do século XIX. Eleva-se para além da materialidade imediata do realismo político que aceita os factos tal como se lhe apresentam e opta por uma visão do mundo que é ou pretende ser essencial e primordialmente ética. A denúncia dos erros e das distorsões do liberalismo dão corpo a uma nova demanda em nome de um hipotético graal da verdade pura e absoluta que é, simultaneamente condição sine qua non de nova cruzada em prol da salvação pública nacional. A vida do autor ganha novo sentido com a recuperação do significado mais profundo e original do liberalismo rebelde e revolucionário da juventude. Não para o brandir simplesmente como arma de arremesso contra a Regeneração, mas para o obrigar a reformar-se sob o impulso do reavivar das recordações e das promessas do passado. Neste contexto, escrevendo para atacar a situação política dos anos de 1858-1860 em nome da classe média, aproveita para fazer uma crítica mais global ao regime e antecipa, em alguns aspectos, a vaga de fundo que a partir de 1867-1868 conduzirá à Janeirinha e à crise política do sistema liberal!

A memória pessoal e o esforço de investigação histórica misturam-se com a defesa do liberalismo moderado de forma permanente na sua obra, mas especialmente nos dois livros referidos de 1858 e 1860 que podem ser analisados conjuntamente pois existe óbvia ligação entre eles salientada ao descrever a utilização de muitos elementos do primeiro trabalho na redacção do segundo ${ }^{3}$. Aliás, a sua justificação pessoal face à opinião pública do tempo é comum aos dois trabalhos. Contudo, os dois opúsculos têm características próprias que importa referir, pois traduzem preocupações diferentes em momentos diversos da sua vida. As Utopias nascem como uma introdução sobre os vícios do sistema liberal em Portugal, que deveria preceder um estudo sobre os últimos vinte anos do reinado de D. Maria II. A relativa extensão destas obras levaram-no a separá-las e a adiar a publicação da parte histórica que provavelmente desejaria reformular e alargar. $\mathrm{O}$ desejo de contribuir para a reforma do sistema liberal explica a urgência de publicar primeiro este texto e só posteriormente o segundo ${ }^{4}$. Mas, o verdadeiro objectivo é explicar a evolução do radi-

${ }^{3}$ Cf. Soriano, Simão José da Luz, Relações da minha vida e memórias de alguns factos, e homens meus contemporaneos, Lisboa, Tipografia Universal, 1860, p.722-723.

${ }^{4}$ Simão José da Luz Soriano utiliza uma linguagem que vai buscar ao seu bacharelato de medicina e provavelmente é influenciado já por uma certa sensibilidade realista-naturalista de cariz próximo do positivismo. Ver também, Reis, Carlos (dir.), O Realismo e o Naturalismo, História da Literatura Portuguesa, Lisboa, Publicações Alfa, 2001, vol. 5, p. 11-40. Consultar: Soriano, Simão José da Luz, Utopias desmascaradas do systema liberal em Portugal ou epítome do que entre nós tem sido este systema, Lisboa, Imprensa União Tipográfica, 1858, 
calismo vintista e tendencialmente republicano da juventude para o constitucionalismo monárquico da maturidade. Situa esta análise no confronto entre a teoria e a prática do regime liberal demonstrando a caducidade dos seus ideais do passado perante as duras realidades do presente. Não desiste totalmente das concepções de outrora porque, através da separação entre teoria e prática, fica fiel aos seus princípios embora reconheça a impossibilidade de os realizar. Apesar deste cepticismo o seu esforço tem uma utilidade pedagógica ao remeter para o esclarecimento da opinião pública sobre os defeitos do regime liberal como primeiro passo para os remediar ${ }^{5}$. No segundo texto, as perspectivas pessoais têm um peso maior pois a justificação das transformações operadas nas suas convicções assume um carácter especificamente autobiográfico e confessional. Aqui identifica-se com o Jean-Jacques Rousseau das Confessions comparando ironicamente o seu destino individual ao do escritor francês - tão ao gosto da leitura romântica daquele teórico feita pelo liberalismo de oitocentos - assumindo o tom intimista do escritor nas suas memórias e simultaneamente a autenticidade e honestidade total na descrição do passado. Este torna-se o modelo para a sua vida quer no plano literário quer no plano polí$t_{i c 0^{6}}$. A dupla identificação tem outra razão de ser que o autor não se inibe de explicitar e que se prende directamente com a publicação deste trabalho: existem três "causas" que o levam a escrevê-lo - a primeira é a franqueza rousseauniana com a qual procura contar a sua vida sem precisar dos elogios de outrem e a terceira o desejo de demonstrar que não deveu a sua fortuna pessoal e posição social à amizade ou favor do marquês de Sá da Bandeira. A mais importante é a segunda que traduz também o desejo de responder às acusações pouco prestigiantes sobre as suas origens sociais. Não enjeita, antes orgulhosamente reconhece, o meio humilde do qual proveio - a passagem pela Casa Pia de Lisboa ${ }^{7}$ ! Trata-se de demonstrar a honestidade e o mérito pessoal que através dum autêntico cursus honoris lhe permitiu elevar-se do proletariado à burguesia. Ao contrário de muitos dos seus contemporâneos nunca ascen-

p. IV. A mesma perspectiva assume um tom ainda mais marcadamente positivista no segundo texto: Soriano, Simão José da Luz, Relações da minha vida e memórias de alguns factos, $e$ homens meus contemporaneos, Lisboa, Tipografia Universal, 1860, p.45-47.

Cf. Soriano, Simão José da Luz, Utopias desmascaradas do systema liberal em Portugal ou epítome do que entre nós tem sido este systema, Lisboa, Imprensa União Tipográfica, 1858, p. IV.

${ }^{6}$ Cf. Soriano, Simão José da Luz, Relações da minha vida e memórias de alguns factos, e homens meus contemporaneos, Lisboa, Tipografia Universal, 1860, p.14. Ver também: Roussel, Jean, Jean-Jacques Rousseau en France après la Révolution 1795-1830. Lectures et Légend, Paris, Librairie Armand Colin, 1972, p.62-208 e p.523-558, Delon, Michel, Mauzi, Robert, Menant, Sylvain «De 1' Encyclopédie aux Méditations», (dir.) Pichois Claude, Littérature Française, t.6, Paris, Éditions Arthaud, 1984, p.320-345 e ainda Cottret, Monique et Bernard, Jean-Jacques Rousseau en son temps, Paris, Perrin, 2005, p.475-610.

Cf. Soriano, Simão José da Luz, ob. cit., p.2. 
deu à aristocracia preferindo viver numa autêntica aurea mediocritas dos proventos adquiridos com o trabalho, as capacidades e o esforço individual. A obsessão com o nascimento deriva essencialmente da campanha desencadeada pelo seu rival no Ministério da Marinha e Ultramar, o oficial maior António Pedro de Carvalho, que procurou obter informações na Casa Pia para servirem de base a um folheto destinado a difamá-1o ${ }^{8}$.

Existiam ainda outras questões de ordem pessoal que o levaram a escrever as suas Revelações e que se relacionavam com as tensões dentro do campo da historiografia nacional. Alexandre Herculano é um dos visados deste opúsculo, como refere expressamente atribuindo-lhe com amargura a autoria de um folheto anónimo de Dezembro de 1858 sobre a educação popular. Considera que as críticas neste texto aos trânsfugas do campo liberal lhe são especialmente dirigidas dada a proximidade com a data de publicação das Utopias em Novembro de 1858. Não é totalmente claro se este ataque lhe é ou não dirigido, pois Alexandre Herculano está em fase de radicalização política em torno dos temas relacionados com o Padroado Português do Oriente (1857) e a Questão das Irmãs da Caridade (1858). O acentuado pendor anticlerical do seu pensamento, neste período traduz, a ruptura com o universo do liberalismo moderado no qual se situa ${ }^{9}$. O autor tem aparentemente razões pessoais de agravo pois considera que Alexandre Herculano o tratou com desprezo numa roda de amigos. Rivalidades e intrigas entre historiadores nos círculos intelectuais lisboetas dos anos 50 e 60 do século XIX explicam este azedume e esta fixação do seu ressentimento naquele escritor. No entanto, o mais grave são as acusações de ter abandonado o liberalismo e ter-se passado para as fileiras dos defensores do absolutismo. A resposta implica da sua parte uma réplica na qual compara o seu impecável historial de militante e combatente liberal desde o vintismo com as posições mais dúbias de Alexandre Herculano que acusa de ter sido miguelista e de sistematicamente mudar de partido ao sabor das circunstâncias. Os ataques mais ferozes centram-se nas posições anticlericais do historiador nas quais vê uma contradição indelével com as afirmações anteriormente proferidas nos anos 40 do século XIX nas cortes ${ }^{10}$. A justificação das

${ }^{8}$ Cf. Soriano, Simão José da Luz, ob. cit., p. 3 e p. 615-616.

${ }^{9}$ Cf. Soriano, Simão José da Luz, ob. cit., p. 723-724. A obra citada de Herculano, A. intitula-se: Ao Partido Liberal Português a Associação Popular Promotora da Educação do Sexo Feminino, Lisboa, Imprensa União Typographica, 1858. Ver sobre esta questão Macedo, Jorge Borges de, "Introdução", Herculano, Herculano, História da Origem e Estabelecimento da Inquisição em Portugal, Obras Completas, Lisboa, Livraria Bertrand, 1979, Vol. I, p. LXXVI-LXXVIII e p.XCV-XCVII.

${ }^{10}$ Cf. Soriano, Simão José da Luz , ob. cit., p. 728-730. Consultar sobre a juventude de Alexandre Herculano: Nemésio, Vitorino, A Mocidade de Herculano (1810-1832), Amadora, Livraria Bertrand, 1979, p. 9-93. 
suas posições políticas são assim um elemento central quer das Utopias quer das Revelações e conduzem directamente às teorizações sobre os regimes políticos, assentes na recusa do despotismo e da demagogia.

\section{A rejeição dos extremos: despotismo e demagogia}

A dupla rejeição dos extremos do espectro político é uma preocupação maior do seu pensamento nos finais da década de 50 e inícios da seguinte do século XIX. O receio de ser confundido com um defensor do regresso a um passado legitimista, levam-no imediato, a realizar uma reflexão sobre a natureza do governo despótico que identifica com o absolutismo ${ }^{11}$. Embora não afaste totalmente um certo fascínio pela visão ideal do monarca absoluto, o autor demarca-se deste tipo de regime condenando-o por ser um tipo de governo arbitrário, onde domina o privilégio e a opressão. A honrosa excepção neste panorama será o despotismo iluminado que identifica com o reinado de $\mathrm{D}$. José I mas sobretudo com a acção de um homem excepcional: o marquês de Pombal. Contudo, a actividade exemplar deste ministro é interrompida pela sua morte o que demonstra a impossibilidade de confiar no acaso para prover o país de uma política consequente de desenvolvimento. A vertente patriótica do despotismo/absolutismo não se encontra na sua perspectiva senão ocasionalmente apontando em sentido contrário alguns exemplos da história de Portugal: os reinados de D. Afonso VI, D. João VI e de D. Miguel. Compreende-se que nos dois textos apareçam referências positivas ao funcionamento do despotismo iluminado, em contraposição à actuação dos ministros liberais. As afirmações feitas, neste sentido, visavam sobretudo salientar os defeitos de funcionamento das instituições do regime representativo e não tanto defender o antigo regime absoluto, mesmo na sua vertente reformista e iluminada. No entanto, o despotismo/absolutismo é sempre um receituário garantido para o desastre no que diz respeito à prosperidade pública. As razões são na sua opinião essencialmente três: o monopólio do poder, a inexistência da liberdade de expressão e a falta de crédito. As duas primeiras pela sua simples existência são o entrave à actividade pública em geral e económica em particular. O mais grave é a falta de crédito dos governos despóticos - elemento central da moderna prosperidade dos estados pela necessidade evidente de capitais em todos

$"$ Cf. Soriano, Simão José da Luz, ob. cit., p. 724-725. A sua posterior definição como precursor das ideologias contra-revolucionárias do século XX é sem dúvida abusiva e de certa maneira anacrónica. É o caso do livro de Campos, Fernando, No saguão do Liberalismo, Lisboa, Edição de José Fernandes Júnior, 1935, p. 43-56. 
os empreendimentos. O crédito não pode ser alcançado num regime onde a segurança e a liberdade não estão devidamente asseguradas face ao governo ${ }^{12}$.

A segurança e a liberdade formam juntamente com a propriedade o clássico trinómio de princípios que presidem ao pensamento político liberal. Não refere, expressamente neste ponto, a propriedade porque está subjacente à questão do crédito, pois sem a garantia de posse dos bens individuais não existe obviamente confiança para investir. Ao longo dos dois textos a importância central dada à protecção e salvaguarda da propriedade implica obrigatoriamente a segurança e a liberdade individuais. Os pensadores europeus do século XIX quer da linha utilitarista inglesa quer da orientação doutrinária e/ou individualista francesa identificam-se com a tradição liberal que tem como expoentes máximos John Locke, Charles Montesquieu e a Fisiocracia francesa. A preocupação essencial desta corrente consiste em criar uma esfera inviolável em torno de cada indivíduo capaz de o proteger dos abusos do governo e por extensão do estado. A importância concedida a esta temática resulta igualmente da importância concedida pelo escritor português aos temas económicos e financeiros na sua relação imediata com a ideia de um estado mínimo. Inspirando-se sobretudo em Adam Smith e em menor grau em Jean Baptiste Say acentua a vertente livre-cambista do seu pensamento e opõe-se ao intervencionismo governamental na esfera económica ${ }^{13}$. As concepções assim delineadas pelo autor acerca do despotismo não se afastam da visão clássica do liberalismo do século XVIII, nomeadamente de autores como Charles Montesquieu que por sua vez se inspiram em vários pensadores dos quais o primeiro, será sem dúvida Aristóteles. Igualmente os seus herdeiros intelectuais do século XIX, como Benjamin Constant, Germaine Stäel e de forma diferente Pierre-Paul Royer Collard e François Guizot, compartilham boa parte destas ideias sobre o despotismo. Todavia, detecta-se no pensamento do autor uma evolução, nesta questão específica, aproximando-se de pensadores mais modernos como John Stuart Mill e Alexis de Tocqueville. Não podemos estabelecer uma relação directa com estes escritores, pois não são referidos como fontes por Simão José da Luz Soriano, ao contrário de autores como Charles Montesquieu ou Jean-Jacques Rousseau. A diferenciação que realiza

${ }_{12}$ Cf. Soriano, Simão José da Luz, Utopias desmascaradas do systema liberal em Portugal ou epítome do que entre nós tem sido este systema, Lisboa, Imprensa União Tipográfica, 1858, p. VI, p. 2-5, p. 41 e p. 96 . Consultar também: Soriano, Simão José da Luz, Revelações da minha vida e memórias de alguns factos, e homens meus contemporaneos, Lisboa, Tipografia Universal, 1860 , p. 639 e p. 731-733.

${ }^{13}$ Cf. Burdeau, Georges, O Liberalismo, Lisboa, Publicações Europa-América, s/d, p. 37-78. Sobre a importância para o autor de Adam Smith e Jean-Baptiste Say consultar: Soriano, Simão José da Luz, Utopias desmascaradas do systema liberal em Portugal ou epítome do que entre nós tem sido este systema, Lisboa, Imprensa União Tipográfica, 1858, p. 78-92. 
entre o governo despótico e o regime constitucional assenta igualmente no papel autónomo do indivíduo na dinamização da economia e do progresso na sua dupla vertente material e espiritual no segundo regime e a sua ausência no primeiro. A ideia não é totalmente nova pois podemos faze-la remontar a uma longa tradição no pensamento político europeu sendo a base das teorizações sobre um despotismo oriental na qual se inserem autores como Charles Montesquieu. Contudo, sofreu uma profunda transformação com John Stuart Mill no seu livro sobre a liberdade, publicado em 1859 e, de certa maneira, com Alexis de Tocqueville na Democracia na América de 1835-1840 e no Antigo Regime e a Revolução de 1856. Com efeito, estabelece-se na prática uma oposição entre o progresso nos governos livres, derivado da actividade empreendedora dos indivíduos e a estagnação resultante da acção inibidora do poder no governo despótico. Os cidadãos activos dominam nos regimes representativos dinamizando as respectivas sociedades mas, estão totalmente ausentes nos governos despóticos, onde predominam os cidadãos puramente passivos e a rotina é soberana ${ }^{14}$.

Assim sendo, encontramo-nos na fronteira do processo de transformação das ideias políticas do antigo liberalismo, nomeadamente no referente ao despotismo. Seja como for, o autor não leva muito a sério o perigo do despotismo que considera um regime arcaico, pertencente ao passado, ainda que, contraditoriamente, por vezes acene com a possibilidade do seu regresso sob a forma de um cesarismo napoleónico. Considera o despotismo um mal mas, menor face ao perigo representado pelo governo demagógico. A definição deste tipo de regime político é dada através da descrição das componentes sociais e do modo de funcionamento das suas instituições políticas, que incluem os elementos marginais da sociedade, juntamente com os oportunistas de todas as origens. O resultado prático é sempre o mesmo: as ambições pessoais e as paixões populares acicatadas por promessas irresponsáveis dos dirigentes conduzem à imoralidade, desordem e desconfiança generalizadas ${ }^{15}$ ! A dema-

${ }^{14}$ Cf. Simão José da Luz Soriano, ob. cit., p. 4-5. Ver Mill, John Stuart, Sobre a Liberdade, Lisboa, Publicações Europa-América, 1997, p. 72-76 e Tocqueville, Alexis, Democracia na América, Lisboa, Editorial Estudios Cor, 1972, p.431-436. Estas temáticas são também desenvolvidas no sentido de uma tendência crescente para uma igualização geral da sociedade e da emergência da tirania da opinião pública nas obras posteriores de Tocqueville, Alexis, O Antigo Regime e a Revolução, (1856) Lisboa, Editorial Fragmentos, 1989, p.13-15, p. 141-188, p. 190-191 e de Mill, John Stuart, O Governo Representativo (1864), Viseu, Editora Arcádia Limitada, 1969, p. 59-87 e p. 161-197. Sobre a importância para o autor de Charles Montesquieu ver: Soriano, Simão José da Luz, Revelações da minha vida e memórias de alguns factos, e homens meus contemporaneos, Lisboa, Tipografia Universal, 1860, p. 656-657.

is A questão da demagogia e do governo demagógico inspira-se claramente nos autores da Antiguidade Clássica principalmente em Aristóteles, Platão e de certo modo em Políbio. Ver a este propósito: Aristóteles, Tratado da Política, Mem-Martins, Publicações Europa-América, 
gogia é assim comparada à acção dos radicais que arrastam atrás de si o povo na base de falsas promessas e/ou ilusões irrealizáveis na prática, assentes em sistemas teóricos totalmente desligados da realidade. Os governos demagógicos materializam o domínio do estado pelas camadas populares por via da actuação populista de políticos sem escrúpulos e da corrupção do povo. $\mathrm{O}$ receio deste "despotismo das últimas classes", cuja inspiração pode encontrar-se também em Charles Montesquieu mas de certa maneira em autores antigos como Aristóteles, torna-se assim em tema central para o autor. Os sucessivos exemplos históricos permitem-lhe responsabilizar "a preponderância do baixo povo" pela "corrupção dos costumes, e a perversão das instituições republicanas. A História assume aqui o papel de instrumento essencial na descoberta da verdade e da investigação rigorosa no campo da política. A genealogia deste fenómeno político obriga-o a recuar no tempo até à Antiguidade Clássica, ou seja, o mundo da cidade-estado grega e da república romana ${ }^{16}$.

Significamente Aristóteles e Platão são os pontos de partida e de chegada do inventário da decadência dos governos republicanos produzido pelo predomínio das classes populares associado ao triunfo da corrupção. No primeiro caso, trata-se de utilizar o exemplo da transformação de Esparta de aristocracia em democracia seguindo as observações de Aristóteles sobre este tema. No segundo exemplo, cita-se um excerto do oitavo livro da República de Platão para condenar os governos populares e predizer a sua inevitável degeneração em tirania: recuperação da concepção circular do tempo e dos regimes políticos de Platão, entremeada com a teoria dos governos de Aristóteles e a defesa implícita do governo misto ou moderado ${ }^{17}$. Seja como for, a análise da história de Atenas, de Cartago e de Roma traduz sempre a identificação entre governos demagógicos e governos populares. A república antiga de cariz essencialmente misto e tendencialmente aristocrática ou oligárquica, cai sempre vítima das "doutrinas populares" que traduzem simultaneamente o triunfo da demagogia e da democracia. Daqui em diante instala-se a anarquia, o "des-

1977, p.148-174; Platão, Diálogos I - A República, 3. edição, Mem-Martins, Publicações Europa-América, 1987, p.306-325; Políbio, «Histórias», Câmara, João Bettencourt, Noites de San Casciano. Sobre a Melhor Forma do Governo, Lisboa, Vega e João Bettencourt da Câmrara, 1997, p.97-108. Sobre a questão da demagogia consultar também: Finley, M. I., Democracia Antiga e Moderna, Rio de Janeiro, Edições Graal Ldta., 1988, p.55-90.

${ }^{16} \mathrm{Cf}$. Soriano, Simão José da Luz, Utopias desmascaradas do systema liberal em Portugal ou epítome do que entre nós tem sido este systema, Lisboa, Imprensa União Tipográfica, 1858, p. 7-8. Sobre a concepção do povo nos pensadores dos séculos XVIII e XIX consultar: Dupuy, Roger, La politique du peuple XVIIIe-XXe siècle. Racines, permanences et ambiguïtés du populisme, Paris, Éditions Albin Michel S. A, 2002, p. 7-28 e também Geremek, Bronislaw, A Piedade e a Forca. História da Miséria e da Caridade na Europa, Lisboa, Terramar Editores, Distribuidores, Livreiros, Lda., 1995, p. 267-291.

17 Soriano, Simão José da Luz, ob. cit., p. 8-9-11. Ver Aristóteles, ob. cit., p. 150-151 e p. $212-$ -220 e Platão, ob. cit., p. 284-316. 
potismo das turbas", ou seja, o domínio das multidões nas ruas e o clima de guerra civil generalizado que conduz directa ou indirectamente ao "despotismo da realeza" e ao triunfo dos tiranos e de homens como Júlio César. Nesta perspectiva os seus heróis são os aristocratas ou membros do "partido moderado" que se opõem a este processo de degenerescência populista das repúbli$\operatorname{cas}^{18}$. Nestas observações aparecem muitas referências aos governos políticos que se aproximam das concepções de Charles Montesquieu no L'Esprit des Lois, sobretudo na oposição entre república aristocrática e república democrática e na concepção do despotismo. As influências teóricas de autores clássicos como Platão, Aristóteles e, eventualmente, Cícero ou Salústio têm de ser entendidas por meio de leituras de autores mais modernos dos séculos XVIII e XIX. A compreensão desta questão obriga a interrogarmo-nos sobre a sua concepção da soberania popular tão cara a Jean-Jacques Rousseau e tão essencial para entendermos a imagem que constrói da democracia nos tempos modernos. Assim podemos referir o seu distanciamento face às concepções políticas daquele autor, consideradas totalmente irrealistas ${ }^{19}$. A sua oposição à soberania popular não implicava necessariamente a oposição à soberania do povo, passível de existir de forma parcial ou limitada num regime republicano, aristocrático ou misto à maneira de Charles Montesquieu e de autores posteriores como Benjamin Constant. As repúblicas antigas, nomeadamente Roma, tinham tido instituições deste tipo que encarnavam a "autoridade do povo".

A rejeição deste conceito político está estreitamente ligado com a leitura que realiza da história moderna também ela caracterizada principalmente pela importância das "exaltações demagógicas" na subversão dos regimes políticos. A Revolução francesa de 1789 tem um papel de relevo neste processo como elemento fundador da época contemporânea ao induzir uma ruptura profunda com as instituições das antigas monarquias. A natureza do processo revolucionário gaulês é caracterizada por uma sequência de desordens e assassínios presente nos estados gerais, na assembleia constituinte e na assembleia

${ }^{18}$ Cf. Soriano, Simão José da Luz, ob. cit., p. 9-11 e também Soriano, Simão José da Luz, Revelações da minha vida e memórias de alguns factos, e homens meus contemporaneos, Lisboa, Tipografia Universal, 1860, p. 589, p.592, p. 618 e p. 714 . Não é possível identificar claramente as obras nas quais se baseia o autor para reflectir sobre a história antiga nomeadamente de Roma, embora seja provável que inclua escritores antigos como Aristóteles, Platão, Políbio, Cícero, Salústio e modernos como Charles Montesquieu, Edward Gibbon, François Guizot, Barthold Georg Niebuhr. É possível igualmente o recurso a obras de divulgação de autores portugueses do seu tempo.

19 Cf. Soriano, Simão José da Luz, ob. cit., p. 45-46. Consultar sobre esta questão Derathé, Robert, "Les Philosophes et le Despotisme", Francastel, P. (ed.), Utopie et Institutions au XVIIIe siècle: Le Pragmatisme des Lumières, Paris, Mouton, 1963, p. 57-75 e também Bobbio, Norberto, «Despotismo», Bobbio, N., Matteucci, N. e Pasquino, G., Dicionário Político, 5. a ed., Brasília/São Paulo, Editora Universidade de Brasília/Imprensa Oficial do Estado, 2000, vol. 1, p. 339-347. 
legislativa. O resultado final da acção da demagogia foram as lamentáveis cenas que expuseram Luís XVI à irrisão da "populaça desenfreada". A populaça e não o povo propriamente dito foram os responsáveis pelo assalto às Tulherias a 10 de Agosto de 1792 e pela execução do rei. Os massacres de Setembro desse mesmo ano e o terror da época da convenção nacional são igualmente da responsabilidade da democracia. Esta é simultaneamente identificada à soberania da nação, enquanto conceito político, e à demagogia, como forma de agir dos políticos radicais denominados: democratas, demagogos e carbonários. A visão que domina a revolução de 1789 é a imagem tradicionalista característica de pensadores contra-revolucionários como o abade Barruel, Joseph de Maistre ou Louis Bonald mas algumas vezes parcialmente partilhada pelos historiadores liberais do século XIX: a conspiração das sociedades secretas! A acção subversiva dos oradores ou tribunos radicais como os montagnards levou o povo à revolta e à anarquia. $\mathrm{O}$ processo revolucionário só terminou com o aparecimento do Primeiro Império francês (1804-1815) que na sua opinião substituiu o "despotismo das turbas" pelo "despotismo civilizador" de Napoleão, preferível sem dúvida ao primeiro. A análise do processo revolucionário não termina aqui pois o autor refere-se a desenvolvimentos semelhantes no período da Restauração (1814-1830) e da Monarquia de Julho (1830-1848) em França através do Livre des Orateurs (1836) do visconde de Cormerin (1788-1868). Algo semelhante ocorre na Espanha desde $1835 \mathrm{com}$ as sucessivas revoluções provocadas pelo partido democrata. $\mathrm{O}$ mais grave acontece na antiga América espanhola onde a demagogia provocou a regressão material e intelectual dos seus habitantes e o triunfo da barbárie provocada pelas constantes guerras civis ${ }^{20}$.

\section{Ultraliberalismo e anti-parlamentarismo}

A identificação negativa da democracia com a demagogia, a soberania popular e o sufrágio universal também se aplica às reflexões sobre a história

${ }^{20}$ Cf. Soriano, Simão José da Luz, Utopias desmascaradas do systema liberal em Portugal ou epítome do que entre nós tem sido este systema, Lisboa, Imprensa União Tipográfica, 1858, p. 11-12. O autor referido é escolhido devido ao seu passado político que o torna uma testemunha insuspeita da evolução histórica a França. Com efeito, o Visconde de Cormerin serviu o Primeiro Império, a Restauração, a Monarquia de Julho mas destacou-se como membro moderado da Segunda República francesa. Não é possível identificar as fontes específicas das suas análises sobre a Revolução Francesa de 1789 embora se aproxime das leituras mais correntes na época dos historiadores liberais e doutrinários na época. Ver sobre esta questão: Furet, François, La gauche et la révolution au milieu du XIXe siècle. Edgar Quinet et la question du Jacobinisme 1865-1870, p. 11-72 e também Winock, Michel, Les Voix de La Liberté. Les écrivains engagés au XIXe siècle, Paris, éditions du Seuil, 2001, p. 314-476. 
do regime representativo em Portugal. A democracia é responsabilizada por todos os desvarios do constitucionalismo no período que se estende de 1834 até aos inícios da década de 60 de oitocentos. A sublevação ou revolução civil e militar - cuja principal figura é Saldanha - a anarquia, o desgoverno político e financeiro, a ameaça de deposição da rainha e a as alianças com o miguelismo, são tudo pecados do radicalismo fratricida: o "ultraliberalismo". É neste quadrante político que se encontra a verdadeira reacção e não no miguelismo que não passa de uma ameaça fantasma. O receio do regresso do absolutismo é considerado uma falácia da esquerda liberal que tem como objectivo assustar os incautos. O perigo real vem da subversão do regime constitucional pois, o defeituoso funcionamento das instituições, pode dar origem a um novo despotismo de natureza militar. A experiência oitocentista do "caudilhismo" espanhol e do bonapartismo francês não augura nada de bom para o futuro do sistema representativo $^{21}$. Os pecados do "ultraliberalismo" projectam-se no conjunto do sistema, conduzindo a uma constante instabilidade política e pervertendo o normal funcionamento das instituições da Carta de 1826. Assim é impossível produzir elites governantes capazes de gerir honesta e eficazmente o estado ${ }^{22}$. Todavia, as suas críticas tem também origem no trabalho atribuído a João de Azevedo Sá Coutinho (1811-1854), intitulado Autopsia dos Partidos Políticos e Guarda-Quedas dos Governos: ou Ensaio Sobre as Continuas Revoluções de Portugal e na respectiva enumeração dos principais defeitos que afectam os governos representativos em Portugal $^{23}$. O seu autor foi sucessivamente miguelista, cartista, cabralista, patuleia e anti-regenerador, representando o liberalismo moderado com o qual Simão José da Luz Soriano se identifica desde o final da década de 40 de oitocentos. Aliás, nas Revelações refere diversas abordagens dos liberais moderados da Regeneração da área cabralista, como o marquês de Valada nas eleições de 1859. A aversão aos regeneradores e aos históricos e ao fontismo em geral explica a convergência ideológica com os cabralistas ${ }^{24}$. Seja como for,

${ }^{21}$ Cf. Soriano, Simão José da Luz, Utopias desmascaradas do systema liberal em Portugal ou epítome do que entre nós tem sido este systema, Lisboa, Imprensa União Tipográfica, 1858, p. 11-15 e p. 47-48. Ver também: Soriano, Simão José da Luz, Revelações da minha vida e memórias de alguns factos, e homens meus contemporaneos, Lisboa, Tipografia Universal, 1860 , p. $572-624$, p. 731 , p. $742-750$ e p. $757-762$.

${ }^{22}$ Cf. Soriano, Simão José da Luz, Utopias desmascaradas do systema liberal em Portugal ou epítome do que entre nós tem sido este systema, Lisboa, Imprensa União Tipográfica, 1858, p. 16-17.

${ }^{23}$ Cf. Anónimo (Coutinho, João de Azevedo Sá), Autopsia dos Partidos Políticos e GuardaQuedas dos Governos: Ou Ensaio Sobre as Continuas Revoluções de Portugal, Lisboa, Typographia da Gazeta dos Tribunaes, 1847, p. 5 e também Soriano, Simão José da Luz, Utopias desmascaradas do systema liberal em Portugal ou epitome do que entre nós tem sido este systema, Lisboa, Imprensa União Tipográfica, 1858, p.16, nota 1.

${ }^{24}$ Cf. Soriano, Simão José da Luz, Revelações da minha vida e memórias de alguns factos, $e$ homens meus contemporaneos, Lisboa, Tipografia Universal, 1860, p.590-591, nota 1. 
preza demasiado a sua independência para aceitar alinhar por um partido político que, como todos os partidos da época, se identifica com o caciquismo e o governo "oculto" dos clubes políticos e sociedades secretas.

Na obra de João António de Azevedo Sá Coutinho, o anti-jacobinismo de tradição cartista transmuta-se num virulento anti-parlamentarismo. Simão José da Luz Soriano segue as suas pisadas escolhendo como alvos preferenciais, as eleições, os partidos políticos e as cortes. As eleições são consideradas uma simples manipulação ministerial para obter maioria favorável ao governo nas cortes. A corrupção, a fraude e a pressão sobre os eleitores são utilizadas por todos os partidos para obterem ou manterem o poder ${ }^{25}$. Assim sendo, não podem ser aceites como um processo transparente, válido e legítimo de representação da vontade da nação. A falsificação deste processo de representação popular supõe necessariamente uma reflexão, comum na época, sobre a formação artificial das maiorias das cortes. O parlamento tornava-se na prática a simples extensão do poder dos mịnistros, coligado com a acção dos partidos, clubes e sociedades secretas ${ }^{26}$. Porém, o domínio do legislativo, por maiorias favoráveis ao ministério, tem consequências ainda mais graves para o sistema constitucional, pois torna inócua a função fiscalizadora das acções governativas. As cortes transformam-se num simples instrumento de ratificação, praticamente automático, das decisões do executivo mostrando-se incapazes de limitar a omnipotência ministerial ou de legislar de acordo com os interesses nacionais. Daqui deriva uma impossibilidade de representar eficazmente a opinião pública e a nação que não se revêm nas eleições a que concorre um número cada vez mais diminuto de indivíduos ${ }^{27}$. Trata-se de um problema, colocado igualmente na época por pensadores de índole liberal como John Stuart Mill ou Alexis de Tocqueville, sobre o perigo efectivo das falsas ou verdadeiras maiorias parlamentares capazes de hegemonizar o sistema e introduzir a tirania das maiorias. Não é surpreendente que o autor se identifique num primeiro contacto com as minorias das cortes pois, simbolizam o bom senso e a resistência às loucas paixões das maiorias. Posição justificada na

${ }^{25}$ Cf. Soriano, Simão José da Luz, Utopias desmascaradas do systema liberal em Portugal ou epítome do que entre nós tem sido este systema, Lisboa, Imprensa União Tipográfica, 1858, p. 40-51 e também Soriano, Simão José da Luz, Revelações da minha vida e memórias de alguns factos, e homens meus contemporaneos, Lisboa, Tipografia Universal, 1860, p. 633-634 e p. $640-642$.

${ }^{26}$ Cf. Soriano, Simão José da Luz, Utopias desmascaradas do systema liberal em Portugal ou epítome do que entre nós tem sido este systema, Lisboa, Imprensa União Tipográfica, 1858, p. 40-41. Sobre a questão do anti-parlamentarismo liberal e reformista que é o caso de Simão José da Luz Soriano, consultar: Winock, Michel, La France politique XIXe-XXe siècle, Paris, Éditions du Seuil, 1999, p. 205-225.

${ }^{27}$ Cf. Soriano, Simão José da Luz, Revelações da minha vida e memórias de alguns factos, $e$ homens meus contemporaneos, Lisboa, Tipografia Universal, 1860, p. 640-643 e p. 660. 
base de uma opção pessoal e solitária que o aproxima da solidão rousseauniana, mas igualmente assente numa incursão pela história antiga e moderna, em busca de exemplos relevantes nos grandes homens do passado. Neste ponto, o seu pensamento não se afasta das concepções de Benjamin Constant, de François Guizot e dos liberais europeus em geral, em torno do receio da irracionalidade das massas populares no interior do sistema liberal e da necessidade de um elitismo político ${ }^{28}$.

Numa reflexão posterior considera igualmente relevante percepcionar o problema do jogo de poder entre a maioria e a minoria nas cortes. Trata-se da simples continuação da luta entre os partidos-facção que anteriormente criticara a propósito das eleições. O confronto entre maioria e minoria é prejudicial ao interesse público pois, se trata de uma luta estéril em torno de posições irreconciliáveis. A maioria aceita acriticamente tudo o que vem do ministério e recusa à partida tudo o que vem da oposição e, vice-versa, a minoria recusa tudo o que vem do ministério apoiando todas as iniciativas destinadas a derrubá-lo ${ }^{29}$. Desta forma, a vacuidade da actividade parlamentar ficou completamente comprovada e o aspecto negativo do funcionamento das cortes reforçado pelas críticas que desenvolve à liberdade oratória da "tribuna parlamentar": as intervenções políticas dos deputados nas cortes dão origem a intrigas, paixões políticas e provocadoras de revolta; os debates parlamentares provocam apenas o triunfo do espírito de partido e de facção e impedem o normal funcionamento das instituições políticas principalmente do governo; os ataques aos ministros trazem, também em si nos seus excessos retóricos o risco da quebra das leis, da desobediência das autoridades e dos horrores da anarquia ${ }^{30}$. A questão dos excessos retóricos dos membros das cortes é apenas uma pequena parte de um problema maior: a liberdade de pensamento. Vimos anteriormente a importância central que dava à liberdade de expressão contrapondo a realidade nos países livres com a vivida debaixo dos governos despóticos. Algo que não se podia evitar para alguém que assume o seu papel de es-

${ }^{28}$ Cf. Soriano, Simão José da Luz, Revelações da minha vida e memórias de alguns factos, $e$ homens meus contemporaneos, Lisboa, Tipografia Universal, 1860, p. 618-619. Ver também: Tocqueville, Alexis, de, ob. cit., idem e Mill, John Stuart, ob.cit., idem. Consultar: Manent, Pierre, Les libéraux, Paris, Éditions Gallimard, 2001, p. 434-543 e Rosanvallon, Pierre, La démocratie inachevée. Histoire de la souveraineté du peuple en France, Paris, Éditions Gallimard, 2000, p. 39-91 e p. 95-126.

${ }^{29}$ Cf. Soriano, Simão José da Luz, Revelações da minha vida e memórias de alguns factos, $e$ homens meus contemporaneos, Lisboa, Tipografia Universal, 1860, p. 585.

${ }^{30} \mathrm{Cf}$. Soriano, Simão José da Luz, Utopias desmascaradas do systema liberal em Portugal ou epítome do que entre nós tem sido este systema, Lisboa, Imprensa União Tipográfica, 1858, p. 55-59 e também Soriano, Simão José da Luz, Revelações da minha vida e memórias de alguns factos, e homens meus contemporaneos, Lisboa, Tipografia Universal, 1860, p. 642-643 e p. $740-742$. 
critor público e o seu compromisso com a verdade. Assume-se como falando para o espaço público e dando valor a uma intervenção política e jornalística, na base da actividade legítima do publicista liberal, dentro de uma pedagogia da cidadania. A concepção da importância desta liberdade de pensamento sofre alterações, pelo menos na interpretação das suas dimensões, entre o primeiro texto das Utopias e o segundo das Revelações. No segundo livro é questionada a sua validade no conjunto do sistema liberal, ou seja, a liberdade de pensamento é aparentemente a única vantagem face aos inúmeros defeitos do sistema constitucional marcado pelas lutas dos partidos, a instabilidade política, a corrupção generalizada e o constante aumento da carga fiscal. As vantagens resultantes do triunfo da liberdade de pensamento, com o liberalismo, não são compensadas ou acabam por ser de certa maneira anuladas pelo mau funcionamento e degenerescência das instituições políticas ${ }^{31}$ !

O seu ponto fulcral é acima de tudo a liberdade de imprensa tal como surge nos periódicos políticos da época. O autor é extremamente crítico contrapondo a concepção teórica liberal do jornalismo político e a realidade quotidiana. O liberalismo estabelece a liberdade da imprensa política como barreira fundamental contra o despotismo - a verdadeira expressão da opinião pública, a defensora dos inocentes e a perseguidora dos maus cidadãos! $\mathrm{Na}$ prática, porém, é o órgão das calúnias e instrumento privilegiado das sociedades secretas, servindo interesses inconfessáveis, prejudicando o normal funcionamento das instituições e subvertendo a ordem pública. A imprensa política é amoral e oscila ao sabor dos interesses de momento e das conveniências partidárias, aniquilando com facilidade reputações impolutas, promovendo sem o menor escrúpulo indivíduos responsáveis por actos criminosos e confundindo a opinião pública. Dominada pelo espírito de partido não serve a verdade pondo em causa o interesse geral numa atitude marcadamente anti-patriótica $^{32}$. Seja como for, a imaturidade do jornalismo político português torna impossível a emergência de uma opinião pública bem informada e portanto capaz de avaliar a acção governativa. As decisões do executivo, com especial destaque para os problemas relacionados com as finanças, escapam efectivamente ao controlo popular permitindo todo o tipo de abusos. A análise que faz

${ }^{31}$ Cf. Soriano, Simão José da Luz, Utopias desmascaradas do systema liberal em Portugal ou epítome do que entre nós tem sido este systema, Lisboa, Imprensa União Tipográfica, 1858, p. III-VII e p. 7 e também em Soriano, Simão José da Luz, Revelações da minha vida e memórias de alguns factos, e homens meus contemporaneos, Lisboa, Tipografia Universal, 1860 , p. $629-630$ e p. $660-661$.

${ }^{32}$ Cf. Soriano, Simão José da Luz Utopias desmascaradas do systema liberal em Portugal ou epítome do que entre nós tem sido este systema, Lisboa, Imprensa União Tipográfica, 1858, p. 52-55 e também Soriano, Simão José da Luz, Revelações da minha vida e memórias de alguns factos, e homens meus contemporaneos, Lisboa, Tipografia Universal, 1860, p. 716-720. 
das questões orçamentais não se reduzem à crítica destes aspectos, mas referem-se principalmente às opções relacionadas com a política fontista dos "melhoramentos materiais". Ele que inicialmente tinha boas relações com António Maria Fontes Pereira de Melo, a seguir ao golpe de estado da Regeneração de 1851, ataca as suas posições a nível das políticas financeiras do estado, corporizadas na célebre frase proferida no parlamento: a nação pode e deve pagar mais $^{33}$. Assim sendo, não é de admirar que centre os seus ataques ao fontismo, no aumento da dívida pública e nos empréstimos destinados a financiar a política dos melhoramentos materiais, nomeadamente a construção de estradas e caminhos-de-ferro. Nestas condições compreende-se que as suas posições se assemelhem à de economistas liberais como Adam Smith e, de certa maneira, Jean-Baptiste Say que remetem para uma intervenção minimalista das finanças do estado central nas obras públicas. Na linha do primeiro reconhece o bem fundado de recorrer às portagens para o pagamento das estradas, embora, aproximando-se do segundo, considere que certas vias de importância nacional devam ser financiadas directamente pelos impostos públicos mas só nos trabalhos iniciais de construção. Ou seja, a manutenção destas estradas e a construção de vias secundárias deviam ser pagas através de portagens ou por impostos lançados localmente. A aversão ao programa das obras públicas da Regeneração e do Fontismo tem, assim, uma forte carga ideológica inserindo-se no interior do pensamento liberal dominante, de carácter antiintervencionista e necessariamente anti-socialista ${ }^{34}$. A concepção minimalista do estado liberal liga-se com a defesa do contribuinte, sobrecarregado com impostos, que mantém um número elevado e desnecessário de funcionários públicos a que chama a "empregomania" nacional. Aliás, na sua opinião, os seus efectivos crescem continuamente, alimentando uma clientela partidária que enche os ministérios de indivíduos ociosos e proletários, vivendo à custa dos cidadãos activos e industriosos. A arbitrariedade destes parasitas, alimentados pelo estado assume o seu aspecto mais cruel e injusto na actuação dos empregados do físco que são alcunhados de "tiranos de campanário" pelas prepotências e humilhações a que submetem os cidadãos e o autor como proprietário de prédios urbanos. As suas queixas contra o "proletarismo" do estado português da Regeneração tornam-no assim, de certa forma, o porta-

${ }^{33}$ Cf. Soriano, Simão José da Luz, Revelações da minha vida e memórias de alguns factos, $e$ homens meus contemporaneos, Lisboa, Tipografia Universal, 1860, p. 685-686.

${ }^{34}$ Cf. Soriano, Simão José da Luz, Utopias desmascaradas do systema liberal em Portugal ou epítome do que entre nós tem sido este systema, Lisboa, Imprensa União Tipográfica, 1858, p. 71-96 e também Soriano, Simão José da Luz, Revelações da minha vida e memórias de alguns factos, e homens meus contemporaneos, Lisboa, Tipografia Universal, 1860, p. $674-$ 688. Consultar sobre o liberalismo económico oitocentista Manent, Pierre, Les Libéraux, Paris, Gallimard, 2001, p.314-372 e p.543-591. 
-voz dos interesses dos proprietários urbanos e das classes médias portuguesas. Estas sentem-se especialmente sobrecarregadas pelos impostos de Fontes Pereira de Melo destinados a financiar os empréstimos externos e que estão na origem da célebre revolta da Janeirinha de $1868^{35}$.

\section{Utopia e reforma}

A crítica ao funcionamento do sistema representativo não implica necessariamente a crença na impossibilidade da reforma das instituições políticas. Todavia, Simão José da Luz Soriano não se identifica com as transformações radicais da sociedade e opõe-se às revoluções na Europa e em Portugal. A aversão à própria ideia de revolução deriva não só do perigo que representa para a preservação da ordem social mas, principalmente das abstracções conceptuais que lhe estão associadas. $\mathrm{O}$ autor não rejeita a priori os fundamentos do pensamento liberal embora rejeite a sua viabilidade. $O$ grande erro do regime constitucional é desconhecer a distância que vai entre a teoria e a prática, e por conseguinte, a inadequação da primeira à realidade política. Assim sendo, compreende-se a importância que dá à condenação implacável da utopia ou discurso utópico dos partidos, grupos ou movimentos políticos que considera extremistas: radicais, republicanos, socialistas e anarquistas. Nesta perspectiva, o mundo do pensamento utópico é o das formulações idealizadas da realidade, puras fantasias da mente humana, geradoras da desordem e da anarquia no seu desejo de fazer "tábua rasa" do passado. As preocupações do autor só são perceptíveis se forem inseridas no respectivo contexto histórico. A primeira metade do século XIX foi marcada pela emergência de variadas utopias de cariz socialista, comunista e anarquista que obtêm uma nova notoriedade com as revoluções europeias de $1848-1849^{36}$. A posição de Simão José da Luz

${ }^{35}$ Cf. Soriano, Simão José da Luz, Revelações da minha vida e memórias de alguns factos, $e$ homens meus contemporaneos, Lisboa, Tipografia Universal, 1860, p. 699-716. Consultar: Almeida, Pedro Tavares de, Eleições e Caciquismo no Portugal Oitocentista (1868-1890), Lisboa, Difel, 1991, p. 97-141, Bonifácio, M. Fátima, Apologia da História Política. Estudos sobre o século XIX português, Lisboa, Quetzal Editores, 1999, p. 239-362 e Sardica, José Miguel, A Regeneração sob o signo do Consenso: a política e os partidos entre 1851 e 1861, Lisboa, ICS, 2001, p. 237-299.

${ }^{36}$ Cf. Soriano, Simão José da Luz, Utopias desmascaradas do systema liberal em Portugal ou epítome do que entre nós tem sido este systema, Lisboa, Imprensa União Tipográfica, 1858, p. III-VII, p. 1-2 e p. 21-22. Sobre os diversos autores das Utopias ver Servier, Jean, Histoire et l'utopie, Nouvelle Édition Paris, éditions Gallimard, 1991, p. 231-270. As revoluções de 1848-1849 podem ser melhor conhecidas consultando: Agulhon, Maurice, 1848 ou l'apprentissage de la république 1848-1852, Paris, Éditions du Seuil, 1973; Sigman, Jean, 1848. Las revoluciones románticas y democraticas de Europa, 2. a edición, Madrid, Siglo vientinuno de 
Soriano é idêntica à dos pensadores liberais que recusam o ideário democrático e social do mal sucedido movimento revolucionário, nas décadas de $50 \mathrm{e}$ 60 do século XIX. A rejeição das abstracções teóricas e do discurso utópico exprime igualmente uma tendência mais antiga que remonta com Edmund Burke e Jeremy Bentham aos finais do século XVIII e inícios do seguinte. A tradição liberal encontra aqui os seus primeiros grandes críticos da Revolução francesa de 1789, que acentuam de forma negativa as "ilusões" revolucionárias. Os liberais de oitocentos não vão ignorar totalmente estas questões, mas será com Alexis de Tocqueville que encontraremos uma formulação adequada do problema no Ancien Regime et la Révolution (1856), embora aplicada expressamente ao caso da França ${ }^{37}$. No entanto, não é possível excluir totalmente uma influência legitimista em Simão José da Luz Soriano pois, no passado, Joseph de Maistre e Louis de Bonald colocaram questões semelhantes. Não obstante, o persistente esforço de distanciamento do absolutismo permite-nos minimizar o peso desta tendência no seu pensamento. O escritor português estava consciente das temáticas dominantes nos debates políticos na Europa do começo da segunda metade de oitocentos.

A modernidade das suas concepções explica igualmente a ligação que estabelece entre a utopia e o progresso material e intelectual. O progresso é um conceito central da visão optimista do indivíduo e da sociedade dos liberais oitocentistas. Todavia, aparece cada vez mais ligado às esperanças dos socialistas utópicos num futuro melhor para a Humanidade. Assim sendo, compreendem-se as críticas muito negativas que o autor faz à ideia de progresso pois contesta a ideia de perfectabilidade social devido à sua descrença nas capacidades humanas de auto-regeneração. Nesta perspectiva considera que se sacrifício de Cristo na cruz não conseguiu reabilitar o homem, também não o fará um sistema de governo baseado no compadrio e afilhadagem. O cepticismo sobre o progresso embora de conteúdo marcadamente cristão não deixa de lembrar o discurso igualmente céptico sobre esta matéria de Jean-Jacques Rouseau um dos seus maîtres penseurs da juventude ${ }^{38}$. A falta de fé na ideia

España Editores, S. A, 1984 e Ribeiro, Maria Manuela Tavares, Portugal e a Revolução de 1848, Coimbra, Livraria Minerva, 1990.

${ }^{37}$ Cf. Tocqueville, Alexis, O Antigo Regime e a Revolução, Lisboa, Ed. Fragmentos, 1989, pp. 127-133 e p. 141-142. Ver também sobre esta questão: Guizot, François, De la Démocratie en France, Paris, Victor Masson, Librairie, 1849, p.8-9.

${ }^{38}$ Cf. Soriano, Simão José da Luz, Revelações da minha vida e memórias de alguns factos, $e$ homens meus contemporaneos, Lisboa, Tipografia Universal, 1860, p. 699-700 e p. 767-768. O regresso ao catolicismo numa linha liberal próxima de Lamennais e Lamartine não deixa de estar presente em Portugal através de António Feliciano de Castilho. Todavia, autores tão diversos como Alexandre Herculano e Rebello da Silva não eram totalmente indiferentes a certos elementos deste neocatolicismo. Ver a este propósito Torgal, Luís Reis, "O Tradicionalismo Absolutista e Contra-Revolucionário e o Movimento Católico", Torgal, Luís Reis e 
de progresso projecta-se nas desilusões com a liberdade, a democracia e o sistema representativo. Não se esgotam aqui as referências indirectas e directas ao progresso, aparecendo-nos implicitamente nas críticas aos melhoramentos materiais do fontismo e ao desaparecimento desnecessário de muitas das instituições do Antigo Regime. A recusa da novidade expressa-se quer na rejeição das instituições educacionais e administrativas de figurino francês, quer na defesa do clero. No entanto, a percepção negativa do progresso entendido como um processo de igualização social dominante nas Revelações contrasta com as posições optimistas reveladas sobre esta questão nas Utopias. Com efeito, aproximando-se do pensamento de John Stuart Mill identifica o progresso com o melhoramento intelectual e material dos indivíduos característico de um governo representativo ${ }^{39}$. A aparente mudança da opinião do autor sobre este tema, só é perceptível se compreendermos a maneira como encara a realidade do seu tempo. A visão do tempo presente é nitidamente pessimista, persistindo firmemente ancorada, no pânico provocado pelas experiências revolucionárias dos finais da década de 40 na França e na Europa. O medo social de uma revolução que destrua a propriedade em nome da pura utopia da fraternidade e igualdade republicana domina o seu pensamento ${ }^{40}$. O espectro da guerra civil parece ameaçar as sociedades europeias no final da década de 50 do século XIX. A noção de "guerra social" desempenha um papel importante na maneira como visualiza os conflitos político-sociais e o risco de desintegração da ordem pública. A concepção que serve de base a esta reflexão é a ideia da luta de "classes" expressa pelos liberais doutrinários sobretudo por François Guizot. A evolução da história é marcada pelo confronto entre a aristo-

Roque, João (coord.), Mattoso, José (dir.), O Liberalismo, Lisboa, Editorial Estampa, 1993, vol. 5, p. 227-239 e também Silva, Júlio Joaquim da Costa Rodrigues, "Memória e História no Liberalismo Ibérico: Luís Augusto Rebelo da Silva e Francisco Martínez de la Rosa", Cultura, Revista de História e Teoria das Ideias, II. ' Série, Vol. XV, Lisboa, Publicação Anual do Centro de História da Cultura da Universidade Nova de Lisboa, 2002 (2003), p. 245-269. Sobre a influência de Jean-Jacques Rousseau em Portugal no vintismo consultar: Castro, Zília Osório de, Cultura e Política. Manuel Borges Carneiro e o Vintismo, Lisboa, INIC-CHC/UNL, 1990, Vol. II, p.533-585 e Machado, Fernando Augusto, Rousseau em Portugal. Da clandestinidade setecentista à legalidade vintista, Porto, Campo de Letras-Editores S.A., 2000, p. 451-603.

${ }^{39}$ Cf. Soriano, Simão José da Luz, Utopias desmascaradas do systema liberal em Portugal ou epítome do que entre nós tem sido este systema, Lisboa, Imprensa União Tipográfica, 1858, p. 4-6. Ver sobre este tema a nossa análise neste artigo p. 7 e nota n. ${ }^{\circ} 14$.

${ }^{40}$ Cf. Soriano, Simão José da Luz, Utopias desmascaradas do systema liberal em Portugal ou epítome do que entre nós tem sido este systema, Lisboa, Imprensa União Tipográfica, 1858, p. 30 e também Simão José da Luz Soriano, Revelações da minha vida e memórias de alguns factos, e homens meus contemporaneos, Lisboa, Tipografia Universal, 1860, p. 628. Consultar sobre este tema: Rosanvallon, Pierre, Le Moment Guizot, Paris, Éditions Gallimard, 1985, p. 87-95 e p. 320-379 e Cuevas, Pedro Carlos González, Historia de las derechas españolas. De la Ilustración a nuestros días, Madrid, Editorial Biblioteca Nova, S. L., 2000, p. 17-148. 
cracia e a classe média e o triunfo final do terceiro estado. Contudo, um novo parceiro surge com a irrupção do "quarto estado" teorizado pelos radicais franceses como Armand Carrel nos anos 30 de oitocentos. O temor do autor perante a novidade política deste fenómeno resulta da facilidade de sedução do "baixo povo" pelos ideais revolucionários espalhados pela imprensa e a tribuna parlamentar. Este facto explica-se pelo aspecto essencialmente passional das "ínfimas classes" da sociedade que contrasta com a racionalidade da classe média. As camadas médias encarnando, na linha de François Guizot e de Donoso Cortès, a soberania da razão (ou soberania da inteligência) são chamadas a dirigir a sociedade, pois só elas têm a capacidade de interpretar correctamente os interesses gerais e o devir histórico. Contudo, o "baixo povo" é também assimilado, não a uma nova etapa da civilização que hipoteticamente pudesse suceder ao triunfo da classe média/terceiro estado de François Guizot, mas sim à sua negação. A plebe é equiparada aos bárbaros que no passado destruíram o império romano que era o símbolo e o paradigma civilizacional da Europa. Estamos verdadeiramente perante uma "recorrência bárbara", à maneira de François Guizot e do liberalismo doutrinário que vê, nesta emergência e autonomia das massas populares no período posterior às revoluções de 1848-1849, uma autêntica guerra social ${ }^{41}$. O ponto de partida desta análise baseia-se numa reflexão sobre a desigualdade natural dos homens. $\mathrm{O}$ autor ao contrário das declarações americanas e francesas dos finais do século XVIII considera que os homens nascem livres mas não são iguais. A ordem do mundo produto da Providencia divina dá aos homens qualidades físicas e intelectuais diferentes, fundando naturalmente as diversas hierarquias da ordem social, em que uns mandam e outros têm forçosamente que obedecer ${ }^{42}$. Nesta perspectiva é preciso recordar as suas já referidas afirmações de não ser proletário, mas não ter também ascendido à aristocracia, ficando-se por uma mediania identificável com uma confortável aurea mediocritas burguesa. Assim sendo, compreende-se a sua tentativa de conciliar as suas origens sociais com o relativo sucesso posterior, não hesitando em citar uma passagem $D u$ Contrat Social de Jean-Jacques Rousseau em seu socorro ${ }^{43}$. Tal facto não o impede de

${ }^{41}$ Cf. Soriano, Simão José da Luz, Utopias desmascaradas do systema liberal em Portugal ou epítome do que entre nós tem sido este systema, Lisboa, Imprensa União Tipográfica, 1858, p. 7-8 e p.65. Ver também Guizot, François, ob cit.p. 106-108. Consultar sobre esta questão: Rosanvallon, Pierre Le Moment Guizot, Paris, Éditions Gallimard, 1985, p. 75-87.

${ }^{42}$ Cf. Soriano, Simão José da Luz, Utopias desmascaradas do systema liberal em Portugal ou epítome do que entre nós tem sido este systema, Lisboa, Imprensa União Tipográfica, 1858, p. 47. Ver sobre esta questão: Jaume, Lucien, Les Déclarations des Droits de L'Homme (Du Débat 1789-1793 au Préambule de 1946), Paris, GF-Flammarion, 1989, p. 67-72 e também Guizot, François,

${ }^{43}$ Cf. Soriano, Simão José da Luz, Revelações da minha vida e memórias de alguns factos, $e$ homens meus contemporaneos, Lisboa, Tipografia Universal, 1860, p. 5. Ver Rousseau, Jean- 
se afastar rapidamente de qualquer identificação política com o ideal republicano do passado, preferindo no presente identificar-se com os princípios aristocráticos. A preocupação em distanciar-se das suas origens populares, em breve remete para uma visão negativa das camadas mais pobres e incultas que designa, de forma depreciativa, pela expressão de classes inferiores e turbas. A utilização de expressões extremamente agressivas como "fezes do povo" permitem-nos avaliar o desprezo por estas camadas populares identificadas com a própria marginalidade social. Assume uma verdadeira mentalidade de casta ao colocar no topo uma elite do poder, da riqueza e da inteligência que deveria assumir a direcção da sociedade. Este é um tema clássico entre os adeptos do liberalismo doutrinário e está presente no pensamento do francês François Guizot e do espanhol Donoso Cortès. A oposição entre "inteligências superiores" e "inteligências inferiores", conduz a uma visão conservadora da sociedade e tendencialmente imobilista do ponto de vista social. No entanto, ao introduzir o tema da superioridade da inteligência ou da "capacidade", tão caro ao doutrinarismo liberal, afasta-se de qualquer' identificação com os pensadores tradicionalistas e contra-revolucionários pois reconhece sem margem para dúvida o valor do mérito individual. Trata-se, assim, de defender uma meritocracia ou "aristocracia da honra e da inteligência" e não a velha aristocracia nobiliárquica do sangue e da árvore genealógica ${ }^{44}$. As revoluções não são o caminho a seguir na reorganização do regime liberal pois, induzem a indesejável participação das massas populares no processo de decisão político.

As "reformas úteis" das Utopias ou as "projectadas reformas políticas" das Revelações são inseparáveis da recusa da ruptura absoluta com o passado. O processo de regeneração do sistema político deve partir da situação actual traduzindo uma "evolução na continuidade" das instituições políticas na linha do pensamento de Edmund Burke e do liberalismo moderado oitocentista. A referência aos grandes legisladores da antiguidade e dos tempos modernos fornece um modelo idealizado a seguir e acentua a sequência histórica que une o passado, o presente e o futuro. Não se trata de arrasar o existente sem se preocupar em conhecê-lo e substituí-lo apressadamente por algo totalmente novo. O importante é estudar os costumes, a experiência histórica, as conveniências públicas e só então optar pelas mudanças realisticamente possíveis ${ }^{45}$. O prag-

-Jacques, Du Contrat Social ou Principes du Droit Politique, Paris, Marabout Université, 1974 , p. 36.

${ }^{44}$ Cf. Soriano, Simão José da Luz, ob. cit., p. 733-734 e p. 764. Ver sobre esta questão: Rosanvallon, Pierre, La démocratie inachevée. Histoire de la souveraineté du peuple en France, Paris, Éditions Gallimard, 2000, p. 108-116 e p. 235-241 e Corral, L. Diez del, El Liberalismo Doutrinario, Madrid, Instituto de Estudios Politicos, 1973, p. 549-588.

${ }^{45}$ Cf. Soriano, Simão José da Luz, Utopias desmascaradas do systema liberal em Portugal ou epítome do que entre nós tem sido este systema, Lisboa, Imprensa União Tipográfica, 1858, p. 21-22. Ver também Soriano, Simão José da Luz, Revelações da minha vida e memórias de 
matismo reformista do autor não o impede de procurar realizar transformações profundas no sistema constitucional vigente. A recusa do sufrágio universal e da possibilidade das cortes representarem adequadamente a nação é característica do pensamento doutrinário. François Guizot e Donoso Cortès recusam a própria ideia da soberania popular de Rousseau ou da soberania da nação de Mably em prol da soberania da razão ou da inteligência. O velho tema da aristocracia electiva, já presente em alguns pensadores da revolução francesa, reaparece pela mão do liberalismo moderado europeu do século XIX e recentra-se em torno do referido tema das inteligências superiores e das capacidades. Os membros das câmaras electivas não podem pretender, através das eleições, representar a vontade popular mas sobretudo não podem almejar constituir uma elite de poder capaz de governar adequadamente de acordo com a razão e o devir social ${ }^{46}$. A alternativa passa por realizar mudanças no sistema eleitoral através de dois processos diferentes mas eventualmente complementares. A primeira traduzia-se numa limitação nos recenseamentos dos eleitores através da imposição prévia de múltiplos quesitos: idade, censo, habilitações, estado, profissão ou indústria e anos de experiência nestas diferentes áreas. $\mathrm{O}$ exemplo é para o autor a França da Monarquia de Julho anterior à Revolução de 1848 onde dominava o sufrágio censitário estabelecido por François Guizot. O censo em França era também mais do dobro do censo para eleitor em Portugal o que, na prática, o leva a considerar que a prerrogativa eleitoral no nosso país é quase equivalente ao sufrágio universal. A originalidade do seu pensamento resultava de exigir que neste caso fossem as cortes e não o governo a fiscalizar o processo eleitoral para garantir a sua imparcialidade e isenção. A segunda alternativa é aquela a que Simão José da Luz Soriano dá mais relevância e considera uma das mais relevantes reformas do sistema constitucional: o sorteio. O processo de escolha permite acabar com a perniciosa influência das sociedades secretas nas eleições e por extensão no governo. Este ficará livre das pressões daquelas e poderá obrar de acordo com a justiça e o interesse público. No entanto, estas afirmações passam por uma definição clara do que é para Luz Soriano o sistema constitucional: "garantias sociaes e individuaes, e em pôr côbro ao arbitrio do executivo". Visão minimalista de uma constituição que acentua, ao lado das garantias sociais e individuais, o papel puramente negativo do legislativo na limitação do poder executivo. $\mathrm{O}$ poder legislativo não tem de ser formado na base de eleições. O sorteio será a

alguns factos, e homens meus contemporaneos, Lisboa, Tipografia Universal, 1860, p.644-655 e p.680-687 p.721-722 e p.736.

${ }^{46}$ Cf. Soriano, Simão José da Luz, Utopias desmascaradas do systema liberal em Portugal ou epítome do que entre nós tem sido este systema, Lisboa, Imprensa União Tipográfica, 1858, p. 46. Ver também Rosanvallon, Pierre, ob. cit, idem e Corral, L. Diez de, ob. cit, idem. 
melhor opção para se obter uma maior equidade seguindo-se aqui as lições dos autores clássicos e eventualmente dos modernos ${ }^{47}$.

Os males apontados pelo autor implicam igualmente a referência aos excesso do jornalismo político e da tribuna parlamentar algo inerente às críticas do liberalismo moderado da época. No primeiro caso está em causa os excesso da liberdade de imprensa que o autor quer remediar seguindo os exemplos tomados pelo Segundo Império (1852-1870) em França ${ }^{48}$. Um redactor de jornal tem de dar garantias de honra, moralidade e inteligência, pois, ilustrar a opinião pública e guiá-la no reflectido exame dos negócios do estado é uma missão muito importante. Na verdade, nem todos os cidadãos têm capacidades para poder julgar com acerto a administração superior do país. Assim sendo, a repressão dos abusos da imprensa encontra-se com a temática capacitária dos doutrinários, embora dentro da concepção da imprensa como um instrumento de educação da opinião pública. $\mathrm{O}$ autor exige um sistema misto de fianças e de habilitações para se obter a autorização para se dirigir um jornal. Contudo, resvala rapidamente para a repressão pura e simples, propondo a criação de um tribunal especial pelas cortes para julgar os abusos da imprensa. Defende igualmente que estes órgãos judiciais exercessem uma espécie de censura prévia em situações excepcionais, anulando perigosamente a separação entre o judicial e o legislativo. No caso da tribuna parlamentar, o autor exige uma solução imediata para coarctar os excessos oratórios dos deputados nas cortes. O ideal seria restringir a publicação e análise das discussões parlamentares segundo o modelo do Segundo Império francês e vedar ao público o livre acesso às galerias. Se a lei marca certos quesitos para poder ser deputado e jurado também seria justo que definisse quem pode assistir às discussões das cortes pois, nem todas as inteligências seriam capazes de avaliar condignamente $o$ que nelas se passava. As posições aqui referidas estão presentes quer nas Utopias quer nas Revelações com a diferença de que o segundo texto vai ainda mais longe do que no primeiro. $\mathrm{O}$ autor quer limitar a iniciativa parlamentar de cada um dos deputados que na sua opinião tinha sido durante quase 30 anos

${ }^{47}$ Cf. Soriano, Simão José da Luz, Revelações da minha vida e memórias de alguns factos, $e$ homens meus contemporaneos, Lisboa, Tipografia Universal, 1860, p. 735. e Soriano, Simão José da Luz, Utopias desmascaradas do systema liberal em Portugal ou epítome do que entre nós tem sido este systema, Lisboa, Imprensa União Tipográfica, 1858, p. 48. Ver Manin, Bernard, Principes du Gouvernement Représentatif, Paris, Flammarion, 1996, p. 93-108 para compreender as perspectivas de Ch. Montesquieu e J-J Rousseau sobre o problema. Sobre a actualidade desta questão nos meios radicais franceses durante a Segunda República (1848-1852) ver: Rosanvallon, Pierre, ob. cit., p. 159 e nota n. ${ }^{\circ} 2$.

${ }^{48}$ Plessis, Alain, «De la fête impériale au mur des fédérés 1852-1871», Nouvelle histoire de la France contemporaine, Paris, Éditions du Seuil, 1973, vol. 9, p. 24-25. Cf. Soriano, Simão José da Luz, Utopias desmascaradas do systema liberal em Portugal ou epítome do que entre nós tem sido este systema, Lisboa, Imprensa União Tipográfica, 1858, p. 505. 
de sistema representativo uma ameaça ao interesse público. De facto era um sistema de controle e censura das temáticas que deviam ser debatidas nas cortes e obviamente uma limitação que tornava quase impossível a expressão de opiniões e/ou projectos heterodoxos ${ }^{49}$.

\section{A terceira via}

No campo das projectadas reformas políticas, defendidas por Simão José da Luz Soriano, situam-se de forma central as questões orçamentais e a crítica à política de melhoramentos materiais do fontismo. A rejeição das inovações introduzidas pela Regeneração nas áreas da educação, cultura e obras públicas, está ligada à recusa do modelo intervencionista e centralizador gaulês. Assimila-o a uma nova forma de despotismo assente, no tão detestado sufrágio universal que caracteriza como anti-liberal. Aliás, considera que os pesados tributos que recaem sobre as classes médias e a errada política de endividamento público, resultam do desejo de imitar o modelo económico do Segundo Império. Tal facto, não o impede de elogiar bom número de medidas anti-parlamentares e limitadoras da liberdade de expressão, impostas autoritariamente à França por Napoleão III. De modo semelhante, existe uma notória contradição entre uma evidente anglofobia no plano da política externa e uma óbvia anglofilia no plano das instituições inglesas e da política económica liberal. No primeiro caso, a Inglaterra é acusada de humilhar internacionalmente Portugal, impondo-lhe uma aliança onerosa em termos políticos que nunca cumpre e que é prejudicial aos interesses nacionais. No segundo caso, o elogio das instituições britânicas a começar pelo funcionamento do parlamento inglês e a descentralização política, que é mais patente nas Revelações do que nas Utopias. No plano da política económica o autor toma a Inglaterra como modelo, a seguir no plano da organização financeira do estado sobretudo no referente à dívida consolidada, elemento central das políticas económicas da Regeneração e do Fontismo. A solução que defende passa por reduzir as despesas públicas seguindo a política orçamental inglesa entre 1813 e 1851 . As concepções livre-cambistas de Simão José da Luz Soriano eram características da economia política inglesa e francesa da época através da identificação com as concepções de Adam Smith e em menor grau de Jean-Baptiste Say. O projecto reformista, que propõem para Portugal, é um curioso entrecruzar de dois

${ }^{49}$ Cf. Soriano, Simão José da Luz, Utopias desmascaradas do systema liberal em Portugal ou epítome do que entre nós tem sido este systema, Lisboa, Imprensa União Tipográfica, 1858, p. 58-59 e Soriano, Simão José da Luz, Revelações da minha vida e memórias de alguns factos, e homens meus contemporaneos, Lisboa, Tipografia Universal, 1860, p. 742. Ver Plessis, Alain, ob.cit., p. 32-36. 
modelos políticos antagónicos da segunda metade do século XIX: o bonapartismo francês e o liberalismo inglês. A aparente incapacidade de percepcionar a contradição do esforço de conciliar propostas de governo tão opostas, só pode ser entendida através da sua plena adesão ao liberalismo moderado de oitocentos. O núcleo duro do seu pensamento político centra-se em torno dos principais pressupostos teóricos dos doutrinários franceses e espanhóis, mas actualizado com autores mais modernos. A defesa dos "homens moderados" face aos radicais do "ultraliberalismo" não implica uma total negação daquilo que para ele sempre foi essencial. $\mathrm{O}$ abandono do republicanismo rousseauniano da juventude não é uma traição ao seu passado, mas a única forma de se manter fiel a valores fundamentais: o bem geral da sociedade, da moralidade publica e da fiel observancia das leis ${ }^{50}$. Assim sendo, compreende-se que tenha colocado, no início das Revelações, um poema do poeta setecentista Garção que sintetiza esta busca incessante de autenticidade e coerência de uma vida ${ }^{51}$ :

"Na presença de Cesar, e Conscriptos

Fui, disse, fui fiel a Galba, e a Roma,

Confesso o meu delicto, se delicto

Á virtude se chama."

${ }^{50} \mathrm{Cf}$. Soriano, Simão José da Luz, Utopias desmascaradas do systema liberal em Portugal ou epítome do que entre nós tem sido este systema, Lisboa, Imprensa União Tipográfica, 1858, p. 74-76 e p. 93-98. Ver também sobre esta questão Soriano, Simão José da Luz, Revelações da minha vida e memórias de alguns factos, e homens meus contemporaneos, Lisboa, Tipografia Universal, 1860, p. 691-721.

${ }^{51}$ Cf. Soriano, Simão José da Luz, Revelações da minha vida e memórias de alguns factos, $e$ homens meus contemporaneos, Lisboa, Tipografia Universal, 1860, p. 1. 


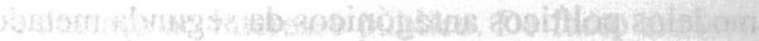

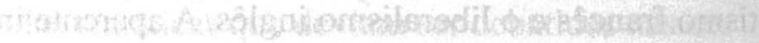

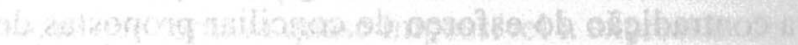

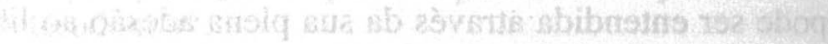

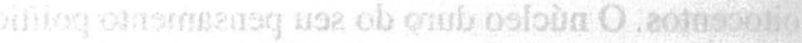

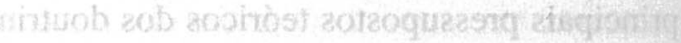

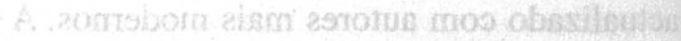

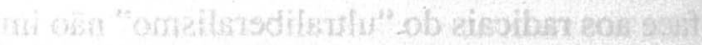

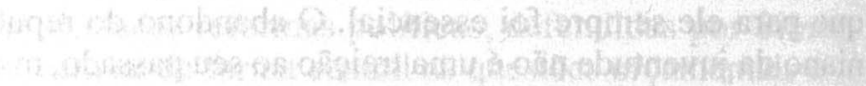

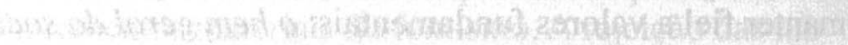

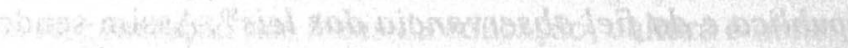

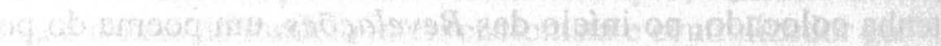

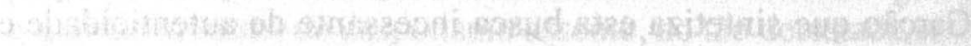

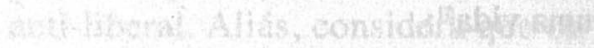

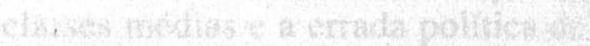

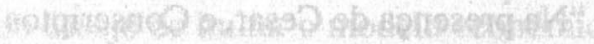

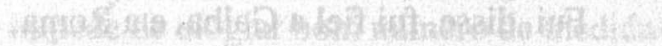

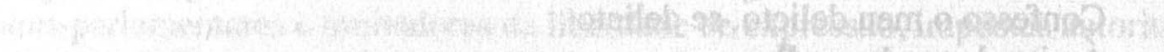

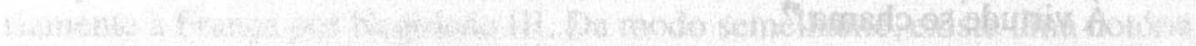

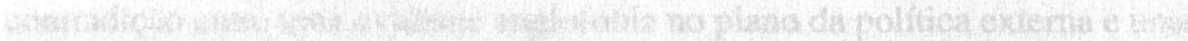

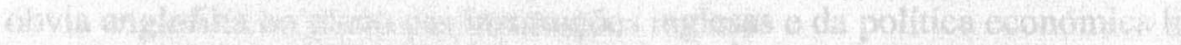

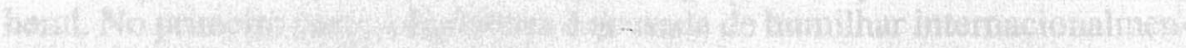

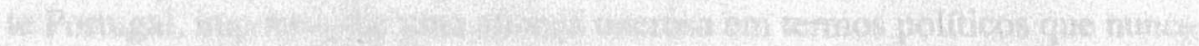

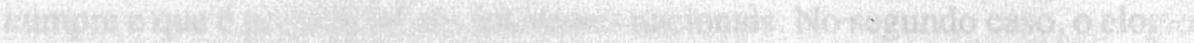

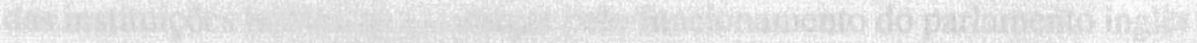

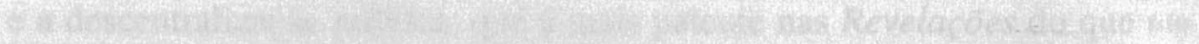

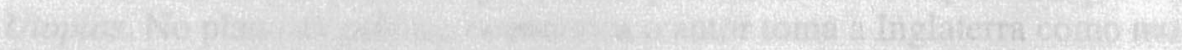

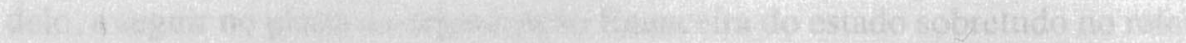

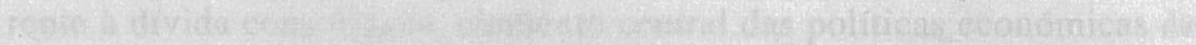

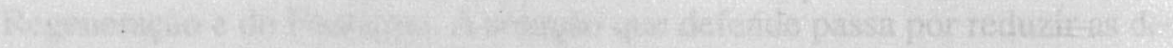

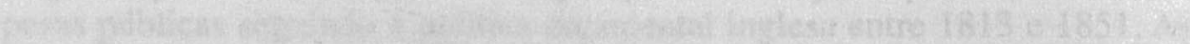

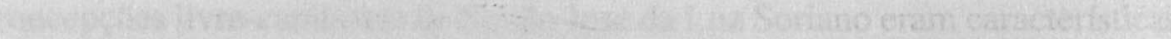

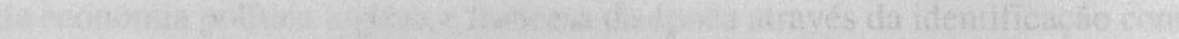
-

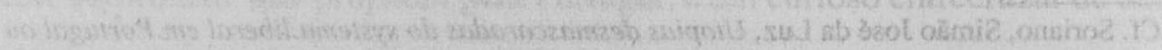

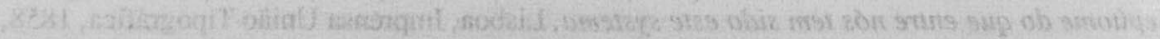

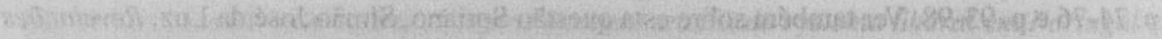

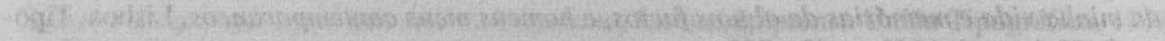
-5.6.

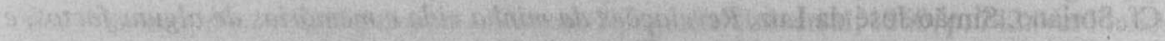

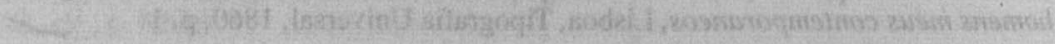




\title{
O MARQUÊS DE POMBAL E A MUDANÇA DE PARADIGMA*
}

\author{
José Augusto dos Santos Alves \\ Centro de História da Cultura \\ Universidade Nova de Lisboa
}

Entrecruzamento de reflexões, subentendidos múltiplos, reminiscências ressuscitadas, aproximações, genealogias, recorrências e reaparições, o século XVIII português apresenta características transformacionais e, muitas vezes, polémicas ao nível das várias esferas, como a literária, por vezes moralizadora e costumeira ${ }^{1}$, a científica ou a técnica ${ }^{2}$.

Neste século "ideofágico" e "mitofágico", em que "desconhecidos" agitadores, anti-escolásticos e defensores de ideais subversores, aparentemente não coniventes com o poder, lançam a discussão no seio do Estado e da Sociedade, à boa maneira de um eclectismo pontual que não esquece a visão conservadora, mas mantendo-se abertos às inovações ${ }^{3}$, o pombalismo ${ }^{4}$ aparenta-se a um marco miliário. Com efeito, a visão panorâmica de Pombal adquire,

* Este texto foi objecto de comunicação apresentada ao XXVIII Symposium on Portuguese Traditions (Europe, America, Africa, Asia), University of California, Los Angeles, 2005, e resulta, em parte, de idêntico tema tratado na tese de doutoramento do autor (FSCH - UNL, 1998), publicada sob o título A Opinião Pública em Portugal (1789-1820). Lisboa: Universidade Autónoma, 2000, Adenda, Excerto - P.

1 Considere-se, entre outros, LUCA, Franco de Assis Amado e - Critica Moral contra os vícios em comum, seu autor. Partes I e II. Lisboa: Na Officina de Joze Filipe, 1758.

${ }^{2}$ Leia-se: Carta apologetica critico-medica. Su author, el doctor D. Francisco Pl. medico en la corte de Lisboa, natural del principado de Cataluña. Dada à luz, por un cavallero portuguez, amante de la verdad, e de la publica salud. Lisboa: En la Imprenta de Joseph Phelippe, 1760, e B. J. de L. C. B. - Juizo verdadeiro sobre a carta contra os medicos, cirurgioens, e boticarios ha pouco impressa com o titulo 'Sustos da vida nos perigos da cura', exposto em huma carta de hum amigo a outro, que sobre ella pedio o parecer. Lisboa: Na Officina de Joseph Filipe, 1758.

3 Veja-se a Ilustração e, a propósito, DIAS, José Sebastião da Silva-Portugal e a cultura europeia (séculos XVI a XVIII). Separata da Biblos, vol XXVIII. Coimbra: Coimbra Editora, 1953, pp. 184 e ss. e PEREIRA, José Esteves - Luzes na Enciclopédia, Luzes em Portugal. Colóquio Internacional Diderot. Lisboa: Universitária Editora, 1987; cfr., sobre o eclectismo em Portugal, DIAS, José Sebastião da Silva - O Eclectismo em Portugal no século XVIII: Génese e destino de uma atitude filosófica. Coimbra: Faculdade de Letras da Universidade de Coimbra, 1972.

4 Veja-se, a este respeito, DIAS, José Sebastião da Silva - Pombalismo e teoria política. Lisboa: Centro de História da Cultura da Universidade Nova de Lisboa, 1982; Pombalismo e projecto político. Separata da Cultura: História e Filosofia, vols. II e III. Lisboa: Centro de História da Cultura da Universidade Nova de Lisboa, 1984, e RAMOS, Luís A. de OliveiraProjecções do reformismo pombalino. Coimbra: Arq. da Universidade, 1984. 
nestas circunstâncias, o seu verdadeiro sentido, graças à força "insurreccional" que o seu pensamento encerra, pois só assim foi possível fugir ao laxismo plural generalizado.

Neste contexto, o discurso, a vários níveis, perpetuador do poder, aproveita, num tempo conturbado, para exercícios obrigatórios de incondicional adesão do vassalo ao soberano e ao incontestável, mas não incontestado, poder do monarca. Trata-se de uma retórica visível em várias manifestações ${ }^{5}$, no quadro de ascensão do poder do saber ilustrado e da aristocracia do mérito, que se incorpora na nova escala de valores em construção ${ }^{6}$, na qual o progresso das ciências se inscreve.

Esta breve referência conjuntural encaminha-nos directamente ao Marquês de Pombal e às mudanças de paradigma, que assegura, enquanto protagonista do poder, contribuindo para a abertura a várias transmutações, numa espécie de inter-comunicabilidade entre paradigmas ${ }^{7}$.

Cfr., entre outros, Nas reaes nupcias do serenissimo senhor D. Jozé, principe da Beira com a serenissima senhora infanta D. Maria Francisca Benedita. Lisboa: Na Officina de João Antonio da Silva, 1777.

${ }^{6}$ Aprecie-se Elogio historico de Pascoal José de Melo Freire dos Reis pronunciado na assembléa publica da Academia R. das Sciencias de 17 de Janeiro de 1799, e dedicado a sua alteza real o principe D. João nosso senhor. Lisboa: Na Typographia da Academia R. das Sciencias, 1799. Sobre Pascoal de Melo Freire, veja-se PEREIRA, José Esteves - Pensamento político em Portugal no século XVIII: António Ribeiro dos Santos. Lisboa: I.N.-C.M., D.L. 1983, sobretudo Parte IV, caps. I-V, pp. 243 e ss..

7 O conceito de paradigma, sempre polémico, independentemente da área do saber que o adopta, deve ser olhado sob a perspectiva concernente à definição de um estado da ciência ou das ciências, que consiste em insistir sobre a especificidade e sobre o carácter determinante das técnicas de pensamento que ele institui, um conjunto de ideias inscrevendo-se num sistema de pensamento, que se manifestam por técnicas precisas e complexas, tanto na materialidade das experiências como na construção dos conceitos. (Cfr. BACHELARD, Gaston - La formation de l'esprit scientifique: contribution à une psychanalyse de la connaissance objective. Paris: J. Vrin, 1993). Na verdade, não é difícil reconhecer, em certas épocas, uma unidade de conjunto do pensamento, quanto à maneira de colocar e de resolver os problemas de determinados domínios da ciência. Contudo, também é verdade que esta unidade de concepção que se impõe tão fortemente aos espíritos, conduz a que toda a tentativa para lhe introduzir rupturas, com lucro de um projecto novo, que lhe alarga e aprofunda o campo, se debate com resistências aparentemente fundadas e que só são ultrapassadas ao preço de uma regeneração. (Cfr. KUHN, Thomas S. - The structure of scientific revolutions. Chicago: The University of Chicago Press, 1996). Todavia, a virtude estabilizadora do paradigma, se é seguramente mantida por constrangimentos económicos e sociais, e talvez sobretudo pela coerência e pela dinâmica interna de uma organização conceptual, entra em colapso, quando o efeito manifesto da acumulação de conhecimento científico, num processo feito de mutações e rupturas, continuidades e descontinuidades, a dialéctica interna do progresso científico, conduz às inovações mais surpreendentes da ciência, as mais imperceptíveis (Cfr. GRANGER, Gilles Gaston - "Épistémologie". Encyclopadia Universalis. Corpus 8. Paris: Encyclopædia Universalis, 2002, pp. 473-480), em que poucos tomam verdadeiramente conhecimento do que está a acontecer. 


\section{Aludo ao inovador inquérito pombalino ao sismo de $1755^{8}$, e correspon-} dentes respostas, que nos transporta para outro paradigma, ao mesmo tempo que dá ao tempo do relógio, a ele imbricado, uma outra significação, ou seja a do paradigmático isocronismo ${ }^{9}$, em que o pombalismo se inscreve e prescreve, para que a sociedade interiorize uma outra temporalidade e um outro exercício

${ }^{8}$ Enviado a 20 de Janeiro de 1756, por Sebastião José de Carvalho e Melo, aos arcebispos e bispos do reino (cfr. IAN-TT. Ministério do Reino: Livro de Avisos 5, n. ${ }^{\circ}$, classe $1 .^{\mathrm{a}}, 1756-$ -1757 , fls. 8). Face aos dados de que disponho, julgo tratar-se do primeiro, e inédito, dos "interrogatórios" ordenados sobre o sismo de 1755 . Outros se seguiram, com modificações e adições, mas mantendo o arquétipo de 20 de Janeiro de 1756 . Uma vez que neste trabalho apenas se abordam, sob a perspectiva da mudança de paradigma, as questões da sismologia e da temporalidade, os diferentes e restantes conteúdos do conjunto do inquérito e das respostas fornecidas serão, futuramente, objecto de estudo.

Sobre outros "interrogatórios", veja-se SOUSA, Francisco Luís Pereira de - Ideia geral dos effeitos do megasismo de 1755 em Portugal. Lisboa: Typ. do Commercio, 1914, pp. 6 e ss.. Este autor informa sobre um questionário, de conteúdo semelhante, que transcreve, mas não idêntico ao trasladado neste trabalho. Não consegue, todavia, esclarecer a data precisa do mesmo. Expressa apenas tratar-se de um inquérito "depois do terramoto de 1755", situa as respostas em meados de 1756 e informa sobre a impossibilidade de "obter todas as respostas a este questionário". Curiosamente, a sua obra, em que utiliza, para avaliação do grau do sismo, a escala de Mercalli (XI graus), assenta em novos interrogatórios, conseguidos por insistência do pe. Luís Cardoso (16--1769), ampliados com mais algumas perguntas, em relação ao primeiro, entre as quais, e.g., "se padeceu alguma ruína no terramoto de 1755 e em quê; e se está já reparada”. Em conformidade com a fonte (António Baião, Director da Torre do Tombo), que SOUSA cita, as respostas, que facultam a base da sua pesquisa, foram fornecidas em 1758, a partir dos novos inquéritos, quando o mesmo pe. Luís Cardoso trabalhava no seu Diccionário (cfr. SOUSA, Francisco Luís Pereira de - O terremoto do $1^{\circ}$ de Novembro de 1755 e um estudo demografico. Lisboa: Serviços Geológicos; Tip. do Comércio 1919-1932, 4 vols., Vol. I. 1919, pp. 5-10). A este propósito veja-se "Interrogatório para a organização do Diccionario de Cardoso". O Archeologo Português - Collecção Illustrada de Materiais e Notícias publicada pelo Museu Ethnographico Português. Redactor - J. Luís de Vasconcelos. Vol. I. Lisboa: Imprensa Nacional, 1895, pp. 267-268, e CARDOSO, Luís - Diccionário geográfico, ou noticia historica de todas as cidades, villas, lugares, e aldeas, Rios, Ribeiras, e Serras dos Reynos de Portugal, com todas as cousas raras, que nelles se encontrão, assim antigas, como modernas. Lisboa: Regia Offic. Silviana, 1741-1751.

9 O isocronismo tem no relógio de pêndulo um vector capital, que é também vital para o desenvolvimento futuro da indústria da relojoaria, a partir de finais do século XVII, quando o holandês, HUYGENS, Christiaan Van Zuylichem (1629-1695), físico, geómetra e astrónomo, aplica o princípio do pêndulo à mecânica do relógio. A invenção, em 1656, do relógio de pêndulo, torna o seu criador extremamente popularizado. Ainda em meados da década de 70 , HUYGENS inventa a espiral de aço, cabelo, para relógios de bolso, substituindo a cerda de porco. Os motivos que estão na origem deste avanço no progresso da avaliação da temporalidade são inteligíveis. É indispensável, em astronomia, um instrumento para bem medir o tempo.As clepsidras e as ampulhetas eram impróprias para fornecer resultados exactos. Após Galileu ter reconhecido o isocronismo das oscilações do pêndulo, os astrónomos tentaram utilizar os seus ensinamentos. HUYGENS aproveitou a lição, fornecendo às engrenagens dos relógios um movimento regular e uniforme, por via de um mecanismo, que dá origem ao 
do poder. Pombal, com a estratégia de eminente homem de Estado ${ }^{10}$, tem a noção da importância que o seu acto ou actos podem trazer ao reino, ao nível do desenvolvimento científico, e as repercussões que essa acção terá no interior da monarquia absoluta.

princípio conhecido sob o nome de pêndulos. YOUNG, Thomas inclina-se a pensar que o árabe Ibn Ionnis já, no século X, tinha aplicado o pêndulo para determinar o tempo. Mas é Sanctorius que, em 1612, parece ter sido o primeiro a aplicar o pêndulo como moderador da engrenagem do relógio (cfr. YOUNG, Thomas - A course of lectures on Natural Philosophy and the Mechanical Arts. London: J. Johnson, 1807, t. I, p. 181; SÉDILLOT, Louis-PierreEugène-Amélie (pseud. Lamst) - Mémoires sur les instruments astronomiques des Arabes. Paris: Impr. Royale, 1841; UMBOLDT, Alexander Von - Cosmos, a sketch of a physical description of the Universe. Translated from the Germany by E. C. Otté. London: H. G. Bohn, 1848, t. II.). A invenção de HUYGENS foi apresentada aos Estados Gerais da Holanda, em 16 de Junho de 1657, e o seu pequeno tratado, Horologium, de dez páginas, foi colocado à cabeça do primeiro volume das suas C. H. Opera varia (Lugduni Batavorum, 1724, 2 vols.). Desejando aperfeiçoar o seu invento, HUYGENS chegou à conclusão, contrariamente a GALILEU, que não havia isocronismo perfeito. Nas cento e sessenta e uma páginas de Horologium oscillatorium, siva De motu pendulorum ad horologia aptato demonstrationes geometrica (Parisiis: Apud F. Muguet, 1673), HUYGENS descreveu os princípios que presidiam à sua inovação teórica acerca do relógio de pêndulo cicloidal, que vieram a ser reproduzidos, com adições, nas suas Opera varia. Não cabe, no âmbito deste trabalho, descrever os desenvolvimentos posteriores da relojoaria até ao relógio atómico, que utiliza as vibrações dos átomos de césio, nem a pesquisa em torno dos objectos cósmicos "pulsar" (estrelas de neutrões de rotação rápida), na busca de uma referência sólida, imune à variabilidade de diversas proveniências observadas no seio do sistema solar. As estrelas de neutrões, ou "pulsar", que emitem impulsões de ondas rádio, extremamente regulares, foram descobertas, com o auxílio de um radiotelescópio, pelos astrofísicos britânicos Anthony Hewish e Jocelyn Bell Burnell, em 1967. Independentemente do posterior desenvolvimento do processo, HUYGENS, entre outros, tinha delineado a via que levaria a um enorme progresso que faria da relojoaria uma indústria de "ponta" até à contemporaneidade. A este propósito cfr. BLAIR, Byron Emerson, editor - Time and frequency: theory and fundamentals. NBS monograph. $\mathrm{N}^{\circ} 140$. [Washington]: Govt Printing Office, 1974, e MILHAN, Willis Isbister - Time and timekeepers: including the history, construction, care, and accuracy of clocks and watches. New York: Macmillan, 1945. Sobre HUYGENS, Christiaan Van Zuylichem, veja-se Nouvelle Biographie Générale depuis les temps les plus reculés jusqu'a nos jours, avec renseignements bibliographiques et l'indication des sources a consulter. Paris: Firmin Didot Frères, Fils et Cie., Editeurs, 1861, [Nova edição], Copenhague: Rosenkilde et Bagger, 1968, tome XXV-XXVI, pp. 666-679). Para uma leitura amena da história do relógio em Portugal, cfr. OLIVEIRA, Fernando Correia de - Historia do Tempo em Portugal: Elementos para uma história do tempo, da relojoaria e das mentalidades em Portugal. [Lisboa]: Diamantouro, 2003.

${ }^{10}$ Coteje-se Parabens a Portugal: falla hum genio contemplativo, com os seus compatriotas portuguezes; ponderando-lhes a inadvertida felicidade em que se achão, pelas disposiçoens do presente governo. Lisboa: Na Officina de Pedro Ferreira, 1767. Veja-se, a propósito, ALVES, José Augusto dos Santos - "A Universidade de Coimbra na memória da emigração liberal no primeiro quartel de oitocentos". Universidade(s): História. Memória. Perspectivas. Actas Congresso "Historia da Universidade" (No $7^{\circ}$ Centenário da sua Fundação). Coimbra: Comissão Organizadora do Congresso "Historia da Universidade", 1991, Actas (5), pp.177-189. 
Neste sentido, trazer à colação, passados duzentos e cinquenta anos sobre o terramoto de Lisboa, de 1755 , um inquérito inédito ao choque cataclísmico e tsunami, e eventuais réplicas, é, a meu ver, oportuno, porque, na verdade, marca o começo de um acto fundador da era moderna da sismologia, porquanto até essa data apenas se têm notícias sobre raras observações que, eventualmente, se tenham efectuado ${ }^{11}$.

Com a data de 20 de Janeiro de 1756, o questionário é enviado aos arcebispos de Lacedemónia, Évora, Algarve e aos bispos do Porto, Coimbra, Guarda, Lamego, Viseu, Miranda, Leiria, Portalegre, Elvas e Tomar, com a seguinte missiva:

"Para o sr. D. José, Arcebispo Primaz, S. Majestade manda remeter a V.A. os interrogatórios inclusos e é servido que, mandando-os V.A. copiar, os remeta a todos os párocos desse arcebispado, ordenando-lhes que no preciso termo que V. Alteza julgar conveniente procurem responder a eles, averiguando e examinando com todo o cuidado e exactidão o.seu conteúdo, remetendo a V.A. as relações e tanto que V.A. for entregue de todas mas enviará, guardando em segredo o conteúdo nelas para as fazer presentes ao mesmo senhor. Deus guarde a V.A., Belém a 20 de Janeiro de 1756, Sebastião José de Carvalho e Melo. A mesma carta se escreveu aos arcebispos e bispos abaixo nomeados"12.

Os "interrogatórios" inclusos apresentam-se de modo a que as perguntas se tornem iniludíveis:

"A que horas principiou o terramoto do primeiro de Novembro e que tempo durou? Se se percebeu que fosse maior o impulso de uma parte que de outra parte v.g. do norte para o sul ou pelo contrário. Se parece que caíram mais ruínas para uma que para outra parte;

Que número de casas arruinaria em cada freguesia, se havia edifícios notáveis e o estado em que ficaram;

Que pessoas morreram, se algumas eram distintas;

Se o mar vazou primeiro ou encheu, quantos palmos cresceu mais do ordinário. Quantas vezes se percebeu o fluxo e refluxo extraordinário;

Se se reparou que tempo gastaria em baixar a água e quanto em tornar a encher; Se abriu a terra algumas bocas, o que nelas se notou e se rebentou alguma fonte de novo. Que providências se deram imediatamente em cada lugar pelo eclesiástico, pelos militares e pelos ministros;

Que terramotos têm repetido depois do primeiro de Novembro, em que tempo e que danos têm feito;

Se há memória de que em outro tempo houvesse outro terramoto, e que dano fez em cada lugar;

Que número de pessoas tem cada uma das freguesias, declarando se puder ser quantas há de diferente sexo;

"Cfr. DAVIDSON, Charles - The Founders of Seismology. New York: Arno Press, 1978.

${ }^{12}$ IAN-TT. Ministério do Reino: Livro de Avisos 5, n. $.^{\circ} 3 .^{\circ}$, classe $1^{\mathrm{a}}, 1756-1757$, fls. 8. 
Se se experimentou alguma falta de mantimentos;

Se houve incêndio e que tempo durou e que dano fez"13.

O conjunto das inumeráveis respostas, vindas de todo o território, de que a seguir se fornece uma triagem, é o evidente testemunho da mudança que se processa no reino sob o ângulo de um outro modo de encarar o tempo, ou seja, a substituição do tempo canónico ${ }^{14}$ pelo "tempo do relógio".

A hora do desencadear sísmico apresenta-se, na maioria dos casos, pelas nove e trinta da manhã, conquanto exista uma variação entre as nove e as dez horas. O espaço de tempo da sua duração varia entre os 3-4 minutos e vai até ao quarto de hora ${ }^{15}$. Para lá da existência, em algumas respostas, de manifestações do tempo canónico, anote-se, praticamente em todo o reino, como facto que não deixa de ser significativo do processo de mudança de paradigma, a homogeneidade do "tempo do relógio" e a sua necessidade como referente.

Se, por um lado, se assinala a coincidência horária no desencadear do sismo e a existência de relógio na torre de grande número de povoações, por outro, verifica-se a mágoa acerca do relógio que "anda poucas vezes certo" ou o lamento daqueles em cuja terra "não há relógio" que ajude à resposta correcta. A existência, ainda, de informação estribada nas "pessoas que estavam em terra de relógio" potencia, em tempo de mutação, as anteriores observações e a necessidade de uma medida de tempo análoga.

${ }^{13}$ Inquérito transcrito, na resposta, pela freguesia de Azinhoso, Mogadouro, Bragança, (cfr. IAN-TT. Ministério do Reino, Maço 638, cx. 742). Respeitei, no traslado, o alinhamento original do texto.

14 "As cátedras principais da Faculdade designadas pela nomenclatura das horas canónicas, eram a de prima, onde serviam de texto as sentenças de Pedro Lombardo, a de véspera, onde era lida a Summa Theologica de S. Tomás de Aquino, a de tércia, em que se comentava a Sagrada Escritura e a de nôa, em que se preleccionava sobre o texto de Duns Escoto (ALMEIDA, M. Lopes d'; BRANDÃO, M. - A Universidade de Coimbra: Esboço da sua história. Parte II. "A Universidade de 1580 a 1937”. Coimbra: Universidade de Coimbra, 1937, p. 33.

${ }^{15}$ Sobre o terramoto de 1755, veja-se, entre outros, ARAÚJO, Ana Cristina Bartolomeu de, "Ruína e sorte em Portugal no século XVIII. A propósito do terramoto de 1755". Revista de História das Ideias. O sagrado e o profano. Homenagem a J. S. da Silva Dias. Vol. 9 (1987), Coimbra: Instituto de História e Teoria das Ideias; Faculdade de Letras; Universidade de Coimbra, 1987, pp. 327-365; ROUSSEAU, J.J. - “A M. de Voltaire. Le 18 Août 1756”. Oeuvres: Correspondance. Paris: Chez Lefèvre, 1820, Tome I, pp. 222-246; SOUSA, Francisco Luís Pereira de -O megasismo do $1^{\circ}$ de Novembro de 1755 em Portugal. Acompanhado dum estudo demográfico e sôbre rochas de construção. Lisboa: Tip. do Comércio, 1915-1916, 2 vols.; Alguns prognósticos possíveis do terremoto de 1755. Separata do Boletim da Academia das Sciencias de Lisboa. Nova Série - Vol. I. Coimbra: Imprensa da Universidade, 1930, além dos já citados do mesmo autor (cfr. supra nota 8), e VOLTAIRE - Poemes sur la religion naturelle et sur la destruction de Lisbonne. Geneve: s.n., 1756, pp. 25-32. 
As respostas, em função das perguntas, expõem-se, por sua vez, com elevada simplicidade:

Agadão (Aveiro) "Primeiramente, quanto ao primeiro interrogatório, como nesta freguesia não há relógio, não se pode averiguar ao certo às horas que principiou e o tempo que durou, porém parece principiaria das oito para as nove horas da manhã e que duraria um quarto de hora, pouco mais (...). 5 de Maio de 1756";

Aguada de Baixo (Aveiro) "As horas em que começou o terramoto, principiou das nove para as dez horas, mais minuto ou menos minuto (...). 12 de Maio de 1756";

Aguada de Cima (Aveiro) "O terramoto (...) principiou às nove horas e meia da manhã, pouco mais ou menos, e duraria sete para oito minutos (...). 31 de Maio de 1756";

Águeda (Aveiro) "Dando resposta aos interrogatórios (...) sucedeu nesta minha freguesia com o terramoto do primeiro de Novembro de 1755 . Segundo o que sei e me informaram algumas pessoas inteligentes, principiou o mesmo terramoto pelas nove horas e três quartos da manhã e duraria cinco para seis minutos (...). 16 de Maio de 1756";

Ançã (Cantanhede) "Principiou pelas nove e meia da manhã e duraria (...) dez até doze minutos (...). 15 de Maio de 1756";

Anceriz (Arganil) "Principiou (...) pelas nove horas e meia da manhã, pouco mais ou menos, e duraria doze minutos (...). 6 de Maio de 1756";

Caçarelhos (Vimioso) "Principiou pelas nove horas da manhã, ou nove e meia (...), e durou o tempo em que se podem rezar duas estações, pouco mais ou menos (...). 23 de Fevereiro de 1756";

Campo de Víboras (Vimioso) "Às nove horas e meia, mais ou menos, principiou (...) e passados dois credos tornou a repetir (...). 23 de Fevereiro de 1756"; Constantim (Miranda do Douro) "Principiou pelas nove horas da manhã com pouca diferença e duraria um quarto de hora (...). 3 de Março de 1756”;

Vilar do Chão (Alfandega da Fé - Bragança) "O terramoto (...) me parece principiou às nove horas da manhã e durou de oito até doze minutos (...). 29 de Fevereiro de 1756""16.

Alandroal "Se sentiu um tremor violento da terra (...) pelas nove horas às dez da manhã, que durou um quarto de hora pouco mais ou menos (...). 10 de Abril de 1756";

Almaça (Viseu) "Esta miserável terra, como nela não há relógio, alguns fregueses que tiveram notícia deles não sabem a que horas foram e nem sabem quantos foram (...). 20 de Maio de 1756";

Almoster (Leiria) "Às nove horas e trinta minutos pouco mais ou menos principiou (...), durando este por espaço de três para quatro minutos (...). 7 de Maio de 1756";

Benavente "Principiou depois das nove horas e meia (...) e teria de duração seis minutos (...). 28 de Fevereiro de 1756";

Castanheira (Chaves) "Respondo que seriam nove horas e meia quando começou e que duraria meio quarto de hora (...). 6 de Março de 1756";

${ }^{16}$ IAN-TT. Ministério do Reino, Mç. 638, cx. 742. 
Ervedal (Portalegre) "Principiou pelas nove e meia, pouco mais ou menos e durou nove ou dez minutos (...). 6 de Maio de 1756";

Linhares (Celorico da Beira) "Pelas nove horas e meia (...), dando notícia dele primeiro o relógio sito na torre do castelo desta vila com o seu toque movido pelos impulsos do tremor e isto pelo espaço de sete minutos pouco mais ou menos (...). 6 de Maio de 1756";

Mangualde "Eram nove meia (...) começou a terra a tremer, cujo tremor e abalo duraria pelo espaço de uma estação (...). 14 de Maio de 1756";

Melo (Gouveia) "Nesta terra (...) o relógio anda poucas vezes certo e por isso não podemos averiguar as horas (...). 7 de Maio de 1756";

Mortágua (Viseu) "Seriam nove horas e meia da manhã (...) e duraria sete até dez minutos de espaço de tempo (...). 3 de Maio de 1756";

Veiros (Estremoz) "Principiou entre as nove e dez horas da manhã pelo relógio da torre desta vila, durou oito minutos pouco mais ou menos (...). $28 \mathrm{de} \mathrm{Fe-}$ vereiro de $1756 "$ "17.

Em sentido semelhante caminha a "HISTORIA DO TERREMOTO DO ANNO DE 1755 ", com a particularidade de anotar, com curiosidade cientificada, outras réplicas sísmicas acontecidas nos dias subsequentes:

"No ano de 1775. Em o 1. de Novembro, às 9 horas e 40 minutos da manhã, sucedeu o lastimoso terramoto que será sempre memorável em todas idades (...). Tremeu a terra com três impulsos (...), durando tudo isto 9 minutos. As terras e planícies pareciam, na sua fuga ou correntes, ondas do mar ou searas por causa dos ventos ondeando, ora se via mover vertical, ora se inclinava para um e outro lado, sendo os movimentos contrários e opostos, fazendo estes precipitar os palácios, os conventos, as igrejas, as torres e todas as casas com incrível impulso" "18; "No 8. dia, pelas 5 horas e 30 minutos da manhã, tremeu a terra com ímpeto furioso e o abalo durou pouco. No dia 15 , pelas 5 horas da manhã, se sentiu um grande impulso. No dia 16, pelas 3 e 30 minutos da tarde, a explosão foi horrorosa (...). No dia 8 de Dezembro, entre as onze e o meio-dia, todos aqueles que viviam em casa saíram para a rua com precipitação (...); no dia 11, pelas 4 horas e 55 minutos da manhã, tremeu a terra duas vezes com violência..."”.

Como pode verificar-se, os "interrogatórios", que Sebastião José de Carvalho e Melo ordena a seguir ao terramoto do dia de todos-os-santos, deixam antever, salvaguardados pressupostos epistemológicos, a escala de Mercalli $^{20}$, ao ponto de poder falar-se, com alguma propriedade, em ruptura téc-

${ }^{17}$ IAN-TT. Ministério do Reino, Mç. 638, cx 743.

${ }^{18}$ IAN-TT. Manuscritos da Livraria, n ${ }^{\circ} 1229$, "Historia do Terremoto do anno de 1755", fls. 51-51v.

${ }^{19}$ Idem, ibidem, fls. $54 \mathrm{v}-55$.

${ }^{20}$ Em 1883, mais de um século depois do inquérito pombalino, Giuseppe Mercalli, propôs a sua escala, um sistema baseado em descrições eivadas de carga subjectiva. A escala foi modificada em 1912, depois em 1931. Na sua última versão, a Escala Modificada de Mercalli, con- 
nico-científica, tal é a inovação que introduzem em Portugal e a contribuição que fornecem para a mudança de paradigma na área de estudo deste tipo de fenómenos.

Eivado de espírito científico, percursor em relação ao seu tempo, o inquérito pombalino, uma espécie de "dodecálogo", produto da sua latente modernidade $^{21}$, assinala um passo para o surgir da sismologia moderna, ao mesmo tempo que, exibindo o pragmatismo de Sebastião José, e entrando na domínio da estatística demográfica, introduz no conjunto das perguntas uma questão que encaminha à tentativa de elaborar o censo da população.

Para compreender a importância da contribuição do inquérito pombalino, é necessário recordar que a escala de Mercalli surgirá mais de um século depois e que a utilização de sismógrafos, inventados no século XIX, e capazes de medir a grandes distâncias das ondas emitidas pelos tremores de terra, data dos anos $1920^{22}$.

tinua a ser actualmente utilizada. Apesar de limitada quanto à energia da origem do sismo, quando os números da escala de Mercalli começaram a ser aplicados aos sismos, os padrões começaram a surgir das miscelâneas das listas informativas. Bem antes de 1920, tornou-se claro que as mais instáveís regiões sísmicas do globo estavam associadas com características da crosta terrestre, i.e., onde esta se apresentava mais enrugada, montanhas e fracturas (cfr. ZEBROWSKI, Jr., Ernest - Perils of a restless planet: scientific perspectives on natural disasters. Cambridge, UK; New York: Cambridge University Prees, 1997). Curiosamente, se a escala de Mercalli é mencionada na história da sismologia, o "inquérito de Pombal" é, por razões óbvias, completamente ignorado, independentemente do sismo e tsunami de Lisboa serem abundantemente referenciados (cfr., a título de exemplo, DAVIDSON, Charles - The Founders of Seismology. New York: Arno Press, 1978).

${ }^{21}$ Modernidade, enquanto categoria vista como síntese interpretativa do real. A consciência da modernidade constitui-se sobre um duplo movimento: 1 - Consciência de pertença/identificação a um tempo específico; 2 - Vontade de dar um sentido a um mundo que se apavora numa inquietude originária.

${ }^{22}$ Por curiosidade, assinale-se que o primeiro instrumento, especificamente designado para registar sismos foi, aparentemente, construído na China em 132. Era um círculo de oito figuras de dragões esculpidas em bronze, cada uma sustentando uma esfera na boca, que, perante um forte abalo de terra, cairia para a boca de um sapo que, supostamente, indicaria a direcção do tremor de terra. Este instrumento era, certamente, uma bela peça de arte, mas de duvidoso valor, enquanto instrumento científico.

Na Europa, pode dizer-se, encontram-se escritos sobre instrumentos para a detecção de sismos desde o princípio do século XVIII (cfr. HAUTEFEUILLE Jean de-Microscope micrométrique, gnomon horizontal, et instrument pour prendre les hauteurs des astres jusques aux tierces, avec un moyen de prevoir les tremblements de terre. 1703), sobretudo, com a preocupação de responder mais às questões da inclinação da superfície terrestre do que aos deslocamentos horizontais. Foi Jean de HAUTEFEUILLE (1647-1724) quem primeiro percebeu claramente a importância da contribuição dos instrumentos para o estudo da sismologia, recorrendo às variações de nível do mercúrio líquido derramado de um recipiente. Este pioneiro, também ligado à relojoaria, e ao relógio de pêndulo ou pêndulo de bolso, entrou, em 
Perante um fenómeno natural de poder devastador, Pombal colocou, como é sabido, no cume das prioridades, a minoração dos efeitos suportados pelos homens. Mas isto implicou, ao mesmo tempo, um conhecimento científico do fenómeno e a posse de meios técnicos de protecçã $0^{23}$, com a finalidade de minimizar, no futuro, dolorosos resultados de idêntico cataclismo. Ou seja, não descurou, a meu ver, o estudo dos efeitos do sismo, abrindo a via para acumular ensinamentos que, pouco a pouco, determinassem as regras de protecção parassísmica e carreassem novas contribuições.

Todavia, para lá da ruptura técnico-científica, que em si encerram, os "interrogatórios" remetem-nos para o sistematizado aparecer de um novo conceito de temporalidade, no mínimo de outra medição do tempo, que devendo ser olhado na perspectiva social, económica, política e cultural, merece, sobretudo, ser visto sob o ângulo em apreço neste trabalho, isto é, no de um outro tempo que se aproxima.

As práticas temporais mudam, as atitudes face ao tempo modificam-se igualmente. Contudo, a "redução" dos tempos da vida a uma representação

1675, a propósito da paternidade deste tipo de relógio, em polémica com HUYGENS, Christiaan Van Zuylichem (cfr. supra nota 9). Hautefeuille tinha inventado o meio de diminuir as vibrações do balanço do relógio; Huygens, que aperfeiçoou o mecanismo, registou a patente, o que decidiu Hautefeuille a reclamar, sem sucesso, a paternidade da invenção (cfr. HAUTEFEUILLE Jean de - Factum, touchant les pendules de poche.... Contre maistre Christian Hugens sieur de Zulichem.... [S.1.]: 1676).

Todavia, a honra de ter sido o primeiro europeu a assinalar o uso de um instrumento mecânico, como auxiliar para o estudo de sismos, cabe a CIRILLO, Nicollò - Memoria sui terremoti. Napoli: 1738. CIRILLO (1671-1734) recorreu ao pêndulo e à observação das oscilações pendulares no estudo de uma série de sismos em Nápoles, em 1731. A utilização do pêndulo permitiu a contribuição de Andrea Bina (1751), assim como a de Domenico Salsano, um relojoeiro de Nápoles, que inventou o "geo-sismómetro", em Fevereiro, de 1783. Posteriormente, a lista de contribuições é extensa. De Atanasio Cavalli (1784), e o "sismoscópio", Duca della Torre, A. Filomarino (1796), e o "sismógrafo" de pêndulo, semelhante ao de Salsano, James David Forbes (1809-1868), e o "sismoscópio" (1841), onde experimentou vários arranjos de pêndulos, até Filippo Cecchi (1822-1877) que, beneficiando de todas estas contribuições, constrói, com sucesso, o primeiro sismógrafo (1875), usando dois pêndulos, um sistema em que um detecta o movimento norte-sul e o outro o movimento este-oeste, orientações ainda hoje em uso. John Milne (1850-1913), nos anos seguintes, trabalhando em Tóquio, introduziu consideráveis melhoramentos na sensibilidade deste instrumento (cfr., sobre este tema, ZEBROWSKI, Jr., Ernest - Perils of a restless planet: scientific perspectives on natural disasters. Cambridge, UK; New York: Cambridge University Prees, 1997; DEWEY, James; BYERLY, Perry - "The Early History of Seismometry (to 1900)". Bulletin of the Seismological Society of America. [Stanford, Calif.]: The Society, Vol. 59, N. 1 (February - 1969), pp. 183-227).

${ }^{23}$ Veja-se a construção "em gaiola", certamente, no momento, a perspectiva mais correcta para uma construção anti-sísmica. 
cronológica torna-se empobrecedor, não apenas para a sociologia e a psicologia, mas também para a história, e, a fortiori, para a interpretação plural dos passados, assim como para a construção previsional dos presentes, a vir, nos ensaios de prospectiva e planificação. Não existe um tempo, mas tempos. Cada um, entre eles, possui características próprias. São irredutíveis uns aos outros. A novidade consiste precisamente em considerar o tempo como um objecto científico, colocar sob estudo o tempo único, homogéneo e regular, inacessível e dominador ${ }^{24}$.

O que é um quadro temporal? A expressão é auto-suficiente. Ela encerra qualquer coisa nos limites definidos, justapondo ou opondo um continente e um conteúdo, uma cronologia e um acontecimento, ou seja uma "geometria" e uma "substância"2s. A noção de quadro temporal distingue um tempo envolvente - a geometria - de tempo envolvido - os da substância. Estes últimos reagem mais ou menos ao envolvimento. O tempo envolvente é um tempo reconhecido, aceite como referência e convenção. Os tempos envolvidos apenas se descobrem com o exercício.

Neste sentido, olhando para o tempo do "relógio pombalino" pode dizer-se que ele assinala o futuro da regularidade que caracteriza o quadro temporal do trabalho. A história dos quadros temporais do trabalho revela uma tendência constante à regularidade: desaparecimento das variações sazonais, melhoramento das relações, principalmente com a adopção do "tempo justo" e do "mesmo a tempo". O quadro temporal duplica-se de um efeito de reiteração indefinida, numa perspectiva de avanço no seio da mesma sociedade, onde as instituições, como os comportamentos, obedecem às regulações do relógio, sem precedentes na história do mundo, em que os quadros temporais passam a ser, muitas vezes, indutores de comportamentos.

O relógio não nivela apenas, ele reduz os homens à autoridade da sua medida e à medida do poder. Transforma-os em indivíduos intercambiáveis de uma população estatística. A gestão das actividades produtivas elimina as soluções de continuidade. Também os quadros temporais se sucedem em série. Os quadros temporais concorrem entre si quando, em lugar de se justaporem, de se sobreporem, de se interpenetrarem, um disputa ao outro uma mesma duração do relógio. Como afirmava Marx "o homem é a carcaça do tempo"26.

${ }^{24} \mathrm{O}$ rio de Heraclito (o escoamento incessante do tempo) gera a ideia da perda inexorável do tempo a cada fracção de segundo, o que sugere que a história do mundo seria apenas o encaminhamento para a morte e a do homem uma teleologia.

${ }^{25}$ Cfr. GROSSIN, W - Les temps de la vie quotidienne. Berlin: Mouton/De Gruyter, 1974, p. 128.

26 "Alors, il ne faut pas dire qu'une heure d'un homme vaut une heure d'un autre homme, mais plutôt qu'un homme d'une heure vaut un autre homme d'une heure. Le temps é tout, l'homme n'est plus rien, il est tout au plus carcasse du temps" (MARX, Karl-Misère de la 
$\mathrm{Na}$ verdade, a modernidade exige que, nos quadros temporais, apenas as suas limitações precisas e rigorosas autorizam a sua designação enquanto quadros temporais. A eleição de um quadro temporal pessoal, sobre medida, "um tempo intersticial" 27 , inscreve-se nos sonhos utópicos, mas também, depois de algum tempo, numa perspectiva futurista, como a que inspira "a revolução do tempo escolhido"28.

O que se identifica com a noção de quadro temporal, são as práticas correntes, os comportamentos regulados sob um instrumento de medida. É esta medida que chamamos o tempo, sem nos perguntarmos o que ela mede verdadeiramente. A medida cronológica abstracta recobre totalmente, de maneira aproximativa ou completamente falsa, os tempos reais. A noção de quadro temporal não pode dissipar esta camuflagem, nem denunciar esta ilusão. Ela serve para tornar mais manifesta a multiplicidade de construções temporais do relógio e a variedade dos seus conjuntos. Diga-se de passagem que ela também sublinha a extensão da nossa sujeição.

philosophie. Paris: Giard et Brière, 1908, p.70). Com efeito, os quadros temporais pessoais ou colectivos distinguem-se igualmente segundo a autoridade das suas limitações. Uns levantam uma barreira inultrapassável para além do momento preciso da abertura. São definidos, precisos, fixos, intangíveis, intransgressíveis. Para além do sinal inexorável, o quadro temporal encerra, conduzindo ao insucesso, à nulidade, à exclusão: "ninguém pode inscrever-se depois da data de encerramento", "depois da hora já não é a hora", "perdeu-se o comboio" (trata-se da via para interiorizar a virtude, o mérito, cujo panoptismo pune ou premeia). O desregulamento do quadro temporal conduz à desordenação dos empregos do tempo e programações ulteriores, individuais ou colectivas. O estorvo dos quadros temporais é tal que as latências e os atrasos ocasionam confusões, embaraços, impaciências, irritações, disputas (o tempo do número é aqui essencial). Em derradeira instância, uma série de questões que nos transportam ao conflito dialéctico entre tempo pessoal (vivido) e tempo do relógio (mecânico/atómico) e a perguntas transcendentes como: Quantos instantes tem um momento? Quanto tempo dura um instante? Quanto tempo dura um quarto de hora?

${ }^{27}$ Cfr. GASPARINI, G. - "L'attesa: un tempo industriale". Studi di Sociologia. Milano: Vita e pemsiero, Vol. 30, N. ${ }^{\circ} 1$ (Marzo - 1992), pp. 23-45.

${ }^{28}$ Se aqui falamos de pombalismo e da importância que tem no Portugal setecentista, que se encontra no limiar da pré-modernidade, esta perspectiva não significa a exclusão de um outro olhar, sobre a concepção de tempo, nos dias de hoje, ou seja uma proposta de ecologia temporal, com perspectivas hedonistas, que ganhará melhores condições temporais para a existência quotidiana. Na verdade, esta ecologia acabará por destruir o principal entrave à concepção de uma nova organização social e pessoal. $O$ quadro, que constitui a representação colectiva de um tempo fundamental único, mantido e posto ao serviço pela sociedade industrial mecanizada, tornou-se anacrónico, paralisa toda a iniciativa de envergadura, condena os espíritos à errância, os projectos políticos à insignificância ou à estagnação. Ao desenvolvimento da automação, da robotização, da informática correspondem novos utensílios de pensamento, uma nova visão das relações sociais, uma ética garantindo a todos, na equidade, o acesso a tempos escolhidos (cfr. GROSSIN, William - Pour une science des temps. Introduction à l'écologie temporelle. Toulouse: Octares, 1996, p. 247). 
O que é um relógio? Um instrumento que transforma uma energia potencial em energia cinética, organizando regularmente o débito desta última. Para que os tempos produzidos pelos relógios sejam concordantes, escolheu-se um modelo comum. O movimento dos astros forneceu-o há muito tempo. Os relógios reproduziram pois, tão fielmente quanto possível, um tempo celeste julgado perfeito. Mudou-se várias vezes de referência astral, depois foram sendo descobertas melhores periodizações ${ }^{29}$. A qualidade do instrumento de medida e a sua referência têm aqui uma importância menor. É a aplicação mensural do tempo do relógio produzida ou reproduzida que constitui o problema. Na medida em que este é regular, homogéneo, contínuo, ele só pode medir tempos que o são também. Dito de outro modo, o relógio aplica-se sobre os tempos que são descontínuos, irregulares, não homogéneos, quer dizer todos os outros. O relógio não dá uma medida. O relógio opera uma assimilação. Distinguir um tempo mensural de uma realidade pretensamente mensurada, é já recusar a unicidade do tempo. Ou seja, existem tempos que não podem ser assim medidos, porque se caracterizam pela sua incomensurabilidade.

Serve este diminuto comentário para recordar que o pombalismo está presente na génese de uma cultura temporal que vai corresponder à expansão da indústria mecanizada, ao tempo do relógio, hipertrofiado em detrimento de outros, desconhecidos, mal conhecidos ou perdidos de vista, tendendo a impor-se em tudo e por tudo. Ele influencia fortemente as atitudes e os comportamentos. A vida pessoal e social sofre os efeitos de um envolvimento temporal demasiado fabricado ${ }^{30}$. Nesta interpretação, o pombalismo coloca um termo ao tempo personificado.

Mas, o tempo é, com o Marquês de Pombal, também expressão de um fenómeno, o terramoto de 1755 , que produz o seu tempo, do mesmo modo que fenómenos análogos produzem tipos de tempos que lhe são próprios. As qualidades de tal tempo - homogéneo ou descontínuo, por exemplo - avaliam-se em comparação com as de tal outro tempo - irregular ou ritmado, por exemplo - provenientes de tal outro fenómeno. O tempo de um fenómeno supõe modificação em curso, actividade, movimento. "O fenómeno é o facto em movimento, é a passagem de um facto a um outro" ${ }^{\prime \prime}$.

${ }^{29} \mathrm{O}$ movimento de rotação da terra, cerca de 24 horas, mas a terra não é um relógio perfeito, porque a velocidade de rotação varia ligeiramente, como um relógio que tanto se adianta como se atrasa.

${ }^{30}$ Cfr. GROSSIN, William - Pour une science des temps..., pp.16-53.

${ }^{31}$ LALANDE, André - Vocabulaire technique et critique de la philosophie. Paris: PUF, 1960, p. 795 . 
Desta relação do tempo com o sismo resulta que o tempo produzido pelo fenómeno tem tanta realidade como o próprio fenómeno. Não se consegue abstrair. Não podemos vê-lo como uma simples imagem da mobilidade ou um número puro, o número do movimento ou de toda a medida convencional. Existe pois tanto de tempo como de fenómeno. No mínimo, isto significa que um só fenómeno pode produzir vários tempos, sucessivamente ou simultaneamente. Associar os tempos aos fenómenos que os produzem conduz ao reconhecimento da sua multiplicidade e da sua diversidade ${ }^{32}$. Quer isto dizer que um só fenómeno pode produzir vários tempos, de que é exemplo o inquérito pombalino, ou seja, ao longo de todo o reino um só fenómeno exprimindo vários tempos.

Percebe-se bem a importância do tempo do relógio na sua articulação com o tempo do sismo. Sebastião José de Carvalho e Melo prepara a modernidade que intuía. Paradigmático nos "inquéritos" ao sismo, inscreve aí um outro paradigma, o do tempo do número, que irá marcar a sociedade futura, o que nos conduz a outra variante a ter em apreço: o exercício do poder.

Embora umas "espécies de tempo" sejam mais naturais que outras, e usualmente o "tempo do relógio" seja olhado como artificial, comparado com a mais "natural" percepção subjectiva do tempo ou da temporalidade que resulta de certas adaptações aos ritmos sazonais e outros condicionalismos ambientais ou biológicos ${ }^{33}$, o facto é que o "tempo do relógio" marca o início de uma transformação vital na maneira de olhar a temporalidade. Com efeito, o "movimento obedece a uma lei matemática. $\mathrm{O}$ tempo e o espaço estão ligados pela lei do número"34.

Na sequência das mudanças produzidas no século XVII, a necessidade de uma outra medição do tempo é uma ocorrência que se articula e adequa a uma duração infinita e a um espaço infinito. Na verdade, as mutações produzidas pela revolução do século anterior ao de setecentos assentam em dois elementos cruciais: a destruição do cosmos e a geometrização do espaço. Ou seja, como afirma Koyré, " $a$ ) a destruição do mundo concebido como um todo finito e bem ordenado (...) e a substituição deste por um universo indefinido, e até mesmo infinito (...) unido apenas pela identidade das leis que o regem (...); b) a substituição da concepção aristotélica do espaço, conjunto diferenciado de locais intramundanos, pela geometria euclidiana - extensão homogénea e

${ }^{32}$ Cfr. GROSSIN, William - Pour une science des temps..., pp. 229.

${ }^{33}$ Cfr. ELCHARDUS, Mark - The Rediscovery of Chronos: The New Role of the Time in Sociological Theory. Brussel: VUB, Centrus voor Sociologie, [1987], p. 10.

${ }^{34}$ KOYRÉ, Alexandre - Estudos Galilaicos. Lisboa: Dom Quixote, 1986, p. 361. 
necessariamente infinita -, daqui em diante considerada como idêntica, na sua estrutura, ao espaço real do universo" 35 .

Unido a este horizonte científico, o tempo é talvez, entre os aspectos de uma cultura, aquilo que melhor caracteriza a natureza. Ele é a incarnação, ele está ligado à concepção do mundo de uma época, ao comportamento dos indivíduos, à sua consciência, ao seu ritmo vital, às suas relações com as coisas ${ }^{36}$. "Até à época capitalista, diz Gourevitch, o tempo foi sempre local. Não existia, com efeito, a medida do tempo único para os territórios extensos e menos ainda para os Estados e regiões mais vastas. O particularismo da vida social aparecia também nos sistemas de cálculo de tempo. Ele sobreviveu ainda muito tempo, mesmo depois da passagem à medida mecânica do tempo, cada vila possuía o seu próprio tempo. Mas este novo meio de determinação do tempo torna possível a sua unificação e os governos, tomando o controlo do tempo, impuseram, como única exacta, a sua própria hora a todos os súbditos. O tempo local separava, enquanto que o tempo do Estado, depois o dos fusos horários, se tornou um meio de união, de reforço dos laços. É assim que nasce uma temporalidade única"37.

Neste sentido, pode afirmar-se que no pombalismo existe uma evidente percepção de como governar a sociedade, que se articula com uma nova noção de tempo, que já não se rege pelo sino do campanário mas pelo relógio da torre, i.e., um tempo que se adequa ao espaço físico, mas sobretudo ao espaço das relações e, obviamente, da comunicação e da informação.

A heterogeneidade qualitativa do espaço é substituída por uma homogeneidade, a física dos espaços suprida pela física das relações, do mesmo modo que a medição do tempo canónico é trocada pela medição mecânica do tempo. E uma nova noção de tempo que suscita uma nova distribuição da linguagem, facilitando as trocas, o progresso do saber, o exercício do poder. A homogeneidade do tempo torna, assim, possíveis novas formas de comunicação e outros tempos de informação, isto é, imaginar e informar, factos e acontecimentos, liberdade e autenticidade.

É uma noção que se inclui num projecto de universalização das relações económicas, sociais e políticas e de poder, da qual faz parte uma "revolução" na nova maneira de medir o tempo que se integra e articula nas trocas, no capital, no mercado, no trabalho e na amplificação do saber, uma nova concepção de tempo que se torna tributária dos interesses da produção e do exercício do poder, logo da comunicação e da informação, em que se pressente, também, o interesse na vocação em servir a sociedade.

${ }^{35}$ KOYRÉ, Alexandre - Do mundo fechado ao universo infinito. Lisboa: Gradiva, D.L. 1987, p. 7.

${ }^{36}$ Cfr. GOUREVITCH, Aaron. J. - Les catégories de la culture médiévale. Paris, Gallimard, 1983, p. 96.

${ }^{37}$ Idem, ibidem, p. 154. 
Tornando-se universal no meio de todas as mudanças, a nova concepção de medida do tempo (englobando e articulando simultaneidade, sucessão, duração e passado, presente e futuro, em que cada instante é o resumo de um espaço) determina vários espaços que vão do físico ao histórico. Aqui, o espaço técnico-económico não coincide com o espaço político, nem com o espaço cultural. A nova medida do tempo integra-os em função da globalidade/pluralidade do espaço que, circunscrito pela homogeneidade do tempo, melhor transforma a natureza em força produtiva e hierarquiza e maximiza a sua utilização com o concurso activo ou passivo de diversos agentes.

Trata-se de uma reorganização (de que o próprio inquérito mandado efectuar por Pombal é um exemplo paradigmático) das funções políticas, sociais, administrativas, etc., entre as diferentes fracções do território. Cada ponto do espaço torna-se pois importante em poder e nos factos, uma via de especialização na utilização do território, seja ela de origem natural ou cultural, ou provenha de intervenções políticas e técnicas, especialização que é significado de uma redescoberta da natureza ${ }^{38}$.

A partir do momento em que a natureza se define de nova maneira e se renovam as suas relações com o homem, uma nova noção de medida do tempo é necessária, instrumento de uma outra crescente solidariedade entre momentos e lugares. Se o tempo é organizado em torno de acções e estas acções formam uma sequência cujo significado aparece no tempo e dá ao tempo um significado, então, numa espécie de "paradoxo dialéctico", que torna possível a visão histórica, o significado das acções mostra-se fora do tempo ${ }^{39}$.

Nesta interpretação, o inquérito pombalino acerca do sismo de 1755 dá ao tempo uma outra significação, que não a intimamente escatológica, mas antes a de uma nova concepção da temporalidade ${ }^{40}$, em harmonia com um outro mundo de vida que se avizinha e a mudança de paradigma político que se anuncia.

${ }^{38}$ Cfr. SANTOS, Milton - "La géographie à la fin du XXe siècle: les nouveaux rôles d'une discipline menacée". Revue Internationale de Sciences Sociales. L'epistémologie des sciences sociales: Statut scientifique, valeurs et institutionnalisation. 102. Vol. XXXVI (4-1984), Paris: UNESCO, 1984, pp. 691-707.

${ }^{39}$ Cfr. POCOCK, John Greville Agard - Machiavellian Moment: Florentine Political Thought and the Atlantic Republican Tradition. Princeton: Princeton University Press, 1975, p. 31.

${ }^{40}$ Se a Revolução Francesa inventa a centralidade do corpo da modernidade, cria o direito da naturalidade (o de nascer num território) e as garantias dos direitos que lhe assistem, colocando em causa todos os outros direitos anteriores, nos quais assentava o poder da aristocracia, contribuindo, assim, para a consolidação histórica do Estado moderno), então, podemos dizer que o tempo do relógio, antecipando-se, concebe o direito da temporalidade (o de nascer em determinada hora), que preconiza uma nova visão do mundo, o da modernidade que se aproxima. 


\title{
Nowera i \\ WREAB CONSTMUCIONAT:

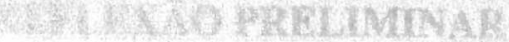

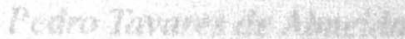

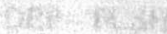

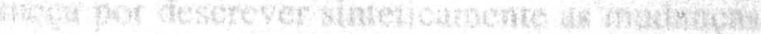

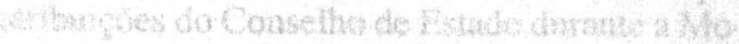

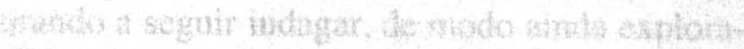

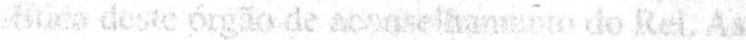

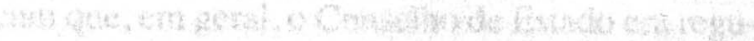

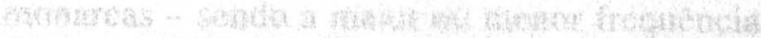

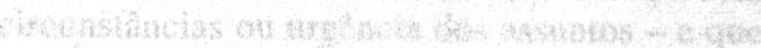

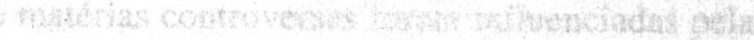

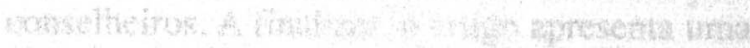

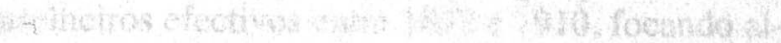

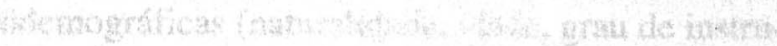

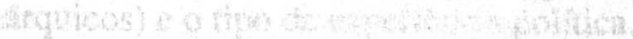

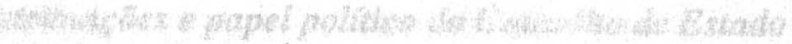

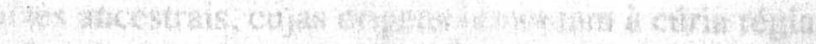

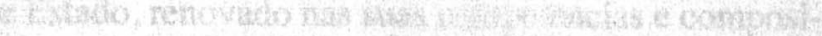

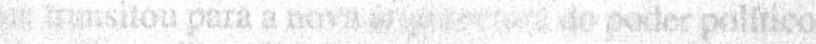

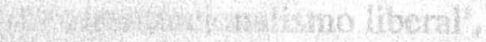

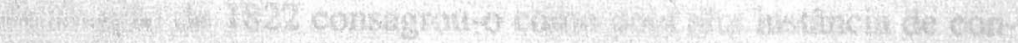

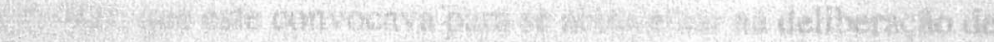

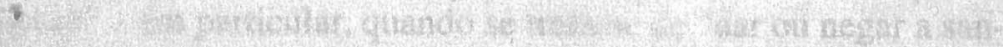

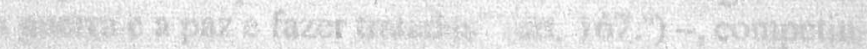

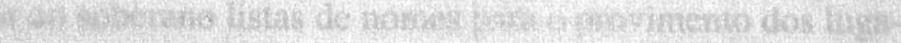

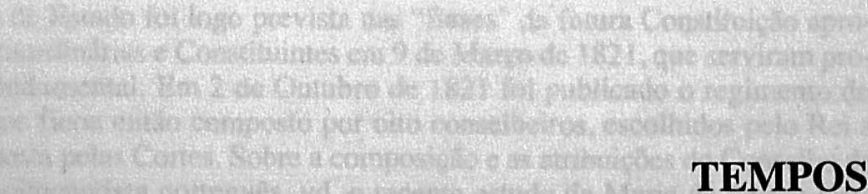




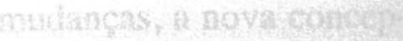

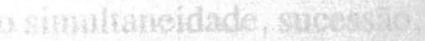
wich instakte é p restumo desula

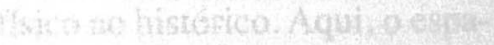
Whar whico, nem con prespon

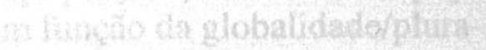
mateidade do tempo mellog

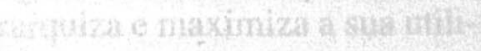
Whatis arentes.

if 9 pripho inquerio mandido

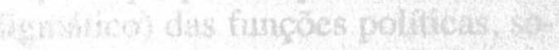

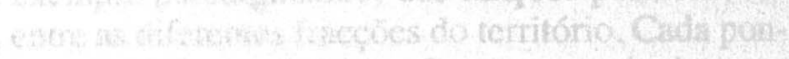

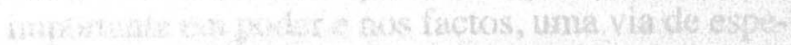

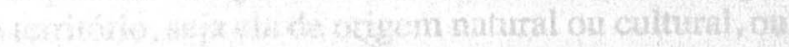

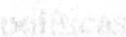

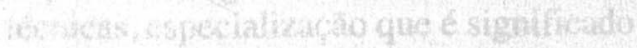

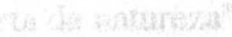

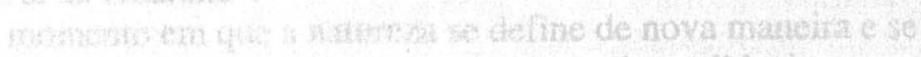

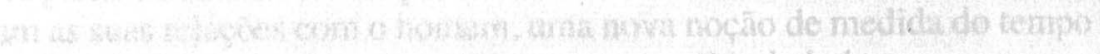

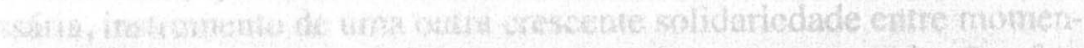

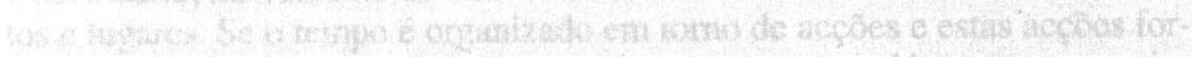

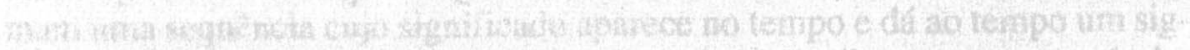

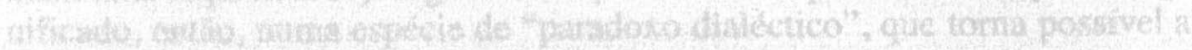

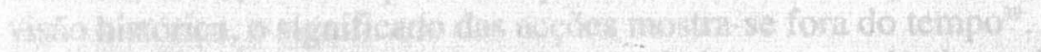

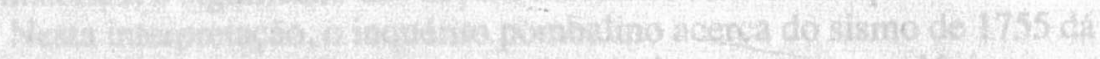

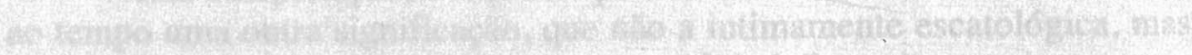

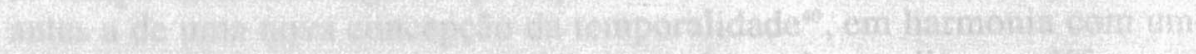

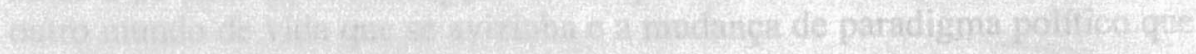

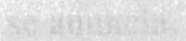

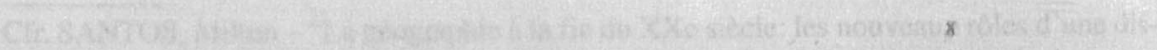

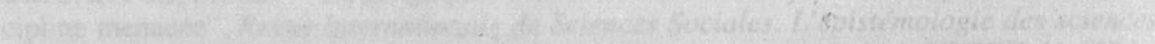

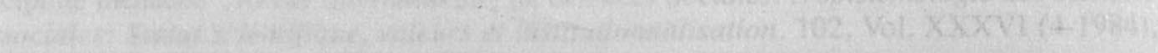

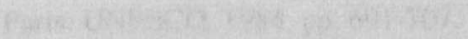

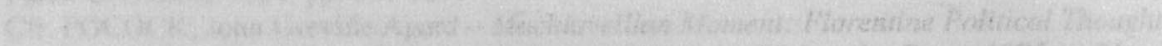

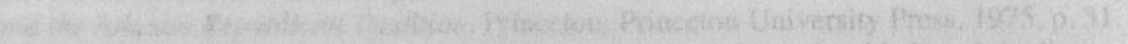

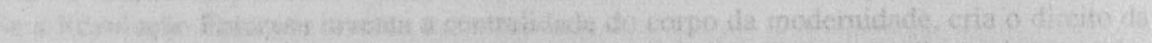

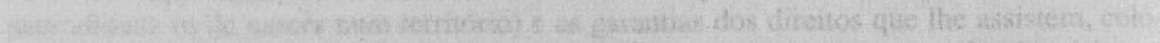

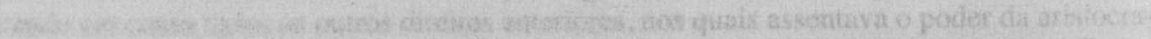

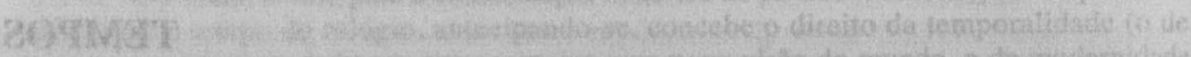

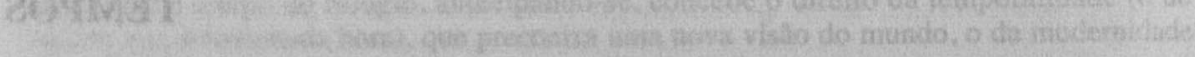




\title{
O CONSELHO DE ESTADO NA MONARQUIA CONSTITUCIONAL: UMA REFLEXÃO PRELIMINAR
}

\author{
Pedro Tavares de Almeida \\ DEP - FCSH
}

O presente artigo começa por descrever sinteticamente as mudanças observadas na composição e atribuições do Conselho de Estado durante a Monarquia Constitucional, procurando a seguir indagar, de modo ainda exploratório, qual foi a relevância política deste órgão de aconselhamento do Rei. As informações recolhidas indicam que, em geral, o Conselho de Estado era regularmente convocado pelos monarcas - sendo a maior ou menor frequência ditada pela gravidade das circunstâncias ou urgência dos assuntos - e que várias decisões régias sobre matérias controversas foram influenciadas pela opinião maioritária entre os conselheiros. A finalizar, o artigo apresenta uma biografia colectiva dos conselheiros efectivos entre 1833 e 1910 , focando algumas características sociodemográficas (naturalidade, idade, grau de instrução, profissão, títulos nobiliárquicos) e o tipo de experiência política.

\section{Composição, atribuições e papel político do Conselho de Estado}

Instituição com raízes ancestrais, cujas origens remontam à cúria régia medieval, o Conselho de Estado, renovado nas suas competências e composição, foi um dos órgãos que transitou para a nova arquitectura do poder político desenhada pelo constitucionalismo liberal ${ }^{1}$.

A Constituição de 1822 consagrou-o como uma alta instância de consulta privada do Rei, que este convocava para se aconselhar na deliberação de "negócios graves" - em particular, quando se tratasse de "dar ou negar a sanção às leis, declarar a guerra e a paz e fazer tratados" (art. 167. .) -, competindo-lhe ainda propor ao soberano listas de nomes para o provimento dos luga-

\footnotetext{
A criação do Conselho de Estado foi logo prevista nas "Bases" da futura Constituição aprovadas pelas Cortes Extraordinárias e Constituintes em 9 de Março de 1821, que serviram provisoriamente de Lei fundamental. Em 2 de Outubro de 1821 foi publicado o regimento do Conselho de Estado, que ficou então composto por oito conselheiros, escolhidos pelo Rei a partir de uma lista proposta pelas Cortes. Sobre a composição e as atribuições do Conselho de Estado no liberalismo oitocentista português, vd. o recente estudo de Maria da Glória Dias Garcia, Do Conselho de Estado ao actual Supremo Tribunal Administrativo', Lisboa, Supremo Tribunal Administrativo, 1998.
} 
res da magistratura e dos bispados. Os treze membros que formavam esta corporação consultiva, recrutados "entre as pessoas mais distintas por seus conhecimentos e virtudes", que tivessem no mínimo 35 anos de idade, eram escolhidos pelo Rei a partir de listas tríplices propostas pelas Cortes. Os conselheiros eram nomeados por um período de quatro anos, findo o qual podiam ser reconduzidos, desde que incluídos nas novas listas saídas das Cortes. Como é sabido, o ordenamento constitucional vintista teve, no entanto, uma efémera duração, sendo desmantelado a seguir ao triunfo do movimento contra-revolucionário da Vilafrancada (Maio de 1823).

$\mathrm{Na}$ Carta Constitucional de 1826, o Conselho de Estado ressurgiu como órgão consultivo do monarca, mas com um figurino alterado. Para além de um membro de direito próprio (o Príncipe Real, assim que completasse dezoito anos), era constituído por conselheiros vitalícios nomeados livremente pelo Rei, deixando assim de ser uma emanação das Cortes. A norma constitucional não estabelecia qualquer requisito na selecção dos conselheiros (excepto a interdição imposta à nomeação de estrangeiros, mesmo que naturalizados) e era igualmente omissa quanto ao seu número, mas este foi fixado em doze pelo Decreto de 19 de Setembro de 1833, que lhes atribuiu também um ordenado de $2.400 \$ 000$ réis anuais. Em virtude da consagração do "princípio monárquico", ainda que limitado por instituições representativas, a Carta ampliou as funções de assistência política do Conselho de Estado:

"Os Conselheiros serão ouvidos em todos os negócios graves, e medidas gerais de Pública Administração, principalmente sobre a declaração da guerra, ajustes de paz, negociações com as Nações Estrangeiras, assim como em todas as ocasiões, em que o Rei se proponha exercer qualquer das atribuições próprias do Poder Moderador" (art. 110. ${ }^{\circ}$ ). [itálico nosso]

Assim, com a excepção (formal, pelo menos) da nomeação e demissão dos ministros, a auscultação dos conselheiros tornou-se obrigatória aquando da sanção régia das leis votadas nas Cortes, da nomeação de pares do reino, da dissolução da Câmara dos Deputados e da convocação extraordinária, prorrogação ou adiamento das Cortes. Além disso, devido à intimidade das funções dos poderes moderador e executivo ${ }^{2}$, os actos correntes deste último podiam ser objecto da consulta do Rei ao Conselho de Estado, apesar de a norma constitucional o não prever $^{3}$.

2 Segundo a Carta Constitucional, " o Poder Moderador [...] compete privativamente ao Rei" (art. $\left.710^{\circ}\right)$ e "o Rei é o chefe do Poder Executivo, e o exercita pelos seus ministros de Estado" (art. 75..$^{\circ}$.

3 Vd., em especial, José Tavares, $O$ poder governamental no direito constitucional portuguez, Coimbra, Imprensa Académica, 1909, pp. 244 e 248-249, e Jorge Miranda, Conselho de Estado, Coimbra, Atlântida, 1970, p. 5. 
Ultrapassado o curto interregno setembrista, em que foi não só revogada a Carta como abolido o Conselho de Estado, este retomou a sua anterior posição no ordenamento constitucional, conhecendo embora uma importante reforma em $1845^{4}$, que alargou as suas competências legais e modificou a sua organização interna. Assim, a par da manutenção das anteriores funções eminentemente politicas, o Conselho de Estado passou a exercer competências puramente administrativas e tornou-se a instância suprema da jurisdição contenciosa da Administração. Para responder a essas novas exigências, de índole mais técnica, criaram-se os lugares de conselheiro extraordinário (doze, no máximo), a serem preenchidos por reputados juristas, e de ouvidor (até dezoito), confiados a bacharéis formados em Direito. O Conselho de Estado político funcionava separadamente das secções administrativa e do contencioso, em reunião plenária dos vogais efectivos - desde que houvesse um quorum de 2/3 -, sob a presidência do Rei.

Simetricamente, a reforma que teve lugar em 1870 voltou a confinar o Conselho de Estado, agora de modo definitivo, às suas atribuições políticas 5 . A jurisdição contenciosa foi, então, transferida para o recém-criado Supremo Tribunal Administrativo, ao passo que as funções propriamente administrativas foram consignadas ao Procurador-Geral da Fazenda e da Coroa. Se estas últimas, segundo o testemunho informado de Joaquim Tomás Lobo de Ávila, e no que respeita sobretudo "a preparar propostas de lei, e a fazer projectos de

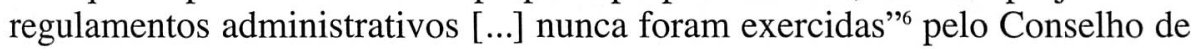

${ }^{4}$ As bases desta reforma foram estabelecidas na Lei de 3 de Maio de 1845, sendo depois concretizadas pelo Regimento de 16 de Julho desse ano; uma regulamentação definitiva, que introduziu apenas algumas alterações de pormenor, seria decretada em 9 de Janeiro de 1850 ( $v d$. Joaquim Tomás Lobo de Ávila, Estudos de Administração, Lisboa, Typ. Universal, 1874, pp. 279-283, e Regulamento do Conselho de Estado..., Lisboa, Imprensa Nacional, 1850). De assinalar que, na mesma altura, se estabeleceu em Espanha, pela Lei de 6 de Julho de 1845, o Consejo Real (a partir de 1858 designado Consejo de Estado), um órgão supremo de consulta para os assuntos administrativos e do contencioso (vd. Tomás Ramón Fernández e Juan Alfonso Santamaria, compil., Legislación administrativa española del siglo XIX, Madrid, Instituto de Estudios Administrativos, 1977, pp. 155-156, e Juan Ramón Fernandez Torres, La formación historica de la jurisdicción contencioso-administrativa (1845-1868), Madrid, Editorial Civitas, 1998, pp. 265 e segs.). [Agradeço a Javier Moreno Luzón as informações bibliográficas sobre o Conselho de Estado em Espanha].

${ }^{5}$ Reforma decretada em 9 de Junho de 1870 . Em finais de 1868, num contexto de crise financeira que recomendava a contenção das despesas públicas, um decreto datado de 31 de Dezembro determinara a redução de doze para oito do número de conselheiros efectivos, a concretizar-se à medida que fossem ocorrendo vacaturas. Esta medida tornou-se desnecessária a seguir à reforma de 1870 , uma vez que os conselheiros efectivos deixaram de ser remunerados. Assinale-se, uma vez mais, a sincronia com as reformas institucionais realizadas em Espanha: em finais de 1868, a jurisdição contenciosa foi transferida do Consejo de Estado para o Tribunal Supremo.

6 José Tavares, ibidem, p. 284. 
Estado, já quanto ao contencioso o seu labor foi intenso, estabelecendo uma importante jurisprudência na matéria?

No contexto europeu oitocentista, e mormente após a reforma de 1870, o Conselho de Estado português parece configurar uma instituição relativamente singular. Essa é, aliás, a conclusão do estudo comparativo feito pelo constitucionalista José Tavares no início do século XX:

"É interessante que, a não ser na Inglaterra, não há nos outros países, pelo menos nas Constituições do nosso conhecimento, instituição análoga ao nosso Conselho de Estado.

Há em quase todos, incluída a República Francesa, um Conselho de Estado. Não é, porém, um órgão de consulta e informação política do Chefe do Estado. É simplesmente um corpo administrativo de consulta do ministério, e contencioso administrativo para a resolução das questões suscitadas entre os cidadãos e a administração pública. É o nosso Supremo Tribunal Administrativo.

O Privy Council inglês foi outrora uma instituição quase idêntica, pelas suas funções, ao nosso Conselho de Estado; e foi de lá certamente que derivou a nossa instituição. [...] Mas, como diz Bruníalti, pode afirmar-se que os [seus] membros têm hoje o único oficio de adornar com o seu nome o anuário oficial. [...]

Na Espanha existiu também, vindo já do Antigo Regime, o Conselho de Estado político; mas está hoje transformado em órgão de consulta administrativa e tribunal supremo do contencioso administrativo.

Pode pois dizer-se que Portugal é o único país onde o Conselho de Estado político conserva a sua especial feição [...] "»"

Acrescente-se, porém, que no Brasil Imperial, em particular durante o Segundo Reinado (1840-1889), o Conselho de Estado, embora também desempenhasse importantes funções administrativas, tinha uma grande relevância política, sendo mesmo designado por um contemporâneo como o "cérebro da monarquia" .

Mas qual foi, afinal, o papel político efectivo do nosso Conselho de Estado? O Rei alinhava sempre com a opinião maioritária entre os seus conse-

\footnotetext{
Vd. José Silvestre Ribeiro, compil. e anot., Resoluções do Conselho de Estado na secção do contencioso administrativo, 18 vols., Lisboa, Imprensa Nacional, 1854-1874.

8 Ob. cit., pp. 246-248. Para um aprofundamento do estudo comparado, vd. E. Laferrière, "Conseil d'Etat", in Maurice Block, dir., Dictionnaire générale de la politique, I, Paris, O. Lorenz Libraire-Editeur, 1873, pp. 470-480; Almeric Fitzroy, The history of the Privy Council, Londres, J. Murray, 1928; José Maria Cordero Torres, El Consejo de Estado. Su trayectoria y perspectivas en España, Madrid, Instituto de Estudios Políticos, 1944; Marie-Christine Kessler, Le conseil d'Etat, Paris, A. Colin, 1968; e AAVV, Studi per il centocinquantenario del Consiglio di Stato, 3 vols., Roma, Instituto poligrafico e Zecca del Stato, 1981.

9 A expressão de Joaquim Nabuco é citada pelo historiador José Murilo de Carvalho, que também sustenta ser o Conselho de Estado a "organização estratégica para se estudar o pensamento da elite política do Império" (in Teatro de sombras: a política imperial, Rio de Janeiro, Edições Vértice, 1988, p. 107).
} 
lheiros? E estes últimos eram um grupo de "espíritos políticos com maturidade e vigorosos", com uma intervenção activa na vida pública, ou, pelo contrário, exerciam o cargo a título honorífico, como "uma recompensa pelos serviços prestados, uma espécie de sinecura para a velhice" ${ }^{10}$ ?

Começando por aflorar este último aspecto, basta percorrer a lista dos conselheiros para nos apercebermos imediatamente que a maioria não só tinha um longo tirocínio parlamentar e ministerial, como continuava activa na "política militante", como se dizia na época. De facto, a prática constitucional conduziu a que a sua "quase totalidade [fosse] sempre constituída por políticos em evidência" "11, com destaque para os principais vultos partidários ${ }^{12}$. A escolha dos putativos conselheiros era, aliás, um momento propício à intriga e às manobras políticas de bastidores. Quando ocorria uma vacatura, por motivo de morte, era comum o Rei ser confrontado com uma proposta do Governo em exercício, sobretudo se a relação de forças no seio do Conselho de Estado the era desfavorável, ou com as pretensões de políticos com ambições pessoais. Por vezes, a própria apresentação de um nome pelo Governo era motivo de celeumas intestinas, como sucedeu em 1887 com a escolha do conde de S. Januário ${ }^{13}$. Nem sempre, porém, o Rei atendia a essas sugestões ou cedia às pressões individuais. Em Outubro de 1857, D. Pedro V recusou liminarmente a nomeação de Passos Manuel, que tinha sido indicado pelo Governo da altura ${ }^{14}$. Quase três anos depois, e logo a seguir ao falecimento de José Jorge Loureiro, Fontes Pereira de Melo apressou-se a escrever ao Rei a apresentar a sua candidatura para a vaga em aberto, mas $\mathrm{D}$. Pedro V, que já não nutria especial simpatia pelo então ministro do Reino, e muito menos apreciou a "forma abrupta de pedir o que não é costume pedir" ${ }^{\prime 5}$, preferiu nomear o visconde de Sá da Bandeira.

Para contrariar a reconhecida tendência para a politização dos critérios

${ }^{10}$ Expressões pedidas de empréstimo a Johann K. Bluntschli, Le droit public général, Paris, Librairie Guillaumin, 1881, p. 179.

"José Tavares, ibidem, p. 244.

${ }_{12}$ A título de exemplo, refira-se que uma vez consumada a ascensão de José Luciano de Castro à chefatura máxima do Partido Progressista (1885), a primeira vaga aberta no Conselho de Estado foi preenchida com o seu nome. Alguns anos mais tarde, o próprio Luciano de Castro recordou que fora "justamente na qualidade de chefe daquele partido, [que] havia sido nomeado conselheiro de Estado pelo Rei" (in Actas do Conselho de Estado, IAN/TT, Livro 5, sessão de 7 de Novembro de 1893).

${ }^{13}$ Os ecos desse conflito chegam-nos através de uma carta inédita de José Luciano de Castro para o seu correligionário Mariano de Carvalho, datada de 21 de Julho de 1887 (Espólio Mariano de Carvalho, Biblioteca Nacional de Portugal).

${ }_{14}$ Vd. Júlio de Vilhena, D. Pedro V e o seu reinado, II, Coimbra, Imprensa da Universidade, 1921, pp. 424-427.

${ }_{15}$ Carta de D. Pedro V ao visconde da Luz, de 3 de Julho de 1860 (transcrita in Júlio de Vilhena, ibidem, p. 90). 
de selecção dos membros do Conselho de Estado, que devia ser uma instituição acima das "paixões partidárias", foram feitas algumas propostas de alteração da sua composição, que nunca chegaram a concretizar-se. Em 1876, no manifesto programático do Partido Progressista, acenava-se com uma futura reorganização em que $2 / 3$ dos conselheiros seriam indivíduos que exercessem elevadas funções públicas, a designar por lei, e os restantes seriam escolhidos pelo Governo "entre pessoas de reconhecido mérito e capacidade". Três décadas depois, Trindade Coelho preconizaria uma solução semelhante, em que os conselheiros seriam recrutados entre "as sumidades hierárquicas da administração civil, da magistratura, das altas corporações docentes e científicas”, ou, em alternativa, escolhidos pelas Cortes, como na antiga fórmula vintista ${ }^{16}$.

Decorrente do carácter vitalício do cargo e do limitado número de titulares, os longos anos de permanência em funções de vários conselheiros e os seus conhecidos vínculos político-partidários eram factores que determinavam uma certa previsibilidade e estabilidade das opiniões veiculadas pelo Conselho de Estado ${ }^{17}$. O recordista absoluto foi António Bernardo da Costa Cabral, que apenas com uma breve interrupção de um ano, por ter sido demitido (um caso excepciona ${ }^{18}$ ), se manteve no Conselho de Estado durante 44 anos. Segue-se-lhe o duque de Saldanha, que exerceu o cargo durante cerca de 37 anos, mas com uma interrupção na vigência da Constituição setembrista, e António José de Ávila (futuro duque de Ávila e Bolama), que permaneceu em actividade perto de 30 anos consecutivos.

A influência real, concreta, do Conselho de Estado no processo político é ainda um assunto por desvendar, e tem sido um tema praticamente ignorado pela historiografia contemporânea. A razão de ser deste desinteresse ou silêncio historiográfico não se deve tanto, supomos, à desvalorização apriorística de um órgão tido como uma espécie de ornamento constitucional supérfluo, mas ao facto de serem muito escassas e dispersas as informações sobre a sua actividade publicadas quer na imprensa, quer na literatura política e memorialística da época. Além disso, os próprios livros de actas do Conselho de Estado, actualmente à consulta nos arquivos da Torre do Tombo, não só formam uma série incompleta ${ }^{19}$, como as súmulas que fornecem das reuniões são em geral parcimoniosas e discretas.

${ }_{16}$ Manual politico do cidadão portuguez, Lisboa, Parceria A.M. Pereira, 1906, pp. 501-502.

17 Apesar da nomeação a título vitalício dos seus membros, a Câmara dos Pares era muito mais permeável às flutuações de opinião e dos equilíbrios de força, não só pela existência (excepto num curto período) de pares por direito hereditário, mas sobretudo por não haver restrições à nomeação de novos pares (até 1885), o que facilitava as célebres "fornadas".

$18 \mathrm{Vd}$. Clemente José dos Santos, Estatisticas e biographias parlamentares portuguezas, I, Porto, Typ. do "Commercio do Porto", 1887, p. 543.

${ }_{19}$ Os livros de actas do Conselho de Estado (IAN/TT, C.F. 77) compreendem os seguintes períodos: Livro 1 (19.10.1821 a 31.5.1823; 15.11 .1833 a $5.8 .1836 ; 12.2 .1842$ a 20.4.1844); 
O exame dos livros de actas e da própria cronologia das reuniões do Conselho de Estado revela todavia que quando estavam em causa "negócios graves" ou o exercício das atribuições do poder moderador, a audição do Conselho de Estado era um imperativo constitucional normalmente respeitado ${ }^{20}$. Por exemplo, em Outubro de 1858, por ocasião do "ultimato" francês motivado pelo apresamento do navio Charles et Georges, o Conselho de Estado reuniu-se "por assim dizer quase que em sessão permanente"21. Quando estava em jogo a prorrogação das Cortes ou a dissolução da Câmara dos Deputados, também era regularmente ouvido ${ }^{22}$. É, aliás, significativo que em 1870, logo após o pronunciamento militar chefiado pelo duque de Saldanha, este tenha solicitado a convocação do Conselho de Estado para ser decretado o adiamento das Cortes ${ }^{23}$. Se o Rei seguia ou não a opinião veiculada pela "maioria" dos conselheiros, aí as informações são díspares. Eis alguns exemplos. Em Março de 1862, apesar do voto desfavorável da maioria dos seus conselheiros, o rei D. Luís autorizou o pedido de adiamento das sessões das Cortes solicitado pelo chefe do governo, o marquês de Loulé ${ }^{4}$. Contudo, em finais desse mesmo ano, o parecer dos conselheiros parece ter sido crucial na recusa do Rei em aceitar o pedido de demissão apresentado pelo ministro da Guerra, visconde de Sá da Bandeira. Nos começos de 1890, a proposta de dissolução da Câmara dos Deputados apresentada pelo recém-nomeado chefe do governo, António de Serpa Pimentel, foi recusada pela maioria dos conselheiros de Estado; não obstante, a proposta do governante teve a sanção régia ${ }^{25}$. Por sua vez, em finais de 1893, uma maioria tangencial (6 contra 5) no Conselho de Estado

Livro 2 (15.5.1854 a 23.11.1859); Livro 3 (28.7.1860 a 7.4.1865); Livro 4 (29.3.1867 a 30.6.1875); Livro 5 (29.11.1888 a 11.5.1905).

${ }^{20}$ Para uma estatística (ainda incompleta) da frequência anual das reuniões do Conselho de Estado, vd. Quadro 1. Durante o Cabralismo, como denunciou Joaquim António de Aguiar, o Conselho de Estado terá sido "desprezado", não sendo convocado em situações "em que a Carta expressamente o exige" (in Discurso do sr. deputado[...] pronunciado nas sessões de 31 de Outubro, e 2 de Novembro de 1844, Lisboa, Imprensa Nacional, 1845, p. 81).

${ }_{21}$ Vd. Manuel Pinheiro Chagas, dir., Historia de Portugal Popular e Illustrada, XII, Lisboa, Empreza da Historia de Portugal, 1907, p. 142 (volume da autoria de Marques Gomes); esta obra é uma das que contém um maior volume de informações, ainda que dispersas, sobre a acção política do Conselho de Estado. Vd. também Fortunato de Almeida, A questão do apresamento da barca Charles et Georges e o Conselho de Estado, separata da Revista de História, Coimbra, 1917, e Eduardo dos Santos, A questão da barca Charles et Georges, Lisboa, Instituto de Investigação Científica Tropical, 1987, capítulo 5.

22 Por exemplo, entre 31 de Maio e 3 de Julho de 1889, o Conselho de Estado foi auscultado cinco vezes sobre outros tantos pedidos governamentais de prorrogação das Cortes (vd. Actas do Conselho de Estado, Livro 5).

${ }^{23}$ Vd. Actas do Conselho de Estado, Livro 4, sessão de 21 de Maio de 1870

${ }^{24} \mathrm{Vd}$. Actas do Conselho de Estado, Livro 3, sessão de 17 de Março de 1862.

${ }^{25} \mathrm{Vd}$. Actas do Conselho de Estado, Livro 5, sessão de 20 de Janeiro de 1890. 
pronunciou-se a favor da dissolução da câmara electiva, e esta foi decretada pelo $\mathrm{Rei}^{26}$. Na viragem do século, em Junho de 1900, a oposição "quase unânime" dos conselheiros de Estado ao projecto de reforma da Carta apresentado pelo governo progressista de José Luciano de Castro suscitou ao Rei fortes reservas quanto à constitucionalidade de uma revisão antecipada, o que acabou por ditar a queda do executivo ${ }^{27}$.

Este é um balanço ainda muito parcelar e com elementos de prova contraditórios, mas que indicia que as atribuições do Conselho de Estado não eram um mero sofisma ou formalidade constitucional, sem uma tradução política efectiva. Regularmente auscultado pelo Rei, em várias ocasiões o seu papel poderá ter sido determinante na formação da vontade régia. Ser conselheiro de Estado significava, assim, a possibilidade de intervir no topo do processo decisório, privando com o Rei e influenciando as suas atitudes e deliberações.

\section{Prosopografia dos conselheiros de Estado efectivos (1833-1910)}

Desde finais de 1833, quando o Conselho de Estado foi instituído por D. Pedro (Decreto de 19 de Setembro), até ao ocaso da Monarquia em 1910, foram empossados 73 conselheiros efectivos (vd. Quadro 2). Um universo restrito que coincide, em larga medida, com o núcleo central da elite governante do liberalismo monárquico. Traçamos, de seguida, a evolução do perfil sociodemográfico e político desse grupo, diferenciando três subperíodos: 1833-1850; 1851-1890; 1891-1910 (vd. Quadros 3, 4 e 5). Os pontos de viragem intermédios são, por um lado, o início da Regeneração (1851) e, por outro, a crise de 1890-91, dois momentos que implicaram mudanças na dinâmica política e uma renovação parcial da elite governante.

\section{Origem geográfica}

O local de nascimento não é um factor que pré-determine as oportunidades de realização pessoal, nem é, só por si, um indicador consistente do arraigamento do indivíduo a um dado território. Independentemente dos laços familiares e de outros vínculos que prendem um indivíduo à sua terra de natu-

${ }^{26}$ Vd. Actas do Conselho de Estado, Livro 5, sessão de 7 de Novembro de 1893. A consonância entre a opinião da "maioria" no Conselho de Estado e a deliberação régia ocorreu também, por exemplo, nas dissoluções da câmara electiva decretadas em 1900, 1901 e 1904 (vd. Actas do Conselho de Estado, Livro 5, sessões de 25 de Outubro de 1900, 4 de Junho de 1901 e 20 de Abril de 1904)

27 Vd. António Cabral, Cartas d'el rei D. Carlos a José Luciano de Castro, Lisboa, Portugal-Brasil Sociedade Editora, s.d. [1927], p. 263. 
ralidade, as etapas decisivas da sua formação e socialização, que lhe poderão rasgar novos horizontes, processam-se frequentemente alhures; não raro, também, o local de nascimento é meramente acidental, fruto de circunstâncias ocasionais, como sucede, por exemplo, quando os progenitores têm profissões que obrigam a uma constante mobilidade territorial.

Apesar destas limitações, a reconstituição das origens geográficas dos membros da elite governante num dado momento histórico é susceptível de revelar algumas regularidades e tendências significativas que ajudam a compreender as articulações entre espaço e poder político, nomeadamente a dinâmica das relações entre centro e periferia. Através dessa pesquisa é, assim, possível averiguar o grau de centralização ou de descentralização geográfica do recrutamento político, bem como identificar as parcelas do território nacional que são mais favoráveis à gestação de certas carreiras públicas (políticas e administrativas).

Analisando a proveniência geográfica dos conselheiros de Estado, o dado mais saliente é a indiscutível primazia de Lisboa (e arredores) como espaço de recrutamento (37,5\% do total). Particularmente expressiva durante o período da "longa" Regeneração (1851-1890), a hegemonia da capital sofre todavia uma quebra significativa nas duas últimas décadas do regime monárquico. A comparação com os padrões de recrutamento geográfico de outros subgrupos da elite governante (ministros, pares do reino, deputados, directores-gerais, governadores civis) revela que quanto mais elevados e selectivos são os cargos políticos, maior é também a tendência para se acentuar o peso relativo dos lisboetas ${ }^{28}$, mercê da fixação e concentração na primeira cidade do país das famílias de estrato social mais elevado - assim, por exemplo, as antigas famílias aristocráticas, pelo menos desde o século XVIII, e diversamente do que sucedia em outros países europeus, residiam todas na capital, onde edificaram as suas residências permanentes ${ }^{29}$. Entre os conselheiros oriundos de Coimbra, o pólo universitário e o segundo mais importante viveiro de recrutamento, ainda que tendencialmente em declínio, importa assinalar que alguns deles provinham de meios familiares ligados à vida académica local: o visconde de Algés era neto de um antigo reitor e filho de um doutor em Leis; António de Serpa Pimentel era filho de um lente de Direito; e Augusto César Barjona de Freitas, ele próprio professor de Direito, era também filho e sobrinho de lentes universitários.

${ }_{28}$ Vd. Pedro Tavares de Almeida, A construção do Estado Liberal. Elite política e burocracia na Regeneração (1851-1890), mimeo., Lisboa, FCSH-UNL, 1995, Parte I.

${ }^{29} \mathrm{Vd}$.Adrien Balbi, Essai statistique sur le royaume de Portugal..., Paris, Rey et Gravier, 1822, p. 163, e Nuno Gonçalo Monteiro, "Poder senhorial, estatuto nobiliárquico e aristocracia", in José Matoso, dir., História de Portugal, IV, Lisboa, Círculo de Leitores, 1993, p. 372. 


\section{Perfil etário}

Posicionado junto ao vértice da hierarquia política, com funções de aconselhamento do monarca, o Conselho de Estado era naturalmente formado por personalidades com uma larga experiência de serviço público, o que implicava em geral que fossem escolhidas num escalão etário mais velho ${ }^{30}$. Por esse motivo, e mercê também do carácter vitalício do cargo, os conselheiros de Estado eram, conjuntamente com os membros do pariato, o subgrupo da elite política onde eram mais acentuadas as tendências gerontocráticas.

Entre 1833 e 1850, a idade média à data da nomeação situa-se nos 55 anos; entre 1851 e 1890 sobe para os 59 anos; e de 1891 a 1910 regride para os 56 anos. No primeiro período, onde $1 / 4$ dos conselheiros tem menos de 50 anos, a relativa juventude do perfil etário reflecte a emergência de uma elite governante radicalmente nova, no contexto de implantação do regime liberal. No período seguinte, sob o signo do consenso e estabilidade da Regeneração, os critérios de selecção tendem a favorecer uma maior veterania. Já a recomposição da elite política suscitada pela crise de 1890-91 veio favorecer o rejuvenescimento do Conselho de Estado.

Particularizando um pouco as idades dos conselheiros à data da sua nomeação, verifica-se que os dois mais novos são João Franco, que ascendeu ao cargo com apenas 39 anos, e António Bernardo da Costa Cabral, que tinha 40 anos. Com menos de 45 anos, só foram nomeados mais sete: Lopo Vaz (41 anos); o marquês de Saldanha, o duque da Terceira e Ernesto Hintze Ribeiro (todos com 42 anos); José António Guerreiro (43 anos); José Bernardo da Silva Cabral e António José de Ávila (ambos com 44 anos). Olhando o reverso da medalha, uma dezena de indivíduos ingressou no Conselho de Estado já no crepúsculo da vida: um octogenário (João Baptista de Andrade, com 81 anos) e nove septuagenários - João de Sousa Pinto de Magalhães (78 anos); Fernando Sousa Barradas, João Crisóstomo de Abreu e Sousa, António Sá Brandão e Luís Gomes da Costa (75 anos); o marquês do Funchal (73 anos); José Marcelino de Sá Vargas (72 anos); o visconde da Carreira (71 anos); e o conde do Sobral (70 anos).

\section{Credenciais académicas}

Num interessante estudo sobre a elite política do Brasil imperial, e a propósito das suas elevadas credenciais académicas, o historiador José Murilo de Carvalho define-a como "uma ilha de letrados num mar de analfabetos"

${ }^{30}$ De assinalar que o Regulamento do Conselho de Estado de 1845 estabeleceu os 35 anos como limite mínimo de idade.

${ }^{31}$ A construção da ordem. A elite política imperial, Rio de Janeiro, Editora Campus, 1980, p. 51. 
Metáfora que se aplica ipsis verbis à sua congénere portuguesa da época, com quem partilha, aliás, outras características.

No Portugal oítocentista, onde persistiam altíssimas taxas de analfabetismo, e onde aqueles que tinham uma formação académica superior representavam um segmento muito restrito da população adulta e não dispunham de um leque muito variado de alternativas ocupacionais, era inevitável, por assim dizer, que os principais cargos da governação pública fossem disputados e ocupados por uma "elite ilustrada".

O principal centro de formação intelectual continuava a ser inegavelmente a Universidade de Coimbra, com relevo para a Faculdade de Direito ${ }^{32}$, apesar da crescente importância das instituições de ensino superior de Lisboa, em particular a Escola do Exército. De realçar, a capilaridade existente entre a Universidade de Coimbra e a Escola do Exército: antes de ingressarem nesta última, vários militares obtinham o bacharelado na Faculdade de Matemática ${ }^{33}$.

No caso especifico dos conselheiros de Estado, os juristas eram indiscutivelmente a categoria mais representada, seguindo-se-lhe a larga distância os indivíduos formados pelas academias militares Dos doze casos identificados como não tendo completado um curso superior, metade eram aristocratas (que, seguindo um padrão tradicional, tinham sido educados por tutores particulares); dos restantes, pelo menos dois (Rodrigo da Fonseca Magalhães e José Jorge Loureiro) tinham chegado a frequentar a Universidade.

\section{Actividade profissional}

A esmagadora maioria dos conselheiros eram personalidades com uma longa carreira de serviço público, destacando-se os militares de alta patente e os magistrados judiciais no topo da carreira como as principais fieiras de recrutamento. Recorde-se, aliás, que no regulamento do Conselho de Estado de 1845 se preconizava a selecção dos que se tivessem distinguido "por talentos

${ }^{32}$ A estatística global do movimento de matrículas na Universidade de Coimbra ao longo de todo o século XIX revela que mais de metade da população estudantil $(62,6 \%)$ frequentou as Faculdades Jurídícas (vd. Manuel Augusto Rodrigues, A Universidade de Coimbra. Marcos da sua história, Coimbra, Arquivo da Universidade, 1991, pp. 191-193). Quanto ao número de bacharéis formados na Universidade de Coimbra, desde finais do século XVIII até 1890, os bacharéis em Direito representaram sempre mais de $70 \%$ do total (vd. Maria Eduarda Cruzeiro, Action symbolique et formation scolaire. L'Université de Coimbra et sa Faculté de Droit dans la seconde moitié du XIXe siècle, mimeo, Paris, 1990, p. 526).

${ }^{33}$ Como esclarece o visconde de Vila-Maior, "a legislação actual estabelece na Faculdade de Matemática dois cursos distintos - o curso geral e o curso preparatório para as escolas de aplicação [...] principalmente destinado para habilitar os alunos militares com os conhecimentos das ciências matemáticas e físicas, necessários para a sua entrada na Escola do Exército“ (in Exposição succinta da organisação actual da Universidade de Coimbra, Coimbra, Imprensa da Universidade, 1877, pp. 183-185). 
e provada capacidade na gerência dos negócios públicos em algum lugar superior do Estado" (art. 3. ${ }^{\circ}$ ). A omnipresença do funcionalismo público só declina no último subperíodo, quando os profissionais liberais e os capitalistas (proprietários e negociantes) representam em conjunto cerca de $28 \%$. Em termos de evolução das várias categorias ocupacionais, há ainda a assinalar a clara tendência para um crescente protagonismo dos professores universitários, bem como o súbito declínio da importância dos militares nas duas últimas décadas.

As informações que foi possível recolher sobre as profissões dos progenitores dos conselheiros revelam que muitos deles já eram servidores do Estado, com predomínio igualmente dos meios castrense e da magistratura. O que significa que, em alguns casos, houve uma clara reprodução familiar de vocações. A título de curiosidade mencione-se um exemplo, ainda que excepcional, em que essa "hereditariedade" teve também uma tradução política: o general de divisão Carlos Maria de Caula e o seu pai, um antigo marechal de campo, exerceram em momentos distintos o cargo de conselheiros de Estado.

\section{Recrutamento social e títulos nobiliárquicos}

Quanto aos meios sociais de origem dos conselheiros, é indiscutível o predomínio dos estratos superiores e privilegiados, não só devido à importância relativa dos aristocratas e fidalgos de linhagem, mas porque muitos dos membros da "classe média" eram filhos de gente com recursos económicos e prestígio social e intelectual, por vezes também com ramificações familiares e sólidas relações de sociabilidade nos círculos da nobreza.

Não admira, por isso, que os conselheiros de Estado fossem, a seguir aos pares do reino, o subgrupo da elite política onde era maior a percentagem de indivíduos com títulos nobiliárquicos ${ }^{34}$. Mas, com excepção dos velhos aristocratas $^{35}$, todos os outros ostentavam títulos de fresca data, sendo alguns deles representantes dessa burguesia "ensanefada de ouropéis fidalgos", para utilizar a expressão sarcástica de Alexandre Herculano ${ }^{36}$. Convém notar, porém, que à medida que o tempo avança vai decaindo continuada e drasticamente a proporção de novos conselheiros que ostentam um título nobiliárquico: entre o primeiro e o terceiro subperíodo diminui de $37,5 \%$ para $11 \%$.

${ }^{34}$ Assim, por exemplo, entre 1851 e 1890 , eram titulares $38 \%$ dos pares de nomeação régia, $29 \%$ dos conselheiros de Estado, 19\% dos ministros e 9\% dos deputados (vd. Pedro Tavares de Almeida, ibidem, Parte I).

${ }^{35}$ Dos descendentes da aristocracia de corte, o conde de Vila Real (cujo título foi atribuído em 1823) era o único cujo pai não tinha título de grandeza: trata-se, no entanto, de uma das raras casas de fidalgos de província que no decurso do século XVIII se foi integrando na primeira nobreza de corte.[Informação prestada por Nuno Gonçalo Monteiro, a quem agradeço].

${ }^{36}$ Opusculos, I, Lisboa, Casa da Viuva Bertrand, 1873, p. 21. 


\section{Carreira política}

Como se depreende de quanto foi dito, a ascensão ao Conselho de Estado constitui, em regra, o ápice de uma longa carreira política, normalmente iniciada nas lides parlamentares, e com frequência prosseguida no exercício de funções governativas.

O elenco dos principais cargos políticos desempenhados pelos conselheiros, antes da sua nomeação para este alto cargo, é descrito em pormenor no Quadro 5. Fazendo uma síntese global dos dados fundamentais, verifica-se que a esmagadora maioria dos conselheiros tinha um tirocínio parlamentar mais ou menos prolongado, como deputados e/ou pares do reino, e experiência ministerial. Foram muito poucos, porém, aqueles que chefiaram o executivo (José Jorge Loureiro, Joaquim António de Aguiar e Venceslau Pereira Lima) antes de se tornarem conselheiros de Estado. A trajectória inversa era a mais comum, sendo por isso o Conselho de Estado um alfobre de putativos primeiro-ministros.

Os três únicos conselheiros sem currículo político, a nível parlamentar ou ministerial, são José de Cupertino de Aguiar Ottolíni, o $1^{\circ}$ visconde da Carreira e o general Carlos Maria de Caula. O primeiro era um conceituado magistrado, que exerceu quase ininterruptamente o cargo de Procurador-Geral da Coroa de 1838 a 1859; segundo uma fonte da época, Ottoliní só aceitou entrar para o Conselho de Estado após insistentes convites do rei D. Pedro $\mathrm{V}^{37}$. O visconde da Carreira, um diplomata e tutor do infante D. Luís, embora tenha chegado a ser nomeado ministro em duas ocasiões, acabou por não tomar posse do cargo. Por último, o general Carlos Maria de Caula, que recusou sempre as propostas que lhe fizeram para ascender ao pariato ou para sobraçar a pasta da Guerra, era ajudante de campo de D. Pedro V e, após a sua morte, de D. Luís.

A finalizar, uma nota comparativa sobre o cursus honorum político dos conselheiros de Estado. No Brasil imperial, dos 72 indivíduos que integraram o Conselho de Estado entre 1841 e 1889, apenas $5(6,9 \%)$ não tinham prévia experiência em cargos políticos ${ }^{38}$, o que corresponde a uma percentagem idêntica à dos seus congéneres portugueses nomeados entre 1851 e 1890.

${ }^{37}$ Sobre a biografia do conselheiro Ottolini, vd. a notícia necrológica publicada no Diario do Governo, 22 de Março de 1859.

${ }_{38}$ Vd. José Murilo de Carvalho, Teatro de sombras..., p. 108 (tabela XI). 
Quadro 1 - Número de reuniões do Conselho de Estado (1834-1904)

\begin{tabular}{cccrcr}
\hline Ano & N. & Ano & N. $^{\mathbf{o}}$ & Ano & N. $^{\mathbf{0}}$ \\
\hline $1834 *$ & 31 & 1868 & 14 & 1896 & 9 \\
1835 & 17 & 1869 & 15 & 1897 & 7 \\
& & 1870 & 17 & 1898 & 7 \\
1842 & 20 & 1871 & 15 & 1899 & 11 \\
1843 & 13 & 1872 & 5 & 1900 & 6 \\
& & 1873 & 7 & 1901 & 5 \\
1855 & 17 & 1874 & 6 & 1902 & 7 \\
1856 & 17 & & & 1903 & 8 \\
1857 & 16 & 1889 & 14 & 1904 & 8 \\
1858 & 18 & 1890 & 14 & & \\
1859 & 17 & 1891 & 15 & & \\
1861 & 20 & 1892 & 10 & & \\
1862 & 17 & 1893 & 10 & & \\
1863 & 12 & 1894 & 4 & & \\
1864 & 13 & 1895 & 4 & & \\
\hline
\end{tabular}

Fonte: Actas do Conselho de Estado, Livros 1 a 5 (IAN/TT, C.F. 77).

* Incluindo as duas primeiras sessões do Conselho de Estado realizadas em finais de 1833. 


\section{Quadro 2 - Conselheiros de Estado efectivos (1833-1910)*}

\begin{tabular}{|c|c|c|}
\hline N. ${ }^{o}$ & Nome & $\begin{array}{c}\text { Data de } \\
\text { nomeação }\end{array}$ \\
\hline 1 & Francisco Manuel Trigoso de Aragão Morato & 20.09 .1833 \\
\hline 2 & Carlos Frederico da Caula & 20.09 .1833 \\
\hline 3 & Duque de Palmela & 20.09 .1833 \\
\hline 4 & Marquês de Saldanha & 20.09 .1833 \\
\hline 5 & Fernando Luís Pereira de Sousa Barradas & 20.09 .1833 \\
\hline 6 & Francisco Simões Margiochi & 20.09 .1833 \\
\hline 7 & José António Guerreiro & 20.09 .1833 \\
\hline 8 & Marquês do Funchal $\left(1 .^{\circ}\right)$ & 20.09 .1833 \\
\hline 9 & Agostinho José Freire & 24.07 .1834 \\
\hline 10 & Fr. Francisco de S. Luís (bispo-conde de Arganil) & 24.07 .1834 \\
\hline 11 & Duque da Terceira & 24.07 .1834 \\
\hline 12 & José da Silva Carvalho & 24.07 .1834 \\
\hline 13 & Conde de Vila Real $\left(1 .^{\circ}\right)$ & 20.05 .1835 \\
\hline 14 & Manuel Gonçalves de Miranda & 20.05 .1835 \\
\hline 15 & Marquês de Valença $\left(5^{\circ}\right.$ ) & 29.09 .1835 \\
\hline 16 & Rodrigo da Fonseca Magalhães & 14.02 .1842 \\
\hline 17 & António Bernardo da Costa Cabral ${ }^{1}$ & 30.12 .1843 \\
\hline 18 & Barão de Chanceleiros $\left(1 .^{\circ}\right)$ & 12.08 .1845 \\
\hline 19 & D. Guilherme H. de Carvalho (bispo de Leiria) & 13.11 .1845 \\
\hline 20 & Conde do Sobral $\left(1 .^{\circ}\right)$ & 23.12.1845 \\
\hline 21 & José Bernardo da Silva Cabral & 26.02 .1846 \\
\hline 22 & Manuel Duarte Leitão & 10.10 .1848 \\
\hline 23 & António José de Ávila & 21.07 .1850 \\
\hline 24 & Visconde de Castro $\left(1^{\circ}\right)$ & 23.07 .1850 \\
\hline 25 & Conde do Lavradio $\left(2 .^{\circ}\right)$ & 08.10 .1857 \\
\hline 26 & José Jorge Loureiro & 08.10 .1857 \\
\hline 27 & Visconde de Algés $\left(1 .^{\circ}\right)$ & 09.10 .1857 \\
\hline 28 & José Cupertino de Aguiar Ottolíni & 12.03 .1858 \\
\hline 29 & João de Sousa Pinto de Magalhães & 26.05 .1858 \\
\hline 30 & Visconde da Carreira $\left(1 .^{\circ}\right)$ & 08.01 .1859 \\
\hline 31 & Marquês de Loulé & 13.04.1859 \\
\hline 32 & Joaquim António de Aguiar & 30.04 .1860 \\
\hline 33 & Visconde de Sá da Bandeira & 09.07 .1860 \\
\hline 34 & Júlio Gomes da Silva Sanches & 03.04 .1865 \\
\hline 35 & José Feliciano da Silva e Costa & 05.05 .1865 \\
\hline 36 & António Maria Fontes Pereira de Melo & 25.04 .1866 \\
\hline 37 & Anselmo José Braamcamp & 29.08 .1866 \\
\hline 38 & Filipe Folque & 18.07.1870 \\
\hline 39 & José Maria Eugénio de Almeida & 18.07.1870 \\
\hline
\end{tabular}




\begin{tabular}{|c|c|c|}
\hline N. ${ }^{o}$ & Nome & $\begin{array}{c}\text { Data de } \\
\text { nomeação }\end{array}$ \\
\hline 40 & Carlos Bento da Silva & 22.01 .1871 \\
\hline 41 & Conde do Casal Ribeiro $\left(1^{\circ}\right)$ & 06.05 .1872 \\
\hline 42 & João B. da Silva Ferrão de Carvalho Martens & 28.05.1874 \\
\hline 43 & José Marcelino de Sá Vargas & 31.12 .1874 \\
\hline 44 & Marquês de Fícalho $\left(2^{\circ}\right)$ & 28.05 .1875 \\
\hline 45 & António de Serpa Pímentel & 21.01 .1876 \\
\hline 46 & João de Andrade Corvo & 14.09.1876 \\
\hline 47 & Carlos Maria de Caula & 23.11.1876 \\
\hline 48 & Conde de Valbom & 22.11.1878 \\
\hline 49 & José da Silva Mendes Leal Jr. & 06.05 .1881 \\
\hline 50 & Augusto Barjona de Freitas & 19.11.1885 \\
\hline 51 & José Luciano de Castro & 18.02 .1886 \\
\hline 52 & João Crisóstomo de Abreu e Sousa & 02.10 .1886 \\
\hline 53 & Conde de S. Januário & 21.06 .1887 \\
\hline 54 & Henrique de Barros Gomes & 07.11 .1889 \\
\hline 55 & Lopo Vaz de Sampaio e Melo & 20.02 .1890 \\
\hline 56 & Ernesto Rodolfo Hintze Ribeiro & 19.12.1891 \\
\hline 57 & José Vicente Barbosa du Bocage & 27.05 .1892 \\
\hline 58 & Conde de Ficalho $\left(4 .^{\circ}\right)$ & 04.05 .1893 \\
\hline 59 & João Franco & 17.01.1895 \\
\hline 60 & António Emílio Correia de Sá Brandão & 20.06 .1896 \\
\hline 61 & Júlio Marques de Vilhena & 20.06 .1896 \\
\hline 62 & Francisco António da Veiga Beirão & 24.11.1898 \\
\hline 63 & José Baptista de Andrade & 29.03 .1900 \\
\hline 64 & Frederico de Gusmão Correia Arouca & 28.07 .1900 \\
\hline 65 & Marquês de Soveral $\left(1^{\circ}\right)$ & 21.02 .1901 \\
\hline 66 & Luís Augusto Pimentel Pinto & 01.06 .1901 \\
\hline 67 & Luís Frederico de Bivar Gomes da Costa & 13.03.1902 \\
\hline 68 & António Cândido Ribeiro da Costa & 13.03 .1902 \\
\hline 69 & Alberto António de Morais Carvalho & 07.05 .1903 \\
\hline 70 & António de Azevedo Castelo Branco & 17.09.1904 \\
\hline 71 & José J. de Abreu do Couto de Amorim Novais & 19.08.1907 \\
\hline 72 & José Adolfo de Melo e Sousa & 14.11.1907 \\
\hline 73 & Venceslau de Sousa Pereira Lima & 22.12.1909 \\
\hline
\end{tabular}

Fonte: Manuel Pinto dos Santos, org., Monarquia Constitucional. Organização e relações do poder governamental com a Câmara dos Deputados, 1834-1910, Lisboa, Assembleia da República, 1986, anexo I.

* Não inclui Francisco Xavier Monteiro, nomeado em 20 de Setembro de 1833, que não chegou a tomar posse.

'Foi demitido do cargo de conselheiro de Estado em 13 de Agosto de 1846. O cargo foi-lhe restituído por Decreto de 22 de Dezembro de 1847. 


\section{Quadro 3. Número de conselheiros de Estado efectivos nomeados entre 1833 e 1910}

\begin{tabular}{|c|c|c|c|c|c|c|c|}
\hline \multicolumn{2}{|c|}{$1833-1850$} & \multicolumn{2}{|c|}{$1857-1890$} & \multicolumn{2}{c|}{$1891-1909$} & \multicolumn{2}{c|}{ Total } \\
\hline $\mathrm{N}^{\mathrm{o}}$ & $\%$ & $\mathrm{~N}^{\circ}$ & $\%$ & $\mathrm{~N}^{\mathrm{o}}$ & $\%$ & $\mathrm{~N}^{\circ}$ & $\%$ \\
\hline 24 & 32,9 & 31 & 42,5 & 18 & 24,6 & 73 & 100,0 \\
\hline
\end{tabular}

\section{Quadro 4. Características sociodemográficas dos conselheiros de Estado efectivos*}

\begin{tabular}{|c|c|c|c|c|c|c|c|c|}
\hline \multirow{2}{*}{$\begin{array}{c}\text { Características } \\
\text { sociodemográficas }\end{array}$} & \multicolumn{2}{|c|}{$1833-1850$} & \multicolumn{2}{|c|}{$1857-1890$} & \multicolumn{2}{|c|}{ 1891-1909 } & \multicolumn{2}{|c|}{ Total } \\
\hline & $\mathrm{N}^{\circ}$ & $\%$ & $\mathrm{~N}^{\circ}$ & $\%$ & $\mathrm{~N}^{\circ}$ & $\%$ & $\mathrm{~N}^{\circ}$ & $\%$ \\
\hline \multicolumn{9}{|l|}{ NATURALIDADE** } \\
\hline Lisboa e arredores & 6 & 26,1 & 17 & 54,8 & 4 & 22,2 & 27 & 37,5 \\
\hline Porto & 1 & 4,3 & 1 & 3,2 & 2 & 11,1 & 4 & 5,6 \\
\hline Coimbra & 3 & 13,0 & 4 & 12,9 & 0 & 0,0 & 7 & 9,7 \\
\hline Resto do país & 11 & 47,8 & 9 & 29,0 & 12 & 66,7 & 32 & 44,4 \\
\hline Estrangeiro e antigas colónias & 2 & 8,7 & 0 & 0,0 & 0 & 0,0 & 2 & 2,8 \\
\hline \multicolumn{9}{|l|}{ IDADE } \\
\hline 39-49 anos & 6 & 25,0 & 5 & 16,1 & 3 & 16,7 & 14 & 19,2 \\
\hline $50-60$ anos & 11 & 45,8 & 13 & 41,9 & 10 & 55,5 & 34 & 46,6 \\
\hline$>60$ anos & 7 & 29,2 & 13 & 41,9 & 5 & 27,8 & 25 & 34,2 \\
\hline Idade média (anos) & 55 & - & 59 & - & 56 & - & 57 & - \\
\hline \multicolumn{9}{|l|}{ EDUCAÇÃO } \\
\hline Sem curso superior & 4 & 16,7 & 7 & 22,6 & 1 & 5,6 & 12 & 16,4 \\
\hline Com curso superior & 20 & 83,3 & 24 & 77,4 & 17 & 94,4 & 61 & 83,6 \\
\hline Direito & 12 & 50,0 & 13 & 41,9 & 11 & 61,1 & 36 & 49,3 \\
\hline Matemática/Filosofia & 4 & 16,7 & 2 & 6,4 & 1 & 5,5 & 7 & 9,6 \\
\hline Militar & 3 & 12,5 & 7 & 22,6 & 2 & 11,1 & 12 & 16,4 \\
\hline Outros & 1 & 4,1 & 2 & 6,4 & 3 & 16,7 & 6 & 8,2 \\
\hline \multicolumn{9}{|l|}{ PROFISSÃO } \\
\hline Funcionário público & 2 & 8,3 & 6 & 19,3 & 2 & 11,1 & 10 & 13,7 \\
\hline Professor universitário & 1 & 4,2 & 4 & 12,9 & 4 & 22,2 & 9 & 12,3 \\
\hline Magistrado judicial & 7 & 29,2 & 6 & 19,3 & 4 & 22,2 & 17 & 23,3 \\
\hline Diplomata & 2 & 8,3 & 2 & 6,4 & 1 & 5,5 & 5 & 6,8 \\
\hline Militar & 8 & 33,3 & 10 & 32,3 & 2 & 11,1 & 20 & 27,4 \\
\hline Padre & 2 & 8,3 & 0 & 0,0 & 0 & 0,0 & 2 & 2,7 \\
\hline Profissão liberal & 0 & 0,0 & 0 & 0,0 & 3 & 16,7 & 3 & 4,1 \\
\hline Proprietário / Negociante & 2 & 8,3 & 3 & 9,7 & 2 & 11,1 & 7 & 9,6 \\
\hline TÍTULO NOBILIÁRQUICO & & & & & & & & \\
\hline Sem título & 15 & 62,5 & 22 & 71,0 & 16 & 88,9 & 52 & 71,2 \\
\hline Com título & 9 & 37,5 & 9 & 29,0 & 2 & 11,1 & 21 & 28,8 \\
\hline
\end{tabular}

* À data da nomeação. As percentagens são sempre calculadas em relação ao total de indivíduos nomeados em cada período.

** Não foi possível apurar o local de nascimento de Carlos Caula, nomeado em 1833, pelo que o número total de casos com informação é de 72 . 


\section{Quadro 5. Experiência política dos conselheiros de Estado efectivos*}

\begin{tabular}{|l|r|r|r|r|r|r|r|r|}
\hline \multirow{2}{*}{\begin{tabular}{|} 
Experiência \\
politica
\end{tabular}} & \multicolumn{2}{|c|}{$1833-1850$} & \multicolumn{2}{c|}{$1857-1890$} & \multicolumn{2}{c|}{$1891-1909$} & \multicolumn{2}{c|}{ Total } \\
\cline { 2 - 8 } & \multicolumn{1}{|c|}{$\mathrm{N}^{\circ}$} & \multicolumn{1}{c|}{$\mathrm{N}^{\circ}$} & $\%$ & \multicolumn{1}{|c|}{$\mathrm{N}^{\circ}$} & $\%$ & $\mathrm{~N}^{\circ}$ & $\%$ \\
\hline & & & & & & & & \\
Sem experiência política & 1 & 4,2 & 2 & 6,4 & 0 & 0,0 & 3 & 4,1 \\
Com experiência política & 23 & 95,8 & 29 & 93,6 & 18 & 100,0 & 70 & 95,9 \\
$\quad$ Governador civil & 0 & 0,0 & 1 & 3,2 & 3 & 16,7 & 4 & 5,5 \\
Governador colonial & 0 & 0,0 & 0 & 0,0 & 1 & 5,5 & 1 & 1,4 \\
Deputado e/ou Par & 17 & 70,8 & 27 & 87,1 & 18 & 100,0 & 62 & 84,9 \\
Ministro & 19 & 79,2 & 26 & 83,9 & 14 & 77,8 & 59 & 80,8 \\
Presidente do Conselho & 0 & 0,0 & 3 & 9,7 & 1 & 5,5 & 4 & 5,5 \\
\hline
\end{tabular}

* À data da nomeação. Na contabilização dos cargos políticos aplicou-se um registo múltiplo.

As percentagens são sempre calculadas em relação ao total de indivíduos nomeados em cada um dos períodos. 


\title{
HISTORICIDADE E RADICALISMO NO LIBERALISMO VINTISTA \\ Caso do município da Horta
}

\author{
Maria Fernanda Enes* \\ $\mathrm{FCSH} / \mathrm{UNL}$
}

O liberalismo político que chegou ao Faial a 12 de Maio de 1821, repercutindo a Revolução de Agosto de 1820 no Reino de Portugal, não é unívoco. Ele encerra em si dois modelos, derivados de tradições distintas, a que F. A. Hayek $^{1}$ designaria de "liberalismo à inglesa" e "liberalismo à francesa" e que Alexandre Herculano não se cansaria de colocar em dicotomia tentando pôr em relevo as liberdades históricas conquistadas pelos concelhos face ao "domínio absoluto" do poder central, qualquer que fosse a sua natureza. O primeiro modelo, em conformidade com a matriz empírica, defende os direitos concretos que a temporalidade foi construindo no devir histórico de longa duração. E apoiando-se no direito natural clássico desenvolveu a ideia da salvaguarda dos direitos individuais pelo "governo debaixo da lei", entendida como common law, onde o reformismo e a vigência dos corpos intermédios e associações sociais de diverso tipo se enquadrariam. Enquanto que o segundo, assente na abstracção racionalista, privilegia o voluntarismo construtivista tendo por base o direito natural moderno.

O modelo "à inglesa" afirma-se com a revolução orangista, desencadeada contra a política absolutizante de Jaime II. Teorizado a priori nas obras de John Locke, é tipificado indirectamente na reflexão efectuada por Edmund Burke sobre a Revolução de 1789 em França. Podemos rastreá-lo nos escritos de Tocqueville, no pensamento de Benjamim Constant e em muitos outros. Não é exclusivo do processo político liberal inglês porquanto como paradigma pode aplicar-se, com maiores ou menores variantes, a outras unidades políticas e mesmo em França.

Efectivamente, a Glorious Revolution de 1688 teve a sua origem no restabelecimento dos direitos dos ingleses. A tentativa absolutizante de Jaime II,

\footnotetext{
* Rendo as mais profundas e gratas homenagens à Historiadora do vintismo - Zília O. de Castro - que soube partilhar as suas ideias, permitindo e incentivando o caminho pessoal, em inteira liberdade, àqueles que com ela trilharam as sendas da História das Ideias. Pela quinhão que me coube neste métier, o muito obrigada.

'Friedrich August von Hayek, "Liberalism", in New Studies in Philosophy, Politics, Economics and History of Ideas, London, Routledge \& Kegan Paul, 1985. De notar o estudo de José Manuel Moreira, Liberalismos: entre o conservadorismo e o socialismo, Lisboa, PF, 1996.
} 
expressa no lançamento de impostos sem o consentimento do parlamento, está na origem imediata do acto revolucionário conferindo-lhe legitimidade, porquanto a quebra do pacto histórico pertencera àquele monarca e não aos revoltosos. Com o cerceamento da prerrogativa régia elevara a primeiro poder o Legislativo, mas o Bill of Rights de 1689, aprovado nesse contexto, reafirmara os direitos dos ingleses, não os do Homem. Assim, a 1. ${ }^{\text {a Revolução liberal não }}$ se apresentou como paradigma universal do liberalismo político, mas tão só como legítima no quadro da historicidade dos cidadãos do Reino Unido. E neste sentido ela é uma Revolução liberal conservadora ${ }^{2}$.

E se John Locke, que nela participara, ao elaborar a teoria fundadora do liberalismo político no " 2 . Tratado do Governo Civil", aliara o empirismo ao racionalismo, que por natureza é universal, não deixou de relevar a matriz histórica dos direitos naturais cuja salvaguarda marca a legitimidade da construção política. Todavia, tratando-se da fundamentação filosófica do liberalismo ela iria ser aproveitada para, no contexto cultural francês, servir de base à afïrmação da universalidade e, portanto, do "liberalismo à francesa".

Ora o $2 .^{\circ}$ modelo, "liberalismo à francesa", releva da tendência eminentemente racionalista que enformou o processo revolucionário francês dando novo sentido ao carácter centralizador e maximalista do político. Resultado da transferência do absolutismo régio para o absolutismo da soberania da Nação. A Revolução Francesa, apropriando-se embora da conceptualidade lockiana, ${ }^{3}$ aliada às ideias contratualistas de Rousseau e combinando-se com a herança do modo de ser centralista do absolutismo iluminista, apresenta a soberania absoluta da Nação e afirma a universalidade dos direitos, em conformidade com a matriz cartesiana da "absolutização do sujeito". Segundo Edmund Burke, em Reflexions on the French Revolution, ${ }^{4}$ a Revolução Francesa tenta a transposição dos direitos metafísicos para a História ao proclamar solenemente a Declaração dos direitos, não dos franceses, mas do Homem e do cidadão. E se esses direitos universais podem ser verdadeiros metafisicamente, a transposição para a historicidade, que é sempre relativa, apresenta-se como

2 Enquanto se inscreve no modelo da "revolução dos astros", submetida a uma repetição indefinida à qual se opõe a ideia de revolução - ruptura - da ordem tradicional que a Revolução francesa tomará enquanto inscrita no optimismo racionalista da evolução sem retorno do Homem. Cf. Georges Gusdorf, La Conscience Révolutionnaire: les idéologues, Paris, Payot, 1978, pp. 51-68.

${ }^{3}$ Montesquieu tanto em L'Esprit de les Lois como em Lettres Persannes e Voltaire, sobretudo em Les Letres Anglaises ou Philosophiques, enfatizaram o "humor liberal dos ingleses", o seu regime político que dava espaço à afirmação da liberdade individual, propondo-o como paradigma. Montesquieu, Oeuvres Completes,Paris, Seuil, 1990; Voltaire, Lettres Philosophiques, Paris, Garnier-Flammarion, 1964.

${ }^{4}$ Obra publicada em 1790, como resposta ao repto lançado por um escol de franceses que lhe pediam um pronunciamento sobre a natureza da Revolução em França. 
uma forma de despotismo inconciliável com a desejável vigência das liberdades individuais. Como continua dizendo o liberal conservador, que estamos a citar, pouco importa se o despotismo é de um só, monarca absoluto, ou de uma Assembleia, caso da Revolução, pois que os efeitos serão sempre os mesmos, ${ }^{5}$ impondo-se, por isso, a mediação das estruturas sócio-políticas - os corpos intermédios.

De resto, o francês Alexis Tocqueville, que ficara rendido ao modelo americano em que a democracia era possível porque partia das estruturas societais de base, em L'Ancien Régime et la Révolution ${ }^{6}$ demonstra como a centralização que a Revolução desencadeara e absolutizara pelo maximalismo político, não era outra coisa senão a manutenção do sistema que a monarquia absoluta havia desenvolvido, transposto para o domínio hegemónico do poder democrático, da soberania da Nação, como então se dizia. Mas também este modelo francês não é mais do que um paradigma que o longo processo revolucionário, desde 1789 à III república, quando se impõe o "possibilismo à Gambetta" ou via média, não faz senão modular.

A dualidade, que representa o balanceamento entre a história - tradição - e o radicalismo construtivista, esteve presente no vintismo, como foi demonstrado por Zília Osório de Castro no artigo "Soberania e política - Teoria e prática do vintismo." A análise da autora, porém, como o próprio título indica, incide sobre a natureza dos princípios ordenadores do liberalismo, mas tomando em consideração a tensão entre a teoria e a realidade concreta, a historicidade: soberania da Nação e defesa de regime; individualismo vs comunitarismo, na relação entre salvaguarda dos direitos individuais e o garantismo do Estado; em torno do bicamarelismo e da questão brasileira, o problema da unicidade da Nação. A Constituição de 1822 expressa bem como o pêndulo se inclinou para o lado da inovação, ou seja do liberalismo "à francesa", mas

${ }_{5}$ Em 1868, Antero de Quental expenderá posição semelhante. Ao defender o federalismo como a organização política que mais respeita a liberdade, critica de forma contundente o sistema francês, sobretudo o que é herdeiro de Rousseau, de que é bastardo. “...O mundo, entretanto, seguiu Rousseau. Ninguém viu que a unidade matava a liberdade, a delegação a iniciativa, a organização republicana a república democrática" In "Portugal perante a Revolução de Espanha" in Prosas sócio políticas, (org. de Joel Serrão), Lisboa, INCM, 1982, pp. 211-241. cit. p. 223.

6 Enquanto que De La démocratie en Amérique, "nascida de a Revolução de 1830", em dois volumes, veio a lume em 1835 e 1840, respectivamente, L'ancién Régime et la Révolution só surgiria em 1856. Alexis de Tocqueville, De La Démocratie en Amérique, Souvenisrs, L'Ancien Régime et la Révolution, Paris, Robert Laffont, 1986.

7 In Cultura. Revista de história e teoria das ideias, Lisboa, CHC, II série, 'vol. VIII, 1996, pp. 183-213. 
também como o ignorar da historicidade concreta pôde inviabilizar a mesma inovação.

Todavia, este balanceamento tem uma outra vertente que os debates no Soberano Congresso muito dificilmente revelariam: o do peso dos corpos intermédios, nomeadamente dos municípios. Em termos teóricos só mais tarde seria perfeitamente apercebida e teorizada em Portugal por Alexandre Herculano. Múltiplas vezes, em diversos debates, e sobretudo nas polémicas do Portuguez, contrapõe a universalidade francesa ao historicismo inglês e é na defesa desta matriz que ele elabora a história e a teoria política do municipalismo, corpo intermédio por excelência onde os direitos individuais e os poderes das estruturas intermédias e da Nação se foram construindo e exercendo. Nas suas palavras: "A centralização, na cópia portuguesa, como hoje existe e como hoje a sofremos, é o fideicomisso legado pelo absolutismo aos governos representativos, mas enriquecido, exagerado; é, desculpai-me a frase, o absolutismo liberal. A diferença está nisto: dantes os frutos que dá o predomínio da centralização supunha-se colhê-los um homem chamado rei; hoje colhem-nos seis ou sete homens chamados ministros... O país de que falam é o seu país nominal; é a sua clientela, o seu funcionalismo; é o próprio governo; é a tradução moderna da frase de Luís XIV l'état c'est moi, menos a sinceridade.""

Antes de ser teorizada ela será expressa na consciência colectiva, nomeadamente pelos Senados dos Concelhos. Que representação tinham de si próprias as vereações municipais que em todo o processo vintista constituíram os foros de adesão, contestação ou defesa dos princípios revolucionários? Abdicaram simplesmente em favor de uma pirâmide de poder, cujo vértice era o Soberano Congresso, ou defendiam o seu espaço na intervenção política e na construção da cidadania dos munícipes?

Por me parecer significativa, no seio do vintismo, a tensão entre a historicidade e a inovação a nível dos corpos intermédios, apresento o estudo de caso do município da Horta.

\section{A temporalidade histórica na adesão faialense ao vintismo}

Ora, o processo de adesão ao liberalismo nas ilhas do Faial e do Pico revela este balanceamento entre o modelo historicista e o universal, ensaiando a sua conciliação. Independentemente do conhecimento efectivo das ideias e ideologias políticas que haviam determinado, pelo menos em parte, a praxis política liberal no âmbito europeu, por parte dos agentes que no contexto da revolução vintista lideraram o processo faialense, eles agiram em conformi-

${ }^{8}$ In "Carta aos eleitores de Sintra" in Opúsculos, I, Lisboa, Presença, p. 323. 
dade com algumas das ideias tipo, caracterizadoras do regime político emergente. Certo é que obras de John Locke e de Condillac chegaram aos conventos, nomeadamente o do Carmo na Horta, na década de setenta do século XVIII, a par dos compêndios dos autores específicos daquele processo como Heinecius e António Genovesi. Daí saíram mestres régios da Reforma Pombalina e do $1 .^{\circ}$ período liberal, ${ }^{9}$ alguns dos quais tiveram intervenção directa no processo político liberal faialense. Mas, muito provavelmente, a centralidade da Horta nas rotas atlânticas teria proporcionado outros modos de contaminação das novas ideias políticas que circulavam na Europa e nos EUA, a esse processo não seria estranha a inserção social da família Dabney, que exercia no Faial funções consulares do recém independente Estado americano. Evidente é o facto de essas ideias, umas de cariz mais racionalista outras de cambiantes mais historicistas, enformarem efectivamente o discurso legitimador e combativo, tanto singular como colectivo, produzido pelas elites faialenses e picoenses. Analisemos alguns casos específicos.

Faustino José da Silveira, cerca de um mês antes da adesão ao vintismo, quando a contra-revolução promovida pelo Capitão General Stockler evoluía na ilha Terceira, ${ }^{10}$ incitara os faialenses a aderir à Revolução vintista, confiando na sua capacidade manifestada ao longo da História, toldada naquele contexto insular pelo medo da acção despótica do governo de Angra. Nas suas palavras: a "quebrar as ferrugentas cadeias"; a subtraírem-se ao fardo do despotismo "debaixo do qual tendes gemido degredados da vossa dignidade, que a não ser a cegueira em que vos submergiram os nefandos satélites de um governo desnaturado, há mais tempo teríeis divisado o mal que vos mortifica e a ignomínia em que jazeis enlodados" 1 No seu discurso, de incitação ao processo revolucionário no Faial, fica bem patente a convicção de que os naturais daquela ilha estão muito mais próximos ideologicamente do vintismo do que das práticas absolutistas do Governador. Ele considera como natural a afeição ao espírito liberal por parte da população, a cujo ideário alude como conquista histórica. Ideário esse que a sujeição a Angra pervertia. Em simultâneo com a afirmação dos princípios universais do liberalismo, que demonstra conhecer profundamente e adiante em análise, no seu discurso está em causa

9 Cf. M. Fernanda Enes, O Liberalismo nos Açores - Religião e Política (1800-1832). Tese apresentada à UNL, Lisboa, Colibri, 1994, vol. I, pp. 26-89.

${ }_{10}$ De notar que a Proclamação de Stockler dirigida aos micaelenses no sentido de os levar a reconsiderar a sua adesão ao vintismo teve repercussão no Faial, quando esta ilha ainda não se tinha pronunciado acerca da sua posição. O pacto exigido pela ideologia liberal e, previsto pelo soberano Congresso, era uma exigêmcia para a participação no novo regime político.

11 "Proclamação promovendo a revolução liberal no Fayal em 1821" in A.A'., v.III, pp.491-93, cit.p.491, sublinhado nosso. 
a defesa de direitos que, no seu entender, os faialenses souberam conquistar e defender ao longo do percurso histórico.

Mas é após o 12 de Maio de 1821 que a consciência da validade da Câmara Municipal como "corpo intermédio", historicamente constituído, se afirma clara e enfaticamente. Não estará em causa apenas nesta consciência a defesa de interesses das populações à maneira dos cahiers de doléance? Nas múltiplas "Representações" dirigidas quer à Regência quer ao Rei ou ao Soberano Congresso, o Senado municipal apresenta-se como espaço de poder e de mediação dos anseios do povo na vertente da defesa dos direitos políticos. Logo em 23 de Maio, os vereadores assumem-se explicitamente "como representantes do corpo municipal" e é nessa qualidade que "cumprem com o dever de levar ao conhecimento da Regência a situação política, em consequência da nossa declaração de adesão ao sistema constitucional." ${ }^{2}$ Estava em causa a justificação da tardia decisão em aceitar a Revolução de 1820, imputando a factores externos esse facto e acentuando o amor à liberdade por parte da maioria dos habitantes da ilha. Só a força militar, estacionada no Castelo e cumprindo ordens do General Garção Stockler, os havia impedido de mais cedo manifestarem a sua vontade, alicerçada em forte espírito liberal.

Em Agosto a vereação reitera mais expressivamente o seu carácter, não apenas como representante do conjunto dos habitantes, antes denominado de corpo municipal, mas ela própria assumindo-se como corpo intermédio. Como tal apresenta-se ao Congresso, - e cito - "movida pelos patrióticos sentimentos que animam o povo da mesma ilha a quem representa na qualidade de corpo municipal." ${ }^{13}$ Ganha, assim, sentido complementar aquela designação. Na missiva em análise estava em causa a defesa da iniciativa popular na adesão ao constitucionalismo, animados com a visão dos brigues Tejo e Providência a aproximarem-se do porto da Horta e confiantes de que deles viriam reforços contra qualquer tentativa militar de esmagamento do movimento liberal popular. Assim, o povo não esperou que a tropa do Castelo se rendesse ou as autoridades municipais tomassem a decisão de proclamar a Constituição, ele espontaneamente se ajuntou para o efeito.$^{14} \mathrm{~A}$ necessidade desta justificação deriva do boato que circulava no Congresso relativo à passividade dos faialenses com objectivos ínvios e que adiante referiremos.

Quando o movimento contra-revolucionário se torna mais evidente, com a recusa de Carlota Joaquina em jurar a Lei Fundamental e se prepara a

12 António Lourenço da Silveira Macedo, A História das Quatro Ilhas, v. II (1871), Angra do Heroísmo, RAA/SREC e DRAC, 1981, Doc. 2, p. 384.

${ }^{13}$ Ibidem, Doc. 3.

${ }^{14}$ Cf. a curiosa e impressionista descrição de António Lourenço Silveira de Macedo, História das Quatro Ilhas, II vol., Horta, Typ. De L. P. da Silva Correa, 1871, pp. 6 e s. 
intentona da Vilafrancada, que conduziria à suspensão da Constituição, a então Câmara constitucional da Horta, protestando fidelidade aos princípios liberais que havia jurado, promete defendê-los mesmo que à custa de sacrifícios. E neste sentido, afirma de forma mais inequívoca ainda, que nas anteriores missivas, a ideia que faz de si mesma na esfera política, corpo no interior da Nação: "A Câmara Constitucional do Faial deseja que a sua voz seja ouvida no meio da representação nacional para que a todos os portugueses conste mais uma vez que os cidadãos habitantes desta ilha são fiéis, zelosos e unanimemente amantes da pátria, da liberdade e da Constituição." ${ }^{15}$ Não se limita a pretender ser ouvida pelos deputados ao Congresso, representantes da Nação, mas na qualidade de corpo intermédio, que ao nível do município representa os cidadãos, os seus eleitores.

Esta posição torna-se ainda mais afirmativa na representação dirigida a D. João VI onde se volta a assumir como poder constituído, não apenas no tecido social mas no especificamente político, no edifício do Estado: "A Nação não pode prosperar sem os porfiados esforços de todas as autoridades; a câmara como as suas luzes lho permitirem não descansará no cumprimento de suas atribuições". ${ }^{16}$ Apresenta-se, dest'arte, como partilhando a soberania da Nação. Há aqui alguma antecipação do pensamento de Herculano que, aceitando a soberania da Nação embora, reitera a partilha da soberania pelos corpos onde a representação do povo, a "democracia", é possível. ${ }^{17}$

Todavia, também este município manifesta, como a maioria dos portugueses, a convicção de que a Constituição vintista tinha ido longe de mais na afirmação da soberania da Nação, assumindo-a como absoluta, dentro da matriz do "liberalismo à francesa". Ao dirigir-se ao monarca, como corpo municipal, espaço de liberdades conquistadas na longue durée, reconhece a historicidade da soberania régia traduzida na expressão, "Vossa Majestade, a fonte da Nação". Esta asserção revela uma conceptualidade oposta à do "liberalismo à francesa" e aos rumos que o vintismo tomara, nitidamente em tensão com o liberalismo radical. No quadro da Constituição vintista, o sufrágio universal e o imperativo da soberania absoluta da Nação ${ }^{18}$ remetem para o pacto político, eminentemente construtivista, excluindo a soberania histórica que o epíteto, - fonte da Nação - atribuído ao monarca pela câmara da Horta, recolocava sem, contudo, pretender sair do âmbito do liberalismo, antes afirmando-o como histórico - "liberalismo à inglesa", como ressalta do contexto discursivo em que a proposição se insere.

${ }^{15}$ Ibidem, Doc. N. ${ }^{\circ} 11$, pp. 409 e s.

16 Ibidem, Doc. 12, p. 411.

${ }^{17}$ Cf. "Carta aos eleitores do concelho de Sintra", in O.c., p. 322.

18 Constituição de 1822 - Art. 4 - "A soberania reside essencialmente na Nação". 
É neste âmbito que se deve entender também a natureza e função da municipalidade, garantia das liberdades históricas dos cidadãos, no seu círculo sócio político. Alexandre Herculano, aprofundando esta dimensão, travaria mais tarde diferentes polémicas, com liberais defensores do maximalismo político e, sobretudo, com os absolutistas-legitimistas do periódico A Nação. No 1. " caso, defende a criação de "círculos de eleição singular", garantes da "restauração da vida municipal, da expressão verdadeira da vida pública do país, e da garantia da descentralização administrativa, garantia da liberdade real." ${ }^{\prime 9}$ Contestando o excessivo centralismo, afirmaria: "os concelhos eram a organização da democracia contra os poderosos"; "o poder municipal o mais vivaz, o mais activo, o mais popular de todos os poderes" ${ }^{20}$. Nas polémicas com $A$ Nação resulta ainda mais claro o seu pensamento sobre a função do município na defesa e afirmação da liberdade, essência do regime cartista e cuja corrupção se dera na escalada absolutista a partir da revisão dos forais com D. Manuel. Na defesa das "liberdades e garantias das cidades e vilas do reino", Herculano chega ao ponto de pôr em paralelo os senados municipais e os pactos que haviam estabelecido os seus "privilégios" com o liberalismo vigente, enquanto integrador dos direitos históricos conquistados no que ele considerava ser espaço de igualdade e liberdade - os municípios. ${ }^{21}$

O espírito liberal que animara o clero do Faial revela outra expressão da validade dos corpos intermédios no seio do liberalismo - as associações religiosas - que no caso insular, onde vigorava o unanimismo católico, correspondiam às igrejas católicas locais. Por várias vezes o corpo clerical aparecera a tecer elogios à Constituição. Não se tratava apenas de um número limitado. $\mathrm{O}$ senado da Câmara da Horta pôde escolher, para as várias celebrações que promovera, diferentes pregadores todos adeptos do regime liberal mitigado. Também não se tratou apenas de mera formalidade por parte destes homens da igreja, pois que após a proclamação de D. Miguel, em 1828, foram depos-

19 "Carta aos eleitores do círculo de Sintra em 1858" in O.C., I, p.321.

${ }^{20}$ Opúsculos, II, p, 203

${ }^{21}$ "Em que dia desceu este [direito divino] do céu sobre el-rei D. Manuel, para ordenar aos seus escribas que rasgassem centenares de pactos constitucionais, onde estavam escritos os foros e liberdades e garantias das cidades e vilas do reino? ... Que eram os nossos parlamentos até 1480 , senão as assembleias onde o povo protestava sempre, ameaçava raro, e castigava algumas vezes cerrando as bolsas, as quebras do que, na linguagem imperfeita daquelas eras, chamava seus privilégios, e que nós hoje chamamos direitos e garantias políticas? Que eram esses parlamentos (concedei-nos o uso dessa palavra revolucionária, de que já usavam nossos avós, os malhados do século XV) senão uma aferição solene entre os actos do governo, o exercício do poder real, por si ou por seus delegados, e as regras do direito constitucional com que crescera e vigorara o país? "Os sete séculos" in O País, n. $22-21$ de Agosto de 1851. Sublinhado nosso. 
tos de seus cargos e alguns deles presos e deportados. O ouvidor, Pe Xavier da Silva, fora apenas deposto e não preso, segundo Silveira de Macedo, em virtude do prestígio e admiração que todos por ele nutriam..$^{22} \mathrm{O}$ mesmo, porém, não aconteceu com os Padres Vitorino José Ribeiro e Mateus de Aquino que oraram a favor da Lei Fundamental vintista, na festividade da criação da comarca da Horta. Ambos foram alvo de ferozes perseguições por parte dos miguelistas tendo sido enviados para a Trafaria. ${ }^{23}$

Tal como em S. Miguel, também no Faial foi um sacerdote eleito para o soberano congresso, o Padre Felisberto José de Sequeira ouvidor eclesiástico na vila de São Roque do Pico que na eleição de 1822 acompanhou Arriaga da Silveira; na reeleição, o Padre Roque Taveira ${ }^{24}$ insigne mestre régio na vila da Horta e aguerrido defensor da ideologia liberal de cariz mais racionalista.

Todo o clero secular e regular da ilha se prestou a fazer os juramentos revolucionários. Seguindo as indicações prescritas no decreto das cortes, de 10 de Outubro de 1821, "espontaneamente concorreram" à Matriz da Horta para aí jurarem a Constituição, em Setembro de 1822. Assinaram o auto 35 indivíduos entre vigários, beneficiados, curas, tesoureiros e meirinho bem como os superiores ou seus representantes dos conventos da ilha. ${ }^{25}$ Algo de semelhante se passara em S. Jorge, na vila das Velas, aquando da adesão ao processo liberal. O clero do concelho jurara a futura Constituição a $21 \mathrm{de}$ Maio de $1821 .^{26}$

A presença do clero do Faial em todos os actos festivos do processo vintista atesta a consonância daquele com o ideário que lhe subjazia. O próprio orador da cerimónia pública promovida pela Câmara para "ratificar $o$ juramento de fidelidade a El-Rei", por ocasião da assumpção dos seus direitos majestáticos, após a suspensão da Constituição, o Pe Miguel José Luís, fora antes "um decidido apologista da constituição" ${ }^{27}$ É necessário recordar que este juramento não teve o sentido restauracionista do legitimismo miguelista como na Terceira, antes fora entendido como moderação do sistema constitucional vintista, onde se poderia combinar a soberania histórica do monárca

22 "Foi este digno sacerdote um insigne ornamento do estado ecclesiástico, distincto por suas virtudes e sciências, desempenhou com dignidade as vigararias das freguesias de $\mathrm{S}$. Matheus, e das villas das Lages e da Magdalena, em ambas as quais foi ouvidor, passando depois a exercer egual cargo na Matriz da Horta, sendo sempre respeitado por todos os partidos a ponto de no meio das perseguições e prisões que se praticarão no tempo do governo miguelista apenas sofreu o desaire de lhe tirarem a ouvidoria apezar da sua conhecida dedicação, à causa liberal..." o.c., pp. 10-11.

${ }^{23}$ Idem, o.c., pp. 17.

${ }^{24}$ Idem, o.c., p. 13.

25 "Doc. n. 8" in Idem, o.c., pp. 404-405.

${ }^{26}$ Pe Azevedo da Cunha, Notas Históricas, v. II, U.A., Ponta Delgada, 1982, 'p. 785.

${ }^{27}$ Silveira de Macedo, o.c., p. 26. 
com a da Nação, pelo que se pode compreender a actuação daquele clérigo. Apenas a residência do deportado miguelista, coronel Morais Âncora, no convento de São Francisco deixa entrever a inclinação ideológica daqueles regulares para o legitimismo miguelista, como de resto acontecia na Terceira.

\section{A desejada autonomia - defesa de direitos históricos?}

A adesão ao liberalismo nesta ilha, como também na de São Miguel, propiciou a manifestação de repúdio do centralismo arquipelágico, criado pela Lei de 1766, desencadeando o processo de autonomia do poder de cada unidade geográfica - os grupos insulares -, de algum modo, corpos intermédios que na maioria das ilhas agregava diversos municípios. No meu entender, não se trata apenas de uma questão de oportunismo. É, sobretudo, a reivindicação dos direitos históricos, da autonomia a nível das estruturas insulares que o despotismo pombalino ameaçara.

A reivindicação dessa autonomia, porém, não resistiu senão fugazmente à tendência centralista. No período vintista o poder insular foi organizado em torno das três comarcas então criadas, pesem embora as dificuldades que os deputados do Faial, chegados tardiamente a Lisboa, enfrentaram no Congresso contra a intenção de subordinar a do Faial à Terceira; no cartismo, a criação da Prefeitura, ${ }^{28} \mathrm{com}$ as sub-prefeituras, permitiu também a resistência àquela força centrípeta apesar da hierarquia rigidamente constituída que vigorava na estrutura de poder. E, se no primeiro caso, os municípios mantiveram a sua função de "corpus intermédios", já no 2. ${ }^{\circ}$ com as exacerbadas tensões, entre centralização e descentralização, com a Reforma Preambular nos Açores surgiram as estruturas societais de base, denominadas Juntas de Paróquia, integrantes do corpo municipal. A autonomia ia a ponto de poderem criar escolas primárias. ${ }^{29}$

Nesta tensão, porém, venceria o despotismo centralista a que Herculano apelidaria de "pirâmide hierárquica tendo por vértice o ministério e por base os cabos de polícia e os esbirros administrativos e fiscais," herdeiro do absolutismo orgânico. Mas diferentemente da análise de Tocqueville quanto ao centralismo francês, Herculano, porque conhecedor do influxo do "liberalismo à inglesa", por ele defendido, reconhece que este processo "herdou todos os farrapos da púrpura que as ideias e as revoluções tinham rasgado, e cerziu com eles um trajo novo".

Mas voltemos à luta dos faialenses pela autonomia, no âmbito do vin-

${ }^{28}$ Decreto de 4 de Junho de 1832.

29 Decreto de 29 de Março de 1832. 
tismo, dos seus direitos históricos que a nova situação política, legítima enquanto salvaguarda dos direitos, deveria defender com mais acuidade. A ilha do Faial reclamava a secessão da Terceira. Clamava-a como um direito que o seu comportamento e os seus sentimentos e convicções políticas lhe conferiam. Os transtornos sofridos, com a centralização em Angra, levaram os faialenses a exporem com crueza a sua situação no sentido de serem ultrapassadas as dificuldades e implementado o almejado desenvolvimento. Protestavam, assim, contra a ideia que chegara à Assembleia Constituinte de subordinar a comarca da Horta à Terceira, precisamente onde se haviam perseguido os Constitucionalistas. O impacto de dois folhetos que haviam circulado com o objectivo de desvanecer a ideia de secessão do Governo central que tomava corpo e se concretizava, como de resto já havia acontecido com S. Miguel, estava na base do regresso da tendência da unificação em Província com capital em Angra. Também a Junta do governo aí estabelecida a 15 de Maio, ainda com a presença do General Stockler como adido ao governo formado pelo Deão Bettencourt de Vasconcelos, o corregedor Rebelo Borges e o comandante Paulo Xavier, fez uma exposição ao monarca sobre a situação financeira, justificativa da manutenção de um governo central..$^{30}$ Nela demonstrava não poder cumprir todas as ordens recebidas do congresso se "a separação já executada da ilha de S. Miguel e a intentada da Ilha do Faial" se mantiverem. Se a situação se não alterasse, isto é, se não viessem as contribuições daquelas ilhas, nomeadamente de S. Miguel, muitas famílias ficariam numa "lamentável consternação." Esta confissão vinha confirmar as reiteradas queixas quanto à espoliação dos bens que o governo central impunha. Ora, tal como sucedera no caso micaelense, os faialenses ao terem conhecimento daquele movimento, que no entender das ilhas era contrário à liberdade prometida, reagiram violentamente.

O Senado do município da Horta contestava e protestava contra a dúvida surgida no Soberano Congresso quanto à veracidade da entusiástica e unânime adesão ao constitucionalismo. Interpretou aquela dúvida como resultado de maquinações, por parte dos centralistas, tendentes a indispor os representantes da Nação com os habitantes da Horta e do Pico. Por isso tomou as seguintes medidas para evitar que as suas pretensões autonómicas fossem lesadas e os seus direitos históricos desrespeitados:

$1 .^{\circ}$ - apressou a eleição dos deputados que ainda não havia sido realizada em virtude do envolvimento da ilha do Pico no mesmo processo, justificada pela existência de três municípios e dificuldades de circulação. Mas essa demora estava a ser encarada como ineficácia e impotência. Efectivamente, as eleições só tiveram lugar após o conhecimento da divisão territorial dos Aço-

${ }^{30}$ ANTT, MR, cx.620, mç. 498, n. $^{\circ} 9$ de 30 de Maio de 1821. 
res, preparada na sessão de 24 de Julho, que submetia o Faial à comarca de Angra. A 15 de Setembro, seguiam para Lisboa os deputados eleitos. Animava-os a esperança de participarem na votação da lei que regularia a divisão administrativa e de poderem com a sua actuação inverter a direcção dos acontecimentos. De facto assim aconteceu, por decreto de 20 de Janeiro de $1822^{31}$ era criada a comarca da Horta;

$2 .^{\circ}$ - a vereação do município enviou ao Congresso a notável representação de Agosto, acima referida, em que expõe de forma muito clara os atropelos do governo central e chama a atenção para o apego à liberdade dos habitantes da Horta que espontaneamente proclamaram a sua adesão ao vintismo. Argumentos "com que reclamou a sua independência da antiga capital $e$ reclama os seus direitos", 32

$3 .^{\circ}$ - a reclamação da vila da Horta a cidade, considerada necessária e justa. Confrontando o comportamento do Faial com o da Terceira: "Foi porventura assim que se recebeu na ilha Terceira a aclamação da Constituição? Abominado este nome augusto, se não pelas classes mais polidas, certamente pela generalidade do povo e da tropa, perseguidos, e confiscados nas aras da liberdade os que tentavam estabelec $\hat{e}-l a " .33$

As representações às Cortes, reafirmando em todos os detalhes a descrição do sucedido em 12 de Maio, reclamavam o direito que assistia ao povo da Horta de ser atendido nas suas necessidades, a mais importante das quais era a separação do governo da Terceira e a ligação directa ao Reino de Portugal, condição da vigência das liberdades históricas.

A actuação dos deputados em Cortes foi decisiva. O Padre Felisberto José de Sequeira publicara uma refutação dos referidos Argumentos, para fazer circular na Constituinte..$^{34}$ Trata-se de um texto curto, incisivo em que contraditava um a um os argumentos a favor da centralização. A tónica mantém-se na espoliação dos direitos históricos e no esgotamento económico e financeiro e, ainda, nas vantagens da ligação directa a Lisboa. Manuel José d'Arriaga Brum da Silveira, por seu turno, além do denodo da defesa tribunícia, elaborou uma relação do estado e das necessidades dos habitantes do Faial e do Pico - Memória Geográfica, estatística e histórica ${ }^{35}$ Como o autor afir-

${ }^{31}$ Idem, o.c., p.17.

${ }^{32}$ Doc. 2 e Doc. $n .{ }^{\circ} 3,-2 .^{\circ}$ representação da câmara da Horta ao soberano congresso, de 10 de Agosto de 1821 in Silveira de Macedo, o.c., pp. 390-397, cit. p.391.

${ }_{33}$ Idem, o.c., doc. n. ${ }^{\circ}$ 3, Idem, O.c., p. 393.

${ }^{34}$ Argumentos que apparecerao em dois folhetos para desvanecer a idéa de se crearem nas Ilhas dos Açores mais duas Juntas Governativas, além da de Angra, a saber: Huma em $S$. Miguel e outra no Fayal; e huma breve refutação seguida aos mesmos, em fórma de Diálogo. Imprensa de Alcobia, Lisboa, 1821.

${ }^{35}$ Memória Geográfica, estatística, política e histórica sobre as ilhas do Fayal e Pico, Lisboa, 1821. 
mava, cumpria daquele modo a sua obrigação de "recomendar a importância dos territórios das ilhas... e conciliar a atenção dos regeneradores a favor da sorte que deve caber à porção de açorianos". Esta ideia de regeneração, que no vintismo nem sempre foi unívoca, no contexto do discurso de Arriaga remete para a defesa dos direitos históricos das unidades insulares, ou como ele diz, da porção de açorianos. Como um dos vectores de maior importância no âmbito da nova ordem liberal, surgia a necessidade da difusão da instrução, que mais do que nunca, agora que toda a população era chamada à decisão política, se constituía como um imperativo. Nas suas palavras, a instrução é o corolário da cidadania e sua condição necessária.

Os argumentos eram idênticos aos usados pelos micaelenses, dando, porém, maior destaque à localização estratégica do Faial no apoio à navegação do Atlântico Norte, ainda maioritariamente à vela, e sobretudo nas ligações com a América. Defendiam a união da ilha do Pico, dependente sob o ponto de vista económico e político do Faial, e das ilhas das Flores e Corvo, por motivos idênticos. Condenavam a centralização como forma ineficaz e dispendiosa de governo que provocava a exaustão das finanças locais e o abatimento da economia. Atendida que foi a pretensão dos faialenses, advogada pelos seus representantes - Arriaga Brum da Silveira e Felisberto José de Sequeira - a notícia da Carta de Lei, estatuindo a organização em comarcas das ilhas dos Açores, desencadeou a mais estrondosa festa liberal naquela ilha. ${ }^{36}$

Tal como sucedera em S. Miguel, os munícipes da Horta, também após a suspensão da Constituição, requereram a D. João VI a manutenção da separação da Terceira. Habilidosamente, o senado da câmara da Horta apelou para a bondade do soberano que mais não desejaria do que a "felicidade da Nação. Assim requerem a Vossa Majestade com o maior ardor e veemência, para que por sua inata bondade seja servido conserva-los assim independentemente livres de todo, e qual quer governo estabelecido em Angra, pois que esta, não só é a vontade geral de tão dignos Povos, mas é sem duvida o primeiro esteio da felicidade que podem gozar, e a que ansiosamente aspiram." ${ }^{37}$

A separação da Terceira que aparecera como um dos efeitos, considerado o "maior de todos os bens que podiam advir a estes Povos com a regeneração Política de Portugal,$^{38}$ era de facto, um anseio profundo, das populações que os corpos intermédios e, agora, os seus representantes eleitos defendiam como direitos históricos, mas também como condição de felicidade, ou seja, de bem comum. A libertação da tutela de Angra significara para os faialenses, como de resto havia sucedido para os micaelenses, um merecido prémio pela

${ }^{36}$ Cf. Silveira de Macedo, o.c., pp. 13-20.

${ }^{37}$ ANTT, $M R$, cx. 621 , mç. 498 , representação de 11 de Dezembro de $1822, f l .2 v$.

${ }^{38}$ fl. $16 v$. 
sua adesão ao liberalismo, um liberalismo que respeitava e repunha os direitos históricos dos povos.

\section{A dimensão racionalista: soberania da nação e o novo pacto social}

O texto de autoria de Faustino José da Silveira, e já atrás citado e interpretado na perspectiva da afirmação dos direitos históricos, concilia a temporalidade histórica com a universalidade da matriz racionalista dos direitos naturais que o pacto transfere para o domínio do político. ${ }^{39}$ Apresenta os valores liberais como a grande conquista da revolução, origem e condição da felicidade dos povos. Defende-a em nome da razão. Nas suas palavras: "É chegado o século da razão." 40

Este apelo veicula a noção de liberdade que se fundamenta na dignidade da natureza humana radicada no direito natural, causa racional, a que só pela via da razão se alcança. "A protecção, a dignidade perdida, o direito a vossas propriedades adquiridas legitimamente... a igualdade de direitos tendentes à vossa comodidade" são expressões equivalentes aos direitos liberais: segurança, liberdade, propriedade, e igualdade perante a lei.

Fazia o discurso da adesão necessária ao processo político em que estava envolvida a Nação, matriz da soberania a que o monarca se deveria sujeitar. Interpretando a História como tempo de afirmação daquela estrutura nuclear, não deixa de a colocar como elemento fundador. Nas suas palavras:

Pensemos por um pouco que o Pai Comum da Nação se queria desunir de seus briosos filhos, a quem deve a coroa e a independência (o que é impossivel), que fariam as ilhas em não se unirem á causa da Mãe Pátria ou da Nação, que faz os Reis e lhe dá os poderes, e que só ao Povo é que eles devem sua autoridade, para bem comum... ${ }^{41}$

A ideia clara de que o poder reside na nação e não no monarca está aqui bem expressa, assim como a do pacto pelo qual o povo transferiu para o monarca os poderes em vista do bem comum.

A ideia, segundo a qual a soberania reside por direito próprio no povo, volta a repetir-se em texto oficial, ${ }^{42}$ elaborado pelos membros da Junta Provisional da Comarca da Horta. Destinado a saudar o monarca pelo juramento da Constituição, este juramento era encarado como a maior "prova do Pater-

${ }^{39}$ Transcrito in A.A., v. III, pp. 491-491.

${ }^{40}$ Ibidem, p. 491.

${ }^{41}$ Ibidem, p. 493, sublinhado nosso.

${ }^{42}$ ANTT. MR., cx.621, mç.498, representação de 11 de Dezembro de 1822. 
nal Amor, que o Real Coração de V. Majestade sempre consagrou à Nação". Foi, porém, mais além e, para que não restassem dúvidas sobre a interpretação que davam à natureza do poder régio e da soberania da nação, conclui: "que para Seu Augusto Chefe (a Nação) o escolheu". ${ }^{43}$

Por seu turno, o Doutor Roque Taveira, professor de filosofia do Faial, encarregava-se de ilustrar os seus conterrâneos a respeito da Constituição ${ }^{44}$ Apresentava os princípios em que se baseara a Revolução do Porto, no encontro entre a tradição histórica e a matriz racionalista, onde a referência à vontade geral de Rousseau e ao equilíbrio de poderes de Montesquieu se combinam com a representação política à Locke. Independentemente do facto de este intelectual conhecer directa ou indirectamente as obras daqueles pensadores, fica evidente a similitude de convicções. Cito:

Já havia muitos anos, que a Lei não era justa senão quando era conforme á vontade geral, e que o Governo, ou poder executivo, era obrigado, bem como o judiciário, a limitar-se á Lei, que acima da Lei não havia nada; mas que a Lei só a podia fazer a Nação por meio de seus Deputados em Cortes, que eles só a podiam interpretar, abolir, ou modificar. Em fim que só nos Deputados das Cortes residia a Soberania. Sua legitimidade. ${ }^{45}$

Ultrapassando o enunciado de princípios, explica o que é a constituição - "Hum código de Leis fundamentais, as únicas legitimas dadas pela Nação, pelos seus deputados juntos em Cortes, em que cada hum de nós também entra”. Num discurso pedagógico, faz a apologia da Constituição de acordo com os direitos naturais e positivos estruturantes do liberalismo político: liberdade, segurança, propriedade e igualdade perante a lei. A segurança é proporcionada pela lei positiva ao estabelecer a legalidade, impeditiva da arbitrariedade no exercício do poder e a salvaguarda dos direitos individuais; o respeito pela propriedade privada inviolável; a igualdade de todos perante a lei, de molde a que cada um seja tratado em conformidade com as suas capacidades e não em função de destrinças estruturais.

A forma como a Junta Provisional da Comarca da Horta ${ }^{46}$ se referia à Constituição aproxima-se da concepção expendida pelo professor régio: "Constituição Política da Monarquia Portuguesa. Este Sagrado Código, fruto feliz da profunda sabedoria, fadigas, e acrisolado patriotismo do Augusto e Soberano Congresso." 47

${ }^{43}$ Ibidem, fl.1, sublinhado nosso.

${ }_{44}$ Publicada a 26 de Maio de 1821, pouco mais de meio mês após a revolta, Manifesto aos faialenses, Lisboa, Impr. da viúva Neves \& Filhos, com um total de 19 páginas

${ }^{45}$ Ibidem, p. 9.

46 Texto citado acima.

${ }^{47}$ ANTT, MR. Ibidem. 
Também o ouvidor do eclesiástico, Padre. Francisco Xavier da Silva, na festividade da proclamação da futura constituição afinava pelo mesmo nota. Ao fazer a peroração do sistema, defendia - e cito - "o direito que o homem naturalmente tem à sua liberdade" ${ }^{48}$ No âmbito da natureza ética do direito natural, assegurada pela estatuição da lei positiva, adverte igualmente os faialenses que a liberdade individual "deve ser subordinada ás leis prescritas pelo mesmo direito a fim de produzir a ordem e a harmonia" ${ }^{49}$ A radicação da noção de soberania e da fundamentação da legitimidade na lei natural fica bem expressa ao mesmo tempo que se afirma a salvaguarda da natureza ética no direito positivo.

Acompanha todo o processo de aclamação faialense a noção de soberania nacional e a importância da constituição conciliados com a salvaguarda dos direitos históricos.

Tanto os textos pedagógicos, acabados de analisar, como o oficial que, de certo modo lhes serve de corolário, apoiam-se em dois pontos fundamentais:

1. ${ }^{\circ}$ - A soberania da nação, estatuinte da Lei Fundamental como a sua expressão máxima e de maior alcance.

A Constituição apresentava-se como o texto que ordenara o "novo Pacto Social". Pelo juramento, que a Nação e o Rei efectuaram aos termos desse pacto - a Constituição. Com ela "quebraram-se os ferros da escravidão, $e$ despotismo, morrerão as esperanças dos cruéis inimigos da Pátria, e do Novo Pacto Social, alçou a frente Majestosa e Risonha, a Liberdade."

Entendia-se a Constituição no quadro das características modernas, apontadas por Prélot. O texto escrito, super-legal, estabelecia a igualdade dos indivíduos em face da lei e determinava o espaço de interferência dos poderes políticos, controlando-o. O juramento que marcava o selar do pacto, em função da unanimidade, impedia os projectos contra-revolucionários, pelo menos assim criam os signatários do documento em causa. Em última análise, a Constituição representava a conquista, reconquista, da liberdade específica do indivíduo estabelecida pelo direito natural, moderada pela natureza ética da mesma, que a liberdade de todos impunha.

Os hinos, e as odes, criados para o efeito, se representam por si mesmos a vigência da ideologia que comportam, induzem a importância do texto fundamental servindo de veículo difusor. No Congresso se configurava a Nação, a sua soberania. Vejamos como tais sentimentos, perpassados de ideias, se expressam num dos ditos poemas:

\footnotetext{
${ }^{48}$ Ibidem.

${ }^{49}$ Ibidem.

so Ibidem, fl. 2.
} 
Exulta, ó Faial, a frente adorna

De cívicos lauréis; e desterrando

Do peito heroico, teu inquieto susto

Honra o Congresso Augusto

Mais que os Ephoros, Sabios; que os Archontes,

Só exercem poder, só Dignidade

A bem da Humanidade.

$\cdots$

He da Nação o Genio quem te falla;

Oh Ilha afortunada! Em branca pedra,

Teus prosperos destinos são escriptos

Por entre mil conflitos ${ }^{51}$

$2 .^{\circ}$ - A partilha do poder pelos corpos intermédios. A câmara da vila, mediatiza o posicionamento ideológico do povo que representava, enquanto por ele eleita constitucionalmente. Declara, em função do conhecimento que tem dos sentimentos colectivos, unânimes, estar preparada para a defesa do sistema liberal, em nome do amor "da pátria, da liberdade e da constituição". ${ }^{52}$

Dentro deste espírito a mesma corporação dirigira-se aos habitantes no sentido de estes lhe prestarem a sua cooperação a fim de satisfazer as necessidades existentes. Visava "dar ao respeitável público, como lhe cumpre, não só uma evidente prova do seu liberalismo" mas também conseguir aquela cooperação que lhe permitisse "dar logo em pronto as providências devidas ao bem público"..$^{53}$

Estava em causa nesta proclamação o desiderato liberal da felicidade da nação, mas pressupondo os direitos específicos dos corpos intermédios. Continuando este mesmo projecto, incitava os munícipes à participação na formação da guarda nacional. O apelo, à incorporação neste novo corpo defensivo dos valores liberais, dirige-se aos cidadãos na convicção de que a sua adesão íntima a esses mesmos valores os motivaria a empenharem-se na sua preservação. Incitava-os do seguinte modo: “...também devemos todos concor-

${ }^{51}$ Assim continua, em estilo heroico celebrando o genio da Nação e a vitória liberal. o seu autor é António Silveira Bulcão, membro da maçonaria como se pode verificar na assinatura dos seus artigos insertos no Atlântico na década de 60 . Esta Ode está transcrita em Silveira de Macedo, o.c., pp. 397-399. Segue-se-lhe outra pp. 399-401 da autoria do juiz de fora José Maria Osório.

52 "Felicitação da câmara da Horta ao soberano congresso" em 26 de Março, de 1823. Idem, o.c., pp.409 e s, cit. 410.

53 "Proclamação" de 26 de Março de 1823, Idem, o.c., pp. 412 e s. 
rer pelo modo regulado pelas leis, para que se conserve a nossa liberdade e sossego, tanto interna como externamente". ${ }^{54}$

O posicionamento ideológico dos faialenses continuava a demonstrar-se na correspondência mantida com o terceirense, ministro de D. João VI, o conde de Subserra, um dos membros da malograda comissão de elaboração do projecto de Constituição, acerca da ocorrência da Abrilada. Não obstante o senado em funções ser o que servira antes da Revolta de 12 de Maio de 1821, este não manifesta qualquer inclinação para o projecto miguelista. O ministro da guerra informava o governador Rocheleben acerca da natureza realista da Abrilada ${ }^{55}$ advertindo-o para os projectos absolutistas, sinal de que em terras faialenses essa não era a ideologia dominante. De resto as missivas desencadearam uma manifestação de apoio a D. João VI e aos ministros que se lhe mantinham fiéis. A Felicitação a D. João VI manifesta essa realidade, enquanto o saúda "por haver salvado a monarquia portuguesa dos perigos $e$ abismos em que esteve quase submergida" ${ }^{56}$ Resulta evidente que estes perigos se relacionavam com o restabelecimento do absolutismo, tanto mais que o conde de Subserra havia dado a informação relativa às intenções da rainhamãe, de D. Miguel e do partido realista que estiveram na base da Abrilada.

Fora com este pendor de um liberalismo mitigado, de tipo cartista, que no Faial se vivera o período que antecedera a outorga da Carta e respectivo juramento nesta ilha. O faialense Silveira de Macedo afirmaria, ao fazer a história deste período, que o sistema cartista "estabelecendo a igualdade perante a lei, extinguindo a odiosa distinção de classes, concedendo ao povo o livre sufrágio para os seus representantes, mas por intermédio de eleitores por ele escolhidos e garantindo ao mesmo tempo ao soberano o direito de nomear os seus pares para assim contrabalançar a soberania do povo era sem duvida a forma de governo mais apropriado ao génio e índole do povo portugues". 57 Expressava assim, o entendimento da bipolaridade da soberania e o balanceamento entre direitos históricos e direitos absolutos, metafísicos, que o vintismo conhecera na comarca do Faial.

${ }^{54}$ Ibidem, "Proclamação" de 21 de Maio de 1823.

${ }_{55}$ Idem, o.c., transcr. dos ofícios do conde enviados ao governador, pp. 425-429.

${ }^{56}$ Ibidem, "Felicitação da Câmara a Sua Magestade".

57 o.c., p. 57, sublinhado nosso. 


\section{A ITÁLIA POLÍTICA DO SÉCULO XVII VISTA POR OLHOS PORTUGUESES}

Alberto Antunes de Abreu

José de Sousa Pereira foi conselheiro de D. Pedro II e membro do seu Conselho da Fazenda e por D. Pedro II enviado a Roma a acompanhar o bispo de Lamego, no sepeténio de 1676 a 1682.

O opúsculo em análise, A politica dos princepes de Italia foi escrito em 1680, e deixado em manuscrito. Denota um grande espírito de oservação, a par de um pensamento original, segundo as palavras do seu benemérito editor, Moses Bensabat Amzalak' ${ }^{1}$ O que Pereira narra ou descreve parece ser aquilo de que teve a oportunidade de ser observador. Aliás, o seu discurso é do tipo do dos historiadores do seu tempo, com recurso a exemplos de casos conhecidos ou observados ${ }^{2}$.

Como eles, também José de Sousa Pereira não consegue esconder as suas simpatias. Primeiro é o deslumbramento tardo-humanístico perante a pseudo-utopia veneziana. Depois é a simpatia pelo ducado de Saboia, donde viera a rainha que fizera a mudança de regime em Portugal: de D. Afonso VI com quem estivera casada e que parece que sempre defendeu até depois liderar a conspiração de D. Pedro II com quem casou. Pereira, homem da clique petrina, não podia considerar este Ducado menos do que como "o adorno de Italia", onde só podia reinar o amor, a fidelidade, a pompa e galhardia, etc. Por outro lado, o próprio Dr. Pereira afirma que a sua análise é incompleta, por omitir aquilo que é consabido, mas também aquilo que não entendeu muito bem ("não penetro", como ele diz), seja pelo seu carácter secreto, seja pela respectiva novidade ${ }^{3}$. Também não me parece que tenha conhecido bem e directamente Génova, nem Modena, Mântua, Parma nem Lucca, tão reduzida é a informação que sobre estas unidades políticas aduz, que acabou por ser preenchida com informações sobre o carácter das populações. De facto, nestes casos (e possivelmente também relativamente a Veneza, pelo menos em parte) Pereira, na impossibilidade de se deslocar a todas elas, poderá ter-se limitado a informações obtidas de pessoas (estas sim, mais ou menos simpáticas ou afáveis).

Mas, fazendo estas ressalvas e mesmo com elas, o texto que passo a

Amzalak, in Pereira 1933: 6-9.

V.g. Pereira 1933: 15.

Pereira 1933: 63. 
analisar bem serve para documentar como um político português do século XVII podia entender a política italiana e, por este meio indirecto, avaliarmos do que da sua política pátria ele poderia pensar.

\section{O território}

A primeira observação, justificável num homem que conhecia a Antiguidade e suas políticas imperiais, que de Portugal à Itália passou por três Estados unificados - Portugal, que o era desde os tempos de D. Afonso III, a Espanha que fizera a sua unidade no doloroso período de 70 anos que foi dos Reis Católicos a Filipe II, a França várias vezes unificada de Júlio César a Luís XI - foi a da falta de unidade territorial da Itália. Este nome designava, ao seu tempo, um conjunto heterogéneo e de desigual poder e dimensão constituído por 10 principados, alguns anexos e outros que "não conhecem superior" (como o Mónaco e Massa) ${ }^{4}$. (Por isso também ele limitou a sua análise a 10 principados, entre os quais os já de si plurais Estados do Papa).

Nos Estados Pontifícios também era desigual a valorização dos vários territórios. Decidido a não os governar directamente em termos de Estado moderno centralizado, o papa governava-os indirectamente: a uns por meio de cardeais, como eram os casos de Ferrara, Bolonha, Urbino e a própria Roma; e as outras terras através de legados e vice-legados, presidentes e governadores ${ }^{5}$. Nesta partilha de poder, ainda havia lugar para vestígios de feudalismo, na " $h o-$ magio" a troco de investidura que ao papa faziam os governantes dos Reinos de Nápoles e da Sicíllia (pelo rei de Espanha), do Ducado de Parma e Piacenza ${ }^{6}$. E o facto de Pereira ter transcrito o termo italiano bem evidencia quanto esta prática se encontrava em desuso em Portugal, onde o termo "homenagem" já estava desligado do sistema senhorial, para se acantonar em outro paradigma sémico. (Pereira que, como jurista, não era, porém, desconhecedor das relações senhoriais, classifica esta situação, de facto como "feudataria" e vai utilizando termos da família semântica de "feudo" sempre que tal se justifica).

\section{Inconvenientes do regime electivo}

José de Sousa Pereira fora criado numa monarquia hereditária que 40 anos antes tinha vencido um projecto de tendência republicana de modelo

\footnotetext{
Pereira 1933: 11.

5 Pereira 1933: 12.

${ }^{6}$ Pereira 1933: 12.

7 Pereira 1933: 25.
} 
neerlandês, e era ele mesmo homem da confiança de D. Pedro II, o príncipe que substituíra o rei legítimo mas sem quebrar os princípios da hereditariedade do cargo dentro da família brigantina. Com efeito, D. Pedro II era irmão do rei deposto e seu sucessor na linha masculina. Liderara a facção que o depusera, ao que parece mais com a intenção propriamente de afastar Castelo Melhor. Serviu-se da declaração de nulidade do respectivo casamento conseguida pela rainha, a qual declaração, ao dizê-lo impotente, o declarava inapto para assegurar a sucessão hereditária legítima. Só depois disso conseguiu das Cortes de 1668 a deposição do seu irmão mais velho como incapaz para reinar. Entretanto, tinha realizado com a cunhada o procedimento antigo utilizado para assegurar a descendência ao irmão e que levava o nome de levirato ${ }^{8}$. E mais tarde, em 1687-88, conseguira das Cortes a definição da legitimidade de sucessão no trono para o príncipe D. João (futuro D. João V), filho que tivera, já não de D. Maria Francisca (falecida em 1683), mas de D. Maria Sofia de Neuburgo.

Um homem assim tão habituado no regime de monarquia hereditária só podia encontrar "imperfeições" no regime de governação papal, que, a seu ver, são comuns a "todo o principado electivo", "por respeito - no caso - da sua continua mudança na eleição do Pontifice", em que ele denuncia as tentativas de influenciação exercidas por parte dos Estados italianos e a França e a Espanha presentes no solo italiano, mas não refere o papel nela desempenhado pela inquisição ${ }^{10}$.

\section{$O$ regime absoluto}

José de Sousa Pereira parece razoavelmente crítico relativamente aos regimes que observou. Do de Nápoles, onde o rei de Espanha se faz representar por um vice-rei, Pereira, que vinha dum País onde o rei se apresentava tradicionalmente como exercendo uma autoridade paternal, em cujos domínios asiáticos o título de vice-rei apenas significava que quem o exercia era da alta nobreza tendo em tudo funções de governador e em cujos domínios americanos nem título de vice-rei alguma vez houve, não pôde deixar de observar que, no reino de Nápoles, o vice-rei governava "com auctoridade absoluta", ao ponto de nem sequer ser admissível o recurso para a corte de Madrid ${ }^{11}$. E como se conseguia tal autoridade que Pereira se não coíbe de qualificar de

${ }^{8}$ Cf Dt 25, 5; Mt 22, 24.

9 Pereira 1933: 13.

${ }^{10}$ Bethencourt 1994: 262.

11 Pereira 1933: 26. 
tirania? Pelo reforço da hegemonia duma clique dirigente e pela sujeição e empobrecimento da massa dos cidadãos.

O prestígio interno e a respeitabilidade externa não havia como um poderoso exército para a conseguir. Veneza construiu uma talassocracia ${ }^{12}$. Saboia constituiu um exército de 12000 homens $^{13}$. Modena poderia armar 25000 soldados e manter em campanha $10000^{14}$. E Lucca, apesar da sua pequenez, podia armar 18000 soldados no seu distrito, afora os que recrutava na cidade $^{15}$. O efeito da aplicação das rendas públicas na manutenção do exército e outros instrumentos de prestígio parece bem evidente da análise que faz da situação da república de Génova, que mantinha uma população pobre, porque as avultadas riquezas dos particulares eram aplicadas para sustentarem a "liberdade e grandeza" da república ${ }^{16}$.

Para estas e outras despesas, o Estado podia recorrer ao fisco até mirrar os súbditos. Foi o que fizeram os vice-reis em Nápoles ${ }^{17}$ e os Médicis em relação aos povos do grão-ducado de Florença, os "mais opprimidos de tributos e imposições que no mundo pode haver"'s.

E por via desta opressão e empobrecimento teriam conseguido, segundo Pereira, criar um "estado de sujeição e miseria", com que se dominavam populações e adormeciam potentados locais "de espirito irrequieto e sublevado", que pudessem "causar alguma inquietação", se "gosassem de qualquer liberdade ou riqueza". Pela mesma razão se lhes não permitia o uso de armas e toda a cidade de Florença se encontrava cheia de espias ${ }^{19}$. Um regime de vigilância mantinham também os Médicis em Siena, servindo-se, para o efeito, não só de tribunais e magistrados, mas até dos próprios oratórios devocionais ${ }^{20}$.

Outro dos procedimentos consistiu em pôr em prática em Nápoles o velho princípio de "dividir para reinar". Sendo os napolitanos "de genio irrequieto", houve, foi, que fomentar as suas desuniões, para que "não possão alterar o seu dominio"21, se porventura alguma vez se puderem desunir. Para ainda mais fomentar a desunião dos povos, o Estado espanhol ia diligenciando por vender os feudos que vagassem e mesmo quaisquer outras terras a súbditos estrangeiros com os quais procuravam casar as senhoras, para fomentar a

\footnotetext{
Pereira 1933: 31 .

Pereira 1933: 42.

14 Pereira 1933: 57.

15 Pereira 1933: 62-63.

16 Pereira 1933: 52.

17 Pereira 1933: 27.

18 Pereira 1933: 46.

19 Pereira 1933: 46.

20 Pereira 1933: 47-48.

${ }^{21}$ Pereira 1933: 26.
} 
variedade (e divisões) entre as pessoas. Discretamente se fomentaria também a infestação do reino por bandidos, para que as pessoas sentissem a necessidade dessa autoridade forte. Rodearam-se duma corte de "confidentes" cuja fidelidade era "paga" pelas exacções que lhes permitiam fazer sobre os seus inimigos e sobre o povo dum modo geral. No caso dos desafectos ao vice-rei, "a qualquer seu pequeno delicto responde hum severo castigo". E "nas cadeas ou desterros se poem freio a qualquer excesso". A consecução da "auctoridade absoluta" mesmo conseguida deste modo tirânico é o que Pereira denomina de "razão de Estado"22. ("Prudência falsa" the teria chamado o $\mathrm{P}^{\mathrm{e}}$ Manuel Bernardes ${ }^{23}$.)

No caso da Sardenha, a actuação da dominação espanhola foi mais directa e mais drástica. Após algumas rebeliões, deportaram-se as populações rebeldes, e o carácter acomodatício das que ficaram fez o resto ${ }^{24}$.

Para não ter oposição interna, o papa, como vieram a fazer os monarcas europeus, de há muito que vinha tentando (e, segundo Pereira, conseguindo) abater o poderio e prestígio das grandes famílias romanas sedentas de hegemonia (como os Urzini, Collona, Bentivoglio, Vicelli, etc) e que, até então, "de alguma maneira davão que entender aos papas"

Pelo contrário, o sumo pontífice governava desconcentrando o poder em congregações, a quem remetia "todas as suplicas que lhe fazem os princepes assim em materias ecclesiasticas como em outras" e a pena explicativa de Pereira acrescenta "de que não tem gosto". E assim os papas faziam cair o odioso da correspondente negação sobre a congregação e o desviavam das suas pessoas ${ }^{26}$.

Tendo de conviver com os vários corpos sociais, os monarcas absolutos do século XVII, quando não puderam disciplinar a nobreza e o clero, procuraram governar o mais equidistantes possível deles. Contudo, em Veneza foram adoptadas algumas restrições para as pessoas de condição nobre. A primeira foi a de só poderem ter senhorios na "terra ferma". Outra foi a proibir que os nobres venezianos se ocupassem da defesa com milícia terrestre, a não ser quando presidiam em alguma praça (na "terra ferma) como seus governadores ${ }^{27}$.

No respeitante ao clero, Veneza apresentava, por esta altura, as primeiras soluções dum Estado laico. A República nunca se intrometeu na eleição papal, "nem consentiu que os ecclesiasticos se mettão no seu governo"22.

\footnotetext{
${ }^{22}$ Pereira 1933: 27.

${ }^{23}$ Bernardes 1696: 1, $92(1,94)$.

${ }^{24}$ Pereira 1933: 28.

${ }^{25}$ Pereira 1933: 18.

${ }^{26}$ Pereira 1933: 16.

27 Pereira 1933: 35.

${ }^{28}$ Pereira 1933: 35.
} 
Mas temos de reconhecer que, pior que a hegemonia concorrencial da Igreja dentro de Estados que, afinal, lhe aceitavam o magistério e a direcção religiosa, era a de "Estados dentro do Estado", como sucedia na república de Génova, cujas rendas, na sua maior parte, eram "applicadas" à Companhia e Monte de S. Jorge, que, segundo as palavras de Pereira, "he como huma republica n'aquella republica" 29 , e onde havia "familias mais ricas que a mesma republica" ${ }^{30}$.

Um dos procedimentos das monarquias modernas para construir Estados unificados de regime absoluto foi o da unidade religiosa. O exemplo mais emblemático foi o dos Reis Católicos Fernando e Isabel, em Espanha. Em Portugal, a inquisição serviu este desígnio. Ora, José de Sousa Pereira nada nos diz sobre o Tribunal do Santo Ofício, que actuou, como sabemos, também na Itália, nomeadamente da hostilidade com que era visto pelos Estados italianos por ser dependente de Roma ${ }^{31}$, o que impediu a sua instalação em Lucca, o controle que sobre ele exerciam as repúblicas de Génova e Veneza ${ }^{32}$, particularmente depois dos escritos de Paolo Sarpi ${ }^{33}$, a recusa, por parte dos Duques de Saboia, de aceitar várias nomeações de inquisidores por não serem "naturais" do Estado ${ }^{34}$ e as revoltas populares de que foi alvo em Nápoles ${ }^{35}$.

Mas deixou-nos uma opinião muito curiosa acerca da tolerância religiosa. A República de Veneza, apesar da prudência que até aí a caracterizava, concedeu aos Gregos de Cândia a "commodidade de formas diversas" de vida religiosa, permitindo-lhes manter-se "separados da obediencia ao papa". Julgava que por esta concessão podia mais facilmente dominá-los. Mas, segundo Pereira, os venezianos não se lembraram que não pode "ordinariamente ser fiel aos homens quem a Deos não he fiel, [e,] unindo-se-lhes a perfidia turqueza", lançaram "no coração da republica as chamas de huma guerra" interminável ${ }^{36}$.

Tipo clássico dos instrumentos da razão de Estado para dominar os súbditos foram os que o regime jurídico colocou ao dispor dos Estados absolutistas. Em Veneza, para manter a paz interna como ambiente de dominação, procurava-se, entre outros meios, a "moderação nas judicaturas que respeitam aos erros da humana fragilidade"; mas isto conjugado com uma extrema severidade na punição dos crimes que afectassem a quietação e paz pública. E procurava-se ser mais severo com os aristocratas, dizendo que para evitar que se

\footnotetext{
${ }^{29}$ Pereira 1933: 51.

30 Pereira 1933: 52.

31 Bethencourt 1994: 262.

32 Bethencourt 1994: 26, 259-260, 287, 353.

33 Bethencourt 1994: 313-314.

${ }_{34}$ Bethencourt 1994: 351, 353.

35 Bethencourt 1994: 26, 315.

${ }^{36}$ Pereira 1933: 36.
} 
tornassem insolentes. Contudo, fugia-se a uma perseguição aos nobres, para evitar a constituição de corpos sociais hostis: na luta contra o crime, só se perseguia, para o punir, o infractor, deixando-se isenta a respectiva família ${ }^{37}$.

Em Florença, o procedimento do Médicis consistiu na criação dum regime de medo generalizado, com a proibição de uso de armas, a atenção a qualquer movimento e com encher a cidade de espias ${ }^{38}$. Consideravam também "razão de Estado" receber no grão-ducado todos os bandidos de Nápoles e dos Estados Pontifícios que utilizavam para "secretas execuções e outras ocurrencias". Depois, para que, depois de ociosos, estes bandidos se não tornassem prejudiciais, o grão-ducado armava uma esquadras de galés com cavaleiros de Santo Estêvão, para que eles dessem largas à sua agressividade fora do Estado florentino. (No tempo de Pereira, porém, este expediente achava-se já reduzido ao efectivo de duas galés, que prosaicamente preferiam dedicar-se ao comércio) $)^{39}$.

\section{Uma república vista como utopia}

Preparado para encontrar na república de Veneza uma situação de excepção, como veremos, José de Sousa Pereira não deixa de referir que aí se vivia em regime de república aristocrática, categoria que sem dúvida hauriu nos estudos sobre política clássica, nomeadamente na interpretação da $\mathrm{Re}$ pública Romana à luz dos conceitos helénicos, que vemos bem claramente utilizados, quando nos informa, por exemplo, que Génova "de republica democratica se reduzio a aristocratica, havendo a nobreza expellido o governo do povo"40.

Relativamente a Veneza, Pereira esclarece-nos que a república do Adriático era governada pelas famílias nobres. (Mas nota também que a guerra com os Turcos obrigou a acrescentar ao conjunto destas famílias algumas outras que ascenderam pela posse de bens de fortuna. Teria também neste caso perante si a história de Roma, nomeadamente na constituição da classe dos optimates a partir da inserção de plebeus ricos no seio do patriciado?). De qualquer modo, como sucedera com o Senado na Roma Antiga, diz Pereira que em Veneza o poder supremo era exercido pelo Grande Conselho ${ }^{41}$. E outras repúblicas havia na Itália e regiões próximas, como Pádua, Verona,

\footnotetext{
Pereira 1933: 37.

Pereira 1933: 46.

Pereira 1933: 48-49.

Pereira 1933: 52.

Pereira 1933: 29-30.
} 
Crema, Brescia, Lombardia, Bergamo, a Dalmácia, alguns lugares da Albânia, Corfu, Ceratonia, Zante, as antigas repúblicas de Candia e Chipre, e outras ${ }^{42}$.

Influenciado decerto pela leitura dos clássicos e dos utópicos dos começos da modernidade, Pereira vai apresentar-nos uma descrição fantasiosa da república de Veneza, que nos aparece como (já que não a ilha) a laguna do bem-estar. A maior preocupação dos seus governantes era a "conservação da paz e da liberdade", pelo que vestiam por igual o rico, o nobre e o pobre e só havia roupas diversas para os magistrados no respectivo exercício. No Grande Conselho (para designar o qual Pereira deixa escorregar o lexema "senado") não havia segredos exclusivos de qualquer pequeno grupo, sendo partilhados por todos os seus membros. Os nobres não tinham lugar nas grandes escolas da cidade nem no governo das igrejas (nem sequer das paroquiais), "para que fiquem aos cidadãos e ao povo estes logares em que possão com honra e proveito ser empregados". De idêntico modo, era ao povo que cabia a chancelaria. As pessoas, todas tratadas com amor, "gosão huma porção de principado" e eram tão livres como nas outras terras o são os governantes: "nada thes he prohibido; cada hum pode caçar, contractar e aproveitar-se dos dons da natureza, sem a minima perturbação ou trabalho". A preocupação é que "se conserve entre os nobres venezianos e os cidadãos, que são as pessoas de menos conta, huma mais reciproca amizade". Não há restrições aos casamentos entre pessoas de estratos diferentes, todos têm acesso às academias e participação nas festas ${ }^{43}$.

\section{A nobreza}

Isto na laguna feita ilha de utopia. De facto, os regimes absolutistas do século XVII assentavam numa classe aristocrática - prévia ou constituída ad hoc como veremos que se fez nos Estados Pontifícios - que ainda não podiam submeter como vão tentar, com êxito vário, os Estados esclarecidos. Por isso a utilizavam como suporte do Príncipe. No Ducado de Veneza também a havia. Mas as competições e lutas internas da nobreza pela hegemonia tinham sido relegadas para a terra firme e territórios sujeitos a Veneza ${ }^{44}$. Era aqui que esta aristocracia dominante desempenhava cargos governativos rendosos e os que se dedicavam à profissão das armas tinham o governo de terras e fortalezas ${ }^{45}$.

Em Florença, a preocupação dos Médicis era que pudesse aparecer um

\footnotetext{
${ }^{42}$ Pereira 1933: 30.

${ }_{43}$ Pereira 1933: 31-32.

${ }^{44}$ Pereira 1933: 33.

${ }^{45}$ Pereira 1933: 33.
} 
forte opositor. Por isso, muito embora mantivessem um bom número de cardeais e senhores estipendiados na corte de Roma, procuravam (também por meio deles) obstar a que fosse eleito papa um florentino, com receio de que ele "fomente os nacionaes a recuperarem a antiga liberdade" 4 .

A nobreza era o elemento mais deletério da república - aristocrática, embora - de Génova. Era ela que alimentava as discórdias civis, com o povo que expulsou do poder, depois entre uma nobreza "velha" e uma nobreza "nova". Porque, segundo o testemunho de José de Sousa Pereira, "muitas vezes succede que os moços nobres das cazas velhas maltratam com insolencias aos das cazas novas e aos cidadãos"47. A república de Génova, por exemplo, teria sido vítima de guerras civis, "que a arruinarão, constrangendo-a a por-se debaixo do dominio dos potentados estrangeiros"48.

\section{A corte do príncipe}

Pereira verificou a persistência na corte papal dum fenómeno característico dos Estados modernos e que lhe era familiar (embora de um certo modo apenas). Homem de corte, ele mesmo assistira, desde o tempo de D. João IV, à sucessão de cliques ou facções que procuravam colocar no poder uma pessoa que lhes favorecesse os interesses. Assim sucedeu à morte deste rei com a subida à condição de Regente de D. Luísa de Gusmão em 1656, na luta pela tutoria do príncipe herdeiro D. Afonso entre as facções do Conde de Odemira e do Conde de Cantanhede, ao tempo da tomada do governo por D. Afonso VI em 1662 apoiado na facção do Conde de Castelo Melhor ${ }^{49}$, a quando da derrota deste e processo de deposição de D. Afonso VI em 1667-68 $8^{50}$. Pereira devia mesmo ter tomado partido neste último caso, naturalmente a favor de D. Pedro e da rainha. Mas o que sucedia habitualmente era que a facção vencedora rapidamente "arrumava a casa" e afastava os adversários (ou eles mesmos se afastavam, como fizeram D. Luísa e D. Luís de Vasconcelos e Sousa, o 3. ${ }^{\circ}$ Conde de Castelo Melhor). (Houve apenas uma excepção: a luta entre os Condes de Odemira e de Cantanhede pela tutoria de D. Afonso VI, facções que se mantiveram acesas na corte e por nenhuma das quais D. Luísa quis tomar partido).

No caso da corte de Roma, o que surpreendeu o Dr. José de Sousa Pereira, foi o facto de se manterem "facções" no seio do colégio dos cardeais que eram, cada um deles, "creaturas" de partido ${ }^{51}$. Era vulgar mesmo os reis cris-

\footnotetext{
46 Pereira 1933: 48.

47 Pereira 1933: 52-53.

${ }^{48}$ Pereira 1933: 51-52.

49 Sérgio 1935: 503b.

50 Sérgio 1935: 505a.

51 Pereira 1933: 13.
} 
tãos pressionarem os papas no sentido de serem feitos cardeais homens da sua confiança. Fora esta, segundo Pereira, a razão por que Sisto V limitara a 70 o número dos cardeais ${ }^{52}$.

Nestas circunstâncias, o papa via-se obrigado a escolher, para a sua entourage, pessoas da sua confiança. Como usualmente, diz ele, "querem os papas aumentar as suas familias, n'ellas accumulam todos os seus interesses dos mais lugares e a administração, empobrecendo a este fim os povos" ${ }^{\prime 3}$. A escolha dos cardeais faziam-na entre os "que mais convem aos seus particulares interesse e da sua familia" ${ }^{54}$. E assim a engrandeciam e conseguiam estar rodeados de pessoas da sua confiança ${ }^{55}$.

Era, deste modo, impossível eliminar todos os inconvenientes duma corte assim venal e influente. Por outro lado, o novo papa via-se obrigado a trabalhar com os homens nomeados pelo seu antecessor. Nestas circunstâncias, o pontífice jogava em seu favor com a obrigação de residência imposta pelo Concílio de Trento e nomeava para lugares afastados da corte romana os cardeais que lhe pudessem "ser de prejuizo ou de algum embaraço" idênticas razões, os papas colocavam fora de Roma os cardeais príncipes, para fugir a contendas ${ }^{57}$.

No reino de Nápoles a situação era bem mais simples e foi resolvida de modo bem mais drástico. O vice-rei espanhol, para governar com autoridade, dividiu os notáveis em dois tipos: os "confidentes" e os outros. Aos primeiros tudo era permitido. Aos outros, como acima se disse, qualquer delito era punido com severidade extrema. Os "confidentes do vice-rey", por seu lado, "uzão em maior desordem dos subditos de menos conta", e por isso com acerto Pereira pôde afirmar que "he a amizade do vice-rey hum instrumento á tyrannia d'aquelle Estado" 58 .

\section{O pensamento económico}

Do ponto de vista económico, Pereira mostra-se compaginado com o que se pensava em Portugal no seu tempo, isto é, num mercantilismo de tipo populacionista como o de Severim de Faria, por exemplo, ao declinar como princípio consabido "sendo a riqueza maior dos reynos a multidão dos sub-

\footnotetext{
Pereira 1933: 15.

53 Pereira 1933: 13-14.

${ }^{54}$ Pereira 1933: 17.

5 Pereira: 1933: 20.

56 Pereira 1933: 15.

${ }^{57}$ Pereira 1933: 17.

58 Pereira 1933: 27.
} 
ditos" ${ }^{29}$, e no mercantilismo crisoedonista por via comercial. Assim o vemos, quando ele critica como opressor o domínio de Espanha sobre o reino de Nápoles, não por não incrementar uma economia produtiva (que não nos diz se fomentou ou se dificultou), mas por impedir o comércio com os estrangeiros. Esse comércio é que constituía a principal fonte de riqueza. Ora, por via dela, diz Pereira que "passa a Castella o mais consideravel cabedal dos subditos"

E que a sangria monetária era o que Pereira tinha em vista bem claro se torna, se repararmos que ele coloca a par com o referido bloqueio comercial o demasiado peso fiscal imposto pela monarquia espanhola ao reino napoli$\operatorname{tano}^{61}$. Que o Dr. José de Sousa Pereira punha o comércio à frente como o mais importante meio para conseguir a riqueza das nações bem o prova a sua afirmação de que esse Estado modelo que é Saboia só não era mais rico por os seus súbditos se desinteressarem da actividade comercial ${ }^{62}$.

Em Forença é, segundo ele, a engenhosidade dos florentinos conjugada com a miséria em que vivem que os faz dedicar à mercancia e às pequenas indústrias de sedas e lãs ${ }^{63}$.

\section{As relações internacionais}

Homem do seu tempo e diplomata do seu tempo, José de Sousa Pereira louvou a política, segundo ele, levada a cabo pelos papas, de abatimento das grandes nações (do género da prossecussão do equilíbrio europeu como a tentara Richelieu). Seguindo-a, os papas conseguiram sacudir a ingerência do Imperador, aliando-se ora à França ora a Veneza, ora às duas e assim foi proscrita da Itália a luta entre guelfos e gibelinos que dominara a sua política interna da Baixa Idade Média até ao Renascimento. De momento, o gigante a abater era o Rei Católico (monarquia espanhola), que, além dos seus vastos Estados, possuía na Itália Nápoles, a Sicília, o Ducado de Milão e algumas fortalezas na Toscana e na região de Génova ${ }^{64}$, e que conseguira impedir que $o$ papa, numa atitude de "contemporização e medo", nomeasse bispos para Portugal no tempo de D. João IV, "por temor de Castella"65.

No interior da Itália, a preocupação pelo equilíbrio de forças era, naturalmente, estrutural em pequenos Estados como Veneza, que tudo tinha a re-

\footnotetext{
${ }^{59}$ Pereira 1933: 14.

60 Pereira 1933: 27.

61 Pereira 1933: 27.

62 Pereira 1933: 43.

${ }^{63}$ Pereira 1933: 47.

${ }^{64}$ Pereira 1933: 25.

${ }^{65}$ Pereira 1933: 18-19.
} 
cear de potentados europeus com domínios na Itália como eram a França e a Espanha $^{66}$. Idêntica foi a política do Ducado de Saboia, que se foi aliando alternadamente à França e à Espanha e até a Veneza, no sentido de impedir que os franceses tomassem Milão para não ficar apenas rodeado por eles, mas também de obstar a que fosse demasiado forte a presença espanhola ${ }^{67}$. Também 0 papa se viu na necessidade de, a Norte dos Estados pontifícios, criar um Estado-tampão. Foi então que Clemente VII, com o apoio de Carlos V, colocou à frente da cidade de Florença os Médicis, a quem ajudou a alargar os respectivos domínios. E S. Pio V deu-lhes o título de Grãos-Duques de Florença com um território ainda mais vasto ${ }^{68}$.

O sistema do nepotismo usado pela papa, porém, também acarretava alguns efeitos perversos. Os nepotes afastavam do papa os ministros que não fossem do seu inteiro agrado ${ }^{69}$, o que não quer dizer que fossem os piores. $\mathrm{E}$ colocavam-nos na dependência deles. De facto, para agradar aos nepotes, os ministros informavam (Pereira diz mesmo "tratam" com) o nepote os assuntos a negociar com o papa e vêm depois do despacho papal colocar o nepote ao corrente da nova situação ${ }^{70}$.

Por esta via, como pela da nomeação para legações e nunciaturas, o nepotismo inquinava também as relações internacionais da Igreja. Ora, muito embora o papa se esforçasse - e, segundo Pereira quase sempre com êxito por uma equidistância entre Estados e príncipes nas relações internacionais, os nepotes, esses, já se inclinavam para um Estado ou uma coroa "como he mais util á sua familia" e para deixarem o seu futuro garantido no caso da sempre esperada, dada a idade com que subiam ao pontificado - morte do papa. O ducado de Parma foi instituído por Paulo III, ao tempo "cabeça desta caza" "11. A ambição fez com que os nepotes de Paulo V e Gregório XV tivessem pendor em favor da Espanha e que da corte de Urbano VIII uns se inclinassem para a França e outros para a Espanha ${ }^{72}$. Os reis de Espanha venderam territórios aos parentes dos papas para assim conseguirem "consideravel auctoridade" na corte pontifícia, por isso sempre inclinada a seu favor ${ }^{73}$, nomeadamente nas relações com Portugal.

E foi assim também que Luís XIII protegeu o cardeal Antonio Barberini, irmão do papa Urbano VIII contra a perseguição do seu sucessor Inocên-

\footnotetext{
${ }_{66}$ Pereira 1933: 33-34, 40.

${ }^{67}$ Pereira 1933: 39-40.

${ }_{68}^{68}$ Pereira 1933:45.

69 Pereira 1933: 21.

70 Pereira 1933: 21.

71 Pereira 1933: 61.

72 Pereira 1933: 22-23.

${ }^{73}$ Pereira 1933: 25.
} 
cio X (Giambattista Pamfili, o candidato espanhol). E também se deve notar que o concerto entre as duas famílias se conseguiu mediante o casamento duma parente do papa (irmã do príncipe Giustiniani) com o Príncipe da Palestina (sobrinho dos Barberini) ${ }^{74}$.

Em consequência deste empenhamento dos cardeais na intriga política interna e internacional, observa o Dr. José de Sousa Pereira que "raras vezes se achão hoje cardeaes cujo cuidado só seja no serviço de Deos e bem da religião, por que, ou como creaturas do princepe seguem as cortes, ou como dos nepotes a creação, ou como dos mais poderosos a dependencia"75.

Como homem do seu tempo também, Pereira admitia também (e até louvava) o cinismo nas relações internacionais, como o que relacionou o papa com as cortes de Espanha e França ${ }^{76}$. Também "com um pau de dois bicos" jogavam os Medicis de Florença, que tinham Siena como apanágio do rei de Espanha e se viam, por isso, a negociar a favor do rei católico, mas "em segredo" se entendiam com o rei cristianíssimo ${ }^{77}$. Modena tinha sido aliada da França, mas na altura em que Pereira visitava a Itália já se tinha alinhado pela França, "pela mudança de interesses" $"$. Por este jogo de interesses, muitas vezes eram as potências estrangeiras que jogavam em seu favor com as clivagens internas. Parece que era assim que acontecia na república de Génova, onde a nobreza se encontrava, como vimos, dividida em duas facções, das quais a "velha" se apoiava em Castela, enquanto os amores da nobreza "nova" se inclinavam para a França ${ }^{79}$.

As relações de domínio em relação a outros povos bem podiam ser relações de exploração. Assim, apesar de ser "hum florido reyno o de Napoles e muito cheio de todas as delicias", encontrava-se então reduzido "a grande miseria", já que lhe não era permitido o comércio com os estrangeiros, de modo a canalizá-lo todo em proveito exclusivamente de Espanha ${ }^{80}$.

Para explicar os diferentes tipos de relações de dominação, Pereira recorre ao conceito clássico das qualidades (nomeadamente temperamentais) dos povos. Os napolitanos são dominados pela Espanha da maneira tirânica acima resumida, porque a Espanha soube canalizar em favor da dominação o "genio irrequieto" dos povos dominados. No caso da Sicília, os Espanhóis conseguiram fazer crer que o seu domínio era preferível ao francês. Os Sardos foram facilmente dominados por causa do seu carácter acomodatício. Mas o

\footnotetext{
74 Pereira 1933: 23.

75 Pereira 1933: 24.

${ }^{76}$ Pereira 1933: 16.

77 Pereira 1933: 48.

78 Pereira 1933: 56.

79 Pereira 1933: 52.

${ }^{80}$ Pereira 1933: 27.
} 
brio e orgulho dos milaneses, incapazes de suportar grandes impostos e "leves extrapassos", apesar do respectivo empobrecimento provocado pela contínua passagem de tropas, obrigava os Espanhóis a contemporizar um pouco mais com eles ${ }^{81}$.

Contudo, os venezianos, procuravam manter os privilégios (já vimos que até a independência religiosa) das províncias e cidades sujeitas, no intuito de "conserval-as em fé e afeição ao seu dominio" benignidade têm os Médicis para com os sienenses, mas, se os não tratam com o despotismo de que usam para com os florentinos apesar de também não confiarem neles, é porque Siena é possuída como um feudo do rei de Espanha e não querem correr o risco de o rei católico denunciar as respectivas relações de suserania ${ }^{83}$.

Foram estas observações de política interna e política internacional que o Dr. José de Sousa Pereira constituiu em memorial, decerto para uso dos ministros dos Estrangeiros de D. Pedro II, e que, lidos hoje, nos permitem avaliar dos projectos, ideias e preconceitos políticos dum português do último quartel do século XVII, que não deixa de projectar a sua alma, ao ver-se num espelho italiano.

\section{OBRAS CITADAS}

SÉRGIO, António

1935, Afonso VI, in "Grande enciclopédia portuguesa e brasileira", Lisboa, Rio de Janeiro, Ed. Enciclopédia, 1, 503a-506a.;

BERNARDES, Manuel

1696, Luz e calor, pref. Mendes dos Remédios, 2 vol., "Obras primas da literatura portuguesa", Porto, Lello \& Irmão, 1991;

BETHENCOURT, Francisco

1994, História das inquisições: Portugal, Espanha e Itália, índ. Helena Galantes, S.1., Círculo de Leitores;

PEREIRA, José de Sousa

1933, A politica dos princepes de Italia compilada pelo Dr. José de Sousa Pereira, ed. Moses Bensabat Amzalak, Lisboa.

\footnotetext{
${ }^{81}$ Pereira 1933: 29.

82 Pereira 1933: 37.

83 Pereira 1933: 47.
} 


\title{
DE CONVERSO A NOVAMENTE CONVERTIDO. IDENTIDADE POLÍTICA E ALTERIDADE NO REINO E NO IMPÉRIO
}

\author{
Ângela Barreto Xavier \\ ICS-UL e CHC-UNL
}

Para estudar os processos de conversão e cristianização que se verificaram em Goa entre os séculos XVI e XVIII, e os seus impactos sociais, importa entender, em primeiro lugar, como é que no reino se pensava e se experienciava a alteridade, e como é que esta se exprimia no quadro legal e institucional. Só então é que se poderá compreender mais profundamente o transplante de uns e outros - tópicas, experiências, e arquitecturas legais e institucionais para os territórios imperiais. Trata-se pois de identificar um outro tipo de viagem: não apenas a das pessoas, mas ainda a das convicções que estas transportaram, que condicionaram a sua percepção, e que inspiraram a sua implantação; a busca de soluções práticas em espaços estranhos e distintos nos quais se reconheceram situações análogas.

Em concreto, com este estudo pretende-se mostrar que as fundações (e utilizo a expressão na sua conotação arquitectónica) das atitudes da coroa portuguesa e dos seus agentes em relação às populações residentes nos territórios do império - as fundações da sua teoria da acção política com respeito à alteridade social - também se inspiraram naquelas que no reino se estava a ter em relação às comunidades de origem judaica, depois cristãs-novas. É que a par do peso que as inspirações clássicas e a releitura dos viajantes medievais, já estudadas por J. J. Silva Dias, W. G. Randles, Luís de Albuquerque, Luís Filipe Barreto, Luís Graça, entre outros, ${ }^{1}$ tiveram na construção dos territórios imperiais, também este outro modo de pensar, identificar e gerir a alteridade (que não está, aliás, em dissonância com aquele, pois foi precisamente nesses passados que se concebeu o modelo de relacionamento entre cristãos e nãocristãos, entre cristãos e judeus) ${ }^{2}$ serviu de grelha referencial para interpretar e modelar as situações sociais que emergiram em tais territórios. A par daquelas, o estabelecimento destas outras analogias teve um impacto prático grande, e conformou boa parte das soluções políticas com efeitos sociais gizadas extra territorium.

Evidentemente, a intensa presença de judeus e de conversos nos ter-

Dias, 1986; Barreto, 1983; Graça, 1983; Randles, 1991; Albuquerque, 1991

Seaver, 1952, in genere. 
ritórios imperiais, e as modalidades adquiridas por essa presença contribuiu para a presentificação de tais paralelos. Por seu turno, o reconhecimento nos judeus/conversos de características grupais que permitiam identificá-los enquanto «casta», ajudou ao seu estabelecimento. ${ }^{3}$ Aliás, esses paralelos foram tão pertinentes que no Estado da Índia não se hesitaria em associar, mas com intenções deprecatórias, as origens das populações residentes em Goa com os judeus, assim como as qualidades de uns e de outro. Por exemplo, em Janeiro de 1557, o jesuíta Gonçalo Silveira escreveu ao cardeal D. Henrique algumas sugestões que visavam remediar os «males da India» e acabar com «os inimigos que entre nós trazemos»: para os cristãos-novos, o remédio era a Inquisição, enquanto que para os «gentios» brâmanes - e atente-se no vocabulário -, «maliciosissima gente e zelosissima de se plantar com sua seita e de acquirir todos a ela, inimicissimos do nome christam, e por huma dissimulaçam diabolica sam os banqueiros do inferno, das onzenas e maleficios», a total separação física, apartando-os da conversa e da co-habitação. ${ }^{4}$ Num contexto muito diferente, e um século mais tarde, Joseph Matinez de lá Puente escreveria no seu Compendio de las historias de los descobrimientos, que a origem dos judeus e dos indianos era a mesma, e que esta se expressava na similitude dos seus vícios: «codicia, mutabilidad, falacias, apostasias, y supersticiones variadas, y corrompidas». ${ }^{5}$ Reproduzindo uma ideia também desenvolvida por frei Juan de la Puente, o autor do tratado da Conveniencia de las monarquias catolicas, esta associação visava a subalternização das elites bramânicas do Estado da Índia, aquelas que depois de convertidas ao cristianismo tinham conseguido preservar uma posição de poder invejável e aspiravam ao estatuto de mediadores imperiais. É certo que tais associações se ancoravam numa tópica antiga, de raízes helénicas. Já então se estabelecera uma homologia entre judeus e brâmanes, o que levara Flávio Josepho a concluir, inclusive, que «os judeus são descendentes dos filósofos da Índia. Estes são apelidados de Calanoi entre os Indianos, e de Ioudaioi entre os Sírios ${ }^{6}$. Contudo, a leitura realizada pelos autores hispânicos e pelo jesuíta português enfatizava a resistência que os dois grupos demonstravam face à dominação cristã, metamorfoseando em negativa a carga positiva que tal associação tivera em circunstâncias diversas.

É, pois, sobre os interfaces entre tópica e experiência da alteridade e política no reino e no império que incide este estudo, no qual me proponho reflectir sobre alguns alicerces experienciais (memórias do vivido) e discursivos (configurações do pensável) destas afinidades, e o modo como elas nos ajudam a perceber os diálogos entre reino e império e o profundo envolvimento

3 Kriegel, 1979, caps. II e III.

4 DI, 4, pp. 1-4.

5 Martinez de la Puente, 1681, p. 57.

${ }^{6}$ Contre Apion, I, 179, cit in Schmidt, 1988, trad. minha. 
de ambas as histórias. Gostaria de deixar expresso que o percurso que agora se inicia retoma e combina os campos de análise desenvolvidos por Arnold Van Gennep e Victor Turner em torno aos ritos de passagem e as suas implicações identitárias, combinando-o com as observações de Norbert Elias sobre a relação entre «os estabelecidos» e «os outros», e de Mary Douglas sobre «pureza» e «poluição».?

De acordo com os primeiros, em qualquer rito de passagem podem ser identificadas três etapas distintas: uma fase de separação entre os membros de duas identidades/comunidades, uma fase em que se processa a passagem de uma para outra identidade/comunidade, e uma fase de integração/inclusão/ /assimilação na nova comunidade e de consolidação da nova identidade, havendo um reconhecimento dessa pertença e desse estatuto quer pelos membros do novo grupo, quer pelos membros do grupo anterior. ${ }^{8}$ Contudo, esta não é só uma grelha que permite comparar situações diferentes que envolvam a conversão religiosa e incluam rituais de passagem (caso do baptismo) e as potencialidades identitárias que estes enformam. Ela é igualmente útil como o fez, por exemplo, Maurice Kriegel, a propósito da identidade conversa - para interpretar as situações em que a plena passagem nunca se chega a concretizar, quando boa parte dos sujeitos são mantidos no estatuto liminar, tornando a sua identidade transitória numa identidade fixa. ${ }^{9}$ Os indícios que possuímos sobre as experiências dos conversos e dos novamente convertidos do reino e do império português na época moderna configuram uma situação análoga, em que a liminaridade se cristalizou, tornando-se numa situação identitária que não facilitava nem o pleno regresso à identidade anterior $^{10}$ nem a aceitação total por parte da comunidade que constituía o grupo receptor. ${ }^{11}$

Qual o mecanismo explicativo desta desaceleração do processo de transição identitária? O que é que travou a plena integração?

Ao analisar a persistência de formas de discriminação no contexto de

7 Van Gennep, A., 1999 (1909); Turner, V., 1969; Elias, N., 1991 (1974), Douglas, 1966.

8 Damatta, R., 2000.

9 Kriegel, 2000, in genere. Segundo Kriegel, os conversos tinham cristalizado na segunda fase deste processo de transição, tornando-se, por conseguinte, em grupos liminares.

${ }^{10} \mathrm{E}$ o recente trabalho de Bruno Feitler mostra bem como é que as reversões eram igualmente problemáticas (Feitler, B., 2003).

"Efectivamente, quando articulada com as noções de pureza e poluição, tal como elas foram desenvolvidas por Mary Douglas em Purity and Danger (1966), mas também com a teorização sobre integração e exclusão desenvolvida por Norbert Elias na introdução a The Established and the Outsiders (1991) a liminaridade torna-se um poderoso instrumento de análise (e de comparação) de processos históricos de transição identitária na época moderna, período no qual as questões da pureza linhagística e da pureza espiritual estavam profundamente interligadas. 
uma comunidade aparentemente «igual», Norbert Elias inventariou um conjunto de variáveis sobre as quais assenta o encontro entre agrupamentos de sujeitos que se auto-percebiam e representavam como grupo/comunidade distinta (mesmo quando as suas delimitações não eram visíveis para outros observadores) e a consequente emergência de formas de distinção/discriminação mais sofisticadas. Essa análise, depois de temperada pelas reflexões de Mary Douglas sobre a construção de noções de «pureza» e "poluição», o seu carácter instrumental e as suas manifestações sociais, é extremamente útil para compreender os processos de transição que são objecto deste estudo.

Tendo em conta a cultura política e a imaginação social da época em causa, podia haver situação mais ambígua que a de um mestiço-converso? E o que dizer de um mestiço-converso nascido na periferia do império? E qual a relação - em termos de estatuto - entre um converso nascido no reino e um converso nascido no império? E o que é que era «melhor»: ser um novamente convertido nascido no império ou um converso nascido no reino? Qual identidade transportava mais vícios e suscitava mais preconceitos e suspeição? Qual era, em contrapartida, a mistura que suscitava mais simpatia?

Como é que estas pertenças - lugar de nascimento, antiguidade da pertença ao «curral catholico», e pertença «étnica» (vulgo, qualidade do sangue, mas não apenas isso) - se entrecruzavam no entretecer do mapa de distinções que operava no Portugal moderno? Como é que estas distinções se manifestavam social e institucionalmente e como é que, por seu turno, se fundamentava e justificava a sua existência, sendo que o objectivo último da conversão religiosa, para além da salvação das almas dos convertidos, era a unidade política e social?

Este grupo de questões encerra um programa ambicioso que tem vindo a ser investigado por muitos estudiosos. Raramente, porém, estas variáveis foram pensadas conjuntamente e, até, comparativamente, e julgo que esse exercício terá alguma utilidade para entender os diversos lugares nos quais estas situações se verificaram. É com uma atitude comparatista (mas não capaz, ainda, de fazer uma comparação), e apetrechada dos instrumentos metodológicos e analíticos atrás referidos, que me proponho reflectir sobre o tema.

Para começar, optei por revisitar os momentos de separação entre as identidades/comunidades não-cristãs e cristãs, ou seja, as situações em que estas tinham estatutos jurídicos distintos, para abordar depois as implicações jurídicas das situações de passagem (muito embora tenha decidido não analisar, aqui, os ritos de passagem propriamente ditos, os quais merecerão, por si só, um outro estudo); e as situações sociais posteriores a essa passagem. A meio do caminho, inseri uma reflexão sobre os trânsitos tópicos que permitiram sustentar o transplante de percepções, enquadramentos jurídicos, atitudes, 
permitindo assemelhar judeus e«gentios» (e entre estes, os brâmanes), conversos e novamente convertidos.

Faço notar que este não é mais do que um ensaio introdutório, pois só estudos comparativos sistemáticos sobre os processos de conversão na época moderna (e suas implicações políticas) poderão vir a responder, de forma precisa, as questões atrás enunciadas. Por agora limito-me a apresentar alguns raciocínios que me parecem pertinentes.

\section{Paradoxos da separação}

A reflexão que aqui se traz decorre, em primeiro lugar, de uma perplexidade surgida na sequência do que foi sugerido por Luís Filipe Thomaz num estudo clássico sobre a formação da sociedade goesa: «Goa: uma sociedade luso-indiana». Aí Thomaz lembra que nos primeiros anos da presença portuguesa na Índia as formas de relacionamento entre a coroa portuguesa e as populações locais se tinham inspirado no modelo de autonomia jurídica tutelada pela coroa de que haviam gozado, na época medieval, as comunidades muçulmana e judia residentes no reino. ${ }^{12}$

Efectivamente, nas primeiras décadas do século XVI ensaiou-se no Estado da Índia um modelo de jurisdições separadas para os que eram cristãos (essencialmente os portugueses, os «colonizadores») e aqueles que o não eram (os locais, os «colonizados»), sistema que tinha afinidades com aquele que operaria nas Índias de Castela, nas quais se diferenciava a «republica de los españoles» da «republica de los índios». Como foi explicado por A. M. Hespanha, a cultura jurídica dominante no mundo ibérico legitimava a aplicação do mesmo ordenamento jurídico que operava no reino às comunidades portuguesas residentes no império, as quais estavam, por isso mesmo, sujeitas ao direito da coroa; ao mesmo tempo que permitia a manutenção dos ordenamentos jurídicos locais na maior parte das situações que envolviam as comunidades que não eram de origem portuguesa. Ou seja, do ponto de vista do direito do reino, eram vassalos os «naturais do reino» ou filhos de pai português, e não eram abrangidos por esse direito - na maior parte das matérias -, os sujeitos que não fossem filhos de portugueses. ${ }^{13} \mathrm{Em}$ termos práticos isto significava que a maioria da população que residia em Goa estava submetida às leis e costumes já vigentes quando da chegada dos portugueses, e é nesse contexto que é elaborado o documento conhecido como «Foral de Mexia», o qual tinha um carácter nitidamente instrumental, pois tornava visíveis (e descodificáveis) as

\footnotetext{
12 Thomaz, 1994, p. 248

13 Hespanha, 1995.
} 
matérias do quotidiano local nas quais a coroa portuguesa pouco ou nada tinha a dizer. Sublinhe-se que essa separação jurídica era complementada por uma separação física, pois as populações cristãs e não-cristãs tendiam a viver em bairros separados. Esferas paralelas que apenas contactavam quando era necessário.

Ou seja, a autonomia jurídica e a separação física foram dois princípios de estruturação do relacionamento político estabelecido entre a coroa portuguesa e as populações locais nos primeiros anos de presença no Índico, e essa não só parecia ser a situação que encerrava mais garantias de estabilidade política e social, quanto era a solução possível para o tipo de poder que aí se sabia/podia/pretendia exercer: um domínio eminente, um poder mais suserano do que «soberano», de um rei de reis..$^{14}$ Um pouco à semelhança do que acontecera - e como Thomaz bem notou - no reino de Portugal em relação às populações de origem judaica.

Para quem não tem essas outras experiências bem presentes, recorde-se muito sucintamente os seus traços essenciais, sintetizáveis, também eles, pelo vocábulo «separar»: ${ }^{15}$ separação fisica expressa na separação urbana e na existência de judiarias, mas também no controlo das entradas e saídas dos judeus das mesmas, e, sobretudo, nos impedimentos colocados às uniões entre judeus e cristãos; separação jurídico-política manifestada na existência de comunas e na adopção do direito talmúdico; separação religiosa e cultural, simbolizada pelas sinagogas onde o culto judaico era praticado publicamente, e pelas bibliotecas e escolas que permitiam a reprodução da cultura judaica, e os seus rabinos. Estas matrizes enquadravam o modus vivendi destas comunidades no reino de Portugal a partir de meados do século XIV. ${ }^{16}$ Quanto às actividades económicas, os judeus urbanos dedicavam-se, sobretudo, à mercancia, a actividades financeiras (financiamento e fiscalidade), assim como as actividades «médicas». Tinham, aos olhos de quem os observava de fora, e recorro propositadamente a uma formulação anacrónica, uma certa especialização profissional. ${ }^{17}$ Também nesse sentido eram facilmente identificáveis. Ao residirem em lugares específicos, ao ostentarem nomes diferentes, e ao praticarem actividades que lhes eram específicas, os judeus eram facilmente reconhecidos (e aceites) como outros.

A verdade é que havia cada vez mais legislação da coroa de Portugal que, ao incidir directamente sobre estas populações, violava a separação jurí-

${ }_{14}$ Thomaz, 1994; Hespanha, 1995.

15 É vastíssima a bibliografia que aborda estas temáticas. Na impossibilidade de a citar sistematicamente, limito-me a destacar os clássicos Lúcio de Azevedo (1989) e José António Saraiva (1985), Isaac Révah (1995) e Maria José Ferro $(1982,1987)$.

16 Ferro, 1982, in genere.

17 Kriegel, 1987, cap. III. 
dica. Por exemplo, o Livro de Leis e Posturas, as ditas Ordenações de D. Duarte e as Ordenações Afonsinas contemplavam um conjunto substancial de normas que delimitavam o quotidiano "público» destes judeus, que se deixava abranger pela jurisdição do rei de Portugal. ${ }^{18}$ Mas algumas normas interferiam em matérias de índole «privada», mas que tinham efeitos «públicos», tais como aquelas que diziam respeito ao contacto físico entre o homem judeu e a mulher cristã, procurando evitar, nesse âmbito, a existência de ligações e de matrimónios mistos..$^{19}$ Efectivamente, o controlo da sexualidade era essencial para que a separação física pudesse ser preservada. ${ }^{20}$ Quer isto dizer que o princípio da autonomia jurídica podia ser sacrificado para preservar a separação física, e, sobretudo, a separação sexual, pois era esta que garantia, por sua vez, a manutenção da autonomia jurídica.

Um dilema semelhante emergiu numa outra área central para a coesão identitária: a pertença religiosa. Recorde-se que a partir de finais do século XIV, quando em toda a Península Ibérica, e na sequência do que vinha a acontecer no resto da Europa cristã, tornaram-se cada vez mais visíveis e violentos os levantamentos e massacres contra as judiarias e as comunas, verificando-se progressivas conversões de judeus ao cristianismo. Se antes da conversão e do baptismo (os momentos que instituíram a passagem formal de uma identidade/comunidade, a judaica, para uma outra identidade/comunidade, a cristã), estes sujeitos e grupos viviam separados, depois da conversão, e pelo menos em teoria, os mesmos sujeitos e grupos adquiriam uma nova identidade e eram, por isso, incorporados na comunidade cristã. Não só religiosa, mas também juridicamente, pois o baptismo (a regeneratio) era equivalente ao nascimento (a generatio). Ou seja, a profissão da fé cristã equivalia ao nascimento, tornando-se, por essa via, num mecanismo de inclusão e de potencial equalização jurídica. A este processo que envolveu milhares de judeus não foi alheia a crescente presença - e hegemonia simbólica - de dominicanos e franciscanos, cada vez mais empenhados na conversão dessas populações. Muito embora essa dinâmica caracterizasse mais os reinos de Castela e de Aragão, também em Portugal, e como assinalou Lúcio de Azevedo, havia judeus que eram obrigados a assistir a sessões de doutrinação cristã que tinham lugar nas próprias judiarias. ${ }^{21}$

Tal como naqueles reinos, e sobretudo após a condenação dos Estatutos de Toledo de $1449^{22}$ os conversos passaram a ser abrangidos pelo direito da coroa, encontrando-se legislação que regulava as matérias nas quais se sobre-

\footnotetext{
${ }_{18}$ Lipiner, 1982, pp. 40-44.

19 LLP, pp. 458 e ss., pp. 763 e ss.; OrdAf., L. 2, tt. 66-93; L. 5, tt. 25; Ord.D, Const. 26.

${ }^{20}$ Nirenberg, 2002.

${ }^{21}$ Azevedo, 1989, pp. 54 e ss.

${ }^{22}$ Révah, 1995, p. 33.
} 
punham ambas as jurisdições, tais como aquelas que eram relativas aos direitos sucessórios e de herança dos conversos, privilegiando cada vez mais aquele que se convertia à fé cristã em desfavor do que optara por permanecer fiel ao judaísmo. ${ }^{23}$

Ora, pode bem dizer-se que aqui residiu um outro paradoxo do sistema de convivência implementado a partir do século XIV: é que ao mesmo tempo que os interesses da respublica christiana apontavam para a necessidade da evangelização extra territorium e intra territorium dos não cristãos, arquitectara-se internamente um ordenamento jurídico-político (e social) que assentava - no essencial -, na diferença religiosa.$^{24}$ Essa contradição tinha expressão, mais uma vez, na maneira como o direito geria de forma ambígua as situações sociais que daí resultavam, e terá sido nesta contradição resultante de uma conversão simultaneamente desejada e indesejável que se iniciou aquilo que Dominguez Ortiz designou como o «problema converso» ${ }^{25}$.

Nessa perspectiva, os filhos de casais mistos, os mestiços, e os produtos da conversão ao cristianismo, os conversos, eram homólogos, e colocavam o mesmo tipo de questões ao poder cristão.

\section{Incertezas da passagem}

Questões parecidas colocaram-se, anos mais tarde, nos territórios imperiais. Referiu-se no início que nas primeiras décadas do Estado da Índia as populações residentes no(s) território(s) de Goa viviam separadas das comunidades colonizadoras, cristãs, portuguesas. Mas também aí surgiram problemas semelhantes aos que identificámos no reino tardo-medieval, os quais boicotavam os mecanismos que garantiam a separação formal: a existência de mestiços e de convertidos ao cristianismo, o que criava instabilidade na própria ordem jurídico-política e social, instabilidade essa que fora potenciada pela política de casamentos mistos favorecida por Afonso de Albuquerque (uma lembrança do incentivo a casamentos entre cristãos-velhos e cristãos-novos, no reino, com o fim de consolidar a fé destes últimos). Pelo tipo de imperium que, nos anos iniciais, se exercia no Estado da Índia, bem como devido à escassa centralidade que tais territórios tinham na economia simbólica do reino, esta situação não ameaçou, contudo, as matrizes que sustentavam essa ordem.

Ao invés, tal imperium e essa escassa centralidade justificaram que à purificação do território do reino se contrapusesse a poluição dos territórios

${ }^{23}$ OrdAf, L. 2, tt. 94; OrdAf, Liv. II, tt. 83. In genere, Ferro, 1982, vols. 1 e 2; 1987, cap. 1.

${ }^{24}$ Novinski, 1972, pp. 24-27; Lipiner, 1992, p. 17.

${ }^{25}$ Dominguez Ortiz, 1991. 
ultramarinos (que eram, à partida, mais impuros), pois foi para estes que se dirigiu boa parte da diáspora cristã-nova após a conversão forçada a que os judeus do reino de Portugal foram sujeitos na transição do século XV para o século XVI. Ao mesmo tempo que procurava libertar o reino desse problema (a diáspora era um primeiro instrumento de limpeza que o Santo Ofício se propunha completar), o trânsito de muitos conversos do reino exponenciava, em contrapartida, a complexidade social dos territórios imperiais.

Não data deste período, porém, o início da presença judaica nos territórios imperiais. A articulação entre judeus/conversos e as experiências imperiais portuguesas era uma realidade anterior àquele momento, tendo emergido num contexto político, social e cultural de contornos distintos. Quer isto dizer que os judeus e conversos (judaízantes ou não) que partiram no contexto da diáspora iniciada em finais do século XV foram ao encontro de outros membros destas comunidades já estabelecidos nas «colónias» extra territorium, frequentemente envolvidos nas suas redes comerciais. ${ }^{26}$ Não se trata, pois, de um movimento unívoco e homogéneo, e as suas cronologias encerraram significados distintos para os destinos de tais pessoas.

Mas no novo contexto político, a situação de todos os judeus que residiam no reino agravou-se, e em 1497, sob pena de perda das fazendas e de morte, foi decretada a expulsão de todos os judeus que não queriam baptizar-se (à semelhança do que acontecera antes no reino vizinho), condição essa que resultara do acordo de casamento estabelecido entre D. Manuel e a filha dos Reis Católicos. A «dureza de seus coraçoes», o serem «obstinados no odio» e «cometerem grandes males» contra Cristo e os cristãos foram algumas das razões invocadas neste poderoso decreto régio que introduzia também no reino de Portugal o princípio político da unidade religiosa. ${ }^{27} \mathrm{Na}$ sequência desta decisão, os filhos com menos de 14 anos de todos os judeus - antigos e novos no reino de Portugal -, ser-lhes-iam retirados e entregues a cristãos, e os muitos milhares de judeus que aguardavam no Paço dos Estaus pela sua partida, foram persuadidos a converterem-se ao cristianismo, sendo muitos deles convertidos à força.$^{28} \mathrm{O}$ baptismo forçado de todos os judeus menores de 25 anos foi decretado no ano seguinte e o assalto a sinagogas, escolas e bibliotecas das judiarias não tardou, tudo isto ao mesmo tempo que Vasco da Gama se aproximava das costas ocidentais da Índia, ancorava nas praias de Calecut, dialogava com o samorim, e iniciava esse conhecido processo expansionista. De pouco serviria que nesse mesmo ano D. Manuel providenciasse para que os novos cristãos não fossem admoestados pelo seu comportamento religioso,

\footnotetext{
${ }^{26}$ Ferro, 1987,pp. 18 e ss..

${ }^{27}$ OrdMan, Liv. II, tt. 61 .

${ }^{28}$ Ferro, 1987,pp. 34-35.
} 
e que ao longo do seu reinado se assistisse «a uma progressão dos privilégios, quer individuais, quer colectivos, aos cristãos-novos». ${ }^{29}$ A decisão de que os conversos não podiam abandonar Portugal, a obrigação de residência no «centro» com a sua nova condição religiosa e política, indiciava a vontade de uma efectiva cristianização dos judeus e da «extinção do judaismo» pela via da dissolução daquela identidade. Os antigos judeus passaram a ostentar nomes cristãos e até puderam regressar às velhas judiarias desde que também estas fossem «cristianizadas», transformando os seus bairros em «vilas novas» e os seus becos e vielas em «ruas novas»..$^{30}$ Para consolidar este processo, D. Manuel equiparou juridicamente os conversos aos restantes súbditos, submetendo-os às leis gerais do reino, proibindo a sua discriminação. Ao mesmo tempo, reiterou a ordem de expulsão dos que tinham permanecido judeus e eram forros.

Judeus, equivalente a exclusão. Conversos, igual a inclusão. Foram estas, teoricamente, as matrizes que estruturaram a conjuntura que se iniciou em 1492 e que teve em 1507 um dos seus possíveis limites cronológicos, e que tinha no baptismo o lugar que permitia a transição identitária.

Balizado por estes princípios e por esta legislação, entre 1507 e 1536, data da instituição do Tribunal do Santo Ofício em Portugal, o relacionamento entre a coroa e estas comunidades foi, como é sabido, hesitante. Contrariando o que fora prometido por D. Manuel, os comportamentos religiosos dos conversos começaram a ser objecto de verificação, e em 1524, uma investigação clandestina identificou vagos indícios de práticas de ritos judaicos, como a guarda do Sábado e da antiga Páscoa. ${ }^{31}$ Ao mesmo tempo, D. João III voltou a reiterar as concessões do tempo de D. Manuel, nomeadamente aquelas que permitiam a saída de conversos do reino ${ }^{32} \mathrm{E}$ durante a década de 1530 e 1540 - ou seja, antes, durante e logo após o estabelecimento do Santo Ofício -, um conjunto de pareceres oferecidos ao rei mostram bem como no reino havia fortes divergências sobre o modo como a coroa se devia relacionar com os judaízantes, e com os conversos em geral.

À semelhança do que se tornara uma constante ao longo da história do relacionamento do poder político cristão com as comunidades divergentes, duas vias emergiram como possíveis: uma via suave, a do Perdão Geral, que era acarinhada pelos próprios conversos, e também aquela que encontrava mais eco no próprio Papado, e uma via dura, a que conduzira à Inquisição, de-

${ }^{29}$ Ferro, 1987, p. 50.

30 Ferro, 1987, p. 43.

${ }^{31}$ Saraiva, 1985, pp. 47-55.

32 Azevedo, 1989, pp. 65-66. 
sejada por D. Manuel durante o seu reinado mas recusada pelo pontífice, e novamente requerido por D. João III e finalmente concedida. ${ }^{33}$

Em suma, a existência da comunidade dos conversos causava preocupação e ansiedade. Muitos conversos eram acusados de não seguirem nem «o christianismo, nem o judaismo», e uma verificação semelhante, muito embora não em tom de acusação, mas sim de compaixão, foi feita por um frei Simão que, da cidade de Ancona, escreveu a D. João III. Na sua emotiva carta o frade registava ter encontrado muitos conversos originários de Portugal, os quais tinham judaízado mas que continuavam a afirmar-se cristãos. «Não se entendem nem são judeus nem christãos», verificaria o religioso acabando por desabafar: «Hé huma confusão».34

Este curto exemplo sintetiza bem um dos problemas que estas identidades voláteis causavam nos dirigentes da época. A par da exclusão ou da inclusão, as situações de indefinição eram tão ou mais difíceis de resolver. A conversão ao cristianismo das populações que não eram cristãs e que, convenientemente, tinham vivido separadas do «gremio da egreja» alterava as regras do jogo social, obrigando a sociedade cristã a enquadrar os recém-chegados. Essa tão ambicionada passagem de estado de barbárie ao de civilização, de ignorância ao de conhecimento, de ignomínia ao de glória, de guerra ao de paz, de desunião ao de união na fé e no amor - foi desta expressiva forma que o franciscano João Cardoso explicou as possibilidades de salvação do «cego povo Iudaico ao qual não cura Christo naquelle pequeno lugar de Betsaida, mas fóra delle, pera dar a entender que na ley \& na Sinagoga não pode ter saude, nem vista»,$-{ }^{35}$ era muito menos fácil do que muitos discursos pareciam deixar entrever. Ao invés, a regeneratio perturbava a ordem social existente, sobretudo por aquilo que a virtual equalização jurídica podia comportar no acesso às mercês e benefícios, económicos e simbólicos, como sempre escassos. Os conver$s o s$, que já dominavam a maior parte das actividades financeiras, comerciais e artesanais do reino e do império português (imiscuíndo-se igualmente nas redes hispânicas a partir de 1580), constituíam-se, por essa via, como candidatos a outro tipo de posições. ${ }^{36}$ Contudo, essa nova e perturbadora economia de «aspirações» voltava a ser baralhada pela negação (dissimulada) da identidade cristã por muitos daqueles que dela tinham passado a fazer parte. Se ter um cristão de pertença recente numa posição de exercício de poder sobre velhos cristãos era uma espécie de ultraje, que dizer dos que só nominalmente eram cristãos ? ${ }^{37}$

${ }^{33}$ Bethencourt, 1995.

${ }^{34}$ GTT, I, p. 656.

${ }_{35}$ Cardoso, 1626, fl. 26v.

${ }^{36}$ Révah, 1995, Tavim, 2003, Wachtel, 2001.

${ }^{37} \mathrm{QE}, \mathrm{XI}$, pp. 10-27, 43-51, 133-149; GTT, I, pp. 78-85, pp. 128-131, GTT, III, pp. 126-146).

Sobre essa instabilidade, veja-se Kriegel, 1992, passim. 
A múltipla incerteza era potenciada pelo impacto psicológico que vias como o Perdão Geral podia ter naqueles que no império davam as suas vidas «contra os mahometanos e outros infieis». ${ }^{38}$ Como é que estes reagiriam ao facto de, intra territorium, a coroa perdoar os hereges, quando eles, extra territorium, morriam pelo aumento da Cristandade?

Entrementes, muitos conversos (judaízantes ou não) tinham abandonado o reino e partido para os territórios imperiais. Mas também a este respeito, a atitude da coroa não foi evidente. É sabido que à década de 1530 , muitos já se tinham estabelecido nos territórios portugueses da Índia ${ }^{39}$, impondo-se nas redes comerciais. Contudo, a permissão de mobilidade foi substituída por uma política régia que tendia a restringir (e a controlar cada vez mais) os seus movimentos ${ }^{40}$ Em 1532 proibir-se-ia a passagem de mais conversos para o Estado da Índia, e "por allguns inconvenientes que aguora ha», ${ }^{41}$ essa decisão continuaria em vigor, sendo renovada em 1535, em 1547, e depois em 1567. Apesar de em 1577, já sob o reinado de D. Sebastião, e pouco antes de Alcácer-Quibir, ela ter sido revogada, em 1612, sob o domínio filipino, em pleno reinado de Filipe II de Portugal, voltou a ser retomada. Ainda assim, houve excepções a estas proibições mesmo enquanto elas estavam em vigor, e disso dá testemunho uma carta de D. João III ao conde da Castanheira, D. António de Ataíde, de 5 de Fevereiro de 1533, na qual o rei permite a partida de conversos para a Índia, «sem embargo da provisam que esta na casa da India».42

Estas oscilações denotam, evidentemente, a importância que a presença judaica e conversa revestiu para os destinos do reino, o que explica, por conseguinte, a busca incessante pela solução simultaneamente mais útil e mais justa ${ }^{43}$. Mas não se pode reduzir a questão judaica à questão económica e financeira, como o fez, de certa forma, António José Saraiva ${ }^{44}$. Ela participou, também e sem margem para dúvidas, de alterações mais vastas no contexto da imaginação política, nos modos como se pensava a respublica ideal, bem como de processos de diferenciação social que transcendiam, por assim dizer, a questão judaica, mas dos quais os judeus e cristãos-novos estavam, ao mesmo tempo, entre os principais protagonistas. Imaginação essa que, com frequência, estimulou correntes e tendências que coabitavam em contrastante

\footnotetext{
QE, vol. 11, p. 16.

Veja-se, a este propósito, Tavim, 2003.

40 Cf. Xavier, C., 1987; Tavares, M. J. Ferro, 1992; Tavim, J.R.S., 1994, 1995.

${ }^{41}$ Ford, John, ed., 1931.p. 75.

${ }^{42}$ Idem, p. 88.

${ }^{43}$ Apesar de D. Manuel ter decidido «com conselho de teologos mestres e doutores em sagrada teologia e como princepe christianissimo e usou com esta gente de grande misericordia em os tirar da morte e poer em caminho da salvaçam» (GTT, III, p. 129), a verdade é que a variância das suas posições não deixa de ser reveladora da complexidade do problema judaico.

${ }^{44}$ Saraiva, 1985, in genere.
} 
tensão (e a oposição entre alguma legislação da coroa e a aplicação dos estatutos de limpeza de sangue é disso um emblema), ${ }^{45}$ e foi nessa espiral que os grupos de judeus e conversos acabaram por ser apanhados.

A mesma espiral abraçou aqueles que no império foram identificados como semelhantes: os «gentios» e os novamente convertidos. Retome-se, pois, a questão inicial: de que forma é que as experiências destes judeus é útil para entender as experiências de conversão e cristianização das populações residentes no império e, em particular, nos territórios de Goa?

Penso que à semelhança do que aconteceu nas primeiras décadas da presença portuguesa no Índico, também num segundo momento - no qual o Estado da Índia adquiriu uma centralidade indiscutível, para aí se transplantando, doravante e diferentemente do que antes acontecera, as instituições que caracterizavam o reino -, a coroa continuou a recorrer à experiência que tinha com o seu outro interno por excelência: aqueles grupos que antes eram judeus e que agora, depois do processo de conversão colectiva ao qual tinham sido submetidos, eram designados por conversos.

Entre as várias pontes que, como se pode adivinhar, podem ser estabelecidas entre ambas as experiências - e limito-me a destacar, aqui, a experiência dos conversos no Estado da Índia (estudados por José Alberto Tavim), o processo inquisitorial a que foram submetidos em meados do século XVI (identificado por Ana Cannas Cunha), que esteve na origem do estabelecimento de um tribunal da Inquisição naqueles lugares, e as suas características específicas (objecto da investigação de Célia Tavares) $-{ }_{, 4}^{46}$ optei por privilegiar os trânsitos semânticos entre discursos anti-judaicos e anti-gentios, assim como a simetria das soluções jurídicas aplicadas no império em relação aos gentios e aos novamente convertidos, e aquelas que tinham sido utilizadas no reino, em relação a judeus e conversos.

\section{Outros trânsitos: Gaspar de Leão}

«Que louvor tera ante Deos este glorioso Rey, cujo zelo foy tam servente, que vendoo em alguas partes tollerava a ygreja ho judaismo, nam pode acabar com seu zelo, de o dissimular em seus Regnos e senhorios? (...)

Que menos vos parece que foy estimado deste zelo sanctissimo o gloriosissimo Rey dom manuel, vendo que avia hi gente que ho tinha a elle por Senhor, e nam a Christo Jesu? ${ }^{47}$

${ }^{45}$ Como foi demonstrado por Fernanda Olival, recentemente. V. Olival, 2004, e bibliografia aí citada.

46 Tavim, 2003; Cunha, 1995; Tavares, 2001.

${ }^{47}$ Pinheiro, 1784, I, p. 29. 
Pronunciadas em 1551 pelo conhecido doutor António Pinheiro, durante a pregação oficial na importante cerimónia de trasladação dos ossos do rei D. Manuel e da rainha D. Maria, e dedicadas à rainha D. Catarina de Áustria, estas palavras, bem como as que constituem o resto deste expressivo sermão, sintetizam bem aquele que era o espírito de muitos cortesãos portugueses de meados do século XVI. Na realidade, Pinheiro realçou o que muitos partilhavam: os judeus não podiam permanecer enquanto tal o reino de Portugal, por não reconhecerem aquela que era única justificação do poder temporal. Sendo que, na perspectiva dos cristãos, o verdadeiro poder derivava do Deus cristão e que o próprio rei reconhecia esse Deus como o primeiro senhor, um governante prudente não podia aceitar a presença de súbditos que não partilhassem esse mesmo credo. Esta asserção assentava sobre a convicção de que quem não tinha a mesma fé não compreendia a sacralidade do vínculo político, a fidelidade ao próprio rei. Daí que a conversão dos judeus não constituísse apenas uma obrigação moral, mas também uma necessidade política.

A maioria das representações sobre os judeus que circulavam no reino de Portugal por essa altura alicerçava um senso comum idêntico, e muitas dessas representações têm sido inventariadas nos estudos desenvolvidos sobre estas temáticas ${ }^{48}$, mas nada melhor do que recorrer aos escritos da época (para não referir os riquíssimos processos inquisitoriais) para ver estes grupos adjectivados de «infiéis», «idólatras», «obstinados», «perversos», «avaros», «hipócritas», «homicidas», «cegos», «ingratos».49

Por exemplo, no Libro dela verdad dela fe, dedicado a D. João III e publicado seis anos antes de Pinheiro pronunciar o seu sermão, frei João Soares, agostinho, confessor e pregador do rei e dos infantes e infantas, recém-nomeado bispo da importante diocese de Coimbra e um dos participantes portugueses no Concílio de Trento, pedia ao monarca que protegesse a impressão do seu livro por este ser a favor das causas da cristandade e da república: a paz perpétua nos reinos, a guerra contínua contra os mouros e os turcos na Índia, a conquista em África, o zelo cristão na criação dos nobres do reino, a reforma dos costumes, a frequência dos sacramentos, a reforma das ordens religiosas, a reforma da universidade de Coimbra, o ensino nas escolas, as obras públicas, a inquisição, e, naturalmente, a extinção do judaísmo. Para Soares, o povo judeu era «contrairo da dios, inimigos suyos, ciegos de entendimientos, rebeldes de voluntad, y obstinados de coraçon: gente que sigue una secta supersticiosa, inventada de sus cabeças contra los prophetas, y contra las escrituras de que se dicen guardadores $»^{50}$.

\footnotetext{
${ }^{48}$ Ferro, 1981, 1987, 1988; Rodrigues, 1987, e bibliografia citada nestes estudos.

${ }^{49}$ Rodrigues, 1987, pp. 294-296.

so Soares, 1545, fl. 110.
} 
Mas nem todos os discursos eram tão radicais. Efectivamente, a par desta violência discursiva que insistia na incomensurável distância entre judeus e cristãos, e que frequentemente - após o fracasso das medidas disciplinares - resultava na defesa da sua separação física, da sua expulsão da comunidade política, ${ }^{51}$ coexistiam os discursos daqueles que, em contrapartida, insistiam na possibilidade de anulação do judaísmo pela pedagogia, pela sua efectiva conversão ao cristianismo e a sua integração no «curral catholico», atitude mais consentânea, aliás, com aquela que fora a estratégia de relacionamento ensaiada pelos poderes ibéricos, desde finais da Idade Média, com respeito a estas comunidades. ${ }^{52}$ Era este sentimento aquele que motivara João de Barros a escrever o Diálogo Evangélico sobre os artigos da fé contra o Talmud dos Judeus, de 1543, que tinha o objectivo de ajudar os responsáveis políticos nas suas tomadas de decisão acerca da comunidade judaica. Aí, o humanista procurava persuadir os judeus à conversão através da apologia dos textos da Escritura e da crítica ao Talmud, encetando, ao mesmo tempo, uma defesa da inteireza da fé cristã. Dedicado ao cardeal D. Henrique, já nessa altura nomeado Inquisidor-mor, mas também a Duarte de Resende, feitor da coroa no Estado da Índia, e da importante família dos Resendes de Évora, o tratado inscreve-se no desejo de Barros de contribuir para que leigos e casados se empenhassem em «converter a Christo os que andão fora delle». ${ }^{53} \mathrm{~A}$ mesma motivação pedagógica parece estar subjacente ao tratado também escrito em diálogo Inquisiçam, e Segredos da Fee, de Diogo de Sá, humanista leigo que tinha servido na Índia e cujo tratado - entre outros que escreveu -, apesar de igualmente dedicado ao cardeal D. Henrique, não obteve licença de publicação da parte do Santo Ofício (à semelhança do seu Tractádo dos Estádos Ecclesiásticos e Seculáres que dedicara a D. Catarina). Para Ana Cristina da Costa Gomes, estes dois livros de Sá fazem parte da literatura apologética anti-judaica e anti-herética, situando-se entre aqueles escritos com um carácter «pedagógico e preventivo», podendo explicar-se a sua não publicação pelo facto de serem escritos em português e, por isso mesmo, serem acessíveis a

${ }^{51}$ No diálogo «Da gente judaica», frei Amador dos Arrais apresenta dois cristãos tipo (um mais popular, o outro mais erudito, um mais novo, o outro mais idoso), os quais defendiam atitudes distintas em relação aos judeus. O mais idoso defendia a conversão dos judeus enquanto obrigação política e religiosa da coroa e da igreja, enquanto que o mais novo, mais pessimista, era da opinião de que mais avisada era a sua expulsão imediata, por a experiência ter mostrado ser impossível alcançar uma conversão autêntica por parte de tal gente (Arrais, 1981,pp. 20 e ss..)

${ }_{52}$ Cinco anos antes fora frei Luís de Granada, no seu tratado Introduccion al simbolo da la Fe, a fazê-lo (Rodrigues, 1987,pp. 307 e ss) e note-se que o mesmo dominicano escreveria um Breve tratado em que se declara el modo que se podrá tener en enseñar y persuadir nostra sancta fe a los infieles, vocacionado para a conversão nas «Indias Orientalés».

${ }^{53}$ BA, 51-VI-36, fls. 53-56; v., a esse propósito, Rodrigues, 1979, p. 293. 
um público mais vasto. ${ }^{54}$ Terá sido por essa mesma razão que o tratado do cisterciense Francisco Machado, de acordo com Révah o autor de um Espelho de cristãos novos e convertidos, de 1541, só veio a ser publicado em 1567, em Coimbra, mas agora com o título de Veritatis reportorium...? Nesse livro, Machado exprimia um «sincero respeito pela pessoas dos cristãos-novos e um imenso desejo de os salvar» ${ }^{55}$ e é possível que esse ideário de contornos erasmistas já não fosse ao encontro das motivações de boa parte da elite política e eclesiástica portuguesa.

Ora, se é verdade que estas tendências participavam de tradições argumentativas de raízes antigas, as quais haviam constituído a identidade cristã por oposição à identidade judaica (e depois islâmica), e as quais previam vias mais suaves ou mais violentas em relação às comunidades tidas por dissonantes em matéria religiosa (e bastaria referir, a esse propósito, as normas práticas de procedimento contra os não-cristãos estabelecidas no Corpus Iuris Civilis, e o discurso que sustenta a Summa contra Gentiles de São Tomás de Aqui$\mathrm{no}^{56}$ ), a verdade é que a sua enunciação no mundo português quinhentista adquiria novos significados, potenciava outro tipo de associações, e estimulava diferentes recepções.

Em concreto, ambas as vias ressurgiram nos discursos que circularam no reino e no império, mas doravante a propósito da conversão dos «gentios». José da Silva Horta mostrou, num estudo sobre o já referido Diogo de Sá, que neste autor a distinção entre as categorias judeu, herege e gentio, era precisa, e esse é um aspecto que não pode ser esquecido. ${ }^{57}$ Contudo, ao mesmo tempo que existia a consciência dessa diferença de estatuto, a sua vizinhança semântica - e as contaminações que ela proporcionava - era também uma realidade indiscutível.

Pelo seu envolvimento com os círculos mais íntimos da corte portuguesa e com a construção eclesiástica do Estado da Índia, bem como pelo facto de alguns dos seus escritos terem sido colocados, também eles, no Index, a pena e a acção do arcebispo D. Gaspar de Leão é a mais sintomática.

Originário do sul de Portugal, Leão estudara Teologia na Universidade de Salamanca, onde, segundo Eugenio Asensio, sofrera a influência de Domingos de Soto, um dos autores coetâneos que mais cita nos seus escritos. ${ }^{58}$ Sabe-se que cerca de 1540 estava a residir em Évora, fazendo parte do séquito de D. Henrique, recebendo a dignidade de cónego daquela sé em 1551, e de

${ }^{54}$ Gomes, 2003, p. 1009, mas também Horta, 2002.

55 Révah, pp. 1xiii-lxiv.

${ }_{56}$ Veja-se, a esse propósito, Hoeffner, 1957, pp. 49-52.

57 Horta, 2002, in genere.

${ }^{58}$ Asensio, in Leão, 1958. 
arcediago em 1557. Para além disso, era capelão e pregador do irmão de D. João III. É ele que o irá persuadir a aceitar o lugar de prelado da diocese de Goa, que com a sua ida passaria a ter o estatuto de arcebispado (e, do ponto de vista geográfico, tornar-se-ia na maior unidade eclesiástica portuguesa). Face à inicial recusa de D. Gaspar, o cardeal recorreria para Roma e «obrigaria» o seu «mestre» a aceitar essa função. ${ }^{59}$

Já em Goa, Leão abordou muito activamente a dignidade que lhe foi atribuída. A «Provisão d'El-Rey sobre a apresentação dos benefícios ecclesiásticos da Índia», permitia-lhe prover e confirmar os benefícios eclesiásticos daqueles lugares, por o monarca confiar que o «dito arcebispo que nomeará a elles pessoas indonias e sobficientes, e taes como pera o serviço da dita see e igrejas convem, e que desencarregará nisso minha conciencia e a sua, como he obrigado, e por este encomendo ao dito arcebispo que o faça asy ${ }^{60}$. O conflito que o oporia, quase de imediato, à Companhia de Jesus, dá conta, por seu turno, de quão seriamente o arcebispo assumiu o que julgava ser a sua esfera jurisdicional. Os inacianos pareciam ter optado, nesse período inicial da sua acção evangelizadora, pela via dura e não tanto pela accomodatio que veio a caracterizar boa parte da sua acção futura. Nesse contexto foi trocada uma sugestiva correspondência entre Lisboa, Goa e Roma, através da qual se percebe a imersão de Leão no espírito tridentino. É possível, aliás, que alguns dos sermões prégados nessa altura tenham sido integrados no Compendio Spiritual da Vida Christãa, publicado em Goa em 1561, que, como consta do título, fora «per elle prégado no primeiro anno a seus fregueses, pera gloria e hõrra de Iesv Christo ... e edificaçam de suas Ovelhas ...», manual de doutrina cristã que, infelizmente, não foi possível consultar, mas que, a meu ver, constitui mais uma peça do puzzle que Leão quis construir naqueles lugares. É que é mais ou menos nesses mesmos anos que o prelado prepara a tradução do tratado de Jerónimo de Santa Fé, e a carta pastoral que inclui como introdução do mesmo, publicado em 1565, assim como as Constituições do Arcebispado de Goa, organizando, ao mesmo tempo, a celebração do $1 .{ }^{\circ}$ Concílio Provincial de Goa, nos mesmos anos em que assembleias semelhantes estavam a ser realizadas nas principais dioceses do reino.

Em suma, a escrita de Gaspar de Leão não pode ser desligada da sua identidade institucional, da maneira como terá encarado a acção episcopal numa província eclesiástica que, diferentemente das do reino, precisava de ser «constituída» - não só administrativamente mas também demograficamente, pois a maior parte dos fiéis «possíveis» ainda não fora sequer convertida.

59 «Carta del Rei D. João III para o Cardeal Infante informando terem chegados as bulas do arcebispado de Goa e bispos de Cochim e Malaca; e breve para Mestre Gaspar, aceitar o Arcebispado (...)» (ANTT, SV, L. 10, fls. 290-291).

${ }_{60}$ APO, F 5, P I, pp.436-438. 
Considere-se, então, a sua tradução do tratado de Jerónimo de Santa Fé, publicada no ano de $1565 .^{61}$ Converso de Saragoça, Santa Fé era um símbolo do convertido cuja religiosidade, cuja adesão à identidade cristã, constituía um modelo para os restantes. Tanto assim que não só Santa Fé redigiu esse tratado que visava a conversão dos seus anteriores correligionários, em 1414, quanto se envolveu, na prática, em acções de punição dos mesmos, tais como a violenta invasão do bairro judaico de Saragoça, em 1415, durante a qual o seu filho esbofeteou um judeu, num gesto carregado de simbolismo. ${ }^{62}$ Ao dirigir-se aos judeus e conversos estabelecidos no Estado da Índia, o primeiro arcebispo de Goa justificou tal edição com «o zello do Autor, a compaixão de vossos enganos, \& também a obrigação do Prelado», lembrando que «dado que estais derramados por essa Turquia fora de jurdiçã, todavia não fora da obrigação de trazer as ovelhas perdidas da casa de Israel, ao curral da ygreja Catholica $»^{63}$. Para Gaspar de Leão era claro que a questão judaica e cristã-nova do reino prolongava-se até ao império, e que era seu dever enquanto prelado do império providenciar pela conversão daquelas «ovelhas perdidas».

Significativamente, na carta pastoral, e depois de fazer um grande elogio à nobreza hebraica anterior à vinda de Cristo, trạsferida e ampliada na comunidade cristã, delega no «engano \& malicia» dos rabis a cegueira em que os judeus tinham caído depois da vinda do Messias. Nesse sentido, Leão também procede (à semelhança do que João de Barros tentara no Diálogo) a uma quase desculpabilização do judeu comum, enganado pelas mentiras veiculadas pelos seus sacerdotes.

Já no convento capucho da Madre de Deus, que ele próprio fundou e no qual se recolheu, Leão compôs o Desengano dos Perdidos, feito pera gloria de Deos, e consolação dos novamente convertidos..., publicado em 1573, tratado místico que veio a integrar o Index, que visava a conversão dos muçulmanos, mas que se constituía, sobretudo, como guia das condutas dos novamente convertidos.

No capítulo 8 da primeira parte deste tratado, o arcebispo explicou que os «mouros sam idolatras», mas também que «os actos humanos não dependem das estrellas», numa clara referência às modalidades de explicação da realidade utilizadas pelos sacerdotes locais, continuando ao longo do livro, a estabelecer afinidades entre os primeiros e os segundos. Tal como fi-

${ }^{61}$ Uma tradução de parte do tratado teria sido feita, c. de 1534, por um mestre António, físico da corte de D. João III, sob o nome Ajuda da fé contra os Judeus. Apesar de copiada em 1534 e em 1545 - o que denunciava a sua circulação pelos meios cortesãos -, esta tradução não tinha visto a imprensa (Orfali, s.d., pp. 247-248).

${ }_{62}$ Nirenberg, 2002, p. 1090.

${ }^{63}$ Leão, 1565, carta introdutória. 
zera antes - mas tendo então como referência os judeus - no tratado de Jerónimo de Santa Fé.

Ou seja, a grelha de Gaspar de Leão parecia ser um continuum semântico que ia dos judeus aos muçulmanos e aos locais, os quais partilhavam, no seu entender, vícios que, sob muitos aspectos eram semelhantes (a codícia, a avareza, a desordem dos apetites), podendo aspirar, ainda assim, às virtudes cristãs.

Apesar de termos destacado, aqui, a figura emblemática de Fr. Gaspar de Leão, e esta não ser plenamente representativa do ethos imperial quinhentista, é de considerar a hipótese, contudo, que o mesmo tipo de trânsitos semânticos conformassem, ainda que não de forma tão sofisticada, os viajantes que atravessavam o Atlântico e o Índico e arribavam no porto de Goa. Assim sendo, nada surpreende encontrar entre os «colonizadores» portugueses o recurso às mesmas vias que tinham sido utilizadas no reino para lidar com os judeus e conversos, o convite e a força, o privilégio e a discriminação, a exaltação do neófito e a punição do relapso.

Considere-se, pois, de que maneira é que a partir de 1530 a coroa portuguesa se foi relacionando com os «gentios» e os novamente convertidos de Goa e como é que neles iria reconhecer características semelhantes às dos judeus, depois conversos, do reino.

\section{A caminho de novas liminaridades}

$\mathrm{Na}$ terceira década de seiscentos, uma provisão do conde de Linhares sobre o direito aplicado aos casamentos dos não-cristãos, aos lugares onde estes se podiam celebrar, e sobre se devia deixar os «gentios» usarem sândalo, terminava com esta justificação: «meço-me nisto com o que se usa com os Judeus em Portugal e Castella, que para que sejão conhecidos se lhes ordena que tragão chapeos amarellos ${ }^{64}$. Três anos depois, o mesmo D. Miguel de Noronha proíbiu os «gentios» de viver em Salcete (uma das províncias dos territórios circundantes da cidade de Goa), expulsão essa que era complementada pela perda de todos os poderes, honras e preeminências que estes grupos detinham localmente, «sob pena de perdimento de vida». Embora lhes fosse permitido entrar no referido território para fazerem mercancia, não se podiam demorar para além de dois meses, e «no dito tempo morarão em bairro particular, que pera o tal effeito assinarão em cada povoação e aldea os Padres da Companhia de Jesus». Aos ditos padres ficava encarregue o controlo da efectiva separação entre cristãos e não-cristãos, e o providenciarem para

${ }^{64}$ APO, f. 6, p. 183. 
que estes nunca se encontrassem de noite, mas apenas de dia e em praças e bazares públicos ${ }^{65}$.

Separação física, mais uma vez, mas cada vez mais um outro tipo de separação física. Não se tratava já do modelo medieval no qual várias comunidades podiam coexistir sob o domínio de um mesmo príncipe, reservando alguma autonomia jurídica e religiosa, habitando em lugares que lhes eram reservados. O que estava em vigor nas primeiras décadas do século XVII era um modelo homogeneizador que não previa a presença de comunidades diferentes (estas eram por vezes aceites por razões de oportunidade política e económica, mas sempre em regime de excepção legal). À semelhança do que acontecera com os judeus de Portugal em finais do século XV e inícios do século XVI, também os não-cristãos que residiam nos territórios de Goa (salvo algumas excepções) se confrontaram, a partir de 1530 , com três alternativas: ${ }^{66}$ continuar a residir naqueles territórios, mantendo a sua fé e comportamentos religiosos clandestinamente; a conversão ao cristianismo; o abandono voluntário das suas terras. ${ }^{67}$ Note-se que as palavras de Miguel de Noronha são pronunciadas num momento em que parte deste percurso tinha já sido percorrido e em que a grande maioria de dispositivos que persuadiram as populações locais à conversão estavam em plena actividade, e com algum sucesso. Estes dispositivos, os quais contemplavam a subalternização discursiva e jurídica da comunidade não-cristã e a atribuição de privilégios aos locais que se quisessem converter ao cristianismo, tinham transformado a paisagem jurídico-político, social e cultural do Estado da Índia das primeiras décadas e, dentro deste, dos territórios conhecidos com Goa.

A subalternização discursiva - implícita em discursos como o de Leão - surgia claramente expressa nas normas então emanadas, e a tópica religiosa que estrutura os seus preâmbulos é disso sintomática. Depois de articuladas com as Cartas e Breves pastorais dos bispos e arcebispos de Goa, e ainda como os Concílios Provinciais do mesmo lugar, estas normas traçaram a lógica da organização social local, um mapa de inclusões e exclusões que permaneceu praticamente inalterado, no seu dever-ser, até às reformas pombalinas. Para além dos efeitos negativos imediatos, as normas que discriminavam as comunidades «gentias» contribuíam para a disrupção da sua coesão social, facilitando, dessa forma, o enfraquecimento da sua posição. Do mesmo modo,

${ }_{65}$ APO, f. 5, P III, pp. 1399-1402, n.. Cf. Couto, 1987, pp. 123-134.

${ }_{66}^{6}$ Sobre os destinos dos não-cristãos, v. Xavier, 1993. Este autor - apesar de se situar numa perspectiva demasiado ideológica - oferece uma interessante sistematização da vida social em Goa.

67. Como consequência, havia zonas do território goês que tendiam a despovoar-se; é neste sentido que surge um decreto durante o reinado de D. Sebastião restituindo as terras aos gentios que quisessem regressar (DHMPPO, IX, p. 615). 
e num sentido inverso, as provisões que favoreciam os sujeitos que se convertiam, beneficiava, o processo de conversão.

Nesses anos, e sob a orientação do padre Miguel Vaz, vigário-geral do Estado da Índia, e clérigo formado no colégio de S. Pedro da Universidade de Coimbra, destruíam-se templos, objectos de devoção, e expulsavam-se os sacerdotes locais, num processo de decapitação material e simbólica da cultura religiosa daqueles lugares que só tem paralelo (pese embora aqui se tratar da maioria demográfica, e não de um grupo minoritário) com aquele que ocorrera no reino nos finais do século anterior, e que se identifica com a violência ocorrida mais ou menos na mesma altura nos territórios atlânticos do reino de Castela. ${ }^{68}$ Quase ao mesmo tempo que se destruíam os templos e se retiravam meios de subsistência aos seus oficiantes, proibía-se a prática pública dos cultos locais. A lei assinada por D. Catarina em 1559 - que já surgia na sequência de legislação anterior - previa a destruição de todos os templos, mesmo aqueles que se situavam dentro das casas, proíbindo a celebração de qualquer rito local, dentro de casa ou fora dela. Assim como a permanência de brâmanes naquele território. Outro decreto igualmente importante era o que obrigava os brâmanes a atenderem a doutrinação na igreja, todos os domingos, durante um hora, igualmente aplicável ... - atente-se nisto - a todos os gentios com mais de 14 anos. E duma provisão de 1560 consta uma lista dos brâmanes que deviam partir da cidade de Goa. Os que eram de Bardez e Salcete podiam aí regressar e «viver em suas aldeias», mas todos aqueles que o não fizessem seriam cativos para sempre, indo para as galés sem remissão, perdendo toda a sua fazenda, metade para quem o acusasse, metade para quem o rei decidisse ${ }^{69}$. Três anos depois seria a vez do conde do Redondo passar uma provisão semelhante, desta vez em cumprimento de uma ordem vinda de Lisboa. Nessa sua provisão - talvez escrita sob reserva de consciência, pois D. Francisco Coutinho contestara as vantagens da política que estava a ser adoptada -, explicita-se quais eram os brâmanes que não deviam ser expulsos (os que lavravam a terra com as suas próprias mãos, porque «parece que não poderão perjudicar, antes que serão utiles à terra, e sendo assy conviria que estes não fossem lançados fora, nem lhes proibisse viver nas minhas terras em quanto elles não fizessem o que particularmente esta prohibido aos gentios por minhas leis e provisões»), e aqueles que o deviam ser, «dando-se modo como todos os ditos officios, ou ao menos alguns delles, que mais convenhão, andem sempre nos christãos portugueses e naturaes da terra, e não em gentios e infiéis».$^{70}$

${ }_{68}$ Wachtel e Gruzinski, 1997, in genere.

${ }_{69}$ APO, F. 5, I, p. 35.

${ }_{70}$ APO, f. 5, P II , p. 543-545. Em 1567, «Capitulo do Regimento, que Elrey deu ao V. Rey D. Antão no anno de 1566 sobre serem lançados fora das terras de Goa os infiéis, que apontar o Arcebispo; não serem gentios os escrivães das aldeas; e os gancares gentios não entra- 
A par destas intervenções, seguiram-se outras com impacto em níveis igualmente profundos: a família, a terra, a residência, o trabalho, a dignidade política. Intervinha-se, por um lado, nos destinos dos órfãos «gentios», retirando direitos às famílias «gentias» sobre os seus familiares órfãos, favorecendo, em contrapartida, os interesses das que se tinham tornado cristãs. Por outro lado, aumentavam-se os direitos das viúvas e filhas de gentios que se fizessem cristãs, permitindo-lhes receber parte das heranças dos seus maridos e pais (o que não era permitido pelo direito local). Ao mesmo tempo, vários decretos episcopais instavam ao favorecimento dos cristãos na distribuição das várzeas (entre todas as terras, aquelas que eram mais rentáveis) dentro de uma aldeia com população mista. Outros subvertiam a distribuição tradicional do poder, passando a proibir o acesso de não-cristãos a determinadas posições. No mesmo sentido postulava o decreto 27 do Concílio Provincial de 1567 «que se não dê nenhum officio, dignidade, honra, preeminencia, nem dominio algum a pessoa infiel sobre pessoa fiel» - em perfeita consonância, aliás, com a doutrina que vigorava no reino. ${ }^{71}$

Importa notar que esta sucessão de medidas tornava o raio de poder e a capacidade de intervenção dos locais cada vez menor, mas era isso mesmo que pretendia a coroa de Portugal pois, como se dizia nos preâmbulos de muitas normas, o rei português fora «informado que privando-se desta honrra mais facilmente se converterão a nossa santa fe catholica».

E se a expulsão dos brâmanes constitui um vértice da estratégia discriminatória, a sua cristalização expressa-se na nova forma de separação física das comunidades, claramente expressa no texto do concílio provincial de 1567. Ainda no mesmo decreto 27 dos artigos em favor da conversão e da protestação da fé, proíbe-se a amizade, o serviço, o trabalho, o convívio e a conversação dos fiéis com os infiéis. «Nem o convide a comer, nem agasalhe os infiéis por portas adentro, nem os tenha às portas assentadas em cadeiras pera fim de conversar com elles, nem os deixe jugar em suas casas», diz-se explicitamente neste decreto, e o mesmo espírito subjaz aos outros decretos emanados desta assembleia. Aí se proíbia os cristãos de participarem em festas gentias e de emprestarem a estes artefactos que pudessem favorecer a realização destes rituais, de partilharem casa com um infiel, de viverem na mesma rua. Em contrapartida, determinava-se que os «gentios» não pudessem passar por terras cristãs quando iam às suas romarias, devendo usar trajes que os identificassem como tal.

rem em camara» (APO, f. 5, P. II, p. 612). Oito anos depois, « Provisão do Governador Antonio Moniz Barreto confiscando as fazendas dos brâmanes, que forão expulsos, e voltarão a estas terras sem sua licança» (APO, f. 5, P II, pp. 903-903).

${ }^{71}$ V. por exemplo, a argumentação dos tratados sobre a nobreza civil e cristã de Jerónimo Osório (1995). 
Numa conclusão muito rápida, mas nem por isso extemporânea, pode dizer-se que a discriminação exercida em relação aos não-cristãos foi praticamente correlativa à protecção dos novamente convertidos. ${ }^{72}$ Tanto as provisões através das quais se canalizavam os bens dos templos para o benefício do culto cristão, de 1541, reforçada pela lei de D. Catarina, de 1559, como a legislação que beneficiava os que se convertiam a cristãos na legislação sucessória, tinham como pano de fundo a promoção da conversão ao cristianismo.

A criação da confraria da Santa Fé deve ser entendida neste contexto, bem como a do hospital onde eram tratados e apoiados os cristãos locais. Do mesmo modo, a criação de escolas paroquiais, por instância do bispo de Goa, em 1544, o qual declarara numa pastoral que em cada paróquia devia haver uma escola onde se ensinassem os rudimentos da fé aos meninos, devendo os párocos fazer pregações públicas, exortando à conversão, contemplava não apenas os filhos de portugueses, mas também os filhos dos novamente convertidos. Mais tarde, e no mesmo sentido (o de proporcionar uma transição identitária mais suave e o de modelar as suas componentes) surgem a Casa dos Catecúmenos e o ofício do Pai dos Cristãos, um espécie de provedor dos interesses destas populações em trânsito identitário.

Enfim, torna-se claro que em meados do século XVI a unidade religiosa de Goa era um objectivo a alcançar, e que tal como estava a acontecer no reino, visava-se a constituição de uma comunidade política cristã em territórios longínquos da coroa de Portugal, o que podia permitir a permanência, a longo prazo, do poder imperial português naqueles lugares, sem hipotecar os interesses da metrópole, resolvendo, ao mesmo tempo, o problema inerente à escassez de recursos humanos com que a coroa estruturalmente se confrontava. Ou seja, para além dos seus fins religiosos, a conversão tinha fins políticos, surgindo como o modelo de enraizamento imperial mais eficaz após a controversa estratégia de Albuquerque: a da misceginação física. Em vez da conversão física, a coroa optou pela conversão religiosa, pela conversão cultural.

Ainda assim, não se pode deduzir que os destinos de cristãos-novos e gentios, de conversos e novamente convertidos do reino e do império foram

72 Abordando o caso espanhol, Gruzinski e Wachtel mostraram que o recurso a três tipos de dispositivos - a instituição da minoridade espiritual das populações locais; a diferenciação jurídica das mesmas, atribuíndo-lhe menos direitos que os da comunidade cristã; a separação física - potenciava o processo de conversão ao cristianismo, muito embora suscitasse outras formas de diferenciação. Apesar da proposta de Gruzinski e Wachtel se referir à colonização espanhola, o facto é que ela soa estranhamente "familiar" quando se pensa na experiência portuguesa em Goa, principalmente durante a segunda metade do século XVI (Gruzinski e Wachtel, 1997, in genere). 
idênticos, nem sequer afirmar, à partida, que os novamente convertidos também foram cristalizados numa identidade liminar. Afirmar isto suporia a adesão a um princípio determinista que não é, de modo algum, aquele que conduz este inquérito. Importa, pois, continuar esta sondagem de modo a perceber se a similitude da transição significou - à semelhança do que acontecia no reino - , um subsequente estatuto liminar.

Recorde-se que a equiparação dos novamente convertidos aos portugueses através da provisão de 1559 reiterava uma outra de 1542, assinada por D. João III, que garantia que os privilégios dos portugueses seriam guardados àqueles que se convertessem e residissem em Goa. Não era esse um sintoma de que se pretendia, efectivamente, a equalização jurídica? Ou estas normas tiveram o mesmo destino daquelas outras que, em 1507, pareciam garantir um igual tratamento a conversos e cristãos-velhos no reino - ou seja, coexistiram com uma progressiva rigidificação do acesso aos bens sociais mais apetecidos?

Abundante documentação testemunha o relacionamento entre cristãos-velhos e novamente convertidos de Goa, e as queixas destes últimos, frequentemente dirigidas ao rei de Portugal, por causa de lhes ser vedado o acesso aos ofícios de governança. ${ }^{73}$ A equiparação que o direito fazia entre baptismo e nascimento de pai português, entre regeneratio e generatio, e o aumento efectivo de cristãos (e, por conseguinte, de súbditos do rei de Portugal no império), obrigou a repensar os «usos possíveis» das elaborações jurídicas. Mais até do que no reino, nos territórios imperiais a «similitude» do estatuto jurídico dos novamente convertidos ao estatuto dos portugueses, suscitava desequilíbrios sociais importantes. Como se terão sentido, por exemplo, os poucos portugueses casados que residiam em Goa (os «colonizadores») quando viram, subitamente, o seu estatuto social ser equiparado ao dos novamente convertidos (os «colonizados» $)^{74}$ ? Como é que isto ameaçava os fundamentos da dominação imperial?

À laia de ilustração, considere-se este pequeno mas sugestivo episódio. Em 1542, nesse ano em que os moradores da cidade de Goa foram equiparados aos de Lisboa, e que a carta de lei de D. João III estendia os benefícios dos «casados» a «toda a pesoa asy portuguez, como de qualquer outra nação, geração, e calidade que seja que na dita cidade casar, que fizer casa de novo, sendo christão» com o intuito de que a cidade «se enobreça e vaa em todo crecimento» - lei reconfirmada várias vezes,$-{ }^{75}$ uma outra carta de lei determinava

${ }^{73}$ Xavier, 2005, pp. 114 e ss.

74 Hespanha, 1995, p. 4.

75 APO, f. 2 , pp. $48-69$, pp. $120-122$; f. 5, I, pp. $386-387$; f. 5, III, pp. 979, 983-984, 987 , 1157-1158. 
que os ofícios de governança da cidade andassem» em «pessoas que a bem saibão reger e governar», «sempre naquelles casados e moradores della, que forem portuguezes de nação e geração, e não em outros nenhuns de nenhuma outra nação, geração, e callidade que sejão. Também dois dias depois da confirmação da equiparação do estatuto dos cristãos ao dos portugueses por D. Catarina de Áustria, uma outra lei restringia as vantagens que a conversão, à partida, traria aos escravos. ${ }^{76}$ Por seu turno, à legislação que valorizava juridicamente as mulheres gentias contrapunha-se a chegada das primeiras orfãs do reino, com o intuito de permitir aos portugueses aí estabelecidos um matrimónio dentro do seu próprio grupo étnico (ou seja, evitando a contaminação física). Deixando implícito, no final de contas, que as «gentias» não tinham qualidade suficiente para aspirar a tais uniões, e que a nova pertença religiosa não apágava a memória de outras distinções.

Variantes deste princípio reapareciam, por exemplo, nos regimentos das confrarias, nos quais se excluía os recentemente convertidos das posições mais altas. Faziam parte dos argumentos das ordens religiosas que não queriam dar todas as ordens sacras aos clérigos de origem local - como se a proximidade temporal do antigo estado, a memória recente das antigas práticas consideradas diabólicas tivesse efeitos perduráveis sobre a substância moral dos sujeitos -, enquanto outras não permitiam o ingresso nas suas fileiras, à semelhança do que acontecia com os conversos. E o mesmo raciocínio aplicava-se no acesso às carreiras militares.

Ou seja, ao mesmo tempo que o critério religioso, expresso na conversão e no baptismo, incluía os indianos na ordem jurídica portuguesa, abrindo-lhes, assim, todo um outro campo de possibilidades sociais, a invocação de outro instituto jurídico, na mesma semana, pelo mesmo rei, podia reduzir o âmbito dessas possibilidades, e excluía-os de um dos bens mais apetecidos a que poderiam aspirar: a governança da própria cidade. A par disso, normas sociais implícitas, e outras tornadas explícitas (como os estatutos de limpeza de sangue) completavam esta arquitectura de distinções.

$$
\text { *** } *
$$

Os casos supracitados mostram bem como é que o potencial inclusivo, assimilador e equalizador inerente à conversão podia ser reduzido através do recurso a vias jurídicas, institucionais e sociais igualmente legítimas. Impedindo que acontecesse o que, numa época em que as fronteiras sociais tendiam a rigidificar-se e a sociedade - e cada vez mais - a hierarquizar-se, parecia impossível de acontecer: a equalização de grupos que, à partida, estavam posi-

${ }^{76}$ APO, f. 2, pp. 115-116; f. 5, I, pp. 390-392. 
cionados em pólos antagónicos do espectro social. A par destes dispositivos que o próprio direito proporcionava e de que os juristas eram conhecedores, os quais thes permitiam jogar com institutos jurídicos com efeitos mais ou menos contraditórios, conciliando-os para se atingirem fins políticos bastante precisos, existiam ainda outros expedientes que garantiam que o «espírito das leis» seria facilmente entendido por quem as devia pôr em prática. Refiro-me, em particular, ao uso mais preciso dos vocábulos de identificação das diferentes comunidades que habitavam aqueles territórios.

Numa carta de lei de 1564 que confirmava um velho privilégio que tinha sido atribuído aos moradores da cidade de Goa, nos tempos de Albuquerque e de D. Manuel, referem-se queixas dos «moradores portugueses christãos e de toda outra calidade» da dita cidade, para mais adiante, no mesmo texto, no momento em que se confirmava, em fatiota, o privilégio de estes poderem vender os produtos das suas hortas sem terem de pagar direitos por isso, se explicitava claramente que o privilégio era confirmado aos «moradores portuguezes e christãos» de Goa. É certo que algumas décadas antes, e a par dos decretos que continham designações mais genéricas como «moradores», «portugueses» «casados», havia muitos outros que elencavam as diversas identidades, nomeadamente a de «christãos portuguezes», «moradores portuguezes christãos $\gg^{77}$. Nestes textos, tornava-se claro que os portugueses e os indianos que se tinham convertido permaneciam comunidades distintas. Logo em 1519, D. Manuel concedera uma esmola aos «christãos novos da terra pobres $\gg^{78}$, distinguindo já nessas primeiras décadas os convertidos dos portugueses cristãos-velhos, que residiam em Goa, aproximando-os - ao mesmo tempo que os distanciava - dos conversos de Portugal. ${ }^{79}$

A insuficiência descritiva da designação de «christão» tornava-se cada vez mais evidente, e o abandono da designação de «christão novo» para identificar a comunidade formada por pessoas de origem local que se tinham convertido ao cristianismo, obrigou a uma formulação alternativa - a de christão da terra, christão da Índia ou de novamente convertido, as quais passaram a surgir nas normas emanadas da coroa ${ }^{80}$.

Quer isto dizer que mesmo do ponto de vista legal a comunidade cristã imaginada e construída em Goa era mais complexa do que alguma legislação pode sugerir. A promoção dos convertidos implicou mais do que o distanciamento entre estes e aqueles que tinham recusado a conversão, pois à semelhança do que sucedeu no reino com os conversos, a emergência de outros critérios de distinção, de outras formas de diferença impediu, praticamente até ao

77 APO,f. 2, pp. 3-10; pp. 155-158; f. 5, I, pp. 42-50.

${ }_{78}$ APO, f. 5, I, p. 41.

79 APO, f. 2, p. 17.

${ }^{80}$ Cf., por exemplo, APO, f. 5, II, p. 512, p. 513. 
fim da dominação imperial portuguesa naqueles lugares, a plena assimilação destes novamente convertidos (por muito que estes reivindicassem tal identidade) aos «colonizadores».

No reino como no império, inclusão política pela conversão ao cristianismo, e diferenciação social, foram dinâmicas paralelas que recorreram a múltiplos dispositivos (e entre estes, os estatutos de limpeza de sangue têm uma centralidade simbólica da maior importância) ${ }^{81}$ Estes permitiam a sua coexistência - tensionalmente, é certo -, bem como a emergência de um tecido social multiplamente hierárquico, no qual se identificam grupos liminares, ou seja, grupos que apesar de fazerem «plenamente» parte da ordem política se localizavam na margem da ordem social, muito embora com constantes e reivindicadas expectativas de inclusão. Em suma, num estado de transitoriedade perene.

$\mathrm{O}$ mesmo direito que servira para incluir e equalizar, facilitara, por outras vias, a rejeição. A mesma religião que prometera igual dignidade justificava, com conhecidos argumentos, a subordinação hierárquica.

Já no século XVII, a lei de 24 de Novembro de 1601, através da qual se mandava que «ninguem possa chamar nem chame Christão novo, ou Confesso, ou Marrano, ou Judeu, nem outro nome algum afrontoso por escrito, nem de palavra, nem de juizo, nem fora delle, a pessoa alguma, que descendente seja dos convertidos à nossa Santa Fee Catholica, nem as que de novo se converterem a ella» e o Perdão Geral de $1604,{ }^{82} \mathrm{em}$ contraponto com os «Interrogatorios das partes, e catidades, que hãode ter as pessoas, a que o VisoRey Aires de Saldanha hade lançar os habitos de nosso Senhor Jesu Christo, Santiago, e São Bento de Aviz nas partes da India, as quaes são conformes aos estatutos das ditas ordens, e bullas de Sua Santidade», de dois anos antes, expressam a mesma contradição. ${ }^{83}$

Mas ao contrário do reino - e esse é um aspecto central e que distingue, nesses aspectos, a experiência dos conversos e dos novamente convertidos -, a conversão dos «gentios» de Goa ao cristianismo encerrava um desequilíbrio demográfico que podia ter consequências centrais para a ordem de relações estabelecida. É que no império, os novamente convertidos eram a maioria demográfica, enquanto que os cristãos-velhos constituíam a sua minoria. Ou seja, os perigos que emergiam da potencial equalização jurídica eram agora exponencialmente maiores, podendo subverter, inclusive, a própria lógica da dominação imperial. Se a partir da terceira década do século XVI, no reino e no Estado da Índia, poucos eram os que defendiam a mestiçagem física (e é inevitável pensar com uma certa ironia o luso-tropicalismo do século XX e a sua

${ }^{81}$ Olival, 2004, maxime.

${ }^{82}$ Figueiredo, 1790, II, p. 288, 289.

83 APO, f. 6, p. 739. 
recepção na sociedade portuguesa), muitos havia, também, que questionavam a conversão religiosa, a conversão religiosa, e os outros perigos que daí podiam advir.

\section{BIBLIOGRAFIA}

ALBUQUERQUE, Luís de, António Luís Ferronha, José da Silva Horta, Rui Loureiro, $O$ confronto do olhar. $O$ encontro dos povos na época das navegações portuguesas. Séculos XV e XVI, Lisboa, Ed. Caminho, 1991.

ARRAIS, Amador dos, Diálogos, Lisboa, Sá da Costa, 1981.

AZEVEDO, J. Lúcio. História dos Cristãos-Novos Portugueses. 3. ${ }^{\text {a }}$ ed. Lisboa: Clássica Editora, 1989.

BARRETO, Luís Filipe, Descobrimentos e Renascimento. Formas de Ser e Pensar nos séculos XVI e XVII, Lisboa, INCM, 1983.

BETHENCOURT, Francisco. História das Inquisições: Portugal, Espanha e Itália Séculos XV-XIX. Lisboa, Círculo de Leitores, 1995.

CARDOSO, Jerónimo, Jornada da Alma Libertada, Lisboa, 1626.

CARVALHO, António Carlos. Os judeus do desterro de Portugal. Lisboa: Quetzal Editores, 1999.

COUTO, Jorge, «Os Judeus de Sinal na Legislação Portuguesa da Idade Moderna», in Inquisição, Actas do $1 .{ }^{\circ}$ Congresso Luso-Brasileiro, 1987, I, pp. 123-134.

CUNHA, Ana Cannas, A Inquisição no Estado da Índia. Origens (1539-1560), Lisboa, ANTT, 1995.

DAMATTA, Roberto. Individualidade e liminaridade: considerações sobre os ritos de passagem e a modernidade. Mana, abr. 2000, vol.6, no.1, p.7-29. ISSN 0104-9313.

Domínguez Ortiz, Antonio, Los judeoconversos en la España moderna, Madrid, Editorial MAPFRE, 1992.

DOUGLAS, Mary, Purity and Danger, 1966.

ELIAS, Norbert; SCOTSON, John L., The Established and the Outsiders. A sociological enquiry into Community Problems, London-Thousand Oaks-New Delhi, Sage Pub., 1994 (1977).

FEITLER, Bruno, Inquisition, juifs et nouveaux-chrétiens au Brésil: le Nordeste, XVIIe et XVIIIe siècles, Leuven, Leuven University Press, 2003.

FERRO, M. ${ }^{a}$ José, «Inquisição: uma catequização pelo medo», in Actas do III Encontro sobre História Dominicana, Tomo III, Porto, Arquivo de História Dominicana Portuguesa, vol. IV/2, 1989.

, Inquisição e Judaísmo, Lisboa, ed. Presença, 1987.

, Os Judeus em Portugal no Século XV, Lisboa, 1. a ed., Faculdade de Ciências Sociais e Humanas, 2 vols., 1982-1984.

FIGUEIREDO, Jozé Anastácio de, Synopsis Chronologica de subsídios ainda os mais raros para a historia e estudo critico da legislacao portugueza (...), Lisboa, Officina da Academia, Tomos I - Desde 1143 até 1549 e II - Desde 1550 até $1603,1790$.

FORD, John, Letters of John III, King of Portugal, 1931. 
As Gavetas da Torre do Tombo (GTT), 11 vols., Lisboa, 1960.

GOMES, Ana Cristina Cardoso da Costa, «Entre as armas e as letras: o percurso do humanista Diogo de Sá», in D. João III e o Império, Actas do Congresso Internacional comemorativo do seu nascimento, Lisboa, Centro de História de Além-Mar, 2004.

GRAÇA, Luís, A visão do Oriente na literatura portuguesa de viagens: os viajantes portugueses e os itinerários terrestres,,1560-1670, Lisboa, INCM, 1983.

GRUZINSKI, Serge e WACHTEL, Nathan, 1997.

HESPANHA, António Manuel, Panorama da História do Direito de Macau, Macau, 1995. HOEFFNER, Joseph, La Etica Colonial Española del siglo de Oro, Madrid, Ediciones Cultura Hispanica, 1957.

HORTA, José da Silva, «A catergoria do gentio em Diogo de Sá: Funções e níveis de significação», Clio, Nova Série, n. ${ }^{\circ}$ 10, 2004.

KRIEGEL, Maurice, «De la «question» des «nouveaux - chrétiens» à l'expulsion des juifs: la double modernité des procès de l'exclusion dans l'Espagne du XVe siécle», in Serge GRUZINSKI et Nathan WACHTEL, Le Nouveau Monde, Mondes Nouveaux. L'expérience Américaine, Actes du Colloque Cermaca, Paris, EHESS, 1992.

KRIEGEL, Maurice, Les Juifs à lá fin du Moyen Âge dans l'Europe Mediterranéene, Paris, Hachette, 1979.

LEÃO, Gaspar de, Desengano de Perdidos, Coimbra, Universidade de Coimbra, 1958 (introd. de Eugenio Asensio).

LIPINER, Elias. O Tempo dos Judeus segundo as Ordenações do Reino. São Paulo: Nobel / Secretaria de Estado da Cultura, 1982.

MARTINEZ DE LA PUENTE, Joseph, Compendio de las historias de los descubrimientos, conquista y guerras de la India Oriental, y sus Islas desde los tiempos del Infante Don Enrique de Portugal su inventor, hermano del Rey D. Duarte; hasta los del Rey D. Felipe II. de Portugal, y III de Castilla (....), Madrid, Imprenta Imperial, 1681.

NIRENBERG, David, «Conversion, Sex and Segregation: Jews and Christians in Medieval Spain», American Historical Review, Oct. 2002, pp. 1065-1093.

NOVINSKY, Anita. Cristãos novos na Bahia: 1624-1654. São Paulo: Perspectiva / Edusp, 1972.

OLIVAL, Fernanda, «Rigor e interesses: os estatutos de limpeza de sangue em Portugal», in Cadernos de Estudos Sefarditas, n. . 2, 2004, pp. 151-182.

Ordenações Del-Rei Dom Duarte, Lisboa, Fundação Calouste Gulbenkian, 1988.

Ordenaçoens do Senhor Rey D. Affonso V (OrdAf), Coimbra, Na Real Imprensa da Universidade, 1792 (Collecção da Legislação Antiga e Moderna do Reino de Portugal. Parte I. Da Legislação Antiga).

Ordenaçoens do Senhor Rey D. Manuel (OrdMan), Coimbra, Real Imprensa da Universidade, 1797.

ORFALI, Moises, «The Portuguese Edition (1565) of Hieronymus de Sancta Fide Contra Iudaeos», in Ora LIMOR and Guy STROUMSA, Sonderduck aus Contra Iudaeos. Ancient and Medieval Polemics between Christian and Jews, Tuebingen, J-C.B. Moher (Paul Siebeck), s.d. 
OSÓRIO, Jerónimo, Tratados da Nobreza Civil e Cristã, Lisboa, INCM, 1996.

PINHEIRO, António, Colleçam das Obras Portuguezas do sabio bispo de Miranda e de Leyria D. Antonio Pinheiro, pregador do senhor Rey D. Joam III e mestre do Principe, feita por Bento Joze de Souza Farinha, tomo I, Lisboa, 1784.

RANDLES, W.G.L., "'Peuples Sauvages' et 'États despotiques': la pertinence, au XVIe siècle de la grille aristotélicienne pour classer les nouvelles societés révélées par les Découvertes au Brésil, en Afrique et en Asie», Mare Liberum: Revista de História dos Mares, n. ${ }^{\circ}$ 3, Dez. 1991, pp. 229-307.

REGO, A Silva Rego, Documentação para a História das Missões do Padroado Português do Oriente, Lisboa, Agência Geral das Colónias.

RÉVAH, Isaac S., Des Marranes à Spinoza, Paris, Librairie Philosophique J. Vrin, 1995. SANTARÉM, Visconde de, Quadro Elementar das Relações Políticas e Diplomáticas de Portugal com as diversas partes do mundo desde o princípio da monarchia até aos nossos dias, Paris, vols. X e XIII (QE), Paris, J. P. Aillaud, 1842.

SARAIVA, António José. Inquisição e Cristãos Novos. Lisboa: Ed. Estampa, 1985.

SILVA, Nuno Espinosa Gomes da (org.), Livro das Leis e Posturas (LLP), Lisboa, Universidade de Lisboa. Faculdade de Direito, 1971.

SOARES, D. Fr. João, Libro dela verdad dela fe, Alcalá de Henares, Juan de Brocar, 1545. TAVARES, Célia, Jesuitas e Inquisidores em Goa, Lisboa, Roma Editora, 2004.

TAVARES, $\mathrm{M}^{\mathrm{a}}$ José Ferro, Tavares, «Judeus, cristãos-novos e o Oriente», in Estudos Orientais. O Ocidente no Oriente através dos Descobrimentos Portugueses, 1992.

TAVIM, José Alberto Rodrigues da Silva, Judeus e Cristãos-Novos de CochimHistória e Memória (1500-1662), Braga, Appacdm, 2003.

«Os judeus e a expansão portuguesa na Índia durante o século XVI. O exemplo de Isaac Cairo: espião, 'língua' e 'judeu de Cochim de Cima'», in Arquivos do Centro Cultural Calouste Gulbenkian, vol. xxxiii, 1994.

«Outras gentes em outras rotas: Judeus e cristãos-novos de Cochim - Entre Santa Cruz de Cochim e Mattancherry, entre o Império Português e o Médio Oriente», sep. das Actas do VIII Seminário Internacional de História Indo-Portuguesa - A Carreira da Índia e as Rotas dos Estreitos, 1998.

, Os Judeus na Expansão Portuguesa em Marrocos durante o século XVI. Origens e Actividades duma comunidade, Braga, 1997.

THOMAZ, Luís Filipe, «Goa: uma sociedade luso-indiana», in De Ceuta a Timor, Lisboa, Difel, 1994.

TURNER, Victor, The ritual process. Structure and anti-structure, 1969.

VAN GENNEP, Arnold, Les rites de passage, Paris, Ed. De la Maison dês Sciences de l'Homme, 1999 (1909).

WACHTEL, Nathan, La Foi du Souvenir. Labyrinthes Marranes, Paris, 2001.

WICKI, Josephus, s.j., Documenta Indica, 1540-1597 (DA), 18 vols, Roma, apud Monumenta Historica Societatis Jesu, 1948-1988.

XAVIER, Carlos, "A Inquisição e a sociedade Indo-Portuguesa», in Inquisição Actas do $1 .{ }^{\circ}$ Congresso Luso-Brasileiro, 1987, I, pp. 385-392.

XAVIER, P. D., Goa: A Social History, 1993. 


\title{
TRIFUNCIONALIDADE MEDIEVAL Notas sobre um Debate Historiográfico
}

José D’Assunção Barros ${ }^{1}$

USS

\section{A Trifuncionalidade como Ideologia}

O estudo das ideologias, no âmbito da História das Idéias, tem gerado algumas das temáticas mais importantes e polêmicas da historiografia das últimas décadas, sendo estas particularmente significativas para a compreensão das relações entre representações sociais e Política nos vários períodos históricos. Neste ensaio, que examinará a clássica discussão historiográfica sobre a 'trifuncionalidade medieval', estaremos considerando "ideologia" como uma noção que se relaciona francamente com um "projeto de agir sobre a sociedade" - embora seja importante aqui a ressalva de que o conceito de "ideologia" é extremamente polissêmico, comportando na verdade inúmeras possibilidades de sentido. Acompanhemos, por ora, algumas palavras bastante oportunas do historiador francês Jacques Le Goff, que exemplificam a utilização do conceito de ideologia na mesma direção que apontamos acima ${ }^{2}$ :

\begin{abstract}
"Quando os clérigos da Idade Média exprimem a estrutura da sociedade terrena pela imagem dos dois gládios - o do temporal e o do espiritual, o do poder real e o do poder pontifical - não descrevem a sociedade: impõem-lhe uma imagem destinada a separar nitidamente os clérigos dos leigos e a estabelecer entre eles uma hierarquia, pois o gládio espiritual é superior ao gládio material. Quando estes mesmos clérigos distinguem nos comportamentos humanos sete pecados capitais, o que eles fazem não é a descrição dos maus comportamentos, mas sim a construção de um instrumento adequado ao combate contra os vícios em nome da ideologia cristã"
\end{abstract}

A ideologia, poderíamos acrescentar, corresponde a uma determinada forma de construir representações ou de organizar representações já existentes para atingir determinados objetivos ou reforçar determinados interesses. É uma visão de mundo que se impõe, de modo a cumprir determinado projeto social ou a atender certos interesses políticos e, por trás destes, eventualmente

1 Doutor em História Social pela Universidade Federal Fluminense (UFF); Professor da Universidade Severino Sombra (USS) de Vassouras, nos Cursos de Mestrado e Graduação em História, onde leciona disciplinas ligadas ao campo da Teoria e Metodologia da História, História da Arte e História Medieval.

2 Jacques LE GOFF, O Imaginário Medieval, Lisboa: Estampa, 1994, p.11. 
interesses econômicos. O nível de consciência ou de automatismo como isto é feito é questão aberta, e que dificilmente poderá ser um dia encerrada. Também se discute se ideologia é uma dimensão que se refere à totalidade social (uma instância ideológica) ou se existem ideologias associadas a determinados grupos ou classes sociais (ideologia burguesa, ideologia proletária). $\mathrm{Na}$ verdade, ideologia é um conceito que tem sido empregado por autores distintos com inúmeros sentidos no campo das ciências humanas, e por isto um historiador que pretenda utilizar este conceito deve se apressar a definir com bastante clareza o sentido com o qual o está utilizando.

$\mathrm{Na}$ acepção mais restrita que empregamos acima, a ideologia estará sempre associada a um determinado sistema de valores. A ideologia, de acordo com este uso, tem a ver com 'poder', com 'controle social' exercido sobre os membros de uma sociedade, geralmente sem que estes tenham consciência disto e muitas vezes sem que os próprios agentes implicados na produção e difusão de imagens que alimentam o âmbito ideológico tenham eles mesmos uma consciência mais clara dos modos como o poder está sendo exercido.

Feitas estas considerações conceituais iniciais, nosso objetivo a seguir será o de examinar a polêmica discussão historiográfica que se tem estabelecido em torno de um dos sistemas ideológicos mais poderosos que recobriu as sociedades do ocidente medieval: a Trifuncionalidade Social.

\section{Trifuncionalidade na Idade Média e em outros contextos}

Não é certamente uma criação exclusivamente medieval, ou de qualquer outro tempo, a tão discutida concepção de uma partição trifuncional do mundo social - um mundo que estaria grosso modo dividido entre aqueles que estabelecem a mediação da sociedade com os deuses ou com o mundo sobrenatural, aqueles que guerreiam para defender e impor esta mesma sociedade diante das outras, e por fim aqueles que trabalham arduamente para manter a base material de todo o conjunto social. Se na Idade Feudal um esquema similar a este pôde ser traduzido em termos de uma sociedade já cristianizada e dividida em oratores, bellatores e laboratores, a verdade é que encontraremos as mais diversas concepções tripartidas em sociedades antigas e nas mais variadas partes do mundo.

Em vista de um quadro tão complexo, há pouca possibilidade de que se chegue algum dia a um consenso entre os historiadores e estudiosos de outros campos das ciências humanas relativamente às origens primordiais desta idéia de uma sociedade tripartida. Estaria Dumézil (1958) correto ao afirmar que o esquema tripartido é uma representação tradicional dos povos indo-europeus? Teria alguma razão Boyancé (1955), ao desacreditar da afirmação dumeziliana 
de que tal esquema tenha estado também muito presente no espírito dos Latinos? Ou tal esquema, como propõe Vasilji Abravael (1963), poderia simplesmente surgir em determinadas sociedades em certos momentos, sem que haja necessariamente uma rede de influências e infiltrações que justifiquem por contaminação a manifestação do pensamento trifuncional nesta ou naquela sociedade histórica? ${ }^{3}$

Estas questões, interessantes mas por demais polêmicas, têm sido habilmente contornadas por historiadores como Jacques Le Goff (1965), Georges Duby (1978) ou Daniel Rouche (1979) em favor de outra, bem mais produtiva para os estudos medievais: que motivações sociais e políticas teriam permitido que o esquema tripartido fosse reapropriado de uma maneira tão específica pelos letrados dos primeiros tempos feudais, e que novas motivações teriam permitido que a idéia fosse reatualizada com tanto sucesso pelos séculos seguintes? ${ }^{4}$ Torna-se assim necessário, para além de investigar apenas as origens históricas e antropológicas das imagens de base que constituem a teoria da trifuncionalidade, ou mesmo de rastrear os seus princípios medievais em textos carolíngios e ainda mais explicitamente nas primeiras décadas do século XI, examinar sobretudo as causas de sua adoção mais generalizada pela Europa Cristã no final do século XI, tal como propõe Daniel Rouche (1979).

Sobretudo, mostrou-se fundamental para os historiadores que examinaram mais sistematicamente a trifuncionalidade medieval, verificar como esta imagem se difunde até que termina por penetrar, conforme bem o demonstrou Georges Duby em As Três Ordens ou o Imaginário do Feudalismo, em uma grande parte das estruturas intelectuais e interinstitucionais da sociedade ocidental nos séculos XI e XII. Adicionalmente, seria mesmo o caso de verificar a força de tal imagem em períodos posteriores à própria Idade Média, tal como se propôs Duby ao examinar a presença da trifuncionalidade nos textos do teórico político Loyseau, já em pleno século XVII, naturalmente que já sob um novo contexto gerador de novos significados 5 . Mas aqui já nos afastamos do

3 (1) DUMÉZIL, Georges. L'Ideologie tripartite dês Indo-Européens. Bruxelas: 1958; (2) BOYANCÉ. "Les origines de la réligion romaine, Theories et recherches récentes" in $L$ ' Information littéraire, VII, 1955, p.100-107; (3) ABRAVAEV, Vasilji I. "Le cheval de Troie. Parallèles caucasiens" in Annales ESC, 1963. p. 1041-1070.

4 (1) LE GOFF, Jacques. "Nota sobre sociedade tripartida, ideologia monárquica e renovação econômica na Cristandade do século IX ao século XII". in Para um novo conceito de Idade Média. Lisboa: Estampa, 1980 [original: Paris: Gallimard, 1977] [artigo original de 1965]; (2) DUBY, Georges. As Três Ordens ou o Imaginário do Feudalismo. Lisboa: Estampa, 1982 [original: Gallimard: 1978]; (3) ROUCHE, Michel. 'De l'Orient a l'Occident. Les origines de la tripartition fonctionelle et les cause de son adoption par l'Europe chrétienne à la fin du XI siècle" in Occident et Orient au X siècle. Paris: 1979, p. 321-355.

${ }_{5}^{5}$ DUBY, As Três ordens ..., p. 13-17. 
nosso tema, que é a relação da trifuncionalidade com a sociedade que se constitui no ocidente europeu pela altura da Idade Média Central.

De qualquer modo, para utilizar as próprias palavras de Le Goff, seria precisamente o caso de perceber que, se o tema da trifuncionalidade, até então ausente da literatura cristã, reaparece entre os séculos IX e X, é porque corresponde a uma nova necessidade ${ }^{6}$. Mais ainda, conforme veremos mais adiante a partir das próprias colocações de Le Goff, esta imagem conceitual da sociedade teria correspondido não apenas a uma forma de expressão da nova sociedade que se consolidava, mas também a um projeto de agir sobre esta mesma sociedade. Teria se constituído mesmo, Le Goff ousa dizer, em um singular "instrumento de propaganda" .

Antes de chegarmos a esta problematização, consideraremos inicialmente algumas das pesquisas sobre o assunto desenvolvidas por Georges Duby, que se empenharam mais especificamente em rastrear com maior precisão alguns elementos, por vezes dispersos, que posteriormente se combinariam em favor da constituição efetiva de uma 'teoria da trifuncionalidade' nos já célebres textos de Adalberón de Laon e de Gerard de Cambrai no século XI.

\section{As origens}

A preocupação inicial de Georges Duby no mais famoso de seus textos sobre a trifuncionalidade - o já clássico A Teoria das Três Ordens ou O Imaginário do Feudalismo (1978) - liga-se à necessidade de identificar com maior precisão os começos medievais deste pensamento trifuncional que seria tão importante para o desenvolvimento do feudalismo. Dois textos medievais escritos por volta de 1030 - muito claros a respeito desta concepção trifuncional que divide o mundo em oratores, bellatores e laboratores - parecem de certo modo "partir do silêncio" através das vozes contemporâneas de Adalberão de Laon e Gerardo de Cambrai, dois bispos da França do Norte na primeira metade do século $\mathrm{XI}^{8}$. Os começos de uma teoria da trifuncionalidade poderiam ser situados aí, conforme sustenta o historiador francês, o que atesta a importância destes famosos textos que desde tempos mais recuados até tempos mais recentes têm merecido importantes estudos da parte de alguns dos melhores medievalistas ${ }^{9}$. O texto de Adalberão, para além de sua publicação

${ }^{6} \mathrm{LE}$ GOFF, Para um novo conceito de Idade Média, p. 76.

7 Id.ibid,p. 76.

8 DUBY, As Três Ordens ..., p. 19.

9 (1) SCHIEFFER, T. «Ein Deutscher Bishof des 11 ihd, Gerard de Cambrai (1012-1051)» in Deutscher Archiv, Berlim: 1937; (2) COOLIDGE, R. T. “Adalbero, Bishop of Laon” in Studies in Medieval and Renaissance History, II. Arizona State University, 1965. 
no Monumenta Germanica Historica, mereceu ainda uma tradução importante para o francês, acompanhada de uma importante tese explicativa (CAROZZI, 1973 $)^{10}$.

$\mathrm{O}$ fato de que a formulação mais precisa da trifuncionalidade medieval surja a partir destes dois textos fundadores não significa, naturalmente, que não apareça em períodos anteriores a idéia de separar mais nitidamente o âmbito religioso do âmbito temporal, ou de delimitar no interior do mundo laico uma oposição entre guerreiros e trabalhadores, ou mesmo de relacionar em um todo mais equilibrado que corresponderia à cristandade os diversos papéis sociais. Na verdade, estas idéias aparecem dispersas em várias fontes bem anteriores aos textos produzidos pelos bispos da primeira metade do século XI, e cabe ao historiador mergulhar em uma busca problematizada que recua para além das origens das formulações mais precisas da trifuncionalidade.

De acordo com as observações de Georges Duby em um ensaio anterior ao seu livro sobre $A$ Teoria das Três Ordens ou O Imaginário do Feudalismo, seria possível identificar indícios de que o pensamento social e político que em breve conduziria à célebre teoria das três ordens teria partido inicialmente de uma divisão mais simples, inscrita no quadro de oposições e interações binárias entre o mundo temporal e o mundo religioso ${ }^{11}$. Assim, é conhecida por exemplo uma "Carta do papa Zacarias a Pepino, rei dos francos" - datada de 747 - que já menciona uma clara oposição entre as duas ordens, "os guerreiros e os que oram"12. De igual maneira, Agobard - em texto datado de 833 - já explicita ainda mais claramente uma oposição entre as duas ordens militar e eclesiástica - isto é, entre a saecularis militia e o sacrum ministerium.

Avançando nas pesquisas desenvolvidas por Georges Duby, a Vida de São Geraldo de Aurillac, escrita em 930 pelo abade Odon de Cluny, já mostraria ainda mais sintomaticamente a maturação de uma teoria que busca ordenar os poderes secular e temporal. É de fato a primeira Vita cujo herói é um leigo, representante autêntico da nobilitas (e não um rei nem um prelado). Intenciona mostrar que um nobre pode chegar à santidade sem depor as armas, tornando-se um miles Christi - e com isto almeja conferir à atividade militar, enquanto função específica da nobreza guerreira, um valor espiritual. $O$ personagem, São Geraldo de Aurillac teria conseguido unir o exercício do poder à

${ }^{10}$ CAROZZI, C. "Carmen ad Rodbertum regem" d' Adalberón de Laon" Paris: University of Paris, 1973.

"DUBY, Georges, "As origens da cavalaria" in A Sociedade Cavaleiresca. São Paulo: Martins Fontes, 1989 , p. 31. [Texto original publicado em:Ordinamenti militar nell'alto medioevo. Spoleto, Presso La Sede Del Centro, 1968, p. 739-761].

12 Fonte 1: ZACARIAS, Codex Carolinus, 3, MGH, Epist. Karolini aevi, I, p.480; Fonte 2: AGOBARD, MGH, Epist. Karolini aevi, 191-192 [apud. DUBY, Georges, "As origens da cavalaria" in A Sociedade Cavaleiresca, p. 31]. 
prática da humildade e à preocupação com os pobres. O texto também se mostra como pretexto para uma delimitação das missões do homem armado. Será igualmente útil observar que Odon, como mais tarde também ocorreria com Adalberón de Laon ou Gerard de Cambrai, ainda não utiliza a palavra miles para designar o grupo de especialistas de combate (bellatore) como será tão comum a partir do século $\mathrm{XI}^{13}$.

Mas, por fim, começam a certa altura a aparecer os textos que não deixam de prenunciar de algum modo uma teoria da trifuncionalidade. Os Miracles de Saint Bertin, texto hagiográfico escrito em fins do século IX, já nos mostram uma divisão tríplice, separando dos oratores e bellatores o "imbelle vuilgus" ${ }^{\prime 4}$.

Estes casos isolados, elementos importantes de uma intertextualidade que deve ser considerada, não alteram contudo o fato de que os textos fundadores - aqueles que os historiadores verificam já explicitarem muito claramente o que poderia ser considerado uma "teoria da trifuncionalidade" - aparecem sintomaticamente depois do Ano Mil, precisamente quando começa a se implantar uma sociedade feudal propriamente dita. É assim que, em 1030, dois dos bispos mais influentes da França do Norte - Gerard de Cambrai e Adalberón de Laon - já propõem muito claramente o esquema da trifuncionalidade [Gerard de Cambrai: Oratores, agricultores, pugnatores; Adalberón de Laon: Orare, pugnare, laborare].

Neste ponto, depois de termos acompanhado as pesquisas de Georges Duby com vistas a destacar de maneira bastante sumária os discursos que contribuem de alguma maneira para o estabelecimento da idéia de uma partição funcional da sociedade - a princípio uma partição dicotomizada entre os poderes temporal e religioso, e depois uma partição já nitidamente trifuncional será oportuno retomarmos a problematização proposta por Jacques Le Goff. Para o historiador francês, conforme veremos, a difusão da trifuncionalidade relaciona-se claramente com os progressos da ideologia monárquica e com a formação das monarquias nacionais na sociedade carolíngia ${ }^{15}$. Desta maneira, a reapropriação medieval da trifuncionalidade corresponderia não apenas a um fenômeno feudal, mas também a um fenômeno associado aos desenvolvimentos das monarquias feudais.

13 ODON DE CLUNY, Vita Geraldi apud. DUBY, Georges, "As origens da cavalaria" in A Sociedade Cavaleiresca, São Paulo Martins Fontes, 1989, p. 35.

${ }_{14}$ Miracles de Saint Bertin, DUBY, op.cit, p. 31.

${ }^{15}$ LE GOFF, Jacques. "Nota sobre sociedade tripartida ...", op. cit. p. 76. 


\section{A trifuncionalidade e o poder régio}

Não é por acaso que Jacques Le Goff, embora também remontando ao século IX, irá buscar em um outro tipo de fontes os começos da trifuncionalidade. Tanto em seu artigo mais antigo intitulado "Notas sobre a Sociedade Tripartida" (1965), como no capítulo "O Rei das Três Funções" incluído na Biografia sobre São Luís (1994), um texto que havia passado desapercebido pelos historiadores chama-lhe a atenção ${ }^{16}$. Começa então por destacar um acrescentamento introduzido, em fins do século IX, na tradução Anglo-Saxônica da obra De Consolatione Philosophia de Boécio ${ }^{17}$. O acrescentamento, determinado pelo rei Alfredo, o Grande, explicita a idéia de que as três ordens são como que utensílios e materiais necessários à realização da obra monárquica e ao exercício do poder com eficácia ${ }^{18}$.

O segundo texto discutido por Ler Goff é datado de 995, portanto anterior ao famoso texto Carmen ad Robertum do bispo Adalbéron de Laon, que possivelmente foi escrito entre 1025 e 1027. O monge Abbon de Fleury, em um texto cujo título resumiremos por Apologeticus adversus [...], descreve a sociedade como constituída por duas categorias principais, os clérigos e os laicos, sendo que estes últimos se subdividem em agricultores - agricolae - $\mathrm{e}$ guerreiros, ou agonistae. Os dois textos, como observa Le Goff, embora se relacionem também a interesses eclesiásticos, são levados na sua busca de apoio real a fortificar a instituição monárquica. É interessante acrescentar que Abbon de Fleury, tal como mostram os estudos de Roger Bonnaud-Delamare (1951), foi também o responsável pelas condenações pronunciadas na época do primeiro concílio de Charroux contra "os clérigos excessivamente apegados ao dinheiro ou que combatiam como leigos" ${ }^{19}$. Isso reforça o terreno de separação interfuncional em que ele já se movimenta.

Por outro lado, seria oportuno lembrar através de outro trecho do Apologeticus adversus, Abbon expressa em outra oportunidade um segundo esquema tripartido que poderíamos denominar "teoria dos três graus". Tal como enuncia Abbon de Fleury, "entre os cristãos dos dois sexos, sabemos bem que existem três ordens e, por assim dizer, três graus: o primeiro é o dos leigos, o segundo o dos clérigos, e o terceiro o dos monges. Embora nenhum dos três seja isento de pecado, o primeiro é bom, o segundo melhor, o terceiro exce-

16 (1) LE GOFF, Jacques. "Nota sobre sociedade tripartida ...", op. cit. p.75-84; (2) LE GOFF, Jacques. "O Rei das três funções" in São Luís - Biografia. São Paulo: Record, 2002. p. 568-596.

${ }^{17}$ SEDGEFIELD, W. J. (org). King Alfred's Old English Version of Boethius "De Consolatione Philosophiae". Oxford: 1899-1900.

18 LE GOFF, Jacques. "Nota sobre sociedade tripartida ...", op. cit. p. 76.

19 BONNAUD-DELAMARE, R. Les institutions de la paix. Paris: Mélanges Halphen, 1951. p. 422. 
lente". Conforme veremos mais adiante, a sutileza do esquema tripartido funcional é que ele substitui esta concepção trinitária anterior, aproximando em uma única ordem os modos de vida de 'clérigos' e 'monges', e criando uma cisão do mundo laico de acordo com o seu modo de vida dedicado à guerra ou ao trabalho. Neste momento, contudo, através das oscilações presentes no texto de Abbon de Fleury, percebemos a silenciosa guerra de representações que se trava no discurso eclesiástico.

O terceiro exemplo trazido por Le Goff remete à Polônia do século XII, e é a Crônica et Gesta Ducum Sive Principum Polonorum (1113-1116), de um cronista que ficou conhecido como Gallus Anonymus. Ao dividir a população laica, a fonte fala nos milites bellicosi e nos rustici laboriosi. O texto constrói-se na verdade em apoio ao círculo real de Boleslaw Boca Torta, e é empregado por Le Goff para trazer um elemento de contraste no tempo e no espaço. Segundo suas conclusões, os três textos mostram que, em fins do século IX e princípio do século XII, de um extremo ao outro da comunidade latina, o esquema tripartido está relacionado aos esforços de certos meios laicos e eclesiásticos para consolidar ideologicamente a formação de monarquias nacionais (LE GOFF, 1980, p.79).

A definição de cada uma das três ordens no conjunto de textos coloca para Jacques Le Goff questões bastante interessantes. A ordem clerical, tendo por função principal a oração, expressa na verdade a capacidade de assegurar para a comunidade, através do exercício profissional da oração, o auxílio divino. A ordem dos bellatores, que tenderá a partir do século XII a ser expressa com o termo milites, é especializada na luta. Ressalta-se que a consolidação da ordem dos bellatores entre os séculos IX e XIII corresponde ao aparecimento de uma nova nobreza e à preponderância da função guerreira nesta nova aristocracia ${ }^{20}$. Mais problemas são colocados pela ordem dos laboratores. Quem seriam? - pergunta Le Goff. Os textos falam nos agricolae, nos rustici. Por outro lado, no seu sentido mais abrangente o termo laboratore referir-se-ia a todo o restante da sociedade - excetuando-se o clero, os bellatores. Neste sentido estendido, aliás, seria oportuno lembrar uma acepção que freqüentemente aparece em algumas capitulares carolíngias, onde "labor" é definido por oposição ao "patrimônio herdado". Niermeyer, em um artigo publicado na revista Moyen Age intitulado "A marge du noveau Ducange" (1957), mostra exemplos tanto de "labor" sendo empregado na acepção de "trabalho agrícola", como na acepção que está registrada na Capitular De partibus Saxoniae (785), onde "labor" designa “o fruto de toda atividade aquisitiva oposta ao patrimônio herdado"21.

${ }^{20}$ LE GOFF, Jacques. "Nota sobre sociedade tripartida ...”, op. cit.p. 79.

${ }^{21}$ NIERMEYER, J. F. “A marge du noveau Ducange” in Moyen Age, Paris: 1957. 
Há por fim uma acepção, também discutida por Jacques Le Goff, em que a ordem laboratore referir-se-ia não a todos os agricultores, mas somente a uma elite dentro do próprio conjunto de camponeses - e neste caso o esquema trifuncional estaria se referindo apenas aos melhores da cristandade: os ordines oratore e bellatore e a parte dos camponeses dignificada pelo seu trabalho e condição social mais elevada do que a dos trabalhadores agrícolas para baixo de um determinado nível de dependência. Aqui, o esquema tripartido não abrangeria portanto toda a sociedade, mas apenas os grupos sociais dignificados, por oposição a toda uma imensa gama de categorias que ficaria de fora.

A posição do rei no esquema tripartido é bastante singular. Rei dos oratores, ele não deixa de participar ao seu modo da natureza e dos privilégios eclesiásticos e religiosos. Rei dos bellatores, ele é o primeiro dos guerreiros, e nesta função concretiza certas ambivalências que dele fazem tanto um rei feudal - um primus inter pares que se apresenta como a "cabeça" da aristocracia militar - como também alguém que é colocado fora e acima dela. Uma avaliação mais completa do esquema poderia ainda situá-lo como o ponto de confluência das três ordens, e o aspecto de "rei dos laboratores" apresenta-se como a função régia de garantir a ordem econômica e assegurar a prosperidade material ${ }^{22}$.

A imagem do rei como aquele que participa simultaneamente das três ordens ajuda a compreender, particularmente, que a função do esquema tripartido seria representar a harmonia entre as ordens, a 'interdependência', a solidariedade entre as ordens. E explica também, conforme propõe Le Goff, o sucesso crescente que apresentaria a imagem do "rei" - árbitro que harmoniza todas as ordens - em relação à imagem de "imperador", condenada por uma dualidade "império" versus "papado" que se fundava na irrealizável distinção entre espiritual e temporal ${ }^{23}$.

O modelo do rei trifuncional também permite compreender governantes concretos da Idade Média, ou pelo menos as suas idealizações, e foi esse um dos objetivos de Jacques Le Goff ao dedicar-se a escrever um capítulo sobre a trifuncionalidade régia em sua biografia sobre São Luís (1996). Através deste rei modelar, Le Goff permite-se captar precisamente a singularidade da trifuncionalidade medieval, notando que, ao contrário do que ocorrera na Índia antiga e na Roma das origens, os reis medievais não apareciam habitualmente, à maneira dos deuses, caracterizados por uma ou outra das três funções - rei essencialmente legislador ou guerreiro, ou então fiador da prosperidade - mas sim um rei que reúne todas as funções $\mathrm{em} \mathrm{si}^{24}$. Mesmo que permanecendo em

${ }^{22}$ LE GOFF, Jacques. "Nota sobre sociedade tripartida ...”, op. cit., p. 80.

${ }^{23}$ LE GOFF, Jacques. "Nota sobre sociedade tripartida ...", op. cit., p. 83.

${ }^{24}$ LE GOFF, Jacques. “O Rei das três funções”, São Luís, p. 369. 
muitos casos como um horizonte imaginário ou idealizado, era este o modelo - um modelo que podia ser encontrado, por exemplo, nos Espelhos de Príncipes do período.

\section{A trifuncionalidade e os movimentos religiosos de seu tempo}

A contribuição de Le Goff mostra-se particularmente importante no que concerne aos relacionamentos e interações da teoria da trifuncionalidade com a ideologia régia e os desenvolvimentos monárquicos, além das implicações econômicas que também são aventadas pelo historiador francês. Por outro lado, as análises de Georges Duby adquirem uma importância significativa em outras direções: ele examina a posição da teoria da trifuncionalidade no interior de um grande movimento produzido pela combinação das necessidades institucionais da Igreja com as necessidades religiosas do período de expansão feudal. A 'trifuncionalidade' é uma peça decisiva para esse grande movimento que apresenta como manifestação importante, na primeira metade do século XI, as campanhas conciliares da "Paz de Deus", e que irá culminar com a Reforma Gregoriana e com as Cruzadas no século XII. Neste contexto, tanto a "Paz de Deus" como a teoria da trifuncionalidade constituirão aspectos importantes para a renovação da noção de "laicato", a partir de proposições geradas no seio da própria Igreja ${ }^{25}$. Uma excelente síntese destas relações está registrada no ensaio "Os leigos e a Paz de Deus", escrito por Duby em 1966 e depois incorporado ao conjunto de ensaios publicado sob o título de A Sociedade Cavaleiresca $(1979)^{26}$.

Visto desta perspectiva, a solução de Duby para compreender o essencial da trifuncionalidade difere das proposições de Le Goff, embora os dois posicionamentos não sejam propriamente antagônicos e possam mesmo ser trabalhados complementarmente. Enquanto Jacques Le Goff enfatiza a reapropriação da teoria da trifuncionalidade pela ideologia monárquica, Georges Duby a examina como parte integrada de um sistema ideológico produzido pela própria Igreja em apoio ao seu projeto universal de conduzir os rumos da cristandade e, sobretudo, de se pôr a salvo dos confrontos com os poderes temporais e de eventuais violências produzidas pela fragmentação dos poderes feudais nas mãos dos cavaleiros. O cenário da consolidação do imaginário tri-

${ }^{25}$ Sobre esta questão, ver DUBY, Georges. "Gerard de Cambrai, la paix et les trois fonctions sociales. 1024" in Resumo das sessões da Academia das Inscrições e Belas-Letras. Paris: 1976.

${ }^{26}$ DUBY, Georges, “As origens da cavalaria” in A Sociedade Cavaleiresca. São Paulo: Martins Fontes, 1989, p. 31. [Texto original publicado em:Ordinamenti militar nell'alto medioevo. Spoleto, Presso La Sede Del Centro, 1968, p.739-761]. 
funcional é portanto um mundo vazado transversalmente por conflitos e comoções de toda ordem, como nos mostra o historiador R. Fossier (1973) ${ }^{27}$.

É das Histórias de Raul Glaber - fontes que foram atentamente examinadas por Georges Duby em sua obra sobre O Ano Mil $(1967)^{28}$ - e particularmente das suas descrições do movimento da Paz de Deus no princípio do século XI, que Duby parte para mostrar que mesmo os contemporâneos da teoria trifuncional puderam perceber todo este movimento que se inicia com a Paz de Deus como um esforço inicial dos altos dignitários de Igreja para "subtrair esta às pressões do temporal, para situá-la, deste modo, em posição dominante e torná-la capaz de uma missão que um dia pertencera à Realeza", ao menos no período de centralismo carolíngio: conduzir os destinos do povo cristão ${ }^{29}$.

Re-inserida neste processo, a trifuncionalidade irá ser vista como parte de um movimento que decorre dos desafios da Igreja diante da necessidade de enfrentar a decomposição das instituições públicas carolíngias, mesmo que em momento posterior - como veio a propor Le Goff - a teoria da trifuncionalidade possa ter atendido também aos propósitos de gradual centralização em torno da figuras do rei. Na análise que Duby desenvolve para integrar a trifuncionalidade em um movimento mais amplo que inclui outros fatores importantes - como a Paz de Deus ou a Reforma Gregoriana - parte-se da constatação de que o poder temporal estava, nos anos 990, nas mãos dos poderes locais. Estes exerciam prerrogativas de comando que outrora thes foram delegadas pelo soberano carolíngio, e que agora eles detinham por direito hereditário. Julgar e punir, neste contexto, era uma oportunidade para os senhores laicos arrecadarem da população taxas bastante lucrativas, as consuetudines. Por outro lado, a Igreja possuía imunidades que lhes haviam sido concedidas pelos soberanos carolíngios, mas como o enfraquecimento da autoridade real praticamente tornara sem efeitos os diplomas de imunidade, agora os senhores laicos começavam a sujeitar cada vez mais a Igreja aos seus poderes. Na Gália meridional, inclusive, os condes detinham o direito de nomear para as mais altas dignidades eclesiásticas, além de dispor das sedes episcopais e das funções abaciais ${ }^{30}$.

O programa eclesiástico que iria se seguir - e que termina por abarcar a teoria da trifuncionalidade como um de seus itens - representará precisamente o desejo de uma parte da Igreja em resistir aos poderes temporais. Um dos

${ }^{27}$ FOSSIER, R. "Remarques sur 1'étude dês commotions sociales aux IX et XII siècles in Cahiers de Civilisation médievale, 16. Paris: 1973, p. 45-50).

${ }_{28}$ DUBY, Georges. O Ano Mil. Lisboa: Edições 70, 1992. [original: 1967].

${ }^{29}$ DUBY, Georges. "Os leigos e a paz de Deus" in A Sociedade Cavaleiresca. São Paulo: Martins Fontes, 1989, p.39 [original: Edition de l’École de Hautes Études en Sciences Sociales: 1979].

${ }^{30}$ DUBY, Georges. “Os leigos e a paz de Deus" in op. cit., p. 39. 
seus mais fortes pontos de apoio será o clero não comprometido com as práticas simoníacas, isto é, que não poderia ter qualquer interesse na sujeição da Igreja pelos poderes temporais locais. Neste sentido, despontará o papel de Cluny. Compreende-se também porque uma questão vital, para este complexo processo de afirmação da Igreja perante os poderes temporais, estará na chamada Reforma Gregoriana, que começará a ser realizada de forma mas intensa entre 1150 e 1226 . Um dos itens programáticos mais importantes desta reforma estará precisamente na libertação da Igreja em relação às interferências temporais, o que inclui desde a perseguição às práticas simoníacas (compra e venda de cargos eclesiásticos) até o estabelecimento do direito exclusivo da Igreja nomear suas próprias autoridades. Para além disto, a exigência de celibato aos padres da Igreja, outro ponto prioritário da Reforma Gregoriana, constitui mais uma maneira de afastar o clero das relações seculares, para além de salvaguardar a Igreja de dispersões patrimoniais. Os lances de oposição entre Igreja e Papado, por fim, também acompanham este mesmo processo.

\section{A trifuncionalidade diante das mudanças de comportamento}

Todos os aspectos acima destacados, pode-se sustentar sem maiores dificuldades, constituem parte de um único movimento cuja expressão institucional mais imediata é a Reforma Gregoriana, enfrentando passo a passo as questões da época que poderiam afetar a consolidação da Igreja como única Instituição que, do ponto de vista da cúria papal, deveria estar habilitada a conduzir os destinos da Cristandade. Os grandes lances desta reforma papal e institucional aparecem como um jogo de xadrez habilmente disputado: da luta papal contra o tráfico das dignidades eclesiásticas e contra o concubinato dos padres locais, passa-se com Humbert de Moyenmoutier ao 'questionamento das investiduras', até se chegar à libertas de Gregório VII, que estabelecia ao mesmo tempo a independência em relação ao Imperador e o direito exclusivo de julgar a sociedade cristã ${ }^{31}$.

Obviamente que nem todas as motivações que movem este complexo xadrez devem ser buscadas no cálculo cuidadoso e nas estratégias político-institucionais que foram habilmente conduzidas pelos Papas e através do apoio das lideranças de Cluny, estas que constituíram em algumas oportunidades um braço importante e vigoroso das medidas reformistas. Em vista disto, historiadores mais especificamente interessados na história das sensibilidades - e mais em uma História Religiosa do que em uma História da Igreja

${ }^{31}$ VAUCHEZ, André. A Espiritualidade na Idade Média Ocidental - séculos VIII a XIII. Rio de Janeiro: Jorge Zahar, 1995, p. 58 [original atualizado: Seuil: 1994]. 
propriamente dita - chamam atenção para o fato de que fatores ligados ao plano das sensibilidades e das mudanças nos comportamentos religiosos também devem aqui ser considerados. Conforme demonstram pesquisas realizadas por medievalistas como André Vauchez, é digno de nota que, por volta do Ano Mil, no momento mesmo em que se prepara simultaneamente o clima reformista e surgem as primeiras formulações trifuncionais, o advento do Milênio e a perspectiva do final dos tempos também fariam surgir em muitos espíritos o "desejo de apresentar a Deus uma Igreja sem Mácula"32. Separar a Igreja do século mais claramente, colocá-la a salvo das relações mundanas que podiam corrompê-la, salvaguardar a sua independência em um mundo que aguardava o fim dos tempos, não deixa de constituir um dos contrapontos mentais que devem ser considerados para a compreensão deste ambiente que gera simultaneamente os primeiros esboços da teoria da funcionalidade e uma vigorosa reforma monástica encabeçada por Cluny. Desta maneira, André Vauchez (1994) sustenta a idéia de que, para compreender esta luta que se trava no interior da Igreja e no seu em torno, é preciso situá-la também em uma perspectiva escatológica. Assim, se combater o concubinato dos padres logo seria uma questão fundamental para reformadores gregorianos que se preocupavam com a dispersão patrimonial através de heranças, já desde o século X, na abadia de Cluny, procura-se desenvolver uma espiritualidade eucarística da qual seria a pureza para se aproximar. É em vista disto que Odon de Cluny, no seu poema Occupatio, fizera da castidade uma necessidade absoluta para aqueles que pretendessem se dedicar à vida monástica, afirmando-se aqui uma incompatibilidade efetiva entre o concubinato e a função sacerdotal.

Apartar-se do mundo - o caminho do monge - era portanto uma via segura para a salvação. Por outro lado, em outros setores da Igreja, e na medida em que nos afastamos das expectativas mais radicalmente escatológicas do início do milênio, "a espera inquieta da catástrofe última daria lugar ao desejo de construir hic et nunc o reino de Deus". É assim que, não só entre os reformadores gregorianos com também em certos setores da religiosidade mesmo laica, uma nova alternativa também seria proposta ao nível da escatologia. Para retomar as palavras do historiador André Vauchez, começa a se consolidar este desejo de "agir diretamente sobre o mundo para torná-lo de acordo com a vontade divina"33.

Esta nova perspectiva permitirá recolocar a questão das relações entre a teoria da trifuncionalidade e a reforma religiosa em toda a sua complexidade. Embora fosse quase consensual entre os clérigos e monges ligados à orientação papal que urgia delimitar muito claramente o espaço religioso do espaço

${ }^{32}$ VAUCHEZ, André. op. cit, p. 57.

${ }^{33}$ VAUCHEZ, André. op. cit, p. 58. 
temporal, de um lado se afirmaria uma corrente que logo levaria a Igreja a intervir com frequiência cada vez maior nos assuntos seculares. De outro lado, eclesiásticos como o bispo Gerard de Cambrai - um dos dois primeiros formuladores do esquema trifuncional - eram de opinião que os religiosos afastavam-se do papel que Deus lhes havia destinado quando se ocupavam de questões temporais. Em vista disto, diante do movimento que ficaria conhecido como "Paz de Deus" - e que de certo modo buscava substituir uma autoridade real em decadência com vistas a organizar o mundo social - Gerard de Cambrai sustentaria que cabia aos governantes temporais e não à Igreja garantir a ordem pública.

Isso nos mostra um dado importante a ser considerado. A teoria da funcionalidade surge no âmbito de uma Igreja que clama por uma delimitação bem nítida entre a esfera religiosa e o mundo laico, e que logo se aperfeiçoa no sentido de prever uma separação igualmente nítida entre as funções bellatore e laboratore. Mas quanto ao tipo de relação que esta Igreja - definida como um corpo em separado - deveria estabelecer com referência às duas demais ordens pertencentes ao mundo laico, aí se abriam duas alternativas: o isolamento e a ação no mundo. A trifuncionalidade permitia, assim, muitas leituras, e isto não passou desapercebido aos seus contemporâneos e aos seus idealizadores. Com relação à "Paz de Deus", um movimento surgido na Igreja e que se propunha a agir sobre o mundo, Adalberão de Laon e Gerardo de Cambrai representam posições diametralmente opostas, embora ambos estejam na raiz da primeira explicitação de uma teoria da trifuncionalidade medieval.

A Paz de Deus ainda nos leva a refletir sobre as posições extremamente ambíguas da Igreja em relação à aristocracia guerreira e à sua função bellatore. Os miles podiam ser em relação à Igreja desde ameaças até aliados. Por outro lado, é extremamente sintomático que tenha sido por ocasião de uma assembléia da Paz, realizada em Clermont em 1095, que o papa Urbano II um antigo monge de Cluny - tenha lançado o apelo que daria origem à primeira das Cruzadas do ocidente contra o mundo islâmico do oriente. De igual maneira, é também do ordo bellatore que a Igreja lança mão para consolidar o seu projeto de expansão da unidade cristã, quando Inocêncio III em 1209 lança o apelo para que soberanos e cavaleiros do Norte da França organizem uma Cruzada dirigida contra a heresia cátara que começava a se expandir na região do Languedoc francês.

\section{Balanceando as diversas perspectivas}

Para retornar à questão mais específica das origens da trifuncionalidade e de sua interação subseqüente com outros movimentos como a "Paz de Deus" 
e a "Reforma Gregoriana", pode-se dizer que, nos seus primórdios, o amplo movimento acima descrito corresponde a uma clara necessidade da Igreja de proteger-se contra a violência e as intrusões dos novos poderes laicos. Isso implicava, naturalmente, em assegurar uma separação mais bem definida, na vida social e nos estatutos jurídicos, entre os leigos de um lado, e os clérigos e monges, de outro. É importante ressaltar que na verdade este impulso de separar muito claramente o âmbito religioso e o âmbito temporal, tal como demonstra o próprio Georges Duby em outro texto intitulado "As origens da cavalaria" (1968), tem precedentes anteriores que remontam ao próprio período carolíngio - onde a Igreja viu-se na necessidade de afirmar sua identidade e autonomia perante os poderes dos soberanos carolíngios. Mas é com o novo contexto de fragmentação dos poderes, que regerá o surgimento da sociedade feudal, que esta necessidade torna-se ainda mais premente, e agora localizada no plano dos poderes locais, de modo que é precisamente neste momento que começa a tomar forma uma 'teoria da trifuncionalidade'.

A emergência de uma teoria que busca clarificar definitivamente a separação entre o âmbito religioso e o âmbito laico - e depois uma nova divisão entre bellatores e laboratores dentro deste último âmbito - situa-se portanto na confluência entre as necessidades dos estabelecimentos religiosos enfrentarem os poderes locais de seu tempo, e a necessidade de se reagir contra uma história anterior que havia misturado estreitamente nas estruturas carolíngias as idéias de Igreja e Cristandade, chegando a até mesmo confundi-las na "pessoa real"

Desta maneira, o rastreamento empreendido por Duby das fontes medievais que precedem a teoria da trifuncionalidade mostra que, primeiro, teria surgido uma necessidade de maior explicitação da divisão entre o âmbito religioso e o âmbito laico - portanto ainda uma oposição binária - mas que logo ficaria claro que seria útil subdividir o âmbito laico entre aqueles que representam os poderes dominantes, os 'guerreiros', e aqueles que trabalham, notando-se que os grandes estabelecimentos monásticos também viviam da exploração desta imensa mão-de-obra agrícola que lhes assegurava a subsistência e o lugar da Igreja, no seu conjunto, como a maior proprietária fundiária da época. Note-se, aliás, que se a teoria da trifuncionalidade aprimora esta divisão do mundo laico em bellatores e laboratores, já no que se refere ao âmbito religioso a sua tendência seria, ao contrário, a de aproximar "as duas principais ordines dos esquemas sociológicos carolíngios", a dos clérigos e a dos monges ${ }^{35}$. A Igreja mostra-se já aqui como um corpo que se quer manter à parte.

${ }^{34}$ DUBY, Georges. «Gerard de Cambrai, la paix et les trois fonctions sociales. 1024» in Resumo das sessões da Academia das Inscrições e Belas-Letras. Paris: 1976, p. 39.

${ }^{35}$ DUBY, Georges. "Gerard de Cambrai, la paix et les trois fonctions sociales. 1024" in op. cit. p. 41. 
Esta aproximação entre os modos de vida do monge e do clérigo secular, de modo a constituir efetivamente a noção mais fortemente enraizada de uma nova ordem - a dos oratores - não se fez naturalmente sem resistências e lutas internas que se deram no próprio seio do mundo eclesiástico. Afinal, o caminho do monge e o caminho do clérigo eram até então considerados coisas distintas. Exemplo disto são os protestos de padres milaneses que, pretendendo se opor à Reforma gregoriana, acusaram o papado de pretender impor aos clérigos seculares um modo de vida e um conjunto de exigências morais que não corresponderiam à vocação específica do seu ordo. Invocavam, como se pode entrever, um esquema tripartido anterior, que já vimos mencionado na 'teoria dos três graus' apresentada por Abbom de Fleury no seu Apologeticus adversus. Este esquema categorizava, como se fossem de certo modo degraus diferenciados, a espiritualidade leiga, o caminho dos clérigos, e o caminho dos monges, sendo este último o mais perfeito. Adaptar o modo de vida clerical dos padres à espiritualidade monástica, desta maneira, era uma operação que não podia se dar de maneira assim tão fácil.

As pesquisas de Georges Duby sobre a 'teoria da trifuncionalidade', enfim, apresentam o mérito inquestionável de, por um lado, situá-la diante de um tempo em transformação, e de, por outro lado, situá-la dentro de uma rede intertextual que remete a formulações anteriores, embora não propriamente trifuncionais. Através desta rede, é possível verificar como os propósitos das diversas formulações que antecedem a trifuncionalidade não se situam apenas no campo dos desejos de assegurar para a Igreja o lugar de um corpo à parte, mas também no campo da vontade de situá-la acima, de definir as outras duas ordens em relação a ela. É assim que já veremos nas Collationes, escritas por volta de 930 pelo abade Odon de Cluny, a afirmação de que "os poderosos recebem de Deus a espada, não para maculá-la, mas sim para perseguir aqueles que vão contra a autoridade da Igreja oprimindo os pobres"36.

Um balanço comparativo, enfim, permitir-nos-á avaliar complementarmente as proposições de Georges Duby e Jacques Le Goff acerca da teoria da trifuncionalidade. A teoria, concebida como uma concepção sujeita a múltiplas reapropriações, é vista por ambos como uma concepção que se constrói diante dos desafios de sua época, e que denota um projeto de agir sobre a sociedade. No caso de Georges Duby, que procura analisar as formulações trifuncionais tanto no contexto de sua época como no interior de uma rede intertextual, a ênfase está nas possibilidades apresentadas pela teoria da trifuncionalidade com vistas a atender aos interesses da Igreja de se colocar como um corpo à parte e perfeitamente protegido, pronto a se beneficiar das duas ordens que constituem o mundo laico. Já no caso de Jacques Le Goff, a ênfase

${ }^{36}$ DUBY, Georges, "As origens da cavalaria" in op. cit., p. 33. 
dirige-se aos modos como a teoria da trifuncionalidade foi reapropriada de modo a fortalecer também a instituição monárquica. Ambas as posições, na verdade, interagem complementarmente, e permitem avaliar a trifuncionalidade como fenômeno complexo, que atende aos diversos interesses sociais e políticos de seu tempo, sem deixar de dialogar com outros tempos através da rede intertextual em que se inscreve.

\section{A trifuncionalidade: suas variações e ambigüidades}

Seria oportuno destacar ainda que o esquema tripartido não se adaptou em todas as sociedades da cristandade ocidental, ainda que tenha desempenhado uma função simbólica importante mesmo nas regiões onde não podia se concretizar funcionalmente. Vale lembrar as observações de José Mattoso sobre a medievalidade portuguesa, e Ibérica de modo mais geral. A idéia de uma trifuncionalidade mais ou menos fechada, conforme indica o historiador português, não teria paralelo na Península Ibérica da Reconquista, onde o combate a cavalo era tantas vezes feito por não nobres ${ }^{37}$ (MATTOSO, 1986).

De igual maneira, convém lembrar que a teoria da trifuncionalidade que em regra impunha um esquema de segregação entre ordens que corresponderiam a funções distintas - também permite nos seus interstícios as ambigüidades e fusões funcionais. O exemplo mais conhecido é o das "ordens militares", que unem em uma única pessoa as ordens oratore e bellatore. Existem por outro lado estudos que procuram mostrar que não estavam tão distantes as representações produzidas na ordem bellatore e na ordem oratore. É o que discute B. H. Rosenwein, em um ensaio intitulado "Feudal war and monastic peace: Cluniac liturgy as ritual agression", onde se mostra a interpenetração das representações guerreias na vida monástica através do miles que, ao entrar para um mosteiro, abandonava seu cavalo e sua espada para passar a empunhar armas espirituais infinitamente mais eficazes que o mundo ${ }^{38}$.

A questão da relação do ordo oratoris com o ordo laboratoris é ainda mais complexa. Sendo uma das maiores proprietárias fundiárias de seu tempo, a Igreja vivia da exploração dos trabalhadores da mesma maneira que os senhores. Mesmo quando os monges conseguiam efetivamente realizar a sua vida individual de pobreza, isto contrastava radicalmente com a riqueza coletiva do seu mosteiro, que por vezes administrava imensos domínios que submetiam os trabalhadores a condições tão duras como ocorria em qualquer pro-

MATTOSO, José. Identificação de um país - ensaio sobre as origens de Portugal 1096-1325. Lisboa: Estampa, 1986, 2 vol.

${ }^{38}$ ROSENWEIN, B. H.. "Feudal war and monastic peace: Cluniac liturgy as ritual agression" in Viator II, 1971, p. 129-157, p. 129 ss. 
priedade senhorial. Por outro lado, a antiga Regra de São Bento preconizava uma divisão em três do tempo: o dia de um monge deveria ser repartido em um terço para a contemplação individual e as preces coletivas, um terço para o trabalho manual, e outro terço para o trabalho intelectual. Embora a maioria dos mosteiros procurasse orientar-se pela regra beneditina, a verdade é que por volta de 1100, nas abadias ligadas a Cluny, os monges quase já não desempenhavam trabalhos manuais, a não ser o serviço especializado de copistas e iluminadores de manuscritos. A difusão da teoria da trifuncionalidade, ao definir monges e clérigos a partir da função oratore, praticamente reforçava esta tendência que estava bem amparada pela própria riqueza eclesiástica: o monge não precisava trabalhar porque não precisava - já que o mosteiro contava com milhares de laboratores à sua disposição e além de tudo estava freqüentemente recebendo doações - e também porque a concepção trifuncional da sociedade legitimava perfeitamente a sua vida contemplativa e oracional.

Um novo tipo de monaquismo iria surgir no século XII propondo precisamente uma revalorização do trabalho. Os monges cistercienses, tendo como nome mais ilustre Bernardo de Clairvaux, iriam empreender precisamente uma crítica ao monaquismo cluniacense com base na opulência dos mosteiros de Cluny e na recusa de seus monges a trabalhar. No esquema tradicional da trifuncionalidade, pode-se dizer que os monges brancos de Cister conseguiram concretizar uma participação nas duas ordens - a dos oratores e laboratores - e de fato incluíram no seu ideal de vida monástica a realização de trabalhos efetivos e úteis. Embora continuassem administrando propriedades que abrigavam agricultores dependentes, eles mesmos freqüentemente trabalhavam e foram até os responsáveis pela descoberta de novas técnicas de trabalho agrícola.

De igual maneira, também em movimentos oriundos do mundo laico poderemos encontrar as interpenetrações entre as ordens laboratore e oratore. Exemplo é o grupo dos Humiliati - surgidos em Milão por volta de 1175 - e que na sua origem eram tecelões que levavam uma vida em comum repartida entre o trabalho e a oração. Seu ideal apostólico incluía o trabalho, a oração, a vida austera, e uma vida pastoral que logo os conduziu a pregar em público sem autorização da Igreja local, razão pela qual foram excomungados em 1184 pela decretal Ad abolendam. Mais tarde Inocêncio III os reintegrou à Igreja (1199), dentro de um conjunto mais amplo de estratégias que visavam considerar a possibilidade de integrar à Igreja as heresias que eram caracterizadas por meras questões disciplinares, como a intenção de pregar sem a devida autorização eclesiástica. Os Humilhados constituíram suas práticas religiosas e suas vidas cotidianas efetivamente no entrecruzamento das ordens laboratore e oratore. André Vauchez, ao analisar a sua posição no quadro da Espiritualidade na Idade Média Ocidental, considera que eles não deixam de 
ser "o primeiro agrupamento leigo a ter associado a uma vida de oração intensa um trabalho concebido como um meio autêntico de existência" 39 .

À parte as interpenetrações concretas e imaginárias entre as ordens, é sempre importante ressaltar que a distância entre clérigos e leigos, que a teoria da trifuncionalidade procura estabelecer com tanta nitidez, encontraria mesmo uma expressão concretizada na arquitetura interna das igrejas. No século XII, lembra André Vauchez, apareceria a jube, "vasta barreira de pedra, ornada de esculturas, que isolava os clérigos agrupados no coro dos fiéis reunidos na nave" ${ }^{40}$. Com estas modificações arquiteturais, poderíamos acrescentar, a trifuncionalidade medieval, ou o registro da passagem desta noção através da História, concretiza-se definitivamente no espaço.

\section{REFERÊNCIAS}

\section{Fontes}

Adalberón de Laon, Poeme au Roi Robert. Tradução Claude Carozzi. Paris: 1979. Gerard de Cambrai, Oratores, agricultores, pugnatores, MGH, SS VII, p. 485. Raul Glaber. Les cinq livres de ses histoires (900-1044). Paris: ed. Maurice Proux, 1886.

SEDGEFIELD, W. J. (org). King Alfred's Old English Version of Boethius "De Consolatione Philosophiae". Oxford: 1899-1900.

\section{Bibliografia}

ABRAVAEV, Vasilji I. "Le cheval de Troie. Parallèles caucasiens" in Annales ESC, 1963. p. 1041-1070.

BATANY, Jean. "Des 'trois functions' aux 'trois États"', in Annales ESC, 1963. p. 933-938.

BONNAUD-DELAMARE, R. Les institutions de la paix. Paris: Mélanges Halphen, 1951.

BOYANCÉ. "Les origines de la réligion romaine, Theories et recherches récentes" in L'Information littéraire, VII, 1955, p. 100-107.

CAROZZI, C. "Carmen ad Rodbertum regem" d'Adalberón de Laon" Paris: University of Paris, 1973.

COOLIDGE, R. T. "Adalbero, Bishop of Laon" in Studies in Medieval and Renaissance History, II. Arizona State University, 1965.

${ }^{39}$ VAUCHEZ, André. A Espiritualidade na Idade Média Ocidental-séculos XVIII a XIII, p. 108.

${ }^{40}$ VAUCHEZ, André. op. cit., p. 63. 
DUBY, Georges. As Três Ordens ou o Imaginário do Feudalismo. Lisboa: Estampa, 1982.

DUBY, Georges, "As origens da cavalaria” in A Sociedade Cavaleiresca. São Paulo: Martins Fontes, 1989.

DUBY, Georges. "Gerard de Cambrai, la paix et les trois fonctions sociales. 1024" in Resumo das sessões da Academia das Inscrições e Belas-Letras. Paris: 1976.

DUBY, Georges. "Os leigos e a paz de Deus" in A Sociedade Cavaleiresca. São Paulo: Martins Fontes, 1989 [original: Edition de l'École de Hautes Études en Sciences Sociales: 1979].

DUBY, Georges. O Ano Mil. Lisboa: Edições 70, 1992. [original: 1967].

DUBUISSON, Daniel. "Le roi indo-européen et la synthèse de trois functions" in Annales ESC, 1978. p. 21-34.

DUMÉZIL, Georges. L'Ideologie tripartite dês Indo-Européens. Bruxelas: 1958.

FOSSIER, R. "Remarques sur l'étude dês commotions sociales aux IX et XII siècles in Cahiers de Civilisation médievale, 16. Paris: 1973, p.45-50).

LANDES, Richard; GOW, Andrew; VAN METER, David C. The Apocalyptic Year 1000: Religious Expectation and Social Change, 950-1050. N. York: Oxford University Press, 2003.

LE GOFF, Jacques. "Nota sobre sociedade tripartida, ideologia monárquica e renovação econômica na Cristandade do século IX ao século XII". in Para um novo conceito de Idade Média. Lisboa: Estampa, 1980 [original: Paris: Gallimard, 1977] [artigo original de 1965].

LE GOFF, Jacques. "Le trois fonctions indo-européenes, l'historien et l'Europe féodale" in Annales ESC, 1979. p.1.184-1.215.

LE GOFF, Jacques. «O Rei das Três Funções» in São Luís - Biografia. Rio de Janeiro: Record, 2002. p.568-596 [original: 1996].

MATTOSO, José. Identificação de um país - ensaio sobre as origens de Portugal 1096-1325. Lisboa: Estampa, 1986, 2 vol.

NIERMEYER, J. F. "A marge du noveau Ducange” in Moyen Age, Paris: 1957.

ROSENWEIN, B. H.. "Feudal war and monastic peace: Cluniac liturgy as ritual agression" in Viator II, 1971, p. 129-157.

ROUCHE, Michel. "De l'Orient a l'Occident. Les origines de la tripartition fonctionelle et les cause de son adoption par l'Europe chrétienne à la fin du XI siècle" in Occident et Orient au X siècle. Paris: 1979, p. 321-355.

VAUCHEZ, André. A Espiritualidade na Idade Média Ocidental-séculos VIII a XIII. Rio de Janeiro: Jorge Zahar, 1995 [original atualizado: Seuil: 1994].

SCHIEFFER, T. «Ein Deutscher Bishof des 11 ihd, Gerard de Cambrai (1012-1051)» in Deutscher Archiv, Berlim: 1937. 


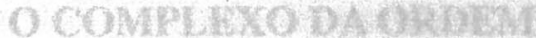

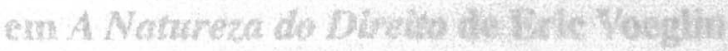

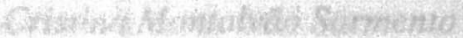

CHCHNA

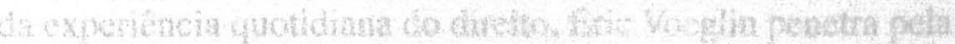

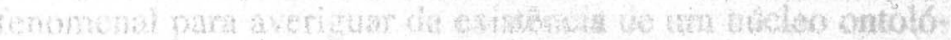

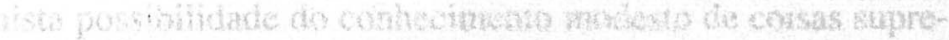

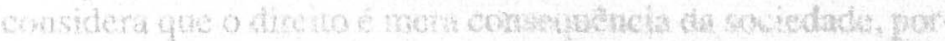

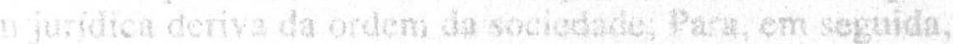

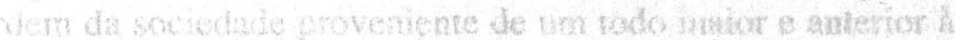

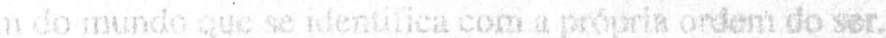

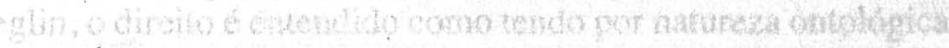

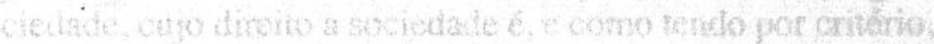

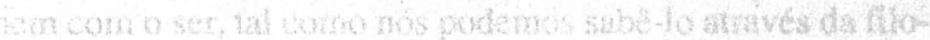

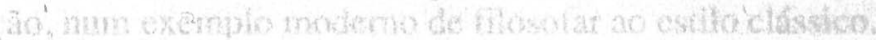

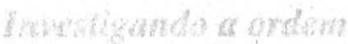

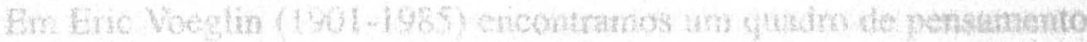

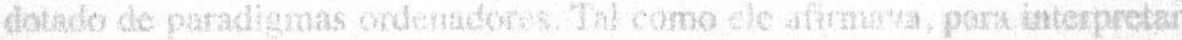

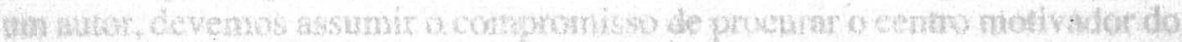

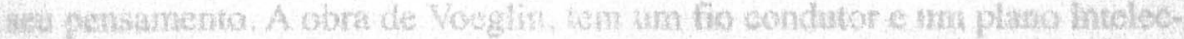

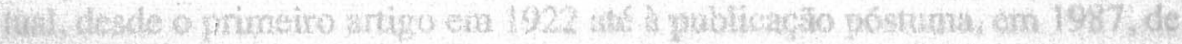

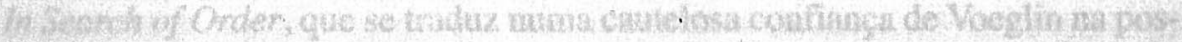

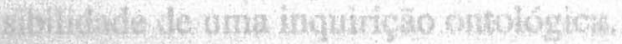

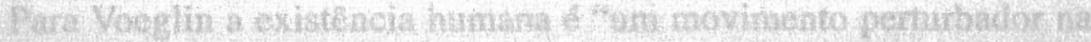

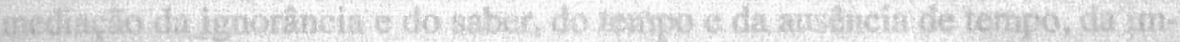

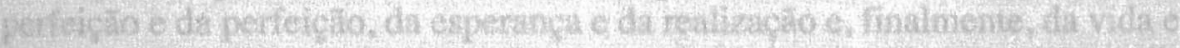

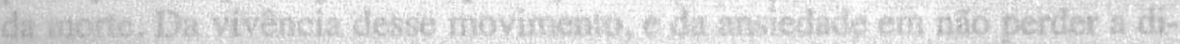

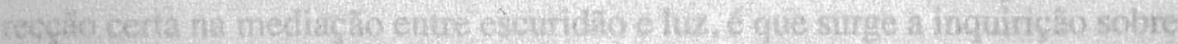

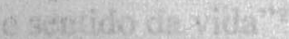

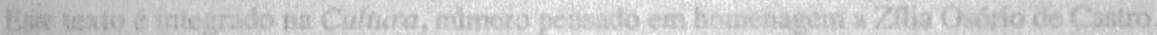

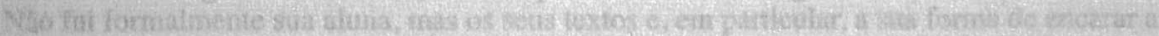

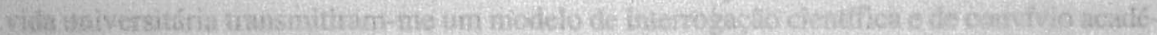

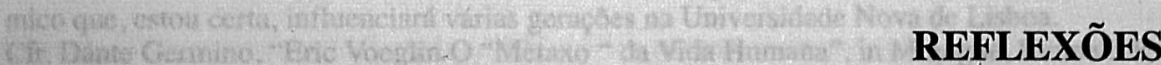

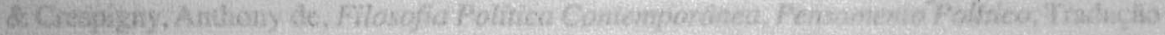

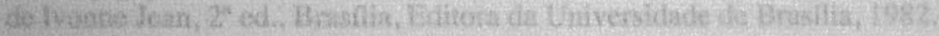




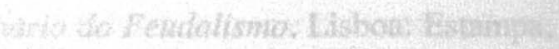

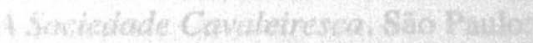

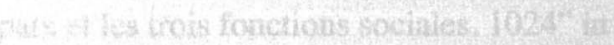

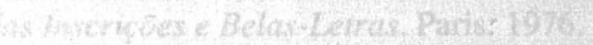

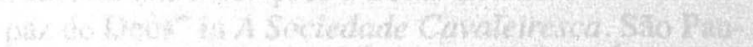

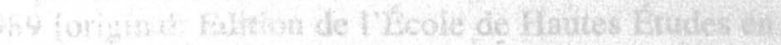
(3)

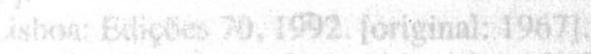

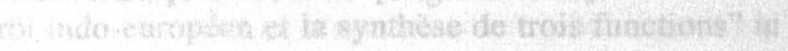
is, 9.21 .34

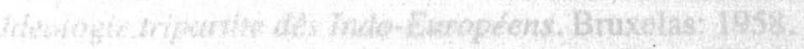

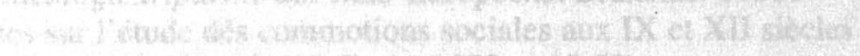

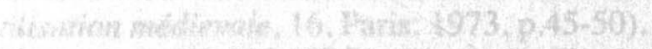

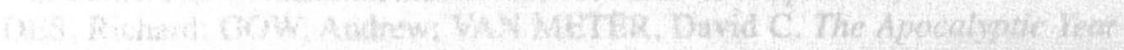

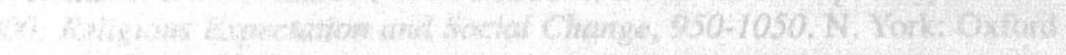

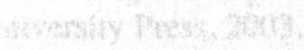

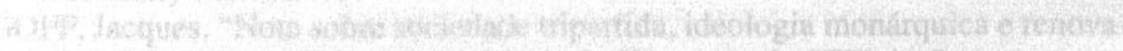

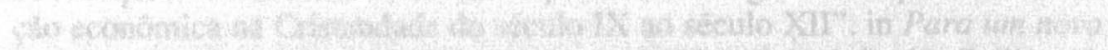

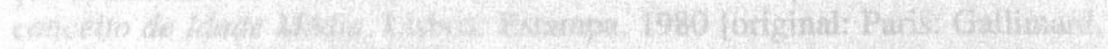

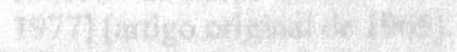

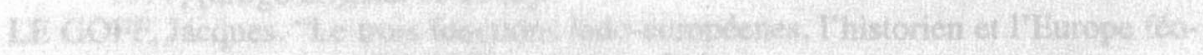

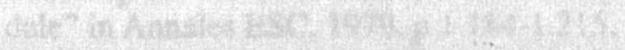

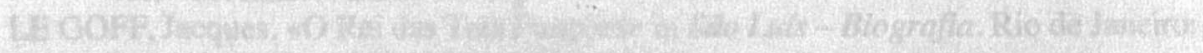

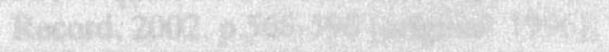

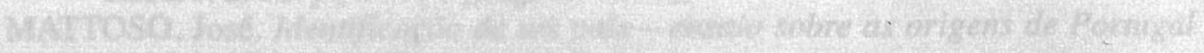

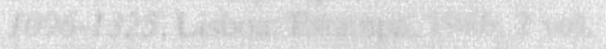

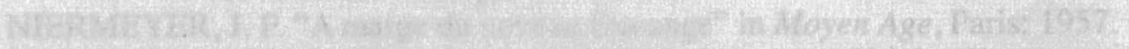

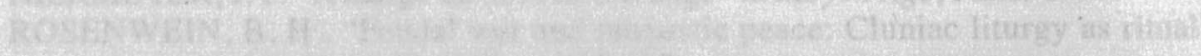

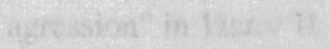

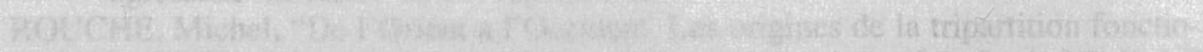

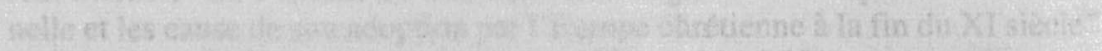

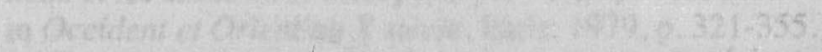

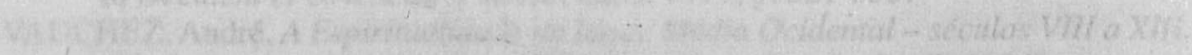

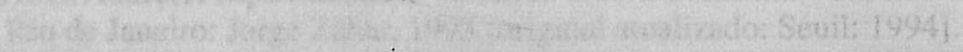

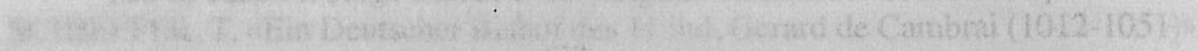

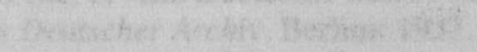

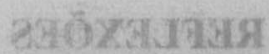




\title{
O COMPLEXO DA ORDEM em A Natureza do Direito de Eric Voeglin
}

\author{
Cristina Montalvão Sarmento ${ }^{1}$
}

CHC-UNL

A partir da experiência quotidiana do direito, Eric Voeglin penetra pela sua superfície fenomenal para averiguar da existência de um núcleo ontológico. Fiel à tomista possibilidade do conhecimento modesto de coisas supremas, primeiro, considera que o direito é mera consequência da sociedade, porquanto a ordem jurídica deriva da ordem da sociedade; Para, em seguida, considerar a ordem da sociedade proveniente de um todo maior e anterior à mesma: a ordem do mundo que se identifica com a própria ordem do ser.

Com Voeglin, o direito é entendido como tendo por natureza ontológica a estrutura da sociedade, cujo direito a sociedade é, e como tendo por critério, a relação do homem com o ser, tal como nós podemos sabê-lo através da filosofia e da revelação, num exemplo moderno de filosofar ao estilo clássico.

\section{Investigando a ordem}

Em Eric Voeglin (1901-1985) encontramos um quadro de pensamento dotado de paradigmas ordenadores. Tal como ele afirmava, para interpretar um autor, devemos assumir o compromisso de procurar o centro motivador do seu pensamento. A obra de Voeglin, tem um fio condutor e um plano intelectual, desde o primeiro artigo em 1922 até à publicação póstuma, em 1987, de In Search of Order, que se traduz numa cautelosa confiança de Voeglin na possibilidade de uma inquirição ontológica.

Para Voeglin a existência humana é "um movimento perturbador na mediação da ignorância e do saber, do tempo e da ausência de tempo, da imperfeição e da perfeição, da esperança e da realização e, finalmente, da vida e da morte. Da vivência desse movimento, e da ansiedade em não perder a direcção certa na mediação entre escuridão e luz, é que surge a inquirição sobre o sentido da vida" 2 .

\footnotetext{
' Este texto é integrado na Cultura, número pensado em homenagem a Zília Osório de Castro. Não fui formalmente sua aluna, mas os seus textos e, em particular, a sua forma de encarar a vida universitária transmitiram-me um modelo de interrogação científica e de convívio académico que, estou certa, influenciará várias gerações na Universidade Nova de Lisboa.

${ }^{2}$ Cfr. Dante Germino, "Eric Voeglin O "Metaxo " da Vida Humana", in Minogue, Kenneth R. \& Crespigny, Anthony de, Filosofia Política Contemporânea, Pensamento Político, Tradução de Ivonne Jean, $2^{a}$ ed., Brasília, Editora da Universidade de Brasília, 1982.
} 
Porque considerava epistemologicamente insustentável a dicotomia entre declarações empíricas e julgamentos de valores, na medida em que o "filosofar" autêntico tem sempre uma base "empírica", e pode ser caracterizado como "um resultado da história da vida do filósofo e, além disso, da história da comunidade cujos símbolos de linguagem partilha, e ainda mais além, da história do cosmos"3, Voeglin explora a participação do homem na realidade ensaiando a articulação de conceitos que permitam compreender o homem na sua existência. Ao afirmar que não há nenhum caminho para "sair do ser", a reflexão filosófica parte da vivência da própria participação do filósofo, numa arrojada interrogação ontológica.

Deste esforço de radicalização, "de superação da instância sujeitoobjecto, tipificada na estrutura ser-no-mundo" que indica uma unidade anterior que reclama a sua própria superação e enraizamento ontológico, resulta, para Voeglin, a necessidade de reorientarmos grande parte do simbolismo herdado da nossa linguagem "científica".

Voeglin afasta idealismo e materialismo por tentarem reduzir o "Ser" ao nível de um segmento ou dimensão particular. O materialismo não alcança justificar a realidade da consciência considerada como um reflexo de um processo material externo. Por sua vez, o idealismo não consegue ver que o esclarecimento que a consciência nos dá a respeito da realidade "interna" não penetra quer no Ser natural criado, quer no terreno do Ser enquanto tal. O natural permanece um mundo externo no duplo sentido de algo fora da consciência e de algo exterior a si próprio. Consequentemente um sistema idealista ou materialista não podem sustentar a inquirição ontológica.

Para Voeglin, tratar a questão da natureza do direito surge como um corolário da coerência de toda uma obra. Um exame ainda que superficial da lista das suas obras mostra a variedade dos seus interesses que abrangem os campos da filosofia, ciência política, economia, sociologia e da teologia num desprezo inaugural pelas fronteiras convencionais entre disciplinas, numa tentativa criadora de reconquistar para o nosso tempo a visão integral perdida no cientismo positivista do séc. XIX.

No entanto, vale a pena lembrar que, ao contrário de muito filósofos políticos, Eric Voeglin começou a sua carreira como estudioso das instituições políticas, e só mergulhou nos problemas filosóficos depois de se lhe ter tornado claro que não é possível compreender acontecimentos ao nível político (prático) ou fenomenológico, enquanto não os tenhamos observado no con-

Dante Germino, "Eric Voeglin's Anamnesis" em The Southern Review, Inverno, 1971, pp. 68-88. ${ }^{4}$ Cfr. Joaquim Cerqueira Gonçalves, Fazer Filosofia,?-Como e Onde?-, Braga, Universidade Católica Portuguesa, 1995, p. 15. 
texto de uma ordem maior das coisas ou, para sermos mais precisos, empregando o seu simbolismo, no contexto da experiência humana da ordem de ser.

Já enquanto estudante de Direito orientado por Hans Kelsen, Voeglin cedo refuta esse positivismo normativo que postula uma teoria pura do direito, herdeira de uma teoria geral do Estado e marcada pela normlogik da Escola de Marburgo, mas não optou em alternativa pelas sendas neo-kantianas, afinadas pela razão prática da Escola de Baden ${ }^{5}$. Procurou uma outra via, ao projectar uma ciência política como construção de uma teoria geral da sociedade, de que resultará na década de cinquenta A Nova Ciência da Política (1952) ${ }^{6}$ que condensa o reconhecimento da afirmação que a ética e a política clássica, e cristã, continham uma proposta de ciência de ordem.

Quando a ciência política se concentra na análise de sistemas de governo e de poder, remete a ordem paradigmática das sociedades para um estatuto ideal e Voeglin foca a sua atenção no que a sociedade tem de substancial: "para analisar o que a sociedade possui de substancial, a sua adequação à ordem de ser descoberta na consciência e concretizada mediante instituições, é preciso questionar a finalidade contida nos actos de fundação, ou seja, ligar representação e verdade"?.

Ao esclarecer que a existência e a ordem das sociedades dependem da estruturação do real, e que a análise dos paradigmas da sociedade, deve preceder a análise dos problemas do poder, imputa à génese de cada sociedade uma relação com a verdade que representa e a que chama ordem. Em Voeglin a verdade da ordem alcançada pela consciência, não deve superar a ordem da sociedade concreta, importa antes, manter uma relação de tensão entre o paradigma da ordem e as formas políticas históricas.

Será a par dos três primeiros volumes de Ordem e História (1956-1957), que Voeglin apresenta as suas categorias centrais de ordem e história. Os homens associam-se numa comunidade, criam uma ordem concreta, a que correspondem símbolos conscientemente elaborados. A ordem nasce de uma interrogação pessoal acerca do ser, transmitida em símbolos articuladores do acto fundador e da institucionalização pública. Para identificar essa ordem o

${ }^{5}$ Cfr., José Adelino Maltez, no prefácio a Eric Voeglin, A Natureza do Direito e outros textos jurídicos, tradução. de F. Virgílio Ferreira, Lisboa, Vega, 1998 e para mais desenvolvimentos, ainda de J. A. Maltez, Princípios de Ciência Política, O Problema do Direito, Elementos de Filosofia do Direito e de História do Pensamento Jurídico, Lisboa, Universidade Técnica de Lisboa, ISCSP, 1996, pp. 407-417.

- Voeglin, Eric Hermann Wilhelm, The New Science of Politics. An Introduction, Chicago, University of Chicago Press, 1952. I2. a ed., Prefácio de Dante Germino, 19871. A Nova Ciência da Política, trad. de José Viegas Filho, introd. de José Pedro Galvão de Sousa, Brasília, Editora da Universidade de Brasília,1979.

7 Cfr. Mendo Castro Henriques, A Filosofia de Eric Voeglin, Lisboa, Universidade Católica Portuguesa, 1994, p. 56-62. 
intérprete tem que experimentar uma tensão ordenadora equivalente à experiência original.

Escrito em 1957, A Natureza do Direito deve ser entendida neste contexto. Sendo o único texto abrangente e sistemático de Voeglin sobre o direito, numa fase de maioridade do seu pensamento, descobrimos o direito entendido à luz da categoria da ordem, categoria central do seu pensamento mas ainda longe dos desenvolvimentos posteriores da sua obra.

Voeglin encontrava-se simultaneamente numa transição ainda incompleta, em que a par da recuperação e diferenciação da tradição política do realismo noético, patente na experiência clássica da razão, assumirá como cerne da sua pesquisa (ao apresentar as formulações posteriores sobre a teoria da consciência), a experiência da ordem (Anamnesis, 1966) e do seu projecto inacabado de uma ciência da ordem.

$\mathrm{Na}$ medida em que a nossa própria busca de sentido é ainda permeada pela interpenetração de sentidos externos, porque há um reconhecimento implícito de limites assumidos, a nossa proposta de leitura parte de uma compreensão cingida ao mero reconhecimento externo do percurso Voegliano na tentativa de apreender o direito como resultado do processo autoconstituinte da sociedade. Como parte do processo pelo qual a sociedade dá a si mesma existência e se preserva a si mesma, em existência ordenada. Porque tem de ligar o homem à sociedade, ao Mundo e a Deus, exige que se entenda o respectivo processo de criação como uma recolha e uma descoberta da ordem verdadeira.

Finalmente, a metodologia Voegliana implica assumir roturas com as noções de natureza, cultura e ciência tal como as assumimos. Questionar a natureza do direito, como realidade cultural como Voeglin fez, prescreve implicitamente a ultrapassagem de modelos científicos, indo mais longe e incluindo, o modo de filosofar.

\section{A natureza do direito}

Por negar a compreensão do direito como um esquema de respostas governamentais às condições e a acções existenciais, internamente consistentes com uma norma básica, divorciado por isso de critérios ontológicos de ordem, a que a sua experiência histórica pessoal obrigou a pesquisar ${ }^{8}$, Voeglin parte dos instrumentos clássicos de análise filosófica a que submete a questão de saber se o direito tem uma natureza.

Recuperando o conceito de natureza entendida como essência, como fi-

${ }^{8}$ Eric Voeglin pertence à geração que atravessou o Atlântico para fugir às perseguições nazis. 
zera S. Tomas ${ }^{9}$, Voeglin é implacável na busca da essência. Apesar de falarmos de direito no singular, o direito existe numa pluralidade de ordens, de modo diferenciado, em diversas sociedades e, no entanto, todas as regras jurídicas são entendidas como essenciais no (próprio) seu ordenamento.

$\mathrm{O}$ direito poderia ser um agregado de regras (espécie ou forma) individualizável e a natureza do direito seria conduzida à finalidade de descobrir as regras comuns, estas comporiam a essência do direito porquanto as regras de conteúdo variável, seriam propriedades não essenciais.

Todavia a relação de espécie e individuação, não se poderia aplicar no caso de considerarmos a ordem jurídica como um agregado de regras válidas, pois toda e qualquer regra é essencial para a ordem onde vigora, independentemente de não existir em qualquer outra ordem. A singularidade da sua ocorrência não diminui a sua validade. Pelo que à superfície dos fenómenos, a validade seria uma categoria mais útil do que a essência para abordar o direito.

Deste modo a tentativa de encontrar a natureza do direito através da comparação de diferentes ordens jurídicas, na esperança de encontrar a essência, deve então ser abandonada face à experiência quotidiana que nos impõe a validade de toda a regra individual, na ordem concreta, como sendo um elemento determinante. Voeglin desviou a análise do direito como um fenómeno isolado, em direcção ao direito no seu contexto social.

Ao afirmar que o "ataque analítico ao problema da essência foi vencido por agora" 10 e tendo em conta que a validade está na origem do transtorno, Voeglin irá questionar este conceito, donde conclui que a partir do conhecimento quotidiano reconhecemos uma dimensão temporal dessa mesma validade. Este elemento poderá ser útil ao problema da existência.

A ordem jurídica muda, mas não muda em todas as suas partes, permanece um corpo imutável de regras suficientemente amplo para reter a identidade da ordem. A preservação da identidade não é diferente de outros domínios do ser.

Neste contexto, observa Voeglin, o direito, no seu significado descritivo é a substância da ordem em qualquer domínio do ser. O processo de criação do direito é o meio de garantir a substância da ordem entre os seres humanos, agrupados em sociedade. Perspectiva a partir da qual Voeglin vai expor, sumariamente, as várias construções teóricas da relação dos processos de criação do direito e de substância da ordem.

9 Saint Thomas D'Aquin, L'Être et L'Essence, Texte, trad. e notas de Catherine Capelle, Paris, Vrin, 1987, p. 18. I De Ente et Essentia,1265 I.

${ }^{10}$ Cfr. Eric Voeglin, The Nature of Law and Other Related Legal Writings, Baton Rouge, Louisiana University Press, 1991. Edição portuguesa, A Natureza do Direito e Outros Textos Jurídicos, trad. de Fernando Vírgílio Ferreira, prefácio de José Adelino Maltez, Lisboa, Vega, 1998. Adiante designada por ND, vide, p. 50. 
Segundo Voeglin, com Platão e Aristóteles, coube ao filósofo indagar o conteúdo da ordem, e o direito é formulado para a garantir. Na Renascença, coube ao príncipe articular o direito positivo aos direitos divinos e natural, posteriormente, só ao direito natural e finalmente ao seu arbítrio. Com a secularização e a desintegração da filosofia, a questão da substância da ordem verdadeira é ignorada colocando-se a ênfase no processo positivo da criação do direito" .

Desta sua demonstração, resulta que é na ordem da sociedade, que a natureza do direito deve ser procurada, recuperando o realismo clássico em que se ensaia descobrir o direito de baixo para cima a partir do ser empírico, procurando detectá-lo no homem comum e na linguagem corrente, fundados no horizonte de uma ordem superior.

\section{Complexo da ordem}

"O direito, no sentido de um agregado de regras válidas, deve ser colocado no contexto social do processo em que ele é criado; e o processo de criação do direito deve, por sua vez, ser colocado no contexto da sociedade que garante a ordem substantiva por meio deste processo. Todo o complexo, é uma unidade de significado, uma entidade" 12 .

O termo direito poderá mudar de significado conforme for usado para significar o todo ou apenas uma parte do complexo. Todo o complexo da ordem é a entidade cuja natureza se deverá analisar quando procuramos a natureza do direito.

Ao analisar o complexo da ordem, Voeglin regista as tensões, por um lado, entre a ordem substantiva verdadeira e o processo de criação do direito e, por outro lado, entre a ordem substantiva verdadeira e a ordem social tal como existe.

Relativamente à primeira tensão, a validade de mudanças na estrutura constitucional não se pode explicar em termos de processo procedimental, mas apenas em termos de continuum da sociedade cuja ordem é conformada por referências extra jurídicas.

Estas fontes extra jurídicas incluem a autoridade da estrutura do poder na sociedade, articulando uma ordem que se pretende conforme aos critérios ontologicamente verdadeiros para a ordem humana substantiva sob condições existenciais. Neste sentido, o direito implica mais do que regras jurídicas; abrange todos os esforços dos seres humanos para estabelecer ordem numa sociedade concreta.

\footnotetext{
"ND, pp. 71-74.

12 ND, p. 75.
} 
Quanto ao segundo tipo de tensões, entre as ordens sociais existentes e a ordem substantiva verdadeira, estas existem porque o homem tem a experiência da sua sintonia com a ordem do ser estar dependente da sua acção. Esta tensão é a fonte ontológica do dever (ou normatividade).

A ordem jurídica não tem estatuto ontológico próprio, mas é parte de um processo pelo qual a sociedade dá a si mesma existência e se preserva a si mesma em existência ordenada. A entidade mais ampla é o objecto da indagação, e a ordem existe de facto na medida em que é parte do complexo mais vasto.

Nesta esfera, Voeglin faz comparecer o direito enquanto ordem normativa, como representação da realidade, exigente à própria realidade. A ordem normativa expressa a tensão entre a ordem empírica - ordem social existente - e uma outra ordem superior, a ordem substantiva, a ordem do ser ou a ordem verdadeira, para utilizar a terminologia voegliana.

Nessa ordem verdadeira residiriam as verdadeiras regras, apenas passíveis de serem descobertas, assumindo-se, deste modo, o carácter autoconstituinte da sociedade.

\section{Direito e ordem}

A ordem jurídica não tem estatuto ontológico próprio, porquanto a tenhamos como objecto de estudo desligada do seu contexto, e neste sentido a validade das suas regras nada é mais do que o significado a temporal das suas proposições.

Com a introdução de fenómenos contextuais a validade das regras adquire um corpo de realidade. As regras jurídicas são proposições acerca da ordem da existência humana na sociedade. A regra jurídica por sua vez não é um significado no vazio mas parte de uma sociedade ordenada. Esta não tem intenção cognitiva mas quer dizer uma verdade que exprime a tensão ontológica do dever sem a qual a ordem ficaria à mercê da força.

A validade da regra jurídica contém, o componente da normatividade no sentido ontológico. Todavia, contém mais, na medida em que não há existência do homem independentemente da ordem na sociedade.

A ordem da existência humana é indivisivelmente a ordem da existência humana na sociedade. E o dever, tal como se descobre a si mesmo na experiência da tensão entre a ordem empírica e a ordem verdadeira, inclui a disciplina da paixão, tanto individual como social.

Neste sentido "o direito não é um comando de um leviatã para pessoas que por medo de uma situação pior, renunciaram a todo o direito de objectar. O direito também não é simplesmente o resultado de um pacto social entre in- 
divíduos autónomos, pelo qual renunciam reciprocamente a licenças no esforço de evitar o mal. O direito igualmente não é só a vontade expressa de uma maioria garantindo o seu próprio interesse auto definido, imediatamente mundano, ou o de uma classe dominante"13. A análise mostra o direito como parte da ordem que uma sociedade gera para si mesma, através dos seus representantes, no esforço de conseguir o bem comum.

Consequentemente uma ordem jurídica particular pode ser julgada pelo grau com que garante a todas as pessoas, seres espirituais bem como materiais, agora vivos ou por nascer, a possibilidade de desenvolver ao máximo a capacidade de cada um participar na vida que, por criação, cada um partilha com Deus e outras pessoas.

A ordem do direito é, em última análise, a ordem social consistente com a plenitude da realidade. Neste sentido, para Voeglin, a ascensão de movimentos doutrinais gnósticos que ensaiam a ordenação da sociedade, pela fusão da autoridade normativa com a autoridade do poder, é uma fusão deliberada de componentes diferenciados diversos da unidade primordial.

A indagação acerca da natureza do direito implica a indagação das fontes normativas da autoridade, da razão e da revelação, problema negligenciado na ciência do direito, ou mesmo completamente desprezado, pois como refere Eric Voeglin "o nosso ambiente cultural tornou-se tanto anti-religioso como anti-filosófico" 14 .

Em consequência advoga que a experiência clássica da razão indica uma atitude originária sem a qual não se pode superar a crise da modernidade. E o essencial dessa atitude reside na descoberta da espírito, como a realidade onde humano e divino se sintonizam, e a partir do qual teoria e prática se deixam diferenciar como modalidades distintas da consciência. $\mathrm{O}$ agir surge como um âmbito ligado à estrutura originária do homem; não é um produto, mas um contexto onde a reflexão ocorre ${ }^{15}$.

Neste regresso à autêntica reflexão teórica, Voeglin propõe para o direito um modelo de ciência dos princípios pois como afirma "Os princípios devem retomados através de um trabalho de teorização que tenha origem na situação histórica concreta do nosso tempo e que atenda à amplitude do saber empírico contemporâneo"'16.

${ }_{13}$ Robert Anthony Pascal e James Lee Babin, no prefácio à 1. edição em inglês de ND/NL, p. 39.

${ }_{14} \mathrm{ND}, \mathrm{p} .128$.

15 "Reason; the classical experience", in Anamnesis, 1966, p. 89-115; Citado por Mendo Crasto Henriques, A Filosofia Civil de Eric Voeglin,... Op. Cit., p. 89.

${ }^{16}$ Cfr. Eric Voeglin, The New Science of Politics. An Introduction, Chicago, University of Chicago Press, 1952. I 2. ed., Prefácio de Dante Germino, 1987।. Edição em língua portuguesa portuguesa, A Nova Ciência da Política, trad. de José Viegas Filho, introd. de José Pedro Galvão de Sousa, Brasília, Editora da Universidade de Brasília, 1979, p. 3. 


\title{
ÉTICA E POLÍTICA NO PENSAMENTO DE VICENTE FERREIRA DA SILVA
}

\author{
José Maurício de Carvalho \\ Departamento de Filosofia da UFSJ
}

\section{I - Considerações iniciais}

A reflexão sobre a ética e a política constitui parte significativa da filosofia de Vicente Ferreira da Silva ${ }^{1}$. Ele era figura humana complicada, como atesta Miguel Reale (2001), "na qual o recato e certa timidez se combinavam com atitudes extremadas" (p. 39). Essa personalidade se manifesta em obra complexa, como avalia o próprio Reale quando diz que "a filosofia, a poesia, a religião, (...) se confundem no último pensamento de Vicente, e isto está em manifesta consonância com o seu ser existencial" (idem, p. 43).

Para os estudiosos da história da filosofia no Brasil, Ferreira da Silva

1 Vicente Ferreira da Silva nasceu e faleceu em São Paulo, respectivamente a 10 de janeiro de 1916 e em 19 de julho de 1963. Quando morreu tinha 47 anos, tendo sua morte interrompido uma brilhante carreira intelectual. Estudou no tradicional Colégio de São Bento e mais tarde cursou Direito. Formado em Direito, "não se interessou pela advocacia ou qualquer outra atividade vinculada ao Direito, decidindo-se aproximar-se da filosofa" (Dicionário biobibliográfico dos autores brasileiros, p. 453). Trabalhou, inicialmente, com o filósofo americano Willard van Orman Quine (nascido em 1908), quando o conhecido professor de Harvard esteve em São Paulo por ocasião da implantação do Curso de Filosofia da Universidade de São Paulo. Dessa fase ficou um livro intitulado Elementos de lógica matemática (1940). Estudioso apaixonado de filosofia, ministrou diversos cursos livres e fundou em 1945, em São Paulo, o Colégio Livre de Estudos Superiores, com base no Colegio Libre de Estudios Superiores que conheceu em Buenos Aires. Nesse mesmo ano, tornou-se um colaborador efetivo do Suplemento Letras e Artes do jornal A Manhã. Em 1949, organizou o Seminário de Filosofia do Museu de Arte Moderna. Nesse mesmo ano, foi Diretor da Divisão Cultural da Reitoria da USP e, ao lado de Miguel Reale, foi o co-fundador do Instituto Brasileiro de Filosofia. Em 1950, escreveu Dialética das Consciências, ensaio preparado para um Concurso de Filosofia na USP, concurso que foi impedido de fazer. O ensaio marcou sua posição existencialista. Nesse mesmo ano, publicou seu terceiro livro: Exegese da Ação. Também fundou, em 1954, juntamente com a esposa, a poetisa Dora Ferreira da Silva, a Sociedade Cultural Nova Crítica, que publicou a revista Diálogo. Ainda em 1954, atuou como um dos organizadores do I Congresso Internacional de Filosofia ao lado de Miguel Reale. Suas obras mais importantes são: Elementos de lógica matemática (1940), Ensaios filosóficos (1948), Exegese da ação (1949), Dialética das consciências (1950), Idéias para um novo conceito de homem (1951), Teologia e anti-humanismo (1953) e Instrumentos, coisas e cultura (1958). Suas Obras Completas foram editadas pelo Instituto Brasileiro de Filosofia: v. 1 (1964) e v. II (1966). 
insere-se no primeiro momento de difusão das idéias existencialistas no país. Seu interlocutor foi Martin Heidegger e não Jean Paul Sartre, como era usual no período. Conforme já mostramos (2001): "Outros autores também parecem the haver influenciado, e destacaríamos J. G. Fichte (1762-1814), G. W. F. Hegel (1770-1831) e F. Schelling (1775-1854)" (p. 333). Jorge Jaime (2000) estende o diálogo vicentino com os românticos alemães dizendo que ele tinha simpatia "pelos filósofos do romantismo, desde Fichte até Novalis" (p. 179). Entre os filósofos com quem Ferreira da Silva dialogou, pode-se acrescentar, como mostraremos nesta comunicação, José Ortega y Gasset (1883-1955) e o etnólogo Leo Frobenius (1873-1938).

Qual foi sua trajetória intelectual? Ele dedicou-se inicialmente à lógica, quando buscou resolver os problemas da filosofia pela redução dos conceitos a símbolos. O principal de seus esforços parece estar centrado na etapa final de sua meditação dedicada à ontologia e ao modo humano de ser, conforme lembra Braz Teixeira (1997): "a especificidade da realidade humana, radicalmente distinta da dos seres naturais, impõe que seja captada através de processos cognitivos próprios, diferentes dos adequados ao conhecimento do mundo da natureza" (p. 185).

Naquele momento, ele considerou o entendimento do ser e do homem como essencialmente lingüístico, revelando influência de Heidegger. O ser só se mostra como determinação ôntica, circunscrito às fronteiras da linguagem; o homem ganha compreensibilidade como produtor da linguagem, sendo a ele que o ser se revela. As possibilidades ônticas só se mostram à natureza humana. Assim, é como ente privilegiado que deve ser compreendido o homem. A linguagem, em suas variadas formas, é a expressão dessa humanidade. A novidade de Ferreira da Silva foi interpretar a desocultação do ser não como poesia, mas como protopoesia, aproximando Heidegger da filosofia da mitologia de Schelling, alterando a teoria dos deuses causadores do processo teogônico deste último.

Esse esforço intelectual significou a busca de um caminho singular, libertando-se dos limites da filosofia existencial. Não sendo lícito aplicar aos deuses categorias utilizadas para desvelar o mundo do homem, o filósofo descobre no mito o modo de manifestação divina e neles o projeto a ser executado pelo homem.

As idéias sobre ética e política constituem parcela importante do pensamento vicentino porque antecipam a direção final de suas idéias. Essas idéias estão reunidas no segundo volume de suas Obras Completas (1966): A crise do direito no mundo atual, $O$ Crepúsculo da nacionalidade, $O$ sofismo da democracia, Sociedade e transcendência, Ócio versus trabalho, Educação e Filosofia, $O$ indivíduo e a sociedade, Marxismo e Imanência, Der Marxismus, $O$ conceito marxista do homem. 


\section{II - A raiz ontológica do conceito de crise}

Utilizando o referencial heideggeriano, nosso filósofo entendeu o homem como um ente em movimento. Em Utopia e liberdade (1964), ele perguntou-se "se o homem tem uma medida invariável através dos tempos, (...), ou se pelo contrário o homem é o fruto de seu fazer histórico" (v. I, p. 65). Concluiria pela segunda alternativa como Ortega y Gasset, apostando na capacidade humana de inovar. As mudanças do homem são o alimento da história concebida como o processo de percepção e registro do real. Uma melhor compreensão do homem pode ser elaborada com o estudo da linguagem, tanto na esfera mítica, com representações teogônicas do mundo, como no discurso lógico, que exprime a racionalidade. Ricardo Vélez Rodríguez observou que foi a aproximação com esse legado heideggeriano que permitiu ao filósofo estabelecer uma profunda crítica às utopias, inclusive a marxista, que povoam o pensamento ocidental. A imprevisibilidade do homem impede a tentativa de quantificar os resultados, de organizar e prever o futuro, tal como preconizam as utopias históricas. Estas esperam criar um novo homem e um novo mundo a partir de um planejamento rigoroso, o que a realidade humana impede. As razões da rejeição são aprofundadas nas suas teses morais e políticas. O homem é a realização da rebeldia, explicou Ricardo, lembrando que

"Ferreira da Silva assinala um aspecto muito importante desta rebeldia metafísica do homem: a liberdade. Aí deita raízes a distinção profunda entre o homem e as coisas que podem ser programadas" (Rodríguez, Paradigmas. 2 (1) dez. 1998. p. 17).

A aproximação com Heidegger constituiu uma etapa importante da obra de Vicente e preparou a transição para a derradeira. Luís Washington Vita explicou em que consiste a passagem para a fase final. Ele diz (1968): "O existencialismo do radical atiramento heideggeriano termina assim no idealismo fantástico de um mundo mágico. É o idealismo crepuscular do Mito, implícito na meditação vicentina que até a morte tentara apresentar uma transcrição pulsional e volitiva das filosofias de Schelling e Heidegger" (p. 231). Nessa fase, aparece o entendimento de que a humanidade passava por uma crise, circunstância descrita na obra A exegese da ação (1949), no ensaio Notas para um novo conceito de homem (1951) e no opúsculo Teologia e anti-humanismo (1953). No livro, o filósofo revelou os motivos pelos quais a civilização ocidental vivia o mal-estar. Algo ocorreu no mundo do homem de modo que ele não mais experimentava a plenitude de suas possibilidades, ficando impedido de efetivar autênticas realizações. O existir, afirmou, "tornou-se a consciência de uma privação, de um esforço, de um vazio espectante que exige um complemento para a sua orfandade" (v. I, p. 137).

$\mathrm{O}$ entendimento do momento derradeiro de seu pensamento se esclarece 
se examinarmos o conteúdo dos livros Dialética das Consciências (1950) e Filosofia do Mito. No primeiro, Ferreira da Silva destacou o aspecto existencial da vida humana, contrapondo-se à interpretação das relações pessoais contidas na filosofia de Hegel. Como diz Miguel Reale (1976): "No pensamento freiriano não encontramos o eu abstrato dos idealistas, ou seja, abstraído de seus atos espirituais e de suas circunstâncias" (p. 168/169). É a vida do homem concreto o que importa a Ferreira da Silva, não a evolução, um absoluto universal. Contra Hegel, elaborou também outra avaliação das relações humanas. Não que não houvesse na sociedade uma dimensão escravizadora, como a descrita por Hegel na dialética do senhor e do escravo, mas a tarefa humana é a de superá-la e construir as relações humanas sobre bases éticas.

Em Filosofia do Mito, completa-se a fase final de seu pensamento. Nela, Ferreira da Silva desenvolveu um conceito próprio de mito e cultura, ou melhor, do relacionamento entre ambas. As culturas, assim entendia, seriam formadas com a explicitação dos mitos. Os mitos representam o momento mais criativo da imaginação criadora, nascendo cada cultura de um poema originário. O desenvolvimento da cultura seria a concretização da história contida no mito originário, que representa as forças mais vivas do grupo humano. Era esse pensamento, e não o lógico ou científico, o melhor canal de manifestação da liberdade humana. Foi porque perdeu essa dimensão, confiou na razão instrumental e operou a redução do real ao dado que o homem caiu em crise, conforme afirma em $A$ exegese da acção. A liberdade do homem é essencial para revelar sua humanidade e esta não se manifesta à parte da liberdade dos deuses, tal como aparece nos mitos. A liberdade do ser tinha a força do apelo e o homem somente implementa sua liberdade deixando-se atrair por esse apelo. A cultura é a realização da liberdade na medida em que realiza o projeto mítico instaurado na origem da civilização.

O que houve com o homem? Por que ele deixou de olhar o apelo de transcendência que a arte é capaz de lhe oferecer? Por que construiu uma visão pragmática e imediatista da vida e da arte? Para o filósofo, vivia-se num tempo de uma filosofia pouco meditada, oculta. É ela que baniu o entendimento de que a arte é mais do que expressão formal de palavras ou coisas. Ele esclarece:

"Só numa época de materialismo e positivismo e portanto de predomínio de uma filosofia inconfessada, mas atuante, é que podem vicejar essas idéias distróficas que reduzem a arte à decoração interna ou externa de uma substância incomovível" (v. II, p. 421).

Uma filosofia materialista e positivista realça o papel da tecnologia na ciência. $\mathrm{O}$ resultado é que a ciência encampa o ideal racional e bane, por falta de sentido, os outros aspectos da cultura. O resultado, resume Ana Maria Ro- 
drigues (2001), é que "Vicente considerava o homem contemporâneo estranho e infeliz no mundo artificial criado pela tecnologia" (p. 62).

A expulsão do transcendente, da arte, do mito e dos deveres da vida quotidiana não apenas empobrece suas possibilidades, ela reduz a realidade a um frágil humanismo que interpreta as criações culturais como expressão dos impulsos e instintos corporais. Isso corrobora a idéia de que a arte é um jogo formal de ritmos e que a criação artística nada tem além de uma técnica e do funcionamento de mecanismos físico-matemáticos e verbais. Se a tanto nos levou esse tempo de filosofia pobre, a alternativa é combater não a ciência e seus benefícios, mas os subprodutos que a ela se vincularam, isto é, a representação material e positiva do mundo que baniu a transcendência.

\section{III - A noção da crise na base do debate ético}

$\mathrm{Na}$ avaliação de Ferreira da Silva, o homem do seu tempo mergulhou numa crise. Qual a origem dela? Vimos que o filósofo fala de mudanças culturais de modo que ele não mais experimenta suas possibilidades, quedando impedido de realizar o que pode. Por isso ele rejeita as normas de conduta e princípios que dão sustentabilidade à vida social. $\mathrm{O}$ que o homem de seus dias rejeita não são só costumes e princípios, mas a organização da sociedade. A rejeição se estende a todos os aspectos da vida. Contesta-se, diz o filósofo, em A crise do direito no mundo atual: "o ideal de vida individual ou social que transmite ao direito sua fundamentação necessária" (v. II, p. 434). Estava, avalia Ferreira da Silva, o homem sem rumo, desencantado das relações pessoais, pois não encontrava nas justificações filosóficas sentido e significado para sua existência. "A vida é expressão de realidades mais amplas que a finitude, mas nosso tempo insiste em não ver as coisas desse modo" (Carvalho, 2004, p. 237). A falta de justificação para a existência, a incapacidade de enxergar os aspectos maiores que os interesses individuais, alcança os princípios morais e as leis. De uma sociedade que não sabe o que fazer de sua vida não se espera que aceite como justo e correto qualquer princípio normativo, nem leis que regulem o comportamento coletivo.

\section{IV - A crise moral e a fragilidade institucional do Estado Brasileiro}

Ferreira da Silva entende que a crise moral alcança o universo político e as instituições brasileiras. Assim, a falta de referência moral afeta o cidadão e a disputa política perde os objetivos nacionais, explica em $O$ crepúsculo da nacionalidade. O comportamento político observado nessa circunstância "parece ditado pela concupiscência dos grupos partidários e em vista dos proventos materiais que possam retirar do assenhoramento dos postos políticos" (v. II, p. 444). A falta de confiança nos destinos nacionais afeta a crença nas ins- 
tituições públicas. A escola é a primeira a ser contaminada pela falta de entusiasmo. O professor não se mostra apaixonado por seu ofício e repete os compêndios. O aprofundamento intelectual é deficitário e a formação do mestre insuficiente.

Quando a crise institucional afeta a esperança no futuro, assisti-se ao surgimento de um individualismo exacerbado, em que o interesse singular não se coaduna com os objetivos coletivos. Nessa situação, as dificuldades são enormes porque "a hipertrofia do indivíduo redunda na subordinação do eterno ao efêmero, do substancial ao acidental" (idem, p. 437). Sem um projeto nacional, o individualismo se resume à disputa egoísta. $\mathrm{O}$ ideal político romântico que ele assume parte do entendimento da vida concreta como um projeto existencial no qual a essência do homem é definida, como para Heidegger, por Sorge. É isso, ele diz, que "devemos entender por existencialidade do homem, pela previdência do possível sobre o real, em sua estrutura" (idem, p. 439). Encontra, assim, Ferreira da Silva, nessa referência à nacionalidade, o contraposto à existência concreta, que termina numa subjetividade isolada à moda cartesiana.

Ferreira da Silva está longe da solução liberal ${ }^{2}$, mas entende que, mesmo quando se admite o Estado como mal necessário, "é mister que o mal seja o menos atuante possível" (idem, p. 441). Finalmente, à moda de Ortega y Gasset, Ferreira da Silva vê na desvitalização da escola uma fragilização da cultura. Ortega entende que o motivo desse fato é o vivermos o tempo das massas Ferreira da Silva avalia que a razão é a ausência de algo maior que a subjetividade capaz de sustentar o entusiasmo para agir bem.

A falta do espírito nacional culmina na desvitalização e corrupção da democracia, o que favorece a ascensão de fortes grupos econômicos aos altos postos do Estado. O sufrágio, arma da democracia, vira um instrumento na mão dos poderosos que o empregam para tomar o comando do Estado. É assim que as elites colocam os estudantes e as lavadeiras a serviço da sua causa.

A ausência de virtudes públicas, como ocorria na Antiga Grécia é tema de outro ensaio importante intitulado Sociedade e transcendência. Nenhuma sociedade se origina por contrato, como supõem os liberais. Também nesse ponto Ferreira da Silva concorda com Ortega y Gasset.

Os indivíduos agindo separadamente não produzem cultura, como ele afirma:

2 As críticas orteguianas ao modelo contratualista de origem das sociedades, bem como sua rejeição do individualismo dos empiristas, encontram-se no capítulo VII A liberdade política e os governos totalitários do livro Introdução à filosofia da razão vital de Ortega y Gasset. 
"O mais interessante, entretanto no que diz respeito à veracidade da concepção individualista (...), é o fato de que não se tem civilização ou uma cultura, a partir da deliberação e da vontade dos indivíduos" (v. II, p. 447).

Ele prefere outra explicação já bastante antiga na cultura ibero-americana. Faustino José já se perguntava, no século XIX, (1823):

"Quem associou as formigas? As abelhas? As gralhas? Seria a natureza ou a convenção? Os tratados de medicina (...) as convenções poderiam ser arranjadas pelos homens antes de observarem uma e muitas vezes as leis e produções da natureza" (p. 41).

Como Ortega, ele rejeita a teoria contratualista. A sua solução não foi, contudo, a encontrada pelos tradicionalistas como Faustino José, nem está nos clubes de jovens motivados pelo desejos amorosos, como ensina Ortega, mas está na alma nacional, como diz a Escola do etnólogo Leo Frobenius (1873-1938), que põe, "na origem dos desempenhos culturais uma espécie de invasão da alma por uma substância divina" (idem, p. 448).

\section{V - Crítica à essência ética do trabalho}

A tradição ocidental adotou o trabalho como indicativo de comportamento ético. No mundo moderno, esse ideal aparece claramente no liberalismo de John Locke e mais tarde foi radicalizado pelos filósofos sociais de direita e esquerda. Tais teóricos, afirma Ferreira da Silva em Ócio versus trabalho, entendem que "o homem tornou-se homem através do trabalho. $\mathrm{O}$ trabalho humanizaria, formaria e educaria" (v. II, p. 449). No entanto, examinando os objetivos dos que trabalham e poupam para ter uma velhice tranquiila observa, que se tem em vista o ócio. Essa observação vai contra a tese de que trabalhar possui uma essência ética. Se admitirmos um humanismo do trabalho, perdemos, na avaliação de Ferreira da Silva, o sentido profundo do viver. Todo momento de criação artística, de aposentadoria, ou de interrupção do trabalho seria um erro ético. Se isso fosse verdadeiro, deveríamos condenar moralmente o descanso dos velhos e a incapacidade das crianças.

Ferreira da Silva não critica o trabalho ou contesta a sua relevância na vida social, apenas rejeita tomá-lo como essencialmente ético porque "o antitrabalho aparece como o antivalor, a ociosidade repulsiva, a criminalidade, a irresponsabilidade e a perdição" (idem, p. 450).

Falar de uma essência ética do trabalho é também difícil num mundo que evolui para reduzir o trabalho formal. $\mathrm{O}$ aumento da tecnologia e das máquinas significa que o homem trabalhará menos no futuro. Mesmo que as sociedades do futuro ocupem parcela intelectualmente privilegiada de seus membros, as massas terão reduzido o seu tempo de trabalho. Ferreira da Silva 
entende que chegará o dia em que "o trabalho humano tornar-se-à anti-científico, antieconômico e antitrabalho" (idem, p. 451). Portanto, a tese parece-lhe indesejável.

\section{VI - Rejeição da visão pragmática da vida}

A rejeição à essência ética do trabalho e a redução da vida ao que é útil estão na base de suas críticas ao pragmatismo e às conclusões pedagógicas que ele sugere. A base da crítica encontra-se em A exegese e acção (1949), na qual diz que o mal estar da nossa cultura se deve à perda da alegria e do uso da plenitude da sua energia, um pensamento que lembra a crítica orteguiana a uma sociedade de massas. Escreve o filósofo:

\footnotetext{
"A cada momento a consciência sente que a rodeia não a vida e a fruição da vida, mas sim qualquer coisa que a precede, prepara e interrompe, e tudo fica sempre relegado para a vida sucessiva. $O$ existir tornou-se a consciência de uma privação, de um esforço, de um vazio espectante que exige um complemento para a sua orfandade" (v. I, p. 137)
}

O ideal educativo do pragmatismo, o filósofo apresenta e rejeita no ensaio Educação e Filosofia. Sintetiza-o como "a redistribuição da juventude, sem entraves, pelas ocupações úteis" (v. II, p. 455). O resultado da educação pragmática é a formação de profissionais capazes de promover o máximo de transformação da natureza pela adesão absoluta à mentalidade técnico científica. Superar a mentalidade positivista e tecnicista, parece-lhe necessário para "a superação de um ciclo cultural já agora, irremediavelmente, abandonado ao dilaceramento dos seus absurdos" (Vita, 1968, p. 231). Reale esclarece a compreensão de Ferreira da Silva sobre a questão (1976):

\footnotetext{
"Seria errôneo, contudo, julgar que quando o pensador paulista condena as implicações preformadas da mentalidade técnico-científica está ele pensando em fugir da realidade. $O$ que lhe parece, ao contrário, é que a realidade captada por esquemas categoriais das ciências é uma realidade incompleta, como incompleta é toda a esfera da mundanidade ou do vivido quotidiano" (p. 170).
}

Acompanhando Ortega y Gasset, que diz que "a pedagogia costuma andar 20 anos atrasada em relação às conquistas mais notáveis do pensamento" (v. II, p. 456), Ferreira da Silva discorda que os princípios individualistas e utilitaristas promovam o bem social. Ao contrário, afirma: "A aventura da liberdade absoluta terminou no terror, porque essa liberdade é em si mesma morte" (idem, p. 457). Se o propósito é formar uma juventude solidária e preocupada com os destinos humanos, é preciso alterar as práticas pedagógicas competitivas que marcam a sociedade capitalista e também a comunista, em que a disputa é camuflada, mas existe por cargos e posições privilegiadas da 
hierarquia. A educação não pode se reduzir ao adestramento científico, moral ou tecnológico, afirma Ferreira da Silva, mas alcançar "a capacidade de criar e de fluir a beleza na dimensão artística" (idem, p. 461). Como lembra Braz Teixeira (1997), a dimensão artística é, para Ferreira da Silva, "um convite ou um incitamento para a transcendência, para um gênero de experiências que derroga a lei da praxis, pois a intenção do artista é (...), provocar o arrebatamento, o movimento do eu que dê livre curso à sua criatividade própria" (p. 186). O ideal pedagógico Ferreira da Silva busca em Ortega y Gasset. Diz o filósofo em Educação e Filosofia: "Não foi outro senão Ortega y Gasset a nos ensinar que a vida é uma faina poética, isto é, um assunto de imaginação, de superação contínua das coordenadas do já dado" (v. II, p. 461).

A educação poética de Ferreira da Silva nada tem de fantasiosa. O que ele apreende de Ortega y Gasset é também o que afirma um dos maiores físicos de seu tempo, Jacob Robert Oppenheimer (1904-1967), Diretor do Centro de Energia Atômica de Los Alamos e ganhador do prêmio Fermi de 1963. Ferreira da Silva concorda com ele quando diz que: "a matemática é uma linguagem. $\mathrm{O}$ artista, o cientista, vivem à beira dos grandes mistérios da vida $\mathrm{e}$ do universo. Ambos procuram um equilíbrio entre o novo e o que existe, ambos procuram por uma ordem no caos. É preciso que todos tenham o espírito o mais alerto possível" (idem, p. 462).

Só a educação calcada nos ideais propostos por Ortega y Gasset e Oppenheimer pode servir ao futuro da humanidade, ideais que, na sua avaliação, não estavam contemplados na lei de Diretrizes e Bases da Educação Nacional sancionada naqueles dias.

\section{VII - Crítica moral ao individualismo abstrato}

Ferreira da Silva entende que a filosofia de seu tempo não fala de subjetividades absolutas desvinculadas do seu meio. A dialética senhor e escravo proposta por Hegel, há muitas décadas, mostrava que só há um porque existe o outro. Afirma o nosso pensador em $O$ indivíduo e a sociedade que "existir é essencialmente um estar no-mundo, estar exposto a um mundo, sendo realmente nossa existência a realidade formadora do mundo" (v. II, p. 466). A melhor forma de referir-se a uma existência circunstanciada é lembrar Ortega y Gasset, conforme esclarece:

\footnotetext{
"Ortega y Gasset procura expor semelhante conjuntura ontológica na conhecida expressão: yo soy yo mi y circunstancia. $\mathrm{O}$ primeiro eu alude à nossa realidade radical que inclui o nosso eu psicológico e, ademais, as eventualidades sócio-mundiais" (idem, p. 466).
}

A existência humana se passa no meio da cultura, em sociedade, recebemos uma herança que não escolhemos, mas que integra nossa vida. Reale sis- 
tematiza o pensamento de Ferreira da Silva afirmando que o existente procura a plenitude de seu ser pessoal. Ele diz que o homem (1976): “concretamente toma posição, pensa, quer, age, realiza, sem jamais se desligar do condicionante de sua sensibilidade intransferível" (p. 169).

Da mesma forma que Ortega y Gasset considera que primeiro vivemos a dimensão do nós e só depois, por força de nossas escolhas, chegamos a nos individualizar pela capacidade de transcender o que se é. Ferreira da Silva entende que a individualidade, própria do homem, não é uma condição isolada de tudo o mais. Primeiro porque é "o indivíduo o destinatário desse apelo do ser, do ser compreendido radicalmente como offenheit, como abertura de possibilidades historiáveis no mural da história" (idem, p. 470). Também porque o vínculo com a cultura possui outra dimensão importante que ele detalha: "é o indivíduo que desenha sofridamente essas configurações da vida, em trágica oposição com o espírito social e suas estratificações rígidas" (idem, p. 470). Isso significa, como observa Esteves Pereira, que é convivendo que o homem descobre o sentido de sua vida (2001): "a filosofia como idioma de apelo e de liberdade também poderá ser o encontro do outro pondo em movimento a consciência de si" (p. 49).

A conclusão é que a defesa do indivíduo não é o mesmo que uma subjetividade abstrata, mas um modo de viver que se realiza na cultura. A busca de um caminho próprio ou da própria verdade é algo que nasce no universo cultural.

\section{VII - A defesa ética do indivíduo}

Rejeitar a subjetividade abstrata não significa desconsiderar a realidade do indivíduo. Já explicamos que para Ferreira da Silva (2000): "o homem vive em grupo, nasce em sociedade e não tem como criar sua singular realidade espiritual senão a partir desta circunstância. No entanto, o homem somente se afirma ao construir um espaço de distanciamento do mundo social" (p. 275). Sabemos que isso lembra o propósito de Ortega y Gasset, que também esperava que o homem elaborasse uma vida única partindo da circunstância em que vive. "Sendo um ente histórico, o ambiente e o próprio homem nesse ambiente constituem uma síntese (...). A noção de circunstância engloba com vantagem o que Hegel chamara espírito do tempo" (Carvalho, 1998, p. 116).

A defesa da liberdade pessoal e do destino singular de cada homem foi resumida, por Ferreira da Silva, na teoria da solidão apresentada no Congresso Nacional de Filosofia da Argentina, de 1949. Ali, disse que "unicamente o nosso ser, como não coisa, como excedente à natureza, pode produzir-se como destino solitário e distante" (v. II, p. 99). A importância da singularidade existencial se explicita na crítica que faz ao marxismo. O problema central é a crença comunista de que o indivíduo é um produto do meio, uma realidade 
forjada, e não uma força em ação. Como observa Pedro Calafate (2001), o eixo da antropologia vicentina é que " tudo depende do nosso consentimento, pela dinâmica da vontade, apresenta-se como um inventor de mundos" (p. 52). No ensaio Marxismo e imanência, o filósofo considera que o marxismo negligencia a consciência pessoal e "pensa o homem exclusivamente em sua coexistência exterior e político-social" (p. 479). O marxismo reduz o heterogêneo ao homogêneo.

\title{
VIII - O marxismo entendido como projecto moral
}

Mesmo considerando que o marxismo coloca mal o problema da liberdade pessoal, Ferreira da Silva enxerga o movimento como uma extensão do projeto moral de Kant. Ele afirma no ensaio Marxismo e imanência que:

\begin{abstract}
"toda concepção marxista do homem, da sociedade e da história nada mais é do que um desenvolvimento do conceito de autonomia da razão humana, afirmada categoricamente por Emmanuel Kant. Neste postulado de autonomia dos poderes humanos, seja no campo do conhecimento, seja no campo da ação ética, é que se inspira a antropologia intrínseca do marxismo" (v. II, p. 473).
\end{abstract}

Kant aplicou o conceito de autonomia moral ao mundo da práxis e fez dela a virtude e guia das ações. A conclusão de Ferreira da Silva é que "o homem autônomo de Kant está na origem da imagem do homem marxista, como ser absolutamente autocriador de si mesmo" (idem, p. 474). Ferreira da Silva aproxima o conceito marxista de alienação da noção de heteronomia da vontade proposta por Kant. Nos dois casos, entende, o comando da ação se localiza fora da vontade, o que é rejeitado no kantismo e no marxismo. O marxismo, acompanhando o iluminismo kantiano, se apresenta como um humanismo que confia na razão e promove a valorização absoluta do homem. Ferreira da Silva, como lembra Crippa (1978), "tem muitas dúvidas a respeito do fastidioso eudesamento do homem" (p. 107). Observa que o marxismo é um humanismo mais radical que o kantismo, pois não se observa em Kant uma opção atéia. Ferreira da Silva afirma, em Marxismo e imanência, que: "na subjetividade do homem está o nosso microteos, que não admite outro Deus a seu lado. A superação de Deus é a própria realização do comunismo, em plena equação e exaustiva equivalência de significado" (idem, p. 478).

É porque toma o marxismo como projeto moral que o filósofo se nega a entendê-lo como científico. Ele afirma, no artigo Der Marxismus, o caráter conjectural das previsões históricas de Marx. Afirma que "os supostos últimos das afirmações apocalípticas de Marx são meras conjecturas sobre a marcha da história" (p. 484). Não parece possível fazer qualquer observação imparcial sobre o futuro humano, equívoco que o próprio Kant cometeu ao deixar de lado a parcimónia que estabelecera com o criticismo. 
É no pensamento heideggeriano que Ferreira da Silva diz encontrar uma análise adequada do trabalho e da tecnologia. Afirma: "segundo a concepção heideggeriana, o voluntarismo e o subjetivismo também formam parte da mesma concepção de mundo" (idem, p. 485). Ele encontra nos mitos primitivos os elementos que fundamentam a história humana. Ela é construída sobre o que há de mais significativo, autêntico e profundo nos mitos ou, como diz Vita, em Antologia do pensamento social e político no Brasil (1968), "a sua crítica à cultura antropocêntrica própria do mundo ocidental de que o marxismo é, talvez, o último capítulo, é a proposição de uma nova via de acesso às fontes primárias do ser" (p. 459/460).

A leitura que faz do marxismo aponta-lhe o caráter materialista e positivista da sua ontologia, divergindo da interpretação de Eric Fromm, que retira do marxismo tais características. O conhecido psicanalista não se dá conta de que o conceito marxista de homem nasce na formulação de Hegel, embora Marx o deturpe e se afaste dele. Outro erro de interpretação de Fromm, Ferreira da Silva aponta no artigo em que comenta o livro $O$ conceito marxista do homem. Ele diz que a idéia de ação e também o conceito de alienação são de Hegel e não, como diz Fromm, de origem bíblica. A sua conclusão é que o livro não acrescenta nada de importante ao que já se conhece do marxismo.

\section{VIII - Considerações finais}

As teses morais de Ferreira da Silva mostram o diálogo que estabeleceu com o existencialismo heideggeriano e com o raciovitalismo de Ortega y Gasset. É esse diálogo que permite o entendimento de que a subjetividade humana não pode mais ser abordada de modo abstrato, afastada da circunstância em que se realiza. É também no pensamento de ambos que se baseia para rejeitar a noção de determinismo socioeconômico. Cabe ao homem romper com o determinado e construir sua vida. A idéia de existência é fundamental porque nela se contempla a presença de algo que supera o eu, situando-o no mundo, mas lhe assegura a possibilidade de superar aquilo que impede a sua realização.

Ferreira da Silva ainda se baseia nos dois autores para afirmar que a vida é a construção de uma trajetória livre de vida. Rejeita, pois, o mito do progresso contínuo da história que lhe parece uma perversão da capacidade humana de alterar as circunstâncias. Volta-se, então, para o campo de influência heideggeriana ao reconhecer, como resumiu Ricardo Rodríguez (1998), que: "só existe um caminho para a verdadeira libertação: a abertura ao pensamento eidético, que é a abertura ao ser e que exige de nós um duro sacrifício" (p. 16). A influência heideggeriana se deixa ver, acrescenta Antônio Paim (2000), porque Heidegger diz, na Carta sobre o humanismo, algo de que Ferreira da Silva assume: "que o corpo do homem é totalmente diverso das unidades biológicas de outros seres" (p. 124). 
O diálogo com Heidegger leva-o a rejeitar o utopismo marxista porque parece-lhe despropositado fazer qualquer afirmação determinista sobre o imprevisível futuro do homem. Ler o marxismo como um projeto moral vinculado ao que concebeu Kant é a sua maneira de corrigir esse abuso elaborado. Outra razão para repudiar o utopismo marxista é o pressuposto de que está nas relações econômicas o principal da cultura. Os povos têm, entende, em seus mitos primitivos, a raiz não racional que os orienta na forma de arquétipo. Os arquétipos, como guias, projetam o divino na existência humana. Essa base mítica e lúdica fundamenta a ação, promovendo um estado interior que se aproxima do que o homem moderno entende por felicidade. A moral lúdica não significa a irresponsabilidade ou frivolidade, mas, como avalia Pedro Calafate (2001), é uma ação que: "é antes um fim em si própria, dando-nos então a emoção da plenitude vital" (p. 59). O homem não adere essencialmente às utopias porque tem em sua condição ôntica uma dimensão lúdica e mítica denominada poética. Esclarece Marcondes Cesar (2001) que, "inspirada em Heidegger, Vicente Ferreira da Silva (...) entende a poesia como o desvelamento da verdade, da origem, através de uma linguagem simbólica" (p. 27). Na avaliação de Antônio Paim (1997), foi Adolpho Crippa quem desenvolveu esta intuição vicentina de que há uma relação entre os mitos e os arquétipos culturais. Isso significa que "a situação existencial e valórica do homem no mundo e na história esclarece-se imediatamente à luz das imagens e dos símbolos que emanam da riqueza por eles delineada" (p. 698).

Ferreira da Silva volta a se aproximar de Ortega y Gasset quando aplica a dimensão lúdica ao processo educativo, toma-a como elemento da conduta ética. Uma educação verdadeira para Ferreira da Silva, diz Calafate (2001), consiste "em propiciar o desenvolvimento da liberdade e esta só se haveria de desenvolver pelo cultivo da imaginação. A imaginação tem sua expressão no universo da arte, da poesia, da música e das festas" (p. 71). É essa aproximação de Ortega que dá ao seu pensamento de cunho existencial, como ainda observou Calafate: "o dinamismo, a alegria e a ludicidade em detrimento da ansiedade" (idem, p. 59). Na verdade, o que Ferreira da Silva, como Ortega y Gasset, espera superar é a angústia existencial de que fala Heidegger, angústia que para o alemão está presente na vida humana, como já dissemos (1999): “a angústia brota do inevitável isolamento do existente, (...). Ela é a atitude humana frente à falta de significação incontestável das coisas do mundo" (p. 61). Dar curso ao que o homem tem de mais profundo não culmina necessariamente na angústia. Ferreira discorda de Heidegger. 


\section{BIBLIOGRAFIA}

Calafate, Pedro. A antropologia na obra de Vicente Ferreira da Silva. In: Atas do V Colóquio Tobias Barreto. Lisboa: Instituto de Filosofia Luso-brasileira, 2001.

Carvalho, José Mauricio de. O homem e a filosofia. Porto Alegre: EDIPUCRS, 1998. . Filosofia da cultura. Porto Alegre: EDIPUCRS, 1999.

. Curso de introdução à filosofia brasileira. Londrina: CEFIL, 2000.

Contribuição contemporânea à história da filosofia brasileira. 3. ${ }^{\mathrm{a}}$ ed. Londrina: CEFIL, 2001.

. Introdução à filosofia da razão vital de Ortega y Gasset. Londrina: CEFIL, 2002.

. Vicente Ferreira da Silva e o sentido da arte. Revista Brasileira de Filosofia, 53 (214): 231-244, abr./jun. 2004.

Centro de Documentação do Pensamento Brasileiro. Dicionário Biobibliográfico dos autores brasileiros. Brasília: Senado Federal, 1999.

Cesar, Constança Marcondes. O grupo de São Paulo. In: Atas do V Colóquio Tobias Barreto. Lisboa: Instituto de Filosofia Luso-brasileira, 2001.

Crippa, Adolpho. As idéias filosóficas no Brasil. São Paulo: Convívio, 1978.

Jaime, Jorge. História da filosofia no Brasil. v. III, Petrópolis: Vozes; São Paulo: Faculdades Salesianas, 2000.

Madre de Deus, Faustino José. Epístola à nação francesa (...). Lisboa: Impressão Régia, 1823.

Paim, Antônio. História das idéias filosóficas no Brasil. Londrina: CEFIL, 1997. . Filosofia brasileira contemporânea. Londrina: CEFIL, 2000.

Pereira, José Esteves. A filosofia como idioma de apelo e de liberdade. In: Atas do V Colóquio Tobias Barreto. Lisboa: Instituto de Filosofia Luso-brasileira, 2001. Reale, Miguel. Filosofia em São Paulo. 2. ed. São Paulo: Grijalbo/EDUSP, 1976. . A posição de Vicente Ferreira da Silva no IBF. In: Atas do V Colóquio Tobias Barreto. Lisboa: Instituto de Filosofia Luso-brasileira, 2001.

Rodrigues, Ana Maria Moog. A moral lúdica segundo o pensamento de Vicente Ferreira da Silva. In: Atas do V Colóquio Tobias Barreto. Lisboa: Instituto de Filosofia Luso-brasileira, 2001.

Rodríguez, Ricardo Vélez. Mito e cultura em Vicente Ferreira da Silva; aspectos éticos e antropológicos. Paradigmas, 2 (1): 15-20, dez. 1998.

Silva, Vicente Ferreira da. Obras Completas. São Paulo: IBF, 1966. v. I e II.

Teixeira, António Braz. O primeiro ciclo do pensamento de Vicente Ferreira da Silva. O Espelho da razão. Londrina: EDUEL, 1997.

Vita, Luís Washington. Pequena história da filosofia. São Paulo: Saraiva, 1968. . Antologia do pensamento social e político no Brasil. São Paulo: Grijalbo/ /União Pan-Americana, 1968. 


\title{
O PENSAMENTO POLÍTICO DE HIPÓLITO DA COSTA
}

\author{
João Pedro Rosa Ferreira* \\ CHC-UNL
}

"Em ser feliz é que consiste a verdadeira liberdade"

Colecção de Máximas Políticas, Correio Braziliense, 175 (Dezembro de 1822), p. 589

Hipólito José da Costa Pereira Furtado de Mendonça foi um homem de pensamento e acção. Defensor dos ideais de liberdade e progresso que o levaram a aderir à Maçonaria, em Filadélfia, e a acamaradar com Francisco de Miranda e Simon Bolívar, em Londres, foi vítima do despotismo e sofreu o cárcere às mãos da Inquisição, em Lisboa, durante três anos, de 1802 a 1805.

Na fuga da prisão do Santo Ofício foi ajudado pelo seu irmão maçon Augusto Frederico, duque de Sussex, filho do rei Jorge III de Inglaterra, que se tornou seu protector durante o exílio em Londres, ao longo de 18 anos, até à morte de Hipólito da Costa, a 11 de Setembro de 1823. Neste contexto, é natural que o redactor do Correio Braziliense tenha adoptado os valores do sistema constitucional inglês e o seu liberalismo tenha a marca da moderação, do gradualismo, como método preferencial de evolução política.

Ao longo dos seus 175 números, publicados ininterruptamente entre Junho de 1808 e Dezembro de 1822, o Correio Braziliense revela-se um órgão de difusão de uma ideologia - o liberalismo - tributária do iluminismo setecentista, corporizada no modelo parlamentar assente na separação e equilíbrio dos poderes e fundada no consentimento dos governados. Tal ideologia de emancipação fundamenta e vindica os interesses imediatos de um grupo social, a burguesia comercial, que o redactor classifica como "a classe de cidadãos mais úteis ao governo e mais interessantes ao Estado do Brasil nas circunstâncias actuais"'.

Ao mesmo tempo, em muitas edições do Correio é patente uma sensibilidade para com a situação das "classes inferiores" e a tónica colocada na possibilidade de "melhoramento" do seu estado, designadamente através da generalização do ensino, na linha do optimismo herdado das Luzes. Testemunham essa sensibilidade os repetidos anúncios a obras de pendor filantrópico publi-

* Inédito em Portugal, o presente artigo retoma, com alterações, ideias desenvolvidas no trabalho "Jornalismo e Pensamento Político", publicado na reedição fac-similar do Correio Braziliense, vol. XXX, tomo 1 (Estudos), São Paulo, Imprensa Oficial do Estado, 2002, pp. 371-402.

Correio Braziliense, 35 (Abril 1811), p. 435. 
cados na secção "Literatura e Ciências" e o acompanhamento da polémica sobre as 'Poor Laws' no Parlamento e na Imprensa britânicos. Exemplo dessa preocupação é a pormenorizada "Análise do folheto intitulado A New View of Society, ou Ensaio sobre o princípio da formação do carácter humano e da aplicação do princípio à prática, por um dos Juízes de Paz de S.M. no Condado de Lanark, Londres, 1813"'2. Trata-se da célebre obra de Robert Owen, que Hipólito integra na corrente filantropista, elogiando a sua proposta de reforma social através da reforma da educação. $\mathrm{O}$ interesse por este problema vinha de longe: enquanto membro da Junta da Impressão Régia, em 1801, traduzira o filantropo e reformador Rumford ${ }^{3}$.

\section{Acção}

Se bem que alicerçada em princípios filosóficos coerentes, a preocupação primeira do Correio não era a elaboração de uma ideologia no sentido de um sistema teórico - a doutrina veiculada pelo periódico tinha uma dimensão fundamentalmente prática.

"O primeiro dever do homem em sociedade é ser útil aos membros dela, e cada um deve, segundo as suas forças físicas ou morais, administrar em benefício da mesma os conhecimentos ou talentos que a natureza, a arte, ou a educação the prestou. $O$ indivíduo que abrange o bem geral de uma sociedade vem a ser o membro mais distinto dela: as luzes que ele espalha tiram das trevas, ou da ilusão, aqueles que a ignorância precipitou no labirinto da apatia, da inépcia e do engano." meiro número.

O que se pretendia era orientar de modo inequívoco a acção transformadora de um real bloqueado - o absolutismo monárquico opressor da sociedade luso-brasileira nas duas primeiras décadas do século XIX. O raciocínio subjacente era, neste aspecto, tributário da corrente utilitarista. Não foi fácil a tarefa do doutrinador. Por um lado, era confrontado com o conservadorismo dos "egoístas defensores do despotismo". Por outro lado, opunha-se-lhe o radicalismo apressadamente bebido em abstracções visionárias de um ordenamento absolutamente racional do real.

${ }^{2} C B, 58$ (Março, 1813), p. 295-299 e 59 (Abril 1813), pp. 426-430. Outro exemplo é o entusiástico acolhimento, nas páginas do Correio, do sistema de educação elementar de Lancaster e Bell, explicado minuciosamente em sucessivos artigos, de Abril a Outubro de 1816 (cfr. $C B$ 95 , pp. 346-350; 96 , pp. 460-467; 97, pp. 591-598; 98, pp. 58-62; 99, pp. 205-209; 100, pp. 317-321; 101, pp. 468-472.

3 Ensayos Politicos, Economicos e Philosophicos por Benjamin, conde de Rumford ... traduzido do vulgar por Hippolyto José da Costa Pereira, 2 tomos, Lisboa, Regia Oficina Tipográfica, 1801-1802.

${ }^{4} C B, 1$ (Junho 1808), p. 3. 
Hipólito da Costa procurou transmitir aos seus leitores a ideia de que esta última pretensão era inexequível, dada a manifesta impossibilidade de o império exclusivo da razão se afirmar perante as paixões que, humanamente, a submergem. Contemporâneo da Revolução francesa, Hipólito fora testemunha de como o "democratismo" conduzira ao Terror jacobino e à tirania napoleónica, cujo perigo foi uma ameaça real, durante os primeiros oito anos de publicação do Correio.

O que estava ao alcance dos homens concretos era, nas próprias palavras do Braziliense, um "meio termo", o "justo equilíbrio" entre atitudes extremas, a contra-revolucionária e a radical. Procurava-se atingir o acessível: "Quando se trata do melhoramento de um governo, não é a sua bondade absoluta que se deve tomar em consideração; mas sim a sua bondade relativa, ou por outros termos, o grau de felicidade que a mudança pode trazer consigo." 5

Porém, na questão fundamental, não havia dúvidas nem hesitações. Em Fevereiro de 1822, Hipólito da Costa reage à acusação de "corcunda" (apodo com que, em tom pejorativo, os liberais designavam os partidários do absolutismo) lançada contra o Correio, devido a críticas feitas ao novo governo:

"Não suponham que nós, notando defeitos no actual sistema, queremos, nem directa nem indirectamente, aprovar o sistema passado: esse era tão mau, que nada de mal que aconteça agora é capaz de o igualar.... é claro que um Sistema de Governo Constitucional, ainda que mau, é preferível a um Sistema despótico aonde não há outra regra senão na vontade sempre variável do déspota ou déspotas que governam."

\section{Epistemologia}

É evidente, nas páginas do Correio, alguma perturbação provocada pelo esforço de matizar o optimismo absolutizante das Luzes com as cores, menos chocantes, do empirismo, este mais exigente no que respeita à fidelidade que os retratos traçam do modelo:

"É verdade que os homens de poucos ou nenhuns conhecimentos seguem a rotina de seus costumes: desta gente se compõe a maioridade em todas as nações. É também verdade que os homens iluminados acham muitas vezes que lhes é necessário seguir a corrente dos costumes da nação aonde vivem, quer os aprovem, quer não. É igualmente certo que muitos legisladores iluminados têm feito leis, não em conformidade de suas ideias justas e aperfeiçoadas, mas em contemplação dos costumes dos povos para quem legislaram, e esta condescendência, quando bem regulada, tem merecido a aprovação dos sábios, pela óbvia razão de que nenhuma legislação, por mais perfeita que

5 Ibidem, 53 (Outubro 1812), p. 675.

${ }^{6}$ Ibidem, 165 (Fevereiro 1822), pp. 172-173. 
seja, pode existir, se estiver em directa oposição aos costumes dos povos a que é destinada. Ao diante desenvolveremos mais estas noções, mas estas condescendências dos homens sábios com os costumes da maioridade da nação não provam que se siga o hábito a despeito da razão: os rotineiros não são homens iluminados, seguem o costume porque mais não entendem, e os sábios conformam-se como costume, porque se não podem opor à multidão."

Está aqui presente a lição de Hume, embora o nome do filósofo não seja citado, o que se repete, aliás, na recensão às Prelecções Filosóficas sobre a Teoria do Discurso e da Linguagem, a Estética e Diceósina e a Cosmologia, de Silvestre Pinheiro Ferreira, onde Hipólito menciona Descartes, Locke e Condillac e faz referências à "combinação de ideias", sem citar o teorizador do conceito ${ }^{8}$.

\section{Modelo}

No pensamento político de Hipólito da Costa, a noção de harmonia social funciona como pedra angular. A Constituição será o garante de que os diversos factores concorrentes para essa harmonia poderão evoluir, livres dos constrangimentos de uma velha ordem anti-natural, mas também sem as imposições de uma novíssima ordem que, por renegar toda a experiência historicamente acumulada, se torna objectivamente anti-social.

"Aqui temos, pois, como se combina a liberdade prática do indivíduo com a obediência às leis, e este acordo tão desejado, esta harmonia social garantida pela Constituição inglesa não foi o efeito de uma só lei minutada teoricamente no gabinete de um político: foi sim o resultado de muitas leis sucessivas que a experiência sugeriu pouco a pouco, e que um direito consuetudinário consolidou no espírito dos povos e arreigou na nação ao ponto de fazer já parte do carácter nacional."

Nesta perspectiva, urgia estabelecer o sistema político por forma a respeitar a representatividade dos factores daquela harmonia - fossem eles da ordem dos interesses e prestígio dos corpos sociais, fossem da ordem das ideias que atravessavam esses corpos. Acima de tudo, impunha-se não agir para com eles de modo a constituí-los em factores de desarmonia. O Correio manifesta repetidamente apreço pelo modelo parlamentar de representação, que permite a solução pacífica dos conflitos naturalmente resultantes de interesses divergentes ou mesmo antagónicos. A composição do Corpo Legislativo francês, em 1819, eleito ao abrigo da Carta Constitucional de Luís XVIII, serve de pre-

\footnotetext{
7 Ibidem, 133 (Junho 1819), pp. 620-621.

8 Ibidem, 77 (Outubro 1814).

9 Ibidem, 175 (Dezembro 1822), p. 606.
} 
texto a mais um discurso de pedagogia liberal - que, não fora a base censitária do colégio eleitoral, poderíamos mesmo qualificar de democrática:

"Lamentam alguns que nas Câmaras existam pessoas destes extremos opostos partidos, mas a essa mesma circunstância atribuímos nós os melhoramentos que se têm feito na legislação da França. As mais extravagantes opiniões, quando sustentadas por muitos indivíduos da nação, têm o direito de serem representadas e discutidas na legislatura. Se as opiniões extravagantes não acham este meio legal de se explicarem, procuram fazê-lo por outro modo, solapando o governo. Essas opiniões encontradas em público, refutadas de maneira legal, cessam de ser perigosas: todo o seu mal consiste em não serem conhecidas e rebatidas."

\section{Vantagens do bicameralismo}

A especificidade da sociedade luso-brasileira, a sua estrutura socio-económica e o peso de toda a sorte de condicionalismos materiais e mentais determinaram a proposta constitucional do Correio Braziliense. O mesmo não se pode dizer das propostas ideologicamente extremadas que caracterizaram os debates nas Cortes vintistas de Lisboa, nomeadamente a que mereceu a aprovação da maioria dos deputados em 1822. Qualquer proposta de reforma, para aspirar à exequibilidade, não podia ignorar o ónus dos grupos sociais privilegiados, designadamente a nobreza. A opinião de Hipólito da Costa sobre a "aristocracia rançosa""l não podia ser mais negativa. Tratava-se, para ele, de uma "oligarquia degenerada"12, desprestigiada por séculos de egoísmo, corrupção e ignorância. O último gesto execrável dos nobres, ainda recente, fora a traição de Baiona, em 1808, quando uma delegação de Grandes do reino fora pedir a Napoleão que nomeasse um rei para Portugal.

Não obstante, havia que dar à nobreza uma representação condigna no sistema constitucional, congraçando-a na grande família nacional. As observações expendidas acerca da Constituição espanhola de Cádis, restaurada em 1820 após a revolução liderada pelo general Rafael de Riego e que marcou o início do Triénio Liberal, valiam como um aviso para a iminente abertura da questão em Portugal:

"Esta nobreza desprezada, e ao mesmo tempo conservada pela constituição, é um cancro que lhe fica encravado e que lhe roerá as entranhas. Outra coisa seria se essa nobreza fosse constituída em uma Casa de Pares nas Cortes, como o é no Parlamento de Inglaterra ou nas Câmaras em França."13

\footnotetext{
${ }^{10}$ Ibidem, 134 (Julho 1819), p. 100.

"Ibidem, 148 (Setembro 1820), p. 342.

${ }_{12}^{12}$ Ibidem, 10 (Março 1809), p. 263.

${ }_{13}$ Ibidem, 143 (Abril 1820), p. 448.
} 
O debate em torno do unicameralismo ou bicameralismo como modelos parlamentares mais adequados à representação nacional foi um dos temas candentes nas reuniões do Palácio das Necessidades, sede das Cortes Constituintes, em Lisboa. Sabe-se que alguns dos expoentes mais lúcidos do sector gradualista do vintismo tinham plena consciência da necessidade de obter um compromisso - e de que a inclusão de uma segunda câmara naquela que ainda poderia ser a Constituição do Reino Unido de Portugal e do Brasil poderia corporizá- $1 \mathrm{o}^{14}$. A actuação quotidiana dos constituintes estava, porém, sujeita a pressões dificilmente suportáveis e, por mais de uma vez, a manobra táctica se revelou imperiosa para assegurar a sobrevivência política imediata ${ }^{15}$.

\section{O Projecto de Constituição para o Brasil}

Escrevendo em Londres, livre dos constrangimentos dos demagogos de Lisboa, como livre estivera da mordaça absolutista antes do 24 de Agosto de 1820, Hipólito da Costa apresenta, em Setembro de 1822 - antes de lhe chegar a notícia da declaração da independência, com que encerrará o jornal em Dezembro daquele ano - o seu próprio Projecto de Constituição Política do Brasil ${ }^{16}$. Fá-lo com o intuito declarado de não deixar "alucinar ou perverter" os brasileiros - ou, na sua nomenclatura, brasilienses, os naturais do Brasil (distinguindo-os dos "brasilianos", os nativos, e dos "brasileiros", os originários de Portugal) pela "monstruosa Constituição de Portugal".

Estamos, obviamente, numa fase avançada da ruptura de Hipólito com o rumo tomado pelo processo português. Sabendo tratar-se de uma questão polémica, procura fundamentar exaustivamente a sua proposta:

“.... nos princípios gerais que neste esboço de Constituição se propõem, só há um que possa admitir dúvida.... Falamos da introdução de duas Câmaras

${ }^{14}$ Cfr. Graça e José Sebastião da Silva DIAS, Os Primórdios da Maçonaria em Portugal, vol. I, tomo II. Lisboa, INIC, 1980, pp. 760-761.

15 O testemunho do deputado Xavier de Araújo é elucidativo do que se passava na capital portuguesa durante o escaldante período vintista: “.... voltando agora a Fernandes Tomás; ele era do voto de se decretarem duas câmaras, e disse a José Joaquim de Moura, deputado como ele, e apologista apaixonado das doutrinas francesas de 1789 - Moura, a questão é séria, e devemos meditar nela; nós somos reconhecidos pelas Potências da Europa logo que decretemos as duas câmaras, e então parece-me que as votemos. - Moura exclamou - Tu não sabes o que por aí vai por essa cidade; no dia em que votarmos as duas câmaras somos precipitados da janela abaixo do palácio das Cortes e perdemos toda a nossa popularidade - Isto é o que mais feria a Moura, muito ávido de aplausos populares" (Xavier de Araújo, Revelações e Memórias para a História da Revolução de 24 de Agosto de 1820 e de 15 de Setembro do Mesmo Ano. Lisboa, 1846, pp. 81-82).

${ }^{16} C B, 172$ (Setembro 1822), pp. 375-384. Reproduzido na íntegra in João Pedro Rosa Ferreira, O Jornalismo na Emigração. Ideologia e Política no Correio Braziliense (1808-1822). Lisboa, INIC, 1992, pp. 191-200. 
no Poder Legislativo, princípio que se rejeitou em Portugal por quererem ali imitar o exemplo de Espanha.... Nenhum desses Tomás, Mouras, Borges Carneiro, etc. de Lisboa, pretenderá ser maior advogado da liberdade do que um Abade du Praedt, um Lanjuinais, um Adams, um Washington, um Franklin; no entanto, todos estes grandes homens têm advogado a instituição de duas Câmaras, com mais ou menos modificações.... Dirão agora que todos esses heróis eram emissários da Santa Aliança?"”7

\section{Rei constitucional precisa-se}

Determinante para a viabilidade do novo sistema, tanto a nível interno como externo, emergia dos projectos constitucionais em confronto, cercada de ambiguidades, a figura do rei. Mesmo os mais radicais cedo se aperceberam de que a revolução deveu a sobrevivência à declaração explícita de fidelidade à dinastia de Bragança, feita logo nas primeiras proclamações da Junta do Porto, em 24 de Agosto de 1820.

Com excepção da Espanha do Triénio Liberal, o novo regime não logrou obter o reconhecimento oficial das principais potências. Não obstante, $o$ respeito, mesmo que meramente formal, pelas prerrogativas do monarca valeu ao Estado português a observância do artigo do Tratado de Amizade e Aliança de 1810, pelo qual a Inglaterra garantia a sua integridade contra os inimigos externos. A isso se terá ficado a dever o facto de a contra-revolução ter acabado por triunfar, em 1823, mas às mãos de nacionais - e não, como em Espanha, dos "Cem Mil Filhos de São Luís", braço armado da Santa Aliança.

O Correio procurou, desde o início, chamar à razão os exaltados e acalmar a efervescência republicana: "Será moda falar dos reis com menos respeito, mas essa moda tem custado caro a muitas nações"18. Reforça a mesma ideia depois do regresso de D. João VI a Lisboa, em 1821. Congratula-se com as demonstrações da adesão voluntária do rei à nova situação, nomeadamente ao jurar as Bases da Constituição (aprovadas em Março de 1821), com o que desautorizava as manobras dos contra-revolucionários e garantia o regime no concerto das nações ${ }^{19}$.

Mas o idílio constitucional não seria prolongado. O Braziliense denuncia nos seus últimos números o estado de coacção do rei, que apresenta como uma figura decorativa, sem vontade livre, sob o domínio das Cortes. $\mathrm{O}$ esvaziamento das competências do soberano - visível na consagração constitucional do veto meramente suspensivo - é, para Hipólito da Costa, não só condenável do ponto de vista político mas também uma incoerência em termos

${ }_{17} C B, 172$ (Setembro 1822), pp. 373-374.

18 Ibidem, 155 (Abril 1821), p. 484.

${ }_{19}$ Ibidem, 158 (Julho 1821), pp. 64-67. 
lógicos, na perspectiva do sistema adoptado. Este valia sobretudo por ser funcional, útil. Se se retirava ao sistema monárquico-representativo a componente monárquica, embora mantendo formalmente o rei, este ficava sem qualquer capacidade de intervenção eficaz e o sistema entrava em desequilíbrio:

"Se a sanção do rei é mera formalidade, fica inútil, e tudo quanto é formalidade inútil na Constituição é pernicioso.... não é este o meio de conservar a forma monárquico-democrática.... Em uma palavra, quando as Cortes puderem fazer tudo, a forma de governo é puramente democrático-representativa, e então o rei será um elemento desnecessário na Constituição." ${ }^{20}$

O Projecto de Constituição Política do Brasil apresentado por Hipólito da Costa prevê um papel activo para o rei. Além de depositário principal do poder executivo (artigos $53 .^{\circ}$ a $61 .^{\circ}$ ), participa com um peso determinante no legislativo: "O Poder Legislativo dependerá de três autoridades: 1. O Rei; 2. O Conselho de Estado; 3. Os Representantes" (artigo 4..$^{\circ}$ ). Cabe-lhe também nomear os primeiros membros do Conselho de Estado, designação proposta para a câmara alta do Parlamento (artigo 11..$\left.^{\circ}\right)^{21}$, e ainda sancionar ou rejeitar as leis - que, para lhe serem apresentadas, carecem da aprovação sucessiva dos Representantes e do Conselho de Estado (artigos 25. a 33..$^{\circ}$ ). Em caso de rejeição, "a matéria se não tornará a propor na mesma sessão" (artigo 35.). Está longe o republicanismo envergonhado da Constituição portuguesa de 23 de Setembro de 1822, que interpretava o silêncio do rei como sanção (artigo $\left.114 .^{\circ}\right)$, e a conseguia automaticamente em caso de segunda aprovação na câmara única das Cortes (artigo $110 .^{\circ}$ ). É ainda prerrogativa real a comutação ou perdão das penas, excepção feita aos processos levantados aos ministros, que respondem perante o Conselho de Estado, mediante acusação dos deputados eleitos da câmara baixa (artigos $60 .^{\circ}$ e $61 .^{\circ}$ ).

Fica patente neste projecto o acolhimento dado por Hipólito da Costa ao conceito de Poder Real, teorizado por Benjamin Constant - e que viria ter consagração explícita na Constituição do Império do Brasil de 1824 e na Carta Constitucional portuguesa de 1826, com o nome de Poder Moderador ${ }^{22}$.

\section{A liberdade como ética}

O pensamento político de Hipólito da Costa, tal como vai sendo enunciado ao longo dos anos de publicação do Correio Braziliense, aponta para um

${ }^{20}$ Ibidem, 163 (Dezembro 1821), p. 529.

${ }^{21}$ À semelhança do Senado dos Estados Unidos, o projecto de Hipólito da Costa prevê que o Conselho de Estado seja composto "do dobro dos membros, quantas forem as províncias" (artigo $10{ }^{\circ}$ ). O nome atribuído à câmara baixa é igualmente revelador do modelo que o inspirou: Casa dos Representantes.

22 "On s'étonnera que je distingue le pouvoir royal du pouvoir éxécutif. Cette distinction, toujours méconnue, est très importante: elle est, peut-être, la clef de toute organisation poli- 
conjunto de princípios gerais visando "cumprir" o objectivo que os homens se propuseram ao organizarem-se em sociedade. $\mathrm{O}$ que lhe importa é ver garantida, em primeiro lugar, a liberdade individual, "porque nenhum benefício (nem talvez a vida) compensa a liberdade"23. Ela é o "primeiro bem", mas para a poder gozar, há que firmar "a segurança pessoal dos indivíduos,... o primeiro dever do governo, o fim primário de sua instituição"24.

Pelas páginas do Correio perpassa uma tal autenticidade na defesa destes valores que não será demasiado sublinhar a dimensão ética da reforma preconizada por Hipólito. Uma manifestação desta constância nos princípios é a associação da ideia de virtude cívica à virtude moral - e de ambas a uma postura crítica face ao poder:

"O melhor dos soberanos, se tem a infelicidade de governar uma nação de aduladores, não poderá fazer florentes os seus Estados, nem conferir aos súbditos aquela liberdade racionável, que todos os homens têm direito a exercitar, mas que a sábia Providência não deixa gozar senão às nações que praticam as virtudes cívicas, as quais exornam o cidadão, assim como as virtudes morais condecoram o pai de famílias"25.

O mesmo cuidado com a justificação perante a "própria consciência" é evidenciado em Abril de 1822, quando apresenta os últimos argumentos em prol da união do Brasil a Portugal:

"Se o Brasil obrar de outra maneira [i.e., declarar já a independência], não será justificável, nem aos olhos das outras nações, nem aos da posteridade e, o que mais é, não se justificarão [sic] em sua própria consciência pelos princípios da justiça, o que é consideração da mais transcendente importância para a felicidade nacional, assim como o é para a individual. ${ }^{.26}$ - em breve tais argumentos seriam superados pelas circunstâncias.

\section{Liberdade ou escravatura}

A escravatura fora abolida no Reino de Portugal durante o consulado do Marquês de Pombal, por alvará de 2 de Abril de 1761 - medida tomada, por

tique", Benjamin Constant, Cours de Politique Constitutionnelle. Bruxelas, 1837, p. 1. Sobre a influência de Constant no projecto de Hipólito e nos textos constitucionais brasileiro e português, ver Mecenas Dourado, Hipólito da Costa e o Correio Brasiliense. Rio de Janeiro, Biblioteca do Exército Editora, vol. II, pp. 565-580.

${ }^{23}$ CB, 13 (Junho 1809), p. 639.

${ }^{24}$ Ibidem, 59 (Abril 1813), pp. 533-534.

${ }^{25}$ Ibidem, 22 (Março 1810), pp. 314.

${ }^{26}$ Ibidem, 167 (Abril 1822), pp. 442. Sobre o conceito de liberdade ética e o seu papel na praxis liberal, ver Ernst Bloch, Droit Naturel et Dignité Humaine. Paris, Payot, 1976, pp. 158-174; e também Jurgen Habermas, La Reconstrucción del Materialismo Dialéctico. Madrid, Taurus, 1983, pp. 28-29. 
coincidência, no mesmo ano em que foi executada em auto-da-fé a última vítima mortal da Inquisição, o jesuíta Gabriel Malagrida, por ter atribuido o terramoto de 1755 a castigo divino. Também sob Pombal foram declarados inteiramente livres os nativos do Brasil e concedidos aos naturais da Índia direitos iguais aos portugueses da Metrópole (em 15 de Janeiro de 1774, precisamente um mês e dez dias antes do nascimento de Hipólito da Costa). Apesar disso, o tráfico e a escravatura mantiveram-se nos domínios ultramarinos.

O Correio Braziliense não tem a mais pequena dúvida: a escravatura é um mal, condenável a todos os títulos. Di-lo e repete-o em sucessivos números. Mas, consciente da importância do trabalho escravo na economia brasileira, Hipólito aborda o problema com uma cautela cirúrgica. De início, e a exemplo dos 'founding fathers' da democracia norte-americana, condescende em guardar o problema na gaveta. Veja-se a "Análise do folheto sobre o comércio franco do Brasil", em Julho de 1809: “....o autor faz voltar os olhos para o comércio da África; seria melhor não falar nisto.... seguindo o conselho, guardo também nisto o silêncio. Se o Governo do Brasil remediar este mal, os filantropos the perdoarão todos os mais"27.

O Governo, a começar pelo regente D. João, concordava - o "mal" é condenado de forma explícita no artigo $10^{\circ}$ do Tratado de Paz e Amizade com a Inglaterra, assinado a 19 de Fevereiro de 1810: "S.A.R., o Príncipe Regente de Portugal, estando plenamente convencido da injustiça e má política do comércio de escravos.... tem resolvido de cooperar com Sua Majestade Britânica na causa da humanidade e da justiça, adoptando os mais eficazes meios para conseguir em toda a extensão dos seus domínios uma gradual abolição do comércio de escravos". A abolição terá de ser gradual, o assunto é tratado com cuidado, visto ser "um ponto sumamente delicado e de grande dificuldade. Estas considerações nos obrigaram sempre, desde que conduzimos este nosso jornal, a não tocarmos na questão da escravatura.... um mal para o indivíduo que a sofre e para o Estado aonde ela se admite; porém este mal não foi introduzido pelo Governo actual, e a tentativa de o cortar pelas raízes imediatamente produziria sem dúvida outros males talvez de maiores consequências"28.

Prudência e gradualismo não significam pusilanimidade nem hesitação. Em Dezembro de 1815, Hipólito da Costa considera chegado o momento de enfrentar o mal "cara a cara": ".... estamos persuadidos, com Montesquieu, que a escravidão não pode ser útil nem ao escravo, nem ao senhor.... o nosso periódico está cheio de clamores contra tudo quanto é autoridade arbitrária; temos mil vezes arguido que os povos do Brasil têm direito a gozar daquela liberdade racionável que consiste em não estar sujeito senão às leis, e não ao

$27 C B, 14$ (Julho 1809), p. 52.

${ }^{28}$ Ibidem, 71 (Abril 1814), pp. 607-608. 
arbítrio dos que governam; etc. Ora como pode um senhor no Brasil gozar destes benefícios, quando tem debaixo de seu poder um escravo, para quem olha quase com a mesma consideração como para o seu cão ou o seu cavalo? Como é possível que o homem branco profira os seus desejos de gozar de liberdade, tendo ao pé de si o negro escravo em todo o rigor da palavra? Conhecemos bem que nos estamos explicando em linguagem um pouco forte, mas é chegado o tempo em que é preciso encontrar o mal cara a cara, e tanto o Governo como o povo do Brasil devem olhar para a questão no seu verdadeiro ponto de vista"29.

No momento de apresentar o seu "testamento político", já depois de anunciada a independência do Brasil, Hipólito considera importante dedicar um artigo ao problema da escravatura no novo país. Em Novembro de 1822, na penúltima edição do Correio, deixa exposto com clareza o seu pensamento sobre o assunto, deixando um sentido apelo à abolição da escravatura, mesmo que isso implique um empobrecimento dos cidadãos. O artigo, intitulado "Escravatura no Brasil", merece uma transcrição extensa:

"É ideia contraditória querer uma nação ser livre e, se o consegue ser, blasonar em toda a parte e em todos os tempos de sua liberdade, e manter em si a escravatura, isto é, o idêntico costume oposto à liberdade. Seria a desesperada medida de um louco destruir de uma vez a escravatura, quando ela, além de constituir parte da propriedade do país, está também ligada ao actual sistema da sociedade, tal qual se acha constituída. Mas, se a sua abolição repentina seria um absurdo rematado, a sua perpetuação num sistema de liberdade constitucional é um contradição de tal importância que uma coisa ou outra devem acabar. Os Brasilienses, portanto, devem escolher entre estas duas alternativas: ou eles nunca hão-de ser um povo livre, ou hão-de resolver-se a não ter consigo a escravatura.... Negamos redondamente, e o provaremos quando for conveniente, que o Brasil deixe de ser igualmente rico quando não tiver escravatura, mas raciocinando mesmo nesta hipótese, que não admitimos, perguntamos: que preferem os Brasilienses, ser pobres, mas serem homens livres, com um Governo Constitucional; ou serem ricos e submissos a governos arbitrários, sem outra constituição política que a que lhes prescrever o Despotismo?.... A maior parte de nossos sentimentos e de nossas acções depende dos acidentes de nossa educação, e um homem educado com escravos não pode deixar de olhar para o despotismo como uma ordem de coisas natural... quem se habitua a olhar para o seu inferior como escravo, acostuma-se também a ter um superior que o trate como escravo". ${ }^{30}$

Fiel à declaração de princípios enunciada no primeiro número do jornal

${ }^{29}$ Ibidem, 91 (Dezembro 1815), pp. 738-739.

${ }^{30}$ Ibidem, 174 (Novembro 1822), pp. 574-576. 
- e honrada ao longo dos 14 anos seguintes - o redactor do Correio concita os escritores do seu país para colaborarem na campanha abolicionista: “... chamamos em auxílio da boa razão a pena dos escritores do brasil, porque não basta que o governo obre segundo o que é conforme aos interesses da nação, é ademais necessário que o povo esteja persuadido que isso assim é realmente, para isto é que se requerem os serviços daqueles homens que se acham em situação de dirigir a opinião pública; e os que nisso se empregarem farão assim um relevante e essencial serviço a sua Pátria"31.

\section{Uma "Porcaria"}

A liberdade de imprensa e a luta contra a censura são temas de primeira ordem no Correio Braziliense. Desde os números mais recuados que o jornal denuncia a censura, a Inquisição e as perseguições aos homens de letras como causas directas da decadência do país. "Aquele freio de que se não possa publicar obra alguma em matéria nenhuma sem que seja aprovada por uns poucos de homens em quem o governo de Portugal lhe aprouve, por uma ficção de direito, depositar todos os conhecimentos humanos, é um absurdo, só por si capaz de aniquilar inteiramente o génio da nação em tudo o que é produção literária." ${ }^{32}$

Pioneiro da comunicação das ideias liberais aos seus leitores de Portugal e do Brasil, zurzindo o atraso económico e a opressão absolutista, é natural que o Correio fosse alvo de ataques com o objectivo de silenciá-lo. Desde manobras intimidatórias - como o processo judicial por libelo movido contra Hipólito da Costa pelo embaixador de Portugal em Londres, o conde de Funchal, D. Domingos de Sousa Coutinho ${ }^{33}$, ou as diligências efectuadas pelo conde de Palmela e pelo secretário da embaixada Rafael da Cruz Guerreiro para impedir o envio do jornal para o Brasil ${ }^{34}$ - à publicação de obras destinadas a desacreditá- $\mathrm{l}^{35}$, passando por medidas administrativas e legais pura-

${ }^{31}$ Ibidem, p. 577.

${ }^{32} C B, 5$ (Outubro 1808), p. 383.

${ }^{33}$ Ver Carlos Rizzini, Hipólito da Costa e o Correio Braziliense. São Paulo, Companhia Editora Nacional, 1957, p. 29.

${ }_{34}$ Ver $C B, 149$ (Outubro 1820), pp. 480-481; e 150 (Novembro 1820), pp. 556-567.

${ }_{35}$ Frei Joaquim de Santo Agostinho Brito França Galvão, Reflexões feitas em abono da verdade sobre o Correio Braziliense, Lisboa, Impressão Régia, 1809-1810; Idem, Apologia do Periódico que tem por título Reflexões sobre o Correio Braziliense caluniosamente atacado pelo Redactor do mesmo Correio, Lisboa, 1810; José Joaquim de Almeida e Araújo Correia de Lacerda, Exame dos Artigos Históricos e Políticos que se Contem na Colleç̧ão Periodica Intitulada Correio Braziliense..., Lisboa, Impressão Régia, 1810; Frei Mateus da Assunção Brandão, Reflexões sobre a Conspiração Descuberta [sic], e Castigada em Lisboa no ano de 1817, Lisboa, Impressão Régia, 1818, p. 41; e o mais truculento de todos os detractores, o 
mente censórias, destinadas a cercear a sua circulação. Estas começaram logo em 1809, com as primeiras apreensões ordenadas pelo governador do Pará, José Narciso Magalhães, e pelo do Rio Grande do Sul, em 1810 e 1811, continuaram com a proibição pela Mesa do Desembargo do Paço da entrada e publicação do periódico "e de todos os escritos de seu furioso e malvado autor", e culminaram com a renovada proibição, em 17 de Junho de 1817, desta vez com honras de uma Portaria dos Governadores do Reino - que, ao ser transcrita no Correio, uma oportuna gralha transforma em "Porcaria". ${ }^{36}$

\section{Imprensa livre}

Era convicção do redactor que a liberdade de imprensa devia ser irrestrita, sujeita apenas à lei geral no tocante a eventuais abusos que caíssem sob a alçada do foro cível ou criminal. Entendia-a como condição sine qua non de toda a liberdade cívica e política e para o explicitar publicou textos de importância histórica para o jornalismo. É o caso da "Memoria sobre la libertad politica de la imprenta", de José Izidoro Morales, obra típica do período gadita$\mathrm{no}^{37} \mathrm{e}$, sobretudo, de "Areopagitica - Fala a favor da Liberdade de Imprensa dirigida ao Parlamento de Inglaterra", o inspirado panfleto de Milton, da época da Guerra Civil inglesa, traduzido pelo próprio Hipólito ${ }^{38}$.

Para o Correio, a liberdade de imprensa, além de uma questão de princípio, de uma ética de alcance cívico e político, tem igualmente uma dimensão útil, de valor económico muito sensível. Para um liberal, familiarizado com as ideias de Hume e de Adam Smith, esse papel não podia deixar de ser evidenciado. É o que faz Hipólito da Costa ao debruçar-se sobre o relacionamento comercial entre Portugal e o Brasil, em Março de 1812, quando afirma que "é preciso facilitar-lhe [ao povo] a leitura das gazetas e jornais em que leiam as notícias políticas e mercantis"39.

Firme na defesa do princípio da liberdade de imprensa, o Correio insurgir-se-á contra a lei de imprensa votada pelas Cortes de Lisboa em 1821. De-

padre José Agostinho de Macedo, Carta de hum Pai para seu Filho, Estudante na Universidade de Coimbra, Sobre o Espírito do Investigador Portuguez em Inglaterra, Lisboa, Impressão Régia, 1812, pp. 12-13; Idem, O Espectador Portuguez, Lisboa, 1816-1818, desde o suplemento ao n. ${ }^{\circ} 26$, intitulado "Hipólito ou o Correio Braziliense", até ao fim da publicação; Idem, Os Burros, Paris, Officina Typographica de Casimir, 1835, pp. 250 e 278-279; e, em colaboração com Joaquim José Pedro Lopes, Gazeta Universal, Lisboa, 1822, nomeadamente o n. ${ }^{\circ}$ 64, de 21 de Março de 1822.

${ }^{36} \mathrm{CB}, 110$ (Julho 1817), pp. 3-4.

37 "Tal e tão poderoso é o escudo que a liberdade da imprensa põe aos atentados do poder, o que constitui inviolável a segurança pessoal quando a imprensa está só debaixo do poder da lei”, $C B, 21$, (Fevereiro 1810), p. 183.

${ }_{38}$ Ibidem, 24 (Maio 1810).

39 Ibidem, 46 (Março 1812), p. 289. 
nuncia-a pelo seu carácter restritivo, fruto dos "prejuízos nacionais" e do temor infundido pelos "partidistas do despotismo" contra a "letra redonda". Optimista quanto ao futuro da liberdade, o redactor oferece o exemplo da sua própria experiência para opinar que todas as tentativas contrárias às luzes da imprensa estão votadas ao fracasso e conclui com um ponto de honra, ao pedir a liberdade de expressão até para os inimigos dessa liberdade: "Até haverá mesmo alguém (posto que raro será) que em sua consciência julgue o sistema antigo preferível ao presente; e se um tal é português, nem lhe deve tirar o direito de dizer o que entende nos objectos públicos; e mui mal seguro estaria o governo constitucional se o grasnar de tais rãs pudesse produzir em abalá-lo o mesmo efeito que outros escritos obtiveram em expor em suas próprias e verdadeiras cores os abusos do governo passado." 40

Hipólito da Costa procuraria ainda consagrar a liberdade de imprensa na lei fundamental do seu país recém-independente. No artigo $46 .^{\circ}$ do já referido Projecto de Constituição Política do Brasil pode ler-se: "Que não se impeça a faculdade de pensar ou de publicar os pensamentos por palavra ou por escrito, salvas as calúnias." ${ }^{41}$

\section{$O$ "justo equilíbrio"}

Para conquistar a liberdade, Hipólito aponta um caminho: o "justo equilíbrio", incessantemente procurado pelo "partido médio", chave do funcionamento do sistema político que preconiza. A expressão "justo meio" é utilizada pela primeira vez, nesta acepção, em Julho de $1810^{42}$, mas o conceito será progressivamente desenvolvido até à sua sistematização. Logo após serem aprovadas as Bases da Constituição, o Correio prevê a breve trecho a criação de três partidos em Portugal. O partido realista, composto pelos que querem "aumentar e fortificar o poder do rei"; o partido democrático, de pessoas que julgam útil "coartar sempre o poder real e aumentar o poder da representação popular"; e o partido médio, "o mais útil, porém o que tem menos influência.... nada é mais comum do que ver este partido médio acusado pelo democrático de favorecer o despotismo, e ao mesmo tempo acusado pelo realista de favorecer a democracia, ou mesmo a anarquia.... enquanto o partido médio é assaz poderoso para decidir com o seu número a maioridade, encostando-se, já a um, já a outro dos partidos extremos, a constituição se preserva." ${ }^{43}$

40 Ibidem, 160 (Setembro 1821), p. 245.

${ }^{41}$ Ver nota 16.

${ }_{42}$ "O incalculável benefício que a nação inglesa pode agora fazer aos portugueses é mostrar-lhe o justo meio entre o despotismo e a anarquia, que é o que constitui a liberdade civil" $(C B, 26$ (Julho 1810), p. 75).

${ }^{43}$ Ibidem, 157 (Junho 1821), pp. 672-673. Sobre os conceitos de "justo equilíbrio" e "justo meio" ver René Rémond, Les Droites en France. Paris, Aubier, 1982, pp. 84-89; Melvin J. 
A enumeração das vantagens do "partido médio" e dos perigos que convergem contra o sistema do "justo equilíbrio" revela uma aguda sensibilidade para a difícil questão do compromisso histórico. É na procura deste que consiste o Projecto de Constituição Política do Brasil. A sua justificação constitui um autêntico manifesto em defesa de um regime político no qual forças sociais com interesses divergentes se possam sentir representadas, mediante um compromisso construído laboriosamente.

A consciência da fragilidade dos consensos obtidos de forma casuística e da perseverança necessária à sua constante renovação, de que depende a sobrevivência do regime constitucional, faz aflorar, no pensamento político de Hipólito da Costa, uma vaga noção de estrutura. Terá que haver, para o sistema funcionar, uma correlação e interdependência do todo e das partes solidárias que o compõem: “.... é essencial que se considere o nexo que propusemos entre os diferentes ramos de administração pública, de eleições e de justiça, para que se não altere alguma parte que, parecendo de pouca consequência, possa contudo destruir a unidade do sistema" ${ }^{44}$.

\section{Da reforma à revolução}

A dimensão eminentemente prática do pensamento político de Hipólito patenteia-se na exigência da positividade e na restrição do âmbito da constituição. Não o preocupam definições dogmáticas, que em mais de uma ocasião rejeita $^{45}$. Em contrapartida, põe todo o cuidado na funcionalidade do sistema: deve existir um instrumento simples, coerente e tanto quanto possível insusceptível de dúvidas, que constitua um quadro mínimo, de tipo estatutário ${ }^{46}$, deixando o máximo de margem para a participação activa do cidadão na vida política.

Àquele não interessa definir teoricamente em quem reside a soberania, ou qual a sua fonte, mas sim saber, de forma clara, as regras do jogo da busca da felicidade. Importa-lhe sobretudo ver garantida a liberdade de aquisição e

Lasky, Utopia and Revolution. Londres, MacMillan, 1977, pp. 600-602 e Georges Gusdorf, La Conscience Révolutionnaire, Paris, Payot, 1978.

$44 C B, 174$ (Novembro 1822), p. 568.

45 Por exemplo quando aponta a Constituição dos EUA de 1789 como modelo a imitar pelo Brasil, ao insistir em que a forma de governo (monarquia ou república) é um factor secundário relativamente ao sistema de administração. Cfr. Ibidem, 89 (Outubro 1815), p. 550; 112 (Setembro 1817), p. 285; 140 (Janeiro 1820), p. 86.

46 "A Constituição deve unicamente conter as regras gerais por que se devem fazer as leis e os limites de poder naqueles que as devem executar. Tudo o mais é objecto de leis regulamentares que a experiência e as circunstâncias do tempo devem ir sugerindo pouco a pouco; do contrário é legislar em teoria, sem poder alcançar o que se precisará na prática" (Ibidem, 171 (Agosto 1822), p. 295). 
usufruto da propriedade, e essa garantia só pode ser dada pela segurança de uma igualdade jurídica. É ela que permite ao cidadão afirmar, pela exibição dos frutos da sua actividade produtiva, a sua plena liberdade na desigualdade social $^{47}$.

Da leitura do Correio resulta claro que um tal modelo de sociedade exige um instrumento jurídico - precisamente a Constituição - que garanta o cidadão/proprietário contra a situação de indefinição legal que torna possível o juízo arbitrário do detentor do poder. Aqui se manifesta, mais uma vez, a opção política de Hipólito da Costa, cujo reformismo acaba por ser forçado a tornar-se revolucionário. Demarca-se explicitamente dos doutrinadores contra-revolucionários ao exigir um texto constitucional escrito, não programático em si mesmo, mas encerrando sem qualquer ambiguidade um programa social muito concreto.

Em que consiste esse programa, do qual a proposta constitucional do Braziliense constitui a vertente política? A nosso ver, num gradualismo lúcido, patente na evolução do próprio conceito de constituição. Mantendo o pano de fundo epistemológico e ideológico da tradição do direito natural, aceita a ideia contratualista $^{48}$, mas acolhe igualmente a crítica utilitarista fundada no empirismo ${ }^{49}$, acabando por posicionar-se próximo dos ideólogos franceses e prenunciar, sobretudo no que toca ao pensamento social, a corrente do liberalismo radical britânico ${ }^{50}$.

\section{Gradualismo}

O Correio Braziliense parte de um tradicionalismo constitucional, mesmo que conscientemente forçado - veja-se a série de artigos intitulada "Paralelo da Constituição Portuguesa com a Inglesa", publicada entre Agosto de 1809 e Maio de 1810 - e termina apresentando para o Brasil um projecto indubitavelmente tributário do modelo inglês, mas tendo como referente preferencial o exemplo norte-americano. Não houve um salto: a evolução deveu-se ao facto de terem sido reunidas, finalmente, as condições políticas para afirmar, sem ambiguidades, o que antes escamoteara com invocações tácticas, mas que progressivamente viera clarificando. Em Agosto de 1819, Hipólito como que

${ }^{47}$ Ver Georges Gusdorf, L'Avènement des Sciences Humaines au Siècle des Lumières. Paris, Payot, 1973, pp. 558-564 e La Conscience Révolutionnaire, pp. 215-260; e André Vachet, L'Idéologie Libérale, Paris, Anthropos, s.d., pp. 193-249 e 305-343.

48 Ver Ernst Cassirer, La Philosophie des Lumières. Paris, Fayard, 1970, pp. 239-273.

${ }^{49}$ Ver Vachet, op.cit, pp. 421-471; Barry Stroud, Hume, Londres, Routledge \& Kegan Paul, 1981, pp. 171-218; e Ross Harrison, Bentham, Londres, Routledge \& Kegan Paul, 1983, pp. $77-194$.

${ }^{50}$ Ver notas 2 e 3 e a tradução quase integral, no Correio, dos Princípios de Economia Política aplicados à Legislação do Comércio, de Sismondi, a partir do n. ${ }^{\circ} 95$ (Abril 1816). 
sintetiza a posição gradualista: levar em conta os obstáculos de preconceitos seculares e procurar contorná-los com o fito de conseguir as reformas desejadas é o objectivo do "legislador bem intencionado". O "entusiasta" (revolucionário) e o "malvado" (absolutista) convergem ao reforçar os preconceitos que se opõem aos melhoramentos conducentes à felicidade. "Quanto a nós, estamos persuadidos que quanto mais graduais forem as reformas, consultando sempre o génio do tempo, as circunstâncias e o carácter dos povos, tanto mais é de esperar que as reformas produzam um bem permanente.".

A lucidez e o pragmatismo de que as suas intervenções e propostas dão constante prova colocam o Braziliense no campo do gradualismo ${ }^{52}$, eventualmente na sua direita (só concebe a democracia e o republicanismo como factores de anarquia e parteiros de novos despotismos, embora ressalve que isso se deve ao estado de degradação dos costumes em Portugal e no Brasil).

Hipólito da Costa não se limita à retórica dos regeneradores de 1820 nem declama o Choix des Rapports, a bíblia dos vintistas ${ }^{53}$. Tem planos concretos para realizar a reforma radical que de há muito considerava indispensável para a felicidade da nação. Planos para a reforma da administração do Brasil, cuja unidade procurou defender a todo o custo; a reforma do comércio entre Portugal, o Brasil e as colónias, e entre o conjunto da monarquia luso-brasileira e os países estrangeiros, incluindo um projecto de pauta alfandegária. Projectos para o fomento da agricultura e o lançamento da indústria, para o desmantelamento dos monopólios e a sua substituição pela livre empresa; a libertação da propriedade agrária e o fim dos constrangimentos corporativos nas actividades industriais, o apelo à dinamização do associativismo rural e comercial; e também para a expansão do ensino elementar, condição básica para o progresso. O Correio apresentou uma cuidadosa e pormenorizada plataforma de acção, unindo indissociavelmente as tarefas da regeneração política com a reforma das estruturas mais profundas da sociedade.

O problema que se colocava, na nova conjuntura pós-1820, era o da concretização desta prática - porque, ao contrário da maior parte dos seus contemporâneos, de uma verdadeira prática se tratava, fruto de uma reflexão teórica amadurecida. O redactor do jornal tinha plena consciência da reduzidíssima base social de apoio do campo constitucional, ainda para mais constantemente restringida pela cegueira dos radicais, alimento do proselitismo dos contra-revolucionários. Havia que buscar compromissos, sobretudo não

$51 C B, 135$ (Agosto 1819), p. 168.

${ }_{52}$ Ver J.S. da Silva Dias, "O Vintismo: Realidades e Estrangulamentos políticos" in Análise Social, 61/62, 2. " série, vol. XVI, Lisboa, 1980, p. 275.

${ }^{53}$ Choix des Rapports. Opinions et Discours Prononcés à la Tribune Nationale depuis 1789 jusqu'à ce jour. Paris, Alexis Eymery, 1818. 
alienar os moderados - e os interesses sociais por eles representados - do campo do novo regime. Era preciso ganhar tempo.

\section{O caminho da independência}

A derrapagem do vintismo, pelas pressões quotidianas da convergência radical-reaccionária, a conjuntura internacional e, principalmente, a questão do Brasil, levaram o Correio à oposição, primeiro, e ao alheamento do processo português, depois, com a separação do novo império.

Desde o início da sua publicação - sobretudo desde a assinatura dos tratados luso-britânicos de Fevereiro de 1810 - o jornal mostrou-se favorável à união entre o Brasil e Portugal. No entanto, já em Junho de 1809 chama a atenção para as razões de queixa do Brasil contra Portugal. E no número seguinte acusa o despotismo colonial de ser um obstáculo ao desenvolvimento económico brasileiro e de contribuir para a ruína de Portugal. No número de Abril de 1810 defende o lugar do Brasil no âmbito de um império português em que todos os domínios gozem da mesma distinção, na unidade da administração e das leis. A primeira manifestação de cariz autonomista, porém, surge na edição de Novembro de 1810, quando afirma que a residência da Corte no Rio de Janeiro não teve como consequência a ascensão de qualquer natural do Brasil a um alto posto do Governo, reservado em exclusivo aos "europeus", "estrangeiros". E, na mesma ocasião, não deixa de chamar a atenção para "as circunstâncias actuais entre a Espanha e as suas colónias". Em Junho de 1811 assinala a morte de um mártir da liberdade brasileiro: o antigo procurador das Câmaras de Minas Gerais José Joaquim Vieira do Couto, "defensor dos seus naturais", que fora preso em Lisboa pela Inquisição e deportado para a Ilha Terceira, nos Açores, por ocasião da vaga repressiva que ficou conhecida como a Setembrizada de 1810.

A elevação do Brasil à categoria de reino, com a mudança de designação da monarquia luso-americana para Reino Unido de Portugal, Brasil e Algarves, em 16 de Dezembro de 1815, é saudada no número de Fevereiro de 1816. Mas a situação vai degradar-se. Na secção "Miscelânea" da edição de Abril de 1817 publica uma carta em que são notórios os sinais de insatisfação em Pernambuco perante actos de corrupção e abusos do general da Capitania. No mês seguinte, o Correio traz já a notícia da fracassada insurreição pernambucana, cujas causas não atribui a "obra de intrigantes" mas sim ao descontentamento "generalíssimo" da "grande nação" - o Brasil - contra a administração militar e as instituições coloniais. A solução para estes males não é a repressão, mas a reforma. Curiosamente, nos números imediatos, Hipólito vai recuar, demarcando-se da "rebelião", que nada, "nem os abusos", justifica (Junho de 1817) - além de ter sido mal preparada e mal dirigida, "as reformas nunca se devem procurar por meios injustos" (Julho de 1817). A condenação 
da revolta de Pernambuco esteve na origem de uma prolongada polémica entre o Braziliense e o Correo del Orinoco, órgão dos insurgentes venezuelanos que, até então, tinham contado Hipólito da Costa entre os seus apoiantes. O número de 13 de Fevereiro de 1818 do Orinoco inclui uma violentíssima diatribe contra Hipólito, acusado de "contradizer os seus princípios" e de "deixar cair sobre os seus escritos um borrão quase indelével", para que o monarca do Brasil "levantasse a proibição imposta ao seu periódico de ser introduzido e lido em Portugal"'54. A controvérsia mantém-se acesa até Setembro de $1819^{55}$.

Já depois da Revolução de 24 de Agosto de 1820, o Correio pronunciase repetidamente contra a separação do Brasil, que considera a cabeça do Reino Unido. No entanto, já no número de Setembro daquele ano sublinha que a manutenção do Reino Unido é de interesse para Portugal, mas apenas de "decoro" para o Brasil. E logo a partir de Outubro denuncia o início de uma campanha "anti-Brasílica" em Portugal com o objectivo de criar divisões entre ambos e fomentar uma união luso-espanhola. A adopção pelo novo poder instalado em Lisboa da Constituição de Cádis, a título provisório, na sequência do golpe da Martinhada, em Novembro de 1820, é interpretada por Hipólito da Costa como "um passo decisivo para a separação de Portugal do Brasil".

Não tardaram outros passos, cada vez mais apressados, no caminho do divórcio luso-brasileiro. O radicalismo das Cortes vintistas ameaça fazer regressar o Brasil ao estado de colónia, denuncia o Correio na sua edição de Março de 1821. Dois meses depois ainda sustenta que manter a união é "prolongar vantagens mútuas". Contudo, em Janeiro de 1822, Hipólito declara a sua oposição às medidas tomadas pelas Cortes relativamente ao Brasil. Em artigos publicados na secção "Miscelânea" desse mês fala contra a visão colonial que na Europa se tem das "nações ricas e poderosas da América" e volta a enumerar as razões de queixa do Brasil pelo desprezo a que foi votado pelos governos absolutistas e pelo novo Governo das Cortes.

O processo sofre nova aceleração. No número de Março de 1822, o Correio avança com uma proposta moderada para uma solução autonómica no Brasil, conservando-se a união dinástica: um governo central sob a autoridade do Príncipe Real D. Pedro. Perante a erupção de revoltas em algumas províncias e a ameaça de secessões que pudessem desmembrar o grande país, Hipólito elege como tarefa essencial garantir a integridade do território brasileiro. Ainda assim, a unidade não deve ser imposta por coacção mas pela persuasão do interesse mútuo, como sublinha na edição de Abril de 1822. Por essa altura, já o redactor concluíra que o processo estava suficientemente amadurecido

${ }^{54}$ Correo del Orinoco, Reproducción Facsimilar, Caracas, Corporación Venezolana de Guayana, 1968, n. $^{\circ} 18,13$ de Fevereiro de 1818, p. 1.

${ }^{55} C B, 136$ (Setembro 1819), pp. 275-277. 
para a proclamação da independência. Considera legítima a recusa do Brasil em obedecer às Cortes, classifica como algo de "pernicioso" a permanência dos deputados brasileiros - cuja "energia" enaltece - em Lisboa e declara, sobre a posição do Brasil, que "se não lhe faz conta comprar a união, passará sem ela" (Junho de 1822).

O compromisso por que tanto se batera o Correio viria a ter por núcleo a Carta Constitucional outorgada em 1826 por D. Pedro IV, o mesmo que lançara o grito do Ipiranga no Brasil. Os princípios da Carta não diferem dos do "Projecto de Constituição", com a significativa excepção da base eleitoral: Hipólito da Costa pretendera alargar o consenso nacional a camadas muito mais amplas da sociedade - daí não ter previsto o regime censitário, obstáculo à participação política de todos os cidadãos. A Portugal, o compromisso histórico custaria ainda o preço da contra-revolução e da guerra civil.

Hipólito não assistiria a este desfecho. Encerrado o Correio, após a proclamação da independência brasileira, foi nomeado sucessivamente encarregado de negócios interino, cônsul-geral em Londres (a 20 de Setembro de 1823) e conselheiro honorário da Legação do Império do Brasil junto do embaixador Caldeira Brant, a 22 do mesmo mês. Não desempenharia, contudo, os últimos cargos: morrera a 11 de Setembro de 1823. O seu nome consta da primeira lista de agraciados com o grau de Oficial da Ordem Imperial do Cruzeiro, instituída a 1 de Dezembro de 1822 por D. Pedro I do Brasil. Além desse, fez jus a outro título, que cala mais fundo no coração dos amantes da liberdade de imprensa: Patriarca dos jornalistas brasileiros ${ }^{56}$. Depois de décadas de ostracismo, em que chegou a ser considerado personagem maldita graças ao eco das diatribes dos seus detractores, que perdurou - o redactor do primeiro periódico liberal de língua portuguesa foi reconhecido oficialmente como o fundador do jornalismo brasileiro. Por lei aprovada no Congresso federal de Brasília e promulgada pelo ex-Presidente da República Fernando Henrique Cardoso, em 2000, o Dia da Imprensa passou a ser comemorado a 1 de Junho: a data da publicação, em 1808, do primeiro número do Correio Braziliense.

56 Manuel Cícero Peregrino da Silva, "Conferência sobre o Patriarcha dos Jornalistas Brasileiros, Hppolyto José da Costa Pereira Furtado de Mendonça 1774-1823" in Revista do Instituto Histórico e Geográfico Brasileiro, tomo 94, vol. 148 (1923), Rio de Janeiro, 1927, p. 785. 


\title{
RABELAIS E “A ABADIA DE THÉLÈME”, GÉNESE DA ANTIUTOPIA NA IDADE MODERNA
}

\author{
J. M. Simões Ferreira \\ (Doutor em Teoria e \\ História das Ideias)
}

O autor sobre que nos vamos debruçar é um caso absolutamente singular da literatura ocidental, ou mesmo, um caso, a nível universal. Com efeito, François Rabelais (1494-1553), como disse Victor Hugo:

"Na ordem dos grandes génios, Rabelais segue cronologicamente Dante; depois da fisionomia severa, a fase trocista. Rabelais é a máscara formidável da comédia antiga separada do proscénio grego, do bronze feito carne, doravante um rosto humano e vivo, continuando enorme e vindo rir de nós entre nós e connosco"1.

Último dos escritores medievais franceses, segundo alguns ${ }^{2}$, primeiro dos humanistas e renascentistas, segundo outros ${ }^{3}$, parece ser, sem dúvida, um homem que se situa numa época de transição entre dois períodos históricos, a Idade Média e o Renascimento, e suas distintas configurações culturais, sendo a sua obra como que uma charneira de articulação entre esses dois universos sociais e mentais, diferenciados e antagónicos, mas, ao mesmo tempo, e paradoxalmente, intrincados um no outro, e mutuamente se implicando. Natural da Touraine, iniciou a sua formação intelectual no Poitou, onde estudou medicina, tendo assumido a condição de monge para poder prosseguir os seus estudos, que versaram também a cultura da Antiguidade, em que adquiriu sólida formação, o que se sente na sua obra, com as remissões e alusões constantes a autores antigos. Aos trinta e oito anos, em 1532, torna-se "médico-chefe do Hospital de Notre-Dame-de-Pitié, em Lyon... o que atesta a reputação médica

1 Victor Hugo, «Prefácio a François Rabelais», in Rabelais, François, Gargântua (1534, 5. a ed. 1542 ne varietur) trad. de M. ${ }^{a}$ Gabriela de Bragança, Lisboa, 1987, p. 9.

2 Tieghem, Philippe van, História da Literatura Francesa, Lisboa, 1956, p. 37: "Rabelais é o último escritor da Idade Média. Depois dele, o Renascimento desviará a literatura para um rumo totalmente diverso. Logo a seguir à sua morte, foi ignorado ou desprezado por todos aqueles que podiam ser considerados os representantes dos novos gostos em literatura."

3 Michel, P., «Introdução a Rabelais», in Rabelais, ob. cit. (1534, 1542), p. 13. - Ver também: Morçay, Raoul, «Introduction» a Édition critique de Rabelais, François, L'Abbaye de Thélème, 1947, apresenta como conclusão: "Tandis que le programme d'études de Gargâtua et la lettre à Pantagruel avaient été un hymne à l'Humanisme, l'Abbaye de Thélème est le poème de la Renaissance"(p. 31)." 
de Rabelais" ${ }^{4}$. A estreia no campo da literatura, dá-se precisamente em ligação com a sua profissão, tendo publicado, entre fins de 1531 e princípios de 1532, "Lettres de Giovanni Manardi", um médico italiano, de Ferrara, e os "Aphorismes" de Hipócrates, a que se seguiu uma sátira humanista, escrita em latim: "Lucii Cuspidii testamentumu" (Pseudo-testamento de Cuspidius). No mesmo ano em que é nomeado médico-chefe, 1532, pelo Outono, publica sobre o nome de Alcofribas Nasier, "anagrama de François Rabelais", segundo Raoul Morçay5, a primeira das suas obras-primas: "Les horribles et espoventables faictz et prouesses du très-renommé Pantagruel, Roy des Dipsodes, filz du grand géant Gargantua"6, a que se segue, em 1534, "La Vie inestimable du grand Gargantua, père de Pantagruel, jadis composée par l'abstractuer de quinte essence, livre plein de Pantagruélisme"7, que será, reeditado no ano seguinte, e de novo, em 1537, com duas edições, uma em Lyon, outra em Paris. A 5. ${ }^{\text {a }}$ edição, de 1542, foi a última revista pelo autor, e é considerada a ne varietur, sendo a usada, quer em francês, quer na tradução portuguesa, para a presente exposição e interpretação, que essencialmente se debruçará sobre os seis últimos capítulos (Cap. LII a Cap. LVIII), onde é descrita a história da fundação de "L'Abbaye de Thélème", e do extraordinário modo de vida dos

4 Michel, «ob. cit.», in Rabelais, ob. cit. (1534, 1542), p. 13.

5 Morçay, Raoul, «Introduction» a ed. critique de... in Rabelais, François, L'Abbaye de Thélème, Paris, 1947, p. 7.

6 Rabelais, François, Les horribles et espoventables faictz et prouesses du très-renommé Pantagruel, Roy des Dipsodes, filz du grand géant Gargantua (1532), première publication critique sur le texte original par V. L. Saulnier, prof. à la Sorbonne, nouvelle édition augmentée, Genève, 1965. - Servimo-nos também da ed. portuguesa, Pantagruel, Rei dos Dípsodos, restituído ao natural com seus factos e proezas espantosos. Compostos pelo falecido Mestre Alcofribas, abstactor de requinte, trad. de Aníbal Fernandes, Lisboa, 1975. - A ed. francesa contém uma nota mencionando o título original da ed. de 1532: PANTAGRUEL, Roy des Dipsodes, restitué à son naturel, avec ses faictz et prouesses espoventales. Composez par feu M. Alcofribas, abstracteur de quinte essence. - Les éditions de [Lyon, François Juste], 1534, et Lyon, Pierre de Sainte Lucie, 1535, ajoutaient, après la première mention «Pantagruel», la devise grecque: $A Y A \theta H$ TYXH.

7 Rabelais, François, La vie très horrifique du grand Gargantua, père de Pantagruel, jadis composée par M. Alcofribas abstracteur de quinte essence. Livre plein de Pantagruelisme (1534, 5. ${ }^{\text {a }}$ ed. 1542 ne varietur), édition illustrée, annotée par Jules de Foucault, agrégé de l'Université, Préface de Jacques Perret, Paris, 1949. - Servimo-nos também da ed. portuguesa, Gargântua (título de capa; por completo: A vida muito horrifica do grande Gargântua, Pai de Pantagruel, em tempos composta por M. Alcofribas, Condensador de Quinta Essência. Livro cheio de Pantagruelismo), trad. de M. ${ }^{\mathrm{a}}$ G. de Bragança, Lisboa, 1987; e da ed. crítica de Raoul Morçay, referenciada na nota 5. - As transcrições dos textos, quer do Gargântua quer do Pantagruel, usadas neste artigo, são feitas a partir das traduções em português referidas. No entanto, são alteradas, sempre que, através do cotejamento com as versões em francês, ou por melhor adaptação ao sentido do texto do artigo, se achou conveniente e apropriado fazê-lo. 
telemitas, seus habitantes. - Rabelais escreveu ainda outros textos, como o "Tiers livre...", de 1546, "La Sciomachie...", de 1549, "La Dignité des Braguettes...", e o famoso "Quart livre...", de 1552, além de textos considerados menores, alguns deles de publicação póstuma. - Para os fins deste artigo, o que mais interessa são os já ditos capítulos de "Gargântua", onde se trata da Abadia de Thélème; vai-se, no entanto, começar por um esboço rápido dos dois livros que são, em conjunto, considerados a sua obra-prima, tendo em vista explorar a contribuição de Rabelais para este universo das utopias urbanístico-arquitectónicas e políticas ${ }^{8}$, adiantando-se desde já que na sua obra se atende a ambas as facetas... e com facécias variadas.

Gargântua e Pantagruel: Em 1532 com a publicação de Pantagruel é lançado no mercado livreiro francês, então em fase de expansão, graças à invenção da imprensa de Gutenberg, e ao tipo de cultura que se estava expandindo por toda a Europa, uma cultura baseada no livro - que mais tarde seria comentada e definida como tendo substituído a cultura de pedra das catedrais medievais: o célebre "Ceci tuera celá"9, de Victor Hugo, em "Nossa Senhora de Paris" -, a história dum herói prodigioso, de seu nome Pantagruel, filho de Gargântua, que o gerara já na avançada "idade de quatrocentos e oitenta e quarenta e quatro anos", sendo sua mãe, "Bicaberta, filha do rei dos Amaurotas da Utopia, a qual morreu de parto por ser a criança tão maravilhosamente grande e pesada que não pôde vir à luz sem sufocar a mãe"10. - Deve-se aqui intercalar um parêntese chamando a atenção para o facto de as figuras de

8 Este artigo foi adaptado de um capítulo da Dissertação de Mestrado em Filosofia, na FCSH/ UNL, intitulada "Visões de Utopia. As Teorias da Arquitectura e as Utopias Politicas nos alvores da Idade Moderna", Lisboa, 2002, que aguarda publicação em livro.

9 Hugo, Victor, Notre-Dame de Paris 1482 (1832), Paris, 1975, L. V, I e II, p. 206 e 209. - Há o que nos parece uma excelente "tradução cuidada" desta obra, para português, de autor não identificado: Hugo, Vítor, Nossa Senhora de Paris, Porto, 1967, 2 vols.; as passagem e frase aludidas encontram-se a p. 218: "...passeando um triste olhar do livro para a igreja: - Infelizmente - disse ele - isto há-de matar aquilo"; e p. 221: "Isto há-de matar aquilo. O livro acabará com o edificio", seguindo-se toda uma reflexão sobre o sentido da expressão que inclui as seguintes previsões: "A imprensa acabará com a Igreja...[e]... A imprensa acabará com a arquitectura"(p. 222), continuando: "Efectivamente, desde a origem das coisas até ao século XV da era cristã inclusivamente, a arquitectura era o grande livro da humanidade, a expressão principal do homem nas suas diversas fases de desenvolvimento, quer como força, quer como inteligência... durante os seis mil primeiros anos do mundo, desde o pagode mais imemorial do Indostão até à Catedral de Colónia, a arquitectura foi a grande escritura do género humano. E isto é de tal modo verdade que não só todo o símbolo religioso, mas também todo o pensamento humano, tem a sua página nesse livro imenso e o seu monumento." (p. 222 e p. 224).

10 Rabelais, ob. cit. (1532), p. 31. - As citações são feitas a partir da edição portuguesa (ver nota 8). 
"Pantagruel", bem como depois, de "Gargântua", serem inspiradas e provocadas por um "romance popular reeditado em Lyon [onde, então, vivia Rabelais] em 1532", cujo título era precisamente "Grandes et inestimables chroniques du grand et énorme géant Gargantua..."(ils. capa). Esta inspiração numa forma de expressão cultural popular é a marca mais distintiva de Rabelais, o "contexto" a que em definitivo remete a sua obra e a explica, como bem o viu Mikhail Bakhtin, no seu incontornável estudo sobre Rabelais"1. Embora a conexão com a "Utopia" de Morus, filiação parodiante até, como se viu, seja estabelecida logo de início e duma maneira que se julga inequívoca. Com efeito, ao mundo regrado, de apetites refreados e comedidos dos utopianos, logo de início é contraposto um outro mundo, essencialmente baseado no descomedimento e desmesura, que o próprio nome de Pantagruel significa, pois que "panta, em grego [é] equivalente a todo, gruel, que é sede na língua mourisca, querendo daqui inferir que todo o mundo estava sequioso à hora da sua natividade e também, num espírito de profecia, que alguma vez ele iria ser dominador entre os sedentos"12. E, realmente, é como grande bebedor e comilão que Pantagruel começa por ser caracterizado, além de ter um tamanho gigantesco, no que seria digno herdeiro de seu pai, um gigante, também, e, de resto, são os feitos e proezas dum herói de tamanho, força e apetites gigantescos que vão ser descritos, começando pelas suas proezas de infância em que devora uma vaca viva, dá cabo dum urso e rebenta umas grossas correntes com que seu pai o tentara manietar no berço, a que se seguem os desbragamentos duma vida de estudante em Paris acolitado por dois companheiros, Epistémon, homem dado à ciência de disparatar (uma singular epistemologia, mas não tão rara como é de supor), e Panurge, que ao anterior não ficava atrás, e tudo sempre bem bebido e com respeitáveis comezainas, grandes amores, e outros folguedos, à mistura. Pelo meio disto tudo Pantagruel começa a ganhar fama como homem sábio e de conselho, sendo chamado a intervir em várias questiúnculas, e até atraíndo sábios do estrangeiro, interessados em o ouvir e medir forças intelectuais com ele que, claro, com sua inteligência de tamanho proporcional ao corpo, e a ajuda dos seus ladinos companheiros, os desancava. - Por fim, chegam notícias duma invasão perpretada pelos Dípsodos que já tinham "desvastado uma extensa região de Utopia, sitiando a grande cidade dos Amaurotas", onde seu pai estava, tendo para lá sido levado pela fada Morgana. É claro que este acontecimento vai interromper a doce vida parisiense e conduzir o nosso herói e seus companheiros a novas aventuras em socorro dos utopianos e do velho Gargântua. Os Dípsodos, que quer dizer "gente com

11 Bakhtin, Mikhail, A Cultura Popular na Idade Média e no Renascimento: o contexto de François Rabelais, trad. de Yara Frateschi, São Paulo-Brasília, 2.a ed. 1993.

12 Rabelais, ob. cit. (1532), p. 33. 
sede", cujo rei se chamava Anarca, ou seja, o que não sabe dirigir ou comandar, tinham um fabuloso exército, com trezentos gigantes comandados por Lobisomem, milhentos soldados, imensa artilharia, e "cento e cinquenta mil putas, belas como deusas", que terá sido o que deu mais trabalho a derrubar, a Pantagruel e seus companheiros que, desde logo, fizeram questão de "não escapar uma, que seja, sem levar aquela conta". Uma vez libertada a cidade dos Amaurotas, resolvem ir conquistar o país dos Dípsodos, cujo rei fica em Amaurota, convertendo a sua actividade profissional em "vendedor de molho verde", e casado com uma utopiana, que tinha "uma grande racha", e que, veio a saber-se mais tarde, "malhava nele como em centeio verde e o Anarca tão mansarrão, nem ousava defender-se". Uma vez conquistado o país dos Dípsodos, Pantagruel torna-se seu rei, e tudo acaba com um enorme banquete, onde o "povo com sede", estimulado pela extraordinária capacidade de beber do seu novo rei, faz fama ao seu nome, e acaba mostrando-se como um povo digno de tal rei.

Também com um banquete, desta vez ao ar livre, uma espécie de piquenique, ocorrera a nascença de Gargântua, cujo nome quer dizer "grande goela", pai de Pantagruel que, tal como o filho, teve uma infância feliz e despreocupada, bebendo rios de leite, e comendo desde logo enormidades, como nem na terra de Cocanha ${ }^{13}$, onde em boa medida se parecem filiar estas histó-

13 Júnior, Hilário Franco, Cocanha. A História de um País Imaginário, prefácio de Jacques Le Goff, São Paulo, 1998, p. 206-207: “Rabelais...em 1532 ainda parecia conhecer, directa ou indirectamente, o fabliau de Cocaingne. Sem dúvida entre as tradições folclóricas que lhe serviram de fonte para o motivo da glutoneria, recorrente em sua obra, estava o poema La bataille de Caresme et de Charnage, de clara intertextualidade com o fabliau. Aliás, o tema medieval do combate entre o Carnaval e Quaresma parece ter conhecido o seu maior sucesso exactamente na época renascentista... É interessante observar que a etimologia dada por Rabelais a seu principal personagem, Pantagruel ("tudo alterado"), pode ter sido inspirada por um texto daquele tipo, que fala em "faict le pentagruel", isto é "alterar"... Outra criação rabelaisiana, a abadia de Thélème, onde não há clausura, restrições de horário, separação de sexos, celibato, voto de castidade, pobreza e obediência, também apresenta claras ressonâncias cocanianas. Ali todas as mulheres são belas, como na Cocanha medieval. Ali o desejo de cada um procura satisfazer o dos outros, da mesma forma que na Cocanha ao atender aos próprios desejos... Ali, expressamente, a única regra é "fay ce que voudras" ("faça o que quizer"), correspondente ao "Ninguém ousa proibir algo do texto do século XIII [o texto referido, que é transcrito na língua original e traduzido para português, nesta obra, é "Fableau de Cocaigne"]." - Alterou-se ligeiramente a ortografia, na transcrição. - Também Bakhtin parece reconhecer reflexos das lendas de Cocanha na obra de Rabelais; ver Bakhtin, ob. cit., p. 259-60 e ss.: "Havia um ciclo de lendas extremamente populares, que apresentava o país utópico da glutonaria e da ociosidade (por exemplo o fabliau do País da Abundância [Pays de cocagne, segundo nota de pé de página]. Encontramos reflexos dessas lendas em numerosos documentos da literatura medieval... Reencontramos a influência desse ciclo de lendas nos episódios da estadia de Alcofribas na boca de Pantagruel..." 
rias de Rabelais. Igualmente teve uma adolescência despreocupada, estudando em Paris, agora mais dado a outras bebidas que não o leite. Tal como já antes - literariamente falando, pois que há outras maneiras de considerar o tempo, sem ser a cronológica, regrada pelos relógios, que estavam abolidos em Thélème - ocorrera com seu filho, os estudos parisienses são interrompidos para intervir numa guerra em auxílio de seu pai, o benévolo rei Grandgousier, cujo reino fora invadido por um desvairado rei vizinho, de seu nome Picrocole. É a chamada guerra dos biscoitos, em que Gargântua, com a ajuda de alguns compinchas, entre os quais o notável frade Frei Jean des Entommeures, dá uma tareia nos invasores, recambiando-os para a sua terra, isto, claro, aos que não ficaram pelo caminho. No fim, celebrando a vitória, durante um daqueles banquetes em que passavam a vida, obsequia o frade com a oferta de um vasto terreno e uma considerável soma em dinheiro para que ele fundasse uma abadia exemplar, à medida do tão extraordinário valor que demonstrara na expulsão dos invasores.

Fundação, primeiras prescrições arquitectónicas, e Estatutos da Abadia de Thélème: A ideia de fundar uma abadia segundo os seus planos, surge na sequência da oferta feita por Gargântua de duas outras abadias, já existentes, e a recusa do nosso abade, na base da consideração seguinte: "Como... poderia eu governar os outros se não saberia governar-me a mim?", acrescentando: "Se vos parece que vos fiz e que posso fazer-vos no futuro algum serviço agradável, deixai-me fundar uma abadia segundo os meus planos". Essa abadia seria situada na região de Thélème, junto ao rio Loire, "e o frade pediu a Gargântua que instituisse o seu convento ao contrário de todos os outros"14. A primeira prescrição sobre os aspectos e regras, que se deveriam observar neste convento, a instituir ao contrário dos outros, vai contemplar, precisamente, uma questão referente ao ordenamento e disposição da construção, implicando claramente com a arquitectura, que surge, assim, vista como determinante das características e tipo de vida da abadia a instituir. Em conformidade com tal, não se deveriam construir muralhas em volta, como nas outras abadias, porque "onde há muro pela frente e por trás há murmúrio, inveja e conspiração mútua". Também seria estabelecida, institucionalmente, a singularidade de não permitir a entrada a religiosos ou religiosas, pois:

"como em certos conventos deste mundo é costume, se alguma mulher lá entra (quer dizer as recatadas e pudicas), limpar-se o lugar por onde passaram, orde-

14 Rabelais, ob. cit. $(1534,1542)$, p. 200 . - As citações são feitas a partir da edição portuguesa (ver nota 8). 
nou-se que, se por acaso ali entrasse algum religioso ou religiosa, se limpassem cuidadosamente todos os lugares por onde tivessem passado."15.

Nessa abadia singular eram proibidos os relógios e os quadrantes solares, "porque nos conventos deste mundo tudo é compassado, limitado e regido pelas horas" 16 , parecendo exprimir-se o desejo de abolição do tempo ou, pelo menos, da sua mensurabilidade:

"pois (como dizia Gargântua) a mais verdadeira perda de tempo que co/nhecemos era contar horas - que bem vinha dai? - e a maior loucura do mundo era governar-se pelo som de um sino, e não pela ordem do bom senso e entendimento." 17 .

Só às belas mulheres - e não às habituais "zarolhas, coxas, corcundas, feias, tolas e empata-famílias" era permitido entrar porque, para o frade, "uma mulher que não é bela nem boa [singular aplicação parodiante do conceito e ideal clássico da "kallokogatia"], para que serve?". Assim, foi decidido que "não se recebessem ali senão as belas, bem feitas e de boa natureza, e os belos, bem feitos e de boa natureza"18. - Enfim, seria uma abadia para gente de escol, embora um escol ditado, essencialmente, pela natureza e a estética; à maneira renascentista: imitação da bela natureza. - E prossegue, enunciando as três regras básicas desta nova organização abacial; regras essas que mais parecem ser anti-regras, ou uma paródia às convencionais regras conven/tuais:

"Item, porque nos conventos das mulheres os homens só entravam de fugida e clandestinamente, decretou-se que não haveria lá mulheres quando não estivessem lá homens, nem homens quando não estivessem mulheres." 19.

Quebra, assim, a primeira regra, a da separação dos sexos, que para ele seria a mais importante e decisiva, no sentido de instituir e caracterizar a sua abadia como um convento ao contrário dos outros - Aqui, nesta singular abadia, era imposta a junção dos sexos, por assim dizer...

"Item, porque tanto homens como mulheres, uma vez entrados no convento e após um ano de noviciado, eram obrigados a permanecer ali perpetuamente a vida

15 Rabelais, ob. cit. (1534, 1542), Liv. LII, p. 200.

16 Rabelais, ob. cit. (1534, 1542), Liv. LII, p. 200.

17 Rabelais, ob. cit. $(1534,1542)$, Liv. LII, p. 200-201.

18 Rabelais, ob. cit. (1534, 1542), Liv. LII, p. 201.

19 Rabelais, ob. cit. (1534, 1542), Liv. LII, p. 201. 
inteira, estabeleceu-se que tanto homens como mulheres que fossem recebidos sairiam quando quisessem, livremente e inteiramente. "20.

Assim, tal como não haveriam muralhas exteriores, também eram abolidas as "interiores": podia-se entrar e sair quando se quisesse e muito bem entendesse.

"Idem, porque ordinariamente os religiosos faziam três votos a saber: de castidade, pobreza e obediência, ficou determinado que ali se pode honradamente ser casado, e que cada qual fosse rico e vivesse em liberdade. "21.

Igualmente, os aspectos dificultosos - muralhados e causadores de murmuração - da vida monástica: os votos que obrigavam à castidade, à pobreza, à obediência, são preteridos como condição deste novo tipo de vida. - Após a descrição das doações feitas por Gargântua para financiar a construção da abadia e a manutenção da comunidade, em que são nomeadas importâncias consideráveis, sempre em dinheiro, e tudo moedas de ouro, exibindo assim o novo ídolo do tempo, vem a descrição das formas arquitectónicas desta:

\section{Ordenamento arquitectónico da Abadia de Thélème.}

"O edificio teve a forma exagonal [(ils. $1 \mathrm{e} 2)$ ] de tal maneira que em cada ângulo havia uma grande torre redonda de sessenta passos [aprox. $108 \mathrm{~m}$ ] de diâmetro, $e$ eram todas iguais na largura e no feitio. O rio Loire corria do lado norte. Ao pé dele assentava uma das torres chamada Ártice [do grego Amktikes, isto é, Norte], voltada para oriente havia outra chamada Calear [do grego, Kallós, belo, e aer, ar], e a outra chamava-se Anatólia [Anatole], a outra Mesembrina [Messenbrine], a outra Hespéria [Espeia], e a última Criera [Kryera]."22.

Esta enumeração das orientações em relação aos quadrantes é uma paródia a Vitrúvio, e seus comentadores renascentistas, e às suas prescrições de orientação da aedificatio em relação à defesa dos ventos e aos quadrantes donde eles sopravam ${ }^{23}$, bem como aos excessos de insolação, porque nem o regime dos ventos, nem o tipo de insolação em França era o mesmo e, aliás,

20 Rabelais, ob. cit. $(1534,1542)$, Liv. LII, p. 201.

21 Rabelais, ob. cit. $(1534,1542)$, Liv. LII, p. 201

22 Rabelais, ob. cit. (1534, 1542), Liv. LIII, p. 202.

23 Vitruve, De l'architecture (De architectura libri decem), L. I, Cap. VI, $\S \S 1-13$, ed. critique de Philippe Fleury et altri, Paris, 2002, p. 31-41. 
Rabelais, como médico, saberia que, se os ventos e a insolação tinham inconvenientes, também teriam as suas vantagens, prosseguindo a descrição:

"Entre cada torre havia um espaço de trezentos e doze passos [aprox. $560 \mathrm{~m}$ ]. Tudo isso com seis andares, incluindo as caves. O segundo era abobadado em forma de as a de cesto; o resto estava revestido de gesso da Flandres em forma de candeeiro e os fundos do telhado cobertos de ardósia fina, com revestimento de chumbo enfeitado com figuras e animais bem escolhidos e dourados, com as goteiras que avançam para fora da muralha, entre os transeptos pintados em diagonal a ouro e azul, até ao solo, onde terminavam em grandes algerozes que conduziam ao rio por baixo da construção. Este edificio era cem vezes mais magnifico que Bonivet, Chambourg e Chantily, pois nele havia nove mil trezentos e trinta e dois quartos, todos guarnecidos de alcova, gabinete, guarda-roupa, capela, e dando para um grande salão. "24.

Os palácios citados como modelos de referência, Bonivet, Chambourg e Chantily, tinham sido construídos ou estavam em construção por aquela época e são marcos na introdução do estilo arquitectónico do Renascimento em França, estando os dois últimos incluídos no tratado de Jacques Androuet du Cerceau (1520-84), "Les plus excellents bastiments de France"25, de 1576-77, que, essencialmente, consta de uma recolha e apresentação de edifícios reais, a maior parte dos quais, já deste período de introdução da arquitectura renascentista em França, e na maioria mandados construir pela rainha Catarina de Médecis, que, por causa desta sua paixão edificatória, deixou um montão de dívidas, quando faleceu. $\mathrm{O}$ bizarro número dos quartos, 9332, para além do seu gigantismo, na soma dos seus algarismos $9+3+3+2$, dá 17 , o que para os "numerologistas" poderá ter tantos e tão extraordinários significados, que se considera dispensável alvitrar algum mais, ficando-nos, contudo, a vaga suspeita de haver nestes extravagantes e desmesurados números, uma intenção parodiante, em relação a certos aspectos extremos do pitagorismo-platonismo, e a algumas das suas sofisticadas e herméticas interpretações renascentistas. De resto, o número mais determinante - ou mais parodiado - no ordenamento de toda esta arquitectura, parece ser o 6, que já para Vitrúvio seria o número ideal para o ordenamento (a ordenatio, ou taxis) arquitectónico ${ }^{26}$, além da carga pitagórico-platónica que este número, segundo tal doutrina, o mais perfeito dos números, teria. Com efeito, além de ser um exágono a forma global, o número de andares eram 6, e as dimensões do diâmetro das torres, 60 passos,

24 Rabelais, ob. cit. (1534, 1542), Liv. LIII, p. 202-203.

25 Androuet du Cerceau, Jacques, Les plus excellents bastiments de France (1576-77), ed. facsimil, s. 1., 1988, L'Aventurine, p. 48-55 e 243-54.

26 Vitruve, ob. cit., L. I, Cap. II, $\S 1$ e 2, ed. critique, 2002, p. 14-15. 
ou as de cada lado do exágono, 312 passos, são múltiplos de 6. Outra leitura, complementar desta, e com ela se conjugando nas constantes intenções parodiantes de Rabelais, é o facto de 6 ser metade de 12 e, este número, além de ser o dos apóstolos, ser aquele com que "o Apocalipse determina a Jerusalém Celeste", configurando-se, com estes especiais números, os thelemitas como meios apóstolos, e o seu especialíssimo habitat "algo assim como "meia" Jerusalém Celeste"27. Também é de salientar que a forma exagonal, enquanto forma centralizada, corresponde a temas ideais da arquitectura desde a Antiguidade, e que agora no Renascimento, estavam na ordem do dia, sendo, por exemplo, a forma escolhida por Sebastiano Sérlio (1475-1553), para o seu projecto de reconstrução do Porto de Óstia. Sérlio, que viveu os últimos anos da sua vida, em França, os últimos três ou quatro, mesmo em Lyon, cidade onde viveu Rabelais, e foi dos principais responsáveis pela divulgação e introdução da Arquitectura Renascentista em França, onde alguns dos oito Livros do seu tratado sobre Arquitectura ${ }^{28}$ foram editados, sendo o Livro Terceiro dedicado ao Rei de França, Francisco I. Mas, todavia, considera-se que a forma descrita a ter alguma mais directa influência seria a de Philibert De L'Orme (1510-70), o maior arquitecto francês dessa época, natural de Lyon, e grande amigo de Rabelais, que, no entanto, e precisamente tomando a arquitectura como alvo, lhe endereça alguns dos seus adereços parodiantes, como no desenvolvimento deste trabalho se verá.

Como nota peculiar, bem francesa, é de notar as preocupações com o conforto, em Thélème, pois que aqui nada havia da habitual cela exígua dos conventos, mas mais até do que uma suite, um autêntico apartamento, dotado de capela e tudo. Esta dotação com capela parece indiciar o reconhecimento do carácter privado e pessoal da relação com Deus que, sob o impulso das Reformas luterana, calvinista, e erasmista, se estava fazendo reconhecer. - De resto, a descrição vai continuar referindo, agora:

27 Kruft, Hanno-Walter, Geschichte der Architekturtheorie. Von der Antike bis zur Gegenwart (1985), 10. Die französische Entwicklung im 16. Jahrhundert, München, 4 Auflage 1995, p. 138.

28 Serlio, Sebastiano, L'architettura, I libri I-VII e Extraordinario nelle prime edizioni (1537 ss.), ed. facsimil a cura de Francesco Paolo Fiore, Milano, 2001. - O Porto de Ostia aparece representado no L. III, Il Terzo libro di Sabastiano Serlio Bolognese, nel qual si figurano, e descrivono le Antiquita di Roma, e le altre che sono in Italia, e fuori d'Italia, p. LXXXIII. - Este L. III é o segundo dos oito livros a ser publicado em Veneza. Em França, segundo traduções de Jean Martin, Serlio é divulgado a partir de 1545 (L. I e L.II), 1547 (L. V), e é publicado, em italiano, o Extraordinario libro di architettura nel quale si dimostrano trenta porte di opera rustica mista..., em 1551, em Lyon, terra onde vivia Rabelais, e onde viveu Serlio. - Assim, o conhecimento entre ambos é altamente provável, embora não hajam provas disso, ou não tenham sido procuradas. 
"Entre cada torre, no meio do referido edificio, havia uma escada de caracol em cujo corpo os degraus eram parte de pórfiro, parte de pedra numídica, parte de mármore serpentino, com um comprimento de xxij pés [aprox. $7 \mathrm{~m}$ ], e uma espessura de três dedos, sendo em número de doze entre cada patamar. Em cada patamar havia dois bonitos arcos antigos por onde entrava a luz do dia, e dando acesso a um gabinete gradeado da largura da dita escada. E por esta subia até ao telhado, onde terminava num pavilhão. Por esta escada entrava-se dos dois lados numa grande sala, e das salas passava-se aos quartos. ${ }^{\prime 2}$.

A descrição dos materiais pétreos, "pórfiro", "pedra numídica", "mármore serpentino", tudo pedras que não existiam nas pedreiras de França, tende a acentuar o carácter extravagante e luxuoso desta abadia, construída com cantarias oriundas do estrangeiro, de aspecto exótico, faustoso e luxuriante, bem longe das medievais prescrições restritivas de Bernardo de Claraval, sobre o fausto e a luxúria das construções, a que, já no seu tempo, o abade Suger, comitente da edificação da abadia de St. Dennis, onde o gótico teve a sua origem, pouco parece ter ligado. - Mas agora estava-se numa época em que se tinha ganho uma nova e mais dilatada consciência da amplidão geográfica da cultura em que se estava imerso, o que se denota bem na descrição que vai fazer da(s) biblioteca(s):

"Entre a torre Ártice e a Criera ficavam as belas e grandes bibliotecas em grego, latim, hebreu, francês, toscano e espanhol, repartidas pelos diversos andares segundo estas linguas. " 30 .

Repare-se como a área mediterrânica está representada, e as línguas que nela mais incidem, que eram, por um lado, o "grego, latim [e] hebreu" da tradição medieval, e por outro, o "francês, toscano e espanhol" que, além das anteriores, eram as novas línguas da cultura humanista e renascentista então emergente.

"Entre a torre Anatólia e a Mesembrina ficavam as bonitas e grandes galerias, todas pintadas com as antigas proezas, histórias e descrições da terra. No meio havia uma subida e a dita porta do lado do rio, na qual estava escrito em grandes letras antigas o que segue":

"Aqui não entreis hipócritas, beatos, Velhos macacos, falsos, inchados,

Pescoços torcidos, pacóvios, ainda mais que os godos,

Nem ostrogodos precursores dos macacos

29 Rabelais, ob. cit. $(1534,1542)$, Liv. LIII, p. 203.

30 Rabelais, ob. cit. $(1534,1542)$, Liv. LIII, p. 203. 
Ciliciados, fingidos, beatos de pantufas,

Pedintes enroupados, debochados, achincalhados,

Injuriados, inchados, fazedores de intrigas;

Retirai-vos e ide vender os vossos abusos para longe".

"Vossos abusos maldosos

Encher-me-iam os campos

De maldade;

E por falsidade

Perturbariam os meus cantos

Os vossos abusos maldosos. "”1

O poema continua com mais seis estrofes em sextilhas e seis em oitavas, que se vão alternando, consistindo, no total, em dois conjuntos de sete. - (Note-se que o bizarro número de 9332 , embora não perfeitamente, é divisível por sete, uma vez que dá resto 1 , mas o resultado de $9332 / 7=1333$, restando 1 (a unidade ou individualidade, que não tem lugar em Thélème), é capaz de estar dentro das intenções parodiantes de Rabelais). - Este poema, nas oitavas, começa sempre por "Aqui não entreis" e indica uma série de exclusões, excepto a última oitava que, ao contrário, convida a entrar as "damas de alta estripe", eleitas para a inclusão. As sextilhas referem-se sempre à razão justificativa ou fundamento das prescrições de exclusão apontadas nas oitavas, mas de um modo alusivo e indirecto. Vejam-se a última oitava e sua sextilha:

"Aqui entrai, vós, damas de alta estirpe!

Com franca coragem entrai felizes,

Flores de beleza com celeste rosto,

De busto direito, e atitude recatada e sensata.

Nesta passagem está a morada da honra.

$O$ alto senhor, que do lugar foi doador

$E$ benfeitor, para vós o ordenou,

E deu muito ouro para pagar as despesas."

"Ouro dado por dádiva

Ordena perdão

A quem o dá,

E muito bem recompensa

Todo o mortal honesto

Ouro dado por dádiva. "32.

31 Rabelais, ob. cit. (1534, 1542), Livs. LIII-LIV, p. 203-205.

32 Rabelais, ob. cit. (1534, 1542), Liv. LIV, p. 207. 
Enfim, a abadia de Thélème seria um mundo reservado, onde não entraria o lado fechado ou amuralhado, odioso, trabalhoso e aborrecido da vida - o lado sombrio dado ao murmúrio, descontentamento e insatisfação -, mas apenas o lado aberto e risonho, dos prazeres e encantos da natureza, da cultura e beleza, de que as mulheres, i. é, "as damas de alta estirpe", seriam o símbolo por natureza; assim, como que umas "Flores de beleza com celeste rosto / De busto direito, e atitude recatada e sensata". Mas claro, que essa natureza, Rabelais percebe que é duma nova natureza que se trata: uma natureza corrigida, melhorada, artificializada; enfim, uma natureza pouco natural, porque construída pela Arte e pela Cultura. E como entre essas arte e cultura, a arquitectura tinha um papel relevante, a descrição da configuração e disposição de todo aquele ordenamento arquitectónico continua, abrangendo, agora os aspectos da ornamentação e arranjos exteriores, nomeadamente os vários equipamentos complementares, que faziam parte do lexical reportório mítico da Arquitectura da Antiguidade, tais como o "hipódromo", "teatro", "natatórios" (piscinas), etc.:

"No meio do páteo interior havia uma magnifica fonte de belo alabastro; por cima as três Graças, com cornos da abundância, deitavam água pelas mamas, pela boca, pelos ouvidos, pelos olhos e por outras aberturas do corpo. O interior do edificio sobre o dito páteo estava assente em grossos 'pilares de calcedónia e pórfiro com belas artes antigas, e dentro havia belas galerias, compridas e amplas, adornadas de pinturas, dentes de elefante e outras coisas admiráveis. Os alojamentos das damas iam da torre Ártice à porta Mesembrina. Os homens ocupavam o resto. Diante dos ditos alojamentos das damas, entre as duas primeiras torres e no exterior, havia, para elas se recrearem, os recintos destinados aos torneios, o hipódromo, o teatro, os natatórios, com os banhos miríficos de três patamares, bem guarnecidos de todos os enfeites e de grande quantidade de água de mirra." 33 .

É toda a gama de recursos da Arquitectura da Antiguidade, em versão renascentista, como era próprio ao tempo, que aqui surge revisitada, no tom parodiante peculiar a Rabelais, que parece não perder oportunidade de tornar as coisas redundantes e enfocá-las pelo lado ridículo ou brejeiro, como acontece com a fonte adornada com as três Graças, que deitavam água, além das "mamas" por todas as "aberturas do corpo", e que é claramente inspirada na descrição e representação gráfica de uma fonte da "Hypnerotomachia Poliphili”, de Francesco Colonna ${ }^{34}$. - A divisão em alas diferenciadas, para homens

33 Rabelais, ob. cit. (1534, 1542), Liv. LV, p. 210.

34 Colonna, Francesco, Sueño de Polifilo (Hypnerotomachia Poliphili)(1499), Cap. VIII, tradl. lliteral del original aldino, introd., coment. y notas de Pilar Pedraza, Murcia, 1981, Tomo II, p. 81. 
e mulheres, viria a ser marca distintiva da arquitectura palaciana francesa, conduzindo ao chamado "esquema pavilhonar", verdadeira pedra-de-toque na disposição espacial da arquitectura dos palácios franceses, do Séc. XVII e XVIII, mas que já se fazia anunciar. Esse esquema visava precisamente dar resposta aos hábitos de independência de cada um dos cônjuges dentro das famílias aristocráticas, onde o casamento era mais uma convenção social do que uma relação de intimidade, coisa que - analogamente a esses hábitos aristocráticos, que Rabelais parece querer parodiar -, como se verá, em Thélème, tinha sido substituída por uma sociabilidade intensa. Correspondente a esta divisão era também a dos equipamentos, uma vez que uns seriam mais acessíveis aos homens, e, assim, estavam dispostos para o lado das alas por estes ocupados, e outros dispostos para o lado das mulheres. - Mas a descrição, contemplando todos estes aspectos e outros, continua:

"Junto do rio ficava o belo jardim de recreio, e no meio dele o belo labirinto. Entre as outras duas torres ficam os jogos da péla e da bola. Do lado da torre Criera ficava o pomar, cheio de todas as árvores de fruto, alinhadas em quicôncio. Ao fundo era o grande parque, repleto de todos os animais selvagens. Entre as terceiras torres ficavam os alvos para o arcabuz, o arco e a arbaleta; as dependências eram fora da torre Hespéria, e só tinham um andar; a estrebaria era depois das dependências e a falcoaria diante delas, sendo governada por criados conhecedores da arte da altanaria, e anualmente fornecida pelos candienes, venezianos e sármatas dos melhores exemplares de aves: águias, gerifaltes, açores, falcões, gaviões, esmerilhões e outros, tão bem treinados e domesticados que, partindo do castelo para voarem sobre os campos, apanhavam tudo o que encontravam. $O$ canil era um pouco mais longe, na direcção do parque. "35.

Enfim, é um mundo em que nada da tradicional e laboriosa agricultura, em que as ordens monásticas, como as dos beneditinos e cisterciences, foram exímias, está contemplado; talvez um lado laborioso que não se coadunaria com esta vida de esplendor e ociosidade de religiosos e religiosas, que mais parecem cortesãos e cortesãs. Assim, a caça, em relação à qual Tomás Morus, na "Utopia", levantara objecções ${ }^{36}$, teria em Thélème um lugar significativo

35 Rabelais, ob. cit. (1534, 1542), Liv. LV, p. 210-211.

36 Morus, Tomás, Utopia (1516), trad. de J. Marinho, L. II, 5, Lisboa, 1961, p. 110-11: “Os utopianos consideram também imaginários os prazeres da caça e dos jogos de azar... Não será coisa mais fatigante do que agradável ouvir latir e ladrar os cães? Será mais agradável ver um cão correr atrás de uma lebre do que vê-lo correr atrás de outro cão? Se é a corrida que dá prazer, ela existe em ambos os casos. Não será antes a esperança de ver o morticínio e a carnificina que tornam a caça tão apaixonante? Como não preferir abrir a alma à piedade, como não ter horror dessa carnificina em que o cão forte, cruel e ousado, dilacerar a lebre fraca, tímida e fugitiva?" 
nas ocupações deste clerc aristocrático. Também na ornamentação dos interiores nada haveria da fria e despojada cela monástica, de paredes nuas e mobiliário escasso. Aqui, neste convento, que fora instituído ao contrário dos outros, tudo era em abundância luxuriante, e de um conforto que faria inveja aos melhores palácios do tempo:

"Todas as salas, quartos e gabinetes estavam forrados de diversas maneiras, segundo as estações do ano. Todo o pavimento era coberto de tecido verde. As camas estavam cobertas de bordados. Em cada alcova (arriere chambre) havia um espelho cristalino, emoldurado de ouro fino e em volta guarnecido de pérolas, e tão grande que podia representar a pessoa inteira [o que ao tempo não era possivel[37]. À saída das salas dos aposentos das damas estavam os perfumistas e cabeleireiros, por cujas mãos passavam os homens quando visitavam as damas. Estes abasteciam todas as manhãs os quartos das damas de água de rosas, água de flores de laranjeira, e água de anjo, e levavam para cada qual um precioso defumador exalando todas as drogas aromáticas. "38.

\section{Vestuário dos Thelemitas, ou sua representação social, e sua especial} "sociologia": Claro que para estar em consonância com todo este ambiente de luxo, não se poderia trajar de qualquer maneira, e assim, o próximo passo a descrever nesta instituição teria de ser o relativo ao vestuário, coisa que, aliás, todas as utopias, sejam a sério, sejam de paródia - como supomos que já se terá percebido ser o caso desta, da Abadia de Thélème - nunca deixam de contemplar com descrições minuciosas, e, neste caso, com razão acrescida, pois que se o hábito não faz o monge, a verdade é que estes, aqui, no mundo sofisticado e glamouroso desta abadia - instituída ao contrário de todas as outras,

"Eis por que os nossos insulares proíbem aos homens livres a caça como exercício indigno deles, e só a permitem aos magarefes que são todos escravos. Em sua opinião, a caça é até a parte mais vil da arte de matar os animais." - Repare-se que na Utopia, afinal havia escravos. Enfim, a utopia não seria para todos... De resto, noutras utopias, como na Cidade do Sol, de Tomás Campanela, a caça era recomendada, como exercício "all'arte di guerra"(p. 53), e até servia para treinar para a guerra os futuros defensores da cidade, que, ainda meninos, eram conduzidos à guerra, a cavalo, familiarizando-os com a matança, e habituando-os à vista e ao cheiro do sangue. - Ver: Campanella, Tommaso, La Città del Sole (início redac-

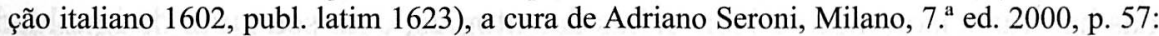
"Usano le cacce per imagini di guerra, e li giochi in piazza a cavalo ed a piede ogni festa, $e$ poi segue la musica." - "Soleno portar seco una squadra di fanciulli a cavallo per imparar la guerra, ed incarnarsi, como lupicini, al sangue."(p. 55).

37 Rabelais, ob. cit. (1534-1542), Liv. LV, p. 211, nota 8: "Espelho de cristal importado de Veneza, geralmente muito pequeno; os de Thélème são de tamanho excepcional. O uso dos espelhos em França era ainda recente."

38 Rabelais, ob. cit. (1534, 1542), Liv. LV, p. 211. 
convém lembrá-lo - também de monges ou monjas nada tinham. - Tanto mais que a esses, como se viu, logo de início, era-lhes pró́bida a entrada.

"No começo da fundação, as damas vestiam-se segundo o seu prazer e arbitrio. Depois foram reformadas de acordo com a sua vontade do modo que segue: Usavam meias de escarlate ou de tecido fino três dedos acima do joelho, debruadas de bordados e recortes. As jarreteiras eram da cor das pulseiras e tapavam os joelhos. Os sapatos, escarpinas e pantufas de veludo carmesim ou violeta eram recortados. Por cima da camisa vestiam um bonito corpete de lã e seda. Por cima deste vestiam uma saia tufada de tafetá branco, vermelho, castanho, cinzento... Segundo as estações, os vestidos eram bordados a ouro e prata, de cetim vermetho coberto de canotilho de ouro, de tafetá branco, azul, preto... Nalguns dias de verão trocavam os vestidos por casacos curtos dos mesmos tecidos ou por casacos sem mangas à mourisca... No Inverno, vestidos de tafetá das mesmas cores, forrados de lobo cerval, gineta preta, marta da Calábria, zibelina e outras peles preciosas. Os rosários, anéis, correntes e colares eram de finas pedrarias, carbúnculos, rubis, diamantes, safiras, esmeraldas, turquesas, granadas, ágatas, berilos, pérolas e magnificas uniões. "39.

Mas a população masculina desta singular abadia não ficava atrás das damas, nestas preocupações com o traje, e os demais adereços e adornos; senão, vejamos:

"Os homens vestiam-se à sua moda: meias de estamenha ou de sarja drapeada de escarlate, de tecido fino, branco ou preto, com dobra de veludo destas cores ou muito próximas, bordado e recortado segundo a sua invenção; o gibão de brocado de ouro, de prata, de veludo, cetim, damasco, tafetá, das mesmas cores, recortados, bordados e confeccionados com perfeição; os cordões de seda das mesmas cores; os agrafos, de ouro bem esmaltados; o saio e a samarra de brocado de ouro ou de prata, ou de veludo debruado a gosto; os vestidos tão preciosos como os das damas; os cintos de seda, da cor do gibão; cada um com sua bela espada de punho dourado, bainha de veludo da cor das meias, e a ponta de ouro lavrado; o punhal a mesma coisa; o chapéu de veludo preto, guarnecido de contas e botões de ouro; a pluma branca com palhetas donde pendiam berloques ornados de belos rubis, esmeraldas, etc. "40.

E no que não se poderá deixar de encarar como uma versão sui generis das habituais isonomias e isomorfias das utopias, com seu culto da igualdade, da homogeneidade, e da perfeita consonância estética - e talvez, também com

39 Rabelais, ob. cit. (1534, 1542), Liv. LVI, p. 213.

40 Rabelais, ob. cit. (1534, 1542), Liv. LVI, p. 213. 
a finalidade de esbater diferenças entre monges e monjas - veja-se, o que, atinente a tal, estava estabelecido na Abadia de Thélème:

"Mas havia tal simpatia entre os homens e as mulheres que cada dia se vestiam de igual e, para não falharem, havia certos gentis-homens encarregados de lhes dizer todas as manhãs os vestidos que as damas queriam usar nesse dia, pois tudo se fazia segundo o arbitrio das damas." 41.

É claro que todo este cuidadoso guarda roupa exigia um batalhão de criados e criadas para dele cuidarem, pois não se imagine que "elas perdiam tempo com trajes tão próprios e toucados tão ricos"; pois que, para isso, "os encarregados do guarda-roupa tinham as vestes tão prontas todas as manhãs e as camareiras estavam tão bem ensinadas que num momento ficavam vestidas dos pés à cabeça". Enfim, a Abadia de Thélème, seria uma instituição para "iguais", não, propriamente, uma instituição igualitária. E agora, atenção, porque a teoria dos fisiocratas ${ }^{42}$ sobre a função da "classe distributiva", isto é, a classe aristocrática, proprietária das terras, que através da fortuna - alimentada pelas rendas que recebia antecipadamente -, e através dos seus hábitos de consumo, justificaria e estimularia a produção, que para ela, antes de mais, seria dirigida, parece estar prefigurada na passagem que se vai transcrever:

"E para melhor se confeccionarem os toucados, havia em volta do bosque de Thélème um edificio de meia légua de comprimento $[2.500 \mathrm{~m}$, o que é uma das enormidades rabelaiseanas, mas perfiguradora das construções fabris do futuro], claro e bem guarnecido, onde moravam os ourives, lapidários, bordadores, alfaiates, tirador de ouro, fabricantes de veludo, tapeceiros, e ali trabalhavam cada um no seu oficio, e tudo para os ditos religiosos e religiosas. E quem lhes fornecia a matéria e os tecidos era o senhor Nausicleto, o qual todos os anos lhes mandava sete navios das ilhas de Perlas e Canibais, carregados de lingotes de ouro, seda crua, pérolas e pedrarias. " 43 .

A "sociologia" do universo de Thélème está concentrada nesta passagem e na anterior sobre os criados e as camareiras. Agora é o exército de artífices que produziam o necessário para alimentar todo aquele esplendoroso luxo e

41 Rabelais, ob. cit. (1534, 1542), Liv. LVI, p. 213.

42 Quesnay, F., Quadro Económico (1759, 3. ${ }^{\mathrm{a}}$ ed.), Lisboa, 1985. - Para Quesnay, a economia e o fluxo monetário processava-se num circuito que envolvia três classes: a classe produtiva (agricultores); a classe estéril (manufactureiros); e a classe proprietária ou distributiva. A classe proprietária tinha a função de estimular toda a produção, através dos seus consumos sumptuários, no quais aplicava (distribuía) as rendas das suas terras, que recebia antecipadamente, para essa função, quedando assim legitimada.

43 Rabelais, ob. cit., Liv. LVI, p. 213. 
ociosidade, que é mencionado, assim como a actividade comercial conexa. Os thelemitas viviam num palácio, os artesãos, numa caserna com "meia légua de comprimento" - sempre o descomunal, o "gigantal" -, devidamente localizada no "subúrbio", ou seja, "em volta do bosque de Thélème". Repare-se que não há a menor alusão nesta "sociologia" do universo thelemita, à actividade agrícola, o que seria de estranhar, pois que a agricultura era, nesse tempo, a principal ocupação, a mais comum e necessária, onde se concentravam 80 a $90 \%$ da população, e principal base da riqueza. Mas, talvez por isso mesmo, é ela aqui ignorada, uma vez que as intenções parodiantes de Rabelais visam, exibir o supérfluo e extravagante, o irreal inverosímil, não o necessário, real e verosímil. A sociedade thelemita, tal como é imaginada pelo seu autor, parece visar a paródia dum mundo regrado por um "ideal mundano", e não por qualquer "ideal moral", que era no fundo, para lá de todos os véus ideológicos e alibis dos engenhosos novos constructos culturais, o que Rabelais, parece divisar que se estava configurando, embora também não denote pena pelo mundo que estava a ser substituído. Os representantes deste último, os "hipócritas, beatos", isto é, os monges medievais, estão banidos desta abadia, substituídos pelas "damas de alta estirpe", sua criadagem, e cortejadores. É isto a representação de um novo ideal de vida? O ideal aristocrático e mundano do Renascimento tal como se gizara em "Il libro del cortegiano" 44 do conde Baldassare Castiglione (1478-1529)? Ou será, mais bem, a encenação crítica e parodiante de um mundo que se estava gizando? - Uma coisa parece certa, é que não deixa de se configurar nesta sociedade acetinada e com abundância de dourados, a sociedade de pesadelo, de separação e segregação social totais, de dissociação com a realidade, e de desregramento e total manipulação, que mais tarde seria objecto de representação em certas anti-utopias.

44 Castiglione, Baldassare, Il libro del cortegiano (1528), a cura di Giulio Preti, Torino, 1965, Einaudi. - Há edição em português: $O$ Cortesão, trad. de Carlos N. M. Louzada, revis. de Eduardo Brandão, São Paulo, 1997, Martins Fontes. - O conceito de sprezzatura (à letra: desprezo, menosprezo, descuido) cunhado por Castiglione nesta obra, e que faria parte do comportamento (ou simulação) do cortesão, representa o ideal de desinteresse, desenvoltura e ligeireza; espírito vivo mas desinteressado; resposta pronta mas cuidada e evasiva; algo de displicência; de fazer sem esforço (o culto do esboço, do inacabado, do gesto gracioso, da mera intenção), e com aparente facilidade ou amadorismo; enfim, aquilo a que os franceses depois viriam a cunhar como "negligé", ou mesmo "blasé" e, essencialmente, "nonchalan$c e$ ". - Mas a leitura de Castiglione, por Rabelais, denota-se numa passagem do L. II, XLV, sobre o riso, "costuma-se dizer que ele [o homem] é um animal inclinado ao riso", que Rabelais parece citar em Gargântua, Aux lecteurs, quando diz: "Pour ce que rire est le propre de l'homme", embora também possa ser uma adaptação duma frase de Aristóteles, De Partibus Animalium (em latim), X, 9, como pretende o anotador Jules de Foucault, in Rabelais, ob. cit. $(1534,1542)$, p. 2 e p. 267. 


\section{Ordenamento da Sociedade Thelemita, ou como "regiam a sua} maneira de viver": Definida toda a envolvência externa e circunstâncias exteriores, condicionadoras da vida dos thelemitas, a nível do espaço arquitectónico em que viviam; as condições do recrutamento da sua população; a sua maneira de trajar; o ambiente cultural que os rodeava; os jogos, entretimentos, e maneiras de passar o tempo; a sua especial "sociologia", etc., faltava ver o mais importante, ou seja, o resultado e objectivo de tudo o anteriormente descrito: o ordenamento e comportamento da sociedade thelemita, ou o modo "como os thelemitas regiam a sua maneira de viver". - Veja-se:

"Toda a sua vida era regida não por leis, estatutos ou regras, mas segundo a sua vontade e franco arbitrio. Levantavam-se da cama quando queriam, bebiam, comiam, trabalhavam, dormiam quando tinham desejo disso; ninguém os obrigava nem a beber nem a comer, nem a fazer outra coisa qualquer. Assim o estabelecera Gargântua. Na sua regra só havia esta cláusula:"

\section{"FAZE O QUE QUIZERES" ("FAY CE QUE VOULDRAS").}

Porque pessoas livres, bem nascidas, bem instruidas, conversando com companhias honestas, têm por natureza um instinto e aguilhão que sempre as impele para factos virtuosos e ao retiro do vício, e a isso chamavam eles honra. E quando por vil sujeição e coerção são abatidos e subjugados desviam a nobre afeição, pela qual tendiam francamente para a virtude, para o rompimento desse jugo de servidão; pois nós empreendemos sempre as coisas proibidas e cobiçamos o que nos é negado. "45.

Esta é a divisa mor, ou por assim dizer, o princípio único a que todos os outros podiam ser reduzidos: "Faz o que quizeres"; e na suposição de que pessoas de boa natureza, bem nascidas e instruídas, apenas quereriam fazer o bem, embora a atracção pelas "coisas proíbidas", e a "cobiça" não deixem de ser aludidas. $O$ poder fazer tudo o que se quisesse era a maneira de ultrapassar essas proibições e cobiça? E como conciliar a vontade e desejo de cada um com os dos demais? Ou como conciliar a liberdade de cada um com a dos outros? Vejamos a resposta de Rabelais:

"Por essa liberdade entraram em louvável emulação de fazer tudo o que a um só viam agradar. Se algum ou alguma diziam: "Bebamos", todos bebiam; se dizia: “Joguemos", todos jogavam." 46.

45 Rabelais, $o b$. cit., Liv. LVII, p. 215.

46 Rabelais, ob. cit., Liv. LVII, p. 215. 
Esta passagem é das mais comentadas pelos intérpretes de Rabelais. Com efeito, nela se expressa a sua resposta à oposição entre o indivíduo e a comunidade, ou entre a unidade e a multiplicidade: não haveria vontades opostas e diferenciadas; o que queria um, todos o queriam; o que todos queriam era desejado por cada um. Formariam, assim, uma comunidade perfeita, onde a vontade de cada um era assumida como vontade do conjunto, e viceversa, operando-se uma total identidade de desejos e vontades, verdadeira fusão da unidade e multiplicidade. Cada um "fazia o que queria", porque todos faziam o que cada um queria, numa espécie de prefiguração do ideal mosqueteiro, de "um por todos, e todos por um". - Parece simples, não é? como um jogo juvenil ou uma paródia. - Mas vejamos que mais nos reservam ainda estes thelemitas:

"E eram tão nobremente instruidos que não havia entre eles um único ou uma única que não soubesse ler, escrever, cantar, tocar instrumentos harmoniosos, falar cinco ou seis linguas, e nelas compor tanto em verso como em prosa. Jamais se viram cavaleiros tão valorosos, tão galantes, tão destros a pé e a cavalo, mais vigorosos, mais mexidos, mais hábeis em todas as armas... jamais se viram damas tão asseadas, tão mimosas, menos aborrecidas, mais doutas de mãos. "47.

É o ideal pedagógico do Renascimento que está aqui encenado. Ideal que visava conjungar a erudição do clerc com a destreza física do cavaleiro, gizando-se deste modo a desenvoltura, a "sprezzatura" do cortesão, o tipo de aristocrata, que os novos tempos anunciavam. De resto, a abadia parecia ser um colégio ou pousada para jovens - a juvenilidade tal como a "jovialidade" é uma das constantes de Rabelais - onde eram instruídos, iniciados e preparados para uma vida cortesã, mais que outra coisa. Tanto assim que:

"quando algum desta abadia, quer a pedido dos seus pais quer por outras razões, queria sair, levava consigo uma das damas, por quem tomara devoção, e casavam um com o outro; e se tinham vivido em Thélème em devoção e amizade, ainda melhor continuavam a viver no casamento: amavam-se tanto no fim dos seus dias como no primeiro dia de núpcias." 48 .

É este lado irónico, duma ironia mordaz, quase jocosa, parodiando o final cor-de-rosa do romance barato, em que, no fim, o herói e a donzela casam-se e são muito felizes para o resto da vida, que autodesconstrói as propostas rabelesianas, pseudo resolutivas da vida dos homens, de quem a sua história se despede encerrando-se com um "Enigma em profecia", dirigi-

47 Rabelais, ob. cit., Liv. LVII, p. 215-6.

48 Rabelais, ob. cit., Liv. LVII, p. 216. 
do aos: "Pobres humanos que esperais a felicidade", e à impossibilidade de predizer ou "Pronunciar as coisas futuras", ou "Da sorte futura ter conhecimento", assim parecendo que tudo o que restaria, em que se poderia confiar e desejar, era o que se expressa nas palavras finais, em que após, ser mais ou menos declarada a incompreensibilidade do profético enigma, que Gargântua alvitra referir-se ao "curso e manutenção da verdade divina", ao passo que para o frade não passaria "de uma descrição do jogo da péla sob palavras obscuras", é, então dito: "E haja alegria" 49.

O lado popular, parodiante, crítico, ou o riso de Rabelais: Na jocosidade que por vezes atinge uma mordacidade virulenta, Rabelais parece colocar aqui uma nota de verosimilhança no inverosímil de toda a sua descrição da abadia e dos seus abades e abadessas, todos viçosos e noviços, ainda por cima. Realmente, tudo o que se podia desejar era a alegria, bastante arredia dum mundo que começava a ser regrado (ou des-regrado) pela nova economia baseada na posse de moeda sonante, de preferência em ouro, com o aumento da separação e antagonismo entre as classes ou ordens que iria provocar; e um mundo dividido pelos cismas religiosos, os novos milenarismos, em que o crepitar das fogueiras já se fazia ouvir, e o erguer das forcas mobilizava braços; bem como o barbaresco ribombar do canhonheio das constantes guerras que assolavam a Europa, agora mais mortíferas, graças a esse novo e prodigioso engenho da artilharia, proporcionado pelas invenções e aperfeiçoamentos da nova cultura científica e tecnológica; essas guerras que tanto contribuiam para apressar aquilo que menos precisava de ser apressado, pois que era o que mais estava garantido aos homens: a morte, para cujo esquecimento e evasão tudo servia, e tudo se revelando igualmente vão, tanto a cultura medieval com os seus ideais de ascetismo e castidade, quanto a renascentista, com os seus ideais mundanos e naturalistas, que deveriam ser incentivados por toda uma cultura e pedagogia de cunho simultaneamente aristocrático e intelectualizante, vizando a edificação de um mundo em conformidade com certos ideais entre os quais avultaria, ou rabelesianamente, se agigantaria, o da construção da felicidade terrena, que Thélème parece querer significar, e que diferia a felicidade celeste para a impredizibilidade do futuro, que não era possível, "pronunciar", nem dele "ter conhecimento".

Assim, o reino do possível baixa à terra, onde tudo seria possível, até confiar na "natureza" e num "instinto", qual "aguilhão" que impelisse as pessoas para "factos virtuosos", o que é sempre possível, e estaria dentro daquilo que no Humanismo e Renascimento se considerava o reino da possibilidade, de um Poder-Ser, e Poder-Fazer, que as utopias urbanístico-arquitectónicas

49 Rabelais, ob. cit., Liv. LVIII, p. 218-220. 
e as utopias políticas passaram a explorar. De resto, Rabelais, tinha um profundo conhecimento da obra de Vitrúvio, Alberti, e de Colonna, como se depreende das alusões e referências directas a estes autores que nas suas obras se observam. Também Tomás Morus lhe era conhecido, uma vez que se refere com ironia a Amaurota e ao país de Utopia, no Pantagruel, como vimos, donde faz vir uma carta de Gargântua endereçada a seu filho - filho gerado da sua união com "Bicaberta, filha do rei dos Amaurotas da Utopia", o que não pode deixar de ser visto como uma ínvia filiação em tal universo literário - e onde se trava toda aquela batalha gigantesca com as hostes masculinas e femininas do rei Anarca. - Além disso, esteve em Roma por duas vezes, em 1534 e 1535, sendo-lhe atribuída a intenção de fazer uma topografia da Roma Antiga, de que desistiu, vindo depois a editar um livro congénere da autoria de Bartolomeu Marliani em 1534. Numa dessas estadias em Roma, terá tido como companheiro Philibert De L'Orme, o mais notável arquitecto dessa época, como já se referiu, e que foi, igualmente, um notável tratadista da arquitectura, ou art de bien bastir ${ }^{50}$, de quem Rabelais foi amigo íntimo, e a quem, às vezes, parece referir-se com ironia, falando das "pedras mortas" com que alguns pretendem edificar o mundo, esquecendo-se que o fundamental nele são as "pedras vivas", isto é, as pessoas, com as suas bizarrias, a sua liberdade e capacidade de riso. E é esse riso que marca dum modo decisivo toda a sua obra, que pode ser vista como uma celebração da capacidade de rir do homem, o que, aliás, é anunciado logo de entrada em "Gargântua", em verso dirigido "Aos Leitores":

"Amigos leitores que lerdes este livro,

Despojai-vos de toda a paixão;

E, ao lê-lo, não vos escandalizeis:

Não contém nem mal nem infecção.

É verdade que aqui pouca perfeição

Aprendereis, a não ser para rir;

Outro assunto não pode meu coração eleger,

Vendo o luto que vos desgasta e consome

Melhor é escrever de riso que de lágrimas,

Pois rir é próprio do homem. "s1

É e o lado libertador do riso que se celebra nestes versos, o que mais visivelmente irradia por toda a obra de Rabelais, que parece querer resumir

50 De L'Orme, Philibert, Nouvelles Inventions pour bien bastir et à petit fraiz(1561), e Le Premier Tome de l'Architecture (1567), ed. facsimil conjunta sob o título de Traités d'architecture, présentation par Jean-Marie Pérouse de Montclos, Paris, 1988, Léonce Laget.

51 Rabelais, ob. cit., p. 25. 
num gargalhar todos os engenhosos constructos culturais presentes no seu tempo, quer os oriundos duma Idade Média escolástica, gastos pela usura do tempo e cada vez mais esvasiados de sentido; quer os dos romances de cavalaria representadores dum ideal heróico e aristocrático que se tinha tornado anacrónico; quer os das novas configurações culturais referidas à Antiguidade, a que se mostra, simultaneamente aberto e crítico; assumindo toda esta envolvência cultural, com suas diferentes tensões, em versões de crítica parodiante e pretextadora de riso. E como o definiu dum modo lapidar, Mikhail Bakhtin, note-se que não é do riso sofisticado do clerc que aqui se trata, pois com efeito: "Rabelais é o herdeiro, o coroamento de vários milénios de riso popular. A sua obra é a chave insubstituível que dá acesso à inteligência da cultura popular nas suas manifestações mais poderosas, profundas e originais"s2. Uma cultura pouco dada a registos escritos - no que Rabelais é uma das mais notáveis excepções - e de que o riso é a mais audível manifestação, no seu ruidoso gargalhar; uma cultura popular, que sempre, em todas as etapas do acidentado, contraditório, e traiçoeiro desenrolar da história, "se opôs à cultura oficial das classes dominantes" 53 ; sofrendo-lhe as pressões, mas resistindo, atenuando-lhe os ímpetos; à vontade de poder destas, opondo o seu atávico instinto de resistência; ao desejo e luxúria sem freio, respondendo com a sua ancestral temperança; explorando-a nas suas contradições, e utilizando-as em seu proveito; expondo os seus ridículos; dissolvendo-a pela comicidade, e servindo-se dela como prato parodiante.

A Abadia de Thélème como Anti-Utopia ou Utopia Libertária: A anti-utopia, ou utopia de paródia, que se expressa na Abadia de Thélème, com que Rabelais coroa a sua evocação das aventuras e feitos prodigiosos do gigantão Pantagruel, et leurs copains, não menos gigantões, marca a dimensão popular e pagã, libertária e anárquica, do Humanismo e Renascimento. Com efeito, Rabelais, profundo conhecedor da cultura clássica, à qual se refere várias vezes nos seus livros, por vezes com ironia, como no episódio do sino enterrado, que descreve em Pantagruel, denota, também, ser conhecedor e reverenciar a cultura medieval dos poemas, autos e comédias, com carácter popular e carnavalesco, referindo explicitamente o "Rabotino, Roberto o Diabo, Ferrabrás, Guilherme sem Medo, Huon de Bordeús, Mandeville e Matabrune", com o seu "ror de virtudes ocultas", e ufana-se da sua "Crónica Gargântua, porque em dois meses foi vendida, nos impressores, como em nove anos ali não foram as Bíblias" 54 . De resto, o mundo popular e a cultura

\footnotetext{
52 Bakhtin, ob. cit., p. 418.

53 Bakhtin, ob. cit., p. 418.

54 Rabelais, ob. cit., p. 21.
} 
que lhe era peculiar, com seu imemorial legado de paganismo e sua proverbial sabedoria, predisposto, ora para a credulidade e compreensão perante o acontecer inexplicável, ora para a incredulidade frente à sua pretendida explicação; sua ancestral resignação e galharda ou pundonorosa aceitação das inextricáveis complexidades e irresolúveis contradições da vida, que eram percebidas mais por instinto ou intuição, do que através de formulações racionais, às quais, esse mundo ligado ao concreto sensível e apreensível, e não a abstracções especulativas, era alheio, estão sempre presentes na sua obra, formando o fundo para que remete sempre o seu lado jovial e parodiante, e donde parece também ser originária a tonalidade brejeira com que vai pintando as cenas que nos descreve e as situações, algumas delas paradoxais e absurdas, perante as quais nos coloca. Assim, pode-se considerar que Rabelais faz a ponte entre um universo medieval popular e fradesco, cheio de contradições, ignorância, crendice e hipocrisia, mas inocente, alegre, vivo e libertário, com o universo humanista e renascentista, do qual parece encarar com irónica suspeição certas pretensões culturais e utópicas, abundantes de formulações abstractas, desossificadas, com algo de irreal e inexequível, para lá da sua aparente perfectibilidade teórica e justeza racional. Se quisermos, no contexto renascentista, em que objectivamente se situa, a dimensão da Antiguidade que explora, será a do epicurismo - mas a que também não é alheio um certo estoicismo -, do cepticismo, dum certo cinismo, diogeniano, e da literatura de viagens e aventuras heróicas, mas numa versão de farsa lucianesca, a que chega a referir-se, quase explicitamente, falando de viagens à Lua. Dessa dimensão da Antiguidade e de algum Renascimento, de que sabiamente urde cozimento com a análoga dimensão anónima e popular, mais que erudita, de certa cultura medieval, obtendo assim uma síntese dimensional humorada, reivindicadora da alegria e do direito ao riso desopilante, que talvez, afinal, seja uma dimensão de todos os tempos, e onde melhor se expressa o sentido da não-crença - a "descrença", que tão extrordinariamente marcou o seu tempo -, ou incredulidade perante as novas crenças que se apresentavam ao serviço, apregoando as excelências de novas virtudes, é que os seus heróis, o gigantesco Gargântua, seu filho Pantagruel, não menos agigantado, e o nosso colega, "frade-arquitecto-utopista", Jean des Entommeures, são excelentes representantes, que vão correndo, derrubando muralhas, batalhando, comendo, bebendo e folgando, pantagruelicamente, enquanto os Amaurotas, isto é, os obscuros e incertos, vão competindo, ordeira e colectivamente, nos arranjos florais dos seus jardins.

Para os fins mais particulares que visa este trabalho: mostrar e comentar a conexão entre certos aspectos das teorias da arquitectura e o pensamento 
utópico5s, a obra de Rabelais está cheia de observações e reflexões onde essa conexão é reconhecida, e posta em questão. Assim, com as muralhas das cidades e dos conventos, nas quais parece ver mais o propósito de encerrar os que lá habitavam do que o de conter inimigos. Também a faustosa arquitectura que imagina para a abadia de Thélème, que seria a simétrica correspondência da vida de fausto que lá se processaria. Igualmente, quando se refere às "terras... conquistadas com a arquitectura", cuja "muda inscrição dos arcos, colunas e pirâmides [estavam], sujeitas às calamidades do ar e por todos [era] invejada"s6, chamando, assim, a atenção para o lado precário e algo ostensivo que envolve a arquitectura, antepondo a esta maneira de conquistar terras, a conquista dos "corações dos vencidos", habitantes dessas terras. Mas onde o seu pensamento sobre a arquitectura, ou sobre a "utopia edificatória" ${ }^{57}$, mais claramente se expressa é no "Tiers Livre...", onde coloca a diferença entre as "pedras mortas" e as "pedras vivas", a que já acima aludimos, afirmando:

"Os belos construtores novos de pedras mortas não estão escritos no meu livro da vida. Só construo pedras vivas; são homens. "58.

E afinal, talvez a sua obra expresse, antes de mais, isto mesmo: a importância destas pedras vivas, que são os homens, empilhadores das pedras mortas que, sem eles, sem o seu esforço abnegado e persistente, em que consiste o verdadeiro heroísmo, e que, verdadeiramente, os agiganta, não mais teriam qualquer espécie de sentido, não sendo possível inscrever os seus constru-

55 Simões Ferreira, ob. cit.; esta dissertação, tal como o seu subtítulo indicia, visou mostrar a conexão entre as utopias urbanístico-arquitectónicas e as utopias políticas; essa conexão, é que está implícita em todas, ou na maioria pelo menos das propostas de cidade ideal, do ponto de vista urbanístico-arquitectónico, uma proposta de sociedade ideal, no referente à organização social e política. E vice-versa, a todas as utopias políticas corresponde uma utopia urbanístico-arquitectónica. Só que algumas, talvez mesmo a maioria dessas utopias, urbanístico-arquitec-tónicas ou políticas, uma vez desmontadas, ou desconstruidas, surgem mais como distopias do que outra coisa.

56 Rabelais, ob. cit., p. 194.

57 Designamos de "utopia edificatória", a elegia da capacidade da arquitectura, ou melhor, da res aedificatoria, para transformar o mundo, a sociedade, e a vida. - Ver: Simões Ferreira, J. M., "A "Utopia Edificatória", em Alberti», artigo pronto para publicação, enviado à Albertiana. Société Internationale Leon Battista Alberti, revue publiée avec le concours du Centre National des Lettres, de la Maison des Sciences de 1'Homme et du Centre de Recherche sur la Pensée Politique Italiene, con il patrocinio dell'Istituto Italiano per gli Studi Filosofici, Firenze, 1998 ss., Leo S. Olschki Editore. - Edita um volume por ano, contendo vários artigos de estudos sobre L. B. Alberti.

58 Rabelais, François, Terceiro Livro (1546), cit. p/ Aníbal Fernandes, in Rabelais, ob. cit. (1532), p. 6. 
tores no "livro da vida". - E, com efeito, nenhuma arquitectura, construção, ou qualquer outro tipo de constructo, se justifica por si, pois que por detrás das "pedras mortas", dos livros, e das formulações culturais, que expressam teorias arquitectónicas, filosóficas, políticas, ou quaisquer outras, estão as " $p e$ dras vivas", e são estas que contam.

\section{Bibliografia}

ANDROUET DU CERCEAU, Jacques, Les plus excellents bastiments de France (1576-7759), présentation et commentaires par David Thompson, traduit de l'anglais par Catherine Ludet, Paris, 1988, Éds. Sand \& Conti.

BAKHTIN, Mikhail, A Cultura Popular na Idade Média e no Renascimento: O Contexto de François Rabelais, trad. de Yara Frateschi, S. Paulo, 1993, Editora Universidade de Brasília.

CAMPANELLA, Tommaso, La Città del Sole (início redacção italiano 1602, publ. latim 1623), a cura de Adriano Seroni, Milano, 7. a ed. 2000, Feltrinelli. - Há edição portuguesa: A Cidade do Sol, trad. de Álvaro Ribeiro, Lisboa, 1980, Guimarães \& C. ${ }^{\text {a }}$ Editores.

CASTIGLIONE, Baldassare, Il libro del cortegiano (1528), a cura di Giulio Preti, Torino, 1965, Einaudi. - Há ed. em português: O Cortesão, trad. de C. Louzada, revis. de E. Brandão, São Paulo, 1997, Martins Fontes.

COLONNA, Francesco, Sueño de Polifilo (Hypnerotomachia Poliphili)(1499), trad. literal del original aldino, introd., coment. y notas de Pilar Pedraza, Murcia, 1981, COAATM/Lib. Yerba.

DE L'ORME, Philibert, Nouvelles Inventions pour bien bastir et à petit fraiz (1561), e Le Premier Tome de l'Architecture (1567), ed. facsimil conjunta sob o título de Traités d'architecture, présentation par Jean-Marie Pérouse de Montclos, Paris, 1988, Léonce Laget.

DENIS, Maurice, História do Pensamento Económico, trad. de A. B. Coelho, Lisboa, s/d., Livros Horizonte.

HUGO, Victor, Notre-Dame de Paris 1482 (1832), Paris, 1975, L. V, I e II, p. 206 e 209. - Há uma "tradução cuidada" em português de autor não identificado: Nossa Senhora de Paris, Porto, 1967, 2 vols..

JÚNIOR, Hilário F., Cocanha. A História de um País Imaginário, pref. J. Le Goff, S. Paulo, 1998, C. ${ }^{\text {a }}$ das Letras.

59 Indicam-se, entre parenteses, as datas das edições originais, sempre que possível. 
KRUFT, Hanno-Walter, Geschichte der Architekturtheorie. Von der Antike bis zur Gegenwart (1985), Studien-ausgabe, München, Vierte Auflage 1995, Verlag C. H. Beck.

MORÇAY, Raoul, «Ìntroduction» a Rabelais, François, L'Abbaye de Thélème, ed. critique Paris, 1947, Lib. Droz.

MORUS, Tomás, Utopia (1516), trad. de J. Marinho, Lisboa, 1961, Guimarães \& C. ${ }^{\text {a }}$ Editores.

QUESNAY, François, Quadro Económico. Análise das Variações do Rendimento de uma Nação (1759, 3. ${ }^{\text {a }}$ ed.), pref. de Bento Murteira, trad. e notas de Teodora Cardoso, Lisboa, 1985, Fund. Gulbenkian.

RABELAIS, François, La vie très horrifique du grand Gargantua, père de Pantagruel, jadis composée par M. Alcofribas abstracteur de quinte essence. Livre plein de Pantagruelisme (1534, 5. ${ }^{\mathrm{a}}$ ed. 1542 ne varietur), édition illustrée, annotée par J. Foucault, Préface de J. Perret, Paris, 1949, Bordas. - Servimo-nos também da ed. portuguesa, Gargântua (título de capa, completo: A vida muito horrífica do grande Gargântua, Pai de Pantagruel, em tempos composta por M. Alcofribas, Condensador de Quinta Essência. Livro cheio de Pantagruelismo), trad. de M. ${ }^{a}$ G. de Bragança, Lisboa, 1987; e da ed. crítica de Raoul Morçay, acima referenciada.

— Les horribles et espoventables faictz et prouesses du très-renommé Pantagruel, Roy des Dipsodes, filz du grand géant Gargantua (1532), première publication critique sur le texte original par V. L. Saulnier, prof. à la Sorbonne, nouvelle édition augmentée, Genève, 1965. - Servimo-nos também da ed. portuguesa, Pantagruel, Rei dos Dípsodos, restituído ao natural com seus factos e proezas espantosos. Compostos pelo falecido Mestre Alcofribas, abstactor de requinte, trad. de Aníbal Fernandes, Lisboa, 1975, Edições \& Etc.. - A ed. francesa contém uma nota mencionando o título original da ed. de 1532: PANTAGRUEL, Roy des Dipsodes, restitué à son naturel, avec ses faictz et prouesses espoventales. Composez par feu M. Alcofribas, abstracteur de quinte essence. - Les éditions de [Lyon, François Juste], 1534, et Lyon, Pierre de Sainte Lucie, 1535, ajoutaient, après la première mention «Pantagruel», la devise grecque: $\mathrm{AYA} \theta \mathrm{H}$ TYXH.

SERLIO, Sebastiano, L'architettura, I libri I-VII e Extraordinario nelle prime edizioni (1537 ss.), ed. facsimil a cura de Francesco Paolo Fiore, Milano, 2001, Edizioni Il Polifilo.

SIMÕES FERREIRA, J. M., Visões de Utopia. As Teorias da Arquitectura e as Utopias Políticas nos alvores da Idade Moderna, Dissertação de Mestrado em Filosofia, FCSH / UNL, 2002, 3 vols.

«A "Utopia Edificatória", em Alberti», artigo pronto para publicação, enviado à Albertiana. 
TIEGHEM, Philippe van, História da Literatura Francesa, Lisboa, 1956, Estúdios Cor.

VITRUVE, De l'architecture (De architectura libri decem), ed. critique de Philippe Fleury et altri, Paris, deuxième tirage 2002 ss., Les Belles Lettres, 10 vols.. Esta edição crítica começou a ser publicada em 1967, mas devido ao incêndio do armazém da editora e distribuidora, actualmente, nem todos os volumes, que entretanto vão sendo reeditados, se encontram no mercado.

Sobre Rabelais, em geral:

AA VV, François Rabelais, ouvrage publié pour le 4e centenaire de sa mort, 15531953, Génève, 1953, Droz.

ALAIN, «Rabelais», in Tableau de la littérature française, Paris, 1962, Gallimard, Vol. I, P. 233-40.

AUERBACH, Erich, Mimesis, la representacion de la realidad en la Literatura Occidental (1942), XI. El mundo en la boca de Pantagruel, trad. I. Villanueva y E. Ímaz, Madrid, 1983, FCE, p. 245-64. - Um dos tradutores, Eugenio Ímaz, é autor de um interessante estudo intitulado: Utopias del Renacimiento. Moro. Campanella. Bacon, México, 1941, FCE. - Inclui trads. de Utopía, La Ciudad del Sol, e Nueva Atlántida.

CURTIUS, Ernst Robert, Literatura europea y Edad Media latina (1948), trad. de Margit y Antonio Alatorre, México, 1955, FCE, 2 vols., Vol. I, p. 50n, 92, 145, 183, 225n, 257, 369n, 487; Vol. II, p. 601,615, 698n.

DEMERSON, G., L'Esthétique de Rabelais, Paris, 1996, SEDES.

DESROSIERS-BONIN, D., Rabelais et l'humanisme civil (Etud. rabelaisien.s XXVII), Génève, 1992, Lib. Droz.

FEBVRE, Lucien, O Problema da Descrença no Século XVI. A Religião de Rabelais (1942), trad. Rui Nunes, revis. de Horácio Camilo, Lisboa, 1970, Editorial Início.

GLAUSER, A., Rabelais créateur, Paris, 1996, Éd. Nizet.

HAMON, Ph., et ROGER-VASSELIN, D., et altri, Le Robert des grands écrivains de langue française, Paris, 2000, Dictionnaires Le Robert, p. 1062-78.

HIGHET, Gilbert, The Classical Tradition. Greek and Romam Influences on Western Literature, Cap. X. Rabelais and Montaigne, Rabelais, London, 1949, Oxford Univ. Press, Vol. I, p. 285-94.

KLINE, M. B., Rabelais and the Age of Printing (Etudes rabelaisiennes IV), Génève, 1963, Librairie Droz. - Um pequeno livro, 60 págs., mas de grande importân- 
cia, e não só para a compreensão de Rabelais, mas também para a do impacto que a Imprensa teve na Cultura, e na História.

LEFRANC, Abel, Rabelais. Études sur Gargantua..., Paris, 1953, Albin Michel.

LENORMANT, Charles, Rabelais et l'architecture de la Renaissance. Restitution de l'Abbaye de Thélème, Paris, 1840. - Esta obra é uma interpretação desenhada da arquitectura da Abadia de Thélème.

PABST, Walter, «Die Pforte von Thélème und Dantes Höllentor», in Wissenschaftliche Zeitschrift der Frierich Schiller Universität 3, Jena, 1955/56, p. 325-28.

PLATTARD, Jean, L'oeuvre de Rabelais, Paris, 1910, Honoré Champion Éditeur.

PORCHER, Jean (dir.), Rabelais. Exposition organisée à l'occasion du quatrième centenaire de la publication de Pantagruel, Paris, 1933, Éditions des Bibliothèques Nationales de France.

SAURET, M., Gargantua et les Délits du corps, Berne, 1997, P. Lang.

SCREECH, M., Rabelais, London, 1979, Duckworth. - Traduzida para o francês recentemente.

TOURNON, A., En sens agile: les Acrobaties de l'esprit selon Rabelais, Paris, 1995, Honoré Champion Editeur.

Études rabelaisienes, Génève, 1956 ss., Librairie Droz, 43 vols. publicados, na prestigiada colecção "Travaux d'Humanisme et Renaissance".

Referências a Rabelais na Literatura sobre o Pensamento Utópico, Político, e Arquitectónico:

BALDINI, Massimo, La storia delle utopie, Roma, 1994, Armando srl., p. 20. - Uma única referência remetendo para Rita Falke, «Problems in Utopie», in Diogène, 1958, 23: "Totalitarismo: la tradizione utopica propugna com pochissime eccezioni soluzioni totalitarie. «Noi conosciamo - scrive Rita Falke - soltanto due utopie nelle quali è ammassa la libertá»: lábbazia di Thélème di Rabelais e l'Eldorado (nel Candide) di Voltaire. In realtà, l'utopismo, nonostante le sue appartenze di pensiero progressista e rivoluzionario, pregia nascostantemente l'autoritarismo, cosicché troppo spesso lo stato prospettato dall'utopista altro non è che límmagine della più perfetta società repressiva."

BIESTERFIELD, Wolfgang, Die literarische Utopie, Stuttgart, 1982, J.B. Metzer. - Escassas refer.s, p. 1 e p. 63.

CHOAY, Françoise, La règle et le modèle - Sur la théorie de l'architecture et d'urbanisme, 2, 2.3. De Thélème à Clarens, Paris, 1980, Éditions du Seuil, p. 52-55. - "É bem verdade que Rabelais leu Morus, que situa nominalmente em Utopia, a pátria de Pantagruel, e que o vento da crítica social sopra em toda a sua obra. Também é verdade que a abadia fundada por Frei Jean graças à generosidade de Gargantua é uma sociedade e um espaço cuja criação resulta de uma crítica da sociedade contemporânea. Mas nem por isso Thélème 
constitui um modelo.... Thélème permite ainda uma transgressão esporádica da ordem estabelecida: ela não está situada num alhures misterioso, mas aqui mesmo, nas margens do Loire... A subversão thelemiana não se faz em proveito de novas (boas) instituições, mas da ausência de instituições"(p. 52-53), e conclui: "Thélème é um local de passagem e a sua arquitectura de festa, que toca ao mesmo tempo o absurdo dos mundos às avessas e a razão dos castelos principescos da sua época, é uma antinomia da arquitectura utópica, modelar e maníaca ilustradas pelo Falanstério"

EATON, Ruth, Ideal Cities. Utopianism and the (Un)Built Environment, London, 2001, Thames and Hudson, p. 24, e principalmente p. 69: "Rabelais's Abbaye de Thélème described in his Gargantua (1534) is rather atypical in this respect for the Thelemites are housed in a large building that resembles a monastery, a castle or even a phalanstery. Indeed the whole text pokes fun at the monastic tradition. Rigid social rules have been reversed and members of the community are told to do as they desire - «Fay que tu voudras' [sic]» - but the anticonformism is illusory, for individual behaviour succumbs to the collective will and everyone acts in unison as in almost all utopias."(p. 69).

GLUCKSMANN, André, Os Mestres Pensadores (1977), I - Panurgo extramuros, trad. de Armandina Puga, Lisboa, 1978, Publicações D. Quixote, p. 13-31. - Apresenta uma interpretação polémica de Thélème, centrada na regra "Fay ce que vouldras", que seria imperativa, impositiva, hiper responsabilizadora, e dum gregarismo totalitário, pois quando um bebia, todos tinham de beber. - Nas suas palavras: "Com toda a certeza Thélème marca uma ruptura. Será entre o obscurantismo e o humanismo? O universo fechado da Idade Média e o mundo aberto do Renascimento? Os historiadores matizam fortemente a oposição apontando as luzes medievais e as sombras do Renascimento, mas Rabelais não será ainda mais irónico? Passa-se do convento para o anti-convento; não a saltar do império da necessidade para o reino da liberdade, mas mais hipocritamente substituíndo uma disciplina por outra.”(p. 20). Mas, mais adiante reconhece que o riso salva tudo, tudo desmanchando, e assim: "Théléme diz-se num riso sonhador"(p. 22).

MANUEL, Frank E., and MANUEL, Fritzie P., Utopian Thought in the Western World (1979), Camb./Mass., Seventh printing, 1997, The Belknap Press of Harvard Univ. Press. - Referências avulsas e anódinas em p. 4, 18, 50, 99, 100 , 102, 134-35, 148,149, 261.

RUYER, Raymond, L'utopie et les utopistes, Deuxième partie, Chap. IX. Les utopies de la Renaissance, L'abbaye de Thélème (1534), Paris, 1950, Presses Universitaires de France, p. 164-66.

SAULNIER, V. L., «L'utopie en France, Morus et Rabelais», in AA VV, Les Utopies à la Renaissance, Bruxelles/Paris, 1961, Univ. libre de Bruxelles/Presses Universitaires de France. 
SIMÕES FERREIRA, J. M., Arquitectura, Desenho Urbano e Tratadística. De Aldo Rossi a Vitrúvio ou o «Breviário Mediterrânico» da Teoria da Arquitectura e do Desenho Urbano, II. ${ }^{a}$ Parte. Da Tratadística na Península Ibérica à Tratadística do Século XIX, A Tratadística em França, François Rabelais e a AntiUtopia, Lisboa, 1999, ISCTE, Vol. II, p. 442-45.

TROUSSON, Raymond, Voyages aux pays de nulle part. Histoire littéraire de le pensée utopique, Bruxelles, 1979, Editions de l'Université de Bruxelles. - Escassas referências, mas significativas, Cap. II, p. 89-90.

Das edições de Rabelais existe: Oeuvres de François Rabelais, edição crítica dirigida por Abel Lefranc, com a colaboração de Boulenger, Loutox, Dorveaux, Plattard, e Sainéan, Paris, 1912-13, Champion; Génève, 1922, e 1931, Droz; e Lille, 1955, Giard, etc., 6 vols. - Difícil de encontrar no mercado e nas bibliotecas públicas portuguesas. - Mais recente: Oeuvres complétes, ed. de M. Huchon, Paris, 1994, «Pléiade», Gallimard. 


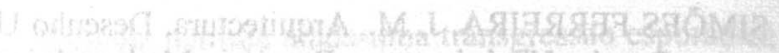

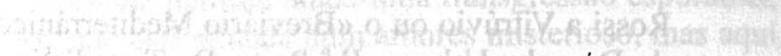

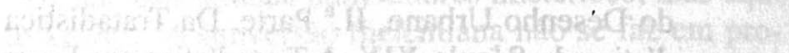

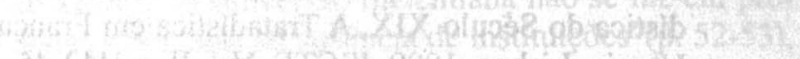

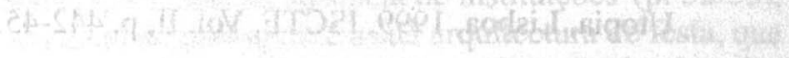

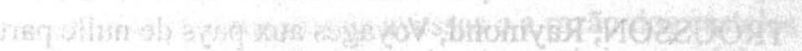

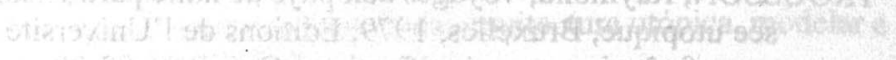

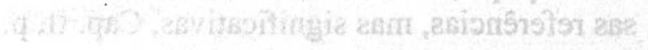

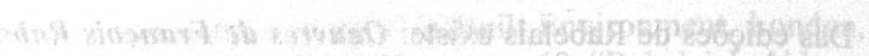

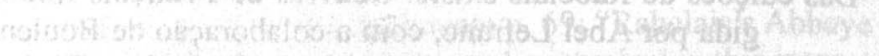

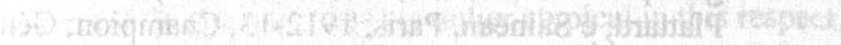

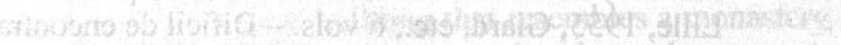

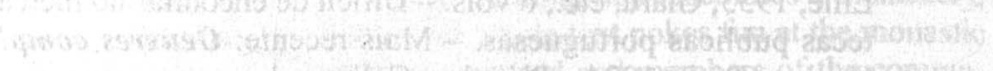

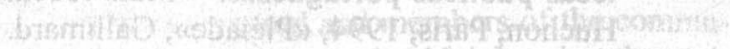
has fondras' (sic)s - but the antist

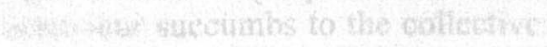

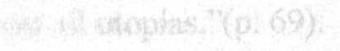

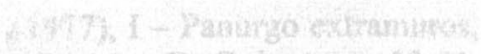

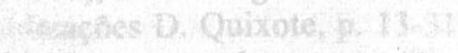

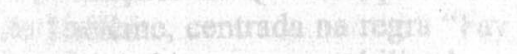

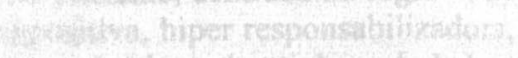

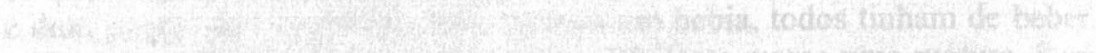

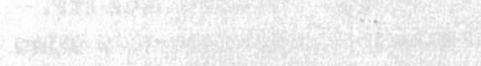

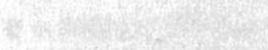

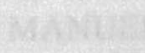

Whestit

(Hine

102

Renthe, Rowe

de lie Pean

silaitus the

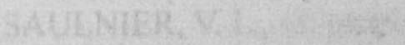

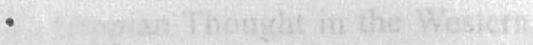
1947, The Beflicasip Pro 0 of

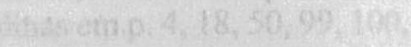

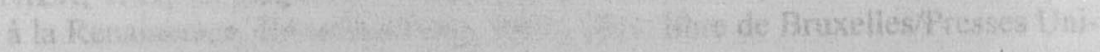

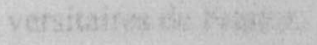




\section{A GEOPOLÍTICA, DA ALEMANHA NACIONAL-SOCIALISTA À AMÉRICA LATINA: OS CASOS DA ARGENTINA E DO BRASIL ${ }^{1}$}

Mario G. Losano

\section{1 - As raízes alemãs da geopolítica}

Este texto propõe-se ilustrar sinteticamente a circulação das idéias geopolíticas da Europa à América do Sul, com particular referência sobre a Argentina e o Brasil ${ }^{2}$. Ainda que a geopolítica como paradigma ideológico tenha recebido o seu nome apenas no século XIX, as aspirações geopolíticas das grandes potências existiam já desde há séculos. Noções vagas como "Estado nacional", "Hispanidad", ou Paneslavismo (e todos os outros "pan-movimentos") identificam esferas de influência que plasmavam a política exterior de um Estado; a geopolítica, para usar a expressão de Henry Kissinger, "developed a rationale for it" , ou seja, oferecia uma explicação racional para certas políticas exteriores animadas pela vontade de potência; a estratégia militar, enfim, "aplicava" aqueles paradigmas ideológicos e aquelas racionalizações

1 Este texto foi apresentado como comunicação no XIV Congresso Internacional AHILA 2005, Europa-América: Paralelismos en la distancia, Universidad Jaume I, Castellón (Espanha), 20 a 24 de setembro de 2005, Simpósio 5: Ideas, intelectuales y pardigmas ideologicos europeos en América Latina, 1850-2000. O texto foi traduzido do italiano ao português pela Profa. Marcela Varejão, da Universidade Federal da Paraíba e da Universidade Federal de Pernambuco; Doutora em Sociologia do Direito pela Università degli Studi di Milano, Itália.

2 Os temas mencionados no texto estão tratados de forma mais extensa nas minhas seguintes publicações: La geopolitica nazionalsocialista e il diritto dei "grandi spazi", "Materiali per una storia della cultura giuridica”, XXXV, 2005, n. 1, pp. 5-63; La teoria nazionalsocialista dei "grandi spazi" dall'Europa al Giappone, Associazione Italiana per gli Studi Giapponesi. Atti del XXVIII Convegno di Studi sul Giappone. Milano, 16-18 settembre 2004, Cartotecnica Veneziana, Venezia 2004,pp. 115-130; Diritto e potere: la geopolitica brasiliana negli anni del governo militare (1964-1984), em Heleno Taveira TôRRES (Coordenador), Direito e poder nas instituições e nos valores do público e do privado contemporâneos. Estudos em homenagem a Nelson Saldanha, Manole, Barueri (São Paulo, Brasil) 2005, pp. 64-104; Um recente livro brasileiro sobre as tensões entre Brasil e Argentina na época das ditaturas européias, "Política Externa" (São Paulo), XIII, 2005, n. 4, pp. 71-81, completado por uma breve nota no fascículo sucessivo: Dois esclarecimentos sobre o volume de Sergio Corrêa da Costa, "Política Externa" (São Paulo), XIV, 2005, n. 2, pp. 113-115.

Henry KISSINGER usa esta expressao a propósito do geopolítico norte-americano (teórico da potência naval dos Estados Unidos) Alfred Thayer MAHAN: Diplomacy, Simon \& Schuster, New York 1994, p. 38. 
geopolíticas, procurando transformá-las em situações de fato (mas freqüentemente usando-as para justificar ex post as próprias acções de conquista).

A geopolítica agrada aos generais, independentemente de sua nacionalidade. As idéias do general alemão Karl Haushofer foram recebidas na América do Sul, na qual a geopolítica circulou intensamente: a Geopolítica del Cono Sur do general argentino Juan Enrique Guglialmelli faz parte de uma "Colección Geopolítica" que compreende, em tradução espanhola, a Geopolitica de Brasil, do general Golbery de Couto e Silva, El expansionismo brasileño, de P. Schilling, a Proyección continental de Brasil, do general Mario Travassos, e a Geopolitica de Chile, do general Augusto Pinochet Ugarte. Mas, antes de tratar destes autores contemporâneos, é oportuno realizar um passo a trás.

A partir do final do século XIX, nos estudos de geografia da área alemã já estavam presentes os conceitos que, em seguida, caracterizaram a geopolítica do nacional-socialismo e que, por este último, foram aplicadas à América do Sul, como será visto mais adiante. Tais ideias ainda oitocentistas foram, porém, revitalizadas e impregnadas com um forte conteúdo emotivo pelas mutilações territoriais impostas à Alemanha com o Tratado de Versailles, no final da Primeira guerra mundial. Em seguida, com o nacional-socialismo, fundiram-se numa doutrina política unitária (que se apresentava, todavia, como fundamentada na ciência), para justificar e explicar as agressivas expansões territoriais, inicialmente da Alemanha, depois, dos seus aliados, Itália e Japão.

Entre os séculos XIX e XX, a geopolítica conta com três precursores, que retornam também em quase todos os escritos sul-americanos de geopolítica. O primeiro é o alemão Friedrich Ratzel (1844-1904), que nos seus primeiros escritos não mencionava ainda a "geopolítica", mas sim a "geografia política": este é o título de seu livro de $1897^{4}$, no qual recorre, pela primeira vez, ao termo 'Lebensraum' (espaço vital), elaborado depois, cientificamente, na sua obra de $1901^{5}$. O espaço vital é a área na qual pode desenvolver-se um ser vivente, planta, animal, ou homem. O ponto de partida de Ratzel é, assim, a geografia botânica e zoológica; porém, nas suas obras a luta pelo espaço que garante a sobrevivência é descrita, também, com referência às grandes batalhas da história.

${ }^{4}$ Friedrich Ratzel, Politische Geographie, Oldenbourg, München 1897, XX-715 pp.; a idéia da guerra está presente no subtítulo da segunda edição de 1903: Politische Geographie, oder die Geographie der Staaten, des Verkehres und des Krieges, Oldenbourg, München 1903, XVIII-838 pp. (3a ed: 1923); id., Der Staat und sein Boden geographisch betrachtet, Hirzel, Leipzig 1896, $127 \mathrm{pp}$.

5 Friedrich RATZEL, Der Lebensraum. Eine biogeographische Studie, em: Festgabe für Albert Schäffle, Laupp, Tübingen 1901, pp. 103-189; ainda: Der Lebensraum. Eine biogeographische Studie, Laupp, Tübingen 1901, 87 pp. 
Desde 1896 Ratzel indicava a guerra como instrumento natural para a conquista do espaço vital ${ }^{6}$. Na sua teoria, fica assim clara a influência do darwinismo social. Semelhante visão do mundo faz dele um consciente teórico do imperialismo europeu e, através da mediação de seu aluno Haushofer (do qual o texto se ocupará a seguir), um involuntário precursor do nacional-socialismo.

Também o sueco Rudolf Kjellén (1864-1922) contribuiu para a afirmação da geopolítica, na qual ingressou quando o debate sobre a eventual dissolução da união entre Suécia e Noruega o levou a estudar a natureza do Estado. Kjellén sofreu a influência da visão biológica e social-darwinística de Ratzel, concebendo o Estado como um organismo biológico que se rege segundo leis naturais e se enraiza no seu território. Na geopolítica, a importância de Kjellén consiste, sobretudo, em ter sistematizado as idéias expostas por Ratzel. Porém, as suas erradas previsões sobre o êxito na Primeira guerra mundial e a sua morte em 1922 determinaram o final da sua influência sobre a política sueca, endereçada, em seguida, para uma visão pacífica e neutra das relações internacionais ${ }^{7}$.

Enfim, as concepções sobre a estrutura geopolítica da Europa do célebre geógrafo e político inglês Halford J. Mackinder (1861-1947) influenciaram fortemente o pensamento de Haushofer, levando-o a afirmar a necessidade de um acordo continental da Alemanha com a URSS, até ao momento em que a declaração de guerra da Alemanha contra aquele Estado pôs um fim nos seus projectos. A relação de Haushofer com as teorias de Mackinder é bem diversa daquela que se observa nas teorias de Ratzel e Kjellén: o alemão e o sueco eram para ele uma fonte de inspiração e admiração, enquanto o inglês ao qual Haushofer não deixa de tributar o máximo reconhecimento cultural restava sempre o inimigo: o inimigo com o qual é necessário aprender, para melhor combatê-lo. Por isso, o futuro declínio da potência naval inglesa, temido por Mackinder, transformou-se, para Haushofer, num projeto político a ser realizado contra a Grã-Bretanha: o projeto de afirmação da potência terrestre na Europa central, "the geographical pivot of history", que Mackinder identificava com a Eurásia, da Alemanha à Rússia.

\footnotetext{
${ }^{6}$ Friedrich Ratzel, Die Gesetze des räumlichen Wachstums der Staaten, "Petermanns Geographische Mittelungen", 1892, pp. 97-107.

7 Os livros que tornaram Rudolf KJELLÉn famoso na Alemanha são: Die Großmächte vor und nach dem Weltkriege, Teubner, Berlin 1930, 348 pp. (esta é vigésima segunda edição da obra publicada em 1914); Die Ideen von 1914. Eine weltgeschichtliche Perspektive, Hirzel, Leipzig 1915, 46 pp.; Grundriß zu einem System der Politik, Hirzel, Leipzig 1920, 106 pp.; Der Staat als Lebensform, Hirzel, Leipzig 1917, VIII-236 pp. (4a ed.: 1924). Sobre o vínculo com a Alemanha: Warum ich es mit Deutschland in diesem Weltkriege halte?, Curtius, Berlin [1914?], 43 pp.; e sobretudo KJELLÉN - HAUSHOFER, Macht und Erde, Teubner, Leipzig - Berlin 1930-34, 3 vols.
} 
As propostas dos três precursores da geopolítica confluem no pensamento de Karl Haushofer, do qual ora é oportuno examinar tanto a discutida figura, quanto a indiscutível influência no mundo científico e político alemão da primeira metade de Novecentos.

Com Karl Haushofer (1869-1946) - general bavaro e, depois, professor: uma das figuras mais enigmáticas e, talvez, uma das eminências pardas mais importantes do século XX - a geopolítica sai do âmbito das reflexões políticas ou acadêmicas, para se tornar uma teoria que guia ou justifica a ação política. Para Haushofer, mesmo unido por laços pessoais ou por estreitos vínculos culturais aos dois precursores da geopolítica, Ratzel e Kjellén, a geopolítica é, de facto, uma "ciência aplicada": ou seja, aplicada pelos políticos.

Dois eventos influíram de modo decisivo para a formação de Karl Haushofer.

No plano científico, a sua missão militar no Japão (1908-1910) determinou seu interesse pela geopolítica e forneceu-lhe um modelo ideal de Estado autoritário sobre o qual plasmar a Alemanha. No plano político, desde 1919-20, ligou-se por estreita amizade a Rudolf Heß, o "vice" de Hitler, com cuja sorte, indissoluvelmente - e tragicamente - viriam a interseccionar-se as vidas de Karl Haushofer e de seu filho Albrecht (1903-1945), também ele geopolítico.

O tratado de Versailles privava a Alemanha de uma parte do território essencial para a sua sobrevivência como grande potência. $\mathrm{O}$ debate sobre o "espaço vital" tornou-se, então, politicamente central e, nele, a "geopolítica" assumia um peso crescente, até se apresentar como a pedra angular da ideologia oficial no Estado nacional-socialista. Tem origem em Haushofer a teoria dos "grandes espaços", usada para justificar as agressões alemãs, italianas e japonesas contra os Estados vizinhos. Tal teoria inspirou também o "novo direito internacional" teorizado por Carl Schmitt, o mais importante jurista da época nacional-socialista, cujo pensamento está vivendo uma intensa reavaliação nos últimos anos.

Sobre a complexa e ainda obscura questão das relações e das recíprocas influências entre Haushofer e o nacional-socialismo, o exilado escritor judeu Stefan Zweig (1881-1942), que conheceu Haushofer exprimiu, pessoalmente, ainda nos anos Quarenta, um juízo equilibrado: "Não vejo nele [...] uma demoníaca 'eminência parda' que ocultamente arquitecta os planos mais perigosos e os sugere ao Führer. Mas não existe nenhuma dúvida de que, tenham sido exatamente as suas teorias, muito mais do que as teorias dos mais tresloucados conselheiros de Hitler, conscientemente ou não, aquelas que transferiram a agressiva política do nacional-socialismo da esfera nacional à universal. Somente o futuro poderá oferecer o exacto peso histórico de sua figura, com base numa documentação melhor do que aquela da qual dispomos, nós, 
contemporâneos"'. Hoje, alguns documentos vieram à luz e a influência também pessoal de Haushofer sobre o nacional-socialismo pode ser considerada demonstrada pelo menos nas suas linhas principais. Um recente e documentado estudo, escrito pelo padre jesuíta Bruno Hipler, intitula-se significativamente $O$ mestre de Hitler: Karl Haushofer como pai da ideologia nacional-socialista ${ }^{9}$.

Em conclusão, Haushofer foi uma eminência parda do nazismo, mas não participou diretamente dos seus crimes de guerra: por isso, foi preso pelos aliados, que, porém, renunciaram a julgá-lo em Nuremberg. No que se refere à América do Sul, como veremos, ele foi responsável pelas associações que mantinham os contactos com os alemães no exterior, respondendo diretamente a Hess (o alter ego de Hitler, até o seu nunca esclarecido vôo para a Inglaterra em 1941). Assim, também a visão do "grande espaço" sul-americano sob a hegemonia argentina está diretamente inspirada nas idéias geopolíticas de Haushofer.

\section{2 - A geopolítica, da Europa das ditaduras à América do Sul}

A geopolítica de Haushofer serviu como justificação "científica" para a conquista da Europa oriental por parte da Alemanha, para a formação da "Greater East-Asia Co-Prosperity Sphere", que levou o Japão às portas da Índia britânica, e para a busca por "um lugar ao sol" africano, por parte da Itália, que foi, porém, a mais reticente partidária da geopolítica entre os Estados do Eixo. Outrossim, a geopolítica nacional-socialista influenciou directamente a política exterior da Argentina e do Brasil. O recente livro do diplomata brasileiro Sergio Corrêa da Costa (1919-2005), dedicado à penetração nacional-socialista na América do Sul e, em especial na Argentina ${ }^{10}$, pode ser lido também como um perfeito manual de geopolítica aplicada. Se os precursores destes estudos ofereciam uma visão da geopolítica in the books, com o nacional-socialismo enfrenta-se a geopolítica in action.

Sergio Corrêa da Costa analisa a "guerra secreta" que a Alemanha nazista conduzia para poder usar as minorias alemãs na Argentina e no Sul do

8 Stefan ZWEIG, Die Welt von gestern. Erinnerung eines Europäers, Suhrkamp, Franfurt 1947, 500 pp.; também Wien 1952, p. 176 (itálico meu); mas originariamente publicado em Estocolmo (Fischer, 1944, 394 pp.).

9 Bruno HIPLER, Hitlers Lehrmeister: Karl Haushofer als Vater der NS-Ideologie, EOS Verlag (Erzabtei St. Ottilien), St. Ottilien 1996, 240 pp.

10 Sergio Corrêa da Costa, Crônica de uma guerra secreta. Nazismo na América: A conexão argentina, Record, São Paulo - Rio de Janeiro 2004, 530 pp. As páginas mencionadas neste item e não acompanhadas de outra indicação referem-se ao volume mencionado. 
Brasil como "quinta coluna", para apoderar-se de toda a América do Sul. Efectivamente, nos anos Trinta, a Alemanha nacional-socialista estava a realizar dois planos estratégicos, um mais antigo e teórico, outro mais imediato e militar.

O plano mais antigo e teórico fundava suas raízes no nacionalismo alemão, no Pangermanismo e na geopolítica alemã, ou seja, numa série de ideologias que remontavam ao final de Oitocentos e ao imperialismo guilhermino, as quais pregavam a unificação de todas as minorias alemãs. Tais visões, aplicadas à América do Sul, estão sintetizadas num mapa do início de Novecentos que representa "A América do Sul em 1950" e que reflete, não a situação geográfica do início do século XIX, mas os desejos do autor que o publicou em 1911: era, assim, a previsão para um nosso futuro que passou. Nesse mapa, a América do Sul estava dividida em três grandes áreas: os "Estados Unidos da América do Norte" desceriam, até ocupar boa parte da Colômbia e da Venezuela; a "América do Sul inglesa" ocuparia o centro do Brasil, o Peru, o Equador e uma parte da Bolívia; enfim, a "América do Sul alemã" (exatamente assim: "Deutsch Südamerika") compreenderia Chile, Argentina, a outra parte da Bolívia e todo o Brasil meridional. O autor do mapa, Otto Richard Tanneberg, não tem dúvidas: “A Alemanha tomará sob sua proteção a Argentina, o Chile, o Uruguai, o terço meridional da Bolívia, por integrar a Bacia do Rio da Prata, e a parte meridional do Brasil, onde reina a cultura alemã""

O plano mais imediato e militar, ligado à guerra de expansão da Alemanha nazista, previa a criação daqueles que, vez por vez, eram chamados, na Alemanha, de "Estados Unidos da América do Sul". Esse futuro Estado vassalo do Terceiro Reich representava uma natural expansão do "espaço vital alemão", ao qual quis endereçar o excesso de população da metrópole: essa era de facto a justificação utilizada pelo nacional-socialismo para os seus objetivos territoriais, em detrimento dos outros Estados, não apenas sul-americanos. A criação desse Estado vassalo tinha, porém, uma função estratégica na condução da guerra: um forte aliado alemão na América do Sul teria distraído os Estados Unidos da América do envio de ajuda ao aliado inglês na guerra na Europa, constrangendo-os a pensar nos problemas do seu "quintal de casa".

Nessa estratégia do Terceiro Reich para com a América do Sul inscreve-se um dos pontos de maior interesse do volume: o caso da carta geopolítica nazi sobre o futuro desenho da América do Sul, após a vitória da Alemanha nazi e dos seus aliados do Eixo ${ }^{12}$. O título em alemão indica que se trata do

"O mapa descrito no texto está na p. 207 e foi pinçado de uma típica obra nacionalista: Otto Richard TANNEBERG, Gross-Deutschland. Die Arbeit des 20. Jahrhunderts, Volger, LeipzigGohlis 1911, do qual é extraída também a citação mencionada no texto (p. 206).

12 A carta está reproduzida em Corrêa da CosTA, Crônica de uma guerra secreta, cit., p. 290. 
mapa da "Rede das linhas aéreas dos Estados Unidos da América do Sul". Sobre o conteúdo e a importância desse mapa, à época secretíssimo, convém deixar a palavra a Sergio Corrêa da Costa:

\begin{abstract}
O mapa mostrava a redistribuição territorial da América do Sul a ser imposta pela Alemanha depois da vitória. O subcontinente seria reduzido a apenas quatro países e uma colónia, todos sob proteção alemã, a saber: 1. Brasil; 2. Argentina, que absorveria o Uruguai, Paraguai, toda a parte baixa da Bolívia e um corredor para o Pacífico na altura de Antofagasta; com isso, o nosso vizinho se adentrava no continente como um verdadeiro braço em direção à Amazônia, indo além da altura de Corumbá; 3. Chile, incluindo o restante do Peru e da Bolívia; 4. Nova Espanha, formada pela Colômbia, Venezuela e Equador, mais o Panamá e mais a zona do canal; 5. as três Guianas unificadas como colónia francesa. A Argentina, portanto, além de reconstituir as fronteiras do vice-reinado do Prata, decepa uma faixa de Chile e assegura a Buenos Aires a almejada saída para o Pacífico $[\ldots]^{13}$.
\end{abstract}

A descoberta desse mapa ultrasecreto - dele existiam dois exemplares, um com Hitler, outro com o embaixador alemão em Buenos Aires - teve repercussões também nos Estados Unidos, porque a referência ao canal do $\mathrm{Pa}$ namá coloca em perigo os interesses daquele Estado e, assim, acciona o mecanismo da Doutrina Monroe.

Mostrado [i.e.: o mapa] ao Presidente Roosevelt, foi por ele citado em discurso irradiado em 27 de outubro de 1941. Depois de evocar reiteradas declarações de Hitler de que suas ambições não se estendiam além-Atlântico, assinalou: "São hoje 14 os países nessa área [...], pois os peritos geógrafos de Berlim obliteraram brutalmente todas as linhas divisórias para reduzir a América do Sul a cinco Estados vassalos, todos sob dominação alemã [...] e o fizeram de forma a que um deles incluísse a República do Panamá [...]. O mapa deixa claro que os desígnios nazis não são apenas contra a América do Sul, mas igualmente contra os Estados Unidos"14.

Por outro lado, os Estados Unidos estavam conscientes de tais ambições alemãs com relação à América do Sul. Em 1914, Roosevelt escrevia, efectivamente: "Do you not believe that if Germany won in this war, smashed the English Fleet and distroyed the British Empire, within a year or two she would insist upon taking the dominant position in South and Central America?"15.

Uma vez que a geopolítica inspirada por Haushofer teve repercussões clamorosas também na Argentina e no Brasil, Haushofer não podia faltar no livro de Sergio Corrêa da Costa, que o recorda como animador de numerosas

${ }^{13}$ Corrêa da Costa, Crônica de uma guerra secreta, cit., p. 289.

${ }^{14}$ Corrêa da Costa, Crônica de uma guerra secreta, cit., p. 291.

15 Theodore Roosevelt a Hugo Munsterberg, 3 de outubro de 1914, em Elting E. Morison (ed.), The Letters of Theodore Roosevelt, Harvard University Press, Cambridge (Mass.) 1954, p. 823, citado em Henry KISSINGER, Diplomacy, Simon \& Schuster, New York 1994, p. 42. 
associações, fundadas já antes do nazismo, para manter os contatos com os alemães no exterior.

Todavia, a importância de Haushofer foi muito exagerada durante a guerra. Por exemplo, o "Reader's Digest" descreve o seu (inexistente) "Instituto de Geopolítica" na Universidade de Munique como uma central com milhares de colaboradores. Ao invés, em Munique realmente existira, sob a direção de Haushofer, uma "Deutsche Akademie" que se ocupara da "germanicidade" (Deutschtum) e das relações culturais não oficiais com o exterior. Fundada em 1925, foi dissolvida em 1945. Ela desenvolvia estudos alemães de alto nível, mas possuía também uma "Seção prática" (Praktische Abteilung) que se dedicava ao ensino do alemão como língua estrangeira. A herança desta secção foi recolhida em 1961 pelo atual "Goethe-Institut", por sua vez fundado em 1932, dissolvido no pós-guerra e reconstituído em 1952. A Academia mesma, no entanto, não foi reconstituída e hoje, de fato, encontra-se quase esquecida.

Sergio Corrêa da Costa recorda ainda um "Verein für das Deutschtum im Ausland" (Associação para o Germanismo no Exterior, VDA), que assumira este nome em 1908, mas existia desde 1880, como associação gestora das escolas alemãs no exterior. Tal associação conheceu grande expansão com o nacional-socialismo e por isso os Aliados proibiram-na em 1945. Foi reconstituída, porém, em 1955 e - assumindo uma posição política de extrema direita - ocupou-se activamente, no início, dos alemães expulsos e refugiados; e após 1989, dos "alemães do Volga". Apoiada pelos governos alemães, mas envolvida em escândalos financeiros, tal associação "expôs-se a si mesma negativamente pelas suas ligações com as ditaduras militares e com os ambientes de extrema direita e neofascistas. Foram objeto de crítica sobretudo suas relações com a junta militar chilena" ${ }^{\text {"16. }}$

Os planos geopolíticos atingiram, assim, um nível paroxístico durante a época nacional-socialista, mas, como foi visto, existiam de forma menos virulenta tanto antes quanto depois das ditaduras européias dos anos Trinta.

\section{3 - Os geopolíticos brasileiros}

É a mesma dimensão subcontinental do Brasil que obriga sempre, de facto, a pensar em termos geopolíticos. Assim o fizeram os portugueses a partir da expansão colonial, para além da linha traçada pelo Tratado de Tordesilhas e para além dos espaços estabelecidos pelo Tratado de Madrid de 1751.

${ }^{16}$ IDGR - Lexikon Rechtsextremismus, alla voce: Verein für das Deutschtum im Ausland nel sito: http://lexikon.idgr.de/v/v e/verein-fuer-das-deutschtum-im-ausland/vda.php, consultado em 17 fevereiro de 2005. 
Assim continuaram os brasileiros após a independência, quando da metade dos Oitocentos até ao início dos Novecentos estenderam o próprio território às custas dos países confinantes. Ainda na primeira parte dos Oitocentos, a área disputada era sobretudo na parte Sul, fronteira com as ex-colônias espanholas; depois, com o final daquel século, o interesse mundial pela borracha deslocou a atenção internacional para a Amazônia ${ }^{17}$. Aquele enorme e despovoado território impunha, com força, o problema da segurança nacional (para dele evitar a ocupação pelos Estados fronteiriços) e da sua integração no tecido brasileiro: tema recorrente até aos dias atuais ${ }^{18}$, ainda que a procura de borracha natural tenha sido muito reduzida.

Partindo destes problemas, a geopolítica brasileira iniciou-se como ciência nos primeiros anos do século XX, com Everardo Backheuser, Carlos Delgado de Carvalho e Mário Travassos, que foram não somente geógrafos, como também pedagogos. Destes precursores ocupar-nos-emos brevemente a seguir. Eles, por sua vez, influenciaram os teóricos do regime militar (1964-1985), que tinham como ponto de referência a Escola Superior de Guerra no Rio de Janeiro. A nossa atenção será concentrada nos generais Carlos de Meira Mattos e Golbery do Couto e Silva.

a) Entre os precursores da geopolítica brasileira, a figura mais relevante é, sem dúvida, Everardo Backheuser (1879-1951), que se colocou na tradição alemã da geopolítica clássica, seguindo os ensinamentos do alemão Friedrich Ratzel e do sueco Rudolf Kjellén, considerados na Europa os precursores da geopolítica. Com a Europa, Backheuser manteve vínculos científicos diretos ${ }^{19}$. Um escrito de Backheuser ${ }^{20}$ - "que difundiu, no Brasil, a geopolítica alemã"21 - foi publicado na revista alemã de geopolítica editada por Karl Haushofer. Na sua longa vida (que ele mesmo em parte narrou ${ }^{22}$ ), interessou-se

17 Para uma análise do mercado mundial naqueles anos, cfr. Alfred VAGST, "Kautchuk-Politik", Zeitschrift für Geopolitik, III, 1926, pp. 631-649. A revista é organizada por Karl Haushofer: este particular deve ser considerado na interpretação da linha política do artigo.

18 Wanderley Messias da Costa, O Estado e as políticas territoriais no Brasil, Editora da Universidade de São Paulo, São Paulo 1988, 83 pp.

19 Veja-se, por exemplo, a sua conferência Brasilio. Farito de la Societo de geografio en Parizo, Hachette, Paris 1909, 26 pp. (em esperanto); o artigo Die neue Auffassung der Erdkunde, Halle a. d. Saale 1934, 8 pp. (extrato da "Geographische Wochenschrift", 1934, n. 2).

${ }^{20}$ Everardo BACKHEUSER, Das politische Conglomerat Brasilien, "Zeitschrift für Geopolitik", 3, 1926, pp. 625-630.

${ }^{21}$ Lúcio CaStelo Branco, Staat, Raum und Macht in Brasilien. Anmerkungen zu Genese und Struktur der brasilianischen Staats- und Großmachtideologie, Finck, München 1983, p. 466, nota 7. Importante, ainda que a bibliografia seja heterogênea: pp. 493-552.

22 Everardo BACKHEUSER, Minha terra e minha vida, Instituto Brasileiro de Geografia e Estatística, Rio de Janeiro 1942, XII-208 pp. 
também pela Amazônia e, enfim, exerceu uma influência determinante sobre os militares. A eles se deve a publicação dos seus escritos nos anos Cinqüenta ${ }^{23}$.

Por seu turno a formação de Carlos Delgado de Carvalho (1884-1980) está ligada à Europa e, em especial, à escola francesa do geógrafo francês Paul Vidal de la Blanche (1845-1918), cujo método interdisciplinar e culturalista tornou-o, na época, o estudioso francês mais relevante neste campo, a ponto de, em seguida, os historiadores dos "Annales" o considerarem um de seus precursores. Explica-se assim porque um dos mais importantes trabalhos de Delgado de Carvalho tenha sido publicado em francês ${ }^{24}$. Os estudos de Vidal de la Blanche imprimiram à escola francesa uma direção bem diversa da geopolítica alemã ${ }^{25}$. Delgado de Carvalho, por sua vez, exercitou uma forte influência no mais representativo dos geopolíticos militares, o general Golbery do Couto e Silva, mencionado a seguir.

Enquanto os dois precedentes autores eram civis, o general Mário Travassos (nascido em 1891) fazia parte da estrutura militar. Nas suas obras, indica dois eixos de expansão do Brasil, um na direção da Bolívia, o outro ao longo do Rio Amazonas, sempre sublinhando a necessidade de povoar as terras excessivamente despovoadas ${ }^{26}$. Backheuser associou-se também a tal proposta. Nos anos Cinqüenta, foram criados, ao longo da fronteira, os territórios federais, ou seja, diretamente controlados pelo governo central. Surgiram assim os territórios do Amapá e de Roraima, a Norte; Acre, Iguaçu, Ponta Porã e Rôndonia a Oeste e Sudeste e não foi esquecida a ilha - pequena, mas estratégica - de Fernando de Noronha.

As idéias de Mário Travassos passaram, depois, aos dois principais geo-

${ }^{23}$ Everardo BACKHEUSER, Problemas do Brasil: estructura geopolítica. O espaço, Omnia, Rio de Janeiro 1933, 173 pp.; id., O Barão do Rio Branco, geógrafo e geopolítico, "Revista da Sociedade de Geografia" (Rio de Janeiro) 1946; id., Curso de geopolítica geral e do Brasil, Biblioteca do Exército, Rio de Janeiro 1952, 275 pp. Esta editora publicara ainda Lísias RoDRIGUES, Geopolítica do Brasil, Biblioteca do Exército, Rio de Janeiro (1947? não encontrado); Sydney M. G. dos Santos, A cultura opulenta de Everardo Backheuser. Os conceitos e as leis básicas da geopolítica, Empresa Carioca de Engenharia, Rio de Janeiro 1989, 493 pp.

${ }_{24}$ Carlos Delgado de CARVAlho, Le Brésil méridional. Étude économique sur les États du Sud, Desfosses, Paris - Rio de Janeiro 1910, 529 pp.

${ }_{25}$ É indispensável recordar que a geopolítica européia atingiu seu ápice após 1918, quando o Tratado de Versailles retirou da Alemanha os territórios renanos, a Ruhr e suas colônias. Os geopolíticos alemães requeriam o retorno daquelas terras à Alemanha em nome do "Blut und Boden" e do "espaço vital"; a eles, Vidal de la Blanche (que no livro La France de l'est, de 1917, tratara da anexação de 1871 da Alsácia-Lorena à Alemanha) opôs a "géographie active" fundamentada no desenvolvimento histórico. Além disso, ele contrapunha profeticamente às pretensões hegemônicas alemãs sobre a Europa "une communauté européenne".

${ }^{26}$ Mário Travassos, Projeção continental do Brasil, Edição Brasiliana, 1938 (trad. mexicana: Proyección continental del Brasil, El Cid, México 1978, 103 pp.); id., Introdução à geografia das comunicações brasileiras, José Olympio, Rio de Janeiro 1942. 
políticos da época da ditadura militar, os generais Carlos de Meira Mattos e Golbery do Couto e Silva. Entre os anos Cinqüenta e Setenta, os militares, partindo da dimensão subcontinental do Brasil e de seu desenvolvimento económico, imaginaram uma sua influência também fora da América do Sul e uma sua posição de primeiro plano como aliado dos Estados Unidos na luta contra o comunismo. Ao mesmo tempo, adoptaram medidas para reforçar a unidade do país e garantir a segurança das fronteiras ${ }^{27}$. Foi a época da construção de estradas e aeroportos militares, de gigantescas barragens para a produção de energia eléctrica, de indústrias estrangeiras incentivadas a instalar-se no Brasil.

Tais medidas econômicas foram acompanhadas por uma dura repressão interna e tiveram também um alto custo social. Por exemplo, os camponeses evacuados das terras cobertas por lagos artificiais foram deslocados para milhares de quilômetros de distância, muitas vezes sem infraestruturas suficientes.

Hoje, o balanço daquelas medidas geopolíticas apresenta luzes e sombras. Algumas áreas desenvolveram-se, tornando-se os actuais Estados de Rondônia, Pará e Tocantins. Os projetos rodoviários, contudo, foram realizados apenas em parte. Mas, o objectivo deste escrito não é tentar um balanço sócio-econômico da geopolítica brasileira, mas apenas o de traçar as linhas de desenvolvimento e os seus laços com os geopolíticos europeus.

b) O general Carlos de Meira Mattos (nascido em 1913) publicou a maior parte de seus trabalhos depois do golpe de Estado de 1964. Logo a seguir, um primeiro grupo de seus escritos delineia a teoria que movera os militares na tomada do poder e que teria guiado o seu exercício ${ }^{28}$. Alguns anos depois, consolidada a ditadura militar, a sua produção concentra-se em temas de geopolítica $^{29}$. Com respeito ao outro geopolítico da ditadura militar, o general

27 José Alfredo do Amaral GURGEL, Segurança e democracia: uma reflexão política, José Olympio, Rio de Janeiro 1975, XII-185 pp.; Joseph Comblin, A ideologia da Segurança Nacional, Civilização Brasileira, Rio de Janeiro 1980 (não encontrado).

${ }^{28}$ Carlos de Meira MatTos, Pensamento revolucionário brasileiro, 1964 (não encontrado); id., Doutrina e política da revolução de 31 de março de 64, 1967 (não encontrado); Ensaio sobre a doutrina política da revolução, SGSF, Brasília 1969, 15 pp.; sua experiência como comandante da Brigada Latino-Americana da Força Interamericana de Paz na República Dominicana é descrita em A expêriencia da FAIBRÁS na República Dominicana, Serviço Gráfico do IBGE, Rio de Janeiro 1966, XIX-215 pp.

${ }^{29}$ Carlos de Meira MatTos, A geopolítica e as projeções do Poder, José Olympio, Rio de Janeiro 1977, 147 pp.; id., Brasil. Geopolítica e destino, José Olympio, Rio de Janeiro 1975, XVII-109 pp.; id., Uma geopolítica pan-amazônica, José Olympio - Instituto Nacional do Livro, Rio de Janeiro - Brasília, 215 pp. e as outras obras citadas nas notas seguintes. Cfr. ainda P. I. Kelly, Geopolitical Themes in the Writings of General Carlos dé Meira Mattos of Brazil, "Journal of Latin American Studies", 16, 1984, pp. 439-461. 
Couto e Silva, Meira Mattos prestou maior atenção à realização das teorias do que à elaboração de grandes planos geopolíticos. Como militar operativo, é a ele que se deve, no momento da tomada do poder pelos militares, a ocupação e o fechamento do Congresso Federal brasileiro. Foi também um dos principais auxiliares do general e presidente Humberto de Alencar Castello Branco $(1900-1967)^{30}$.

Em comum com Couto e Silva, resta o fato de terem participado, durante a Segunda Guerra Mundial, da força expedicionária brasileira que actuou na Itália ao lado dos norte americanos, e também em comum possuem a docência na Escola Superior de Guerra no Rio de Janeiro. Meira Mattos, além disso, desenvolveu esta actividade didáctica também nos Estados Unidos, no Inter-American Defense College de Washington.

A presença destes dois eminentes geopolíticos fez da Escola Superior de Guerra o centro de tais estudos no Brasil ${ }^{31}$. Ainda que as escolas militares brasileiras tenham uma tradição secular, as origens desta escola são recentes. Os oficiais brasileiros que compuseram a força expedicionária na Itália foram treinados no U.S. National War College, de Washington. Esse período deixou-lhes uma impressão tão profunda e favorável que, com a assistência de militares americanos e franceses, fundaram em 1949 uma Escola análoga no Rio de Janeiro. Entre os fundadores da Escola encontramos o general Castello Branco, futuro Presidente após o golpe de 1964, e Everardo Backheuser, cujos sucessores naquela escola foram Couto e Silva e Meira Mattos.

A Escola Superior de Guerra distinguia-se do modelo americano na medida em que eram estudados os factores políticos e diplomáticos que podiam condicionar a política da segurança nacional; mas, sobretudo, porque a instituição admitia, também, civis entre seus estudantes. Assim, a ideologia da Escola circulava numa elite brasileira, tanto militar, quanto civil: entre $1950 \mathrm{e}$ 1967, e cerca da metade dos diplomados na Escola eram civis ${ }^{32}$. Depois do golpe de Estado, os postos-chaves militares e civis foram quase completamente confiados a personalidades formadas na Escola Superior de Guerra ${ }^{33}$.

A política de Meira Mattos para o controle das áreas de fronteira visava realizar acordos com os países vizinhos, mas sempre sob a hegemonia brasi-

${ }^{30}$ Foi Meira Mattos quem organizou uma edição comemorativa, após a morte de Castello Branco em um incidente aéreo: Castello Branco e a Revolução. Depoimentos de seus contemporâneos, Biblioteca do Exército, Rio de Janeiro 1994, 204 pp.

${ }^{31}$ Sobre a ideologia inspiradora: Escola Superior de Guerra, Manual Básico da Escola Superior de Guerra, Escola Superior de Guerra, Rio de Janeiro 1976, 648 pp.; Antonio de ARRUDA, A doutrina da Escola Superior de Guerra, “A Defesa Nacional”, LXV, 1978, n. 679, pp. 65-73.

32 Alfred C. StePAN, The Military in Politics. Changing Patterns in Brazil, Princeton University Press, Princeton (NJ) 1971, p. 176: de 1276 diplomados, 646 eram civis.

${ }^{33}$ Leonardo TrevisAn, O pensamento militar brasileiro, Global, São Paulo 1985, p. 55. 
leira. Nasceram, assim, os projectos conjuntos com a Argentina, o Uruguai e o Paraguai para a construção de centrais eléctricas, barragens, estradas e portos. Com o "Tratado de cooperação para a Amazônia" de 1978, o Brasil reuniu os oito países interessados numa cooperação que estabilizaria a fronteira do Norte (Bolívia, Colômbia, Equador, Guiana, Peru, Suriname e Venezuela) ${ }^{34}$. Todavia, a sua visão ia além das fronteiras brasileiras: ele imaginava um Brasil que unificasse a área que originariamente fora dos portugueses na América, na Âfrica e na Europa, opondo-se - ou até mesmo em parte substituindo - a hegemonia dos Estados Unidos ${ }^{35}$.

c) O general Golbery do Couto e Silva (1911-1987) fundou e dirigiu o tristemente famoso Serviço Nacional de Informações da ditadura militar e foi uma figura di primeiro plano na formulação e na aplicação da geopolítica à realidade brasileira, na qual seguiu inicialmente os esquemas traçados nos anos Trinta por Mário Travassos. A obra que o divulgou foi um manual de estratégia, e a elaboração da sua construcção geopolítica do Brasil revela essa origem $^{36}$. O seu esboço do Brasil futuro levava em consideração não tanto as fronteiras internacionais existentes, mas sim a heterogeneidade das diversas zonas brasileiras e a necessidade de garantir as fronteiras nacionais. As suas cinco "zonas operativas" cobrem, assim, não somente o Brasil, mas a América do Sul no seu todo.

$\mathrm{O}$ "coração" da futura conformação continental era a zona que reagrupava os ricos territórios do Sul (Rio de Janeiro, São Paulo, Minas Gerais e o Rio Grande do Sul, a terra natal de Couto e Silva): a "área central de manobra".

Este rico Sudeste era, ainda, contornado por três "penínsulas": o Nordeste tropical, o Sul e o Centro-Oeste de clima temperado. Dentre tais "penínsulas", o Nordeste premanece inteiramente interno ao Brasil; ao invés, as outras áreas, na visão de Couto e Silva, eram estendidas até incluir também os outros Estados sul-americanos. Assim, a área "Sul” para ele incluía, também, a Argentina, o Uruguai, o Chile e uma parte do Paraguai (denominada "Área Platino-Patagônica"), enquanto a área "Centro-Oeste" se estendia sobre o

${ }^{34}$ Carlos de Meira MatTos, Uma geopolítica pan-amazônica, José Olympio, Rio de Janeiro 1980, pp. 119-139 (corresponde ao capítulo: O Pacto Amazônico e sua articulação com o Pacto Andino). Mas também: Biblioteca do Exército, Rio de Janeiro 1980, 215 pp., que não pude consultar.

35 Carlos de Meira Mattos, Brasil: Geopolítica e destino, José Olympio, Rio de Janeiro 1979 , XV-151 pp. (2a ed.); Geopolítica e Trópicos, Biblioteca do Exército, Rio de Janeiro 1984, 157 pp. Cfr. também Moniz BANDEIRA, $O$ expansionismo brasileiro: o papel do Brasil na Bacia da Prata da colonização ao Império, Philobiblion, Rio de Janeiro 1985, 311 pp.

${ }^{36}$ Golbery do Couto e Silva, Planejamento estratégico, Biblioteca do Exército, Rio de Janeiro 1955; reimpresso pela Editora da Universidade de Brasília, Brasília 1981, 536 pp. 
restante do Paraguai e sobre a Bolívia (e tomava o nome de "Área do escudo central", shield).

A quinta zona era a "Área da Amazônia", que teria como centro Manaus, mas que estaria destinada a estender-se a todos os outros Estados andinos e costeiros da parte setentrional da América do Sul (terminando, assim, por coincidir mais ou menos com a hispânica e colonial Nova Granada).

Esse grandioso projeto - que certamente não entusiasmava os países limítrofes - correspondia, porém, exatamente às concepções políticas européias dos anos Trinta, quando Carl Schmitt teorizara a aglomeração dos Estados nacionais em "grandes espaços", sob a guia de um Estado hegemônico.

Partindo destas cinco áreas, Golbery de Couto e Silva indicava os quatro "passos operativos" que levariam o Brasil a dominar pacificamente o continente sul-americano. Inicialmente, era necessário consolidar o próprio Brasil. Assim, as "penínsulas" do Sul e do Nordeste deviam ser integradas na "área de manobra"(o rico Sudeste), através do desenvolvimento econômico e das vias de comunicação que um tal projeto exige. As áreas de confins, através da criação dos territórios federais, deveriam ser confiadas aos militares, que nelas teriam criado pólos de desenvolvimento para lhes garantir os laços com o restante do Brasil. O planalto central devia ser, por uma lado, colonizado a partir da área central e, por outro, unido à "ilha" amazônica por uma ligação viária que consolidasse aquele território no Estado brasileiro.

Tal visão geopolítica traduziu-se em obras concretas. As duas mais famosas são a transferência da capital da costa para o planalto central (ou seja, do Rio de Janeiro para Brasília, em 1960 $0^{37}$ ) e a construção da estrada Transamazônica, que transformou de modo irreversível a região.

Depois do golpe de Estado de 1964, os escritos de Golbery de Couto e Silva caracterizaram-se pelo anticomunismo (estimulado pela então recente revolução cubana) e pela atenção aos problemas da segurança nacional ${ }^{38}$. Mas ainda hoje o seu pensamento continua a suscitar interesse. Em 2003, as suas obras foram reunidas num amplo volume ${ }^{39}$, juntamente com alguns dos seus es-

${ }^{37}$ A exigência geopolítica de deslocar o baricentro do Brasil para o interior remonta ao momento da independência e era asserida já no art. $3^{\circ}$ da constituição de 1891 . A decisão oficial foi tomada em 1956 e a nova capital foi inaugurada em 21 de abril de 1960. À geopolítica acrescenta-se o argumento místico da profecia do beato Giovanni Bosco: Cosimo Semeraro (a cura di), Don Bosco e Brasilia. Profezia, realtà sociale e diritto, Cedam, Padova $1990,281 \mathrm{pp}$.

${ }^{38}$ Golbery do Couto e SILVA, Conjuntura política nacional. O poder Executivo e geopolítica no Brasil, José Olympio, Rio de Janeiro 1980 (3a ed. 1981, XIV-37-273 pp.). Sua obra mais famosa, na qual resume seu pensamento é Geopolítica do Brasil, José Olympio, Rio de Janeiro 1967, XIV-275 pp. (2a ed.).

${ }^{39}$ Golbery do Couto e SILVA, Geopolítica e poder, UniverCidade, Rio de Janeiro 2003, XVI633 pp.: além dos inéditos, o volume contém Planejamento estratégico (1955) e Geopolítica do Brasil, citado na nota anterior. 
critos inéditos que tiveram um forte impacto na vida brasileira. Todavia, convém apenas termos menção desses inéditos pois o seu exame imporia, que passássemos da geopolítica para a história política contemporânea.

\section{4-A geopolítica entre descrição e avaliação}

Hoje, a geopolítica pode ser considerada como a metafísica do nacional-socialismo apenas sob o ponto de vista histórico, não obstante no pós-guerra muitos estudos científicos a tenham reabilitado. Em muitos casos, ela voltou a ser uma geografia do mundo como é, e não do mundo como deveria ser. $\mathrm{O}$ historiador espanhol Vicens Vives viveu as duas esferas da geopolítica, tendo escrito um livro sobre tal assunto em $1940^{40}$ e retomado os estudos criticamente em 1950, escrevendo no prefácio ao último volume: "La Geopolítica, que interpreta el pasado geográfico e histórico para justificar la actualidad, adolecerá siempre del inminente peligro de caer sojuzgada bajo la presión de un régimen totalitario triunfante"; ao invés, diante dos fatos, sua tarefa é: "Comprender, no justificar; hacerlos asequibles, por tanto, a una posible ordenación y sistematización, invulnerable a los caprichos de los publicistas extrauniversitarios" ${ }^{41}$.

Porém, a geopolítica é caracterizada por uma forte carga interpretativa da realidade sócio-espacial e, assim, as suas pesquisas tendem a deslizar ao longo de um plano inclinado, no qual a geo-política se transforma gradualmente em geo-política; ou seja, no qual se passa do ser ao dever ser, da geografia descritiva à geografia prescritiva, da representação do mundo como é à prefiguração do mundo como deveria ser.

Por isso, também em tempos recentes e também na América do Sul, a geopolítica promove uma certa visão da sociedade futura, usando o dado geográfico como um argumento a favor dessa mesma visão. Por exemplo, o argentino Norberto Ceresole defende uma "geopolítica", e não uma "geografía política", porque lhe interessa não a descrição da realidade, "sino también (y sobre todo) la liberación de la voluntad de transformarla. Porque no es sólo interpretación académica lo que queremos, sino transformación del mundo". Esta "filosofia da acção e da esperança" remete-se ao "Prinzip Hoffnung" de Ernst Bloch ${ }^{42}$. Para Ceresole, o espaço interessa, então, como categoria social,

4o Jaime ViCEns Vives, España. Geopolitica del Estado y del Imperio, Editorial Yunque, Barcelona 1940, 215 pp.

${ }^{41}$ Jaime Vicens Vives, Tratado general de geopolítica. Segunda Edición, Universidad de Barcelona - Editorial Teide, Barcelona 1956, p. 8.

42 Norberto CERESOLE, Argentina: sobre transiciones y decadencias. Cinco ensayos geopolíticos para la re-interpretación de la realidad argentina, Prensa y Ediciones Iberoaméricanas, Madrid-Buenos Aires 1987, p. 51. 
como estrutura de poder, e não como dado físico-natural. Afirmações como esta abrem controvérsias ásperas sobre a natureza da geopolítica, nas quais se debate se a geopolítica "verdadeira" é somente descritiva, ou até que ponto, a geopolítica é também prescritiva oferecendo cada livro sobre o assunto uma definição de geopolítica que se coloca entre estes dois pólos de discussão ${ }^{43}$.

A mim, como observador externo, esta propensão da geopolítica para se tornar instrumentum regni - do reino presente ou do reino que virá, é indiferente - parece ínsita na natureza mesma da geopolítica. Tanto diante das fronteiras resultantes da Primeira Guerra Mundial, quanto em face da globalização e do controle monopolista dos recursos económicos - para citar apenas dois exemplos - é difícil permanecer weberianamente neutral; é mais fácil, e muitas vezes é quase inevitável, afirmar que a situação presente é injusta, e indicar qual poderia ser o projeto (geo)político para corrigi-la. No plano inclinado que vai da geopolítica descritiva à prescritiva, são possíveis muitas nuances. Nas páginas anteriores foram vistas sobretudo as geopolíticas de direita; mas existem também as de esquerda, sobre as quais não foi possível falar. No continente que gerou uma teologia da libertação, existe o espaço, e, mais ainda, existe a necessidade, também, de uma geopolítica da libertação ${ }^{44}$.

43 Um elenco pode ser visto, por exemplo, na abertura do volume do general Juan Enrique Guglialmelli, Geopolítica del Cono Sur, El Cid, Buenos Aires 1979, 268 pp.

${ }^{44}$ É exatamente o título de um outro livro de Norberto Ceresole. 


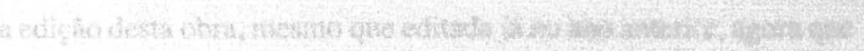

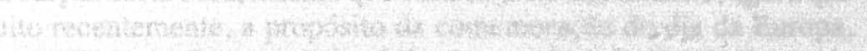

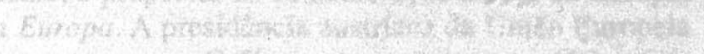

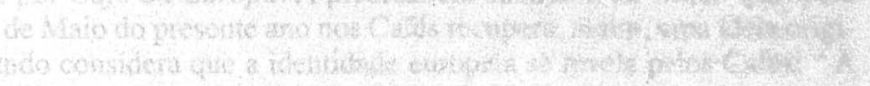

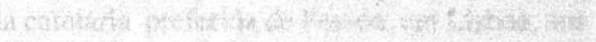

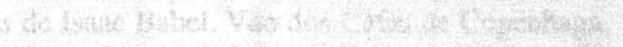

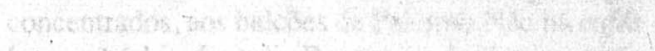

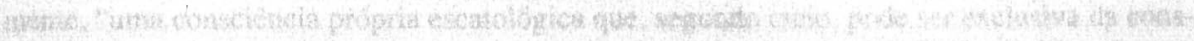

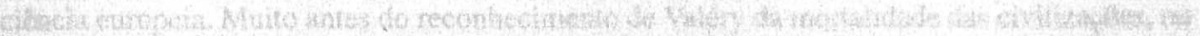

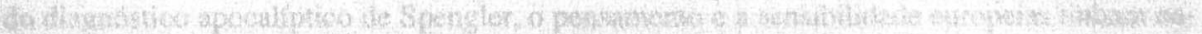

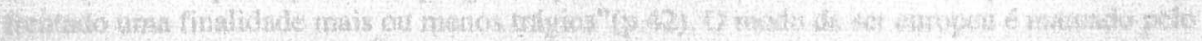

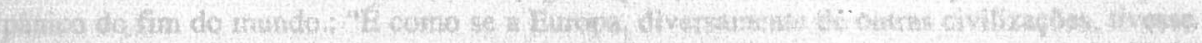

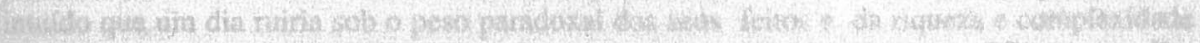

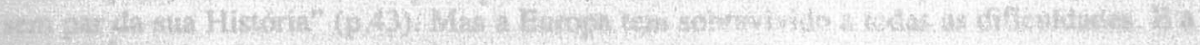

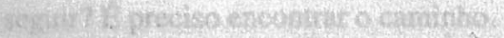

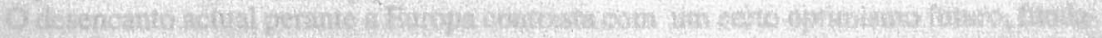

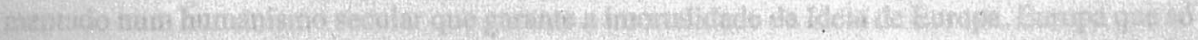

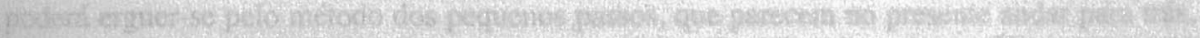

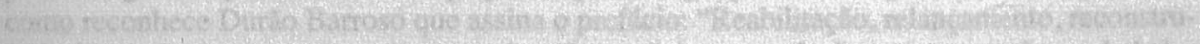

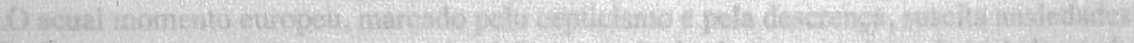

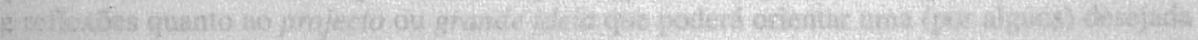

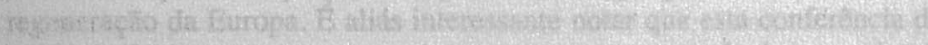

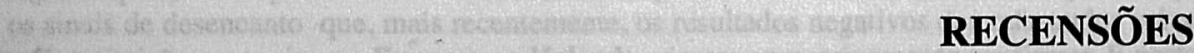

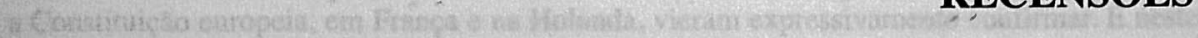

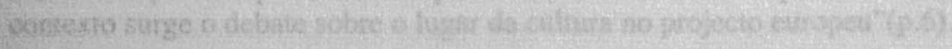




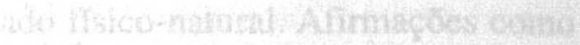

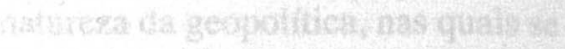

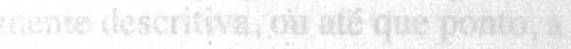

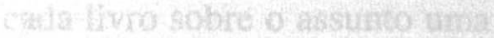

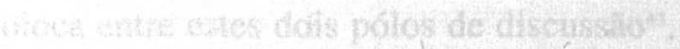

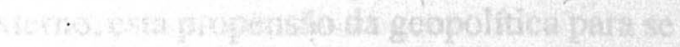

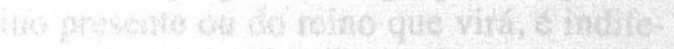

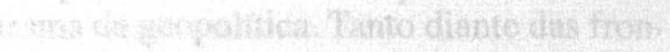

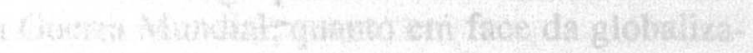

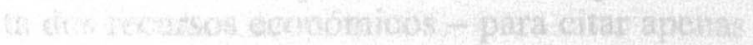

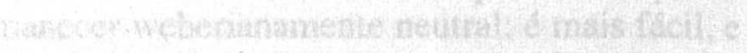

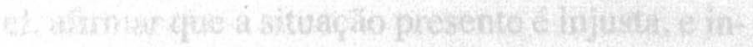

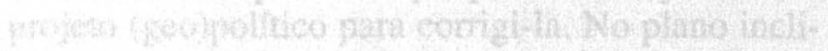

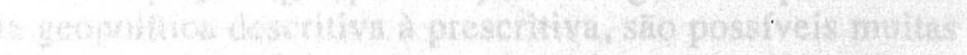

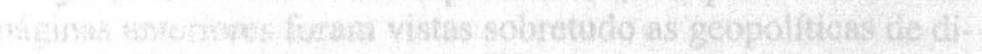

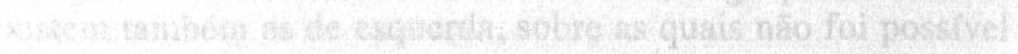

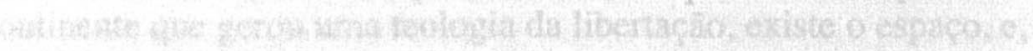

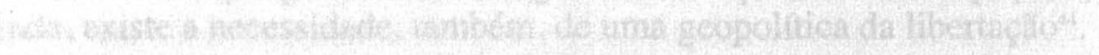

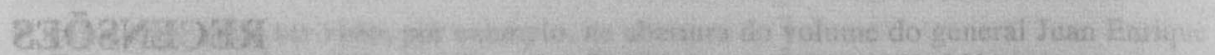

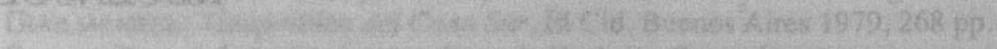

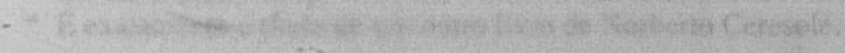


Vale a pena referir a edição desta obra, mesmo que editada já no ano anterior, agora que voltou a ser divulgada, muito recentemente, a propósito da comemoração do dia da Europa, numa iniciativa designada por Café da Europa. A presidência austríaca da União Europeia decidindo assinalar o dia 9 de Maio do presente ano nos Cafés recupera, assim, uma ideia original de George Steiner, quando considera que a identidade europeia se revela pelos Cafés: " A Europa é feita de cafetarias, de cafés. Estes vão da cafetaria preferida de Pessoa, em Lisboa, aos cafés de Odessa, frequentados pelos gangsters de Isaac Babel. Vão dos Cafés de Copenhaga, onde Kierkegaard passava nos seus passeios concentrados, aos balcões de Palermo.Não há cafés antigos ou definidores em Moscovo, que é já um subúrbio da Ásia. Poucos em Inglaterra, após um breve período em que estiveram na moda, no século XVIII. Nenhuns na América do Norte, para lá do posto avançado galicano de Nova Orleães. Desenhe-se o mapa das cafetarias e obter-se-á um dos marcadores essenciais da ideia de Europa" (p.26). Marinho da Arcada foi o escolhido como representante português; os outros, um de cada estado-membro, além da Bulgária e Roménia (em processo de adesão), associaram-se a esta ideia. Todos para comemorarem o dia da Europa a partir da cultura gastronómica, à procura de serem "seduzido(s) pela Europa", tema de debate comum.

Como definir a Ideia de Europa? Qual o sentido de falar em Identidade Europeia? O autor da obra sugerida encontra respostas muito concretas para uma realidade que embora continue a parecer um objecto político não identificado, usando a célebre expressão do Jaques Delors, tem uma "alma" que lhe dá um certo ar de eternidade. A expressão física escolhida são os Cafés, lugar de alimento desta ideia e primeiro critério escolhido por Steiner para definir a Ideia de Europa: "O café é um local de entrevistas e conspirações, de debates e mexericos...Aberto a todos, é todavia um clube, uma franco-maçonaria de reconhecimento político ou artístico-literário e presença programática...Na Milão de Stendhal, na Veneza de Casanova, na Paris de Baudelaire, o café albergava o que existia de oposição política, de liberalismo clandestino"(p.26).

A Europa tem características particulares:" a Europa foi e é percorrida a pé" (p. 27), única forma de reconhecer as belezas da Europa, que perduram no tempo - um tempo humanizado - e fazem a sua História. Na Europa tudo tem significado: “As ruas e praças nomeadas segundo estadistas, cientistas, artistas e escritores do passado"(p.44). No entanto, foi a síntese de duas culturas, Atenas e Jerusalém, que determinou a cultura europeia : "Muito frequentemente, o humanismo europeu, de Erasmo a Hegel, procura diversas de compromisso entre ideais áticos e hebraicos ...Assim, a ideia de Europa é, na verdade, um conto de duas cidades" (p.42). Finalmente, "uma consciência própria escatológica que, segundo creio, pode ser exclusiva da cons-" ciência europeia. Muito antes do reconhecimento de Valéry da mortalidade das civilizações, ou do diagnóstico apocalíptico de Spengler, o pensamento e a sensibilidade europeias tinham enfrentado uma finalidade mais ou menos trágica"(p.42). O modo de ser europeu é marcado pelo pânico do fim do mundo.: "É como se a Europa, diversamente de outras civilizações, tivesse intuído que um dia ruiria sob o peso paradoxal dos seus feitos e da riqueza e complexidade sem par da sua História" (p.43). Mas a Europa tem sobrevivido a todas as dificuldades. E a seguir? É preciso encontrar o caminho.

O desencanto actual perante a Europa contrasta com um certo optimismo futuro, fundamentado num humanismo secular que garante a imortalidade da Ideia de Europa. Europa que só poderá erguer-se pelo método dos pequenos passos, que parecem no presente andar para trás, como reconhece Durão Barroso que assina o prefácio: "Reabilitação, relançamento, reconstrução...O acual momento europeu, marcado pelo cepticismo e pela descrença, suscita ansiedades e reflexões quanto ao projecto ou grande ideia que poderá orientar uma (por alguns) desejada regeneração da Europa. É aliás interessante notar que esta conferência de Steiner apontava já os sinais de desencanto que, mais recentemente, os resultados negativos dos referendos sobre a Constituição europeia, em França e na Holanda, vieram expressivamente confirmar. E neste contexto surge o debate sobre o lugar da cultura no projecto europeu"(p.6). 
Uma obra de leitura obrigatória para quem deseja (re)pensar a Europa. A Europa do passado, a Europa do presente e a Europa do futuro. Encontrar um futuro para a Europa passa por encontrar as razões da sua identidade ou, pelo menos, os alicerces onde se fundamenta a história comum do povo europeu. Uma história feita de encontros e de desencontros, em sintonia com o seu indefinido espaço geográfico. Mas apesar de todas as ambiguidades, existe um património cultural comum que subsiste ao artificialismo arquitectado por tratados. Para além da diversidade cultural ou do aparente mosaico e labirinto de culturas, há uma história e cultura comuns, cujo substracto é muito mais do que uma mera justaposição das histórias e culturas nacionais que alguns pretendem ver. Há uma "unidade na diversidade", lema adoptado na actualidade. A herança comum europeia é a riqueza da Europa e a possibilidade do seu futuro. O legado greco-romano, as invasões bárbaras e a conversão cristã da Europa são os fundamentos históricos da sua identidade.

Uma identidade que no presente continua a ser alimentada pela cultura e pela memória. Uma identidade que se reconhece nos espaços de sociabilidade, muito particularmente nos Cafés, lugar de encontro por excelência dos intelectuais, os principais vultos de cultura. George Steiner consegue ser provocatório quando afirma: "Enquanto existirem cafetarias, a ideia de Europa terá conteúdo"(p.28), parecendo sugerir que o futuro para a Europa está na sua cultura, como já reconhecera Jean Monnet. Afinal não será a Ideia de Europa o motor da construção europeia? Assim se compreendem os aparentes falhanços da União Europeia que se encontra num labirinto porque esqueceu o verdadeiro caminho, escolhendo caminhos que não levam a parte nenhuma, parafraseando Heidegger. Está numa densa floresta onde não avista saída. É tão fácil a solução, e tão complicados os caminhos constitucionais percorridos, que procuram erguer o edifício europeu e abrigar as políticas diplomaticamente aprovadas.

George Steiner, de uma forma muito subtil, mostra que há uma Ideia de Europa e uma Ideia para a Europa. A Europa do Espírito. Os que a transmitem e lhe dão vida são os tradicionais frequentadores de Cafés. Nas entrelinhas pode concluir-se que serão os intelectuais os únicos capazes de alimentar a Ideia de Europa. Um sério aviso dado no âmbito de uma palestra proferida no Nexus Institut de Amesterdão, durante a presidência holandesa da União Europeia, em 2004, e, agora, (re)lembrado pelos austríacos, dando vida à ideia de que a Europa vive e sobrevive nos Cafés. Rob Riemen, director fundador do Nexus Institute , na introdução à palestra, mostra bem a essência da questão no título escolhido: A Cultura enquanto convite. A Europa tem futuro? Eis a resposta de Steiner: "Pode ser que estas palavras sejam insensatas, que seja demasiado tarde. Espero que não, só porque estou a dizer estas palavras na Holanda, onde Baruch Espinoza viveu e pensou (p.55).

Isabel Baltazar CHC-UNL 
J. Martins Lampreia, Lóbi - Ética, Técnica e Aplicação, Lisboa, Texto Editores, 2005, $128 \mathrm{pp}$.

\section{Portugal e a Europa: o caso dos lóbis}

Palavra geralmente mal conotada, e pior compreendida, ««lobby»» já foi 'aportuguesada' mas continua a ser mal empregue. Se se acreditar na bondade intrínseca do mundo das Letras é coisa para estranhar, especialmente depois da publicação deste livro; mas, conhecendo o modo como normalmente as coisas se passam, é apenas lógico. Depois de várias obras sobre temas hoje comuns, mas na altura dos seus trabalhos ainda pouco estudados (técnicas de comunicação, assessoria de Imprensa, comunicação empresarial, gestão de crise), J. Martins Lampreia publicou no final de 2005 uma obra dedicada à sua actual causa e, como já sucedera anteriormente (especialmente ao escrever sobre gestão de crise), a sua visão europeísta das realidades associadas ao lóbi torna este trabalho invulgar e valioso, mas suscitará ainda por bastante tempo resistências várias e não declaradas. Como observa, no prefácio, José Miguel Júdice, «Portugal é um país profundamente conservador e com uma cultura de hipocrisia e de "manhosice" proverbiais.» (p. 9). E, por ser assim, aquele que é o grande objectivo do autor neste trabalho e noutras iniciativas, a regulamentação legal do lóbi em Portugal, é uma causa cívica.

Apesar de logo no preâmbulo o autor declarar que este é um trabalho essencialmente técnico (p. 13), isso não obsta a que a divulgação da técnica de lóbi se revista, no contexto português, de uma faceta não neutra, isto é, de intervenção política descomprometida em defesa de um bem comum (o que, grosso modo, irei referir como civismo). Na sua estrutura este livro corresponde ao seu título: a ética do lóbi (o seu carácter próprio), são abordados nos capítulos 2 e 3 (definições, regulamentos), já aí numa perspectiva europeia - e por fortes razões a que nos referiremos daqui a pouco; as técnicas que compõem a actividade são objecto da parte de leão do livro, capítulos 4 a 6 (abrangendo meios, intervenientes, etc.); por fim, a aplicação e a aplicabilidade futura do lóbi são analisadas nos dois últimos capítulos. O carácter técnico do conjunto não desilude, ao oferecer não só informação habitualmente não acessível ao público não especializado mas também por indicar fontes (sobretudo na internet) que servirão de meios para os interessados poderem continuar o seu percurso no estudo do tema. Contudo, é a dimensão cívica desse conjunto que distingue este trabalho e reclama uma crítica mais do que uma notícia do seu lançamento.

Aquilo que se encontra descrito no livro de Martins Lampreia é um, mais um, retrato da longa pré-modernidade portuguesa, que hoje degenera, em coisas como esta e muitas outras, em submodernidade. De novo nós e a Europa, ainda como um par desavindo, pois da nossa parte verifica-se uma rejeição da modernidade precisamente por parte daqueles (as ditas «elites») que mais a deveriam viver. Nada disto é novo: o ensaísmo cívico português do início do século XX, de homens como os 'seareiros', muito notou esta pré-modernidade (à qual ninguém era completamente imune); e mesmo na segunda metade do século alguma da melhor sociologia portuguesa (por sinal de autores tão diferentes como Hermínio Martins ou Adérito Sedas Nunes) observou o modo como as elites portuguesas não promovem a modernização na sociedade, antes optam repetidamente por manter o statu quo enquanto ensaiam uma subversão dos dados da técnica moderna em seu favor particular, apelando ao «respeitinho», etc. Sucede que estas estratégias de dominação social dependeram sempre de uma situação de isolamento político face à modernidade europeia, que justamente se perdeu com a adesão à CEE e hoje se prolonga na União Europeia. (E talvez este fosse motivo suficiente para não ver na actual República apenas uma reedição da Primeira, mas esse é assunto para outras discussões.) Este livro é escrito, nitidamente, a partir da perspectiva europeia que já referimos e identificámos também em trabalhos anteriores do autor, por isso não surpreende o silêncio que acompanhou o seu lançamento: nele se contraria aquela desinformação sistematicamente promovida em torno do termo lóbi que visa melhor se manter o tipo de situação que se acusa o lóbi de promover, num conservadorismo cleptocrático que se estende desde a extrema direita à extrema esquerda.

$\mathrm{O}$ contraste entre a situação comum na União Europeia no que toca à regulamentação 
do lóbi e o que sucede em Portugal, mesmo se mitigado por uma razoável diversidade na regulamentação e por uma afinidade pré-moderna dos países do sul da Europa, resulta bem claro para o leitor. A defesa do modelo ocidental de democracia liberal empreendida por Martins Lampreia através da regulamentação das actividades de lóbi e «public affairs» surge como um compromisso cívico livre das guerras de alecrim e manjerona em torno do federalismo, da Constituição, etc. - trata-se de um compromisso que resulta de escolhas quanto à acção e aos modos correctos para a empreender, sem buscar na discusão um modo de se eximir à responsabilidade social da acção, à sua inevitabilidade. Caso claro disso mesmo é a atenção não só ao quadro europeu mas também a outros (EUA e Canadá) fora dos esquemas de oposição primários repetidos por todos os conservadorismos escondidos atrás de discusões que visam manter o acordo tácito (quando não explícito) sobre 'a ordem das coisas'. Dada a brevidade do livro, as diferenças na ética e na prática de lóbi entre europeus modernos e americanos não é muito explorada, mas fica claro que o autor tem bem presente como essa diferença se deve em muito às numerosas outras diferenças políticas e sociais (em particular na relação com os mass media) patentes nos dois blocos.

Mas ainda maior do que a distância entre o lóbi americano e o europeu, é a distância entre os que na Europa persistem na pré-modernidade (a perorar contra a globalização) e os que vivem em sociedade modernas. Sinal de como estas circunstâncias não nos são exclusivas é a já acertada publicação de uma tradução desta obra em Espanha. Caso raro e que torna as iniciativas do autor nesta área ainda mais merecedoras de atenção, pois, como se lê na p. 62, na nossa actual geopolítica todos os caminhos vão dar a Bruxelas. Não é de estranhar, até porque a história moderna de Portugal indica claramente que as grandes mudanças no país ocorrem sempre não por iniciativa própria mas por resposta a pressões exteriores. E, sintomaticamente, Martins Lampreia escreve «esperemos agora por uma directiva comunitária, no sentido de mudar as coisas. Pode ser que a partir daí se possa escrever a história do lóbi em Portugal.» (p. 25). Este livro será parte indispensável dessa história.

Carlos Leone 
A mais recente biografia do imperador D. Pedro I do Brasil e rei D. Pedro IV de Portugal começa por ser uma obra de divulgação, destinada a um público alargado de leitores interessados e informados, mas não especialistas - é esse o espírito da colecção Perfis Brasileiros, da editora Companhia das Letras, em que se integra. Contudo, é, mais do que isso, um trabalho que abre as portas a uma nova maneira de ver, pelo menos do ponto de vista da historiografia deste lado do Atlântico, a figura do Rei-soldado duplamente libertador.

Há neste projecto de biografias de figuras indispensáveis à construção da identidade brasileira algo de inovador: a importância reconhecida ao olhar original do autor sobre a personagem estudada. E quando o olhar é de uma historiadora com a preparação teórica, a obra prestigiada e a perspectiva de Isabel Lustosa, isso faz a diferença. Que começa logo no subtítulo: "Um Herói sem nenhum caráter". Está dado o mote para as 340 páginas seguintes, que bem podiam intitular-se "Uma biografia politicamente incorrecta do Pai da Pátria".

Doutora em Ciência Política, Isabel Lustosa ocupa actualmente o topo da carreira de investigação na Fundação Casa de Rui Barbosa, no Rio de Janeiro, de cujo Centro de Pesquisa é responsável. É autora de 14 livros e de mais de uma centena de artigos sobre história do Brasil, principalmente história das ideias, história política e história da Imprensa, com destaque para $O$ Nascimento da Imprensa Brasileira (Rio de Janeiro, Jorge Zahar Editores, 2003) e Insultos Impressos. A Guerra dos Jornalistas na Independência (1821-1823) (São Paulo, Companhia das Letras, 2000, com base na tese de doutoramento sobre o mesmo tema). Organizou (com Alberto Dines), a monumental edição fac-similar do Correio Braziliense, em 31 volumes, publicada em 2003. Mais recentemente, foi a coordenadora-geral do $1^{\circ}$ Seminário Internacional sobre Imprensa, Humor e Caricatura: a Questão dos Estereótipos Culturais, que decorreu em Agosto de 2006, no Rio de Janeiro.

Partindo do estado actual dos conhecimentos sobre a figura apaixonante de D. Pedro, pai da independência brasileira e da liberdade portuguesa, a autora não hesita em integrar no retrato os elementos mais controversos que estão documentados - e o resultado é a biografia polémica de um homem contraditório, como de contrastes profundos foi a época em que viveu: "Ao lado de suas tantas qualidades, tinha defeitos tão tremendos que quase os obscureciam. Péssimo e cruel marido para a primeira imperatriz; arrogante e despótico após a dissolução da Constituinte e ao longo de todo o Primeiro reinado [....] imoral e corrompido, ostentando a amante sabidamente corrupta diante de todo o Brasil e do mundo, para humilhação de sua esposa e escândalo da sociedade brasileira; mesquinho até a avareza no que dizia respeito a dinheiro e bens pessoais; talvez mesmo desonesto; injusto, desconfiado e traiçoeiro com os seus melhores auxiliares." (pp. 20-21).

A ambivalência dos traços psicológicos de D. Pedro e as grandezas e misérias dos seus feitos justificam a pergunta com que Isabel Lustosa termina a Introdução e a resposta que vai marcar todo o livro - a história de "um macho": "Quem foi esse homem que começou a governar o Brasil como regente aos 22 anos, fez a nossa Independência - porque sem ele talvez ela não tivesse acontecido de forma a garantir a unidade do Brasil -, deu a Constituição que regeria o país por mais de 65 anos, comandou um exército na Europa para retomar a coroa da filha em Portugal, aonde não voltava desde os nove anos, e morreu ali cercado de glória, como um verdadeiro herói? D. Pedro I é, sem dúvida, o personagem mais fascinante da história do Brasil. Este livro pretende contar a história desse homem que foi, sobretudo, um macho, na acepção mais crua da palavra, no que esta tem de sensual e de rude, mas também de valente." (p. 21).

A obra está dividida em nove partes, acompanhando cronologicamente a vida do biografado. Na primeira parte, intitulada "A maldição da Casa de Bragança", apresentam-se, em pinceladas largas, os antepassados mais próximos: a avó, rainha D. Maria I; a mãe, D. Carlota Joaquina; e o pai, o príncipe $\mathrm{D}$. João, que assumiu definitivamente a regência quando $\mathrm{D}$. Pedro era ainda um bebé de meses. Em relação a D. Carlota, a obra segue a opinião da generalidade das fontes, retomando os temas da ausência de beleza física e da promiscuidade. Já quanto ao príncipe D. João, a fraca figura, a falta de higiene e o medo são matizados - e até mesmo, de al- 
gum modo, compensados pelo reconhecimento da perspicácia oportunista, da astúcia e da habilidade política. Depois de um curto capítulo dedicado ao nascimento e à infância de $\mathrm{D}$. Pedro, a primeira parte termina com a fuga da corte para o Brasil, à frente das tropas de Junot, em fins de Novembro de 1807. Recordam-se os gritos da rainha louca - D. Maria I saía à rua pela primeira vez depois de 16 anos de reclusão - acompanhada pelo neto D. Pedro, então um menino de nove anos: "Não corram tanto! Acreditarão que estamos fugindo" (p. 42).

A segunda parte - "A paisagem e o homem" - mostra a importância do meio tropical na formação do carácter do futuro imperador. A forma solta como cresceu no Rio de Janeiro, o gosto pelas armas, pelos cavalos, pela música, a convivência com a plebe, os sinais precoces de uma sexualidade pouco contida, numa "corte de negros e escravos".

"Pedro e Leopoldina" é o título da terceira parte, onde se fala das más companhias do jovem príncipe, das semelhanças e diferenças de feitio relativamente ao irmão D. Miguel, e da sua aparência, maneiras e cultura. Um capítulo é dedicado à epilepsia, a doença que o afectou com maior ou menor frequência ao longo de toda a vida. Além disso, a autora sublinha que, hoje, D. Pedro seria possivelmente diagnosticado como hiperactivo: "Vivia em permanente movimento, não sabia o que era sossego, repouso, tédio, e também não conhecia a fadiga. [....] Matinal, dinâmico, sóbrio (quase não bebia, apenas um copo de vinho do Porto nas refeições, acompanhado de muitos copos de água), ocupava integralmente o seu tempo. Levantava-se da cama entre cinco e seis horas da manhã e, segundo o reverendo Walsh, 'por já estar acordado, não se mostra disposto a deixar os outros continuarem dormindo', começando a disparar a sua espingarda de caça pelo palácio até que a família inteira estivesse de pé.” (p. 71).

Os capítulos seguintes são dedicados ao casamento com a arquiduquesa D. Leopoldina de Habsburgo, "cunhada de Napoleão, educada por Metternich, amiga de Schubert e Goethe" (p. 79). Ao idílio inicial sucederam, porém, depressa demais, os primeiros desencontros, em boa medida porque o ambiente moral da corte do Rio de Janeiro não era de molde a agradar à princesa austríaca, designadamente o comportamento da rainha D. Carlota Joaquina, sobre quem confidenciava, em 1818, numa carta à irmã Maria Luísa, ex-mulher de Napoleão: "Sua conduta é vergonhosa, e desgraçadamente já se percebem as consequências tristes nas suas filhas mais novas, que têm uma educação péssima e sabem aos dez anos tanto como as outras que são casadas" (p. 93). Com o ambiente tropical a potenciar a herança genética, "nessa matéria, D. Pedro puxara à mãe. Seu apetite sexual foi sempre excessivo e não conhecia limites nem diante da honra da família ou do marido da mulher desejada" (p.93).

As complexas relações, quer a nível psicológico, quer a nível político, entre D. Pedro e seu pai, o rei D. João, são analisadas na parte 4, "De espectador a ator: a descoberta da política". O capítulo intitulado "O pai e o filho" dá conta do acumular de tensões entre ambos, sobretudo quando D. Pedro mostra vontade de voltar a Portugal, na sequência da Revolução de 24 de Agosto de 1820 - e D. João hesita, com medo que à chegada a Lisboa o filho mais velho fosse aclamado rei pelo povo. O rei sabia que o seu primogénito se tinha deixado seduzir pelas "novas ideias". E este, admirador do concunhado Napoleão, percebera que "era vão e e perigoso não seguir o espírito do século" (p.98).

O golpe de 26 de Fevereiro de 1821, que obrigou D. João VI a aceitar a futura Constituição, marcou a entrada de D. Pedro na cena política luso-brasileira. Daí em diante não cessou de reforçar poder e influência, que cresceram ainda mais com o regresso do rei a Lisboa e o célebre "Fico", de Janeiro de 1822, para o qual terá contribuído a acção decididamente pró-autonomista de D. Leopoldina.

A importância crescenta da jovem imprensa brasileira e a atitude de D. Pedro em relação à escravatura merecem também a atenção de Isabel Lustosa. No capítulo "D. Pedro, abolicionista", escreve: "D. Pedro I foi um governante muito à frente da elite brasileira do seu tempo. Ele afrontou os valores da escravidão, combatendo com vigor o hábito de alguns funcionários públicos de mandar escravos para trabalhar em seu lugar" (p. 131). 
$\mathrm{Na}$ quinta parte, "O movimento da Independência", acompanham-se as peripécias do processo que culminou no grito do Ipiranga, mas também o papel de José Bonifácio, de Joaquim Gonçalves Ledo e de outros protagonistas da emancipação. É nesse contexto que surge um capítulo dedicado ao "Jornalismo de Insultos", que remete para outra obra de fôlego de Isabel Lustosa, Insultos Impressos, a Guerra dos Jornalistas na Independência (1821-1823), em que se digladiam o Revérbero, o Espelho ou A Malagueta, trocam insultos Soares Lisboa, o visconde de Cairu, os irmãos Andrada (José Bonifácio e António Carlos), o próprio D. Pedro, editorialista sob pseudónimo, acompanhados à distância, de Londres, pelo patriarca Hipólito da Costa, nas páginas do Correio Braziliense.

Depois da queda de José Bonifácio e da dissolução da Assembleia Constituinte, em Novembro de 1823, inicia-se um período de governo autoritário de D. Pedro, à luz da Constituição de 1824, embora o imperador continue a jurar a sua adesão ao liberalismo. Os dilemas políticos e existenciais do biografado são tratados na parte 6, "Entre brasileiros e portugueses, liberais e absolutistas". Aí se fala da influência de uma das "más companhias" plebeias do imperador, o valido Francisco Gomes da Silva, "o Chalaça". É também aí que entra em cena "A bela Domitila", a mais famosa amante de D. Pedro, que faria dela Marquesa de Santos, a quem chamaram "a Nova Castro" e que teria um papel fundamental no primeiro reinado.

"O Brasil e o mundo" é o tema da sétima parte, que abarca desde o reconhecimento da independência, em 1825, passando pela guerra contra a Argentina pela posse do Uruguai, pela morte de D. João VI, o nascimento do futuro D. Pedro II e a morte de D. Leopoldina - desesperada pela humilhação de ver Domitila exibida publicamente como amante do marido que, por causa dela, terá chegado a agredir fisicamente a imperatriz (pp.238-239) - até ao fim da relação com a Marquesa de Santos, em 1829.

Os acontecimentos que conduziram à abdicação e ao exílio de D. Pedro, em 1831, são abordados na oitava parte, "Imperador do Brasil", enquanto o título da última, "D. Quixote", tem um duplo sentido. Por um lado, remete para a dimensão trágica de toda a vida de D. Pedro - sintetizada no gesto "quixotesco" quando, na véspera de embarcar de França para vir fazer guerra em Portugal contra o irmão usurpador, o ex-imperador e ex-rei se ajoelha aos pés da filha D. Maria da Glória e declama: "Minha senhora, aqui está um general português que vai defender os seus direitos e restituir-lhe a coroa" (p. 320). Por outro lado, refere-se ao quarto do Palácio de Queluz onde D. Pedro nasceu, a 12 de Outubro de 1798, e onde veio a morrer, em 24 de Setembro de 1834, dias antes de completar 36 anos, "rei, filho e neto de reis, defensor das instituições livres na América e na Europa, que dera constituições às suas duas pátrias e que deixou a filha reinando em Portugal e o filho no Brasil" (p. 324).

As características divulgativas da colecção em que se integra a obra impuseram à partida alguns condicionalismos destinados a facilitar a dinâmica da leitura, desde logo a ausência de notas de rodapé. Apesar disso, o leitor mais exigente ou mais curioso não fica a perder: no fim do volume encontra, além de indicações bibliográficas, uma cronologia e um índice onomástico de grande utilidade. Merecem igualmente destaque as 24 páginas de extra-texto com imagens, incluindo uma colecção de retratos de D. Pedro ao longo de diversas fases da vida, desde os cinco anos, numa pintura da autoria de sua tia-avó, D. Maria Francisca Benedita, até à representação no leito de morte. Algumas das reproduções são de imagens pouco conhecidas em Portugal, como é o caso de um retrato de D. Maria da Glória, futura D. Maria II, e de uma alegoria de pai e filha com as constituições dos dois países.

Num país em que o género biográfico só agora começa a fazer o seu caminho, urge dar a conhecer esta obra entre os leitores portugueses. Até para que o rei D. Pedro IV possa estar à altura, para o bem e para o mal, do imperador D. Pedro I. 
Pacheco Pereira, José, Álvaro Cunhal, uma biografia política - volume 3 «O prisioneiro», Lisboa, Temas \& Debates, 2005, 748 páginas.

O terceiro volume da biografia política de Álvaro Cunhal por Pacheco Pereira ( «O prisioneiro») centra-se no período 1949-1960, o do encarceramento mais longo a que Cunhal esteve sujeito e do qual só saiu numa das mais céleres fugas prisionais da nossa história, a de Peniche. Curiosamente, os elogios desmedidos de que foram objecto os dois volumes anteriores começam agora a justificar-se, apesar de a recepção a este volume ter sido bem mais discreta, ainda que como de costume unanimista (nem faltou a habitual desinformação por parte do $\mathrm{PCP}$ ). O que se verifica é a vantagem de o elemento romanesco bem presente nos dois primeiros volumes estar aqui muito condicionado, pela vida monótona da prisão e pela escassa informação sobre ela. Privado desse elemento tão ao gosto do público, o trabalho de Pacheco Pereira é conduzido, com naturalidade, em direcção a uma história social da clandestinidade portuguesa durante os chamados anos de chumbo. E, mesmo com a escassez de fontes (sobretudo fidedignas), neste volume a históória do PCP sobressai mais do que nos anteriores.

Menos uma biografia de Cunhal do que um estudo das posições de Cunhal face ao partido a que pertencia quando não podia actuar nele como queria, este volume sofre as contingências naturais de se basear em testemunhos pessoais e inverificáveis sem poder confrontar com arquivos como os do próprio PCP (e se este se queixa, deve começar por queixar-se de si). Não obstante, a história do prisioneiro Cunhal torna-se num relato da Oposição portuguesa ao Estado Novo, em que a dialéctica entre Cunhal e as sucessivas direcções do PCP na década de 1950 serve de fio condutor. Não há grandes descobertas, embora as referências bibliográficas sejam recentes, e o conjunto é uma história política do Portugal contemporâneo em que o mérito maior está no cruzamento da história cultural (meio literário, sobretudo) com a história política (situação colonial, campanhas eleitorais) e a institucional (do PCP, do movimento comunista internacional, dos instrumentos de repressão do Estado Novo). A própria atribulação destes anos, tanto a nível do movimento comunista internacional como a nível da situação de clandestinidade interna do PCP, contribui para a reunião destes diferentes contributos historiográficos, desenvolvendo com sucesso tentativas semelhantes nos volumes anteriores (compare-se a nota sobre a polémica entre Régio e Cunhal, no volume 1, com o capítulo 6 deste volume, sobre a relação do PCP com os intelectuais).

Mantendo aspectos menos defensáveis (mas muito celebrados) dos volumes anteriores, como um tom por vezes romanesco e um grande recurso a especulações para suprir pedaços de informação em falta, certo é que este terceiro volume recorre a essas opções com muito maior parcimónia. A falta de memorialismo, neste tema como em geral, limita também o autor, e a única surpresa desagradável é o tom meio apressado do conjunto, por vezes a nível da escrita e quase sempre a nível da revisão, que deixou passar bastantes «gralhas».

Mais útil para os leigos do que para os especialistas na história do PCP (como seria de prever, e como é desejável), o conjunto formado pelos três volumes publicados até ao momento é positivo, sobretudo para efeitos de familiarização com a cultura política comunista - e portuguesa - do século XX. A julgar pelo que está feito até aqui, esperar grandes novidades nos próximos volumes será descabido mas, sobretudo a partir dos avanços formais deste terceiro volume, vale a pena esperar pelo que ainda falta. Só se espera que a fuga do prisioneiro não signifique também nova evasão para um registo semi-ficcional.

Carlos Leone (BPD/FCT) 


\section{Autores}

Alberto Antunes de Abreu, Licenciado em História e especializado em Ciências Documentais pela Universidade do Porto. Dirigiu e organizou a Biblioteca Municipal de Viana do Castelo de 1985 a 1990 e lecciona "Indexação por Assuntos" na Faculdade de Filosofia do Pólo de Braga da Universidade Católica Portuguesa. É membro do Instituto de Filosofia Portuguesa e Brasileira, do Instituto Católico de Viana do Castelo e sócio correspondente da Academia Portuguesa de História. Participou e dirigiu várias campanhas arqueológicas, e investiga História Local e Regional, tendo em execução a História de Viana do Castelo. Investigador também da arte e religião, está a preparar doutoramento sobre $O$ jansenismo e a cultura portuguesa seis e setecentista.

Ângela Barreto Xavier (Goa, 1968) licenciou-se em História, variante de História da Arte, mestre em História Cultural e Política pela Universidade Nova de Lisboa, e doutorou-se no Instituto Universitário Europeu, em Florença. É investigadora contratada do Instituto de Ciências Sociais, docente do ISCTE. Colabora, ainda, com o Centro de História da Cultura, da Universidade Nova de Lisboa e o Centro de Estudos de História Religiosa da Universidade Católica Portuguesa. A investigação que vem desenvolvendo incide sobre a política, a sociedade e a cultura em Portugal e no seu império na época moderna, e foi nesse contexto que publicou livros e artigos e participou em conferências nacionais e internacionais.

António Camões Gouveia, Licenciado em História e doutorado em História das Ideias, especialização em História das Ideias Sociais, pela F.C.S.H. da U.N.L. Nessa mesma Faculdade dá aulas desde 1981, tendo estado entre 1992 e 1997 na Comissão dos Descobrimentos. Enquanto docente tem leccionado matérias no âmbito da história da cultura e das ideias, predominantemente dos séculos XV a XVIII. A sua área de interesse científico centra-se na História Social e das Sociabilidades quando aflorada nas dimensões da História da Cultura e da História Religiosa.

Cristina Montalvão Sarmento, Licenciada em Direito (UCP-1985) e em História (FLUL-1997), fez os cursos de Mestrado em Relações Internacionais (IEHEI-França, 1987), em Ciência Política (ISCSP-UTL, 1994) e em Filosofia (FLUL-1999). Doutorou-se em Ciência Política na área de Teoria Política (UNL-2004). Exerceu funções docentes nas Universidade dos Açores e do Algarve, sendo actualmente Professora Auxiliar na Universidade Nova de Lisboa, Faculdade de Ciências Sociais e Humanas, Departamento de Estudos Políticos. Colabora com diversas instituições, nomeadamente com o Instituto Superior de Ciências Policiais e de Segurança Interna. Na qualidade de Sub-Directora do Centro de História da Cultura da UNL (2004) tem coordenado editorialmente a Revista Cultura. Revista de História e Teoria das Ideias. Desde 2006 é secretária-geral da Associação das Universidades de Língua Portuguesa.

Fernando Pinto dos Santos, Licenciado em Filosofia pela Universidade Católica, Faculdade de Filosofia de Braga. Licenciado em Ensino de Filosofia e Humanidades pela mesma Universidade. Mestre em Ciências da Educação, Ramo de Especialização em História da Educação e da Pedagogia, pela Universidade do Minho, com a Tese: "A Sociedade Martins Sarmento, Espaço Privado de Leitura Pública: A Importância do Doador na Formação do Leitor". É Professor do Ensino Secundário, em Guimarães.

Isabel Cluny, Doutorada em História e Teoria da Ideias Políticas, 2003, FCSH, UNL. Professora Escola Sec. D. Luísa de Gusmão. Investigadora do Centro de História da Cultura da UNL. Membro do Projecto Ciência Política e Relações Internacionais do CHC, da UNL. Orientadora do núcleo e estágio. FLL, UL. Professora Conferencista do Curso de Ciência Política / Relações Internacionais, 2000/2001, FCSH, UNL. Conferencista do Mestrado de Didáctica da História da FLL, 2003-2004, 2004-2005, 2005-2006. Directora-adjunta de Leituras, Revista da Biblioteca Nacional, 1997/1998. De entre a obra publicada recentemente destacam-se "La diplomatie portuguaise et la guerre de sucession d'espagne", Revista Cheiron, n³9 40, Bulzoni Editore, 2004.; "Os diplomatas de negociação e de repre- 
sentação."Diplomatas e Diplomacia. Retratos, cerimónias e práticas, Livros Horizonte, 2004; O conde de Tarouca e a diplomacia na época Moderna, dissertação de doutoramento, texto policopiado, (no prelo, Livros Horizonte).

João Luís Lisboa, Professor na FCSH, UNL. Director do Centro de História da Cultura da UNL onde é também responsável pelo projecto "Livro e leitura". Publicou, entre outros trabalhos, Teoria da história em Francisco Manuel de Melo (com Teresa Amado) [1983], Ciência e politica. Ler nos finais do Antigo Regime (1991), Gazetas. A informação política nos finais do Antigo Regime (coord.) (2002) e, com Tiago C.P. dos Reis Miranda e Fernanda Olival, Gazetas manuscritas da Biblioteca Pública de Évora, 2 vols. 2002 e 2005.

João Pedro Rosa Ferreira, Jornalista, Mestre em História Cultural e Política pela FCSH e investigador do CHC UNL. Professor convidado da European University. Publicou O jornalismo na emigração. Ideologia e política no «Correio Braziliense» (1807-1822); co-autor com Ferreira Fernandes de Frases que fizeram a História de Portugal (2006). É editor do jornal Correio da Manhã.

José Augusto dos Santos Alves, Doutor e Agregado em História e Teoria das Ideias pela Faculdade de Ciências Sociais e Humanas da Universidade Nova de Lisboa. É investigador do Centro de História da Cultura da Universidade Nova de Lisboa, e membro da Association International des Sociologues de Langue Française, da Asociación de Historiadores de la Comunicación, do Foro Iberoamericano sobre Estrategias de Comunicación (FISEC). É autor de Ideologia e Política na Imprensa do Exílio: O Portuguez - Londres, 1814-1826 (1992); A opinião pública em Macau: a imprensa macaense na terceira e quarta décadas do século XIX (2000); A opinião pública em Portugal (1780-1820) (2000); Comunicação e História das Ideias: A Génese do "Editorial Político" (2004), O Poder da Comunicação (2005).

José D’Assunção Barros é Historiador e Professor Universitário com Doutorado em História Social pela Universidade Federal Fluminense. Atua desde 2000 nos cursos de Graduação e Mestrado em História da Universidade USS de Vassouras (Brasil), onde leciona disciplinas ligadas à Teoria e Metodologia da História e à História Cultural. Também leciona História da Arte e História da Música nos cursos de Graduação em Música do Conservatório Brasileiro de Música - Centro Universitário. Tem publicado livros e artigos nas áreas de História Cultural, História Política, Historiografia, Teoria da História, História da Música, História da Arte, História Cultural, e Metodologia Científica. Entre as obras mais recentes, destacam-se os livros $O$ Campo da História (2004) e O Projeto de Pesquisa em História (2005), ambos editados pela Editora Vozes.

José Maurício de Carvalho, Graduou-se em Filosofia, Pedagogia e Psicologia pela Faculdade Dom Bosco de Filosofia, Ciências e Letras que deu origem à Universidade Federal de São João del-Rei. É Especialista e Mestre em Filosofia pela UFJF e Doutor em Filosofia pela UGF - Rio. Professor Titular no Departamento de Filosofia da Universidade Federal de São João del-Rei - UFSJ. Como bolsista da FAPEMIG fez estágio de Pós-doutorado na Universidade Nova de Lisboa (1994) e na Universidade Federal do Rio de Janeiro - UFRJ (2000). Integra o Conselho Editorial das Revistas Paradigmas (CEFIL-UEL), Crítica (UEL) e Anais de Filosofia e Vertentes (UFSJ). É membro da Academia de Letras de São João del-Rei, do Instituto Brasileiro de Filosofia (SP) e do Instituto de Filosofia Luso Brasileira.

José Manuel Simões Ferreira, Licenciado em Arquitectura (ESBAL/FAL), Mestre em Desenho Urbano (ISCTE) e em Filosofia (FCSH/UNL), obteve o Doutoramento em Teorias e História das Ideias, com a tese intitulada «Arquitectura para a Morte. A Questão Cemiterial e seus reflexos na Teoria da Arquitectura». Particularmente interessado na análise do ordenamento urbanístico e arquitectónico a que assimilada a percepção dos respectivos contex- 
tos históricos, sociais e culturais, tem estudado a teoria da arquitectura em especial no tocante à arquitectura, às práticas e arte funerárias.

Júlio Joaquim da Costa Rodrigues da Silva, doutorado em História e Teoria das Ideias, pela Faculdade de Ciências Sociais e Humanas da Universidade Nova de Lisboa em 1999, é Professor Associado da F.C.H.S. da Universidade Lusíada de Lisboa onde lecciona desde 1987. Publicou em 1992 As Cortes Constituintes de 1837-1838. Liberais em Confronto e em 2002 Ideário Politico de uma Elite de Estado. Corpo Diplomático (1777-1793). Investigador (1993) e Membro do Conselho Científico (1999) do C. H. C. da U. N. L. Académico Correspondente da Academia Portuguesa de História (2001).

Luis Crespo de Andrade, Professor na FCSH, UNL. Investigador do Seminário Livre de História das Ideias e do Centro de História da Cultura. Autor, entre outros estudos, de Planetário utópico e cultura integral. Aspectos do discurso utópico português contemporâneo (1996) e de Fundamentos da esperança política. A alegria comunista (2006).

Luis Reis Torgal é Professor Catedrático da Faculdade de Letras da Universidade de Coimbra e Coordenador Científico do Centro de Estudos Interdisciplinares do Século XX (CEIS20). Dedica-se, actualmente, sobretudo ao estudo da história do Estado Novo, numa perspectiva de história das ideias.

Maria Fernanda Diniz Teixeira Enes, Doutorada em História das Ideias com a tese Liberalismo nos Açores (1800-1832): Religião e Política, UNL, Colibri, 1994, é professora associada da FCSH/UNL nas licenciaturas de Filosofia e de Ciência Política e Relações Internacionais. Autora de diferentes comunicações em Congressos e de divulgação cultural. Publicou Reforma Tridentina e Religião Vivida - Os Açores na época moderna, Ponta Delgada, Signo, 1993; Ideias Religiosas em História das Ideias - Aproximação à matriz civilizacional do Ocidente, Cadernos Cultura, CHC/UNL, 2003; Piedade Popular: sociabilidades, representações, espiritualidades, (dir.), Lisboa, CHC e Ed. Terramar, 1999. Dentre os últimos artigos publicados em Revistas da especialidade destacam-se: "Sociedade dos Amigos de Letras e Artes - um caso de associativismo moderno" in Ernesto do Canto, Ponta Delgada, UA, 2003, pp.71-106; "Ideia de Europa e Construção Europeia: a propósito do "Preâmbulo" da Constituição" in Cultura, 19, CHC/UNL, 2004, pp. 13-36.

Maria João Cabrita, Autora de A Ideia de Justiça em Antero de Quental, dissertação de mestrado em História Cultural e Política, orientada por Zília Osório de Castro e defendida na F.C.S.H./U.N.L, faz parte do Seminário Livre de História das Ideias, desta mesma instituição. Doutoranda na área de História das Ideias Políticas, no Departamento de Filosofia da F.C.S.H./U.N.L., desenvolve o projecto O Liberalismo, a Justiça Social e o Papel do Estado: As Propostas de John Rawls e Robert Nozick, subsidiado pela F.C.T. Ultimamente publicou «Com os Olhos Postos no Mundo: A Vigília de Susan Sontag (1933-2004)», na revista Faces de Eva (n' 14, 2005).

Maria Manuela Tavares Ribeiro, é Professora Catedrática da Faculdade de Letras da Universidade de Coimbra. Sócia-correspondente da Academia Portuguesa da História; Vice-Coordenadora do Centro de Estudos Interdisciplinares do Século XX (CEIS20); Directora dos Cursos de Mestrado e Pós-Graduação, Estudos Sobre a Europa - Europa as Visões do Outro; Coordenadora da Colecção Estudos sobre a Europa, Coimbra, Quarteto Editora (5 vols.); Directora da Revista Estudos do Século XX, do Centro de Estudos Interdisciplinares do Século XX da Universidade de Coimbra. Recebeu o Prémio de História Contemporânea - Joaquim Veríssimo Serrão/Fundação Eng. ${ }^{\circ}$ António de Almeida, atribuído pela Academia Portuguesa da História em 2004 à sua obra A Ideia de Europa. Uma Perspectiva Histórica, Coimbra, Quarteto Editora, 2003.

Mario Losano é Professor Titular de Filosofia do Direito e Informática Jurídica na Università del Piemonte Orientale "Amedeo Avogadro", Alessandria, Itália; Prêmio Alexander- 
-von-Humboldt, Bonn, Alemanha; Doutor honoris causa da Universidade de Hannover, Alemanha.

Onésimo Teotónio Almeida, Natural de S. Miguel, Açores, é doutorado em Filosofia pela Brown University (1980), Providence, RI (EUA), onde é Professor Catedrático no Departamento de Estudos Portugueses e Brasileiros, leccionando cursos sobre história cultural e história das ideias. Tem ainda a seu cargo um curso sobre Mundividências e Valores no Wayland Collegium for Liberal Learning, um departamento interdidsciplinar da mesma universidade. O seu mais recente título é "Livro-me do Desassossego" (dia-crónicas) (Temas e Debates, 2006). Em breve sairá na Gradiva "A Obsessão da Portugalidade", o primeiro de uma série de volumes que reunirão os seus ensaios de revisitação crítica da problemática da identidade nacional.

Pedro Tavares de Almeida, licenciado em História e doutorado em Sociologia Política, é Professor do Departamento de Estudos Políticos da FCSH-UNL. Foi investigador visitante do Center of International Studies da Universidade de Princeton (1997) e membro do comité director de «EURELITE» (European Political Elites in Comparison), uma rede de investigação da Fundação Europeia de Ciência (2001-2004). As suas investigações têm incidido sobre os processos de construção do Estado moderno, a história eleitoral e o recrutamento das elites políticas e administrativas. Autor de vários estudos, publicados em Portugal e no estrangeiro, recentemente co-dirigiu as obras colectivas Lei e Ordem (Lisboa, Livros Horizonte, 2006), Quem Governa a Europa do Sul? (Lisboa, ICS, 2006; tradução do original em inglês) e Burocracia, Estado e Território (Lisboa, Livros Horizonte, 2006).

Vamireh Chacon, Professor emérito da Universidade de Brasília. Doutorou-se, em Sociologia do Direito na Faculdade de Direito do Recife, uma das duas mais tradicionais do Brasil. O doutoramento foi realizado simultaneamente na Universidade de Munique na Alemanha, o pós-doutoramento na Universidade de Chicago nos Estados Unidos. Foi inicialmente professor na mesma Faculdade de Direito da Universidade Federal de Pernambuco, em seguida na de Brasília, de assistente a adjunto e catedrático titular. Ensinou como professor visitante, em Universidades da Europa e Estados Unidos, sobretudo na de Erlangen-Nuremberg na Alemanha, na qual veio a receber o título de doutor honoris causa. Vamireh Chacon escreveu vários livros, publicados no Brasil como a História dos Partidos Brasileiros e Gilberto Freyre (Uma Biografia Intelectual). Em Portugal, O Humanismo Ibérico pela Imprensa Nacional-Casa da Moeda e $O$ Futuro Político da Lusofonia pela Editorial Verbo. 


\section{Resumos/Abstracts Palavras-Chave/Key-Words}

\section{Liberdade - Liberalismo e Democracia}

Na esteira da distinção entre «liberalismo» e «democracia», este artigo sonda a ideia de liberdade do vintismo, tema privilegiado pelo magistério e ensaísmo de Zília Osório de Castro. Lançando o olhar sobre a governação vintista, procura-se responder às questões: «a ideia de Constituição e a lei eleitoral são ou não expressão da liberdade?» e «a maioria vintista corresponde ou não a um ideal de liberdade?».

Palavras-Chave: Liberdade; Igualdade; Estado; Liberalismo; Democracia; Vintismo.

\section{Liberty - Liberalism and Democracy}

Following the path drawn by the distinction between «liberalism» and «democracy», this article questions the vintismo idea of liberty, which has been Zília Osório de Castro main focus through out her teaching's and essays. Casting an eye through vintismo government, we seek an answer to: «are not an expression of liberty, the idea of constitution and electoral law?», and «does the vintista majority match an ideal of liberty?».

Key Words: Liberty; Equality; State; Liberalism; Democracy; «Vintismo».

Maria João Cabrita

\section{Modernidade, pós-modernidade e outras neblusidades}

Os conceitos de modernidade e pós-modernidade têm sido usados em sentidos múltiplos a ponto de se terem generalizado confusões profundas que não raro enfermam de enorme ignorância histórica e de uma grande falta de rigor analítico. $\mathrm{O}$ presente ensaio elabora uma breve arqueologia do termo 'pós-moderno' e a partir dele procura identificar os elementos fundamentais da modernidade de modo a se poder estabelecer o que caracteriza afinal a pós-modernidade. Palavras-chave: Modernidade; Pós-modernidade; Pós-modernismo; Ciência; Verdade; Razão; Democracia; Progresso; Valores; Justiça; Liberdade; Iluminismo; Dicotomias sujeito-objecto; Facto-valor; Ficção-história; Racionalidade-emotividade.

\section{Modernity, post-modernity and other}

The concepts of modernity and post-modernity have been used in so many senses that misunderstandings of all sorts have become quite common. Ignorance of history and lack of analytical rigor do not help. After an overview of the archeology of the term "postmodern" the present essay endeavors to identify the key elements of modernity in an effort to obtain a better grasp of the concept of post-modernity.

Key-words: Modernity; Post-modernity; Science; Truth; Reason; Democracy; Value; Justice; Liberty; Enlightenment; Dichotomies subject-object; Fact-value; Fiction-history; Rationality-emotions.

Onésimo Teotónio Almeida

\section{Utopia. Conceito e concepção}

A publicação de De optimo Reipublicae Statu, deque nova insula Utopia, de Thomas More, no final de 1516, está na origem de uma nova modalidade de discurso político. Ao unir a representação racional e a descrição imaginária da comunidade desejável de forma indissociável, a construção utópica releva tanto do foro filosófico quando do âmbito da elaboração sensível. Pretende-se, em primeiro lugar, caracterizar o conceito de utopia, tal como resulta da narrativa fundadora do género, lida à luz dos seus principais pressupostos. Visa-se, de seguida, captar o olhar sobre a reflexão antiga acerca da cidade racional que More desenvolve. Tenta-se, por fim, 
confrontar o conceito moderno de utopia com o discurso utópico contemporâneo, tal como surge na segunda metade do século XVIII.

Palavras-chaves: Utopia; Thomas More; Humanismo; Pensamento revolucionário.

\section{Utopia. Concept and conception}

The printing of De optimo Reipublicae Statu, deque nova insula Utopia, by Thomas More, in late 1516 , is at the origin of a new form of political discourse. By irrevocably uniting the rational representation and the imaginary description of the desired community, the utopian construction stems as much from the philosophical field as from the scope of sensible elaboration. Our first goal is to characterize the concept of utopia, such as it is presented in the founding narrative of the genre, under the light of its most important premises. Next, we attempt to capture a view of the ancient reflection on the rational city developed by More. Finally, we try to confront the modern concept of utopia with the contemporary utopian discourse, such as can be found in the second half of the $18^{\text {th }}$ century.

Keywords: Utopia; Thomas More; Humanism; Revolutionary thought.

Luis Crespo de Andrade

\section{"A Bem da Nação" Costa Brochado "político funcional” \\ $e$ "historiógrafo" ao serviço do regime de salazar}

A questão dos intelectuais do Estado Novo tem sido um dos temas ultimamente tratados pelo autor deste artigo. Todavia, no caso de Idalino da Costa Bochado, depois de ter analisado a sua personalidade, a sua acção e a sua obra publicada, entendeu que não se poderia propriamente considerá-lo um "intelectual orgânico" do Estado Novo. Jornalista, historiógrafo e político salazarista ligado à União Nacional, desempenhou nestes aspectos um papel significativo ao serviço do regime que defendia. A categoria de "político funcional" pareceu ao autor ser, pois, a designação mais adequada.

Palavras-chave: Estado Novo; Idalino da Costa Brochado; Intelectual Orgânico; Político funcional.

\section{“A Bem da Nação" Costa Brochado "functional politician" and "historiographer" at the service of the Salazar regime}

The question of the intellectuals of the Estado Novo ("New State") has been one of the subjects lately studied by the author of this article. However, after analysing Idalino da Costa Brochado's personality, action and published work, he decided that he could not be strictly considered an "organic intellectual" of the Estado Novo. Journalist, historiographer and politician, a supporter of Salazar connected to the União Nacional ("National Union"), he played a significant role in these areas at the service of the regime that he supported. To classify him as a "functional politician" seemed to be a more correct choice to the author.

Keywords: Estado Novo; Idalino da Costa Brochado; Organic Intellectual; Functional Politician.

Luís Reis Torgal

\section{Louise Weiss - Viagens de uma Europeia}

Louise Weiss (1893 - 1983) percorre, em múltiplas viagens, o Ocidente europeu, a América, as longínquas paragens do Oriente, o continente africano. A sua obra, em particular as Mémoires d'une_Européenne, revela-se um testemunho eloquente de sua força anímica e do olhar atento e crítico das décadas vividas no século XX. É no espaço e no tempo das suas múltiplas viagens que Weiss diagnostica e espelha a relação de Alteridade Ocidente / Oriente, entre a Europa e o Outro. A vida e a acção militante no curso de sua longa vida centrou-se em três pólos nucleares: combate pela paz, combate pelo voto feminino e combate pela construção da Europa. 
É nesta luta incessante que Louise Weiss - a Europeia cumpria o lema que a norteava - participar na aventura do seu século.

Palavras - chave: Louise Weiss; Europa; Paz; Viagens; Feminismo.

\section{Louise Weiss - The Travels of a European Woman}

On her many travels, Louise Weiss $(1893$ - 1983) journeyed across Western Europe and America and made long voyages to the East and the continent of Africa. Her work, in particular Mémoires d'une Européenne, is an eloquent testimony of her strength of mind and close and critical observation of the decades of the 20th century that she witnessed. It is within the framework of the space and time of these many journeys that Weiss diagnoses and reflects on West/East alterity in relation to Europe and the Other. Her experiences and militant activities throughout the course of her long life focussed on three central concerns: the fight for peace, for votes for women and for the construction of Europe.

Thus, through her ceaseless campaigning, Louise Weiss, a European woman, fulfilled her guiding principle - to take part in the adventure of one's century.

Keywords: Louise Weiss; Europe; Peace; Travel; Feminism.

Maria Manuela Tavares Ribeiro

\section{Jorge Luís Borges: Nacionalista e Cosmopolita}

Pouco antes de falecer, Jorge Luís Borges determinou que sua esposa, Maria Kodama, não publicasse seus livros regionalistas de juventude em suas obras completas, que assim ficariam incompletas, uma decisão tipicamente borgiana. A viúva preferiu não cumprir a determinação e as obras editadas se tornaram completas, na medida em que possam ser descobertos manuscritos ainda inéditos. Elas revelam um amplo arco, correspondendo à sua longa vida, da juventude muito argentina e profundamente bonaerense, do seu país e cidade natal Buenos Aires, ao mundo. Os seus artigos, publicados mais em revistas literárias que jornais, desde cedo revelam esta vocação universal. Jorge Luís Borges escreveu com frequiência sobre autores estrangeiros. Depois, os próprios temas dos livros vão mudando dos regionalismos e até localismos, rumo às dúvidas e ambigüidades intrinsecamente humanas de todas as partes do mundo, onde ele as imaginariamente situa.Ao fim e ao cabo, Jorge Luís Borges - traduzido e homenageado em muitos países - preferiu morrer em Genebra e lá ser sepultado, onde estudara na adolescência, quando fora muito feliz na descoberta inicial de outras culturas. Elas demoraram a nele predominarem, mas terminaram acontecendo. Mesmo assim, ele no íntimo nunca deixou de todo a argentinidade. Crescentemente cosmopolita, o nacionalismo jamais abandonou por completo o espírito de Jorge Luís Borges. Sua atitude pró-britânica, durante a própria Guerra dos Malvinas, pode ser interpretada como protesto e advertência diante de uma derrota próxima.

Palavras - chave: Jorge Luís Borges; Nacionalismo; Argentina; Cosmopolitismo.

\section{Jorge Luís Borges: Nationalist and Cosmopolitan}

Just before dying Jorge Luís Borges asked his wife Maria Kodama not to publish his regionalist books from his youth in his complete works; these were to remain incomplete, a typically borgian decision. The widow chose not to follow his last wishes and the published works became complete works, while some unpublished manuscripts can still be found. The range is proliferous, mirroring his long life, from his profoundly bonarense youth in Argentina, his country and hometown of Buenos Aires, to the world. His articles mainly published in literary magazines rather than newspapers, from the early stages reveal this universal vein. Jorge Luís Borges often wrote about foreign authors. Later, the themes of his books change from localisms and even regionalisms towards the intrinsically human doubts and ambiguities of all places in the world, where he places them in his imaginary. At the end of his life Jorge Luís Borges - translated and honoured in many countries - chose to die and be buried in Geneva where he had 
studied as a teenager and had been very happy when at his initial discovery of other cultures. These took time to take hold of him but they finally did. Nevertheless, in his deeper self he never gave up being a true Argentine. Increasingly cosmopolitan, Jorge Luís Borges never stopped being a nationalist. His pro-British position during the Maldives War can be interpreted as a protest and a warning against the defeat that was soon to come.

Keywords: Jorge Luís Borges; Argentine; Nationalism; Cosmopolitan.

Vamireh Chacon

\section{A Biblioteca da Sociedade Martins Sarmento}

Quantas vezes nos deslocamos para tão longe,à procura dos segredos da nossa história local, quando temos bem próximo de nós a resposta, se não na totalidade, pelo menos de forma parcial. É isso que pretendemos mostrar neste artigo sobre a Sociedade Martins Sarmento, enquanto espaço privado de leitura pública,marco que deixou marcas na história local de Guimarães e que, rapidamente,conseguiu que o seu reconhecimento ultrapassasse fronteiras. Porque surgiu? Como surgiu? São perguntas a que este artigo pretende dar resposta.

Palavras-chave: Martins Sarmento; Sociedade Martins Sarmento; Biblioteca; Leitor; Leitura; Liberalismo; Mistério; Livro de movimento da biblioteca; Reconhecimento; Homenagem.

\section{Martins Sarmento Society Library}

So many times we move so far away looking for the secrets of our local history, when we have the answer right next to us, not entirely, but in a parcial way. That's what we want to show in this article about the "Sociedade Martins Sarmento" as a private place of public reading, that marked the local history of Guimarães and quickly achieved its tribute beyond borders. Why and how did it happen? These are questions that this article wants to answer.

Key-words: Martins Sarmento; Martins Sarmento Society; Library; Reader; Reading; Liberalism; Mistery; Library regitration book; Gratitude; Tribute.

Fernando Pinto Santos

\section{Simão José da Luz Soriano e o Liberalismo Moderado (1858-1860)}

Simão José da Luz Soriano (1802-1891) é principalmente conhecido pelos livros que escreveu sobre a guerra civil de 1828-1834 e a implantação do liberalismo em Portugal. As reflexões políticas realizadas em 1858 e em 1860 revelam-nos uma outra faceta da sua obra: a crítica apaixonada dos erros do regime constitucional. Contudo, as suas observações só podem ser entendidas se forem relacionadas com o liberalismo moderado da segunda metade do século XIX. O presente artigo pretende fazer a análise da relação entre o estudo da realidade política e o pensamento do autor.

Palavras-Chave: Liberalismo; Democracia; Utopia; Reforma; Despotismo.

\section{Simão José da Luz Soriano and the Moderate Liberalism (1858-1860)}

Simão José da Luz Soriano (1802-1891) is mostly known for his books about the 1828-1834 civil war and the implantation of liberalism in Portugal. The political analysis he made in 1858 and 1860 reveal to us another aspect of his work: the passionate criticism of the mistakes of the constitutional regime. However, his observations can only be understood in the context of the moderate liberalism of the second half of the nineteenth century. This article intends to analyse the relation between the study of the political reality and the thoughts of the author.

Key Words: Liberalism; Democracy; Utopia; Reform; Despotism.

Júlio Joaquim da Costa Rodrigues da Silva

\section{O Marquês de Pombal e a Mudança de Paradigma}

Num século "ideofágico" e "mitofágico", em que "desconhecidos" agitadores, anti-escolásticos e defensores de ideais subversores, aparentemente não coniventes com o poder, lançam a dis- 
cussão no seio do Estado e da Sociedade e tentam o centro, o meio-termo, à boa maneira de um eclectismo pontual que não esquece a visão conservadora, mas mantendo-se abertos às inovações, o pombalismo aparenta-se a um marco miliário que apresenta características transformacionais e, muitas vezes, polémicas ao nível das várias esferas, como a literária, por vezes moralizadora e costumeira, a científica ou a técnica. Esta breve alusão conjuntural encaminha-nos ao Marquês de Pombal e às mudanças de paradigma em que se envolve, e assegura, enquanto protagonista do poder que contribui, nesta ambiência, para a abertura a várias transmutações, numa espécie de inter-comunicabilidade entre paradigmas. É sob este ponto de vista da mudança, que o inquérito pombalino, só por si inovador, mandado realizar, após o terramoto de 1755, nos envia, para lá da ruptura técnico-científica que em si encerra, para o sistematizado aparecer de um novo conceito de temporalidade, no mínimo de outra medição do tempo, que devendo ser olhado na perspectiva social, económica, política e cultural, merece, sobretudo, ser visto sob o ângulo em apreço neste trabalho, isto é, no de um outro tempo que se aproxima.

Palavras-chave: Pombal; Paradigma; Temporalidade; Terramoto.

\section{The Marquis of Pombal and the shift of Paradigm}

In a "ideiophagic" and "mythophagic" century in which "unknown" agitators, anti-scholastic individuals and defender of subversive ideals who, apparently not in accordance with the law, create discussion in the hearth of the State and Society and try a centre or mid-term position in an eclectically fashion which does not disregard conservative perspectives but maintains itself open to innovation, pombalismo appears as a milestone which presents transformational features that are many times polemic within certain spheres namely literary(many times moralising and customary),scientific and technical. This brief conjunctural allusion leads us to the Marquis of Pombal and to the paradigmatic shifts in which he was involved. As the protagonist of power within this context, the Marquis of Pombal contributed to the emergence of various transmutations in what may be considered a kind of inter-communicability among paradigms. It is within this perspective of change, that the pombalino official inquiry, requested after the earthquake de 1755 , is not only in itself, innovative but leads us beyond the scientific and technological rupture it represents into a systemised emergence of a new concept of temporality which should be looked upon from a social, economical, political and cultural perspective and also from the perspective of the scope of this study, which is that of another era that arises.

Key words: Pombal; Paradigm; Temporality; Earthquake.

José Augusto dos Santos Alves

\section{O Conselho de Estado na Monarquia Constitucional}

$\mathrm{O}$ artigo descreve sinteticamente as mudanças observadas nas funções e composição do Conselho de Estado durante a Monarquia Constitucional, procurando indagar a relevância política de uma instituição concebida desde o início para aconselhar o monarca. Não obstante a parcimónia das fontes coevas, e até alguns exemplos contraditórios, parece inquestionável que em vários momentos críticos as decisões políticas do monarca foram influenciadas pela opinião dominante no Conselho de Estado. A finalizar, o artigo apresenta uma biografia colectiva dos 73 indivíduos que foram nomeados conselheiros de Estado efectivos entre 1833 e 1910 - e que podemos definir como o núcleo central da elite governante -, focando algumas características sociodemográficas (naturalidade, idade, educação, profissão, títulos nobiliárquicos) e tipos de experiência política.

Palavras-chave: Conselho de Estado; Elite Política; Liberalismo; Portugal.

\section{The State Council in the Portuguese Constitutional Monarchy}

This article summarises the transformations in the State Council's functions and membership throughout the Portuguese Constitutional Monarchy, and makes a preliminary attempt to scruti- 
nise the political role played by an institution designed since its inception to advise the monarch. In spite of the parsimony of contemporary sources, and even contradictory empirical evidence, it seems indisputable that in several critical occasions the monarch's political decisions were influenced by the dominant view in the State Council. Finally, the article presents the collective biography of the 73 individuals appointed to the State Council between 1833 and 1910 - who may be defined as the inner circle of the ruling elite - focusing on basic background features (birthplace, age, education, occupation, and noble titles) and types of political experience. Keywords: State Council; Political Elite; Liberalism; Portugal.

Pedro Tavares de Almeida

\section{Historicidade e Radicalismo no Liberalismo Vintista Caso do Município da Horta}

$\mathrm{Na}$ tentativa de tornar compreensível o processo vintista nas suas componentes ideológicas ao nível das estruturas orgânicas da Nação, analisamos um caso - o do município do Horta. Utilizando as categorias do liberalismo historicista, de matriz inglesa, e as do radicalismo liberal, de coloração racionalista à francesa, procuramos demonstrar como o liberalismo vintista se estabelece entre o balanceamento dos dois modelos. A teoria do municipalismo, levada a cabo por Alexandre Herculano, mais não faz do que elevar ao nível da conceptualização uma consciência que os "corpos intermédios" manifestaram na adesão ao vintismo, quando a ideia da "soberania da Nação" tendia a afirmar-se como absoluta.

Palavras-chave: Historicismo; Municipalismo; "Corpos Intermédios”; Soberania da Nação; Radicalismo.

\section{Historicism and Radicalism on Liberal «Vintismo» Horta Municipality's case}

In the attempt to understand the ideological components of the "vintismo", the Portuguese political process of the 1920 's, in what concerns the organic structures of the Nation, we shall analyse one case - that of the Municipality of Horta. Using the categories of both historicist liberalism, of the English school, and of liberal radicalism, of French rationalist colours, we attempt to demonstrate how the Portuguese liberalism of the 1920's consolidates in the balance between both of these models. The theory of municipalism developed by Alexandre Herculano, but raises, at the conceptual level, a conscience manifested by the "intermediate bodies" in their adhesion to the "vintismo", when the idea of the "sovereignty of the Nation" was leaning to presenting itself as absolute.

Key-words: Historicism; Municipality's; «Intermediate Bodies»; Nation Sovereignty; Radicalism.

Maria Fernanda Enes

\section{A Itália política do século XVII vista por olhos portugueses}

José de Sousa Pereira, membro do Conselho da Fazenda de D. Pedro II, foi enviado a Roma com a embaixada do Bispo de Lamego entre 1676 a 1682. Consignou as impressões da viagem A politica dos princepes de Itália em 1680 , decerto com a finalidade de fornecer modelos críticos aos governantes portugueses. Da apreciação da política italiana ressaltam simpatias pela república veneziana, pelo Ducado de Saboia, mas também um conhecimento deficiente das políticas de Génova, Modena, Mântua, Parma e Lucca, tão reduzida é a informação que sobre elas aduz. Fez ressaltar o peso da falta de unidade territorial da Itália, os inconvenientes do regime electivo e as vantagens do absolutismo, este através do modelo da corte papal e na participação da nobreza, ao nível dos outros Estados. Mas a sugestão utópica vai para a república, através duma idealização do regime veneziano. Diplomata como era, Pereira não enjeitou também interessantes observações sobre política internacional.

Palavras-chave: José de Sousa Pereira; Diplomacia; Itália; República; Política Internacional. 


\section{The political Italy of the $18^{\text {th }}$ century seen through Portuguese eyes}

José de Sousa Pereira, a member of the Conselho da Fazenda (Fiscal Institution) of D. Pedro II, was sent to Rome, between 1676 and 1682, with the commission of the Lamego bishop. In 1689 he recorded his impressions of this mission in A politica dos princepes de Itália; certainly with the objective of providing critical models to the Portuguese governors. From his appreciation of Italian politics stands out not only his liking for the Venetian republic, for the dukedom of Savoie, but also a defective knowledge of the politics of Genoa, Modena, Mantua, Parma and Lucca, as he only gives very little information about these cities. He highlighted the weight of the non-unified Italian territory, the inconveniences of the elective regime and the advantages of absolutism; the latter through the model of the papal court and in the participation of nobility at the level of other States. But the utopian suggestion goes to the republic through the idealisation of the Venetian regime. As a diplomat, that he was, he did not reject interesting comments on international politics.

Keywords: José de Sousa Pereira; Diplomacy; Italy; Republic; International Politics.

\section{Alberto Antunes de Abreu}

\section{De converso a novamente convertido. Identidade política e alteridade no reino e no império} Para estudar os processos de conversão e cristianização que se verificaram em Goa entre os séculos XVI e XVIII, e os seus impactos sociais, importa entender como é que na tópica dominante no reino se explicava a alteridade, como é que esta se manifestava no quadro legal e institucional, e, simultaneamente, se transplantava para os territórios imperiais. Com este estudo pretende-se mostrar que as atitudes da coroa portuguesa em relação às populações residentes nos territórios do império se inspiraram naquelas que no reino se estava a ter em relação às comunidades de origem judaica, depois cristã-nova. Creio que a par das revisitações «clássicas», também este modelo de pensar, identificar, e gerir a alteridade no interior do reino serviu de grelha referencial das novas situações sociais, e desse paralelismo resultaram, intra e extra territorium, grupos sociais (conversos e novamente convertidos) cujas identidades liminares persistiram pelo menos durante dois séculos.

Palavras-chave: Império; Política; Conversão; Identidade; Diferença.

\section{From «converso» to «novamente convertido»}

\section{Political identity and difference in the Portuguese kingdom and empire}

In order to explain the processes of conversion and christianization of the habitants of Goa, during the 16th and 17th centuries, it is necessary to understand, first, the ideas of otherness that were underlying the legal and institutional order in the Portuguese kingdom during the same period. This study aims at showing that the attitudes of the Portuguese Crown in some of the territories of its empire were inspired by those towards the Jews, called New Christians after conversion. This model of thinking, identifying and ordering the internal «other» became a reference for new social situations. Such parallelism allowed, intra and extra territorium, the emergence of social groups (conversos and novamente convertidos) whose liminal identities persisted at least for two centuries.

Key-words: Empire; Politics; Conversion; Identity; Difference.

Ângela Barreto Xavier

\section{O Complexo da Ordem em A Natureza do Direito de Eric Voeglin}

A partir da experiência quotidiana do direito, Eric Voeglin penetra pela sua superfície fenomenal para averiguar da existência de um núcleo ontológico. Fiel à tomista possibilidade do conhecimento modesto de coisas supremas, primeiro considera que o direito é mera consequência da sociedade, porquanto a ordem jurídica deriva da ordem da sociedade; Para, em seguida, considerar a ordem da sociedade proveniente de um todo maior e anterior à mesma: a ordem do 
mundo que se identifica com a própria ordem do ser. Em Voeglin, o direito é entendido como tendo por natureza ontológica a estrutura da sociedade cujo direito a sociedade é, e como tendo por critério a relação do homem com o ser tal como nós podemos sabê-lo através da filosofia e da revelação, num exemplo moderno de filosofar ao estilo clássico.

Palavras-Chave: Direito; Eric Voeglin; Ordem.

\section{The Complexity of Order in The Nature of Law by Eric Voeglin}

Starting from the daily experience of law, Eric Voeglin pierces through its phenomenal surface to inquire into the existence of an ontological nucleus. Loyal to the Thomist possibility of having a humble knowledge of supreme things, first he ponders that law is a mere consequence of society, since the legal system comes from the order in society; immediately after he considers that the order in society comes from something greater and previous to society itself: the order of the world which identifies itself with the order of the being. Voeglin understands law as having as its ontological nature the structure of society, whose law is the society itself, and as having as a criterion the relationship of man with the being, as we can know it through philosophy and revelation, in a modern example of philosophising according to the classic style.

Keywords: Law; Eric Voeglin; Order.

Cristina Montalvão Sarmento

\section{Ética e política no pensamento de Vicente Ferreira da Silva}

Neste trabalho examinamos as idéias de Vicente Ferreira da Silva sobre ética e política. Partindo do entendimento de que se vivia num tempo de crise porque o homem deixou de lado suas possibilidades, propõe uma rejeição ao que o sustentava: o individualismo abstrato, a fragilidade das instituições, o imanentismo, o materialismo, o tecnicismo, o positivismo, o marxismo e o autoritarismo. Com alternativa propõe uma educação que leve em conta a dimensão mítica e lúdica da vida capaz de liberar as potencialidades do homem.

Palavras chave: Crise; Moral; Existência.

\section{Ethics and politics in the thought of Vicente Ferreira da Silva}

In this paper the ideas of Vicente Ferreira da Silva on ethics and politics are analysed. Starting from the understanding that we lived in a time of crisis because man left aside his possibilities, he proposes the rejection of what used to sustain him: abstract individualism, the weakness of the institutions, immanentism, materialism, technicality, positivism, Marxism, and authoritarianism. Alternatively, he suggests an educational system that takes into consideration the mythical and entertaining dimension of life, capable of freeing the potentialities of man.

Keywords: Crisis; Moral; Existence.

José Mauricio de Carvalho

\section{O pensamento político de Hipólito da Costa}

Hipólito da Costa (1774-1823) foi o redactor do primeiro periódico liberal de língua portuguesa, o Correio Braziliense, e é considerado o patriarca do jornalismo brasileiro. Exilado em Londres, desenvolveu no Correio um corpus doutrinal que culminou num Projecto de Constituição para o Brasil, tributário dos valores do modelo constitucional inglês. Anti-absolutista, anti-esclavagista e anti-democrático, o seu liberalismo tem a marca do gradualismo como método preferencial de evolução política e social.

Palavras-chave: Hipólito da Costa; Correio Braziliense; História das ideias políticas; História da Imprensa; Jornalismo; Constituição; Liberalismo; Absolutismo; Gradualismo; Maçonaria; Brasil.

Hipólito da Costa (1774-1823) was the editor of the first liberal newspaper in Portuguese, 
Correio Braziliense, and is credited as the founding father of brazilian journalism. During his exile in London he developed a consistent doctrine which eventually led to submitting a Political Constitution for Brazil grounded on the values of the british constitutional model. Antiabsolutism, anti-slavery and anti-democracy are the tenets of Da Costa's liberal agenda, which bears the trademark of gradualism as the most effective tool for political and social evolution. Keywords: Hipólito da Costa; Correio Braziliense; History of political ideas; History of the press; Journalism; Constitution; Liberalism; Absolutism; Gradualism; Freemasonry; Brazil.

João Pedro Rosa Ferreira

\section{Rabelais $e$ «A Abadia de Théléme», génese da antiutopia na Idade Moderna}

Este artigo refere-se ao conhecido episódio da famosa novela "Gargantua", de Rabelais, e a sua intenção é mostrar que naquelas singulares sociedade e arquitectura se apresentam ou prefiguram, em larga medida, as questões que mais tarde foram exploradas no pensamento utópico ocidental sobre o tema de "Antiutopia". Em particular, há a intenção de mostrar as relações entre as "Sociedades Ideais" e as "Arquitecturas Ideais"... Como se mutuamente se implicassem. E, claro, os hilariantes equívocos relacionados com tal...

Palavras-chave: Arquitectura; Utopia; Pensamento utópico ocidental.

\section{Rabelais and «The Theleme Abbey», genesis of anti-utopia in Modern Age}

This article reports to the known episode of the famous novel "Gargantua", by Rabelais, and its intention is showing that in those singulars society and architecture are presented or prefigured, in largest measure, the questions that later were presented in the utopian Western Thought about the theme of "Anti-utopia". In particular, there is the intention to show the relations between the "Ideal Societies" and the "Ideal Architecture"... Has if they where mutually implicated. And, of course, the hilarious equivoques related with this...

Key-words: Architecture; Utopia; Utopian Western Thought.

\section{J. M. Simões Ferreira}

\section{A geopolítica, da Alemanha nacional-socialista à América Latina: os casos da Argentina e do Brasil}

Este artigo trata de três assuntos: $a$ ) As origens alemãs da geopolítica (em particular, a teoria dos "Grandes Espaços" de Karl Haushofer, o geopolítico da cúpula nazista) e sua extensão na América do Sul, sobretudo na Argentina, no período das ditaduras européias, até o final da Segunda guerra mundial; $b$ ) Os planos geopolíticos da Argentina na América do Sul (com particular atenção à sua expansão no Brasil meridional) até o final da Segunda guerra mundial; c) A geopolítica e os geopolíticos da ditadura militar brasileira e a "reabilitação" da geopolítica depois dos anos setenta-oitenta.

Palavras-chave: Geografia política; Nazismo; Governo militar brasileiro.

\section{Geopolitics, from the national-socialist Germany to Latin America: \\ The cases of Argentina and Brazil}

This article looks at three different topics: a) The German origins of geopolitics (in particular the theory of "Larges Spaces" by Karl Haushofer, the geo politician of the Nazi regime) and its expansion through South America, mainly Argentina, during the period of the European dictatorships and until the end of the Second World War; b) The geopolitical plans of Argentina in South America (with particular focus on its expansion in southern Brazil) until the end of the Second World War; c) The geopolitics and the geo politicians of the Brazilian military dictatorship and the "rehabilitation" of geopolitics after the seventies and eighties.

Keywords: Political geography; Nazism; Brazilian military governm.

Mário G. Losano 


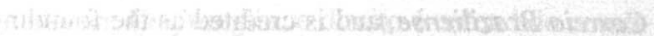

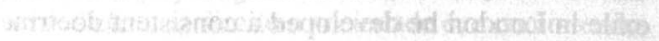

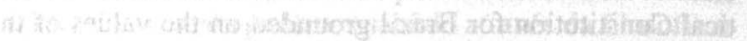

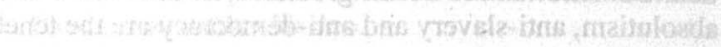

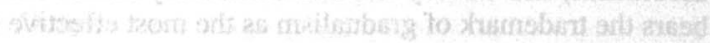

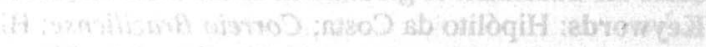

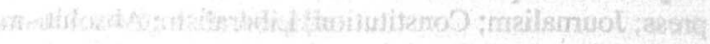

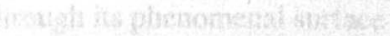

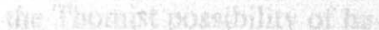

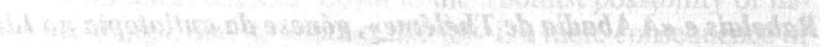

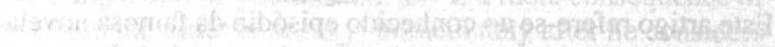

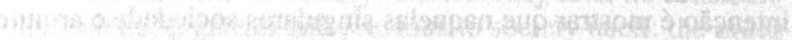

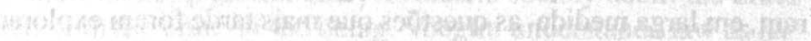

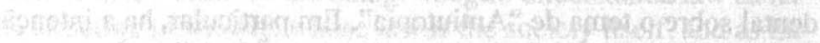

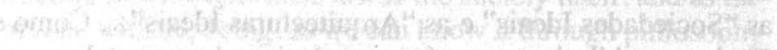

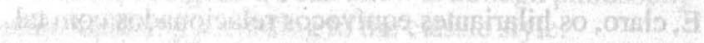

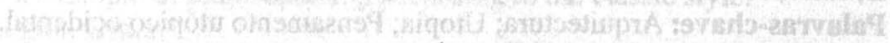

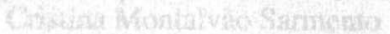

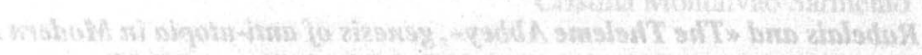

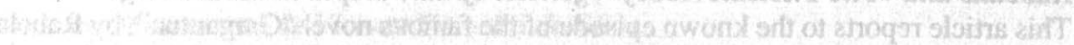

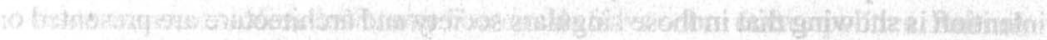

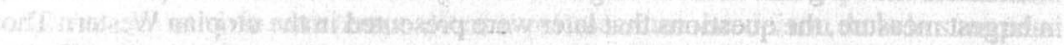

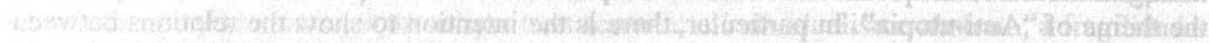

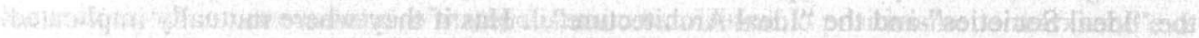

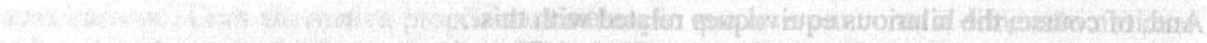

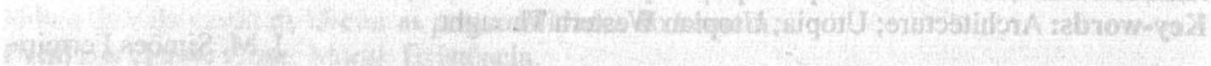

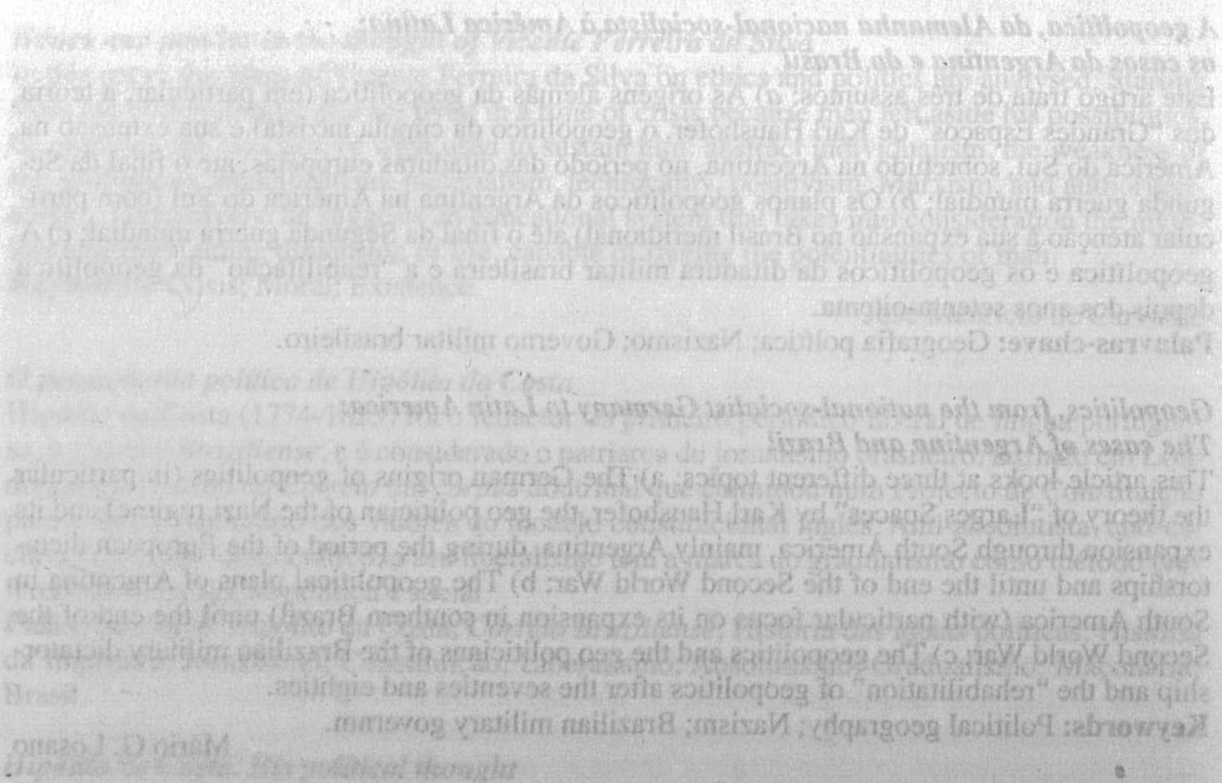

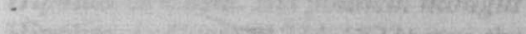

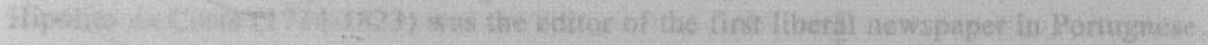


Conkexhe

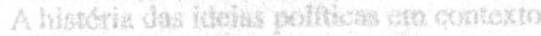

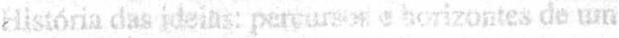

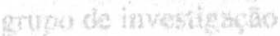

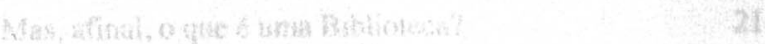

t'mpaceithra

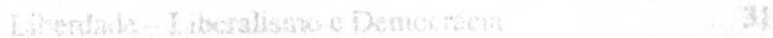

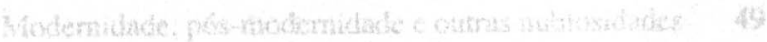

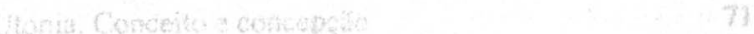

Pincringits

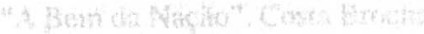

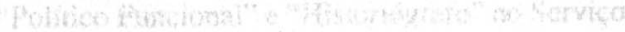

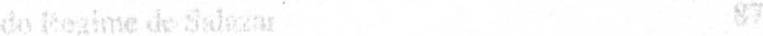

ingere latis tienger

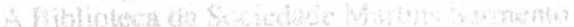

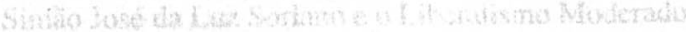

$(1958-1260)$.

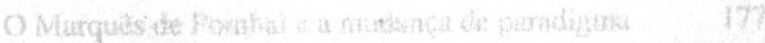

\section{Fenteos}

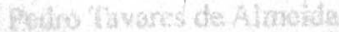

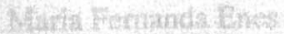

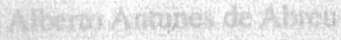

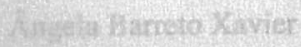

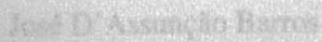

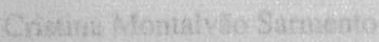

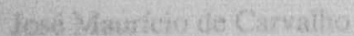

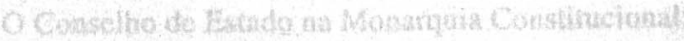

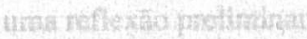

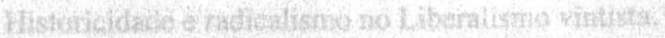

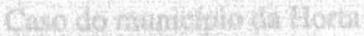

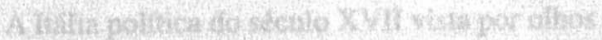

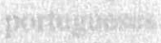

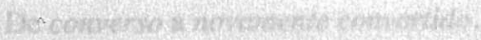

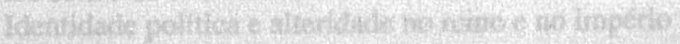

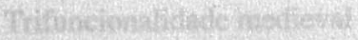

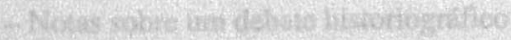

\section{nolished}

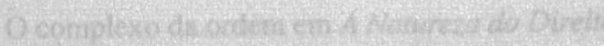

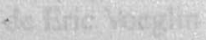

ÍNDICE

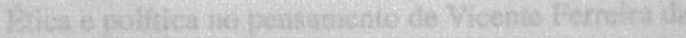
Sitopat 
arorh 


\section{Contextos}

João Luís Lisboa

Isabel Cluny

António Camões Gouveia

Maria João Cabrita

Onésimo Teotónio Almeida

Luís Crespo de Andrade

Luís Reis Torgal

Maria Manuela Tavares Ribeiro

Vamireh Chacon

Fernando Pinto Santos

Júlio Rodrigues da Silva

José Augusto dos Santos Alves

\section{Pedro Tavares de Almeida}

Maria Fernanda Enes

Alberto Antunes de Abreu

Ângela Barreto Xavier

José D’Assunção Barros

\section{Cristina Montalvão Sarmento}

José Maurício de Carvalho
A história das ideias políticas em contexto

História das ideias: percursos e horizontes de um grupo de investigação

Mas, afinal, o que é uma Biblioteca?

\section{Conceitos}

Liberdade - Liberalismo e Democracia

Modernidade, pós-modernidade e outras nublosidades

Utopia. Conceito e concepção

\section{Percursos}

“A Bem da Nação”. Costa Brochado.

"Político Funcional" e "Historiógrafo" ao Serviço do Regime de Salazar

Jorge Luís Borges: Nacionalista e Cosmopolita

A Biblioteca da Sociedade Martins Sarmento

Simão José da Luz Soriano e o Liberalismo Moderado (1858-1860)

O Marquês de Pombal e a mudança de paradigma

\section{Tempos}

O Conselho de Estado na Monarquia Constitucional: uma reflexão preliminar

Historicidade e radicalismo no Liberalismo vintista. Caso do município da Horta

A Itália política do século XVII vista por olhos portugueses

De converso a novamente convertido. Identidade política e alteridade no reino e no império Trifuncionalidade medieval

- Notas sobre um debate historiográfico

\section{Reflexões}

O complexo da ordem em A Natureza do Direito de Eric Voeglin

Ética e política no pensamento de Vicente Ferreira da Silva 
João Pedro Rosa Ferreira

J. M. Simões Ferreira

Mario G. Losano

Isabel Baltazar

Carlos Leone

João Pedro Ferreira

Carlos Leone
O pensamento político de Hipólito da Costa

Rabelais e «A Abadia de Thélème», génese da antiutopia na Idade Moderna

A geopolítica, da Alemanha nacional-socialista à

América Latina: os casos da Argentina e do Brasil

\section{Recensões}

George Steiner, A Ideia de Europa, Lisboa, Gradiva, 2005, 55 pp.

J. Martins Lampreia, Lóbi - Ética, Técnica e Aplicação, Lisboa, Texto Editores, 2005, 128 pp.

Lustosa, Isabel, D. Pedro I. Um Herói sem nenhum caráter, São Paulo, Companhia das Letras, 2006, 340 pp.

Pacheco Pereira, José, Álvaro Cunhal, uma biografia política - volume 3 «O prisioneiro», Lisboa, Temas \& Debates, 2005, 748 pp.

Autores

Resumos e palavras-chave

Índice 
RURARA

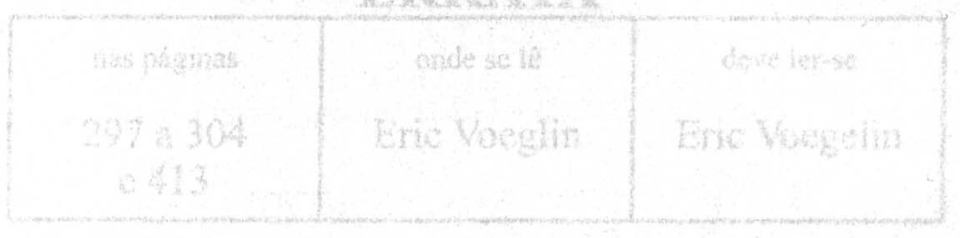




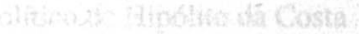

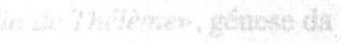

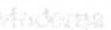

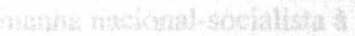

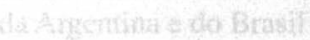

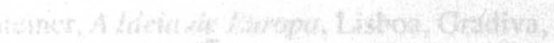

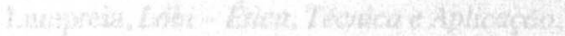

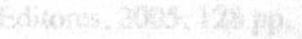

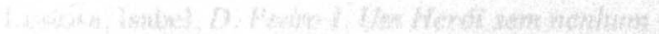

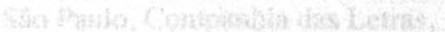

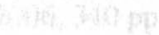

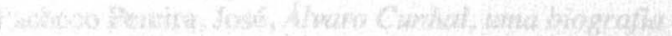

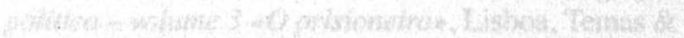

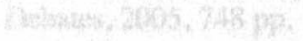

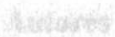

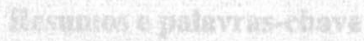

(rosine 


\section{ERRATA}

\begin{tabular}{|c|c|c|}
\hline $\begin{array}{c}\text { nas páginas } \\
297 \text { a } 304\end{array}$ & onde se lê & deve ler-se \\
e 413 & Eric Voeglin & Eric Voegelin \\
\hline
\end{tabular}


ATAMBIF

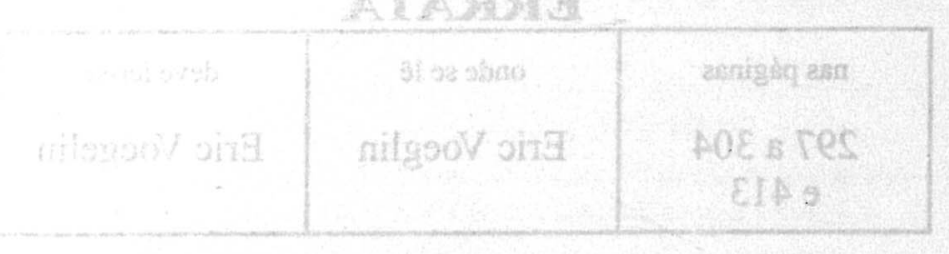




\section{Cultura. Revista de História e Teoria das Ideias Recomendações aos Autores}

\section{Envio}

- Pelo correio, um exemplar em papel acompanhado de uma disquete (Formato Word) para:

Cultura. Revista de História e Teoria das Ideias

Centro de História da Cultura

Faculdade de Ciências Sociais e Humanas

Av. de Berna, $n^{\circ} 26-C$

1069-061 Lisboa

- Por correio electrónico para:

\section{chc@,fcsh.unl.pt}

\section{Forma e Dimensão}

\section{Artigos}

- Preferencialmente, até cerca de 70000 caracteres, seja 20 páginas com 3 450 caracteres por página, Times New Roman, 12 (formatação a um espaço e meio).

- Referências bibliográficas inseridas nas notas de rodapé de página (tendo bibliografia no final não pode exceder uma página).

- Apresentação das referências segundo o modelo seguinte: apelido, nome, título da obra (Itálico), local, editora, ano; ou, para artigos, apelido, nome, «título do artigo», revista (Itálico), $\mathrm{n}^{0}$ de volume, data, páginas.

- Artigos longos deverão ter subtítulos.

- Ilustrações, gráficos e quadros - a preto e branco, com legenda, fonte e numeração.

\section{Recensões}

- Até cerca de 10000 caracteres, seja 3 páginas, Times New Roman, 10 (formatação a um espaço).

\section{Resumo e Biografia}

- Resumo de cerca de 750 caracteres, acompanhado de uma tradução em inglês de idêntica dimensão.

-Biografia do autor que refira o estatuto profissional, principais publicações, domínios de investigação e morada.

\section{Procedimento}

- Será acusada a recepção ao autor no dia de chegada do texto.

- Avaliação do artigo sob orientação da comissão científica.

- A decisão de publicação será comunicada nos 90 dias seguintes à data da recepção. 


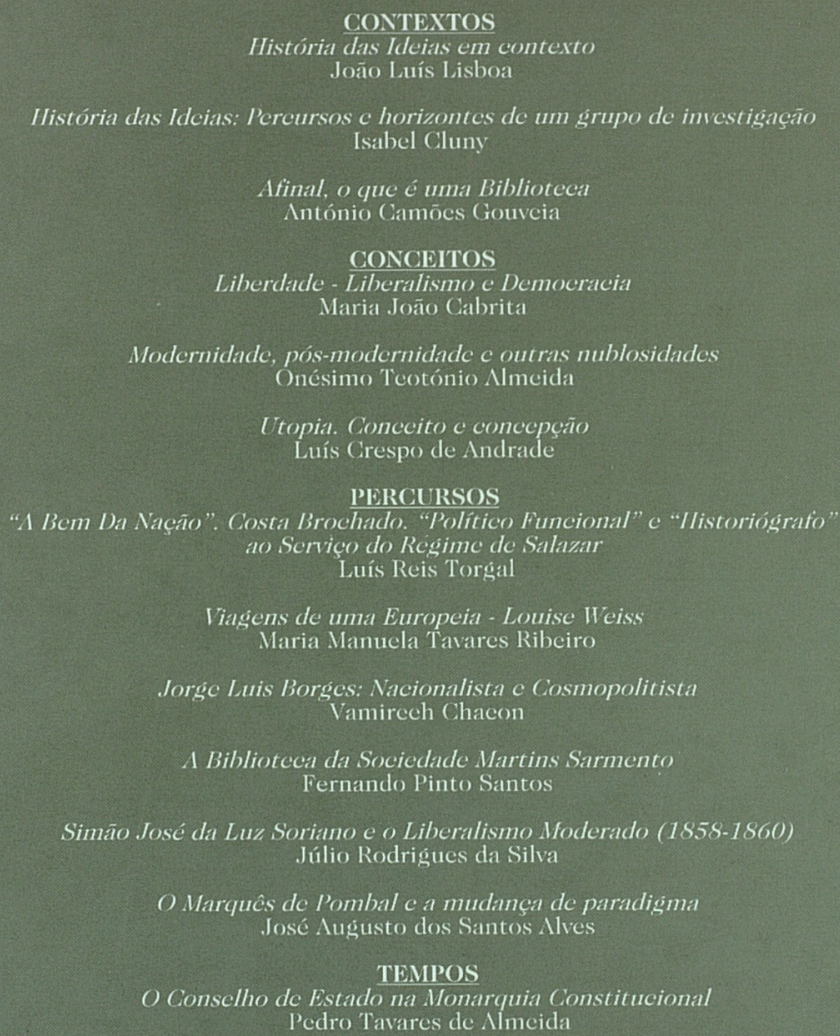

Uistória das Ideias: Percursos c horizontes de um grupo de insestigaçāo Isabel Cluny

Afinal, o que é uma Biblioteca

António Camōes Gouveia

\section{CONCEITOS}

Liberdade - Liberalismo e Democracia

Maria Joāo Cabrita

Modernidade, pós-modernidade c outras nublosidades

Onésimo Teotónio NImeida

Utopia. Conceito c concepcão Luís Grespo de Andrade

\section{PERCURSOS}

"A Bem Da Nacióo". Costa Brochado. "Polítien Funcional" e "Ilistoriograto" ao Serviço do Regime de Salazar

Luís Reis Torgal

Viagens de uma Europeia - Louise IVeiss

Maria Manucla Tavares Ribciro

Jorge Luis Borges: Nacionalista e Cosmopolitista

Vamirech Chacon

A Biblioteca da Srociedade Martins Sarmento

Fernando Pinto Santos

Simño José da Luz Soriano e o Liberalismo Moderado (1858-1860)

Júlio Rodrigues da Silva

O Marqués de Pombal e a mudanca de paradigma

José Augusto dos Santos Alves

TEMIPOS

O Conselho de Estado na Monarquia Constitucional

Pedro Tavares de NImeida

IIistoricidade e radicalismo no Liberalismo vintista. Caso do município da Ilorta.

Maria Fernanda Enes

A Itália política do século XVII vista por olhos portuǵueses

Alberto Antunes de Abreu

De converso a novamente convertido. Identidade política e alteridade no reino e no império Angela Barreto Xavier

Trifuncionalidade Medieval - Notas sobre um Debate Historiogrático José D'Assunçāo Barros

\section{REFLEXÕES}

O Complexo da Ordem em A Natureza do Direito de Eric Voeglin

Gristina Montalvāo Sarmento

Ética e política no pensamento de Vieente Ferreira da Silva

José Maurício de Carvalho

O pensamento político de llipólito da Costa

João Pedro Rosa Ferreira

Rabelais e A Abadia de Théléme, génese da antiutopia na Idade Moderna J. M. Simốes Ferreira

A geopolítica, da Alemanha nacional-socialista à América Latina: os casos da Argentina c do Brasil Mario G. Losano

\section{RECENSÕNS}

George Steiner, A Ideia de Europa, por Isabel Baltazar

J. Martins Lampreia, Lóbi-Ética, Técnica e Aplicação, por Carlos Leone

Lustosa, Isabel, D. Pedro I. Um Ilerói sem nenhum earácter, por Joāo Pedro Ferreira

Pacheco Pereira, José, Álvaro Cunhal, uma bioǵrafia política - volume 3 \& prisioneiro», por Carlos Leone 